The Principle of Equality of Arms in International Criminal Proceedings 
Cover image (C) wikimedia commons, 'Gerichtlicher Zweikampf' image from 'Dresdener Bilderhandschrift des Sachselspiegels'

School of Human Rights Research Series, Volume 55

A commercial editon of this dissertation will be published by Intersentia under ISBN 978-1-78068-111-5

The titles published in this series are listed at the end of this volume.

Typesetting: G.J. Wiarda Institute for Legal Research, Utrecht University 


\title{
The Principle of Equality of Arms in International Criminal Proceedings
}

\author{
Het Equality of Arms - Beginsel in Internationale Strafprocedures \\ (met een samenvatting in het Nederlands)
}

\author{
PROEFSCHRIFT \\ ter verkrijging van de graad van doctor aan de Universiteit Utrecht \\ op gezag van de rector magnificus, prof. dr. G.J. van der Zwaan, \\ ingevolge het besluit van het college voor promoties \\ in het openbaar te verdedigen \\ op vrijdag 7 september 2012 \\ des middags te 16.15 uur
}

door

Maria Igorevna Fedorova

geboren op 25 januari 1980

te Vladivostok, Rusland 
Promotoren: Prof. dr. C. Flinterman

Prof. dr. G.K. Sluiter

Dit proefschrift werd mogelijk gemaakt met financiële steun van de Nederlandse Organisatie voor Wetenschappelijk Onderzoek (NWO) 


\section{ACKNOWLedgements}

It would probably take a book half this size to describe all of my experiences and to thank everyone for all the support I have received. My mother always knows some fitting, short words to say, so I tried to follow her example and found several Russian proverbs to summarize the process I went through while writing this dissertation.

Аппети́т прихо́дит во вре́мя еды. Appetite comes with eating. When I started working at the Netherlands Institute of Human Rights (SIM) some time after my graduation at Utrecht University, little did I know what it meant to write a PhD dissertation. During my two years of being a junior researcher, my 'appetite' for conducting legal research grew and I ended up writing a proposal that was approved by the Netherlands Organization for Scientific Research (NWO) for a four-year research grant, for which I am very grateful. I had already acquired a fascination for the field of international criminal law when I wrote my Masters thesis, so for the purposes of a PhD, I decided to stay in this field. However, this time, I decided to focus on international criminal procedure. I started my research in November 2006.

I could not have dreamed of a better 'job' to feed my curiosity: a young and developing field of law to write about; many interesting and challenging conferences, summer schools, colloquia, round table discussions; and opportunities to publish, teach, present and discuss. I had so much to learn. My mother always says: Век живи́ - век учи́сь. Live for a century - learn for a century. I try. A short time into my $\mathrm{PhD}$ research a new experience entered my life. It is amazing how much motherhood can teach one about the principle of relativeness, the balancing metaphor and the question of time. Twentyfour hours a day is all one has. I felt that I had to say goodbye to my perfectionist nature. Although my dedication to my research grew with every sleepless night, due to the fact that I realized that I actually loved doing what I was doing, it was a hectic time. I learned that Вы́ше головы́ не прыгнешь. You cannot jump above your head.

I am happy to acknowledge that there are many people for whom I owe my deepest gratitude for all their support throughout the years. First of all, I would like to recognize my supervisors, Prof. Cees Flinterman and Prof. Göran Sluiter. Thank you both for your guidance and for your trust and confidence. Thank you, Göran Sluiter, for guiding me towards SIM and supporting me from the moment of the writing of my Masters thesis. And thank you, Cees Flinterman, for giving me a chance when I most needed one, my gratitude is indescribable. Of course I would also like to thank my reading committee, Prof. Jenny Goldschmidt, Prof. Geert-Jan Alexander Knoops, Prof. Guénaël Mettraux, Prof. Héctor Olásolo and Prof. Stefan Trechsel, for taking the time to read this, not all too concise, book and for your guiding comments. 
Acknowledgements

Special attention and gratitude also goes to my 'SIM-family'. Jenny Goldschmidt, thank you for believing in me and motivating me to find my way. Thank you, Ineke Boerefijn, for helping me to order my thoughts when I most needed to, when writing my $\mathrm{PhD}$ proposal and the conclusions to my book. Thank you, Antoine Buyse, for all of your advice whenever I needed it, and thank you, Hanneke van Denderen, Maeyken Hoeneveld, Esther Heldenbergh, Maaike Hogenkamp, Marcella Kiel, Peter Malcontent, Ilse van Vugt, Leo Zwaak and Remko Zwerver for all of your support. All the lunches, brown bags, drinks, barbeques, dinners, (pep) talks and discussions with my colleagues, past and present, at Utrecht University and elsewhere were not only very inspiring but also a lot of fun. Therefore, I would like to say thank you to Ramona Biholar, Diana Contreras Garduno, Jill Coster van Voorhout, Quirine Eijkman, Katherine Fortin, Marie Elske Gispen, Irene Hadiprayitno, Marianne Hirsch Ballin, Saima Husain, Ginney Liu, Jayshree Mangubhai, Karel de Meester, Chiseche Mibenge, Paulien Muller, Marloes van Noorloos, Fleur van Leeuwen, Ianina Lipara, René Rouwette, Cedric Ryngaert, Hana van Ooijen, Sarah Haverkort-Speekenbrink, Desislava Stoitchkova, Sergey Vasiliev, Marthe Lot Vermeulen and Gentian Zyberi. Moreover, I would like to thank Annemarieke Beijer for helping me 'met de laatste loodjes', Titia Loenen and Renée Kool for their support as $\mathrm{PhD}$ deans, and Klaartje Hoeberechts and Peter Morris for editing this book.

A special thank you also goes to my new colleagues at the Radboud University Nijmegen, Sven Brinkhoff, Richard van Elst, Piet Hein van Kempen, Maartje Krabbe, Mirjam Krommendijk, Sjarai Lestrade, Asha Parisius, Geert Pesselse, Henny Sackers, Renze Salet, Gracia Sieben, Martine van der Staak, Jan Terpstra, Mikhel Timmerman and Dave van Toor. Thank you all for your support and understanding, your insights and stimulating discussions, for the lunches and the coffees and for making me feel 'at home'.

I cannot even find the words to thank my paranimphs Saskia Bal and Brianne McGonigle Leyh. Your support, affection and confidence have been no less than essential for the survival of this project. Thank you for the laughs, dinners, drinks, kids' play dates and babysitting, and more, more and more.

Last but not least, I would like to thank my family and friends for all their love, understanding and patience with me. A special thank you goes to the Lomme-family for all their trust and love and for giving me security when I needed it, to Titia Korff for her friendship, and to Wilma van den Endt and Bert Sleurink for their confidence, attention and support. My dearest sister, I would like to thank you for bearing with me all these years, for listening and understanding and for bringing me back to reality whenever I tried to hide behind my books. And of course my mama, thank you for your love. I am what I am because of you. My last words of gratitude go to my partner, Giovanni van Heusden, who supported me beyond imagination. Schatje, thank you for loving me. This book is for you, and for our Roman and Elena.

Any errors or omissions are my own, which brings me to my last saying: He ошибается тот, кто ничего не делает. Only he who does nothing makes no mistakes.

Utrecht, July 2012 


\section{TABle of Contents}

Acknowledgements

\section{Chapter 1 Introduction}

1.1 Equality of arms 1

1.2 Challenging 'equality of arms' in international criminal process 2

$\begin{array}{ll}\text { 1.3 Central aim and question of this research } & 6\end{array}$

$\begin{array}{ll}\text { 1.3.1 The principle } & 7\end{array}$

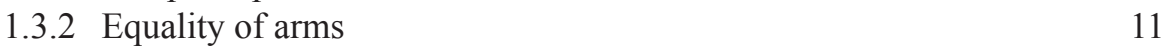

$\begin{array}{ll}\text { 1.3.3 International criminal proceedings } & 12\end{array}$

$\begin{array}{ll}\text { 1.3.4 Should be interpreted and applied } & 15\end{array}$

$\begin{array}{ll}1.4 \text { Methodological choices and limitations } & 17\end{array}$

$\begin{array}{ll}1.5 \text { Structure of the book } & 19\end{array}$

\section{Chapter 2 Human Rights Perspective}

2.1 Introduction 23

2.2 Human rights and - international - criminal law 23

2.2.1 Sources of the law 26

2.2.2 The role of human rights jurisprudence 28

$\begin{array}{ll}2.3 \text { Equality of arms: origin and legal basis } & 30\end{array}$

2.3.1 General concept: the right to a fair trial 31

2.3.2 The meaning of equality of arms 36

$\begin{array}{lll}\text { 2.3.3 Establishing a violation of equality of arms } & 39\end{array}$

$\begin{array}{ll}\text { 2.3.4 Considerations of 'equality' } & 41\end{array}$

2.4 The connection to other rights 46

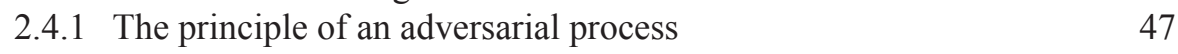

2.4.1.1 The right to be present in person at proceedings 49

2.4.1.2 The right to challenge an adversary's observations $\quad 52$

2.4.2 The right to have adequate time and facilities to prepare a defence 55

2.4.3 The right to examine witnesses under the same conditions 60

2.5 Concluding remarks 66 


\section{Chapter 3 Criminal Process Perspective}

3.1 Introduction 69

3.2 Goals and values of a criminal process 70

3.2.1 Conflict resolution and societal values $\quad 74$

3.2.2 Truth-finding 75

3.2.2.1 The importance of truth in the criminal process 76

3.2.2.2 What kind of truth can be achieved in a criminal process? $\quad 77$

3.2.2.3 A process model most committed to truth? 81

$\begin{array}{ll}3.2 .3 \text { Fairness } & 81\end{array}$

3.2.3.1 The concept of procedural justice 82

3.2.3.2 Conceptions of procedural justice 83

$\begin{array}{ll}3.2 .4 \text { Efficiency } & 87\end{array}$

3.2.5 Due process v. crime control 88

3.3 Adversarial and inquisitorial models of procedure $\quad 92$

3.3.1 Explaining the use of terms 92

3.3.1.1 Adversarial 94

3.3.1.2 Inquisitorial and mixed 96

3.3.2 Two ideal-types of procedure 97

3.3.2.1 A pure adversarial fact-finding model 98

3.3.2.2 A pure inquisitorial fact-finding model 99

3.3.2.3 Damaška's ideal-types 101

3.4 The role of equality of arms in adversarial and inquisitorial procedures 105

3.4.1 The Roman origin: the principle of audi et alteram partem 106

3.4.2 The 'balance of advantages' in the adversarial process 109

3.4.2.1 Early starting point and ideological underpinnings $\quad 109$

3.4.2.2 Equality of arms as a corollary of adversarial procedure? $\quad 110$

3.4.2.3 Parity of information: pre-trial disclosure regime $\quad 115$

3.4.3 Equality of arms and inquisitorial process: a missing link? 121

3.4.3.1 'Dialogue' in the pre-trial process: defence participation $\quad 124$

3.4.3.2 The function of the dossier 126

3.4.3.3 Active judge 128

3.5 International criminal procedure: reassessing goals, values and procedures? 131

$\begin{array}{ll}3.6 \text { Concluding remarks } & 140\end{array}$ 


\section{Chapter 4 Parties' Role During Investigations}

4.1 Introduction 143

4.2 The role of the international prosecutor 144

4.2.1 Prosecutorial ethos: a dichotomy? 145

4.2.2 Prosecutorial function within the institutional design 157

4.2.2.1 Structural parameters 158

4.2.2.2 Prosecutorial discretion $\quad 162$

4.2.2.3 Judicial control 164

4.3 Prosecutor's ability to prepare for trial: the approach to investigations 168

$\begin{array}{ll}\text { 4.3.1 Yugoslavia and Rwanda Tribunals } & 169\end{array}$

4.3.2 The Special Court for Sierra Leone $\quad 170$

4.3.3 The International Criminal Court 173

4.3.3.1 Confidentiality agreements 176

4.3.3.2 Protection of witnesses $\quad 181$

4.3.3.3 Victim participation $\quad 183$

4.4 The defence's ability to prepare for trial: defence investigations 186

4.5 Parties' access to state cooperation 190

4.5.1 State cooperation order requirements 196

4.5.1.1 Ad hoc tribunals 196

4.5.1.2 International Criminal Court 202

4.6 Other issues surrounding the collection of evidence 210

4.6.1 Ad hoc tribunals - Rule 54 orders necessary for trial preparation $\quad 210$

4.6.2 Compellability of witnesses at the ICC 218

4.6.3 Ad hoc tribunals - Search and seizure warrants 218

4.6.4 Functional immunity for defence team members 221

$\begin{array}{ll}4.7 \text { Concluding remarks } & 227\end{array}$

\section{Chapter 5 Disclosure of INFORMATION}

5.1 Introduction 233

5.2 Prosecutorial disclosure: general obligations 234

5.2.1 ICTY, ICTR and SCSL 235

5.2.2 International Criminal Court 241

5.3 Exceptions to disclosure: the protection of other interests 245

5.3.1 Protection of state interests and other third entities 249

5.3.1.1 ICTY, ICTR and SCSL 249

5.4 Disclosure of exculpatory evidence 250

5.4.1 ICTY, ICTR and SCSL 252

5.4.2 ICC 265

5.4.2.1 The Lubanga disclosure crises 271 
5.5 Reciprocal disclosure obligations: defence disclosure 278 $\begin{array}{lll}\text { 5.5.1 ICTY, ICTR and SCSL } & 279\end{array}$

5.5.2 International Criminal Court 287

$\begin{array}{ll}5.6 \text { Remedying disclosure violations } & 291\end{array}$

5.7 Inter partes disclosure and the role of the judges 297

$\begin{array}{ll}5.8 \text { Concluding remarks } & 300\end{array}$

\section{Chapter 6 Institutional Support for the Defence}

6.1 Introduction 303

6.2 Equality of arms, adequate facilities and the legal aid system 305

$\begin{array}{ll}6.3 \text { Institutional support for the defence } & 310\end{array}$

6.3.1 Legal aid arrangements 311

6.3.1.1 Ad hoc tribunals 311

6.3.2 Avenues of redress for challenging the inadequacy of resources 316

6.3.3 Defence Support Sections 323

6.3.3.1 ICTY/ICTR 324

$\begin{array}{lll}6.3 .3 .2 & \text { SCSL } & 326\end{array}$

$\begin{array}{ll}6.3 .3 .3 \mathrm{ICC} & 330\end{array}$

$\begin{array}{lll}6.3 .3 .4 \text { ECCC } & 332\end{array}$

6.3.3.5 STL 332

6.4 Legal aid and self-representation: to have one's cake and to eat it too? 333

$\begin{array}{ll}6.5 \text { Other facilities } & 337\end{array}$

$\begin{array}{ll}6.6 \text { Concluding remarks } & 340\end{array}$

\section{Chapter 7 Case Presentation}

$\begin{array}{lll}7.1 \text { Introduction } & 343\end{array}$

$\begin{array}{ll}\text { 7.2 Shaping the case before trial } & 344\end{array}$

7.2.1 ICTY, ICTR and SCSL: Pre-Trial and Pre-Defence Conferences 344

$\begin{array}{lll}\text { 7.2.1.1 Pre-trial conference } & 345\end{array}$

$\begin{array}{ll}7.2 .2 \text { ICC } & 373\end{array}$

$\begin{array}{lll}7.2 .3 \text { ECCC } & 377\end{array}$

$\begin{array}{lll}7.3 \text { Trial Issues } & 380\end{array}$

$\begin{array}{ll}\text { 7.3.1 Case presentation scheme } & 380\end{array}$

7.3.1.1 ICTY, ICTR and SCSL: The 'two-case' approach 381

7.3.1.2 ICC: 'Open-ended' approach 382

7.3.1.3 ECCC: A 'Judge-led' approach 385 
7.3.2 Examination and cross-examination of witnesses 386

$\begin{array}{lll}\text { 7.3.2.1 ICTY, ICTR and SCSL } & 387\end{array}$

$\begin{array}{ll}7.3 .2 .2 \text { ICC } & 398\end{array}$

$\begin{array}{lll}\text { 7.3.2.3 ECCC } & 400\end{array}$

$\begin{array}{ll}\text { 7.3.3 Admissibility of evidence } & 400\end{array}$

7.3.3.1 ICTY/ICTR and SCSL $\quad 400$

$\begin{array}{lll}7.3 .3 .2 \text { ICC } & 405\end{array}$

$\begin{array}{lll}\text { 7.3.3.3 ECCC } & 410\end{array}$

7.3.4 Admissibility of additional evidence after the close of the case $\begin{array}{ll}\text { in chief } & 412\end{array}$

$\begin{array}{lll}\text { 7.3.5 Expert witnesses } & 418\end{array}$

7.3.5.1 ICTY, ICTR and SCSL $\quad 418$

$\begin{array}{ll}\text { 7.3.5.2 ICC } & 421\end{array}$

7.4 Victims' participation in the trial: facing multiple accusers? 423

$\begin{array}{ll}\text { 7.4.1 Lead and challenge evidence } & 425\end{array}$

7.4.2 Victims' applications and testimony $\quad 430$

$\begin{array}{ll}7.5 \text { Concluding remarks } & 432\end{array}$

\section{Chapter 8 Conclusions}

$\begin{array}{lll}8.1 & \text { Introduction } & 435\end{array}$

8.2 Human rights approach 436

8.3 International criminal courts' interpretation of equality of arms 440

8.4 Application of equality of arms in international criminal proceedings 444

8.5 Normative considerations: conceptualizing fairness and the principle of the equality of arms in international criminal proceedings 454

8.5.1 Fairness and the right to a fair trial 454

8.5.2 Two functions of the equality of arms 459

$\begin{array}{ll}8.6 \text { Final comment } & 462\end{array}$

Samenvatting (Summary in Dutch) 465

$\begin{array}{ll}\text { Bibliography } & 481\end{array}$

Table of Cases $\quad 501$

$\begin{array}{ll}\text { Curriculum Vitae } & 527\end{array}$ 


\section{List of Abbreviations}

$\begin{array}{ll}\text { A. Ch. } & \text { Appeals Chamber } \\ \text { ACHR } & \text { American Convention on Human Rights } \\ \text { ACtHR } & \text { Inter American Court of Human Rights } \\ \text { App. No. } & \text { Application Number } \\ \text { Comm. No. } & \text { Communication Number } \\ \text { D\&R } & \text { Decisions and Reports } \\ \text { DRC } & \text { Democratic Republic of Congo } \\ \text { DSS } & \text { Defence Support Section } \\ \text { ECCC } & \text { Extraordinary Chambers in the Courts of Cambodia } \\ \text { ECHR } & \text { European Convention on Human Rights } \\ \text { ECtHR } & \text { European Court on Human Rights } \\ \text { EU } & \text { European Union } \\ \text { GA } & \text { United Nations General Assembly } \\ \text { HRC } & \text { United Nations Human Rights Committee } \\ \text { ICC } & \text { International Criminal Court } \\ \text { ICCPR } & \text { International Covenant on Civil and Political Rights } \\ \text { ICJ } & \text { International Court of Justice } \\ \text { ICTR } & \text { International Criminal Tribunal for Rwanda } \\ \text { ICTY } & \text { International Criminal Tribunal for the former Yugoslavia } \\ \text { ILC } & \text { International Law Commission } \\ \text { NGO } & \text { Non-Governmental Organization } \\ \text { OPCD } & \text { Office of Public Council for Defence } \\ \text { OTP } & \text { Office of the Prosecutor } \\ \text { RPE } & \text { Rules of Procedure and Evidence } \\ \text { SCSL } & \text { Special Court for Sierra Leone } \\ \text { STL } & \text { Special Tribunal for Lebanon } \\ \text { T. Ch. } & \text { Trial Chamber } \\ \text { UN } & \text { United Nations } \\ \text { UNDU } & \text { United Nations Detention Unit } \\ \text { UNMIK } & \text { United Nations Interim Administration Mission in Kosovo } \\ \text { UNSC } & \text { United Nations Security Council } \\ \text { VPRS } & \text { Victims Participation and Reparations Section } \\ \text { VSS } & \text { Victim Support Section } \\ \text { VWU } & \text { Victims and Witnesses Unit } \\ & \end{array}$




\section{Chapter 1 INTRODUCTION}

\subsection{Equality OF ARMS}

The term equality of arms originated in modern European procedure in the context of Article 6 of the European Convention on Human Rights, although the roots of this legal concept date back long before the adoption of this convention. It is said to be an expression of the ancient principle of audi alteram partem or audiatur et altera pars or, to put it simply, 'hear the other side'. ${ }^{1}$ In the common law tradition " $[\mathrm{t}]$ he 'equality of arms' principle arose in the context of the "trial by wager or battle'." According to Blackstone this trial is of "great antiquity" and can be found in the "laws of Gundebald, A.D. 501." 3 The court would sit in a specially designated field and the parties would be "dressed in a suit of armour, with red sandals, barelegged from the knee downwards, bareheaded, and with bare arms to the elbows." allowed were "batons, or staves, of an ell long and a four-cornered leather target; so that death very seldom ensued this civil combat." ${ }_{5}$ Later, in Germany, the concept of equality of arms or Waffengleichheit turned up for the first time in the mid $19^{\text {th }}$ century in legal writings at the time of the discussions surrounding the fundamental reform of the German criminal process. ${ }^{6}$ In the mid $20^{\text {th }}$ century the former European Commission of Human Rights (the European Commission) introduced the term equality of arms into the Strasbourg case law for the first time in the criminal cases of Ofner and Hopfinger v. Austria and Pataki and Dunshirn v. Austria. ${ }^{7}$ The unifying

1 Translated as 'hear the other side of the question', meaning 'listen to what each party may be able to advance, otherwise you cannot be sure that your decision will be impartial or just', Moore, 1831, p. 30. See also FawcetT, 1987, p.154; See also, NowaK, 2005, p. 321. The Latin proverb libra justa justitiam servat (translated as 'a true weight servers the cause of justice' Moore, 1831, p. 205; or 'a just balance preserves justice' in Riley, 1866, p. 205. Stone, 2005, p. 54) has also been mentioned with reference to 'equality of arms'. See SILVER, 1990, p. 1032.

2 BufFord, 2007, p. 395, footnote 311.

3 Blackstone, 1966, p. 337. Introduced by William the Conqueror, "it was only used in three cases, one military, one criminal, and the third civil". The battle begins by sunrise and lasts "till the stars appear in the evening". BlacKstone, 1966, pp. 339-340.

4 Blackstone, 1966, p. 339.

5 Blackstone, 1966, p. 339. The battle begins by sunrise and lasts "till the stars appear in the evening". Blackstone, 1966, pp. 339-340.

6 Glaser, 1883 cited in SANDERmann, 1975.

7 Ofner and Hopfinger v. Austria, App. No. 524/59 and 617/59, report of 23 November 1962, Yearbook, volume 6, 1963, p. 680. Pataki and Dunshirn v. Austria, App. No. 596/59 and 789/60, report of 28 March 1963, Yearbook, volume 6, p. 718. The concept behind equality of arms was 
point in these cases was that the accused had not been given an opportunity to be heard unlike the opposing side. The Commission determined that "the equality of arms, that is the procedural equality of the accused with the public prosecutor, is an inherent element of "fair trial." "Essentially, it guarantees defence participation in the criminal process that is procedurally equivalent to that of the public prosecutor.'

This principle is now firmly established in domestic and international human rights case law. When monitoring state compliance with international human rights, the human rights bodies, such as the ECtHR and the Human Rights Committee (HRC), have considered whether the individual complainant has enjoyed equality of arms in a domestic criminal process. Thus, the focus lies with an individual, whereas the prosecution, notwithstanding its possible role as a party to domestic criminal proceedings, is allied with the state or is seen as an organ of the state. International criminal courts, such as the International Criminal Tribunals for the former Yugoslavia and Rwanda (ICTY/ICTR) and the International Criminal Court (ICC), in line with the approach of the human rights bodies, have accepted equality of arms as an inherent element of a fair trial. ${ }^{10}$ Derived from the case law of the ECtHR (and the former Commission) the principle of equality of arms is expressed in terms of an obligation of the court to ensure that neither party is put at a disadvantageous position when presenting its case as compared to the opposing party.

\subsection{Challenging 'EQuality of ARMS' in international CRiminal PROCESS}

In a 2011 educational documentary released by the International Bar Association's Human Rights Institute, entitled "In the Dock: Defence Rights at the ICC", several issues regarding the protection of the rights of the suspect and accused before the International Criminal Court (ICC) are brought to light. The Head of the ICC's Office of Public Counsel for the Defence explicitly states that equality of arms does not exist at all at the ICC. In this context, he emphasizes that an inherent inequality between the individual defendant and the machinery of the court system is a natural state of affairs not only for national but also for international criminal justice systems. ${ }^{11}$

introduced earlier in a case concerning civil proceedings: $X v$. Sweden, App. No. 434/58, 30 June 1959, Yearbook, volume 2, 1958-1959, p. 370.

8 Pataki and Dunshirn v. Austria, App. No. 596/59 and 789/60, report of 28 March 1963, Yearbook, volume 6, p. 732 [emphasis added, MF].

9 Foucher v. France, App. No. 22209/93, 18 March 1997.

10 E.g. ICTY, Prosecutor v. Tadić, Judgment, IT-94-1-A, A. Ch., 15 July 1999, par. 44..

11 Statement of Mr. Xavier-Jean Keïta, Documentary "In the Dock: Defence Rights at the ICC", International Bar Association's Human Rights Institute, release date May 2011, http://www.ibanet. org/Article/Detail.aspx?ArticleUid=4b9cd7f3-9185-4ebc-b40b-d54b8cc8d01e ("Equality of arms does not exist at all in ICC, why? It is natural and it is not only ICC, it is in all systems. The defence arriving is not organised like the prosecutor. It is just a counsel freely chosen by his client and who 
More generally, from this perspective of inherent inequality between parties in a criminal process, certain guarantees have been provided for an accused person in order to elevate the defence to equal the position of the state thereby providing a fair opportunity to present their cases in court. In international criminal practice, the defence has consistently challenged a wide array of procedural and structural elements underlying the international criminal courts, arguing for more 'equality of arms' for the defence. Consequently, equality of arms has been used as a tool for focusing attention on and advancing the interests of the defence in international criminal trials.

However, the liberal assumption of inherent inequality in the criminal process has been challenged in the context of international criminal courts. For instance, in the same documentary the ICC Prosecutor argues that an international prosecutor does not possess the same amount of power over an accused as in a national setting. At the international level "a fair trial ... is not just about defence rights, ... it is also about Prosecutor's rights ... ." ${ }_{12}$ In fact, in the first case at the ICTY, the Appeals Chamber infamously pronounced in its judgment that the principle of equality of arms should be given a more liberal interpretation than that given in a national setting considering the dependence of the international tribunal on state cooperation. ${ }^{13}$ This more 'liberal interpretation' constitutes an important triggering point for this study that focuses on the interpretation and application of the principle of equality of arms in international criminal proceedings, of which no comprehensive scholarly account has been provided to date..$^{14}$

The international prosecutor's affiliation with a particular state, as opposed to the domestic level, is lacking in the international criminal law context. An international prosecutor is part of an independent organ of a particular international criminal justice system, charged with the duty to prosecute those perceived to be the most responsible for international crimes. The dependence on state cooperation for virtually every investigative effort has been advanced as one of the most crucial factors that make the international criminal tribunals different from their domestic counterparts. ${ }^{15}$

organises his defence team, facing the machine, the big machine, of the Office of the Prosecutor.").

12 Statement of Luis Moreno-Ocampo, Documentary "In the Dock: Defence Rights at the ICC", International Bar Association's Human Rights Institute, release date May 2011, http://www.ibanet. org/Article/Detail.aspx?ArticleUid=4b9cd7f3-9185-4ebc-b40b-d54b8cc8d01e ("Our crimes are committed by people with power, to make power or to retain power. That is why we are always fighting with those in power, and it is not such an easy battle. In the national setting the prosecutor normally has much more power than the accused. Here, no. In fact, I cannot go to Sudan. So a fair trial in this setting is not just about defence rights, which I respect, it is also about Prosecutor's rights, for instance to have witnesses, who are not killed or threatened.").

13 ICTY, Prosecutor v. Tadić, Judgment, IT-94-1-A, A. Ch., 15 July 1999, par. 51.

$14 C f$. Byrne, 2010, p. 251: "However, there has been limited consideration of the principle [of equality of arms] in light of the distinctive realities of international trial process. The legal [jurisprudential] analysis remains pragmatic and skeletal" [footnote omitted].

15 E.g. CAssese, 1997. 
Whereas the prosecutor is expected to represent and serve the so-called international community in general, and the victims of mass atrocities in particular, practice has shown that state cooperation has been far from forthcoming. In fact, persuading states to cooperate both in individual cases and, more generally, in supporting the tribunals politically and financially has been the main preoccupation of a chief international prosecutor. ${ }^{16}$ If one takes into account the fact that most accused before international criminal courts are individuals who were or are part of the highest echelons of state power in their domestic systems, it comes as no surprise that the unequal stateindividual relationship underlying a domestic criminal process, as perceived by the liberal theory, is said to have vanished at the international level. Consequently, how does this have to be reflected in the interpretation and application of equality of arms in the international criminal process? Does this perceived specificity of the international criminal context merit a different approach to this principle?

The defence would answer in the negative. Indeed, equality of arms has been continuously challenged by the defence in these international criminal cases from their inception. When the focus is on prosecutions and the rhetoric is charged with references to the most heinous crimes and in these terms the most heinous defendants, what kind of 'fair trial' can be expected to result from the prosecution of individuals who are imprisoned far away from anything familiar, within a new, still developing criminal justice system, where the languages spoken are as distant as the references to the legal standards used? In fact, the defence, as an institution, was rather an 'afterthought' when the first modern international criminal tribunals, the ICTY and ICTR, were established in the 1990s. Lacking any institutional position or even support in the initial stages of operation of these courts, the defence has struggled to improve its secondary position. Full equality with the prosecution in a material and procedural perspective is advanced as a goal to overcome the structural and the perceived inequality resulting from the 'prosecution bias' with its emphasis on 'ending impunity' as the cornerstone of these institutions. This aim of 'full equality' has been set partly because of the initial emphasis on the Anglo-American model of criminal proceedings. However, it has been argued that "the international setting makes it almost impossible for an adversarial system of fact-gathering to grant the defence the substantive equality necessary to make the most effective case against the prosecution." "17 Whereas the tribunals have routinely emphasized the "procedural' rather than the 'substantive' nature of equality of arms, the latter aspect has been central to many institutional and procedural developments during the life span of the international criminal courts.

The challenges to the liberal perception of the state-individual relationship in a criminal process are nothing new when it comes to domestic criminal justice systems. ${ }^{18}$

$16 C f$. Del Ponte and Sudetic, 2009.

17 JACKSON, 2009-a, p. 28.

18 See for a discussion e.g. Goldstein, 1960; Gershmann, 1992; Luban, 1993, (discussing and 
The more powerful position of the state and the need to protect the individual against the abuse of state power are then responded to as being an exaggeration. In reality, the state as an adversary in a criminal process does not differ so much from a private adversary. ${ }^{19}$ Luban challenges these attacks against the liberal position by considering four categories of the balance of advantages in criminal proceedings in the context of US jurisdictions: (1) the balance of resources, (2) the balance of procedural advantages, (3) the balance of political and psychological advantages, and (4) the balance of bargaining power. ${ }^{20}$ The last category is determined "partly by the other three and partly by the penalties attached to the substantive criminal law." ${ }_{21}$ As to resources, Luban concludes that their balance sways towards the prosecution with the police backing it up. ${ }^{22}$ When it comes to procedure, Luban concludes that the prosecutor "continues to enjoy overwhelming procedural advantages." ${ }_{23}$ In this regard, he considers that the discovery rights against the prosecution are weak or non-existent in most US jurisdictions and the prosecutor's obligation to disclose exculpatory evidence constitutes, for the most part, an ethical obligation that is hardly enforced in practice. ${ }^{24}$ But, the greatest advantage of the state can be found in "the enormous imbalance of credibility between prosecutors and police on the one hand, and criminal defendants on the other." ${ }^{25}$ The initial credibility is already present in citizens who believe that a state is democratic and legitimate. Moreover, the state retains the legitimacy aura through the process: the trust in the initial screening process by the prosecution results in the 'prosecution bias' of the jurors. In addition, it is questionable whether the judges are less susceptible than lay jurors to this "defendant-is-probably-guilty predisposition", according to Luban. ${ }^{26}$ Lastly, Luban pays attention to the fact the most cases are disposed of by plea bargaining and highlights the prosecutorial advantage.

Translated to the international level, a tentative parallel can be drawn with the challenges as presented by many defence proponents. One of the commonly expressed challenges in relation to equality of arms in international criminal proceedings relates to the application of the right of the defence to have adequate time and facilities to prepare a defence, as well as adequate resources in doing so. Generally, it has been

criticizing Simon, 1993); Groenhuijsen, 1994.

19 Luban, 1993, p. 1730.

20 LuBan, 1993, p. 1731.

21 LuBAN, 1993, p. 1731.

22 LuBAN, 1993, pp. 1735-1736.

23 Luban, 1993, p. 1737.

24 Luban, 1993, The 'Brady rule', which establishes that a refusal to provide exculpatory evidence to the defence constitutes reversible error, was weakened in the subsequent case law establishing that the prosecution are not obliged to provide exculpatory material in the absence of a specific request from the defence, and "a harmless error standard for Brady review".

25 LuBAN, 1993, p. 1741.

26 Luban, 1993, pp. 1741-1744. 
advanced that although the disadvantage of lacking state cooperation can target both the prosecution and the defence, "as an official organ of the tribunal and with certain coercive powers of its own, prosecutors are better equipped to enter the territory of even uncooperative states while it is next to impossible for the defence to operate in states that are uncooperative with it." ${ }^{27}$ Facilities include the defence's rights to access (incriminating) information, which are derived from the disclosure obligations of the prosecution. The vast amount of disclosure materials, the inadequacy of the search engines and the struggle with the identification and disclosure of favourable evidence to the defence constitute just a few points to consider. Moreover, the inability of the defence to conduct meaningful on-site investigations due to obstructive behaviour by the state authorities; the lack of an institutional position of the defence within the framework of the international courts, which has resulted in difficulties in requesting state cooperation; and the general atmosphere of prosecution bias surrounding these institutions, seem to weigh the political and psychological advantages in favour of an international prosecutor. Lastly, in the framework of international prosecutions, plea bargaining does not seem to have been applied very broadly in international criminal trials, and this practice will therefore not be considered in detail. ${ }^{28}$

\subsection{Central AIM AND QUESTION OF THIS RESEARCH}

This research aims to examine the function of equality of arms in a criminal process and the way it has been conceived in the decisions of international criminal courts. Moreover, the aim is to develop normative reasoning as to the effect of the application of this principle on fairness in international criminal proceedings. For these purposes, this study's central research question is formulated as follows:

\section{How should the principle of equality of arms be interpreted and applied in international criminal proceedings?}

Three sub-questions underlie this central question:

1. What meaning is given to the principle of equality of arms in international human rights law?

2. How is the principle of equality of arms interpreted and applied in international criminal proceedings?

3. Do the particularities of the international criminal context require a different interpretation and application of the principle of equality of arms as developed in international human rights law?

27 JACKSON, 2009-a, p. 26 [footnote omitted].

28 See for more details, e.g. ComBs, 2007. 
Introduction

\subsubsection{The principle}

From the outset, it is important to emphasize the basic assumption underlying this study. Equality of arms, by its nature, is viewed as constituting a principle, rather than a rule or a specific right. This section considers this particular nature of equality of arms. In legal philosophical writings many different approaches to distinguish principles from rules are suggested; ${ }^{29}$ the writings refer to a plurality of criteria: some scholars focus on generality, whereby the principles, as opposed to rules, represent norms of relatively high generality. ${ }^{30}$ As such, it is a distinction of degree. ${ }^{31}$ Others argue that the difference cannot be stated simply as a matter of degree but is rather qualitative. ${ }^{32}$

Most prominently, Dworkin emphasized the distinction between legal principles and rules in his critique of Hart's general structure of a legal system..$^{33}$ Dworkin contended that Hart omits other standards like principles (and policies), which are central to the structure of law and play a central role when it comes to making decisions in "hard cases." ${ }_{34}$ The logical distinction between principles and rules finds its basis in the mode of application and the normative relation of these standards. Rules apply 'in an all-or-nothing fashion' meaning that in certain factual circumstances the rule is either valid or not. In the first scenario, the consequences it stipulates must be accepted; in the second the rule does not contribute to decision-making. ${ }^{35}$ Defined in this way, it is clear that rules cannot conflict with each other and there is consequently no need to balance or weigh them. They can merely be subject to exceptions. ${ }^{36}$ The mode of operation of principles is different. Even the most concrete principles "do not set out legal consequences that follow automatically when the conditions provided are met." ${ }^{37}$ Inherently indeterminate legal principles can conflict because of the dimension of weight they possess, as opposed to rules. This is most

29 For an overview see Ávila, 2007, pp. 8-11. This distinction not only allows one "to anticipate the features of normative species so that when judges find them their task of interpreting and applying the Law must be eased," but consequently also "to lighten the burden of argumentation by structuring it, since the classification of normative species allows lowering - though never eliminating - the need for justification by at least pointing to what is to be justified." (Ávila, 2007, p. 30).

30 See e.g. Raz, 1972, p. 838; Christie, 1968, p. 669.

31 For an opposite view see e.g. LARENZ, 1979, p. 26: "it is not the degree of generality which is decisive for something being a principle, but its nature as a justifying reason".

32 See e.g. Dworkin, 1977; AlEXy, 2002.

33 For a more elaborate description see $e . g$. BAYLES, 1991.

34 According to Schwarzenberger " ... legal principles are the only means of creating order in a gradually unwieldy mass of case law". Schwarzenberger, 1965, p. 72. For a different view see Alexander and Kress, 1997.

35 DWORKIN, 1977, p. 24.

36 Dworkin, 1977, pp. 26-27: “ ... we cannot say that one rule is more important than another within the system of rules, so that when two rules conflict one supersedes the other by virtue of its greater weight. If two rules conflict, one of them cannot be a valid rule."

37 DWORKIN, 1977, p. 25. 
clearly demonstrated when principles collide as then the principle with relatively more weight takes precedence over the other, without the latter losing its validity. In drawing a similar qualitative distinction between principles and rules, Alexy views principles as "optimization requirements." ${ }^{38}$ The decisive point is that "principles are norms which require that something be realized to the greatest extent possible given the legal and factual possibilities." ${ }^{39}$

In his reply to Dworkin's critique, Hart contended that he did not intend to exclude principles; however, the distinction is best seen as a matter of the degree of specificity and the difference in functions..$^{40}$ Hart considered that:

$[\mathrm{P}]$ rinciples are, relatively to rules, broad, general, or unspecific, in the sense that often what would be regarded as a number of distinct rules can be exhibited as the exemplifications or instantiations of a single principle. [B] ecause they refer ... to some purpose, [they] are regarded ... not only as providing an explanation or rationale of the rules which exemplify them, but as at least contributing to their justification. ${ }^{41}$

According to Hart the 'all-or-nothing' character of the rules and the 'non-conclusive' character of the principles does not apply as strictly as Dworkin presents it. Rules can be equally valid in a particular factual situation in which case they, too, must be weighted. ${ }^{42}$ In addition, a principle that provides for a superior reason can render a rule invalid, thus triumphing over the rule. According to Hart, the existence of such a conflict between the principle and the rule only goes to show that rules do not have this all-or-nothing nature. ${ }^{43}$

The debate about the differentiation of principles and rules has been expanded by many other contributions. Ávila refers to four criteria that are usually used to differentiate between principles and rules. ${ }^{44}$ Firstly, he mentions the hypothetical-

38 DwORKIN, 1977, p. 25.

39 Alexy, 2002, p. 47. The degree of realization of a principle depends on the factual and legal possibilities. Rules, however, "are either fulfilled or not"; they "contain fixed points in the field of the factually and legally possible." (ALEXY, 2002, p. 48).

40 HART, 1994, p. 263.

41 HART, 1994, p. 260.

42 HART, 1994, p. 261. Also Raz, 1972, p. 830.

43 HART, 1994, p. 262: "this is the example of a principle winning in competition with a rule, but the existence of such competition surely shows that rules do not have an all-or-nothing character, since they are liable to be brought into such conflict with principles which may outweigh them". Ávila talks in this context about cases "in which rules are not applied although their conditions have been met" due to a "superior reason" (ÁviLA, 2007, p. 19).

44 Cf. Perry, 1997, p. 788. Perry mentions three of these criteria. Firstly, the logical character of rules, in the sense of their specificity or conclusiveness. Rules point towards a particular action/ behaviour, as opposed to more abstract and general principles, which only point out a direction towards unspecific action/behaviour. Secondly, the 'value-oriented' content of principles as opposed to 'action-oriented' rules. Thirdly, the justificatory relationship between rules and principles: "principles can justify rules, but not vice versa." As to this justificatory relationship Perry points out 
conditional aspect, meaning the more specific character of rules which "present a condition and a consequence that pre-set the decision, being applied in an "if, then fashion', while more general principles only 'point to the foundation'." ${ }_{45}$ The second criterion is the final mode of application of rules in an 'all-or-nothing' fashion and of principles in a 'gradual more or less mode'. ${ }^{46}$ Thirdly, he refers to the normative relation between conflicting norms: the dimension of the validity of rules and the dimension of the weight of principles. ${ }^{47}$ The last criterion is the axiological foundation of principles for a decision to be made, as opposed to rules. ${ }^{48}$

What becomes clear from the writings of the above-mentioned scholars is that the strict application of Dworkin's division between the "all-or-nothing" character of the rules and the general, indeterminate character of legal principles does not provide an agreeable criterion in itself for the separation of these norms. It is more a matter of the degree of specificity; ${ }^{49}$ rules too, in Hart's words, have an "open texture." 50 Arguably, principles are regarded as highly abstract and general norms that do not prescribe a specific action or behaviour and can only show a direction towards a solution in a particular case. ${ }^{51}$ Central to the structure of law and "hard cases," principles do not directly conflict with each other on that abstract level where they are situated. ${ }^{53}$ For example, when a legal system is based on the fair trial principle, nothing could interfere with that principle in the sense of presenting an acceptable counter-norm without undermining the whole foundation of that legal system. ${ }^{54}$ Thus, it seems more appropriate to regard the weighing or balancing of principles in the

in footnote 5 that: "Principles are, as noted, first-order reasons that are moral in character; as such, they will necessarily possess some minimum degree of generality. Not all first-order reasons need be general; a reason of self-interest might only be relevant to a specific person on a specific occasion, for example. The generality of principles means that, given their value-oriented content, they will ordinarily be relevant to more than a single type of action; thus a single principle could figure in the justification of more that one moral rule. On the other hand, a moral rule could, given its actionoriented content, conceivably be justified by more than one set of principles".

45 Ávila, 2007, p. 11.

46 Ávila, 2007, p. 11.

47 Ávila, 2007, p. 11.

48 Ávila, 2007, p. 11; also pp. 133-134.

49 Schwarzenberger, 1965, p. 73: "The essential point is that every one of such principles is an abstraction and generalisation from individual cases or legal rules, frequently of more limited scope".

50 HaRT, 1994, p. 128. Similarly see Ávila, 2007, p. 17: "The scope of application of some rules is not exactly delimited beforehand and in light of particular factual circumstances, the absolute character of the rule is lost in favour of a more or less mode of application."

51 Similar Ávila, 2007, p. 18: "Principles set forth a state of affairs that is aimed at, but do not directly describe which behaviours lead to it."

52 DwORKIN, 1977, p. 28.

53 ÁvILA, 2007, p. 31: "Principles, viewed as norms that set forth goals to be accomplished, do not conflict directly. In abstract they simply entangle."

54 JACKSON, 2005, p. 760: "The Court is not suggesting that the principles of fair trial be balanced against other Convention rights. The principle of a fair trial remains absolute." 
sense of complementarity, mutual support and aggregation between principles: "[ $t]$ he balance of principles ... yields an overall conclusion about what ought to be done." ${ }_{55}$ Seen from this perspective, principles can only be regarded as absolute norms to which no exceptions of any kind would be applicable and the degree of abstraction or generalization between different legal principles can vary. ${ }^{56}$

A legal principle can thus be seen as a general abstract norm that does not prescribe a concrete resolution of some particular factual circumstances, but does contain a certain value and, consequently, directs the decision-maker towards a particular result. This abstract form is the axiological basis and interpretational fundament for the application of the more specific rule(s) and is not subject to any kind of exception. The relationship between different principles is a matter of the degree of generality and is complementary in nature. In this sense, the purpose of the application of principles is to achieve an overall balance of principles by aggregation; therefore, no conflict between these abstract norms can exist, but only plays a role on the level of specific rules. ${ }^{57}$

Determining the exact normative content and scope of a legal principle, which is by definition a general and open-ended norm, in abstracto is impractical. It acquires meaning in its application in a certain context and in a specific case. Moreover, "[e]quality of arms does not guarantee specific rights, such as the right to be heard, but instead it seeks to ensure that these rights are fairly applied." ${ }_{88}$ As such, the "idea of balance is a vital part of understanding the scope of the principle." understanding of the nature of equality of arm as a principle generally sets out the point of departure for its examination in a criminal process.

55 Perry, 1997, p. 788: "the principles that are relevant to a particular situation are assumed to be commensurable and capable of being aggregated, along with their dimension of weight, so as to produce an overall balance of principles." See also ÁvILA, 2007, p. 39: "Principles, therefore, expect to complement one another, as they cover only part of the aspects relevant to make a decision and thus expect not to generate a specific solution but to contribute to decision-making beside other reasons. Therefore, principles are norms that expect to be complementary and partial."

56 SCHWARZENBERGER, 1965, p. 74: "individual principles can be subsumed under the heading of even more general principles and so forth until, in the end, all such principles are brought under one or several even wider headings". The definition of 'equality of arms' given by the HRC exemplifies this: the principle of 'equality of arms' derives from the right to equality before the courts under Article 14(1) ICCPR which in turn is a specific manifestation of the more general right to equality under Article 26 ICCPR.

57 See also individual opinion of Human Rights Committee members Louis Henkin, Rajsoomer Lallah, Cecilia Medina Quiroga, Ahmed Tawfik Khalil and Patrick Vella, Joseph Kavanagh v. Ireland, Comm. No. 819/1998, par. 2: “Article 14, paragraph 1, of the Covenant, in its very first sentence, entrenches the principle of equality in the judicial system itself. That principle goes beyond and is additional to the principles consecrated in the other paragraphs of Article 14 governing the fairness of trials, proof of guilt, procedural and evidential safeguards, rights of appeal and review and, finally, the prohibition against double jeopardy" [emphasis added, MF].

58 Summers, 2007, p. 104.

59 Summers, 2007, p. 104. 
Introduction

\subsubsection{Equality of arms}

Being a constituent element of the right to a fair trial, the principle of equality of arms is "a lens through which the requisite procedural fairness in any criminal proceedings can be ascertained." " ${ }^{60}$ As noted by Cassese, the principle of equality of arms has two distinct notions: (i) as a concept developed in the case law of the ECtHR and (ii) as an essential element of the adversarial structure of proceedings. Due to the fundamental importance of Cassese's differentiation for this study, it is worth citing him in full:

First, there is a concept developed in the case law of the European Court of Human Rights over the years. It implies that the accused may not be put at a serious procedural disadvantage with respect to the prosecutor. This applies to the accused only: human rights treaties do not grant the prosecutor the right to be put on a par with the defence. On the other hand, human rights treaties do not forbid, and sometimes even require, the accused to be put in a 'better' or more advantageous position than the prosecution in order to preserve an overall balance in the proceedings (the prosecutor normally being better equipped than the defence for the collection of evidence).

Secondly, equality of parties is an essential ingredient of the adversarial structure of proceedings, based on the notion of the trial as a contest between two parties. Under this approach, it is indispensable for both parties to the proceedings to have the same rights; otherwise, there is no fair fight between the two 'contestants', and the spectators will not be convinced by the outcome. Here fairness works both ways and therefore also the prosecutor is entitled not to be put in a disadvantageous position. Similar worries do not exist in inquisitorial systems of justice, where proceedings are conceived of as an 'official inquiry. ${ }^{61}$

Thus, two related but distinct equality considerations interact within the concept of equality of arms:

(1) Formal equality: ensuring equality between two equally situated parties; this corresponds to 'a level playing field' where the advantage of one party would lead to an unfair outcome; and

(2) Material equality: the idea that a state should ensure some level of equality between the stronger and a weaker party (through, for example, a legal aid system).

60 TONey, 2002, p. 438.

61 Cassese, 2008, pp. 384-385. In footnote 18 Cassese indicates that "[i]t would seem that there is some confusion of the two concepts of procedural equality and some misunderstanding of the case law of the European Court of Human Rights in the case law of the ICTY, e.g. with regard to the admissibility of evidence and to disclosure of evidence. ... This confusion in case law may be due to the fact that the two different conceptions of equality may, in certain situations, clash". 
This study examines these two notions of equality of arms and the way they interplay in international criminal proceedings. From the human rights perspective, the ECtHR has authoritatively interpreted equality of arms in a criminal process as a party's right to "a reasonable opportunity to present his case under conditions that do not place him at a disadvantage vis-à-vis his opponent." ${ }_{22}$ The ECtHR based equality of arms not only on the general principle of fair trial, but also on the specific rights afforded to the accused. ${ }^{63}$ Equality of arms is a necessary but not exhaustive element of the fair trial requirement, which implies that an independent examination of an instance of procedural inequality would have to be assessed in light of the fairness of the proceedings as a whole. In addition, it has been recognized that equality of arms is a relevant consideration both in the pre-trial and trial phase of proceedings. As, essentially, equality of arms constitutes a balance of fairness reasonably adjusted to the roles and responsibilities of the participants in a criminal process, these roles and responsibilities represent the niche against which the discussion will proceed.

\subsubsection{International criminal proceedings}

This study focuses on various stages of criminal proceedings at international courts and tribunals that were established to prosecute individuals who are considered to be the most responsible for international crimes. Particularly, genocide, crimes against humanity and war crimes have been considered to warrant the establishment of specialized institutions, which were created in differing ways with the aim of ending impunity for these crimes by prosecuting alleged individual perpetrators. After the Nuremberg and Tokyo Military Tribunals, which were established to prosecute the leaders of the Second World War Axis Powers, the establishment of the International Criminal Tribunal for the former Yugoslavia (ICTY) in 1993, and subsequently, the

62 E.g. ECtHR, Bulut v. Austria, App. No. 17358/90, 22 February 1996, par. 47.

63 A one-time consideration in this regard is instructive (but unfortunately has not been referred to as such in subsequent case law), see Jespers v. Belgium, App. No. 8403/78, Commission's report of 14 December 1981, par. 55: As regards the interpretation of the term "facilities", the Commission notes, firstly, that in any criminal proceedings brought by a state authority, the prosecution has at its disposal, to back the accusation, facilities deriving from its powers of investigation supported by the judicial and police machinery with considerable technical resources and means of coercion. In order to establish equality, as far as possible between the prosecution and the defence, national legislation in most countries entrusts the preliminary investigation to a member of the judiciary or, if it entrusts the investigation to the Public Prosecutor's Department, instructs the latter to gather evidence in favour of the accused as well as evidence against him. It is also, and above all, to establish that same equality that the "rights of the defence", of which Article 6(3) of the Convention gives a nonexhaustive list, have been instituted. The Commission has already had occasion to point out that the so-called "equality of arms" principle could be based not only on Article 6(1) but also on Article 6(3), especially subpara. (b). Referring to Ofner and Hopfinger v. Austria, App. No. 524/59 and 617/59, report of 23 November 1962, par. 46 and Pataki and Dunshirn v. Austria, App. No. 596/59 and 789/60, report of 28 March 1963, par. 36. 
International Criminal Tribunal for Rwanda (ICTR) in 1994, marked the revival of international criminal law. Both tribunals were established under the auspices of the UN Security Council to bring peace, justice and reconciliation to the war-torn societies in the former Yugoslavia and Rwanda. Undoubtedly, with the creation of these courts the road was opened to agree on the framework for a permanent institution for the universal prosecution of international crimes, the International Criminal Court (ICC). This court was created by a multilateral treaty in 1998 (entering into force in 2002). In addition, several other so-called internationalized or hybrid tribunals were established to address mass human rights violations in particular states. ${ }^{64}$ These tribunals combine a mixture of national and international components in law and/or personnel.

Whereas the academic focus was initially on the substantive criminal law these systems were to apply, the shift to procedural law and fairness has swiftly been made in light of the realization that the international criminal justice systems will also be judged by the quality of justice they deliver in the sense of the fairness of their proceedings. In fact, their ability to nourish the perception of fairness is essential to their perception of legitimacy. ${ }^{65}$ However, the practicalities of mass-crime prosecutions within a context of law enforcement powerlessness of the international criminal courts have necessitated a reshaping of the procedural framework compared to what first existed in the ICTY Rules of Procedure and Evidence. The debate about the most appropriate procedural framework for these international criminal courts has been dominated by and framed in terms of the dichotomy represented in the ideal types of adversarial/inquisitorial modes of criminal processes.

Moreover, the uncertainty surrounding and the lack of consensus on the specific aims, goals and objectives which the international criminal justice systems are to pursue has exacerbated the debate on procedural frameworks. Whereas the practice of these courts has only been very limited in the sense of their years of existence and the number of adjudicated cases, the scholarly attention has followed this practice every step of the way. To some extent, the observers' scrutiny of the practice of these courts has been very necessary in light of the lack of any supervisory mechanisms on the international level. Individuals who are processed and convicted within these institutions have no other possibility of redress, like access to an international human rights institution. Moreover, taking into account the enlightened role of international

64 Including Special Panels for Serious Crimes in East Timor (as part of the Dili District Courts); Special Court for Sierra Leone; Extraordinary Chambers in the Courts of Cambodia; UNMIK panels in Kosovo, and the Special Tribunal for Lebanon.

65 LuBAn, 2008, p. 24: "Against the bloodshed of mass political violence, the ICL project has little to offer except the dramatic force of legal trials that attach labels like 'war crimes', 'genocide', and 'crimes against humanity'. Lacking the authority of world government, these norms build their legitimacy from the bottom up, by the fairness of their proceedings and the moral power they project." 
criminal courts in the dominating darkness of impunity for international crimes, this attention has been warranted for the development of the 'model-like' procedural framework. While some consider that "[t]he institutions of ICL [international criminal law] are fragile, weak, and - to be perfectly honest - far less important than the attention they receive warrants" ${ }^{66}$ the international criminal justice enterprise has thrived under this attention. In fact, it has not only developed the law of international criminal institutions into a more effective endeavour, but has helped to fill the 'impunity gap' in many gross human rights violations around the world. In terms of specific institutions that are chosen for this study, the focus lies with:

(1) the ad hoc tribunals, ICTY and ICTR, as the pioneers of the modern international criminal law and procedure, and the predecessors of

(2) the permanent ICC, which can be regarded as the future of international adjudication of mass atrocities at the international level, and,

(3) to a somewhat lesser degree, the Special Court for Sierra Leone (SCSL), an ad hoc tribunal that was born from the countenance of the ICTR and was intended to offset the drawbacks of the ICTY and ICTR (in terms of being institutions that are too remote and too expensive); and the Extraordinary Chambers in the Court of Cambodia (ECCC), which is a 'hybrid' tribunal established to prosecute former Khmer Rouge leaders, but which presents an 'extraordinary' view on the difference in the procedural framework adopted.

From legal and practical perspectives, the primary points of reference constitute the procedural frameworks and decisions of the ICTY and the ICC. The other selected courts are referred to in case of any novelty as compared to these two courts. In terms of their legal significance, the ICTY was the first modern international criminal institution that has created an impressive body of law over the last 19 years. The legal framework of the ICTY stood as a model for the ICTR and subsequently for the SCSL. Moreover, the legal framework and the developed case law of the ICTY has been particularly progressive, and is often referred to by its sister institutions. The ICC, as a permanent court, was set up against the background of the development of the ad hoc tribunals. In many respects the ICC's legal framework was intended to codify the ad hoc tribunals' achievements, to improve their shortcomings and to clarify any lacuna. The East Timor Panels were partly modelled on the ICC legal framework, but will not be considered in this study mainly for practical reasons (such as the small number of relevant decisions and the linguistic limitations).

With regard to the stages of the proceedings covered in this study, the primary focus is on the pre-trial, trial and, to a limited extent, the appeal proceedings before the selected courts. At the ad hoc tribunals, the pre-trial stage covers the time frame 
from the issuance of the indictment and the apprehension of the accused person to the start of the actual trial. The trial stage officially ends with a verdict issued by the Trial Chamber. From the appellate stage only the decisions issued by the Appeals Chamber assessing the interpretation and application of equality of arms by the Trial Chamber have been included in this study.

At the ICC, delineating the particular stages of the proceedings is somewhat more complicated. Before any charges are issued, the prosecution can be involved in a preliminary investigation into a situation or a particular case. If the investigation leads to the issuance of the charges in a particular case, and after the suspect has appeared at the Court, it is up to the judges to confirm the charges against that individual. This stage is referred to as the confirmation of charges stage, during which a limited hearing on the merits of the case as presented by the prosecutor and possibly the defence is held. If the charges are subsequently confirmed, the case is transferred to the Trial Chamber ${ }^{67}$ which is responsible for preparing the case for the actual trial and the trial proceedings proper. For the sake of clarity, at the ICC the preparation of the trial can be divided into at least three phases: preliminary investigations, the pre-confirmation of charges stage and the post-confirmation of charges stage or the immediate pre-trial stage.

At the ECCC, the structure of proceedings resembles the inquisitorial tradition in the sense that the case, after a preliminary investigation by the Office of the Prosecution (OTP), is assigned to the co-investigating judges for a judicial investigation. These judges collect evidence, which is then compiled into the case file, and which is later presented to the trial judges at the substantive hearing of the case.

Notwithstanding all these differentiations in the processes before these courts, it is possible to make a formal separation between the pre-trial and the trial phases of the proceedings. On a more substantive level, i.e. assigning the appropriate activities, rights and responsibilities between the participants according to the different stages, no strict separation between the various stages of the proceedings before these courts is possible. For example, investigations can run into the trial stage proper, just as with the disclosure of evidence. As will be discussed later, from the perspective of equality of arms, a separation between case preparation and case presentation seems meaningful.

\subsubsection{Should be interpreted and applied}

The last element of the central research question that merits a definition and delineation is the normative nature of the question. The normative nature of equality of arms has already been touched upon when considering its nature as a principle: equality of arms, as such, sets out a general goal that has to be optimally achieved without

67 Article 61(11) ICC Statute and Rule 130 ICC RPE. 
postulating the exact way of achieving it. Moreover, as argued above, the newly developed system of the international adjudication of international crimes merits close scrutiny for its further development and the necessary consideration of its value in itself. In this light, it is important to consider how the principle of equality of arms should be applied in the framework of international criminal courts to effectively promote the general fairness of proceedings before these courts.

The analysis of the conception of equality of arms within the human rights framework and the different domestic criminal law models will provide the framework for evaluation. It is interesting to examine how the human rights supervisory mechanisms have defined, interpreted and applied equality of arms in their judgments in individual cases and general comments as a starting point for the evaluation of international criminal proceedings. The importance of the human rights framework is twofold: (1) human rights represent minimum standards which are necessary for the protection of an individual's dignity; and (2) the case law of international human rights monitoring bodies presents a sophisticated analytical tool for the assessment of state compliance with human rights standards. The relevance of this framework for the international criminal courts can be substantiated with reference to the founding documents of these courts, which contain references to the fair trial standards that should be interpreted and applied in their proceedings. Moreover, as subjects of international law, these criminal institutions are bound by the general norms of international law of which human right norms form part. Although the exact delineation of the 'internationally recognized human rights' has been subject to debate and controversy, they have been given a prominent place in the procedural framework of the ICC, through their inclusion in Article 21(3) ICC Statute as a primary guiding norm for the interpretation and application of the ICC procedural framework.

However, the application of human rights standards in criminal proceedings is naturally contextual. In fact, the concept of fairness depends on the institutional and procedural aspects of the proceedings involved. ${ }^{68}$ Fair trial presents a goal to be achieved, but it does not set out specifically how it should be achieved. In this light, consideration will be given to the different procedural models that underlie domestic criminal trials and the more general procedural aims and goals of a criminal justice system and process. Understanding the underlying values and goals and gaining familiarity with the procedural models as presented on the domestic level can provide invaluable guidance for an evaluation of international criminal trials. Indeed, the interplay between different criminal process philosophies and approaches has been central to the debate on international criminal procedure, as the persons engaged in international criminal trials necessarily take guidance from their domestic framework of reference. More specifically, the principle of equality of arms seems to have an 
innate connection to one particular procedural model, namely the adversarial process, to the exclusion of the other dominant model, the inquisitorial model, as visible in Cassese's explanation of the two notions of equality of arms presented above (par. 1.3.2). However, it is exactly this adversarial structure of proceedings, as developed by the ad hoc tribunals, that has been stated to raise "so many obstacles to ensuring a meaningful equality of arms between the prosecution and defence" that the principle has been considered to be reduced to "a melodious yet vacuous slogan, a consoling though ineffectual mantra." ${ }_{69}$

\subsection{Methodological ChOices ANd Limitations}

The normative nature of the central question, as explained above, necessitates normative legal research. It seems that, to lawyers, legal methods and methodology are as latent as they are self-explanatory. ${ }^{70}$ Only sporadically can one find a methodology section in a publication based on legal research. ${ }^{71}$ This does not mean that no explanation is warranted as to how this study is conducted and last but not least, to explain and embrace its limitations.

Central to this study is the understanding of how a legal principle has been interpreted and applied in the proceedings before several international criminal courts. Through description, understanding and interpretation, the existing accounts are problematized with the aim of coming to an alternative interpretation. The primary focus is thus on the analysis of the relevant statutory provisions and legal reasoning regarding equality of arms, as found in the decisions of international criminal tribunals, supported by the filings of the participants.

However, before studying the law and jurisprudence of the international criminal tribunals, the historical roots and meaning of equality of arms need to be traced within the human rights framework. Whereas the conceptual roots of this principle date back some centuries, the use of the term, as such, can most explicitly and prominently be traced to the opinion of the former European Commission of Human Rights (the European Commission) and the case law of the ECtHR. The interpretation of the other important international human rights monitoring body, the Human Rights Committee (HRC), will also be investigated. Due to contextual

69 JACKSON, 2009-a, p. 25, referring to KARNAVAS, 2007, p. 92.

70 Traditional legal research usually involves collecting and reading relevant legal provisions and jurisprudence, historical research into the development of these provisions and jurisprudence, analyzing the underlying argumentation and providing a (critical) well-reasoned, logical (alternative) argumentation. Cf. e.g. Westerman And Wissink, 2008. See also Rubin, who argues that in contrast to other disciplines, legal scholarship provides a "prescriptive practice, not a theoretically-derived category of knowledge". RuBIN, 1997, p. 541 (he defines standard legal scholarship "as work which frames recommendations, or prescriptions, to legal decision-makers", p. 522).

71 On the extent to which legal scholars ( $\mathrm{PhD}$ researchers in the context of the Netherlands) make explicit and justify their methodological choices see TuJssen, 2009. 
and practical restraints, the case law of the Inter-American Court of Human Rights (ACtHR) will be given only limited attention. ${ }^{72}$ The selection of relevant cases has proceeded along the lines of identifying and analysing case law which interprets and applies the principle of equality of arms. Other case law documents, which did not contain a literal reference to equality of arms, were selected on the basis of references within the directly identified relevant case law, and also where these documents were needed to improve a proper understanding of the subject evaluated.

From the identification and analysis of relevant documents that all pertain to interpreting and explaining human rights norms, the focus diverts to the institutional and procedural framework that arguably guides and informs any application of human rights norms. In light of equality of arms' vivid affiliation with an adversarial structure of proceedings, a proper analysis must include an understanding of this principle in different procedural settings. Due to practical constraints the analysis is based foremost on legal theoretical considerations rather than a more practical application of equality of arms in so many different systems that follow the adversarial structure..$^{73}$ In this context, it is crucial to understand that the interpretation of equality of arms in the human rights context does not depend on the different domestic criminal procedural models. However, the application of this principle can only be understood having regard to the contextual features of one particular model. In other words, although the human rights case law provides a general minimum understanding of the values and norms involved, it can only guide the application in concreto. Therefore, to consider the appropriateness of a particular instance of applying equality of arms in international proceedings, the institutional and procedural aims, goals and values of the international justice system and procedure have to be taken into account.

The overarching nature of the principle of equality of arms has, as a consequence, a wide scope of application concerning many different practical issues. It would be impossible to include all the relevant arguments and decisions in this study. As stated so eloquently by one commentator, "[f]ollowing the Tribunal's [ICTY] jurisprudence over the past decade is, as I have learnt to my chagrin, like trying to get a glass of water from a fire hydrant." ${ }^{74}$ Within the general framework of all the publically available decisions of the ICTY, ICTR, SCSL, ICC and ECCC, a selection of the case law was made thematically, rather than by singling out separate cases..$^{75}$

72 In this regard, it is important to note that the case law of this body mostly interprets the principle of equality of arms in its own proceedings, while the focus of this study is on a criminal law context. In addition, only a limited amount of the case law is available in English.

73 Chapter 3 explains more about the selection of national jurisdictions which provide for several sources that this study draws upon.

74 JoNES, 2004, p. 487.

75 The databases most accessed to identify the relevant case law of these tribunals include the ICTY's general website and Court Records database (http://icr.icty.org/default.aspx); the ICTR's general website and Public Judicial Records Database (http://www.unictr.org/); the ICC's general website 
After the identification of all the accessible case law documents that contain literal references to equality of arms, a preliminary examination and selection of documents and themes to be investigated was made. Guided by the four categories of potential instances of inequality presented by Luban above (par. 1.1), four themes for the evaluation of international criminal practice were selected: (1) a party's ability to prepare for trial and the scope of investigations; (2) access to mutual information between parties through the disclosure regime; (3) the defence's resources and facilities from the perspective of institutional position; and (4) the case presentation issue, mainly focusing on the delineation of the party's case presentation. Whereas each theme covers a very broad number of relevant issues a selection was made on the basis of the case law which is most relevant to the interpretation and application of equality of arms. Although the right to legal assistance constitutes an important element of the principle of equality of arms, to the extent that it relates to assignment of defence counsel (access to legal counsel and the right to choose one's counsel as well as the qualitative requirements of assignment of counsel), it is not covered by this study. ${ }^{76}$ The issue of legal aid provisions, also part of the more general right to legal assistance is included under (3), issues surrounding defence's institutional position (including resources and facilities).

The analysis was carried out making use of the common legal methods of interpretation: textual (literal meaning), contextual (specific context), historical (intentions of drafters) and teleological (object and purpose). Although a strict comparative approach was neither intended nor attainable, this approach was of course inspirational to some important extent. As the procedural framework of the ICC was developed taking account of the accomplishments and failings of the ad hoc tribunals, a comparative angle for the evaluation of these institutions was of particular interest.

The study takes into account the legal developments up until 1 January 2012.

\subsection{Structure OF THE BOOK}

Chapters 2 and 3 provide for the evaluative perspective. In these chapters, the two notions of equality of arms (human rights and adversarial), that serve as an analytical framework for this study, are examined in-depth, thus laying down the foundation

and the Legal Tools Database, the SCSL's general website and the ECCC's general website. In addition, the Netherlands Institute of Human Rights (SIM) database on tribunals has been an invaluable tool for collecting and systemizing the relevant case law (http://sim.law.uu.nl/sim/ caselaw/tribunalen.nsf). The most common key words for the search engines were: 'equality of arms', 'equality between parties', 'inequality', 'disadvantage', and 'disadvantageous (position)'.

76 See for a recent discussion of effective legal assistance in international criminal law TEMMINCK Tuinstra, 2009. 
for the evaluation of the practice of international criminal tribunals. Chapter 2 pays attention to the role of human rights in international proceedings, and interpretation and application of the principle of equality of arms in international human rights case law. In this regard, the borderline function of the minimum human rights norms, as established by supranational bodies, in practice is approached as the bottom line. ${ }^{77}$ Lowering this line for the sake of international criminal courts would make their continued existence problematic because "the minimal requirements of fairness belong to the hard-won achievements of civilization." "78

Chapter 3 focuses on the different procedural approaches that are presented within the dichotomized framework of 'adversarial' and 'inquisitorial' ideal types. Whereas one notion of equality of arms is necessarily connected with the adversarial structure of proceedings in theory, achieving a meaningful equality of arms in a criminal law context presents some substantial challenges. Although the roads towards this achievement vary from system to system, the central point of departure must be the protective function of equality of arms within the rights of the accused. It has been widely considered that the international criminal justice system presents a sui generis structure that should be approached as such. In the absence of a governmental structure of authority that lines up the values and policy considerations which are relevant for a criminal justice system, the sui generis approach to international criminal justice necessitates a clear vision of the aims and goals of that system. Chapter 3 offers some observations in that regard.

Chapters 4 to 7 are devoted to the international criminal process. Firstly, Chapter 4 focuses on the early stages of the criminal process, namely the investigation stage and the ability of the parties to prepare for trial. Secondly, Chapter 5 looks at the regime underlying access to material between the parties that is collected during the parties' investigations. In most international criminal tribunals this regime has followed the more adversarial setting of proceedings, namely through inter partes disclosure obligations. Next, Chapter 6 pays particular attention to the issue of the perceived inequality in resources and facilities that need to be in place for a proper case preparation by a party. It consequently focuses on the institutional structures that exist at the international criminal courts, and more specifically on the institutionally unequal situation of the defence. Lastly, Chapter 7 addresses the issues that are most clearly associated with the case presentation at the trial phase, such as the time and the number of witnesses the parties were allowed to present and the issues relating to the examination of witnesses and the admissibility of evidence.

As mentioned earlier, the chosen themes are based on the issues considered to be most challenging in relation to equality of arms, and more specifically on issues that have a potential to lead to (perceived) inequality of arms. Moreover, the themes 
followed, to the extent possible, the chronology of the criminal proceedings: from investigation to evidence presentation at trial. Clearly, a strict separation of the pre-trial and trial stages can only be postulated in a formalistic way, particularly in international criminal proceedings where, due to the immense nature of the cases, investigations and disclosure can run into the trial phase proper. Therefore, the division can only be based on the theoretical separation of case preparation and case presentation. Following the pre-trial/ trial phases, this division of chapters (3 to 1) might seem unbalanced. However, in light of the fact that a strict division of the process stages in practice is illusive, this division of issues clearly underlines the importance that equality of arms has been given in the pre-trial stage of the proceedings. In fact, it is exactly this application of the principle of equality of arms that marks one significant point that enriches the existing international (human rights) jurisprudence on the subject. 


\section{Chapter 2 \\ Human Rights Perspective}

\subsection{INTRODUCTION}

This chapter investigates the role of human rights in international proceedings generally, and the interpretation and application of the principle of equality of arms in international human rights case law specifically. The main aim of this chapter is to position the concept of equality of arms within the human rights discourse for a better understanding of its meaning. Consequently, the meaning and scope of the application of equality of arms in the case law of international human rights bodies, namely the European Court of Human Rights (ECtHR) and the Human Rights Committee (HRC), are analyzed in this chapter. ${ }^{1}$ Firstly, some general observations on the link between human rights and (international) criminal law are presented. Then, the origin and definition of equality of arms in the context of the ECtHR and HRC will be discussed and compared. Also, these institutions' approach to determine whether equality of arms has been violated is analyzed. And lastly, the concrete scope of application of the concept in the case law of the human rights bodies will be examined. This overview will provide the necessary 'bottom line' for the evaluation of international criminal proceedings.

\subsection{HUMAN RIGHTS AND - INTERNATIONAL - CRIMINAL LAW}

It has been argued that human rights reflect the most fundamental values in a society. ${ }^{2}$ In criminal law particularly, human rights play a remarkable, seemingly paradoxical, defensive and offensive role. This role both neutralizes and triggers the application

1 European Convention on Human Rights and Fundamental Freedoms, concluded under the auspices of the Council of Europe in 1950 and entered into force in 1953, is the main instrument guaranteeing the application of human rights in Europe and is widely regarded as being the world's most effective system for the protection of human rights. See e.g. Buergenthal, 2002, p. 139. It is mostly due to the elaborate nature of the case law of ECtHR, in relation to fair trial generally and equality of arms specifically, that it constitutes a primary point of reference for the purposes of this chapter. Moreover, international criminal courts have referred extensively to the case law of the ECtHR. The opinions in individual cases of the HRC thus primarily constitute an additional source of reference in this chapter. This choice has been made due to practical constraints and does not reflect any normative superiority of or preference for ECtHR's case law above that of HRC.

2 Trechsel, 2000, p. 3. 
of criminal law. ${ }^{3}$ Traditionally, human rights in criminal law represent fundamental principles that intend to protect an individual from an unlimited use of state power. ${ }^{4}$ The limitations to this power are clearly expressed in the requirement of the right to a fair trial and other protective guarantees that bind state coercive interference in the realm of criminal law enforcement. However, by its very nature, criminal law has the function of protecting individuals against each other. In this role, criminal law is seen "as a driving force for intervention and as justification for states' deployment of their power, in particular that of coercion." International human rights institutions in fact require the use of criminal law as part of positive obligations for states in their protection of individual rights even in "the sphere of the relations of individuals between themselves". ${ }^{6}$ At a minimum, these positive obligations were found to exist in cases of intentional violations of physical and sexual integrity and the right to life, as a means of expressing societal disapproval of these violations and "to protect/highlight the fundamental values of society." In addition to this general aim of criminal law as such, the ECtHR has emphasized, in other cases, the goals of criminal sanction and the results of criminal proceedings. ${ }^{8}$ In fact, a shift towards the latter 'sword' function of criminal law, to the detriment of its 'shield' function, has been observed to be taking place in the last few decades. ${ }^{9}$ Could this shift be observed to extend to international criminal law, where, in fact, international institutions were established to prosecute those most responsible for gross human rights violations that have been labelled international crimes? The other side of the coin, i.e. the protective nature of human rights law, has been subject to discussion within international criminal law. Therefore, some reflection is merited on the exact status of international human rights standards and the role of human rights case law in the international criminal law context.

Several complex and intertwined issues relating to the relationship between international human rights law and the law of international criminal tribunals arise: the exact nature of the international criminal tribunals' commitment to the former body of law, the relationship between the two bodies of law considering the fulfilment of fair trial rights, and the exact scope of application of those rights within the latter. While a more elaborate discussion of some of these issues has been conducted elsewhere, ${ }^{10}$ the following section contains only limited observations with the aim of

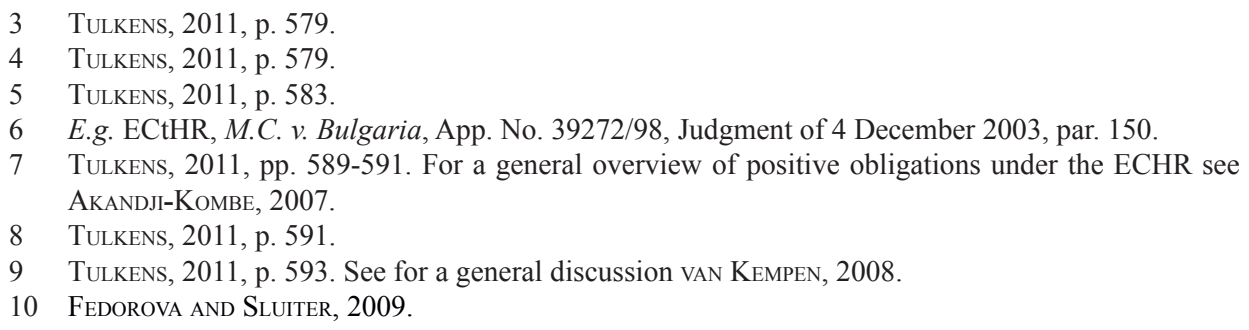


connecting the two relevant normative fair trial frameworks: (1) the human rights law corpus relating to fair trial standards and (2) the legal framework of the international criminal courts.

Analogous to the approaches taken to depict the relationship between the domestic and the international legal regimes, a 'monistic' and a 'dualistic' vision can be formulated. The former vision stipulates that as instruments of implementation of the international human rights regime, international criminal courts are directly bound to comply with and to apply that regime including the case law of international human rights bodies. From the 'dualistic' perspective, the peaceful but fragmented co-existence of equal, self-contained subjects of international law makes the implementation of fair trial norms solely dependent on the institutional preferences of these international institutions. Except for occasional opportunistic cross-reference opportunities, international criminal courts, in general, are only bound by their own unique legal framework in which to apply 'their' fair trial standards because the international human rights regime targets states only. ${ }^{11}$ International criminal courts are not parties to the international human rights conventions and are thus not bound by them in a strict legal sense. ${ }^{12}$

A logical middle road between these two extremes would seem to connect international criminal law and the human rights regime through the applicable sources of law. In that sense, international human rights standards, as formulated in international conventions and authoritatively interpreted by the monitoring bodies, constitute an authoritative source of international law that international criminal jurisdictions, as subjects of international law, are bound to apply. ${ }^{13}$ This approach would have to acknowledge the universality and primacy of international human rights standards that find their contextual application within the practice of different criminal justice systems. 'Contextual' would then imply that international criminal systems have to align their practice with the international human rights regime while taking into account their specific characteristics. Although the nature of human rights standards as minimum standards is widely accepted in international law, what this minimal nature exactly means and more importantly prescribes has been subject to discussion. Of further interest for the international criminal administration of justice is the exemplary role of its institutions following from the idea that their establishment was prompted by the failure of states to punish those responsible for gross human rights violations. ${ }^{14}$ However, these institutions are not a priori exempted

11 All international criminal tribunals contain an elaborate list of fair trial standards, see Articles 18(3) and 21 of the ICTY Statute; Article 17(3) and 20 of the ICTR Statute; Article 17 of the SCSL Statute; Rule 42 of the ICTY, ICTR, and SCSL RPE; Articles 55 and 67 of the ICC Statute15-16 STL Statute.

12 ICTY, Prosecutor v. Galić, Separate Opinion of Judge Shahabuddeen, Judgment, IT-98-29-A, A. Ch., 30 November 2006, par. 25.

13 CASSESE, 2003, p. 19.

14 Gradoni, 2006, p. 847. Schabas, 1997, p. 516. 
from an abusive use of power that is inherently possible in any criminal justice system and they can thus find themselves in a position of contributing to a violation of fundamental human rights, such as the fair trial rights, habeas corpus rights, the rights to privacy and freedom of expression. ${ }^{15}$ The extent to which the exemplary role must entail subjecting international criminal courts to evaluation from the perspective of the highest human rights standards has not yet been clarified. ${ }^{16}$

\subsubsection{Sources of the law}

In the absence of an explicit provision detailing the sources of law, which the ICTY and ICTR are to apply, ${ }^{17}$ the customary rule on the sources of international law as detailed in Article 38(1) of the International Court of Justice (ICJ) Statute must be considered. ${ }^{18}$ The tribunals' positive law has been acknowledged to be largely based on Article 14 of the International Covenant on Civil and Political Rights (ICCPR). ${ }^{19}$ The famous and often referenced phrase in this regard comes from the UN SecretaryGeneral's Report on the ICTY Statute: "[i]t is axiomatic that the International Tribunal must fully respect internationally recognized standards regarding the rights of the accused at all stages of its proceedings and in particular those enshrined in Article 14(1) of the ICCPR." ${ }^{20}$ As a result of their legal personality under international law, the ad hoc tribunals are bound by the legal obligations incumbent upon their parent body, the United Nations. ${ }^{21}$ Internationally recognized human rights standards that are part of general international law by virtue of customary norms or of general principles of law are thus binding upon the ad hoc tribunals beyond any explicit recognition in their founding framework. As such, no human rights treaties are directly binding upon international criminal institutions; however, "[w]hat applies is the substance of the standards - or goals - set by the provisions of those instruments, not the provisions themselves." 22

15 SLUiter, 2003, p. 935.

16 DAMAŠKA, 2011.

17 More generally, see AKANDE, 2009, p. 47.

18 Article 38(1) of the ICJ Statute: "The Court, whose function is to decide [disputes] in accordance with international law ..., shall apply: a. international conventions, whether general or particular ... ; b. international custom, as evidence of a general practice accepted as law; c. the general principles of law recognized by civilized nations; d. subject to the provisions of Article 59, judicial decisions and the teachings of the most highly qualified publicists of the various nations, as subsidiary means for the determination of rules of law."

19 Møse, 2003, p. 185. ICTY, Prosecutor v. Tadić, Judgment, IT-94-1-AR72, A. Ch., 2 October 1995, par. 42.

20 Report of the Secretary-General Pursuant to Paragraph 2 of Security Council Resolution 808 (1993), UN Doc. S/25704 of 3 May 1993, par. 106.

21 Mégret and Hoffmann, 2003.

22 ICTY, Prosecutor v. Galić, Separate Opinion of Judge Shahabuddeen, IT-98-29-A, A. Ch., 30 November 2006, par. 19: "It is good jurisprudence that particular provisions of internationally 
Although the most general human rights principles might not be difficult to identify as customary norms, ${ }^{23}$ it is the delineation of the exact scope of application of these principles that is the most challenging exercise. ${ }^{24}$ No normative hierarchy can be identified between the human rights provisions included in various human rights conventions and the determination of a customary nature of a provision can arguably only be made on a 'case-by-case' basis. Methodological challenges underlying the identification of general principles of law parallel those of customary provisions. By their very nature, general principles of law might be less helpful for the identification of a concrete modality of the fair trial standard. Moreover, the specificities of domestic approaches to procedural issues and the different underlying philosophies make the identification of a single principle virtually impossible. ${ }^{25}$

The ICC Statute is more explicit about the applicable sources: Article 21 contains a detailed list, comparable to but not a verbatim reproduction of Article 38(1) ICJ Statute, of the applicable sources of law and their hierarchy. ${ }^{26}$ The normative primacy of internationally recognized human rights has been embraced by the ICC Statute's Article 21(3), which states "the application and interpretation of law pursuant to this article must be consistent with internationally recognized human rights." What the meaning and sources of these 'internationally recognized human rights' are have been subject to discussion. ${ }^{27}$ Naturally, the right to a fair trial was considered particularly relevant. ${ }^{28}$ To some extent, the exact nature and scope of this provision

recognised human rights standards do not apply to the Tribunal lock, stock and barrel; it is superfluous to cite authority."

23 For example, the right to a fair trial has been acknowledged to constitute an international customary norm. See e.g. ICTY, Prosecutor v. Aleksovski, Judgment, IT-95-14/1-A, A. Ch., 24 March 2000, par. 104: "The right to a fair trial is, of course, a requirement of customary international law". See also ICC, Prosecutor v. Lubanga Dyilo, Situation in the DRC, Separate Opinion of Judge Georghios M. Pikis, Decision on the Prosecutor's 'Application for Leave to Reply to "Conclusions de la défense en réponse au mémoired'appel du Procureur'”, ICC-01/04-01/06-424, A. Ch., 12 September 2006, par. 3: "the right to a fair trial has been proclaimed as a legal norm and its incorporation in international instruments denotes comprehensive assent to its emergence as a principle of customary international law."

24 SLUiter, 2003, p. 938.

25 On the difficulties encountered by ICTY in identifying general principles see CASSESE, 2001, pp. $43-55$.

26 For a recent discussion of Article 21 (3), see Young, 2011.

27 E.g. Young, 2011. The Appeals Chamber seems to align these rights with "universally recognized human rights norms", see ICC, Situation in the Democratic Republic of the Congo, Judgment on the Prosecutor's Application for Extraordinary Review of Pre-Trial Chamber I's 31 March 2006 Decision Denying Leave to Appeal, ICC-01/05-168, A. Ch., 13 July 2006, par. 38.

28 ICC, Situation in the Democratic Republic of the Congo, Judgment on the Prosecutor's Application for Extraordinary Review of Pre-Trial Chamber I's 31 March 2006 Decision Denying Leave to Appeal, ICC-01/04-168, A. Ch., 13 July 2006, par. 37, noting that the Statute "must be interpreted and more importantly applied in accordance with internationally recognized human rights; first and foremost, in the context of the Statute, the right to a fair trial". 
still seems uncertain. In practice, most Chambers have conceptualized Article 21(3) as 'a general principle of interpretation' 29 that is to serve as a framework of reference when interpreting and applying the law derived form the relevant sources (Article 21(1)). ${ }^{30}$ In addition, Article 21(3) has been referred to as constituting a gap-filling device for lacuna in the written law of the Statute, Rules and Elements of Crimes. ${ }^{31}$ This arguably erroneous view, however, seems to align Article 21(3) to the sources of law proper, and more importantly, to place it in the hierarchical relationship under those written law sources. ${ }^{32}$ In general, the ICC Chambers have embraced references to the major universal and regional human rights conventions and their derivative jurisprudence in order to substantiate and confirm their interpretation and application of the law, in line with those human rights references..$^{33}$

\subsubsection{The role of human rights jurisprudence}

Failing to identify a priori the customary nature of a human rights provision or its status as a general principle of law, the fragmented identification of those human rights norms in practice is an uncertain and very time-consuming exercise. From this, international criminal tribunals took a pragmatic approach by focusing on the leading opinions of the human rights monitoring bodies and the identifiable and directly

29 E.g. ICC, Prosecutor v. Katanga and Ngudjolo Chui, Decision on the Powers of the Pre-Trial Chamber to Review proprio motu the pretrial detention of Germain Katanga, PTC I, ICC-01/0401/07-330, 18 March 2008, p. 6; ICC, Prosecutor v. Katanga, Decision on the Joinder of the Cases Against Germain Katanga and Mathieu Ngudjolo Chui, ICC-01/04-01/07-257, PTC I, 10 March 2008, par. 7; ICC, Prosecutor v. Lubanga Dyilo, Situation in the DRC, Decision on the Practices of Witness Familiarisation and Witness Proofing, ICC-01/04-01/06-679, PTC I, 8 November 2006, par. 10; ICC, Prosecutor v. Lubanga Dyilo, Situation in the DRC, Decision Establishing General Principles Governing Applications to Restrict Disclosure pursuant to Rule 81 (2) and (4) of the Statute, ICC-01/04-01/06-108, PTC I, 19 May 2006, par. 7(i). Cf. SALAND, 1999, p. 214, referencing Article 21(3) as a rule of general consistency.

30 ICC, Prosecutor v. Lubanga Dyilo, Situation in the DRC, Judgment on the Appeal of Mr. Thomas Lubanga Dyilo against the Decision on the Defence Challenge to the Jurisdiction of the Court pursuant to Article 19(2)(a) of the Statute of 3 October 2006, ICC-01/04-01/06-772, A. Ch., 14 December 2006: 'human rights underpin the Statute; every aspect of it ...' $C f$. ScHABAs, 2010-a, p. 385 .

31 ICC, Prosecutor v. Al Bashir, Decision on the Prosecution's Application for a Warrant of Arrest against Omar Hassan Ahmad Al Bashir, ICC-02/05-01/09-3, PTC I, 4 March 2009, par. 44: “Third, the consistent case law of the Chamber on the applicable law before the Court has held that, according to Article 21 of the Statute, those other sources of law provided for in paragraphs (1)(b) and (1)(c) of Article 21 of the Statute, can only be resorted to when the following two conditions are met: (i) there is a lacuna in the written law contained in the Statute, the Elements of Crimes and the Rules; and (ii) such lacuna cannot be filled by the application of the criteria of interpretation." provided in Articles 31 and 32 of the Vienna Convention on the Law of Treaties and Article 21(3) of the Statute.

32 Young, 2011, p. 201.

33 See YounG, 2011, p. 201, p. 203, footnotes 67 and 68; p. 205, footnote 80, for some case law references. 
relevant domestic jurisprudence. However, one has to keep in mind the distinction between the internationally recognized human rights standards and their practical interpretation and application by the human rights bodies. Whereas the former, as part of customary rules or general principles of law, bind international criminal tribunals as a matter of law, the latter, as manifestations of contextual (and casespecific) application, do not possess the same normative force as far as international criminal tribunals are concerned. ${ }^{34}$

Although starting off with a somewhat dismissive approach to the case law of the ECtHR in the first, infamous, Tadic case, ad hoc tribunals came to embrace references to this human rights body's jurisprudence ${ }^{35}$ It can be argued that "jurisprudential cross-fertilization" 36 is, indeed, a necessary and much needed approach to be embraced by international criminal institutions so as to earn and/or retain the perception of the legitimacy of their processes and, thus, their existence. Considering the lack of any meaningful precedent or supervision, the most fruitful approach for these institutions might prove to take the human rights jurisprudence as an authoritative indication of the bottom line, which marks the borderline between the permissible/impermissible

34 ICTR, Barayagwiza v. Prosecutor, Decision, ICTR 97-19-AR72, A. Ch., 3 November 1999, par. 40. ICTY, Prosecutor v. Kupreškić et al., Judgment and Sentence, IT-95-16-T, 14, January 2000, par. 540. See also ICTY, Prosecutor v. Tadic, Decision on the Defence Motion for Interlocutory Appeal on Jurisdiction, IT-94-1-AR72, A. Ch., 2 October 1995, par. 11: "International law, because it lacks a centralized structure, does not provide for an integrated judicial system operating an orderly division of labour among a number of tribunals, where certain aspects or components of jurisdiction as a power can be centralized or vested in one of them but not the other."

35 ICTY, Prosecutor v. Tadic, Decision on the Prosecutor's Motion Requesting Protective Measures for Victims and Witnesses, IT-94-1-T, T.Ch., 10 August 1995, par. 28: "The fact that the International Tribunal must interpret its provisions within its own legal context and not rely in its application on interpretations made by other judicial bodies is evident in the different circumstances in which the provisions apply. The interpretations of Article 6 of the ECHR by the European Court of Human Rights are meant to apply to ordinary criminal and, for Article 6(1), civil adjudications. By contrast, the International Tribunal is adjudicating crimes which are considered so horrific as to warrant universal jurisdiction. The International Tribunal is, in certain respects, comparable to a military tribunal, which often has limited rights of due process and more lenient rules of evidence." Moreover, par. 30: "As such, the Trial Chamber agrees with the Prosecutor that the International Tribunal must interpret its provisions within its own context and determine where the balance lies between the accused's right to a fair and public trial and the protection of victims and witnesses within its unique legal framework. While the jurisprudence of other international judicial bodies is relevant when examining the meaning of concepts such as 'fair trial', whether or not the proper balance is met depends on the context of the legal system in which the concepts are being applied." Also, ICTY, Prosecutor v. Mucic', Judgement, IT-96-21-A, A. Ch., 20 February 2001, par. 24: 'although the Appeals Chamber will necessarily take into consideration decisions of other international courts, it may, after careful consideration, come to a different conclusion' (while this pronouncement concerned the ICJ, it is demonstrative of the general attitude of the ICTY to the authority of other international courts). See further CASSESE, 2003, p. 26 and 49. See also NEgRI, 2007, p. 24: 'tribunals "necessarily take into consideration other decisions of international courts" while firmly claiming their position of absolute autonomy in relation to the others'.

36 Cançado Trindade, 2004, p. 312. 
divide; a permissible limitation of human rights and an impermissible intrusion upon them. ${ }^{37}$ The following sections will try to uncover this bottom line of equality of arms from the human rights perspective.

\subsection{EqUALITY OF ARMS: ORIGIN AND LEGAL BASIS}

As mentioned in Chapter one, the term equality of arms originated in modern European procedure in the context of Article 6 of the ECHR, although the roots of this legal concept date back long before the adoption of this convention. Although this principle has not been explicitly included in the text of international human rights conventions, equality of arms has been recognized in the practice of human rights bodies as a fundamental principle of the right to a fair trial. ${ }^{38}$ The European Commission introduced the term equality of arms into the Strasbourg case law ${ }^{39}$ for the first time in the criminal cases of Ofner and Hopfinger v. Austria ${ }^{40}$ and Pataki and Dunshirn v. Austria. ${ }^{41}$ The unifying point in these cases was that the accused had not been given an opportunity to be heard unlike the opposing side. The Commission determined that "the equality of arms, that is the procedural equality of the accused with the public prosecutor, is an inherent element of 'fair trial'." 42 No elaboration on the question of why the Commission considers this to be the case was provided. Considering the legal basis of equality of arms the Commission only briefly stated that:

whether such equality has its legal basis in paragraph 3 depends upon the interpretation of subparagraphs (b) ... and (c) ... . The Commission needs not express a definitive opinion on this question, since in any case it is beyond doubt that the wider and general provision of a 'fair trial', contained in paragraph 1 of Art. 6, embodies the notion of 'equality of arms'. ${ }^{43}$

37 For a critical note on that 'borderline' see BREMS, 2009.

38 "It is a fundamental aspect of the right to a fair trial that criminal proceedings, including the elements of such proceedings which relate to procedure, should be adversarial and that there should be equality of arms between the prosecution and defence". ECtHR, Rowe and Davis v. United Kingdom, App. No. 28901/95, Judgment of 16 February 2000. Nowak refers to the principle of equality of arms as "the most important criterion of a fair trial", NowaK, 2005, p. 321.

39 The concept behind equality of arms was introduced earlier in a case concerning civil proceedings: Xv. Sweden, App. No. 434/58, 30 June 1959, Yearbook, volume 2, 1958-1959, p. 370.

40 Ofner and Hopfinger v. Austria, App. No. 524/59 and 617/59, report of 23 November 1962, Yearbook volume 6, 1963, p. 680.

41 Pataki and Dunshirn v. Austria, App. No. 596/59 and 789/60, report of 28 March 1963, Yearbook volume 6, 1963, p. 718.

42 Pataki and Dunshirn v. Austria, App. No. 596/59 and 789/60, report of 28 March 1963, Yearbook volume 6, 1963, p. 732 (emphasis added, MF).

43 Ofner and Hopfinger v. Austria, App. No. 596/59 and 789/60, report of 28 March 1963, Yearbook volume 6, 1963, p. 732. 
Later, the proposition that equality of arms can be based both on Article 6(1) as well as 6(3) of the ECHR was cited with approval. ${ }^{44}$ The fact that equality of arms is inherently connected to the general fair trial requirement (Art. 6-1) makes the principle applicable in civil, criminal and administrative proceedings. ${ }^{45}$ Consequently, equality of arms is an inherent, independent and derivative element of the right to a fair trial, concealed under the first paragraph of the fair trial provisions that have a broader scope of application than the minimum rights applicable in criminal cases. Before turning to the analysis of the interpretation of equality of arms and the approach establishing impermissible inequality used by the human rights bodies, the overriding concept of the right to a fair trial will be considered briefly.

\subsubsection{General concept: the right to a fair trial}

The right to a fair trial has been recognized in many international human rights instruments. ${ }^{46}$ It is based on the Anglo-Saxon common law tradition of 'due process of law' and can be traced to the Magna Carta Liberatum of $1215 .{ }^{47}$ States' allegiance to democracy and the rule of law is underlined and measured by the fair trial principle. The ECtHR often uses a standard sentence to emphasize its importance: "[i]n a democratic society within the meaning of the Convention, the right to a fair administration of justice holds such a prominent place that a restrictive interpretation

44 E.g. Jespers v. Belgium, App. No. 8403/78, Commission's report of 14 December 1981, D\&R 27, par. 55.

45 See e.g. ECtHR, Dombo Beheer BV v. Netherlands, App. No. 14448/88, Judgment of 27 October 1993, par. 33: "Nevertheless, certain principles concerning the notion of a 'fair hearing' in cases concerning civil rights and obligations emerge from the Court's case-law. Most significantly for the present case, it is clear that the requirement of 'equality of arms', in the sense of a 'fair balance' between the parties, applies in principle to such cases as well as to criminal cases". See also ECtHR, Feldbrugge v. The Netherlands, App. No. 8562/79, Judgment of 29 May 1986, par. 44.

46 See, inter alia, Article 14 of the International Covenant on Civil and Political Rights (ICCPR) Article 6 of the European Convention for the Protection of Human Rights and Fundamental Freedoms (ECHR), Article 8 of the American Convention on Human Rights (AHRC). Also Article 10 of the Universal Declaration of Human Rights (UDHR), Common Article 3 of the four Geneva Conventions of 12 August 1949, Article 96, 99-108 Geneva Convention relative to the Treatment of Prisoners of War, Article 54, 64-74, 117-126 Geneva Convention relative to the Protection of Civilian Persons in Time of War, Article 6 Additional Protocol II to the Geneva Conventions. Although both the ICCPR and the ECHR refer to a 'fair hearing' the right to a 'fair trial' has been used synonymously. See VAn DijK ... (et AL.), 2006, p. 578. Also e.g. Ofner and Hopfinger v. Austria, App. No. 596/59 and 789/60, report of 23 November 1962, Yearbook volume 6, 1963, p. 680, Nielsen v. Denmark, App. No. 343/57, decision of 2 September 1959, Yearbook volume 2, 1958-1959, pp. 414-415: “Fair trial' is as such not only a procedural guarantee but also a human right protected by the instrument." Article 8 of the American Convention on Human Rights does not refer to the word fair at all, but mentions "due guarantees". This is probably due to its (American) common law origin, and there is no reason to assume that a different meaning than that under the ICCPR and ECHR was intended. See Trechsel, 2005, p. 81.

47 Nowak, 2005, p. 305. Cf. Trechsel, 2005, p. 82. 
of Article 6 para. 1 (art. 6-1) would not correspond to the aim and the purpose of that provision." ${ }^{48}$ Nevertheless, it might be more accurate to link the importance of the fair trial principle to the rule of law, rather than to the abstract notion of democracy. ${ }^{49}$ The meaning of the rule of law concept, however, may differ among states..$^{50}$

The content of the right to a fair trial is usually defined in terms of different basic principles underlying a criminal justice system and the enumeration of some minimum guarantees for the accused in a criminal trial. ${ }^{51}$ The relevant human rights instruments first set out a general right to a fair trial and then specify some specific rights of the defence as minimum guarantees. ${ }^{52}$ In the case law a holistic approach is endorsed when determining the fairness of proceedings. ${ }^{53}$ The effect of Article 6(1) is to place a tribunal under the duty to conduct a proper examination of the submissions, arguments and evidence adduced by the parties without prejudice to its assessment of whether they are relevant to its decision..$^{54}$ According to the well-established case law of the ECtHR, the Convention has to be interpreted in an autonomous way, whereas similar expressions in the national laws of the Member States are not decisive for determining the wording of a provision but can be taken into account. ${ }^{55}$ Generally, Article 6 of the ECHR "taken as a whole, guarantees that a person charged with a criminal offence should ... be entitled to be present and participate effectively in the hearing concerning the determination of criminal charges against him." ${ }^{56}$ Moreover,

48 E.g.: ECtHR, Delcourt v. Belgium, App. No. 2689/65, Judgment of 17 January 1970, par. 25; Also, ECtHR, Moreira de Azevedo v. Portugal, Judgment of 23 October 1990, par. 66; ECtHR Perez v. France, App. No. 47287/99, Judgment of 12 February 2004, par. 64.

49 See Trechsel, 2005, p. 83.

50 On the European continent see Mineshima, 2002, p. 73.

51 A detailed consideration of the broader notion of a fair trial, namely applying to all proceedings (civil, criminal and administrative) falls outside the scope of this study. Reference to civil proceedings will only be made in so far as it is relevant to the definition of the fair trial principle in the context of a criminal trial (e.g. the rights of victims as a civil party in criminal proceedings).

5232 States have made a reservation/declaration to Article 14 ICCPR, most of which concern paragraph 3(d) (the presence of the accused at trial and free legal assistance), par. 5 (appeal/review), par. 6 (compensation) and par. 7 (double jeopardy). See: http://sim.law.uu.nl/sim/library/RATIF.nsf/ (ReservationsT)?OpenView\&Start=1\&Count=30\&Expand=2\#2.

53 "It is not for the Court to substitute its view for that of the national courts which are primarily competent to determine the admissibility of evidence (see, among other authorities, Schenk $v$. Switzerland, App. No. 10862/84, Judgment of 12 July 1988, Series A No. 140, p. 29, par. 46). It must nevertheless satisfy itself that the proceedings as a whole were fair, having regard to any possible irregularities before the case was brought before the courts of trial and appeal and checking that those courts had been able to remedy them if there were any". E.g. ECtHR, Miailhe v. France (No.2), App. No.18978/91, Judgment of 26 September 1996, par. 43.

54 ECtHR, Kraska v. Switzerland, App. No. 13492/88, Judgment of 19 April 1993, par. 30.

55 ECtHR, Engel and others v. The Netherlands, Judgment of 8 June 1976, par. 82 (in the context of determining the meaning of a "criminal charge").

56 ECtHR, Zhuk v. Ukraine, App. No. 45783/05, Judgment of 21 October 2010, par. 26. 
importance is to be attached to, inter alia, the appearance of the fair administration of justice and to the increased sensitivity of the public to the fair administration of justice [and] as in other aspects of Article 6, the seriousness of what is at stake for the applicant will be of relevance to assessing the adequacy and fairness of the procedures. $^{57}$

The manner in which Article 6 is applied can differ depending on the stage of the proceedings.$^{58}$ In addition, the principle is designed to ensure 'procedural justice' and not 'result-oriented justice'. ${ }^{59}$ The ECtHR has stressed that it does not function as a fourth instance and, thus, does not have as a task to ascertain whether the domestic law has been applied correctly or to evaluate the assessment of the facts. ${ }^{60}$

The idea of fairness is regarded as an overarching concept that can be achieved by respecting certain specific guarantees. ${ }^{61}$ These minimum guarantees are not exhaustively enumerated in the relevant legal provisions and constitute several essential elements of the general right to a fair trial. Thus, the absence of a violation of a specific right does not render the examination of the fairness of the trial as a whole superfluous. The European Commission has rejected the idea that the notion of fairness is completely embodied by the minimum guarantees of the third paragraph:

Article 6 of the Convention does not define the notion of 'fair trial' in a criminal case. Paragraph 3 of the Article enumerates certain specific rights, which constitute essential elements of that general notion, and paragraph 2 may be considered to add

57 ECtHR, Zhukv. Ukraine, App. No. 45783/05, Judgment of 21 October 2010, par. 27.

58 VAN DiJK ... (ET AL.), 2006, p. 579.

59 TREChSEL, 2005, p. 83. For a more elaborate discussion of 'procedural justice', see Chapter 3 of this study.

60 "It is not the function of the ECHR to deal with errors of fact or of law allegedly committed by a national court unless and in so far as they may have infringed rights and freedoms protected by the Convention. It is not the role of the ECHR to determine, as a matter of principle, whether particular types of evidence - for example, unlawfully obtained evidence - may be admissible or, indeed, whether the applicant was guilty or not. The question which must be answered is whether the proceedings as a whole, including the way in which the evidence was obtained, were fair." ECtHR, Allan v. UK, App. No. 48539/99, Judgment of 5 November 2002, par. 42.

61 In Can v. Austria, App. No. 9300/81 report of 12 July 1984, par. 480 the European Commission held that "the guarantees enshrined in Article 6(3) are not an aim in themselves ... Their intrinsic aim is always to ensure, or to contribute to ensuring the fairness of the criminal proceedings as a whole ... They must accordingly be interpreted in the light of the function they have in the overall context of the proceedings." See also e.g. ECtHR, Barbera, Messegué and Jabardo, App. Nos. 10588/83, 10589/83, 10590/83, Judgment of 6 December 1988, par. 68, ECtHR, Kostovski v. Netherlands, App. No. 11454/85, Judgment of 20 November1989, par. 39. The Human Rights Committee has interpreted the concept of a fair hearing in the context of Article 14(1) of the Covenant "as requiring a number of conditions, such as equality of arms, respect for the principle of adversary proceedings, preclusion of ex officio reformatio in pejus, and expeditious procedure", see HRC, Morael v. France, Comm. No. 207/86, Views of 28 July 1989. 
another element. The words 'minimum rights', however clearly indicate that the six rights specifically enumerated in paragraph 3 are not exhaustive, and that a trial may not conform to the general standard of 'fair trial', even if the minimum rights guaranteed by paragraph 3 - and also the right set forth in paragraph 2 - have been respected..$^{62}$

The reference to the specific rights as 'minimum guarantees' implies that any disrespect for one of those rights would render the trial unfair. However, this theory has not always been reflected in practice. Trechsel criticizes this approach as it jeopardizes an important task of the Court, namely the development of clear and consistent jurisprudence. ${ }^{63}$

By its nature, the right to a fair trial is a principle which implies that in the abstract it is absolute in its application with no possible exceptions. As such, it provides only a general value-charged abstract form that in a concrete case only gives a direction towards a certain result, but it does not instruct us how to get there ${ }^{64}$ In the context of human rights law, the fair trial principle must find its application in a variety of criminal procedural systems and is thus regarded as independent from a particular criminal procedural model. ${ }^{65}$ That many European states with different legal traditions are parties to the same human rights convention bears witness to this fact. The practical challenge of reconciling different models of procedure with basically competing underlying assumptions under a vague notion of fair trial, while remaining impartial as to the concrete form and function of a particular criminal model, has not generated much theoretical evaluation in human rights case law. ${ }^{66}$ In the Borgers case, for example, the ECtHR clearly distanced itself from a perception of fairness as being dependent on a particular procedural setting and accommodating existing national practices ${ }^{67}$ The HRC considers, as a general rule, that "the procedural practice applied

62 Nielsen v. Denmark, App. No. 343/57, report of 15 March 1961, Yearbook volume 4, 1961, p. 548, par. 52.

63 See Trechsel, 2005, pp. 87-88.

64 See Chapter 1 of this study.

65 According to the ECtHR a fair trial "is one of the fundamental principles of any democratic society, within the meaning of the Convention". See e.g. ECtHR, Axen v. Germany, App. No. 8273/78, Judgment of 8 December 1983, par. 25.

66 "Whilst the member States of the Council of Europe all subscribe to this principle of publicity, their legislative systems and judicial practice reveal some diversity as to its scope and manner of implementation, as regards both the holding of hearings and the 'pronouncement' of judgments. The formal aspect of the matter is, however, of secondary importance as compared with the purpose underlying the publicity required by Article 6 par. 1 (art. 6-1). The prominent place held in a democratic society by the right to a fair trial impels the Court, for the purposes of the review which it has to undertake in this area, to examine the realities of the procedure in question" [emphasis added, MF], ECtHR, Axen v. Germany, App. No. 8273/78, Judgment of 8 December 1983, par. 26.

67 ECtHR, Borgers v. Belgium, App. No. 12005/86, Judgment of 30 October 1991, Series A No. 214. In this case ECtHR departed from its previous ruling in the case of Delcourt v. Belgium and found 
by domestic courts is a matter for the courts to determine in the interests of justice;" it is the complainant who needs "to show that a particular practice has given rise to unfairness in the particular proceedings". ${ }^{68}$ The absence of an underlying procedural structure makes it even harder to understand the meaning and function and to depict the content of principles such as fair trial and equality of arms.

In this regard, Jackson has argued that the ECtHR, rather than merging the two dominant procedural models (adversarial and inquisitorial), has developed a third model that is properly characterized as 'participatory', based on the principles of equality of arms and adversarial proceedings. The adversarial conception of fairness does not in itself resemble the traditional understanding of an adversarial process, but:

as the European Court refines and develops its vision of participatory proof in the light of modern day conditions and takes criminal procedure beyond the traditional boundaries of adversarial/inquisitorial discourse, the European states are given considerable freedom of manoeuvre in realigning their procedures in a manner that respects the rights of the defence. ${ }^{69}$

Criminal procedure, in its nature, realizes substantive criminal law by regulating the process of investigating, prosecuting and punishing those considered responsible for a violation of a particular criminal law provision. Every criminal process is, thus, directed towards truth-finding in the sense of uncovering what factual circumstances underlined the commission of the crime and delivering appropriate punishment. Many different opinions exist concerning how to achieve these goals. Different derivative principles and rules give some direction towards the achievement of the goals of criminal law in a fair manner. As such, the principle of equality of arms presents a particular setting that is best considered to achieve a fair and accurate judgment and punishment. In this sense, human rights bodies have submitted that in a judicial process that leads to the acquittal or the conviction of an accused person, the truth can only be ascertained in a way that provides an equal opportunity for the defence and the prosecutor to seek the establishment of that truth.

However, as argued by Summers, "the regulation of the institutional setting must ... be seen to be a prerequisite to enabling the consistent application of procedural rights and to the creation of an uniform standard of procedural fairness across different jurisdictions." ${ }^{\prime 70}$ This follows from her argument that, from a historical

that the Belgian practice of having an Avocat Général present at the deliberations of the Court of cassation and submitting his views on the case, while this opportunity is denied to the accused, was incompatible with equality of arms and a fair trial.

68 HRC, Ä̈̈relä and Näkkäläjärvi v. Finland, Communication No. 779/1997, Views of 24 October 2001, par. 7.3.

69 See JACKSON, 2005, p. 763.

70 Summers, 2005, p. 172. 
perspective, defence rights in Continental Europe have developed as part of structural and institutional forms of criminal proceedings, based upon the understanding that an effective criminal justice system must provide a fair and legitimate basis for delivering accurate decisions. According to Summers, the fact that Article 6 principles are readily accepted and applied in different European legal systems is due to the fact that "these principles form part of the foundations on which modern European criminal procedure law is based." 71 Thus, regulating fairness only on the basis of individual rights without taking into account the institutional framework in which to apply these rights would necessarily be incomplete. ${ }^{72}$ Although the ECtHR's focus on individual rights might be understandable to some extent, these rights "are not, and cannot be, applied in a structural vacuum." 73

In this regard, it is relevant to consider the idea that the fair trial standards encompass both individual rights and procedural guarantees. As an individual right, fair trial guarantees "are seen as an expression of individual autonomy - the right of the accused to be respected as an individual throughout the criminal process and to participate in his or her defence." 74 The protection of human dignity lies at the heart of the relevant human rights. Additionally and overlapping the first notion, fair trial standards "are an expression of the need for trials as the public face of justice to reach accurate verdicts by means of a system of accusatorial or adversarial truth finding." 75 A clear example of this division is the right to an effective defence. Ensuring an effective defence can be considered an autonomous obligation upon state authorities, even if the measures taken, in this regard, would violate an individual's autonomy and subjective will in relation to his defence strategy. ${ }^{76}$ This dual nature of fair trial guarantees is important to consider for the practice of international criminal courts and their understanding of the concept of fairness.

\subsubsection{The meaning of equality of arms}

Although the principle of equality of arms is more commonly associated with adversarial proceedings and, as such, with the common law tradition, in human rights case law the principle has not been applied in a tradition-specific manner. In addition, it functions in both civil and criminal proceedings. In the context of civil proceedings, the ECtHR has formulated the principle of equality of arms to imply "that each party must be afforded a reasonable opportunity to present his case - including his evidence under conditions that do not place him at a substantial disadvantage vis-à-vis his

71 Summers, 2005, p. 177.

72 Summers, 2005, p. 172.

73 Summers, 2005, p. 183.

74 JACKSON, 2009-b, pp. 5-6.

75 JACKSON, 2009-b, p. 6.

76 For a discussion see JACKSON, 2009-b, pp. 7-18. 
opponent." ${ }^{77}$ Moreover, the Court has referred to the nature of the civil proceedings as "litigation involving opposing private interests."

In a criminal setting, equality of arms has been considered in similar terms, with only some minor differences. The reference to evidence and the term 'substantial' are omitted: "each party must be afforded a reasonable opportunity to present his case in conditions that do not place him at a disadvantage vis-à-vis his opponent." regard to evidence, one can assume that in criminal proceedings the defence does not actually have to present any evidence as the onus is on the prosecutor to prove the case. However, the omission of 'substantial' could imply that any disadvantage for the defence must be avoided. Could this difference be traced back to the different nature of civil and criminal proceedings? It can be argued that any disadvantage for the principally weaker party (due to the higher individual stakes involved in a criminal process), namely the accused, would lead to an unjustifiable inequality, which would render the trial unfair. We will return to this issue later in the context of discussing the meaning of equality. Unfortunately, the Court does not provide any explanation for this difference in description. According to Trechsel, "it can be assumed that this difference is of little significance." ${ }^{\circ 0}$ In its practice, the Court has not used the descriptions consistently. ${ }^{81}$

The Human Rights Committee in its case law and general comments refers to the principle of equality of arms as an element of a fair hearing and a consequence of the right to equality before the courts and tribunals:

The right to equality before courts and tribunals also ensures equality of arms. This means that the same procedural rights are to be provided to all the parties unless distinctions are based on law and can be justified on objective and reasonable grounds, not entailing actual disadvantage or other unfairness to the defendant." ${ }^{\prime 2}$

77 ECtHR, Dombo Beheer BV v. Netherlands, App. No. 14448/88, 27 October 1993, par. 33. The concept was first introduced in the case of civil proceedings in $X$ v. Sweden, App. No. 434/58, 30 June 1959, Yearbook volume 2, 1958-1959, pp. 370-372.

78 ECtHR, Dombo Beheer BV v. Netherlands, App. No. 14448/88, Judgment of 27 October 1993, par. 33.

79 ECtHR, Bulut v. Austria, App. No. 17358/90, Judgment of 22 February 1996, par. 47. The same definition is applied in administrative cases, see e.g. ECtHR, Gorraiz Lizarraga and others v. Spain, App. No. 62543/00, Judgment of 27 April 2004, par. 56; ECtHR, Foucher v. France, App. No. 22209/93, Judgment of 18 March 1997, par. 34.

80 Trechsel, 2005, p. 97.

81 For a combined definition, see e.g. ECtHR, Zhuk v. Ukraine, App. No. 45783/05, Judgment of 21 October 2010, par. 25: "The Court reiterates that the principle of equality of arms - one of the elements of the broader concept of a fair trial - requires each party to be given a reasonable opportunity to present his case under conditions that do not place him at a substantial disadvantage vis-à-vis his opponent."

82 HRC, Dudko v. Australia, Comm. No. 1347/2005, Views of 23 July 2007, par. 7.4; HRC, General Comment No. 32, Article 14: Right to equality before courts and tribunals and to a fair trial, Ninetieth 
This approach seems like a clear-cut definition containing all the relevant elements: (1) in principle, both parties should have the same procedural rights; however (2) if justified, rights can be dissimilar, but not if (3) this dissimilarity would actually be unfair towards the accused. Speculating about the pre-trial phase, where the roles of the parties and, thus, the 'rights' differ considerably, it can be argued that this difference can be justified objectively and specifically on the basis of the different roles, powers and obligations involved. From this perspective, if the difference (for example, in material means) would lead to an actual disadvantage for the accused (not being able to prepare his case), equality of arms would be endangered.

The case law of the ECtHR and HRC has largely influenced the Inter-American Court of Human Rights (ACtHR) in its application and interpretation of due process requirements. ${ }^{83}$ Interestingly, while the focus of ECtHR (and HRC) is on the application of equality of arms in domestic systems, the ACtHR has focused on the application of equality of arms between the parties appearing before both the Commission as well as before the Court itself. Equality of arms has been discussed particularly in connection with preliminary objections and evidentiary matters. ${ }^{84}$ As the focus of this study is on the interpretation and application of equality of arms in criminal proceedings, the case law of the ACtHR is less instructive in this matter and is not studied in depth.

session, 23 August 2007, par. 13. The right to equality before the courts expressly guaranteed in Article 14 (1) ICCPR is a specific manifestation of the general right to equality (Article 26) and must be read in conjunction with the general prohibition of discrimination under Article 2(1). It means a right of equal access to a court by all persons, without distinction as to race, religion, sex, property, etc. This right is broader than equality before the law, which means the application of laws without discrimination by the judiciary. See NowaK, 2005, p. 308.

83 See The Right of Information on Consular Assistance in the Framework of the Guarantees of the Due Process of Law, Advisory Opinion OC-16/99, 1 October 1999, Series A No. 16, paras. 117-119.

84 With regard to evidential matters: E.g. Case of the "Juvenile Reeducation Institute" v. Paraguay, ACHR, Judgment of 2 September 2004, Series C No.112, par. 63. Case of the Plan de Sánchez Massacre v. Guatemala. Reparations and Costs, ACHR, Judgment of 19 November 2004. Series C No. 116, paras. 27-28: "The proceedings before the Court are not subject to the same formalities as domestic proceedings. When incorporating certain elements into the body of evidence, particular attention must be paid to the circumstances of the specific case and to the limits imposed by respect for legal certainty and the procedural equality of the parties."

With regard to preliminary objections: E.g. Case of Castillo-Petruzzi et al v. Peru, Preliminary Objections, ACHR, Judgment of 4 September 1998. Series C No. 41, par. 44: "The right of access to justice at international level ought in fact to be accompanied by the guarantee of procedural equality (equality of arms/égalité des armes) in the proceedings before the judicial organ, an element essential to any jurisdictional mechanism of protection of human rights, without which such mechanism will be irremediably mitigated."; Case of the 19 Merchants v. Colombia Preliminary Objection, ACHR, Judgment of 12 June 2002, Series C No. 93, par. 28, 31. 


\subsubsection{Establishing a violation of equality of arms}

Generally, the ECtHR employs a two-step approach for establishing a violation of equality of arms. Firstly, the lack of procedural or institutional balance is established, and secondly, the effect of this imbalance on the fairness of the proceedings as a whole is examined. In Lanz v. Austria, ${ }^{85}$ the ECtHR stated that "the principle of equality of arms does not depend on further, quantifiable unfairness flowing from a procedural inequality", which seemed to imply that any inequality to the detriment of the defence would lead to a violation of the fair trial requirement, whether or not the defence actually suffered any prejudice. ${ }^{86}$ In other cases, however, the Court has stressed the prejudice suffered by the defence and in the absence of which no violation of the principle was found ${ }^{87}$ Thus, after establishing the imbalance between the parties, the effect of this inequality on the fairness of the proceedings is assessed. In this regard, some 'disadvantage' is taken into account. If inequality is compensated in some way during the proceedings, no disadvantage can be suffered. In Kremzow v. Austria the ECtHR stated that single and minor inequalities during the procedure ${ }^{88}$ could be outweighed by the general fairness of the proceedings. ${ }^{89} \mathrm{~A}$ contrario it could be argued that, indeed, "the cumulative effect of defects in themselves of minor importance" could account for a violation of the principle of equality of arms. ${ }^{90}$

As to the role of the appearances, the ECtHR found in the Borgers case a violation of Article 6(1) " ... having regard to the requirements of the rights of the defence and of the principle of the equality of arms and to the role of appearances in

85 ECtHR, Lanz v. Austria, App. No. 24430/94, Judgment of 31 January 2002, par. 58. See also ECtHR, Bulut v. Austria, App. No. 17358/90, Judgment of 22 February 1996, par. 49.

86 See also the first criminal case that introduced equality of arms, where the European Commission held that the fact that a party was given an opportunity to influence the court, which the other party lacked, amounted to a violation of equality of arms. There was no need to show actual prejudice. ECtHR, Pataki and Dunshirn v. Austria, App. Nos. 596/59 and 789/60, report of 28 March 1963, Yearbook volume 6, 1963 p. 732: "Even on the assumption ... that the Public Prosecutor did not play an active role at this stage of the proceedings, the very fact that he was present and thereby had the opportunity of influencing the members of the Court, without the accused or his counsel having any similar opportunities or any possibility of contesting any statements made by the Prosecutor, constitutes an inequality which ... is incompatible with the notion of a fair trial.

87 ECtHR, Kremzow v. Austria, App. No. 12350/86, Judgment of 21 September 1993, par. 75; ECtHR, GB v. France, App. No. 44069/98, Judgment of 2 October 2001 paras. 64-70; ECtHR, Solakov v. Former Yugoslav Republic of Macedonia, App. No. 47023/99, Judgment of 31 October 2001, par. 62; ECtHR, Kuopila v. Finland, App. No. 27752/95, Judgment of 27 April 2000, par. 35; ECtHR, Ernst and others v. Belgium, App. No. 33400/96, Judgment of 15 July 2003, par. 61.

88 The accused had complained e.g. of the absence of time-limits for the submission of the Attorney General's croquis; of the fact that (only) the Attorney General was informed of the name of the reporting judge; etc.

89 ECtHR, Kremzow v. Austria, App. No. 12350/86, Judgment of 21 September, par. 75.

90 Kolb, 2000, p. 358. 
determining whether they have been complied with ... . ${ }^{91}$ Appearances are referred to in connection with "the increased sensitivity of the public to the fair administration of justice." ${ }^{2}$ The Court did not elaborate on the role these appearances should play in the determination of the violation of equality of arms. Arguably, these can play a role in examining the fairness of the proceedings as a whole (step 2). Appearances of inequality then function as an aggravating factor mitigating the need to ascertain the 'actual' disadvantage suffered. In other words, the stronger the appearance that a certain institutional or procedural inequality violates equality of arms, the less need there is for the defence to show that it suffered actual prejudice arising from that inequality.

A two-step examination is also used by the HRC. For the purposes of admissibility, the petitioner has to sufficiently substantiate, by presenting a prima facie case, his complaint by indicating the disadvantage suffered by him. ${ }^{93}$ After establishing inequality and, thus, a possible violation of Article 14, the Committee looks at the reasons provided by the state for that particular procedural inequality. If the state does not meet its burden of proof and provide for reasonable and objective grounds for that inequality not entailing an actual disadvantage or other unfairness to the defendant, a violation of the principles of equality before the courts and a fair trial, as contained in Article 14(1), will be found. ${ }^{94}$ To some extent, this reversal of the onus of proof seems to differentiate the ECtHR and the HRC approaches. After a finding of inequality, the ECtHR examines the effect of this inequality on the fairness of the proceedings as a whole. The onus of proof thus lies with the applicant to show that the suffered procedural inequality led to prejudice and, thus, to unfairness in the proceedings. The approach of the HRC seems to differ in that as soon as the applicant has satisfied his

91 ECtHR, Borgers v. Belgium, App. No. 12005/86, Judgment of 30 October 1991, par. 29 [emphasis added].

92 ECtHR, Borgers v. Belgium, App. No. 12005/86, Judgment of 30 October 1991, par. 24.

93 E.g. HRC, José Antonio Martínez Muñoz v. Spain, Comm. No. 1006/2001, Views of 30 October 2003, par. 6.3 .

94 HRC, Dudko v. Australia, Comm. No. 1347/2005, Views of 23 July 2007, par. 7.4: “The Committee observes that when a defendant is not given an opportunity equal to that of the State party in the adjudication of a hearing bearing on the determination of a criminal charge, the principles of fairness and equality are engaged. It is for the State party to show that any procedural inequality was based on reasonable and objective grounds, not entailing actual disadvantage or other unfairness to the author. In the present case, the State party has offered no reason, nor does the file reveal any plausible reason, why it would be permissible to have counsel for the State take part in the hearing in the absence of the unrepresented defendant, of why an unrepresented defendant in detention should be treated more unfavourably than unrepresented defendant not in detention who can participate in the proceedings. Accordingly, the Committee concludes that a violation of the guarantee of equality before the courts in Article 14, paragraph 1, occurred in the circumstances of the case." See also e.g.: HRC, Äärelä and Näkkäläjärvi v. Finland, Comm. No. 779/97, Views of 24 October 2001, par. 7.4, HRC, Jansen-Gielen v. Netherlands, Comm. No. 846/99, Views of 3 April 2001, par. 8.2. 
initial onus of proof for the purposes of the admissibility of his complaint (Art. 2 Optional Protocol to ICCPR), by convincingly presenting a procedural inequality, it is up to the state to substantiate that this inequality was not only justifiable, but that it did not disadvantage the accused. ${ }^{95}$ In theory, this division of the burden seems to be justified. If the applicant can sufficiently substantiate that he has suffered inequality, it is up to the state to provide an explanation for this. Practically, there seems to be little effect to this. The ECtHR also takes into account the explanations presented by the state that serve as a justification for a certain approach leading to inequality.

Although the approaches of the HRC and ECtHR differ somewhat at face value, the net result of their interpretation is comparable: any procedural inequality will only be considered to violate the principle of equality of arms if there is actual prejudice to the accused arising from the procedural inequality. Before considering the scope of application of equality of arms, and the principle's relationship to other rights and principles, some limited reflection on the concept of 'equality' seems appropriate for a better understanding of the function of the principle and the difference in its interpretation and application within the different stages of criminal proceedings.

\subsubsection{Considerations of 'equality'}

According to the HRC, equality of arms follows from the more general principle of equality before courts and tribunals guaranteed under Article 14(1). ${ }^{96}$ In a criminal

95 E.g. HRC, Jessop v. New Zealand, Communication No. 1758/2008, Views of 29 March 2011, par. 8.6: “ ... The Committee recalls that Article 14, paragraph 3 (e), guarantees the right of accused persons to examine, or have examined, the witnesses against them and to obtain the attendance and examination of witnesses on their behalf under the same conditions as witnesses against them. [Footnote 25, See the Committee's General Comment No. 32, supra, note 86, par. 39.] The Committee observes that a reading of the victim's statement to the jury could have fallen short of the requirement, under Article 14, paragraph 3 (e), to be given a proper opportunity to question and challenge witnesses, a fortiori where their evidence is of direct relevance for the resolution of the case, and where the charges faced are of such serious nature. However, in the particular circumstances of the case, the fact that the author, as claimed by the State party and uncontested by the author, was convicted based on her own confession and without the victim's statement having been read to the jury, does not support a finding of violation of the principle of equality of arms under Article 14, paragraph 3(e)."

96 General Comment No. 32, 23 August 2007, par. 8: "The right to equality before courts and tribunals, in general terms, guarantees, in addition to the principles mentioned in the second sentence of Article 14, paragraph 1, those of equal access and equality of arms, and ensures that the parties to the proceedings in question are treated without any discrimination". Equality before courts and tribunals in turn is a lex specialis of the general equality before the law under Article 26 ICCPR. Although Article 26 does not contain a limitation clause, the HRC uses the general criteria of "reasonable and objective grounds" for justifying inequality. HRC, Joseph Kavanagh v. Ireland, Comm. No. 819/1998, Views of 4 April 2001, par. 10.2: "Under Article 26, the State party is therefore required to demonstrate that such a decision to try a person by another procedure was based upon reasonable and objective grounds". The finding of the failure on the part of the State Party to demonstrate such 
law setting, the conceptions of 'equality' may acquire a different meaning. Equality before courts implies the non-discrimination of similarly situated persons, while the principle of equality of arms governs the relationship of persons not similarly situated and with opposing interests. ${ }^{97}$ In this latter relationship, a symmetrical approach to equality is principally unattainable in the inherently asymmetrical criminal process where the parties have differing roles and rights. Equivalence might provide a more appropriate terminology. However, equivalence implies 'sameness'. And the focus on the conception of equality as sameness can result in the systemic negligence of the differences that might constitute important considerations for the achievement of preset goals. ${ }^{98}$ Theories of equality are usually linked to the concept of justice; through their role as principles of justice the equality principles receive their normative significance and a theory of justice cannot be explained without the principles of equality. The basic formal understanding of equality, namely that the same cases should be treated alike, is further specified by the proportionality principle which stipulates a relative equality. Different substantive principles of equality try to identify the specific conception of equality: the equality of what?

The meaning to equality of arms given by the ECtHR provides for a reasonable opportunity that each party must have to present its case. Equality of opportunity forms a minimum egalitarian conception of distributive justice. However, according to the resource equality principle, represented by Rawls and Dworkin, equal opportunity is not sufficient because it does not compensate for unequal innate gifts. ${ }^{99}$ By its very nature, a criminal process begins with a fundamental inequality between the parties. ${ }^{100}$ The individual finds himself at the disposal and under the power of the

"reasonable and objective grounds" leads to the conclusion that the general right to equality has been violated and thus renders the investigation into the violation of the more specific equality before the courts and tribunals contained in Article 14(1) superfluous. See Joseph Kavanagh v. Ireland, Comm. No. 819/1998, Views of 4 April 2001, par. 10.3.

97 Trechsel 2005, p. 95. See also: ICTY, Delalic et al., Judgment, IT-96-21-A, A. Ch., 20 February 2001, par. 605: "This provision [Article 21(1)] reflects the corresponding guarantee of equality before the law found in many international instruments, including the 1948 Universal Declaration of Human Rights, the 1966 International Covenant on Civil and Political Rights, Additional Protocol I to the Geneva Conventions, 1021 and the Rome Statute of the International Criminal Court. All these instruments provide for a right to equality before the law, which is central to the principle of the due process of law. The provisions reflect a firmly established principle of international law of equality before the law, which encompasses the requirement that there should be no discrimination in the enforcement or application of the law. Thus Article 21 and the principle it embodies prohibits discrimination in the application of the law based on impermissible motives" [footnote reference omitted].

98 The reference to sameness and the difference conceptualizing equality is taken from VAN LEEUWEN, 2010, pp. 10-11.

99 See RAWLs, 1971 and Dworkin, 2000.

100 Individual opinion by Nisuke Ando (dissenting), HRC, Lloydell Richards v. Jamaica, Comm. No. 535/1993, Views of 31 March 1997: “ ... the purpose of a criminal trial is to ascertain what actually 
state. The (procedural) advantage of the prosecutor over the accused at the beginning of the trial, it can be argued, must be fairly distributed. The HRC speaks of the same procedural rights that must be provided to all the parties and any justifiable distinction may not disadvantage the accused. ${ }^{101}$ The 'special' position of the accused is already included in this understanding, as it does not speak of the disadvantage to other parties in the proceedings. The ECtHR does not make this distinction, implying that any disadvantage to parties other than the accused would lead to inequality and, thus, to a violation of the fair trial requirement. This leads to the question of the relevant parties in a criminal trial among which the principle applies: equality among whom?

Both the ECtHR and the HRC talk about parties to the proceedings ("each party"/"all the parties"). Traditional liberal models of the criminal process perceive the public prosecutor and the defendant as the parties in a criminal process. In fact, many debates on and reforms of the form of criminal proceedings characterized nineteenth century Continental Europe, which led to the acceptance of "accusatorial trinity:" the prosecutor, the defendant and the judge. ${ }^{102}$

In the case law of ECtHR an understanding of the adversary 'parties' has evolved over time. Particularly the institution of a neutral Attorney General that can be found in several civil law systems has led to an important change of perspective in that regard. In Delcourt v. Belgium, the Court held that the involvement of the Advocat Général, who is a member of the Public Prosecutor's office, in the appeal proceedings could not be regarded as an "adversary" of the applicant. ${ }^{103}$ The deliberations of the

took place in the case at issue, that is, to find 'true facts' of the case, on which conviction and sentence should be based. Of course, 'true facts' as submitted by the defendant may differ from 'true facts' as submitted by the prosecution, and since defendants are generally at a disadvantage compared to the prosecution, various procedural guarantees exist to secure a 'fair trial'. The requirement of equality of arms, rules of evidence, control of the proceedings by independent and impartial judges, deliberation and decision by neutral juries, and the system of appeals are all part of these guarantees".

101 This, however, would imply a very formalistic concept. How would equality of rights between the accused and prosecution ever be possible in view of the very nature of a criminal process and the role of the parties. See also Dworkin, 1977, p. 100: “ ... geometry of a criminal prosecution, which does not set opposing rights in a case against one another, differs from the standard civil case in which the rights thesis upholds symmetrically". Article 14 ICCPR "guarantees procedural equality but cannot be interpreted as guaranteeing equality of results or absence of error on the part of the competent tribunal". See HRC, B.d.B. et al. v. The Netherlands, Comm. No. 273/1988, Inadmissibility decision of 2 May 1989, par. 6.4.

102 Summers, 2007, p. 27, citing VARGHA, 1879, p. 288: "a growing consensus as to the idea that the trials should be impartially adjudicated and that both the defense and the prosecution ought to have the opportunity to convince the court of their position, a constellation that Vargha rather poetically refers to as the 'accusatorial trinity'...."

103 ECtHR, Delcourt v. Belgium, App. No. 2689/65, Judgment of 17 January 1970, paras. 33-35. The Court considered the Advocat General to be impartial and independent and merely assisting the 
Court clearly show its attempt to reconcile long-developed domestic practice with the newly established human rights standards enshrined in Article 6 of the ECHR. ${ }^{104}$

However, some 20 years later, the Court changed its opinion. In Borgers v. Belgium, the Court stated that the rights of the defence and the principle of equality of arms had "undergone a considerable evolution in the Court's case-law, notably in respect of the importance attached to appearances and to the increased sensitivity of the public to the fair administration of justice." 105 Although the objectivity with which the Procureur Général's department discharged his functions cannot be questioned due to the political consensus in Belgium, the opinion of this department "cannot be regarded as neutral from the point of view of the parties to the cassation proceedings." 106 The restriction of the rights of the accused by not allowing him to present his submissions to the Avocat Général's views and the furtherance of the inequality by the Avocat Général's participation in the court's deliberations are incompatible with Article 6(1) ECHR. ${ }^{107}$ Whereas in Delcourt, the focus of the Court's deliberations was on the fairness of the Belgian system with regard to the Avocat Général; in the Borgers case, the focus switched to the explicit attention to the rights of the accused and the perception of adversarial parties. This may also explain the explicit mention of the negative submissions (concerning the accused's appeal) by the Avocat Général in Borgers, ${ }^{108}$ while no such mention was made in Delcourt. The Borgers judgment seems to tighten the "perception of fairness in Article 6 as reliant on procedural systems involving two opposing parties and an impartial judge."109 While this seems like a radical break with the Court's own case law, according to

Court to supervise the lawfulness of the decisions being contended and ensuring the uniformity of judicial precedent. In the case of Ofner and Hopfinger v. Austria, the Commission considered the involvement of the Attorney General who had not influenced the decision-making process in any way and was, thus, not prejudicial to the accused. Ofner and Hopfinger v. Austria, App. No. 524/59 and 617/59, report of 23 November 1962, Yearbook volume 6, 1963, p. 680. However, in Pataki and Dunshirn v. Austria, the Commission considered the Public Prosecutor as the 'opposing party' even though he "did not have an active role" in the proceedings before the Court of Appeal, where the accused or his counsel were denied the opportunity to participate. Pataki and Dunshirn v. Austria, App. No. 596/59 and 789/60, report of 28 March 1963, Yearbook volume 6, 1963, p. 732.

104 ECtHR, Delcourt v. Belgium, App. No. 2689/65, Judgment of 17 January 1970, par. 36: “ ... the system now challenged dates back for more than a century and a half. While it is true that the long standing of a national legal rule cannot justify a failure to comply with the present requirements of international law, it may under certain conditions provide supporting evidence that there has been no such failure. The Court is of the opinion that this is the case here."

105 ECtHR, Borgers v. Belgium, App. No. 12005/86, Judgment of 30 October 1991, par. 24.

106 ECtHR, Borgers v. Belgium, App. No. 12005/86, Judgment of 30 October 1991, par. 26. When the Procureur Général's office provides an opinion in an individual case concerning whether the appeal should be allowed or dismissed, "the official of the department becomes objectively speaking [the accused's] ally or his opponent."

107 Several judges strongly dissented from the majority ruling.

108 ECtHR, Borgers v. Belgium, App. No. 12005/86, Judgment of 30 October 1991, par. 27.

109 Summers, 2007, p. 109. 
Summers, "the seeds of the Borgers decision were already shown in the reforms of the nineteenth century." 110 This view is strengthened by the Court's frequent reference to the principle of adversarial proceedings in connection with equality of arms: "[t]he principle of equality of arms is only one feature of the wider concept of a fair trial, which also includes the fundamental right that criminal proceedings should be adversarial" 111 and "it is a fundamental aspect of the right to a fair trial that criminal proceedings, including elements of such proceedings which relate to procedure, should be adversarial and that there should be equality of arms between the prosecution and the defence." 112

Another important development that has influenced the understanding of 'parties' in a criminal trial is connected to newly arisen perceptions of criminal processes based on a different conception of victims' rights. ${ }^{113}$ Many justice systems, particularly Continental European systems, have incorporated these new perceptions and have developed some kind of participatory model for victims in the criminal process. The parties or participants in a criminal process can thus be considered to be the prosecution, defence and a victim participant. ${ }^{114}$ In the Perez case, the ECtHR held that " ... a civil-party victim ... enjoys the benefit of being a party to the criminal trial ...",${ }^{115}$ and that a civil party complaint falls within the scope of Article 6(1) of the ECHR. ${ }^{116}$ This obviously changes the perception of the 'adversarial trinity' and introduces many questions as to the relationship of the accused to the civil party and

110 Summers, 2007, p. 110.

111 ECtHR, Brandstetter v. Austria, App. Nos. 1170/84, 12876/87, 13468/87, Judgment of 28 August 1991, par. 66.; ECtHR, Ruiz-Mateos v. Spain, App. No. 12952/87, Judgment of 23 June 1993, par. 63; ECtHR, Belziuk v. Poland, App. No. 23103/93, Judgment of 25 March 1998, par. 37.

112 ECtHR, Rowe and Davis v. United Kingdom, App. No. 28901/95, Judgment of 16 February 2000, par. 60.

113 See e.g. RoAcH, 1999, pp. 671-716, where he criticizes Packer's theories as "becoming out of date" and introduces the punitive and non-punitive model of victims' rights.

114 A suggestion that victims are or should be on the side of the public prosecutor was rejected by the ECtHR: “ ... A civil party could not be regarded as the opponent of the prosecution, nor necessarily as its ally, given that their respective roles and purposes were clearly distinct." (ECtHR, Berger v. France, App. No. 48221/99, Judgment of 3 December 2002, par. 38.).

115 ECtHR, Perez v. France, App. No. 47287/99, Judgment of 12 February 2004, par. 61.

116 ECtHR, Perez v. France, App. No. 47287/99, Judgment of 12 February 2004, par. 63: “ ... all joined civil parties are in their own right both parties to the proceedings for the defence of their civil interests and entitled to claim compensation at any stage in those proceedings (par. 63). "The Court concludes that a civil-party complaint comes within the scope of Article 6 par. 1 of the Convention, except in case of "private revenge" or an action popularis, to which the Convention does not confer any right. The right to have third parties prosecuted or sentenced for a criminal offence cannot be asserted independently: it must be indissociable from the victim's exercise of a right to bring civil proceedings in domestic law, even if only to secure symbolic reparation or to protect a civil right such as the right to a "good reputation" (paras. 70-71)." 
the application of equality of arms. The human rights courts have not yet discussed this issue.

\subsection{The CONNECTION TO OTHER RIGHTS}

As explained in Chapter 1, the principle of equality of arms does not prescribe specific rights but is instructive for the form of criminal process and seeks to ensure the application of rights in a fair and balanced manner. The idea of a 'fair balance' is thus essential in understanding the scope of this principle. ${ }^{117}$ Equality of arms is closely linked to many other aspects of the right to a fair trial and it emerges, explicitly or implicitly, in many different contexts (at all stages of the criminal process):

In criminal trials, where the prosecution has all the machinery of the state behind it, the principle of equality of arms is an essential guarantee of the right to defend oneself. The principle of equality of arms ensures that the defence has a reasonable opportunity to prepare and present its case on a footing equal to that of the prosecution. Its requirements include the right to adequate time and facilities to prepare a defence, including disclosure by the prosecution of material information. Its requirements also include the right to legal counsel, the right to call and examine witnesses and the right to be present at the trial. This principle would be violated, for example, if the accused was not given access to information necessary for the preparation of the defence, if the accused was denied access to expert witnesses, or if the accused was excluded from an appeal hearing where the prosecutor was present. ${ }^{118}$

Whereas the connection between the principle of equality of arms and the more overarching principle of fair trial was considered above, this section focuses on the connection between equality of arms and other principles underlying fair trial and the more concrete rights of the accused. This connection is central to understanding the function of equality of arms; however, an exhaustive examination of all the aspects of the right to a fair trial and the minimum rights of the accused is not intended. Anticipating the discussion within the framework of international criminal proceedings, particular attention is given to the right to adversarial proceedings, the right to adequate time and facilities to prepare a defence and the right to examine witnesses under the same conditions. As mentioned in Chapter 1, one important element of the principle of equality of arms, namely the right to legal assistance (to the extent it relates to issues on assignment of legal counsel) is not covered by this study. ${ }^{119}$

117 ECtHR, Gorraiz Lizzarraga and others v. Spain, App. No. 62543/00, Judgment of 27 April 2004, par. 56: "Equality of arms principle does not define specific rights but implies a balance of fairness between parties: a 'fair balance'."

118 ECtHR, Foucher v. France, App. No. 22209/93, Judgment of 18 March 1997.

119 See for a recent discussion of effective legal assistance in international criminal law TEMMINCK Tuinstra, 2009. 


\subsubsection{The principle of an adversarial process}

There exists a special and indeed inherent connection between the principles of equality of arms and adversarial process. As mentioned, the principle of equality of arms seems to have an innate connection with the adversarial model of the criminal process. ${ }^{120}$ In fact, equality of arms constitutes a necessary condition for proceedings to be called adversarial in its traditional meaning associated with common law criminal justice systems. The former principle is thus subsumed by the latter. However, as argued above, the principle of adversarial proceedings, as developed in human rights case law, do not necessarily parallel the understanding of an adversarial procedural model as traditionally developed on the national level.

From the human rights perspective, both principles are considered to be fundamental aspects of the right to a fair trial and are increasingly mentioned together in the case law of human rights bodies. Standardized references include: "[t]he Committee recalls its case law to the effect that the concept of a fair trial within the meaning of Article 14, paragraph 1, of the Covenant also includes other elements, including respect for the principles of 'equality of arms' and the right to adversarial proceedings" ${ }^{121}$ And, "it is a fundamental aspect of the right to a fair trial that criminal proceedings, including elements of such proceedings which relate to procedure, should be adversarial and that there should be equality of arms between the prosecution and the defence"; 122 or "[t]he principle of equality of arms is only one feature of the wider concept of a fair trial, which also includes the fundamental right that criminal proceedings should be adversarial." 123

Although the definitions imply an autonomous and independent meaning of both principles that are to be considered on an equal footing as sub-principles of the right to a fair trial, the common reference to both principles together does not make it easier to uncover the exact relationship between them. ${ }^{124}$ Moreover, this relationship has been obscured in the case law of ECtHR when it considered that equality of arms, in principle, implies an adversarial trial. ${ }^{125}$ On other occasions, the formulation used

120 See Chapter 1.

121 HRC, Salvador Martines Puertas v. Spain, Communication 1183/2003, Inadmissibility decision of 27 March 2006, par. 6.4.

122 ECtHR, Rowe and Davis v. United Kingdom, App. No. 28901/95, par. 60.

123 ECtHR, Brandstetter v. Austria, App. Nos. 1170/84, 12876/87, 13468/87, Judgment of 28 August 1991, Series A No. 211, par. 66.

124 Summers, 2007, p. 111; TreChSEL, 2005, p. 90.

125 ECtHR, Zhuk v. Ukraine, App. No. 45783/05, Judgment of 21 October 2010, par. 25: "The Court reiterates that the principle of equality of arms - one of the elements of the broader concept of a fair trial - requires each party to be given a reasonable opportunity to present his case under conditions that do not place him at a substantial disadvantage vis-à-vis his opponent. This implies, in principle, the opportunity for the parties to a trial to have knowledge of and comment on all evidence adduced or observations filed, even by an independent member of the national legal service, with a view to influencing the court's decision." 
by the Court implies a subordinate relationship of equality of arms to the principle of adversarial trial. ${ }^{126}$ However, the roles of both notions can be distinguished, although in a criminal case they will often come together. ${ }^{127}$

According to the standard definition provided by the ECtHR, the right to an adversarial trial "means in a criminal case, that both prosecution and defence must be given the opportunity to have knowledge of and comment on the observations filed and the evidence adduced by the other party." ${ }^{128}$ In other cases, this definition has been somewhat expanded: "the opportunity for the parties to a criminal or civil trial to have knowledge of and comment on all evidence adduced or observations filed, even by an independent member of the national legal service, with a view to influencing the court's decision." 129 The difference in approach compared to other cases, where the Court considered a violation of equality of arms in the context of the defence's inability to challenge the prosecution's or the Avocat Général's submissions, is not immediately clear. ${ }^{130}$

The difference between the concepts lies in the relative nature of equality: when both parties are denied something (presenting submissions, evidence, or attending a hearing) there can be no violation of equality of arms. ${ }^{131}$ The comparative element of equality of arms implies that no disadvantage in relation to the other party is allowed. A contrario, an equal disadvantage to both parties formally preserves equality of arms. ${ }^{132}$

126 ECtHR, Garcia Alva v. Germany, App. No. 23541/94, Judgment of 13 February 2001, par. 39: “A court examining an appeal against detention must provide guarantees of a judicial procedure. The proceedings must be adversarial and must always ensure "equality of arms" between the parties, the prosecutor and the detained person. Equality of arms is not ensured if counsel is denied access to those documents in the investigation file which are essential in order effectively to challenge the lawfulness of his client's detention. In the case of a person whose detention falls within the ambit of Article $5 \S 1$ (c), a hearing is required .... These requirements are derived from the right to an adversarial trial as laid down in Article 6 of the Convention, which means, in a criminal case, that both the prosecution and the defence must be given the opportunity to have knowledge of and comment on the observations filed and the evidence adduced by the other party."

127 Summers, 2007, p. 111.

128 ECtHR, Belziuk v. Poland, Judgment of 25 March 1998, par. 37. See inter alia: ECtHR, Brandstetter v. Austria, App. Nos. 1170/84, 12876/87, 13468/87, Judgment of 28 August 1991, paras. 66-67; ECtHR, Rowe and Davis v. United Kingdom, App. No. 28901/95, Judgment of 16 February 2000.

129 ECtHR, Reinhardt and Slimane-Kaïd v. France, App. No. 23043/93 and 22921/93, Judgment of 31 March 1998, par. 103. See also Summers, 2007, p. 111, footnotes 47 and 48 for other case references.

130 E.g. Pataki and Dunshirn v. Austria, App. No. 596/59 and 789/60, report of 28 March 1963, Yearbook volume 6, 1963, p. 718; ECtHR, Borgers v. Belgium, App. No. 12005/86, Judgment of 30 October 1991, paras. 24-27.

131 ECtHR, Jasper v. United Kingdom, App. No. 27052/95 Judgment of 16 February 2000, par. 57. See also the case law references in TRECHSEL, 2005, pp. 97-98, and footnote 110.

132 ECtHR, Monnell and Morris v. United Kingdom, App. No. 9562/81 and 9818/82, Judgment of 2 March 1987, par. 62: "To begin with, the principle of equality of arms, inherent in the notion of fairness under Article $6 \S 1$ (art. 6-1) (see the above-mentioned Delcourt judgment, Series A No. 11, 
In relation to the principle of adversarial procedure, Summers considers that it "encompasses two main facets: first the requirement that the accused be present and, secondly, the requirement that the defence be able to challenge the submissions and observations of the prosecution and to lead its own evidence." ${ }^{133}$ Both facets are also unequivocally linked to the principle of equality of arms. It seems that a strict distinction is impossible to make in abstracto. In addition, the human rights case law has not paid particular attention to the distinction between both principles. Interestingly, in the context of the right to attend certain proceedings in person, there has been some case law that sheds some light on this distinction.

\subsubsection{The right to be present in person at proceedings}

As considered above, the ECtHR has found that when both the prosecution and the defence have been denied an opportunity to be present at a hearing or to file submissions, no inequality of arms arises. However, the Court considered that equality of arms is only one feature of the wider concept of a fair trial, and, in particular, "even in the absence of a prosecuting party, a trial would not be fair if it took place in such conditions as to put the accused unfairly at a disadvantage." 134 From this, one may assume that this 'disadvantage' falls outside the scope of application of equality of arms and is not directly connected or measured to the adverse party. Being connected to the general notion of a fair trial, this 'disadvantage' seems to relate to the opportunity to mount a meaningful defence in the most general sense of this term.

In Monnell and Morris v. United Kingdom, the ECtHR, after establishing formal equality of arms in that both parties were not represented before either the single judge or the full Court of Appeal, continued to consider whether there were other elements present that denied the accused a fair trial. In the circumstances of the case, the ECtHR considered that the ability to present only written submissions to the Court of Appeal did not violate Article 6(1). ${ }^{135}$ Although the Court did not mention the principle of adversarial trial in this case, it seems possible to find a violation of this principle in the absence of a violation of equality of arms. ${ }^{136}$ In this

p. $15, \S 28)$, was respected in that the prosecution, like the two accused, was not represented before either the single judge or the full Court of Appeal."

133 Summers, 2007, p. 113.

134 ECtHR, Monnell and Morris v. United Kingdom, App. No. 9562/81 and 9818/82, Judgment of 2 March 1987, par. 62, referring to ECtHR, Delcourt v. Belgium, App. No. 2689/65, Judgment of 17 January 1970, paras. 28, 34.

135 ECtHR, Monnell and Morris v. United Kingdom, App. No. 9562/81 and 9818/82, Judgment of 2 March 1987, paras. 63-70.

136 Cf. ECtHR, Juričić v. Croatia, App. No. 58222/09, Judgment of 26 July 2011, par. 73: "although the Court has not found a breach of the principle of equality of arms (see the previous paragraph), it nevertheless has to examine whether the same set of facts breached the applicant's right to adversarial proceedings." 
regard, in the case of Ekbatani v. Sweden, the ECtHR found a violation of Article 6(1) where the applicant was denied a public hearing on appeal, which was instead held on the basis of written submissions only. ${ }^{137}$ Here again, the principle of equality of arms was observed when neither the prosecution nor the accused were allowed to appear in person on appeal and both were given an equal opportunity to present their cases in writing. ${ }^{138}$ However, emphasizing the appellate court's duty to make a full assessment of the question of the accused's guilt, the ECtHR found that "that question could not, as a matter of fair trial, have been properly determined without a direct assessment of the evidence given in person by the applicant." ${ }^{139}$ No mention of adversarial proceedings is made in this case either. The same conclusion was reached in Kremzow v. Austria, where the accused was denied the opportunity to be present at the appeal sentence hearing. The ECtHR considered that "given the gravity of what was at stake for the applicant, he ought to have been able 'to defend himself in person' as required by Article 6 para. 3 (c) (art. 6-3-c) and that the State was under a positive duty, notwithstanding his failure to make a request, to ensure his presence in court in such circumstances." ${ }^{140}$

Interestingly, in Kampanis v. Greece, the Court found a breach of the principle of equality of arms only, when the applicant was not allowed to be present at the hearing in relation to his application for provisional release. ${ }^{141}$ It is not entirely clear why no violation of the right to adversarial proceedings was considered by the Court, when "the applicant had not seen the prosecutor's submissions and had consequently not been able to reply to them either in writing or orally." ${ }_{142}$ In relation to the state's argument that the prosecutor was not a party to the proceedings but merely an impartial organ responsible for assisting the court in finding the truth, the Court emphasized the fact that a prosecutor "essentially represents the interest of society in criminal proceedings" and that in this case the prosecution argued that the detention of the applicant should be prolonged. ${ }^{143}$ In light of the fact that the case concerned a long pre-trial detention, up to the maximum allowed by the Constitution, the Court found "that to ensure equality of arms it was necessary to give the applicant the opportunity to appear at the same time as the prosecutor so that he could reply to

137 ECtHR, Ekbatani v. Sweden, App. No. 10563/83, Judgment of 26 May 1988, par. 32-33.

138 ECtHR, Ekbatani v. Sweden, App. No. 10563/83, Judgment of 26 May 1988, par. 30.

139 ECtHR, Ekbatani v. Sweden, App. No. 10563/83, Judgment of 26 May 1988, par. 32.

140 ECtHR, Kremzow v. Austria, App. No. 12350/86, Judgment of 21 September 1993.

141 ECtHR, Kampanis v. Greece, App. No. 17977/91, Judgment of 13 July 1995, par. 58. The Court found a breach of equality of arms as the applicant had been detained for a long period of time (up to the maximum permitted) and should have been given an opportunity to appear in person and to reply to the arguments of the prosecutor, in view of equality of arms.

142 ECtHR, Kampanis v. Greece, App. No. 17977/91, Judgment of 13 July 1995, par. 54.

143 ECtHR, Kampanis v. Greece, App. No. 17977/91, Judgment of 13 July 1995, paras. 55-56. 
his arguments" so as to "afford the applicant an adequate opportunity to participate in proceedings ...." 144

However, in other cases where the accused was not allowed to be present at a hearing, contrary to the prosecution, the Court found a violation of both the principle of equality of arms and the right to adversarial proceedings. For example, in the Belziuk v. Poland case, the public prosecutor, "as the guardian of the public interest", was present on appeal and made submissions which were unfavourable to the applicant while the applicant was not granted leave to appear. The fact that the prosecutor made submissions directed at having the applicant's appeal rejected placed him in the traditional role of a prosecuting authority. ${ }^{145}$ The Court held that Article 6(1) had been violated because the principle of equality of arms and the right to adversarial proceedings required that the applicant be allowed to attend the hearing. ${ }^{146}$

The same line of reasoning can be detected in the case law of the HRC. In the case of Wolf $v$. Panama the HRC emphasized the link between equality of arms and the right to be present at proceedings in general terms when it considered that:

the concept of a 'fair trial' within the meaning of Article 14, paragraph I, must be interpreted as requiring a number of conditions, such as equality of arms and respect for the principle of adversary proceedings. These requirements are not respected where, as in the present case, the accused is denied the opportunity to personally attend the proceedings, or where he is unable to properly instruct his legal representative. ${ }^{147}$

In addition, the Committee stressed that "where the accused is not served a properly motivated indictment," the principle of equality of arms is violated. ${ }^{148}$ Also in Dudko v. Australia, the HRC reiterated its previous jurisprudence that an oral hearing is not, in principle, required for appeal proceedings. However, when the appellate

144 ECtHR, Kampanis v. Greece, App. No. 17977/91, Judgment of 13 July 1995, par. 58.

145 ECtHR, Belziuk v. Poland, App. No. 23103/93, Judgment of 25 March 1998, par. 39.

146 ECtHR, Belziuk v. Poland, App. No. 23103/93, Judgment of 25 March 1998, paras. 39-40. See also ECtHR, Reinhardt and Slimane-Kaïd v. France, App. No. 23043/93 and 22921/93, Judgment of 31 March 1998, par. 103: "The fact that the reporting judge's file, including his report and one or more draft judgments, had been communicated to the advocate-general whereas the applicants could only be informed of the recommendations of the report meant that there had been inequality of arms between the applicants and the advocate-general. The imbalance had been accentuated by the fact that the advocate-general's submissions had not been communicated to Mrs Reinhardt and Mr Slimane-Kaï. The right to adversarial proceedings meant in principle "the opportunity for the parties to a criminal or civil trial to have knowledge of and comment on all evidence adduced or observations filed, even by an independent member of the national legal service, with a view to influencing the court's decision" (see the report, paragraph 31). The parties should in addition have a "genuine opportunity" (ibid.) to comment on the advocate-general's submissions. In the present case, however, if the applicants' lawyers had been present at the hearing they would only have been able to make an impromptu reply. There had therefore been a breach of Article 6."

147 HRC, Dieter Wolf v. Panama, Comm. No. 289/1988, Views of 26 March 1992, par. 6.6.

148 HRC, Dieter Wolf v. Panama, Comm. No. 289/1988, Views of 26 March 1992, par. 6.6. 
court decides to conduct a hearing on appeal, the absence of the accused in those proceedings violates "the guarantee of equality before the courts of Article 14(1) ICCPR."'149

What is clear from the above discussion is that the right to be present has been linked to several other rights and principles under the general notion of the right to a fair trial or the minimum rights accorded to the accused. Summers considers that the specific link of the right to be heard with the principle of equality of arms is "problematic in that ... the principle serves only to ensure that the accused receive the same procedural opportunities as the prosecution." ${ }^{50}$ When both the prosecution and the defendant are absent, equality of arms is preserved. This, however, does not imply that the proceedings were fair as far as the accused was concerned. Indeed, linking the right to be heard to equality of arms would only be problematic when the former would be exhausted by the latter. This formalistic approach to the right to be heard, implying a mere comparison between the opportunities afforded to the parties, cannot in fact be considered as affording the accused the best protection of his right to a fair trial. However, the indiscriminate approach to the right to be present and the right to be heard, linking it to the principles of equality of arms and the right to adversarial proceedings, does not advance "a clear elucidation" of the principles involved. ${ }^{151}$ With regard to equality of arms, only a formalistic understanding of its link to the right to be heard transpires: if the prosecution was present and the accused was not, there is a violation of equality of arms.

\subsubsection{The right to challenge an adversary's observations}

Another element of the right to adversarial proceedings is the right to challenge the other party's observations. Instructive is the Nideröst-Huber v. Switzerland case where the observations of the Cantonal Court were not communicated to either party to the dispute before the Federal Court. ${ }^{152}$ The applicant appealed against the Cantonal

149 HRC, Dudko v. Australia, Comm. No. 1347/2005, Views of 23 July 2007, paras. 7.2-7.3, 7.4: "The Committee observes that when a defendant is not given an opportunity equal to that of the State party in the adjudication of a hearing bearing on the determination of a criminal charge, the principles of fairness and equality are engaged. It is for the State party to show that any procedural inequality was based on reasonable and objective grounds, not entailing actual disadvantage or other unfairness to the author. In the present case, the State party has offered no reason, nor does the file reveal any plausible reason, why it would be permissible to have counsel for the State take part in the hearing in the absence of the unrepresented defendant, or why an unrepresented defendant in detention should be treated more unfavourably than an unrepresented defendant not in detention who can participate in the proceedings. Accordingly, the Committee concludes that a violation of the guarantee of equality before the courts in Article 14, paragraph 1, occurred in the circumstances of the case."

150 Summers, 2007, p. 117.

151 Summers, 2007, p. 117.

152 ECtHR, Nideröst-Huber v. Switzerland, App. No. 18990/91, Judgment of 18 February 1997, par. 23. 
Court decision, whereby this court transmitted the appeal, the case file and a page of observations to the Federal Court. The ECtHR considered that the Cantonal Court, as an independent tribunal, was not the adversary of either party to the proceedings, and thus no violation of equality of arms followed. ${ }^{153}$ However, the Court reiterated that the concept of a fair trial "implies in principle the right for the parties to a trial to have knowledge of and comment on all evidence adduced or observations filed." 154 These Cantonal Court's observations constituted "a reasoned opinion on the merits of the appeal, and explicitly called for it to be dismissed", as such they were "manifestly aimed at influencing the Federal Court's decision." 155 The Court thus found a violation of the principle of adversarial proceedings. ${ }^{156}$ Interestingly, the Court considered that neither the effect of these observations on the appeal decision nor the fact that the observations did not contain any new arguments not included in the impugned decision had any bearing on the ECtHR's decision. In fact, it is the objective nature of the observations that according to the Court necessitated these observations to be communicated to the applicant as it was unlikely that the Federal Court would not pay attention to them. ${ }^{157}$ Moreover, it was for the parties to the dispute to assess whether the observations contained any new arguments and to decide whether to file any comments. Importantly, the Court considered that "[w] hat is particularly at stake here is the litigant's confidence in the workings of justice, which is based on, inter alia, the knowledge that they have had the opportunity to express their views on every document in the file." 158

With regard to equality of arms, the explicit mention of the Cantonal Court's independence merits some consideration. Whereas the observations were not communicated to both parties, the Court explicitly considered the negative effect, both in appearance and in substance, of these observations upon the appeal of the applicant, and the fact that these observations were intended to influence the appellate decision. In light of the Court's other case law, where the uncorresponded and unchalleged opinion of an independent body was considered to violate equality of arms, the decision in Nideröst-Huber $v$. Switzerland is not immediately convincing. ${ }^{159}$ From these cases it follows that as soon as an opinion is given as to the substance

153 ECtHR, Nideröst-Huber v. Switzerland, App. No. 18990/91, Judgment of 18 February 1997, par. 23.

154 ECtHR, Nideröst-Huber v. Switzerland, App. No. 18990/91, Judgment of 18 February 1997, par. 24.

155 ECtHR, Nideröst-Huber v. Switzerland, App. No. 18990/91, Judgment of 18 February 1997, par. 26.

156 ECtHR, Nideröst-Huber v. Switzerland, App. No. 18990/91, Judgment of 18 February 1997, par. 31.

157 ECtHR, Nideröst-Huber v. Switzerland, App. No. 18990/91, Judgment of 18 February 1997, par. 27.

158 ECtHR, Nideröst-Huber v. Switzerland, App. No. 18990/91, Judgment of 18 February 1997, par. 29.

159 See the cases involving the opinion of the Advocat General, e.g. ECtHR, Borgers v. Belgium, App. No. 12005/86, Judgment of 30 October 1991; ECtHR, Bulut v. Austria, Judgment of 22 February 1996; ECtHR, Reinhardt and Slimane-Kaïd v. France, App. No. 23043/93 and 22921/93, Judgment of 31 March 1998; ECtHR, Kress v. France, App. No. 39594/98, Judgment of 7 June 2001; ECtHR, Fischer v. Austria, App. No. 33382/96, Judgment of 17 January 2002; ECtHR, Lanz v. Austria, App. No. 24430/94, Judgment of 31 January 2002. 
of the argument, the instance providing the opinion becomes, objectively speaking, either the accused's ally or his opponent. ${ }^{160}$ Notably, in another civil case, the Court concluded that the principle of equality of arms, in the sense of a fair balance, had been violated when a prosecutor, as a third party, participated in the proceeding by supporting the argument of one party while the other party was not given an opportunity to challenge the prosecutor's observations. ${ }^{161}$ The Court considered that whatever the effect of the prosecutor's intervention on the final decision, the intervention had the intention of influencing that decision. ${ }^{162}$ It seems that in this case, the balance of advantages tipped too much towards one party to the proceedings. Going back to Nideröst-Huber $v$. Switzerland, the fact that the observations were filed by independent members of the judiciary seems to have constituted the decisive factor in finding no violation of the principle of equality of arms. It might also be the fact that this case concerned civil proceedings, "where the national authorities [...] enjoy greater latitude than in the criminal sphere." 163 In the latter sphere, there seems to be less space for third party observations that cannot be associated with either the defence or the prosecution.

Considering the right to an adversarial process, the Court in Nideröst-Huber clearly attached importance to the appearances, both objective (no consideration to the effect on the decision itself) and subjective (the feelings of legitimacy advanced by the participants). The same line of reasoning can be detected in criminal cases where particular attention was given "to appearances and to the increased sensitivity of the public to the fair administration of justice." 164

In Ilijkov v. Bulgaria, the ECtHR found a violation of both adversarial process and equality of arms when the accused was not able to comment on the prosecutor's observations filed on appeal against detention. ${ }^{165}$ More specifically, the Court considered that in this case, "it was evident that the parties to the proceedings before the Supreme Court were not on an equal footing ... [when] the prosecution authorities had the privilege of addressing the judges with arguments which were not communicated to the applicant" and that the "proceedings were therefore not adversarial." 166 In conclusion, the Court found that the judicial review of detention in this case "did not provide the procedural guarantees of equality of arms." 167 Although of minor substantive importance, the wording in this decision in relation to the

160 ECtHR, Borgers v. Belgium, App. No. 12005/86, Judgment of 30 October 1991, par. 26.

161 ECtHR, Korolev v. Russia (no. 2), App. No. 5447/03, Judgment of 1 April 2010, par. 37.

162 ECtHR, Korolev v. Russia (no. 2), App. No. 5447/03, Judgment of 1 April 2010, par. 37.

163 ECtHR, Nideröst-Huber v. Switzerland, App. No. 18990/91, Judgment of 18 February 1997, par. 28.

164 ECtHR, Borgers v. Belgium, App. No. 12005/86, Judgment of 30 October 1991, par. 24.

165 ECtHR, Ilijkov v. Bulgaria, App. No. 33977/96, Judgment of 26 July 2001, paras. 103-105.

166 ECtHR, Ilijkov v. Bulgaria, App. No. 33977/96, Judgment of 26 July 2001, par. 104.

167 ECtHR, Ilijkov v. Bulgaria, App. No. 33977/96, Judgment of 26 July 2001, par. 105. 
principles involved seems to subordinate the principle of adversarial trial to that of equality of arms as one of its guarantees.

More generally, the case law on adversarial proceedings has mostly revolved around two types of cases: (i) where the defence could not properly challenge the prosecutor's submissions; and (ii) cases relating to the prosecution's disclosure obligations. ${ }^{168}$ In relation to the latter category, the link between the adversarial process and equality of arms is even more evident. ${ }^{169}$ In order to be able to comment on the submissions of the other party, one has to be aware of those submissions by way of disclosure or access to the case file. This right of the defence to access the prosecution's materials forms an essential part of the defence's right to have adequate facilities to prepare one's defence.

\subsubsection{The right to have adequate time and facilities to prepare a defence}

The right to have adequate time and facilities for the preparation of one's defence is one of the corollaries of the principle of equality of arms. ${ }^{170}$ The definition of what constitutes 'adequate time and facilities' and the scope of the guarantee is virtually impossible to give in abstracto and, thus, it has not been clearly defined in the human rights case law. ${ }^{171}$ The scope of the term 'facilities' is potentially very far-reaching and there is no clear delineation of what falls specifically under this right and what is covered by other minimum rights. ${ }^{172}$ There is an innate link between the right to have adequate time and facilities to prepare one's defence and the right to be informed promptly of the charges against oneself. ${ }^{173}$ A more practical link can be detected with the right to have legal assistance, if necessary through a legal aid system. In the

168 TReChSEL, 2005, p. 91.

169 ECtHR, I.J.L. and others. v. The United Kingdom, App. No. 29522/95, 30056/96 and 30574/96, Judgment of 19 September 2000, par. 112: "The right to an adversarial trial means, in a criminal case, that both prosecution and defence must be given the opportunity to have knowledge of and comment on the observations filed and the evidence provided by the other party. In addition Article $6 \S 1$ requires that the prosecution authorities should disclose to the defence all material evidence in their possession for or against the accused."

170 HRC, Little v. Jamaica, Communication No. 283/1988, Views of 19 November 1991, par. 8.3. HRC, Sawyers and McLean v. Jamaica, Communications Nos. 226/1907 and 256/1981, Views of 11 April 1991, par. 13.6: “As to the authors' claims relating to Article 14, paragraph 3 (b) and (e), the Committee notes that the right of an accused person to have adequate time and facilities for the preparation of his defence is an important element of the guarantee of a fair trial and an emanation of the principle of equality of arms. The determination of what constitutes "adequate time" depends on an assessment of the circumstances of each case." This right is laid down in virtually identical texts in Articles 14(3)(b) ICCPR, 6(3)(b) ECHR, and 8(2)(b) ACHR.

171 Trechsel, 2005, p. 209, including the reference in footnote 9.

172 For example, the right to freely access and communicate with counsel is sometimes dealt with as constituting a 'facility', see TrECHSEL, 2005, p. 210.

173 E.g. ECtHR, Mattoccia v. Italy, App. No. 23969/94, Judgment of 25 July 2000, par. 60. See also Trechsel, 2005, pp. 217-218; VAN DiJK ... (ET AL.), 2006, pp. 632-633. 
practice of ECtHR, many problems in relation to the adequacy of time have arisen particularly in the context of legal assistance. ${ }^{174}$ To some extent, the right to adequate time and facilities has an "overarching" and "subsidiary" role: it is only invoked when the other more specific guarantees are not applicable. ${ }^{175}$

The relative nature of the guarantee to adequate time and facilities is discernible from its formulation and it necessarily means that there can be no violation of this provision in the case of an acquittal. ${ }^{176}$ For an application contending a violation of this right to succeed, the defendant must show prejudice arising from a denial of specifically requested but not obtained time or facilities. ${ }^{177}$ However, this demonstration of 'actual prejudice' places "an almost unbearable burden on the applicant." 178 According to Trechsel, the scope of the guarantee is not made any clearer by the linguistic difference between the English and the French texts of Article 6(3)(b) ECHR: the former talks about adequate time and facilities and the latter about nécessaires. ${ }^{179}$ The latter test is seemingly more stringent as it would require the defendant to show that without the requested time and/or facilities the defence could not succeed. The English version, however, seems more flexible as the adequacy requirement would only demand the showing of increased opportunities for a better defence if the requested time and/or facility would have been provided. ${ }^{180}$

Moreover, the exact connection of equality of arms in relation to the right to have adequate time and facilities to prepare a defence is not immediately obvious. In fact, according to Trechsel, the fact that equality of arms is occasionally mentioned in connection with the right to have adequate time to prepare the defence "can only mean that the same amount of time must be available to the defense and to the prosecution." 181 In practice, this proposition would be unattainable, especially in relation to the investigative stages of the process. ${ }^{182}$ Clearly, no direct comparison can be made between the adequacy of time and facilities for the prosecution and the defence to prepare their respective cases. A more abstract understanding of equality of arms transpires in this context. Just as the prosecutor has the time to prepare the case, the defence must have that opportunity too. What this opportunity exactly entails depends on the circumstances of the case but must, in any event, be 'adequate'.

174 Trechsel, 2005, p. 218. See e.g. ECtHR, Ferrari-Bravo v. Italy, App. No. 9627/81, Judgment of 14 March 1984, par. 23; ECtHR, Öcalan v. Turkey, App. No. 46221/99, Judgment of 12 May 2005, paras. $134,137,147$.

175 Trechsel, 2005, p. 209.

176 TReChSEL, 2005, p. 211.

177 TReChSEL, 2005, p. 211

178 Trechsel, 2005, p. 211.

179 The same difference can be found in Articles 21(4)b ICTY Statute and 20(4)(b) ICTR Statute as well as $67(1)(b)$ ICC Statute.

180 Trechsel, 2005, p. 212.

181 Trechsel, 2005, p. 216.

182 Trechsel, 2005, pp. 216-217. 
Moreover, equality of arms is underlined by the equality of access to information: both parties must have equal access to materials which are relevant to the case, and, consequently, the accused has the right to have access to the prosecutor's collected accusations - which were initiated by the prosecution - at a minimum. ${ }^{183}$

The element of 'adequate facilities' within the right to have adequate time and facilities to prepare one's defence incorporates the prosecutorial obligation to provide access to the materials that form the basis of the accusation. Even more than the element of time, the adequacy of facilities is relative and undetermined. In Jespers v. Belgium, the European Commission stated that the meaning of facilities within Article 6(3) (b) "include the opportunity to acquaint himself, for the purposes of preparing his defence, with the results of investigations carried out throughout the proceedings." 184 The right to access the prosecution file is inferred from Article 6(3)(b) ECHR. ${ }^{185}$ This right is also seen as an inherent element of the principle of equality of arms and the Commission expressed it as follows:

As regards the interpretation of the term 'facilities', the Commission notes firstly that in any criminal proceedings brought by a state authority, the prosecution has at its disposal, to back the accusation, facilities deriving from its powers of investigation supported by judicial and police machinery with considerable technical resources and means of coercion. It is, in order to establish equality, as far as possible, between the prosecution and the defence that national legislation in most countries entrusts the preliminary investigation to a member of the judiciary or, if it entrusts the investigation to the Public Prosecutor's Department, instructs the latter to gather evidence in favour of the accused as well as evidence against him. It is also, and above all, to establish that same equality that the 'rights of the defence', of which Art. 6(3) of the Convention gives a non-exhaustive list, have been instituted. The Commission has already had occasion to point out that the so-called 'equality of arms' principle could be based not only on Art. 6(1) but also on Art. 6(3), especially sub. para. (b). ${ }^{186}$

$183 C f$. JACKSON, 2005, pp. 751-752 [footnote reference to Jespers v. Belgium].

184 E.g. ECtHR, Jespers v. Belgium, App. No. 8403/78, Commission's report of 14 December 1981, D\&R 27, par. 56.

185 E.g. ECtHR, Jespers v. Belgium, App. No. 8403/78, Commission's report of 14 December 1981, D\&R 27, par. 56, referring to X. v. Austria, App. No. 1816/63, 7 March 1964, Yearbook volume 7, 1964, p. 205, 211: Haase v. Germany, App. No. 7412/76, 12 July 1977, paras. 115-117, D\&R 11 p. 108.

186 E.g. ECtHR, Jespers v. Belgium, App. No. 8403/78, Commission's report of 14 December 1981, D\&R 27, par. 55. Referring to Ofner and Hopfinger v. Austria, App. No. 524/59 and 617/59, report of 23 November 1962, Yearbook volume 6, 1963, p. 680, Pataki and Dunshirn v. Austria, App. Nos. 596/59 and 789/60, report of 28 March 1963, Yearbook volume 6, 1963, pp. 730-732. See also HRC, Paul Perterer v. Austria, Comm. No. 1015/2001, Views of 20 July 2004, par. 10.6: “ ... the Committee observers that the principle of equality of arms implies that the parties to the proceedings must have adequate time and facilities for the preparation of their arguments, which, in turn, requires access to the documents necessary to prepare such arguments". 
This citation clearly extends the scope of application of equality of arms beyond a mere formalistic review of some procedural rights between the parties towards a more encompassing understanding of equality of arms as a mechanism to counterbalance the inherent inequality between an individual and a state in a criminal process. Eloquent as this citation might be, there is no indication that the ECtHR has adopted this vision either in its literal or substantive form (except for finding a basis of equality of arms in both paragraphs 1 and 3 of Article 6).

To prepare the defence, an accused has the right to be put on notice not only of the accusation as such, but also to know the basis for that accusation. ${ }^{187}$ The accused has the right "to have at his disposal, for the purposes of exonerating himself or of obtaining a reduction of his sentence, all relevant elements that have been or could be collected by the competent authorities." 188 Of course, the 'facilities' need to be adequate and are, thus, "restricted to those which assist or may assist [the accused] in the preparation of his defence." 189 Trechsel distills four aspects of this right to access the investigation file: (1) the right of access under the continental system; (2) discovery under the Anglo-Saxon system; (3) discovery of 'hidden material' under both systems; and (4) investigation by the defence. ${ }^{190}$ While the case law of the human rights bodies offers only limited guidance for the evaluation of the adequacy of the facilities provided to the defence, the procedural context becomes even more important for a proper evaluation.

The temporal scope of application of the right to the full disclosure of prosecutorial evidence runs from the early stages of the criminal process, when the accused is to have adequate access to the investigation file so as to be able to challenge provisional

187 HRC, e.g. Paul Perterer v. Austria, Communication No. 1015/2001, Views of 20 July 2004, par. 10.6: “... the Committee observers that the principle of equality of arms implies that the parties to the proceedings must have adequate time and facilities for the preparation of their arguments, which, in turn, requires access to the documents necessary to prepare such arguments".

188 ECtHR, Jespers v. Belgium, App. No. 8403/78, Commission's report of 14 December 1981, D\&R 27, par. 56: "It matters little ... by whom and when the investigation is carried out. In view of the diversity of legal systems existing in the States Parties to the Convention the Commission cannot restrict the scope of the term 'facilities' to acts carried out during certain specified phases of the proceedings, e.g. the preliminary investigation ... Any investigations it [the Public Prosecutor's Department] causes to be carried out in connection with criminal proceedings and the findings thereof consequently form part of the 'facilities' within the meaning of Article 6 paragraph 3(b) of the Convention".

189 ECtHR, Jespers v. Belgium, App. No. 8403/78, Commission's report of 14 December 1981, D\&R 27, par. 57: "Despite the slight difference in meaning between the adjective in the French text ["nécessaire"] and the one in the English text ['adequate']."

190 TRECHSEL, 2005, p. 223. All of these aspects present a particular challenge with regard to international criminal practice, in fact, one of the biggest challenges in light of the equality of arms principle. Although the first aspect only seems to be of relevance to the ECCC and the Special Tribunal for Lebanon (STL), the other three aspects play a major role in the proceedings before the ad hoc tribunals, the ICC and the SCSL. 
detention. ${ }^{191}$ In fact, "[e]quality of arms is not ensured if counsel is denied access to those documents in the investigation file which are essential in order effectively to challenge the lawfulness of his client's detention." 192 Moreover:

in view of the dramatic impact of deprivation of liberty on the fundamental rights of the person concerned, proceedings conducted under Article $5 \S 4$ of the Convention should in principle also meet, to the largest extent possible under the circumstances of an on-going investigation, the basic requirements of a fair trial, such as the right to an adversarial procedure. ${ }^{193}$

More generally, the Court has considered that Article 6, especially the specific rights of the accused mentioned in paragraph 3, "may also be relevant before a case is sent for trial if and in so far as the fairness of the trial is likely to be seriously prejudiced by an initial failure to comply with them."194

The right to access the investigation file is, however, not absolute. The Court has accepted that "national security considerations may, in certain circumstances, call for procedural restrictions to be imposed in the case involving state secrets." 195 However, even when national security might be endangered, "the concepts of lawfulness and the rule of law in a democratic society require that measures affecting fundamental human rights, such as the right to a fair trial, should have a lawful basis and should be appropriate to achieve their protective function." ${ }^{196}$ A procedure in which it is only the prosecutor who determines whether certain evidence should be withheld from the accused on public interest grounds has been found to violate the right to a fair trial. ${ }^{197}$

191 ECtHR, Garcia Alva v. Germany, App. No. 23541/94, Judgment of 13 February 2001, par. 39. ECtHR, Mooren v. Germany, App. No. 11364/03, Judgment of the Grand Chamber, 9 July 2009, paras. 124-125.

192 Cf. ECtHR, Lamy v. Belgium, App. No. 10444/83, Judgment of 30 March 1989; ECtHR, Niedbala v. Poland, App. No. 27915/95, Judgment of 4 July 2000.

193 ECtHR, Lamyv. Belgium, App. No. 10444/83, Judgment of 30 March 1989; cf.: ECtHR, Lexa v. Slovakia (no. 2), App. No. 34761/03, Judgment of 5 January 2010, par. 69: “The fundamental guarantees under Article $5 \S 4$ include, inter alia, the right to an effective hearing by the judge examining an appeal against detention. Proceedings concerning an appeal against detention must ensure equality of arms between the parties"; and "One of the most important implications of equality of arms is the right of access to the investigation file; the opportunity of effectively challenging the statements or views which the prosecution bases on these documents presupposes in principle that the defence has access to them." See also ECtHR, Toth v. Austria, App. No. 11894/85, Judgment of 12 December 1991; ECtHR, Chahal v. the United Kingdom, App. No. 22414/93, Judgment of 15 November 1996; ECtHR, Winterwerp v. the Netherlands, App. No. 6301/73, Judgment of 24 October 1979, par. 60; ECtHR, Sanchez-Reisse v. Switzerland, App. No. 9862/82, Judgment of 21 October 1986.

194 E.g. ECtHR, Imbrioscia v. Switzerland, App. No. 13972/88, Judgment of 24 November 1993, par. 39.

195 E.g. ECtHR, Moiseyev v. Russia, App. No.62936/00, Judgment of 9 October 2008, par. 216.

196 E.g. ECtHR, Moiseyev v. Russia, App. No.62936/00, Judgment of 9 October 2008, par. 216.

197 ECtHR, Rowe and Davis v. The United Kingdom, App. No. 28901/95, Judgment of 16 February 2000, par. 66 . 
When the trial judge assesses the appropriateness of the non-disclosure of certain materials to the defence, the ECtHR has stressed the importance of (1) weighing the public interest against the interest of the accused; and (2) affording the defence an opportunity to participate in the decision-making process to the maximum extent possible. ${ }^{198}$ Relevant factors to be investigated include "whether those materials would have been of any assistance for the defence, and whether their disclosure would, at least arguably, have harmed any identifiable public interest." 199 Central for the proper decision-making is whether the non-disclosure was counterbalanced by adequate procedural guarantees and whether it was sufficiently justified. ${ }^{200}$

\subsubsection{The right to examine witnesses under the same conditions}

The minimum right of the accused "to examine or have examined witnesses against him and to obtain the attendance and examination of witnesses on his behalf under the same conditions as witnesses against him" gives the most visible expression to the principle of adversarial proceedings and the principle of equality of arms under the human rights conventions. ${ }^{201}$ An accused must have a genuine opportunity to participate in the proceedings initiated against him, to have a fair opportunity to challenge evidence presented against him and to present his own evidence and this must be done under the same conditions as are applicable to the prosecuting authority. ${ }^{202}$ This latter aspect constitutes a limitation of the right itself and is an expression of the relative character of this right. ${ }^{203}$ On a more substantive level,

198 E.g. ECtHR, Mirilashvili v. Russia, App. No. 6293/04, Judgment of 11 December 2008, par. 205.

199 E.g. ECtHR, Mirilashviliv. Russia, App. No. 6293/04, Judgment of 11 December 2008, par. 206.

200 E.g. ECtHR, Mirilashvili v. Russia, App. No. 6293/04, Judgment of 11 December 2008, paras. 203, 209. See also ECtHR, Edwards and Lewis v. United Kingdom, App. Nos. $39647 / 98$ and 40461/98, Judgment of 27 October 2004.

201 Article 14(3)(e) ICCPR, Article 6(1)(d) ECHR, Article 8(2)(f) ACHR [emphasis added]. E.g. ECtHR, Barberà et al v. Spain, App. No. 10590/83, Judgment of 6 December 1988, par. 78: "Paragraph 1 of Article 6 taken together with paragraph 3 (art. 6-1, art. 6-3), also requires the Contracting States to take positive steps, in particular to inform the accused promptly of the nature and cause of the accusation against him, to allow him adequate time and facilities for the preparation of his defence, to secure him the right to defend himself in person or with legal assistance, and to enable him to examine or have examined witnesses against him and to obtain the attendance and examination of witnesses on his behalf under the same conditions as witnesses against him. The latter right not only entails equal treatment of the prosecution and the defence in this matter (see, mutatis mutandis, the Bönisch judgment of 6 May 1985, Series A No. 92, p. 15, para. 32), but also means that the hearing of witnesses must in general be adversarial." ECtHR, Brandstetter v. Austria, App. No. 11170/84; 12876/87; 13468/87, 28 August 1991, par. 67: "The right to an adversarial trial means, in a criminal case, that both prosecution and defence must be given the opportunity to have knowledge of and comment on the observations filed and the evidence adduced by the other party."

202 Trechsel, 2005, p. 292. ECtHR, Barberà et al v. Spain, App. No. 10590/83, Judgment of 6 December 1988, par. 78 .

203 NowAK, 2005, pp. 341-342: "The right of the accused to obtain the examination of witnesses on his 
this right has a close connection to the admissibility of evidence and fact-finding processes more generally. ${ }^{204}$ As such, truth finding can be enhanced where evidence is tested from different perspectives, thus, laying a broader and firmer ground for the final factual and legal determinations. In addition, his substantive element restricts the right to examine or obtain witnesses by providing the court with the power to exclude any evidence it considers does not assist in ascertaining the truth. ${ }^{205}$

Two elements are central to this right: (1) the right to question witnesses at different stages of the proceedings, and (2) the right to call witnesses. The application of this right clearly demonstrates the difference of vision as to the mode of the criminal process. While in adversarial systems the rights to cross-examine and to present witnesses assume a fundamental systemic nature; in an inquisitorial setting, these rights are only of an ancillary nature alongside the principal responsibility of the judges for evidence-gathering and proof-taking. ${ }^{206}$

The right to examine witnesses is naturally connected to the principles of immediacy and orality with regard to the presentation of evidence. The first principle

or her behalf is, however, not absolute ... [It] is subjected to the restriction that this be "under the same conditions as witnesses against him .... Of principal importance here is that the parties are treated equally with respect to the introduction of evidence by way of interrogation of witnesses".

204 Trechsel, 2005, p. 293.

205 E.g. ECtHR, Austria v. Italy, App. No. 788/60, Report of the European Commission on Human Rights of 31 March 1963, paras. 112, 115. See also HRC, General Comment No. 32, Article 14: Right to equality before courts and tribunals and to a fair trial, Ninetieth session, 23 August 2007, par. 39: "Paragraph 3 (e) of Article 14 guarantees the right of accused persons to examine, or have examined, the witnesses against them and to obtain the attendance and examination of witnesses on their behalf under the same conditions as witnesses against them. As an application of the principle of equality of arms, this guarantee is important for ensuring an effective defence by the accused and their counsel and thus guarantees the accused the same legal powers of compelling the attendance of witnesses and of examining or cross-examining any witnesses as are available to the prosecution. It does not, however, provide an unlimited right to obtain the attendance of any witness requested by the accused or their counsel, but only a right to have witnesses admitted that are relevant for the defence, and to be given a proper opportunity to question and challenge witnesses against them at some stage of the proceedings. Within these limits, and subject to the limitations on the use of statements, confessions and other evidence obtained in violation of Article 7, [85. See para. 6 above.] it is primarily for the domestic legislatures of States parties to determine the admissibility of evidence and how their courts assess it."

206 Cf. ICTY, Prosecutor v. Delalic et al., Decision on the Motion of the Joint Request of the Accused Persons Regarding the Presentation of Evidence, Dated 24 May 1998, IT-96-21-T, T. Ch., 12 June 1998, par. 32: "This provision [Article 21(4)(e) ICTY Statute] which is ambiguous is deceptively simple in its construction. It is important to appreciate that the right of the accused, though guaranteed is subject to the power of the Trial Chamber in Article 20(1) to ensure a fair and expeditious trial. Again, it should be construed within the context of the accusatorial system of procedure, where the accused decides, subject to the control of the court, which witnesses he wishes to call; as well as in the inquisitorial system where the court decides for itself which witnesses it wishes to hear. It is well known that in the accusatorial system, witnesses are examined and cross-examined by the parties or their counsel. The court is also free to put questions to witnesses. In the inquisitorial system, only the court examines witnesses." 
relates to the duty of the adjudicator to obtain the information first-hand in order to be able to assess its credibility. This presentation of evidence is preferably done in a setting that promotes the oral presentation of that information and is connected to the protections provided by the public nature of the trial hearings. ${ }^{207}$ The minimum content given to the right to examine witnesses within the human rights context is that somewhere during the proceedings, whether pre-trial or trial, an accused must have had the opportunity to question the witnesses against him. ${ }^{208}$ Whereas the use of statements obtained at the investigation stage is not in itself incompatible with the right to a fair trial and the right to examine witnesses, "the rights of the defence are restricted to an extent that is incompatible with the requirements of Article 6 if the conviction is based solely, or in a decisive manner, on the depositions of a witness whom the accused has had no opportunity to examine or to have examined either during the investigation or at trial." ${ }^{209}$ The way an accused is allowed to have that

207 De Smet, 2009, pp. 412-413, footnote 42.

208 See Trechsel, 2005, pp. 305-322. Also e.g. ECtHR, Lüdi v. Switzerland, App. No. 2433/86, Judgment of 15 June 1992, par. 47. See Trechsel, 2005, pp. 305-322. ECtHR, Asch v. Austria, App. No. 12398/86, Judgment of 26 April 1991, par. 27: '[a]11 the evidence must normally be produced in the presence of the accused at a public hearing with a view to adversarial argument. This does not mean, however, that the statement of a witness must always be made in court and in public if it is to be admitted in evidence, in particular, this may prove impossible in certain cases.'

209 See e.g. ECtHR, Saïdi v. France, App. No. 14647/89, Judgment of 20 September 1993, par. 43: “All the evidence must normally be produced in the presence of the accused at a public hearing with a view to adversarial argument. However, the use as evidence of statements obtained at the stage of the police inquiry and the judicial investigation is not in itself inconsistent with paragraphs 3 (d) and 1 of Article 6 (art. 6-3-d, art. 6-1), provided that the rights of the defence have been respected. As a rule these rights require that the defendant be given an adequate and proper opportunity to challenge and question a witness against him either when he was making his statements or at a later stage of the proceedings (see, among other authorities, the Isgrò v. Italy, App. No. 11339/85, Judgment of 19 February 1991, Series A No. 194-A, para. 34)". ECtHR, Luca v. Italy, App. No. 33354/96, Judgment of 27 February 2001, par. 40: "As the Court has stated on a number of occasions (see, among other authorities, ECtHR, Isgrò v. Italy, Judgment of 19 February 1991, Series A No. 194A, p. $12, \S 34$, and Lüdi, cited above, p. $21, \S 47$ ), it may prove necessary in certain circumstances to refer to depositions made during the investigative stage (in particular, where a witness refuses to repeat his deposition in public owing to fears for his safety, a not infrequent occurrence in trials concerning Mafia-type organisations). If the defendant has been given an adequate and proper opportunity to challenge the depositions, either when made or at a later stage, their admission in evidence will not in itself contravene Article $6 \S \S 1$ and 3 (d). The corollary of that, however, is that where a conviction is based solely or to a decisive degree on depositions that have been made by a person whom the accused has had no opportunity to examine or to have examined, whether during the investigation or at the trial, the rights of the defence are restricted to an extent that is incompatible with the guarantees provided by Article 6 (see Unterpertinger v. Austria, Judgment of 24 November 1986, Series A No. 110, pp. 14-15, para. 31-33; Saïdi v. France, Judgment of 20 September 1993, Series A No. 261-C, pp. 56-57, para. 43-44; and Van Mechelen and Others, cited above, p. 712, par. 55; see also Dorigo v. Italy, App. No. 33286/96, Commission's report of 9 September 1998, par. 43, unpublished, and, on the same case, Committee of Ministers Resolution DH (99) 258 of 15 April 1999)". 
opportunity is very much dependent on the legal system (either in the course of crossexamination or through a judge), but also on the important considerations within the context of the specific circumstances of the case, such as the need to protect (vulnerable) witnesses, which could legitimately be invoked to restrict the right to examine witnesses. ${ }^{210}$ The formulation of the right includes the wording "to examine or have examined", which leaves room for this right to be observed whenever a (an investigative) judge has questioned a witness and the accused has the opportunity to suggest questions. ${ }^{211}$ From the Court's case law it appears that whenever the defence's rights are limited an analysis has to be made of whether these limitations are strictly necessary, whether the intrusion on the rights of the defence was kept to a minimum, and whether the defence was duly compensated. ${ }^{212}$ In addition, it is important to have due regard to the precise nature of the complaint: although the right to examine witnesses is based on considerations of the principles of equality of arms and adversarial proceedings, the right to confront a witness in person is not to be conflated with an opportunity to express critical arguments about a witness statement to a judge. ${ }^{213}$

The second element of the right to examine witnesses, namely the right to call them, is intrinsically connected to active participation in the proceedings and the general right to defend oneself. Particularly in systems based on the civil law tradition, where the parties' autonomy to design their case is limited, this right has been interpreted as the right to suggest possible and relevant witnesses. The defence thus has the burden of indicating in a "precisely reasoned argument" how a proposed witness would materially advance its case. ${ }^{214}$ Because of the obviously close connection to evidentiary matters, the trial judges have been accorded wide discretion in this regard as they are in the best position to properly assess whether

210 Trechsel identifies four types of situation giving rise to a limitation of the right to examine witnesses: (1) where a witness does not appear at trial, for various reasons; (2) anonymous witnesses; (3) necessary protection to the witness due to a fear of reprisals; and (4) avoiding re-traumatization of vulnerable victims and witnesses. TRECHSEL, 2005, p. 312.

211 TreChSEL, 2005, p. 311.

212 Trechsel, 2005, p. 313. Trechsel takes issue with the Court's "balancing of the failings of the evidence against its importance for the conviction" as expressed by the Court: "In the Court's view, in assessing whether the procedures involved in the questioning of the anonymous witness were sufficient to counterbalance the difficulties caused to the defence due weight must be given to the above conclusion that the anonymous testimony was not in any respect decisive for the conviction of the applicant". This approach, according to Trechsel, "cannot be said to reach the standard of precision and reliability expected of legal rules [and] provides an opening for immaterial subjective preferences or dislikes". Referring to Stavros, Trechsel points to his even more radical view in this regard, when Stavros points out that "Art. 6 ... does not allow for limitation to protect conflicting interest" (TREChSEL, 2005, p. 313, footnote 113).

213 Trechsel, 2005, p. 313.

214 Trechsel, 2005, p. 324. 
a proposed witness would materially advance the truth finding in a case. ${ }^{215}$ Indeed, the ECtHR has "shown a great reluctance to intervene in this area" and "in a number of cases the Court followed a path already sketched out by the Commission which involved withdrawing behind the curtain of the equality of arms." ${ }^{216}$ Exemplary is the case of Engel v. The Netherlands, where the ECtHR used the following formulation:

Notwithstanding the contrary opinion of the applicants, this provision [art. 6-3-d] does not require the attendance and examination of every witness on the accused's behalf. Its essential aim, as is indicated by the words 'under the same conditions', is a full 'equality of arms' in the matter. With this proviso, it leaves it to the competent national authorities to decide upon the relevance of proposed evidence insofar as is compatible with the concept of a fair trial which dominates the whole of Article 6 (art. 6). ${ }^{217}$

Later, in the Vidal case, the ECtHR used the same formulation but added that "[t]he concept of equality of arms does not, however, exhaust the content of paragraph 3(d) of Article 6 (art. 6-3-d), nor that of paragraph 1 (art. 6-1), of which this phrase represents one application among many others." 218 In this case, the applicant had been convicted on appeal, after a first instance acquittal, only on the basis of the case file, and the Court implicitly refused to hear four witnesses proposed by the defence. Although strict equality of arms was preserved as both the accused as the prosecution did not hear witnesses, the rights of the defence were restricted to the extent that the applicant did not receive a fair trial. The ECtHR emphasized that it was not its function to express an opinion on the relevance of the evidence; however, the Court considered that the complete silence of the appellate court as to the refusal to hear those witnesses was not in accordance with a fair trial. ${ }^{219}$

215 Cf. HRC, Lassâad Aouf v. Belgium, Comm. No. 1010/2001, Views of 17 March 2006, par. 9.3: “... recalling that Article 14, paragraph 3 (e), does not provide an unlimited right to call any witness requested by the accused or his counsel, the Committee is of the view that the material before it does not disclose that the judgement of the Court of Appeal, subsequently upheld by the Court of Cassation, was of a nature to compromise the application of the principle of the equality of arms of the prosecution and the defence."

216 TRECHSEL, 2005, p. 324. Although some authors have taken a mathematical approach to the number of witnesses and the time spent on them, Trechsel remarks that such an approach was rejected by the Commission.

217 ECtHR, Engel et al. v. The Netherlands, App. Nos. 5100/71; 5101/71; 5102/71; 5354/72; 5370/72, Judgment of 8 June 1976, par. 91.

218 ECtHR, Vidal v. Belgium, App. No. 12351/86, Judgment of 22 April 1992, par. 33.

219 ECtHR, Vidal v. Belgium, App. No. 12351/86, Judgment of 22 April 1992, par. 34. See also HRC Larrañaga v. The Philippines, Comm. No. 1421/2005, Views of 24 July 2006, par. 7.7. When defence witnesses are not allowed to be examined without further justification other than the evidence was "irrelevant and immaterial" and the time constraints, while, at the same time the number of witnesses for the prosecution is not similarly restricted, this does not meet the requirements of Article 14 and violates Article 14(3)(e) ICCPR. 
One other specific area of witness examination where the connection to equality of arms was stressed is in relation to expert witnesses. Although the right to examine witnesses does not strictly cover experts, the ECtHR has considered such witnesses under the umbrella of equality of arms and the right to a fair trial.220 Thus, equality of arms and the right of the defence to call its own expert witnesses to counter the prosecution's arguments were emphasized in Bonisch v. Austria, where the court expert and the expert witness for the defence were not accorded the same treatment. ${ }^{221}$ In Brandstetter v. Austria, the Court used a test of independence for the expert witness appointed by the Court to consider whether the expert witness could objectively be associated with the prosecution. ${ }^{222}$ Where this could not objectively be established, there was no inequality of arms. ${ }^{223}$ Moreover, the ECtHR considered that a violation of the right to a fair trial was apparent as this right "does not require that a national court should appoint, at the request of the defence, further experts when the opinion of the court-appointed expert supports the prosecution case." 224 It seems that in this case the particularity of the criminal justice system has to be taken into account. Where the expert is court appointed, a strict impartiality test must be applied. Where the prosecutor calls its own expert witness, the principle of equality of arms demands that the defence be given an opportunity to call its own expert witness.

Another area of heated debate and litigation concerns the protection of victims/ witnesses. The leading ECtHR case on this issue is Doorson v. The Netherlands:

It is true that Article 6 (art. 6) does not explicitly require the interests of witnesses in general, and those of victims called upon to testify in particular, to be taken into consideration. However, their life, liberty or security of person may be at stake, as may interests coming generally within the ambit of Article 8 (art. 8) of the Convention. Such interests of witnesses and victims are in principle protected by other, substantive provisions of the Convention, which imply that Contracting States

220 ECtHR, Brandstetter v. Austria, App. Nos. 1170/84, 12876/87, 13468/87, Judgment of 28 August 1991, par. 42. ECtHR, Balsyte-Lideikiene v. Lithuania, App. No. 72596/01, Judgment of 4 November 2008, par. 63.

221 ECtHR, Bonisch v. Austria, App. No. 8658/79, Judgment of 6 May 1985, paras. 33-35.

222 ECtHR, Brandstetter v. Austria, App. Nos. 1170/84, 12876/87, 13468/87, Judgment of 28 August 1991, paras. 44-45.

223 ECtHR, Brandstetter v. Austria, App. Nos. 1170/84, 12876/87, 13468/87, Judgment of 28 August 1991, par. 45.

224 ECtHR, Brandstetter v. Austria, App. Nos. 1170/84, 12876/87, 13468/87, Judgment of 28 August 1991, par. 46. See also ECtHR, G.B. v. France, App. No. 44069/98, Judgment of 2 October 2001, par. 68 (here a violation was found due to the particular circumstances whereby the expert changed his mind in the course of one hearing and "such an abrupt turnaround would inevitably have lent the expert's opinion particular weight". In this circumstance, the rejection of the applicant's second opinion violated the right to a fair trial and the right of the defence. ECtHR, G.B. v. France, App. No. 44069/98, Judgment of 2 October 2001, paras. 69-70). 
should organise their criminal proceedings in such a way that those interests are not unjustifiably imperilled. Against this background, principles of fair trial also require that in appropriate cases the interests of the defence are balanced against those of witnesses or victims called upon to testify. ${ }^{225}$

Even though, according to Article 6(3)(d), a defendant must be given a full opportunity to challenge and question an adversarial witness, the use of statements made by anonymous witnesses in obtaining a conviction is not, under all circumstances, incompatible with the Convention. ${ }^{226}$ As such, an adequate equilibrium of the conflicting rights must be sought; the essence being that "no violation of Article 6 para. 1 taken together with Article 6 para. 3 (d) (art. 6-1+art. 6-3-d) of the Convention can be found if it is established that the handicaps under which the defence laboured were sufficiently counterbalanced by the procedures followed by the judicial authorities." 227 This seems "to require the interests of victims and witnesses to be built into the principles of fair trial." 228 In this case, the examining judge was aware of the identities of anonymous witnesses, and defence counsel was present and given an opportunity to pose questions to the witness. ${ }^{229}$ However, the Court emphasized that "even when 'counterbalancing' procedures are found to compensate sufficiently the handicaps under which the defence labours, a conviction should not be based either solely or to a decisive extent on anonymous statements." 230 In Van Mechelen $v$. Netherlands the ECtHR added that, formulated as a general rule, preference should always be given to the measure that least restricts the rights of the defence. ${ }^{231}$

\subsection{CONCLUding REMARKS}

This chapter's particular focus was on the exact meaning and scope of application of equality of arms in the human rights context. As a starting point some reflection on

225 ECtHR, Doorson v. Netherlands, App. No. 20524/92, Judgment of 26 March 1996, par. 70.

226 ECtHR, Doorson v. Netherlands, App. No. 20524/92, Judgment of 26 March 1996, par. 69.

227 ECtHR, Doorson v. Netherlands, App. No. 20524/92, Judgment of 26 March 1996, par. 72.

228 JACKSON, 2005, pp. 760-761: "This statement appears to require the interests of victims and witnesses to be built into the principles of fair trial. The Court is not suggesting that the principles of fair trial be balanced against other Convention rights. The principle of a fair trial remains absolute. However, the principles of fairness enshrined in Article 6 need to take account of the interests of victims and witnesses as well as defendants".

229 ECtHR, Doorson v. Netherlands, App. No. 20524/92, Judgment of 26 March 1996, par. 73.

230 ECtHR, Doorson v. Netherlands, App. No. 20524/92, Judgment of 26 March 1996, par. 76. Also ECtHR, Luca v. Italy, App. No. 33354/96, Judgment of 27 February 2001, par. 43; ECtHR, Birutis and others v. Lithuania, App. Nos. 47698/99 and 48115/99, Judgment of 28 March 2002.

231 ECtHR, Van Mechelen v. Netherlands, App. Nos. 21363/93, 21364/93, 21427/93, 22056/93, Judgment of 23 April 1997, par. 58: "Having regard to the place that the rights to a fair administration of justice holds in a democratic society, any measures restricting the rights of the defence should be strictly necessary. If a less restrictive measure can suffice then that measure should be applied." 
the status of human rights in the sources of international criminal procedure and the role of human rights institutions' case law was provided in the first section. The norms developed in international human rights law represent minimum standards that, to the extent that they are part of general international law, are binding upon international criminal institutions. The jurisprudence developed by the international human rights institutions constitutes an important guide for the implementation of these norms. In fact, this jurisprudence may be a useful indicator of the 'borderline' which marks the division between permissible restrictions of human rights and violations of those rights.

In the abstract, equality of arms places an obligation upon a court to ensure that a party to the proceedings has a reasonable opportunity to present his case under conditions that do not place him in a disadvantageous position as opposed to his opponent. The meaning of equality of arms as given by the ECtHR contains two relevant elements, objective: a reasonable opportunity, and subjective - as compared to the adversary. However, the ECtHR has not paid specific attention to these elements. The examination rather proceeded in two steps: (1) establishing procedural inequality; and (2) determining the prejudice resulting from that inequality. As such, the principle of equality of arms has been applied in a rather formalistic way, limiting the scope of its application to ensuring that the same procedural rights were afforded to the defence. Most clearly, this has found an expression in cases where both parties were denied something: no inequality of arms could arise. However, in several cases the ECtHR still found a violation of the right to a fair trial more generally and the right to adversarial proceedings specifically. The exact relationship between equality of arms and an adversarial trial is rather confusing. From some reasoning, equality of arms seems to encompass an adversarial trial, whereas other reasoning, in effect, claims the contrary. Notwithstanding this difference, the concepts can be separated exactly in those cases where the formal equality of arms was preserved, but the rights of the accused were not satisfactorily protected.

To some extent, having regard to the definitions of both principles, it might be argued that the difference between the two lies in the positioning of the parties. The principle of adversarial proceedings ensures that both parties know what is presented on the other side to be able to challenge that contention before the court takes a decision. While the principle of equality of arms aims to position both parties, in their relatively equal position, vis-à-vis the court. Equality of arms thus has a limiting function: both parties have an opportunity to present their case and comment on the adversary's case, but that opportunity is limited as compared to that of the other party. From this perspective, when one considers the two elements expressed in the definition of equality of arms, the right to an adversarial trial seems to fit neatly into the first objective element of a reasonable opportunity to present one's case.

Interestingly, the concepts of equality of arms and adversarial trial have arisen gradually in the context of ECtHR's case law. In fact, "[t] owards the end of the 1980s, 
the Court began to develop this right to be heard and to speak not just of the principle of equality of arms, but also of the principle that 'all the evidence must be produced in the presence of the accused at a public hearing with a view to adversarial argument."'"232 Initially, the Commission in Jespers v. Belgium seemed to assign a broader meaning to equality of arms. ${ }^{233}$ The Commission clearly extended the application of equality of arms beyond a mere formalistic review of the same procedural rights between the parties, towards a more encompassing understanding of equality of arms as a mechanism to counterbalance the inequality between an individual and a state in a criminal trial. Eloquent as the Commission's vision might be, there is no indication that the ECtHR has adopted this vision either in its literal or substantive form. In fact, it seems that the ECtHR 'pushed' back this expanded understanding of equality of arms to a more formal appreciation of the same procedural opportunities. The expanded notion seems to have been replaced by the notion of an adversarial trial as an addition to the principle of equality of arms: both principles as such 'fill out' the right to a fair trial, and are given more concrete meaning through the minimum rights of the accused.

Some uncertainty as to the exact meaning of equality of arms and an adversarial process might emanate from the inherent connection between equality of arms and a specific model of criminal process: the adversarial trial. Jackson argues, in this regard, that the ECtHR has developed the right to an adversarial trial as a mixture of the Continental notion of une procédure contradictoire and the traditional common law party-led adversary trial. As such, while accused persons are guaranteed rights to legal assistance, to have access to all relevant information, to be present at the trial and to present their evidence at trial, "[b]ut this does not rule out considerable participation by judges in asking questions or even calling witnesses." 234

The next chapter will position the principle of equality of arms within the several most common, approaches to the criminal process. Moreover, it will consider the different goals and values that are served by a criminal process in general and the international criminal process in particular so as to obtain a better understanding of the direction and the development of international criminal proceedings.

232 JACKSON, 2005, p. 752 [footnote reference omitted].

233 Jespers v. Belgium, App. No. 8403/78, Commission's report of 14 December 1981, D\&R 27, par. 55. Referring to Ofner and Hopfinger v. Austria, App. No. 524/59 and 617/59, report of 23 November 1962, Yearbook volume 6, 1963, p. 680, Pataki and Dunshirn v. Austria, App. Nos. 596/59 and 789/60, report of 28 March 1963, Yearbook volume 6, 1963, pp. 730-732. See also HRC, Paul Perterer v. Austria, Comm. No. 1015/2001, Views of 20 July 2004, par. 10.6: “ ... the Committee observers that the principle of equality of arms implies that the parties to the proceedings must have adequate time and facilities for the preparation of their arguments, which, in turn, requires access to the documents necessary to prepare such arguments".

234 JACKSON, 2005, pp. 752-753 [footnote omitted]. 


\section{Chapter 3 \\ Criminal Process Perspective}

\subsection{INTRODUCTION}

In this chapter, Cassese's second typology of equality of arms, as a procedural device to uphold the adversarial nature of proceedings, is examined. ${ }^{1}$ The previous chapter considered equality of arms as developed in the human rights framework. It was argued that human rights norms represent the minimum standards that have to be implemented by international criminal courts. As human rights jurisprudence shows, the principles of the right to a fair trial, and specifically equality of arms and adversarial proceedings, have acquired an autonomous meaning as they are deemed to be applicable in countries with civil as well as common law traditions and procedural systems that are adversarial as well as inquisitorial. However, the principles "are not, and cannot be, applied in a structural vacuum" and, thus, the interpretation of equality of arms depends on the nature of a particular procedural system. ${ }^{2}$ It is generally regarded as inherent in the systems following the common law tradition "that both sides will be given equality in procedural opportunities to advocate their respective opposing positions." 3

To understand the delicate balance, which is intended at the level of international criminal proceedings, of combining different procedural approaches necessitates an examination of particular procedural systems that are familiar to the domestic settings. It is not intended, nor is it necessary, to provide a comprehensive comparison between the different procedural systems. However, it is necessary to investigate the different world perspectives in order to understand and evaluate the role of equality of arms in the international context. This investigation will necessarily be somewhat superficial and limited to the ideal-type modelling of the different procedural approaches.

Before proceeding with the examination of the different procedural models and the role of equality of arms in 'adversarial' and 'inquisitorial' proceedings, some general observations on the particular goals that a criminal process is to achieve and the values that such a process is to implement or serve are appropriate. These goals and values partly determine the method that is chosen to achieve them: a particular procedural paradigm. Distinguishing between goals or aims of the criminal justice system and values that influence "what one regards as desirable in the pursuit of that

\footnotetext{
See Chapter 1; CASSESE, 2008, p. 385.

Summers, 2007, p. 183.

Bassiouni, 1993, p. 278.
} 
goals" is helpful in the discussion of the different procedural models that are designed to achieve these aims and serve those values. ${ }^{4}$ The observations on the goals, and values of a criminal process and the particular methods to achieve these goals and serve these values will then be 'translated' to the international level.

\subsection{GOALS AND VALUES OF A CRIMINAL PROCESS}

The structure of a particular society and the role that the authority plays in that society and its organization can be seen reflected in the goals of adjudication that the society pursues. An instrumental view of procedure is to regard it as a means to a particular substantive result, a particular decision in adjudication. However, the realization that the kind of decisions that are achieved - fair, just, accurate - are also determined by the process by which they are achieved determines the distinctive contours of substantive and procedural law, giving both their particular values in the framework of a legal order. ${ }^{5}$ For a proper understanding, analysis and evaluation of a procedural framework it is important to determine the aims, goals and values that underlie that process. The role and meaning of these notions differs from stage to stage of a criminal process and in terms of a general-specific continuum. In addition, these notions usually coincide and intertwine, which makes it difficult to determine the exact aim, goal or value division.

Apprehending and adequately punishing those individuals who are guilty of a crime and, thus, to control crime, is generally seen as the 'general justifying aim' of the administration of criminal justice. ${ }^{6}$ Ashworth identifies three principal 'qualifiers' to this general justifying aim of crime control. ${ }^{7}$ These qualifiers represent the other values or goals which have to be preserved in the operation of a criminal justice system. One such qualifier is "termed 'considerations of systems': the system must operate within the constraints of public expenditure, and it must work through the particular individuals and groups who staff its various agencies (cost-efficiency considerations)". ${ }^{8}$ As the second qualifier, the principles of fairness are considered,

4 DufF, 1998, p. 614.

5 For an interesting thought-experiment to disentangle substance and procedure by way of an idealization see Solum, 2004.

6 Ashworth, 1979, p. 412. Ashworth takes the term 'general justifying aim' and its concept from HaRT, 1968, chapter 1. See also SANDERS AND YounG, 2006, who present a 'freedom model': "freedom as the ultimate goal of criminal justice" (see chapter 1).

7 Ashworth, 1979, p. 413, in the footnote referring to HART, 1968, p. 10: 'In relation to any social institution, after stating what general aim of value its maintenance fosters, we should inquire whether there are any and if so what principles limiting the unqualified pursuit of that aim or value. Just because the pursuit of any single social aim always has its restrictive qualifiers, our main social institutions always possess a plurality of features which can only be understood as a compromise between partly discrepant principles.'

8 Ashworth, 1979, p. 413. 
which promote respect for the rights of the members of a society, "a respect which places limitations on the methods which may properly be used in crime control" (procedural fairness). ${ }^{9}$ As the third qualifier, Ashworth mentions the "control of abuse" by authorities that operate the criminal justice systems, thus preserving a "balance between individual liberty and state power to control crime." 10 Both the second and the third qualifiers find their foundation in "a general principle of maximizing individual liberty." 11

The evaluation of a process is usually done in terms of its achievement of good or intended results. A process that leads to good results is good as a process, which Summers terms the "good result efficacy."12 However, merely focusing on good results hides the risk of a purely instrumental vision of the process. Today, this purely 'end justifies the means' approach cannot be attained as the values that underlie a particular process and that have to be implemented or served by that process have their distinctive value notwithstanding the quality of the results that the process achieves in a certain instance. A simple example to illustrate this point is the famous procedure for dividing a cake. The person who cuts the cake into pieces picks his piece last. ${ }^{13}$ The 'slicer picks-last rule' is regarded as fair and is independent of the outcome of the process (whether the slicer gets a smaller or bigger piece). ${ }^{14}$ Summers refers to 'process values' as "standards of value by which we may judge a legal process to be good as a process, apart from any 'good result efficacy' it may have." 15 As such, the process is evaluated, as a process, from two possible perspectives, first by the achievement of good results ${ }^{16}$ and, second, by its ability to implement or serve process values, ${ }^{17}$ such as participation, procedural fairness and rationality and humanness. ${ }^{18}$

9 Ashworth, 1979, p. 414.

10 Ashworth, 1979, p. 414.

11 AshwORTH, 1979, p. 414.

12 Summers, 1974, p. 2.

13 Solum, 2004, p. 238, referring to Rawls, 1971, p. 85.

14 Solum, 2004, p. 239.

15 Summers, 1974, p. 3.

16 Summers, 1974, p. 9: Process results include immediate outcomes, side effects and collateral consequences.

17 Summers, 1974, p. 4: "Although the first kind of goodness is 'result-oriented', it is nonetheless a form of process-related goodness, for one process is generally preferable to another, as a process, to the extent that is it a more efficacious means to good results. The second variety of goodness - the extent to which a process implements or serves process values - is exclusively 'process oriented' ...".

18 Summers, 1974, p. 11: Also, a differentiation must be made between a legal process and the nonprocedural law applicable within the process: like the law of evidence which may obstruct the discovery of truth and therefore contribute to injustice, but, the process would not necessarily be to blame. Non-procedural law can be evaluated on its own terms distinct from the processes within which and to which these laws apply. 
Most values are both process-oriented and result-oriented. For example, the right to participate in a hearing can be considered to facilitate fact-finding as the intended outcome of a criminal trial. In addition, participation in itself is a process value that is considered desirable. ${ }^{19}$ Of course, a strict division between process-oriented and result-oriented values cannot be attained. Process and outcomes are intrinsically connected; process exists because particular outcomes are intended. Summers accepts that "process values are 'parasitic' on processes"; however, he contends that from this "it does not follow that process features that serve those values are valuable only because they further good results desired by those who set up the process." ${ }^{20}$ In this sense, Solum contends that the relationship between "the value of process and participation [as 'process value'] on the one hand and accuracy or cost [as desired outcomes of a process] on the other" is one of dependence, rather than reducibility. ${ }^{21}$ This means that the process value of participation is dependent on its effects on outcomes or accuracy; however, it cannot merely be reduced to accuracy. ${ }^{22}$

Ashworth and Redmayne distinguish between the internal and external values of the criminal process. The former are the core values, which all systems of criminal process should implement, and the latter are the values more particular to a specific jurisdiction or values that are set externally to the criminal process. ${ }^{23}$ Ashworth and Redmayne define criminal process in a narrow sense, as a "mechanism that authorizes the State to apply the criminal law to its citizens." 24 Their theory of criminal process is 'trial-centred', implying that the principal aim of a criminal process is to achieve an effective trial, which in turn, aims at generating the fair and accurate disposition of cases. ${ }^{25}$ They further distinguish the dispositive values, as values that are concerned with the disposal of the case, "diversion from the formal process." 26

Accurate fact-finding and fairness are seen as internal values of a criminal process. The external values, some of which are jurisdictionally specific, are, for example, lay fact-finders (trial by jury) and adversarialism. ${ }^{27}$ There is of course interaction between internal and external values. Respect for human rights constitutes an internal aspect of a criminal process; however, the content of the rights to be

Summers, 1974, p. 47: “ ... this right [to participate in a hearing] might be built into the process both to secure the participatory process value and to serve the outcome value of truthful fact-finding."

20 Summers, 1974, p. 32.

21 Solum, 2004, p. 285.

22 Solum, 2004, p. 285.

23 Ashworth and Redmayne, 2010, pp. 21, 26-28.

24 Ashworth and Redmayne, 2010, p. 22.

25 Ashworth and Redmayne, 2010, pp. 24-25.

26 Ashworth and Redmayne, 2010, pp. 8-9, 55-57. They mention (a) prevention of crime, (b) consent and fairness, (c) victim compensation, and (d) proportionality of disposition under the heading of dispositive values.

27 Ashworth and Redmayne, 2010, p. 27. 
respected are set externally to the criminal process. Because international human rights instruments demand the uniform application of certain rights, these cannot be considered jurisdictionally specific. ${ }^{28}$ The internal or 'core values' will be discussed in this section, focusing on fairness, including humanness and efficiency. The next sections will pay attention to the external values when discussing a specific approach to criminal procedure.

The last general consideration with regard to goals and values of a criminal process is the notion of balancing that has been accepted as an appropriate method for a criminal process to incorporate and serve the different value (systems). Moreover, balancing competing interests has been central to any adjudication and seems particularly essential in any discussion of the principle of equality of arms, which by definition implies a fair balance. The most common conflicting interests are associated with the triangular relationship between the interests of the state, the accused individual and the particular victims of the crime. Moreover, the goals and values underlying the process itself can be in a (seemingly) conflicting relationship. In this sense, truth-finding is often seen as a seeming antipode of procedural fairness, specifically towards the accused. But also within notions such as the principle of fairness or the right to a fair trial, diverse underlying principles and rules do not always pull towards a similar end and consequently have to be aligned. For example, the right to have adequate time to prepare a defence can conflict with the principle of expeditiousness.

However, Porat observes that in adjudication "balancing consciousness" can be detected, meaning "the view that every problem can and should be solved through balancing conflicting considerations". ${ }^{29}$ An elaborate discussion of the theory and practice of balancing is not intended in this chapter; however, it is important to emphasise that a rigorous and structured approach to balancing is preferable. ${ }^{30}$ Ashworth and Redmayne warn against the inarticulate use of the metaphor of balancing. In their view,

the metaphor of balancing is a rhetorical device of which one must be extremely wary. At worst, it is a substitute for principled argument: 'achieving a balance' is put forward as if it were self-evidently a worthy and respectable goal, rather like

28 Ashworth and Redmayne, 2010, p. 28.

29 PorAt, 2006, p. 1394. Although the focus lies with constitutional adjudication, where the criminal process is concerned with conflicting rights and interests of individuals, Porat's model may prove a helpful tool. $C f$. Cohen-Eliya and Porat, 2010.

30 Ashworth and Redmayne, 2010, p. 45: "That is, the concept of 'balance' should be reserved for the conclusion of a lengthy and careful process, whereby rights and interests are identified; arguments for including some and excluding others are set out; appropriate weights or priorities are assigned to particular rights and interests, either generally or in specific context, and so forth. Above all it must be an empirically grounded, reasoned, and principled course of argument, not simply the pronouncement of a conclusion." 
'achieving justice'. [...] The difficulty is that many of those who employ this terminology fail to stipulate exactly what is being balanced, what factors and interests are to be included or excluded, what weight is being assigned to particular values and interests, and so on. ${ }^{31}$

Furthermore, considering the argument that greater protection of an individual defendant should be provided to counterbalance the resource disparity between him and the prosecutor, Ashworth points to a distinction between principled and practical considerations. ${ }^{32}$ In his view, the extent to which "the rules of criminal justice should be weighted against the state and crime control, to compensate for the weaker position of the individual defendant, is "an important practical issue"." ${ }_{33}$ Although this is a valid point, one must not forget that this distinction is really two sides of the same coin: principles are abstract building blocks of a legal system, and inform the more concrete rules, which are used to implement those principles in practice. ${ }^{34}$ Practical problems require practical solutions; however, every rule can be traced back to its justifying, much more general, principle.

Next, several general (internal) values of liberal criminal justice systems will be considered in some more detail.

\subsubsection{Conflict resolution and societal values}

Generally, the aim of conflict resolution is regarded as central to the process of adjudication. A society is ordered by way of creating means to achieve peaceful conflict resolution, which also serves to prevent self-help by citizens. In criminal adjudication, this aim is to resolve the conflict between the society whose norms have been bridged and the person who is suspected of bridging these norms. The general objective of the criminal process in a society that is based on the rule of law is to create a truthful account of what happened, to determine whether a person committed a criminal act, and to provide for appropriate sanctions if the person is

31 Ashworth and Redmayne, 2010, pp. 41-42. For a discussion of the difference between interests and rights, which can serve the purposes of proper decision-making (or the 'balancing' exercise) see LUCAS, 1980.

32 Ashworth, 1979, p. 415: "The distinction is that certain rules and procedures aim to counterbalance the defendant's disadvantageous position, so that if the particular disadvantage could be remedied by other means any rule or procedure which 'feeds' upon it could be abolished; whilst other rules and procedures aim to protect certain principles, and they remain unaffected by these factual contingencies." As an example he mentions the 'right of silence'. If practical disadvantage of an individual is the main consideration behind the right to remain silent, then practical safeguards (such as the tape-recording of interrogation) should provide adequate protection. But if the right to silence is based on the principle of fairness, the considerations will concern the manner in which that principle can best be secured and whether there could be any exceptions.

33 AshwORTh, 1979, p. 414.

34 See the considerations on the distinction between principles and rules in Chapter 1 of this study. 
held accountable. The general aim of conflict resolution is "tempered by other goals that limit how conflicts can be resolved." ${ }^{35}$

The process of adjudication incorporates the societal values that are central to a particular society, such as individual autonomy, humanness and communitarian values. Democracy, in the sense of democratic values, is also considered an important procedural value system. It includes the principles of transparency, accountability, public confidence or legitimacy and participation. ${ }^{36}$ Fairness is central in determining the legitimacy of a particular authority, law or process of adjudication, which is expressed in terms of societal acceptance of "the system's ability to promote goals the society sees as important." ${ }^{37}$ For a legal system to work, the procedures and their outcomes should be regarded as legitimate sources of authority by the parties involved in adjudication, officials and third parties and the public in general.

The tension between the liberal and communitarian theorists of the proper balance between individual and the community's rights and interests is central to the way conflict resolution in that society takes place. A society that emphasizes individual autonomy is expected to organize its system of adjudication in a way that promotes individual participation, control and initiative. More community-oriented societies, which place communitarian values above those of the individual, would be expected to emphasize an approach to conflict solving in terms of cooperation, social responsibility and restoration. ${ }^{38}$ Of course, societies' emphasis on individual or communitarian values does not in itself determine how the process of adjudication is organized. Western democracies are usually seen to be (extremely) liberal, with their emphasis on individual rights and freedoms. However, the way the criminal process is organized in these societies can differ immensely. Obviously, balancing the interests of the individual and society in a criminal process is just one of the factors responsible for a certain organization of a criminal process. The way the society's authority is structured and the goals it is expected to achieve in general are other essential elements for the analysis of the structure of a criminal process. This discussion will be returned to later in this chapter, where Damaška's political conception of the legal process will be discussed in more detail.

\subsubsection{Truth-finding}

As stated above, truth-finding is a central element in the criminal adjudication of a society based on the rule of law. Truth and truth-finding or fact-finding exemplifies the overlapping nature of different goals and values (result and process-oriented).

35 SwARD, 1989, p. 304. Truth finding and fairness are representative of these 'other goals'.

36 Sanders, 2002, p. 326. Cf. Summers, 1974, p. 20. Summers identifies it as a process value of 'participatory governance'.

37 SWARD, 1989, p. 306.

38 Sward, 1989, p. 311. 
Truth functions as a result-oriented value that has to be served by the criminal process, truth-finding or fact-finding is the intended result or goal of the criminal process. Accurate truth-finding in a criminal process is an important topic, which, in any criminal justice system, will never become outdated..$^{39}$

\subsubsection{The importance of truth in the criminal process}

The importance of finding the truth, that is accurate fact-finding, in a criminal process is to some extent rather self-evident. Generally, a criminal process, at least in Western legal traditions, aims at establishing an accurate account of the events labelled as criminal and on the basis of that information thereby coming to adequate punishment for the perpetrator of that criminal act. Individual victims and society have a strong interest in getting to the truth of what happened and why, as a criminal act causes societal disturbance and if it goes unattended and unpunished it can cause feelings of anxiety and distrust in the legal and law-enforcement system. As such, truth has a strong legitimizing effect for if the results of a criminal process are trustworthy, the right person is convicted for the crime he/she has committed and is punished accordingly, society's feelings of security and trust are ascertained. ${ }^{40}$ In addition, a criminal sanction is regarded as the "most severe expression of moral blame" and makes it extremely important to sanction only those who are in fact guilty of a criminal act. ${ }^{41}$ However, the interest-guided criminal process, as a venue to establish truth, is intrinsically flawed. The morally appalling character of the criminal act, and the seriousness of the consequences that are attached to this morally and legally unacceptable behaviour would not likely contribute to an openhearted discourse from the perpetrator's point of view. Frequently, the one person who is most likely to lead to the most reliable version of the truth about what actually happened is, at the same time, the least inclined to aid the investigation. Consequently, the relationship between truth and a criminal process is somewhat paradoxical. Arguably, truth in a criminal process depends on the "perceived legitimacy of the finder of that 'truth', the means by which 'truth' is discovered, and the manner in which the system acts upon that 'truth'." 42

Many attempts are made to design a criminal process that is most likely to get to the truth. Two principal designs are the well-known inquisitorial and adversarial

39 E.g. Ashworth and Redmayne, 2010 (problems and discussions surrounding truth-finding in English criminal law); KAPTEIN, 2009 (problems and discussion surrounding truth-finding in Dutch criminal law).

40 The other legitimizing factors such as the fairness of proceedings will be discussed later.

41 Weigend, 2003, p.158.

42 BRACEY, 1999-2000, p. 710 [emphasis in the original], 727: "To promote 'truth' within the criminal process, one must first secure a level of legitimacy for that process, so that "truth' discovered by legal actors and acted upon by legal institutions is perceived as truth." 
procedural models. But before looking at the particular designs of a criminal process, some reflection about what kind of truth can be achieved in a criminal process setting, and what is the proper place of truth among other, seemingly conflicting, values that manage the criminal process is in order.

\subsubsection{What kind of truth can be achieved in a criminal process?}

The debates about what 'truth' is and how we know that something is 'true' range from theories that identify a substantive meaning of "truth' 43 to theories that deny such a meaning, proposing that the label 'true' merely reflects a discursive tool to express an agreement. ${ }^{44}$ The different objects about which statements of truth are made may, in fact, be the subjects of different theoretical insights of that truth predicate. ${ }^{45}$ The points of controversy are easily stated: is truth absolute, objective, subjective, or relative? The debate centres on the question of whether it is possible to have knowledge of the external world; whether objective knowledge exists. And if yes, what kind of methods must be employed to gain this knowledge; how to explain what is true? ${ }^{46}$

43 Generally divided into correspondence, coherence, constructionist, consensus, pragmatic and pluralists theories of truth.

44 Minimalist or deflationary or disquotation theories of truth.

45 DAVID, 1994, p. 7 (“... important differences between the various kinds of objects [sentences, propositions, statements or beliefs] that might function as the bearers of truth may well induce important differences between the theories that are designed to explain what it is for an object of one such kind to bear truth.")

46 See generally BorChERT, 2006. The correspondence theory of truth, a classical theory which dates back to ancient Greek philosophy, asserts, simply said, that something (thought, believed) is true when it corresponds to empirical facts. Thus it is possible to establish an independent objective reality that can be expressed trough language or symbols. Other theorists challenge this absolute and objective account of what constitutes 'truth'. Damaška expresses it as follows: "Ordinary common sense takes this match [between our statements about the world and the world itself] for granted, of course, but not much of contemporary philosophy that treats 'correspondence' theories of the truth with utter contempt”. [DAMAŠKA, 1997-b, p. 37, footnote omitted].

According to the constructionist version of 'truth', reality is something that is socially constructed, historically and culturally contingent. By ascertaining that truth represents "a 'match' between a cognizer's statement and phenomena that can be either intrinsic to nature or socially constructed" the correspondence theory takes the constructionists' view into account. [DAMAŠKA, 1997-1998, p. 291] The coherence theory of truth challenges this mirroring of the world to a proposition, and contends that something is true only when it is part of a coherent system, emphasizing the mutual relation between the different beliefs and, as such, denying an ontological distinctiveness between beliefs and the objective conditions of the real world that make this belief true. This distinctiveness is also absent from the consensus theory which contends that something is true when it is agreed upon, the kind of consensus needed to assert that something is true qualifies the different theoretical branches of this theory. The pragmatic approach to truth criticises the correspondence theory for providing only a nominal definition of truth, and purports to go further by relating one's beliefs to the practice and thus verifying them. Contrary to these substantive theoretical accounts of 'truth', the 
The present framework of discussion is a criminal process, which is based on the premise that a true account of events underlying the criminal prosecution can be discovered with a degree of accuracy that legitimizes a verdict and, thus, the process as such. ${ }^{47}$ The adjudicator tries to "establish events and phenomena in the socially created world" that to some extent can be objectively ascertained. ${ }^{48}$ Yet, ascribing one definition of objectivity to all facts and situations, which all have a different 'ontological status', ${ }^{49}$ that are central in a criminal process is difficult, to say the least. Therefore, a distinction is made between factual guilt and legal guilt, the latter having a moral dimension..$^{50}$

Damaška proposes that a conception of objective, although socially contingent, knowledge "is at large - a conception stronger than one identifying this knowledge with what is right under dominant societal views, and yet weaker than knowledge independent of human beliefs and practices." ${ }^{51}$ Thus, he concludes that although the aim of legal proceedings is a socially contingent and not absolute truth "this does not imply that our aspiration to objective knowledge is misconceived, or quixotic." 52 In fact, he contends, complete knowledge of socially constructed phenomena can be more easily justified than phenomena with a basis in nature the truth of which we can only attempt to approximate..$^{53}$

However, several 'anti-realist' approaches to fact-finding emerged when the scepticism from various theoretical disciplines about the concept of truth and the ability to discover it had affected the debate in the realm of legal, particularly criminal, adjudication. The debate not only challenges the epistemological tradition

deflationary or minimalist accounts deny any metaphysical relevance of 'truth'. They deny that there is a nature of truth, in this sense it is an antithesis of truth. According to one version the addition of the adverb 'true' is redundant as it adds nothing to the statement nature but is only an expressive convenience without any deeper meaning.

47 DAMAŠKA, 1997-1998, p. 289.

48 DAMAŠKA, 1997-1998, p. 292: 'adjudicators cannot acquire objective knowledge in the strong sense of knowing how things are independently of human beliefs. But they are not in the business of seeking this metaphysical knowledge anyway: they seek to establish events and phenomena in the socially created world. What constitutes this world - think of the days of the week - is objectively ascertainable: ontologically subjective matter can be epistemically objective' [footnote omitted].

49 DAMAŠKA, 1997-1998, p. 299, footnote 24: 'Some matters exist as natural phenomena, while others are produced by social agreements of varying complexity'.

50 BRACEY, 1999-2000, p. 696: a distinction should be made between establishing a "historical fact - that is, whether person ' $\mathrm{X}$ ' committed a particular act proscribed by law' and 'a full-blown guilt determination - that is, whether person ' $\mathrm{X}$ ' should be criminally sanctioned for having committed the act in question."

51 DAMAŠKA, 1997-1998, p. 296. For another defence of objective truth and a severe attack on scepticism about truth, see AlLEN, 1997-1998. See also JACKSON, 1988, p. 521: "If objective knowledge means knowledge outside the persona, it is incapable of achievement. We have no direct access to the truth. This is not, however, to deny the possibility of knowledge."

52 DAMAŠKA, 1997-1998, p. 297.

53 DAMAŠKA, 1997-1998, p. 297. 
(the objectivity of knowledge), but also the fact-finding methods to achieve this truth. ${ }^{54}$ These alternative, to the realist vision of fact-finding, theories like the communicative, dialectical or consensus theories, present a "shift of emphasis from truth to the process of justification of claims to knowledge." ${ }_{55}$ This shift, Damaška argues, is problematic because the practical implementation of these accounts is not realistic in a criminal process. ${ }^{56}$ Moreover, "by blurring the lines between truth and successful justification, they obfuscate the distinction between procedural doctrines that were created to promote fact-finding accuracy and those rooted in considerations of fairness", something that Damaška considers as damaging. ${ }^{57}$

With his emphasis on the possibility of objective, although socially construed, knowledge, Damaška emphasizes 'substantive truth' that can possibly be obtained in the course of a criminal process. ${ }^{58}$ Generally, it is argued that the inquisitorial procedural approach is overly committed to this 'substantive truth'. By contrast, it is said that the adversarial procedural system adheres to the opposing 'procedural truth' due to the historically entrenched scepticism about the ability to uncover 'substantive truth' in general and in a criminal process in particular, and, thus, "the fairness of proceedings becomes the main foundation of the verdict's legitimacy, and any result that has been found in conformity with procedural rules becomes acceptable." 59 To some extent, this conception of procedural truth merely prioritizes other values that have to be reconciled in a criminal process. Truth-finding, in the sense of substantive

54 For a comprehensive account of the historical development of fact-finding in a criminal process see JACKSON, 1988. See also: DAMAŠKA, 1997-b, p. 37: 'In fact, a radical discord is emerging between existing proof practices and influential epistemological currents'.

55 DAMAŠKA, 1997-1998, p. 294. Note that Damaška, in defending (the aspired) objective knowledge in adjudication, contends that complete knowledge of socially constructed phenomena can be more easily justified (footnote 15 and accompanying text). Indeed discovery and justification are two essential components of the 'scientific method', which necessitates one to defend the methods of discovery as well as the object thereof. JACKSON, 1988, p. 522. Arguably, Damaška only criticized the shift of attention to the former to the detriment of the latter.

56 DAMAŠKA, 1997-1998, p. 296. Damaška argues that the practical implementation of these new approaches, like the dialectic approach, is an ideal aspiration at best. It depends on a procedural environment that is free from psychological pressures, strategic behaviour of the participants and can accommodate the demand for full and early disclosure of all the relevant information, something that a criminal process in reality just cannot provide.

57 DAMAŠKA, 1997-1998, pp. 296, 306: "If truth values are to be properly balanced against their competitors, doctrines and institutions that promote fact-finding accuracy and those that serve other goals should be clearly distinguished. Failing this prerequisite double-counting and other distortions can mar the balancing process."

58 Grande refers to it as 'ontolgical truth', "based as it is on the belief that an objective reconstruction of reality is attainable." Grande, 2008, p. 147.

59 Weigend, 2003, p. 168. Cf. Summers, 1999, p. 498, differentiating between the substantive truth and the formal-legal truth (defined as whatever is found as fact by the legal fact-finder). Grande refers to it as 'interpretative truth' as "the product of a contest between two interpretations of reality." Grande, 2008, p. 147. See also the discussion in Weichbrodt, 2012, pp. 19-33. 
truth (meaning socially constructed but objectively ascertained knowledge) is not considered as an ultimate or overarching goal of a criminal process. Other values such as "social peace, human dignity, stability of decisions, or cost" manage a criminal process next to truth-finding. ${ }^{60}$ Truth-finding is thus a necessary but not sufficient condition underlying a criminal process. ${ }^{61}$ Notwithstanding whether truth is taken as a goal among others or as a means to be reached for the ultimate goal of conflict resolution, it cannot be denied that truth-finding is an essential element of a criminal process. However, other values have to be taken into account and the formal legal truth that emerges from this interactive process can occasionally diverge from the substantive truth that could be achieved when it is taken as an ultimate goal through tunnel vision. ${ }^{62}$

Before discussing how these different values relate to each other in different procedural settings, another division of truths that is of particular importance for international criminal justice has to be briefly mentioned, and that is the 'legal' and 'historical' truths. The latter is usually equated to 'substantive truth' as a fact-finding goal. To a large extent this is warranted because the factual account of the events that underlie criminal prosecution has to be established: what happened and why? This historical account of what happened is taken as the basis for the legal judgment on the guilt of an accused person. This account should approximate 'substantive truth'. Notwithstanding this necessity, the ability of a legal process to establish an accurate historical record has very much been doubted. ${ }^{63}$ The primary culprit is the subjectivity of the methods that can be employed in a legal setting and its valueoriented and interest- driven nature. The judge is only interested in the general context to the extent that this is necessary for the determination of legal charges. Hence, the focus is on the elements of the events that can fit the legal definition. In an international criminal setting, establishing an accurate/reliable/trustworthy historical record of the world-shocking events that took place in the conflict areas over which these tribunals exercise jurisdiction has been defined as a general aim of international criminal justice. Voices of criticism have emphasized the 'aiming too high' nature of this objective. ${ }^{64}$

60 DAMAŠKA, 2003, p. 117.

61 Weigend, 2003, p.169. Weigend contends that "the discovery of 'truth' is not the objective of the criminal process, but only a means to reach that objective ... [which] is not to find facts but to resolve a conflict." This conflict can be defined as being between the prosecutor and the defendant, between the victim (society) and the offender, or the 'social unrest caused by the suspicion of crime'. See also KAPTEIN, 2009, p. 59, who speaks of the 'mere instrumental nature of truth-finding in criminal law: the ultimate goal being the punishment of the guilty when appropriate and the avoidance of punishment of the innocent'.

62 I am not saying that the 'substantive truth' should not be the ultimate goal of fact-finding; it just cannot be the ultimate goal of a criminal process.

63 DAMAŠKA, 2008; Wilson, 2005; ARENDT, 2006.

64 See the discussion in section 3.5. 


\subsubsection{A process model most committed to truth?}

As mentioned above, there are different epistemic and non-epistemic values in a criminal process. What priority can be established between these values? Moreover, can it be said that one particular system is more committed to truth than another? ${ }^{65}$ The inquisitorial process is generally perceived as being more committed to truth than is the adversarial procedure, which is more associated with fairness. ${ }^{66}$ As argued by Jackson, it is not the epistemological tradition that differentiates the continental and adversarial modes of procedure, but two different means of achieving the truth in the same "empiricist" tradition. ${ }^{67}$ Arguably, the civil law or continental procedural traditions envision that 'substantive truth' can be achieved in and should be the focus and the result of a criminal process. As such, the process is designed as an inquisitorial inquiry dominated by an independent 'truth-seeking' panel (a judge). By contrast, the adversarial process is based on the assumption that the establishment of 'substantive truth' through a criminal process is at best uncertain, and the best 'version' of procedural truth can be gained in a process that is characterized by a partisan contest. In this sense both systems have an objective to search for the truth; ${ }^{68}$ however, the vision on what kind of truth and how it is best achieved is divided. ${ }^{69}$

\subsubsection{Fairness}

Considerations of 'fairness' or 'justice' in the realm of criminal justice either start with the discussion about the risk distribution: whether it is indeed better that a guilty person would go free than convicting an innocent person; or about the protection

65 This question has been traditionally one of the most fascinating, specifically in the empirical studies on the criminal process. See Lind, Thibaut And Walker, 1973. For a review see DamašKa, 19721973.

66 This of course does not imply that the inquisitorial system is also better equipped to establish this 'substantive truth'. See JACKSON, 1988, p. 501-502, where he contends that most of the AngloAmerican writers on procedure and evidence prefer the adversarial procedure over the continental one, not only because the adversarial model is deemed to be "better able to cater to values other than truth finding, such as the values of party participation, human individuality, and dignity, but also because it is a better aid to truth finding itself" due to utilizing the methods of natural science to better effect than the continental model through the practice of examination and cross-examination.

67 JACKSON, 1988, p. 502.

68 Jörg, Field AND Brants, 1995, p. 42.

69 Grande, 2008, p. 146. Whitman argues that Anglo-American and Continental traditions differ in their committment to the pursuit of definitive correct answers; while the "Continental systems tend to seek answers that are not only correct but also definitive [because] [t] hey tend to treat the rule of law as requiring that all legal officials will generally produce the same answer to any given question ... [o]ther legal traditions, including the American, tend to devote themselves to the search for correct answers in a way that largerly excludes the possibility that those answers could be definitive." Whitman, 2008, p. 373. 
of an individual during a criminal process. ${ }^{70}$ The first discussion clearly focuses on the substantive understanding of 'fairness' or 'justice'. In a society that is based on the rule of law, the conviction of an innocent person is viewed as a greater harm than the release of a guilty person. A 'cardinal value' of the criminal process is its error preference; acquitting the guilty above convicting the innocent. ${ }^{71}$ However, a discussion about what the margins of this risk distribution are or should be is not intended, as it directs the discussion too far into the realm of substantive (distributive) justice justifications, while the focus of this chapter is on the criminal process. Thus, the discussion hereunder will focus on procedural fairness or the procedural conception of justice. What makes a process fair? ${ }^{72}$ Of course, the answer to this question is culturally and temporally contingent; however, there are some theoretical notions that provide a starting point for an evaluation of a particular criminal process. ${ }^{73}$

\subsubsection{The concept of procedural justice}

As mentioned above, the utilitarian approach or instrumentalist view of procedure reduces procedural fairness to calculations of the costs of adjudication and the benefits of accuracy. ${ }^{74}$ Procedure is seen as a means to serve substantive law, to achieve particular substantive results. What is the point of a fair procedure if it results in unjust outcomes? This deflationary view of procedural justice eliminates the distinctive contours of substantive and procedural law, but of course, it does not make procedure redundant. Procedural fairness includes, next to the cost and benefits, an "old and powerful idea that a process that guarantees rights of meaningful participation is an essential prerequisite for the legitimate authority of action-guiding

70 Ashworth, 1979, pp. 416-418.

71 Ashworth and Redmayne, 2005, p. 25. Reflecting the famous expression commonly referenced to Blackstone's Commentaries on the Laws of England: 'the law holds that it is better that ten guilty persons escape, than that one innocent suffer' (1765, Boston: Beacon Press, 1962), Bk. IV, Ch. 27, p. 420. Laufer observes that 'This maxim may be traced to Hale who noted in the late 1600 s that is it better that five guilty men should be acquitted before one innocent man is convicted'. Matthew Hale, Pleas of the Crown, or, A Brief but Full Account of Whatsoever Can Be Found Relating to that Subject, 289 (1678). Similar reference may be found in the work of Fortescue, who wrote: "I would rather with twentie evil doers escape death through pitie that one man to be unjustly condemned." De Ladibus legume Angliae c. 27 (1545)', Laufer, 1995, p. 334. For a discussion see Halvorsen, 2004, pp. 3-13.

72 The use of the term 'fairness' is preferred as in my view 'justice' has a more 'substantive' quality within the term, or at least it is used more in that sense. See also DAMAŠKA, 2004, p. 1035, footnote 28: fairness is 'pre-eminently a quality of procedure', whereas justice is 'pre-eminently a predicate ascribed to results'.

73 U.S. Supreme Court, Kremer v. Chemical Constr. Corp., 456 U.S. 461 (1982): "We must bear in mind that no single model of procedural fairness, let alone a particular form of procedure, is dictated by the Due Process Clause. ..." Uviller, 1999, p. 280.

74 E.g. Kaplow and Shavell, 2003. 
legal norms." ${ }^{.75}$ As discussed above, certain values are served or implemented by the process and are valuable as 'process values' independent from the substantive results. Fairness can thus be regarded as an objective of the criminal process as well as a 'system value'. ${ }^{76}$

Making and implementing decisions according to fair procedures is the central concern of procedural justice and, as mentioned above, fair procedures are seen as essential to guarantee fair outcomes. ${ }^{77}$ Fair procedures tend to inspire feelings of loyalty towards one's group, legitimize the authority of leaders, and help to ensure voluntary compliance with the rules. ${ }^{78}$ The principles of transparency of processes, impartiality of decision-makers, consistency in the application of law and the participation of those affected by the process/decision are central to the concept of procedural justice. Nelson interprets Rawls' vision of a 'case' of procedural justice as "a situation in which (1) justice is a matter of importance and (2) it is desirable from the point of view of justice that we establish or comply with some procedure." 79 According to Solum, "the hard question of procedural justice [is]: How can we regard ourselves as obliged by legitimate authority to comply with a judgment that we believe (or even know) to be in error with respect to the substantive merits?" 80 An unjust outcome cannot be the source of legitimate authority; however, "only just procedures can confer legitimate authority on incorrect outcomes." ${ }^{\prime \prime 1}$

\subsubsection{Conceptions of procedural justice}

Rawls distinguishes three types of procedural justice: prefect, imperfect and pure. ${ }^{82}$ Two elements characterize perfect procedural justice: (1) "there is an independent criterion of what is a fair division, a criterion defined separately from and prior to the procedure which is to be followed"; and (2) "it is possible to devise a procedure that

75 Solum, 2004, p. 183: 'Meaningful participation requires notice and opportunity to be heard, and it requires a reasonable balance between cost and accuracy'.

76 SANDERS, 2002, p. 326.

77 Solum, 2004, p. 238: 'In the context of the modern nation-state, procedural justice is concerned with the adjudicative methods by which legal norms are applied to particular cases and the legislative processes by which social benefits and burdens are divided'.

78 Tyler and Belliveau, 1995, p. 297.

79 Nelson, 1980, p. 503.

80 Solum, 2004, p. 190. Of course, this question relates to adjudication in general and not to criminal adjudication in particular. One can even regard this question as invalid in the context of criminal law because of its coercive nature. An obvious point to the contrary is the general nature of the legitimacy of authority of criminal judgments: it does not only relate to the subjective perception of the defendant(s). For officials, third parties and the public in general this question is validly posed in the context of criminal law as well.

81 Solum, 2004, p. 190.

82 RAWLS, 1971. 
is sure to give that desired outcome." ${ }^{83}$ As an example, Rawls mentions the procedure of cake slicing (discussed above, process values). A correct outcome is achieved through a procedure that was designed to achieve this correct outcome. ${ }^{84}$ Solum refers in this context to the accuracy model, "the correct application of law to the facts." ${ }^{85}$ However, accurate results are not enough as "[j] ustice has a price, and there is a point at which that price is not worth paying." ${ }^{\prime 86}$ Another problem surrounding the notion of accuracy is its ambiguous nature: does it promote 'case accuracy', a correct result in a particular case (an ex post perspective) or 'systemic accuracy', a correct result in all the future cases (an ex ante perspective) ${ }^{87}$ Sometimes, the two do not always go hand in hand. ${ }^{88}$ In dismissing accuracy as the sole foundation for a theory of procedural justice, Solum argues that because perfection (in the sense of perfect accurate results) is an ideal at best, "a fair procedure must, at a minimum, strike a fair or reasonable balance between the benefits of accurate outcomes and the costs imposed by the system of procedures." 89

In case of imperfect procedural justice, there is an independent criterion for a correct desired outcome, but it is not possible to design a procedure that would always achieve this correct outcome. ${ }^{90}$ The best that can be achieved is designing a procedure that minimizes injustice. As an example of imperfect procedural justice Rawls mentions a criminal trial. The correct outcome is finding a person guilty only if he has actually committed the crime that he is charged with; however, no design of procedure can surely lead to this desired result. Inspired by this, Solum proposes the balancing model of procedural justice. Two interpretations of the balancing model are possible. Firstly, the utilitarian view balances accuracy and costs only; secondly, the

83 RAwLs, 1971, p. 85.

84 For a brief but critical reflection on the division between perfect and imperfect procedural justice see GustafsSON, 2004.

85 Solum, 2004, p. 244 [footnote omitted].

86 Solum, 2004, p. 247 [footnote omitted]: 'Moreover, we have every reason to believe that accuracy is subject to the law of diminishing returns. If we were to make perfect accuracy out highest commitment, we would find that as we got closer to our goal, the cost of reducing the marginal rate of error would become higher and higher. We would reach a point where society would be required to invest enormous resources for an infinitesimal gain in accuracy'.

87 Solum, 2004, p. 247.

88 Solum, 2004, p. 248. Exemplary in the realm of criminal procedure are rules that exclude evidence because of the manner in which it was obtained: as a deterrent to ensure proper police conduct in the future to enhance 'systemic accuracy' the 'case accuracy' in a particular case is obviously undermined by exclusion of reliable evidence. Of course, undermining the case accuracy in that particular case is justified on other grounds than general enhancement of systemic accuracy: it is unfair to use illegally obtained evidence against the defendant, as it gives an unfair advantage to the prosecutor or because the violation of the rights of the accused is so severe that a 'reparation' in the form of exclusion of the evidence is considered fair.

89 Solum, 2004, p. 185 [footnote omitted].

90 RAWLS, 1971, pp. 85-86. 
rights-based approach "assumes that procedural justice requires attention to the fair distribution of the costs imposed by the system of procedure." 91

The third conception of procedural justice is the pure form: there is no independent criterion for a correct outcome; however, there is a correct or fair procedure that leads, if it is properly followed, to a correct outcome. ${ }^{92}$ Here, fairness is a function of procedure and not an independent criterion. As long as the procedure is followed, the outcome is considered to be fair. In this context, Solum refers to the participation model of procedural justice. ${ }^{93}$ According to this model, procedural fairness is achieved only if individuals directly affected by the decision can participate in the process. ${ }^{94}$ Different interpretations can be given to this pure conception of procedural justice.

First, there is the gaming interpretation, which is mentioned by Rawls as an example of pure procedural justice. As long as the game procedure is followed fairly, the distribution of winnings is regarded as fair, whatever this distribution may be. From this perspective, a comparison of an adversary system of adjudication to a sporting event of a game has been made repeatedly. ${ }^{95}$ Of course, in criminal adjudication, a defendant does not choose to play the game, but is forced to do so. The metaphor of a 'level playing field' is sometimes applied in judicial opinions to express the view that for the 'game' to be fair, one side cannot be given an unfair advantage. ${ }^{96}$

Second, there is the dignity interpretation of pure procedural justice, which "connects the independent value of process with the dignity of those who are affected by legal proceedings." ${ }^{97}$ People have the right to be treated with respect and where the determination of their rights is at stake to have their 'day in court' .98

91 Solum, 2004, p. 243.

92 RAWLS, 1971, p. 86.

93 Solum, 2004, p. 243.

94 Solum, 2004, p. 259: "The key notion is that it is the process itself and not the outcome that defines procedural justice." [footnote omitted].

95 See e.g. Brennan, 1989; Frank, 1973, p. 91, criticizing the gaming theory: 'Wigmore (following up a suggestion made by Bentham) suggested that "the common law, originating in a community of sports and games, was permeated by the instinct of sportsmanship" which led to a "sporting theory of justice," a theory of "legalized gambling." This theory, although it had some desirable effects, "has contributed," said Wigmore, "to lower the system of administering justice and in particular of ascertaining truth in litigation, to the level of a mere game of skill or chance" ... in which lawyers use evidence "as one plays a trump card, or draws to three aces, or holds back a good horse until the homestretch ..."

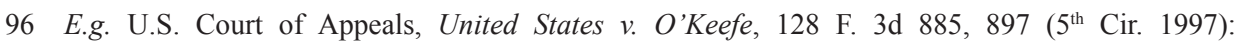
"Accordingly, we find that the disclosure to the jury of Donaldson's falsehoods coupled with the prosecution's disclosures to the defense prevented those falsehoods from being material because enough information was provided to the jury to enable them to adequately perform their fact-finding function and to maintain the level playing field between the prosecution and the defense." [emphasis added, MF].

97 Solum, 2004, p. 262, see footnote 208 for extensive references of the dignity argument.

98 Solum, 2004, p. 264. This interpretation of the participation model "is rooted in a rights-based or fairness-centred conception of political morality." 
Third, the more utilitarian approach to the participation model is the satisfaction interpretation: "a process that provided participants an opportunity to tell their stories and make litigation decisions may be most satisfactory to participants, even if the process is less accurate or more costly than alternatives that afford less opportunity for participation." $" 99$

Fourth, based on Habermas's discourse theory of truth, another interpretation of the participation model can be called the discourse theory interpretation. This interpretation assumes "a deep, constitutive connection between participatory process and correct outcomes." "100 'Truth' emerges from universal, rational consensus under conditions of ideal speech situation. ${ }^{101}$ A legally correct outcome can only be described in terms of a fair legal procedure. Participation that can lead to rational consensus can only take place in an ideal communication situation: there must be equality in opportunity to engage in the communicative process that would lead to 'truth' or a correct outcome. ${ }^{102}$ In the context of criminal procedure, the equal opportunity to participate, or the rules of the ideal communication situation, justify the rules of procedural due process, like the right to be informed of the charges, the right to be heard, and other rules which equalize the opportunity to present one's case, including the rules of pre-trial disclosure, the presentation of evidence, witness presentation, examination and cross-examination. ${ }^{103}$

An obvious critique of this discourse interpretation of the participation model of procedural justice is that the sole focus on procedural fairness, even if the process maximally approximates the ideal communication situation, does not guarantee the emergence of truth. The rules of evidence law, for example, are justified on the

99 Solum, 2004, p. 264. Procedural justice has been an important research topic of social psychology, see for an elaborate list of references, Solum, 2004, p. 265, footnote 213.

100 Solum, 2004, p. 267.

101 Solum, 2004, pp. 267-268, citing MCCARThy, 1978, p. 303. The key notion is that 'ultimately there can be no separation of the criteria for truth from the criteria for the argumentative settlement of truth claims.'

102 Comparable to the 'level playing field' requirement of the gaming theory discussed above. SoLum, 2004, pp. 269-270. Solum formulates three rules for an ideal communication situation, which are based on Habermas account: (1) Rule of Participation ('each person who is capable of engaging in communication and action is allowed to participate'); (2) Rule of Equality of Communicative Opportunity ("each participant is given an equal opportunity to communicate with respect to the following: each participant is allowed to (i) call into question any proposal, (ii) introduce any proposal into the discourse, and (iii) express attitudes, sincere beliefs, wishes, and needs; (3) Rule against Compulsion ('no participant may be hindered by compulsion - whether arising from inside the discourse or outside of it - from making use of the rights secured under (1) and (2)').

103 Duff, 1986, pp. 115-116. This communicative vision of the criminal trial was advanced by Duff, who contended that as a communicative process, a trial is about calling the defendant to account: 'The aim of a criminal trial is not merely to reach an accurate judgment on the defendant's past conduct; it is to communicate and justify that judgment - to demonstrate its justice - to him and others'. A trial is a 'rational process of proof and argument which seeks to persuade the person whose conduct is under scrutiny of the truth and justice of its conclusions'. 
notion that they maximize the accuracy of the fact-finding process and are "not structured around the notion that equal opportunity to present evidence guarantees the emergence of truth." 104 The input and, thus, the content of the evidence is essential for the achievement of truth. As contended above, substantive (or objective) truth, as the ultimate goal of fact-finding in a criminal process, does not always approximate procedural (or formal-legal) truth, which represents the outcome of a criminal trial.

Independently, all the different interpretations of the participation model do not complete the whole story of procedural fairness, which combines the values or principles of participation, accuracy and cost-efficiency. What priority should be given to what value? The principle of participation has at its core two elements: the right to notice and the right to be heard, which can be stated to represent the minimum core content. In light of the rights-based formulation of the participation principle ${ }^{105}$ priority should be given to the minimum content of this principle above the considerations of accuracy. ${ }^{106}$ Once these basic rights are upheld, the procedure's focus should be on obtaining a correct outcome, a focus which is encapsulated by the cost-efficiency considerations, as truth has its price. ${ }^{107}$

\subsubsection{Efficiency}

Efficiency is another dominant or core value that incorporates limited resources and, thus, "puts a price on justice." 108 As the resources are always limited, hard choices have to be made with regard to the allocation of those resources. This is not only true within the criminal justice system of a particular state, but more broadly within the public services, such as education, housing and/or health care that that state provides. Efficiency can take on many different meanings depending on the context of applicability. It can be expressed in terms of the number of processed cases, the cost-case ratio, and the accuracy of the results or the speed in which the results are obtained. As an economic/instrumental discussion is neither intended nor attainable; this brief consideration of efficiency will suffice. Some of the meanings of efficiency

104 Solum, 2004, pp. 271-272.

105 Compare SANDERs, 2002, p. 326. Sanders contends that fairness "incorporates several distinct decision making processes. First, there is the application of legal rules according to due process and human rights standards. ... Second, there is fact-finding. This includes deciding who or what to believe, and making choices between conflicting accounts. Third, there is problem-solving. This includes making risk assessments when deciding bail applications, and choosing between rehabilitative and retributive sentences".

106 The more substantive understanding of participation can be considered as a necessary condition for truth-finding as such. One of the fundamental assumptions of an adversarial trial structure is that truth emerges from a confrontation of two adversaries who are given a fair opportunity to confront each other's propositions. Participation in this process is thus a prerequisite to get to the best truth possible.

107 This proposition is consistent with that of Solum, 2004, pp. 307-308.

108 SANDERS, 2002, p. 327 [footnote omitted]. 
will be illustrated in the next section where two important models of balancing the values underlying a criminal process are contrasted.

\subsubsection{Due process v. crime control}

When discussing criminal procedure's goals and values the concepts of truth, fairness, crime control and due process are dominating. The last two refer, of course, to the famous models developed in the 1960s by the American legal scholar Herbert Packer. Although these models have been subjected to a great deal of criticism for their supposedly restrictive and theoretically unsound nature, they still dominate any discourse which is directed towards understanding the different value (systems) operating in a criminal process. Packer's intention has been put into practice as his models "merely afford a convenient way to talk about the operation of a process whose day-to-day functioning involves a constant series of minute adjustments between the competing demands of two value systems and whose normative future likewise involves a series of resolutions of the tensions between conflicting claims."109

When discussing Packer's models, one has to keep in mind that his normative framework of the two value systems was developed within the framework of the American society in the $1960 \mathrm{~s} .{ }^{110}$ All generalizations are thus to be undertaken at one's own risk. ${ }^{111}$ Packer's models represent two distinct systems of a possible balancing of values that compete for realization in a criminal process, more specifically in the American adversarial process. ${ }^{12}$ These models show two possible ways to prioritize the different values. ${ }^{113}$ In this sense, his terminology ("two models of the criminal process') might be somewhat confusing suggesting that he talks about two models of criminal process while his idea reflects the balancing of the different values such as reliability, efficiency, expeditiousness, finality, individual protection against abuse of power by the state and equality. These values are prioritized in two possible schemes: due process and crime control. One should remember that 'the models are distortions of reality' and that "values are too various to be pinned down to yes-or-no answers." 114

109 PACKer, 1968, p. 153 [emphasis added]. First published 1964, (PACKer, 1964).

110 PACKer, 1968, p. 152.

111 A great deal of criticism of Packer's models and confusion about terminology and their application arises just from the fact that the underlying framework is 'forgotten'. See e.g. RoBERTs, 2008, p. 378: 'Packer's reward for his ingenuity is thus to become a kind of Dr Frankenstein of criminal justice theory: a victim of his own fantastic creation, which (just like Mary Shelley's original) was turned into a monster by other people's lack of comprehension and insensitive handling'. For an overview of existing critiques of Packer's framework see Macdonald, 2008, pp. 265- 274.

112 PACKer, 1968, p. 154.

113 PACKer, 1968, p. 154: "The models are polarities, and so are the schemes of value that underlie them".

114 PACKer, 1968, p. 153. 
Indeed, Packers presentation is merited for its simplicity and convenience when talking about the competing values of a criminal process.

The value system of the Crime Control Model represents the idea that the repression of crimes is the most important function of a criminal process in order to safeguard social security and freedom. ${ }^{115}$ The primary focus of this model is on the efficiency that is achieved in apprehending, prosecuting crime and punishing offenders. ${ }^{116}$ "Speed and finality" are needed to "produce a high rate of apprehension and conviction," while dealing with a magnitude of cases in the framework of limited resources". ${ }^{117}$ Informality and uniformity through standardized administrative procedure is, thus, preferred above judicial proceedings and the appeal possibilities are limited. ${ }^{118}$ The Crime Control Model is an early screening process of the probably guilty persons who are then passed quickly through the remainder of the process. This attitude of a 'presumption of guilt' allows the Crime Control Model to deal efficiently with a large number of cases and expresses confidence attached to the reliability of informal administrative fact-finding at the initial stages of a criminal process. ${ }^{119}$ This model, in its pure form, "offers two possibilities: an administrative fact-finding process leading (1) to exoneration of the suspect, or (2) to the entry of a plea of guilty." 120

The Due Process Model "looks very much like an obstacle course" that is "designed to present formidable impediments to carrying the accused any further along in the process." "121 The Due Process ideology is not the opposite of Crime Control in that the former also acknowledges the social desire for crime repression; however, it emphasizes the formal structures of the law due to distrust in the reliability of the informal fact-finding processes. Thus, the due process model insists on "formal, adjudicative, adversary fact-finding processes in which the factual case against the accused is publicly heard by an independent tribunal and is evaluated only after the accused has had a full opportunity to discredit the case against him." ${ }^{122}$ In a pure Due

115 PACKer, 1968, p. 158.

116 PACKER, 1968, p. 158: "Efficiency of operation is ... the system's capacity to apprehend, try, convict, and dispose of a high proportion of criminal offenders whose offences become known."

117 PACKER, 1968, p. 159.

118 PACKER, 1968, p. 159: "The image that comes to mind is an assembly line or a conveyor belt down which moves an endless stream of cases, never stopping, carrying the cases to workers who stand at fixed stations and who perform on each case as it comes by the same small but essential operation that brings it one step closer to being a finished product, or, to exchange the metaphor for the reality, a closed file."

119 PACKER, 1968,p. 160. The presumption of guilt is not considered to be the opposite of the presumption of innocence, but a different idea, namely a prediction of outcome and not a direction to officials on how they are to proceed and to treat the suspect. " ... the presumption of guilt is descriptive and factual; the presumption of innocence is normative and legal." (pp. 161-162).

120 PACKeR, 1968, pp. 162-163.

121 PACKER, 1968, p. 163.

122 PACKER, 1968, pp. 163-164. 
Process Model, a subsequent scrutiny of the possible human error must be available "at least as long as there is an allegation of factual error that has not received an adjudicative hearing in a fact-finding context." 223

Reliability in the sense of accurate fact-finding ${ }^{124}$ and efficiency in the sense of a quick handling of cases ${ }^{125}$ are competing values. Whereas the Crime Control model accepts reliability deficits up to a level where it interferes with the goal of supressing crime; ${ }^{126}$ the Due Process model rejects shortcuts around reliability in the name of efficiency. ${ }^{127}$ Consequently, in the Crime Control Model the aim of convicting the guilty individual is prioritized above the acquittal of the innocent, the relative accepted rate between the two aims is more lenient in the Crime Control Model than in the Due Process Model.

According to Packer, this, however, 'is only the beginning of the ideological differences between the two models'. ${ }^{128}$ The concept of the "primacy of the individual and the complementary concept of limitation on official power" are the primary values that direct the maximization of reliability at the expense of efficiency in the Due Process Model. An individual is found guilty of a crime, following the proper procedure, when reliable evidence shows that that he did indeed commit that crime. ${ }^{129}$ The rules that protect the integrity of the process must be applied even if it means letting a guilty person go free. Another strand on which the Due Process Model is based is the notion of equality, which ensures that every defendant, notwithstanding his financial situation, can present a defence through a legal representative. ${ }^{130}$ The final strand of the Due Process Model is the sceptical attitude towards the usefulness of a criminal sanction. ${ }^{131}$ In Packer's view, “doubts about the ends for which power is being exercised create pressure to limit the discretion with which that power is exercised."'132

Packer's terminology has led to some confusion in the debate about the application of his models. Smith, for example, has contended that these models cannot be regarded as two alternative types of criminal justice system because the

123 PACKER, 1968, p. 164. Finality thus has very low priority.

124 "... a high degree of probability in each case that factual guilt has been accurately determined." PACKER, 1968, p. 164.

125 "... expeditious handling of the large numbers of cases that the process ingests". PACKER, 1968, p. 164.

126 PACKER, 1968, p. 165: “ ... accepts the probability of mistakes up to the level at which they interfere with the goal of repressing crime, either because too many guilty people are escaping or, more subtly, because general awareness of the unreliability of the process leads to a decrease in the deterrent efficacy of the criminal law."

127 PACKer, 1968, p. 165.

128 PACKER, 1968, p. 165.

129 PACKER, 1968, p. 165.

130 PACKer, 1968, p. 168.

131 PACKer, 1968, p. 170.

132 PACKer, 1968, p. 171. 
Crime Control Model pursues the fundamental goals of a criminal justice system, while the Due Process Model sets the appropriate limits to the pursuit of those goals. ${ }^{133}$ Duff proposes to rename the Crime Control Model as the Efficiency Model, to accommodate confusion in the debate which originates from the duality of the crime control concept: "to describe the goal of the criminal justice system and ... to summarize a complex of values which influence its operation." 134 Although this proposition seems as a viable solution to the confusion, two complicating factors, in this regard, need to be mentioned. Firstly, the line between goals and values is not clear, and depends primarily on the evaluative point of view. Moreover, as mentioned, most values are both process-oriented and result-oriented. ${ }^{135}$ Secondly, Packer himself used 'efficiency' in an inconsistent manner which emphasizes the complex nature of identifying and defining values in a criminal process. ${ }^{136}$

According to Damaška, Packer did not intend to construct "two rival ideal-types in designing the criminal process." ${ }^{137}$ Although the Crime Control Model could be seen as such, the Due Process Model is presented as "basically a negative model"138 and "it is conceptually impossible to imagine a criminal process whose dominant concern is a desire to protect the individual from public officials." 139 Damaška thus contends that the Due Process Model's overriding concern is the protection of individual rights arising from the primacy of the individual and not the concern for fact-finding reliability. ${ }^{140}$ In fact, he objects to Packer's typology of Crime Control and Due Process as models and contends that "what Packer is offering us ... within the framework of the American criminal process, a stimulating depiction, rich in implication, of two clashing inner tendencies: the tendency toward efficiency and the tendency toward protecting the rights of the defendant."141 Indeed, these competing tendencies represent "part and parcel of the dialectics of any criminal process." 142 This seems an agreeable account of Packer's presentation, although he did not generalize the application of his 'models' as his analytical framework was the American criminal procedure at that time. As contended above, his models show two possible hierarchies of values underlying a criminal process. Arguably, a model as a methodological tool

133 SмIтH, 1997, p. 335.

134 Duff, 1998, p. 611.

135 For example, the right to participate in a hearing can be regarded to facilitate fact-finding as the intended outcome of a criminal trial, but also because participatory governance in itself as a process value is considered desirable. See Summers, 1974, p. 47: “ ... this right [to participate in a hearing] might be built into the process both to secure the participatory process value and to serve the outcome value of truthful fact-finding."

136 Macdonald, 2008, p. 278.

137 DAMAŠKA, 1972-1973, p. 575.

138 PACKER, 1968, p. 173.

139 DAMAŠKA, 1972-1973, p. 575.

140 DAMAŠKA, 1972-1973, p. 556.

141 DAMAŠKA, 1972-1973, p. 576.

142 DAMAŠKA, 1972-1973, p.576. 
is a simplification of reality suitable for a better representation, description, analysis or evaluation of a particular phenomenon taken from reality, and thus is and can be used in a variety of scenarios. ${ }^{143}$

Concerning the relationship between Due Process and Crime Control ideologies and the possible methods of resolving the underlying conflict of values, i.e. the adversarial and non-adversarial modes of procedure, Damaška contends that "the pure adversary model tends to resolve the conflict in a synthesis coming closer to the Due Process ideology than does the non-adversary model." 144 This position is informed by his understanding of the preference given to truth-finding in the adversarial and nonadversarial criminal proceedings, discussed above. In this sense, Goldstein contends that both the inquisitorial and adversarial process models reconcile the tension between legality and efficiency, but neither system is principally better equipped to suppress crimes or serve the due process of the law. ${ }^{145}$ In fact, the operation of any model will depend on different interactive factors, such as "the normative content of the standards to be applied in making decisions, how the participants are perceived and trained, the controls introduced at strategic points, and the resources assigned to implement policies and controls." 146

The next section will consider these two types of criminal procedure, namely adversarial and inquisitorial ideal types.

\subsection{AdVERSARIAL AND INQUiSITORIAL MODELS OF PROCEDURE}

\subsubsection{Explaining the use of terms}

The adversarial and inquisitorial concepts are almost habitually used terms throughout comparative criminal procedure scholarship. They represent "familiar and simple models" 147 and encompass some central ideas agreed upon for the identification of the dichotomy between adversarial and inquisitorial procedures. The use of these terms, however, is also heavily criticized from time to time as being "outdated and irrelevant, vague, inconsequent or even perhaps meaningless." 148 It is thus important to reflect upon the way these terms are used in this study. This study attempts to develop normative reasoning as to the interpretation and application of a particular procedural principle, namely equality of arms, in international criminal proceedings. A comprehensive description of particular criminal procedural systems that are found on the continent or in the Anglo-American world is neither intended nor realistic.

143 In Damaška’s words: “ ... all models are by definition suggestive caricatures and simplifications departing from reality.” DAMAŠKA, 1972-1973, p. 577.

144 DAMAŠKA, 1972-1973, p. 577.

145 Goldstein, 1974, p. 1021.

146 Goldstein, 1974, p. 1021.

147 JACKSON, 2005, p. 740.

148 Summers, 2007, p. 5. 
However, to employ normative thinking about international criminal procedure, is seems helpful to resort to this 'traditional' divide to understand the underlying principles and assumptions and the way these can and have been translated into concrete procedural features.

The divide between adversarial and inquisitorial processes is approached as conceptualizing particular 'legal traditions' and not as 'a conceptual device for understanding criminal process through classification or taxonomy." 149 Merryman refers to a legal tradition as "a set of deeply rooted, historically conditioned attitudes about the nature of law, about the role of law in the society and the polity, about the proper organisation and operation of a legal system, and about the way law is or should be made, applied, studied, perfected, and taught." ${ }^{150}$ According to him, a legal tradition is the link between a culture and a particular legal system that reflects, partially, that culture. ${ }^{151}$ Field proposes a "dialogic and fluid notion of tradition" contending that legal traditions are (re)invented through dialogue that leads to social change; and thus are not stable and static objects. ${ }^{152}$ In its basic understanding a (legal) tradition incorporates a movement, something is passed down from the past to the present. The concept of (legal) culture seemingly encompasses this 'present' where social attitudes, practices, goals, values, human beliefs, knowledge and behaviour are cultivated. 'Legal culture' is another term that is used in modern scholarly writings, and is broadly defined as "one way of describing relatively stable patterns of legally oriented behaviour and attitudes." 153

The uncertainty about the specific interpretation of the terms 'adversarial' and 'inquisitorial' are widespread in socio-legal scholarship as these concepts "are, and will remain, politically contested interpretations of the past." 154 Both in theory and in practice the adversarial-inquisitorial distinction is complex. ${ }^{155}$ In addition, many scholars contend that there is a theory of convergence of the opposing procedural modes, particularly due to the strong influence of the European Court of Human

149 FIELD, 2009, p. 369.

150 Merryman, 1969, p. 2.

151 Merryman, 1969, p. 2.

152 Field, 2009, p. 370.

153 NelKen, 2007, p. 11: The identifying elements of legal culture range from facts about institutions such as the number and role of lawyers or the ways judges are appointed and controlled, to various forms of behaviour, such as litigation or prison rates, and, at the other extreme, more nebulous aspects of ideas, values, aspirations and mentalities. Like culture itself, legal culture is about who we are, not just what we do. There is a lot of confusion about the usage of the term 'legal culture' as it can have various meanings. According to Nelken, "in practice it is most often used in an unsophisticated manner just to point to the distinctiveness of legal actors, institutions or doctrines." See NelKen, 2007, p. 24. When used as an equivalent to a 'legal system' it loses its explanatory potential.

154 FIELD 2009, p. 372.

155 Ashworth and Redmayne, 2010, p. 417 [footnote omitted]. 
Rights on the continent. ${ }^{156}$ However, being aware of the shortcomings and the critics, the traditional basic understanding of the terms and their widespread use cannot be denied and is seen as helpful in its simplicity to clarify the basic tenets of a particular criminal process. Adversarial and inquisitorial labels are not the end but are only a starting point for a discussion of "how those traditions have been interpreted, adapted and resisted in the light of national political and legal cultures." 157 They also represent a common vocabulary underlying international criminal process and thus present a convenient rhetorical device for further discussion.

\subsubsection{Adversarial}

The term adversarial procedure is used to refer to the traditionally developed adjudicatory styles in the jurisdictions based on the common law tradition like that in England and Wales, Ireland, the United States, Australia and Canada. Although it is usually assumed that countries which originate from the common law tradition also assume an adversarial style in their adjudicative processes, the division is not as clear-cut as it seems. Different traditions assume different modes of procedure, which may depend on the field of law (civil/criminal law) and on the stage of proceedings.

In the literature, the phrase adversary system is used in three senses. Traditionally, adversariness refers to the aspirations and also the distinctive features of the AngloAmerican criminal justice system. It is characterized as an adversarial system of justice to which the key is the division of responsibilities between the decision maker and the parties. ${ }^{158}$ In this system, the parties control the procedural action and the decision maker remains largely passive. ${ }^{159}$ Simplistically, an adversarial trial is a court contest between two equal parties who seek to resolve a dispute before an impartial, passive judge who acts as an umpire. In the context of ascertaining facts and legal issues, partisan advocacy sustained by legal ethics is the essential feature of an adversary system. ${ }^{160}$ From the perspective of the protection of the defendant in the course of a criminal trial, the privilege against self-incrimination is regarded as the foundation of the adversary system. ${ }^{161}$ Indeed, the adversarial system, based as it is on liberal ideology, is often seen as the best way of protecting the accused in a criminal

156 Ashworth and Redmayne, 2010, p. 417, referring to Jörg, Field and Brants, 1995; and DelmasMarty AND SPENCER, 2002. In relation to the possible 'convergence' between the different systems Pradel's metaphor seems suitable: the contemporary continental and common law criminal procedures are like 'two brothers who anxiously compare experiences, but for all that, each remains privately convinced of the superiority of his own.' Pradel, 1992, p. 31.

157 FIELD, 2009, p. 373.

158 U.S. Supreme Court, McNeil v. Wisconsin, 501 U.S. 171, 111 S.Ct. 2204 (1991).

159 DAMAŠKA, 1997-a, p. 74.

160 FulLer, 1961, p. 32.

161 E.g. U.S. Supreme Court, Malloy v. Hogan, 378 U.S. 1 (1964). 
trial, which is often set apart from the sinister inquisitorial system. The US Supreme Court has expressed this position articulately in one of its judgments:

The privilege against self-incrimination 'registers an important advance in the development of our liberty -- one of the great landmarks in man's struggle to make himself civilized.' [...] It reflects many of our fundamental values and most noble aspirations: our unwillingness to subject those suspected of crime to the cruel trilemma of self-accusation, perjury or contempt; our preference for an accusatorial, rather than an inquisitorial, system of criminal justice; our fear that self-incriminating statements will be elicited by inhumane treatment and abuses; our sense of fair play which dictates 'a fair state-individual balance by requiring the government to leave the individual alone until good cause is shown for disturbing him and by requiring the government in its contest with the individual to shoulder the entire load,' [...]; our respect for the inviolability of the human personality and of the right of each individual 'to a private enclave where he may lead a private life,' [...]; our distrust of self-deprecatory statements; and our realization that the privilege, while sometimes 'a shelter to the guilty,' is often 'a protection to the innocent.' [...]. ${ }^{162}$

In addition, some scholars have argued that the adversary system of proof taking, zealous partisanship in combination with an impartial passively leading judge and a tabula rasa decision maker, is the best way to get to the historical truth of the events that underlie the criminal trial. As stated by Wigmore, cross-examination is "the greatest legal engine ever invented for the discovery of truth." 163

Another use of the term 'adversarial system' refers to a theoretical model that best promotes the central goal of adjudication, namely conflict resolution. On the continent, rationalist natural law scholars have experimented with the ideas of adversarial or party-dominated process (Parteiverfahren); however, these ideas were mostly transferred to the civil proceedings and were deemed rationally inapplicable in criminal process. In the criminal process, the accusatorial principle or the principle of contradiction had its influence. ${ }^{164}$ In Anglo-American legal culture, the emerging interest of empirical social studies in the workings of a criminal process led to the formulation of different theoretical models of adversarial and inquisitorial systems

162 U.S. Supreme Court, Murphy v. Waterfront Comm'n, 378 U.S. 52 (1964) [footnote references omitted].

163 Wigmore, 1976, par. 1367 at p. 32; Cf. Silver, 1990, p. 1035: "The adversarial process rests on a basic tenet: the truth will most often and most completely emerge through the tension between two equally armed advocates aggressively asserting their strongest positions." The adversarial process is considered superior both as a means to discover the truth and "to the extent that the adversarial process is an optimum means of discovering truth, the process is also an essential element of due process'; SWARD, 1989, p. 302: 'The current ideology extols the adversary system primarily as the best system for protecting individual dignity and autonomy, but some theorists continue to profess the original ideology, which says that adversarial presentation and argument are the best way to arrive at the truth'.

164 See generally EsmeIn, 1913. 
to facilitate the comparison between different styles of procedure as to their truthfinding capability and efficiency. These models formed the basis for research in a laboratory experimental setting. ${ }^{165}$

The third understanding of an adversarial system is found in comparative legal scholarship. Typology by denominators that are common to all Anglo-American procedures, but also the use of ideal-types to capture the characteristic features of different modes of procedure have been employed to make a comparative approach possible. The use of ideal-types has been the most widespread and successful approach to structure and analyze different procedural styles, and will be the subject of discussion in the next section.

\subsubsection{Inquisitorial and mixed}

To be clear, the term inquisitorial in this context does not refer to the disturbing practice of the Inquisition of the $13^{\text {th }}$ to $18^{\text {th }}$ centuries, but to the modern approach to procedure which was developed on the continent since the French 1808 Code d'instruction criminelle. ${ }^{166}$ Historically, the term inquisitorial is essentially "a generalized description of criminal proceedings which prevailed in continental European countries from the thirteenth until the first half of the nineteenth century." 167 According to Damaška, "the aura of dread and mistrust surrounding the adjective 'inquisitorial' can mostly be explained by the confusion between secular proceedings and the Holy Inquisition, by the "harshness and cruelty of the substantive criminal law of the times" and particularly by "the mistaken belief that the institution of torture was essential to the inquisitorial type." 168 Criminal procedure as it developed on the continent after the mid-19th century is referred to by continental scholars as 'mixed' or 'reformed'. Compared to the inquisitorial process, which still seemingly dominates the initial investigation phase of the process, the "procedural stages following the investigation are said to be predominantly accusatorial in inspiration."169 Since the reforms of the continental procedure in the 19th century, the investigating and prosecuting activities were separated into two distinct institutions and "[s]ince that time the adjective 'accusatorial' is often used by continental lawyers to denote proceedings in which the prosecutor's charge is both a prerequisite for investigatory

165 E.g. Sheppard and Vidmar, 1980; Thibaut and Walker, 1975. For contemporary research see Block ... [ET AL.], 2000.

166 For contemporary literature on comparative criminal procedure see e.g. DELMAS-MARTY AND SPENCER 2002; Fairchild and Dammer, 2001; Reichel, 1999; Hatchard, Huber and Vogler, 1996; Cole, Frankowsky and Gertz, 1987. For a social sciences perspective see e.g. Van Koppen and Penrod, 2003.

167 DAMAŠKA, 1972-1973, p. 556.

168 DAMAŠKA, 1972-1973, p. 558 [footnotes omitted].

169 DAMAŠKA, 1972-1973, pp. 558-559. 
activities and the limit on the scope of inquiries. The term 'inquisitorial' is applied to proceedings where there are no such restrictions on fact finding activity." 170

For common law lawyers, inquisitorial or mixed procedures might seem "two branches of a common parent stem, that of non-adversary proceedings." ${ }^{171}$ Damaška considers the term inquisitorial inappropriate and unfair with reference to the modern criminal procedure on the continent. ${ }^{172}$ However, as mentioned above, the term inquisitorial has no reference to the dark ages of the Inquisition and its practices. The division between adversarial and inquisitorial is maintained in this study for its heuristic value and simplicity and, moreover, for the purpose of depicting two idealtypes of criminal procedure. ${ }^{173}$ The two styles are chosen for their direct and almost exclusive relevance for the contemporary international criminal proceedings.

\subsubsection{Two ideal-types of procedure}

As mentioned, the inquisitorial-adversarial dichotomy can also refer to models or ideal-types 174 "whose greatest value is heuristic" 175 and thus the labels inquisitorial and adversarial "refer to the determining procedural feature of the systems." "Th6 This feature refers to the opposing "internal logic of the procedural design of an official

170 DAMAŠKA, 1972-1973, p. 561 [footnote omitted].

171 DAMAŠKA, 1972-1973, p. 559.

172 DAMAŠKA, 1972-1973, To be fair, the inquisitorial system, developed by the Catholic Church in the Middle Ages, was adopted by the ecclesiastical courts in England in the thirteenth century. Witnesses and defendants were required to take an inquisitorial or the so-called ex officio oath, swearing to tell the truth, on penalty of imprisonment and other sanctions. The system became infamous in the sixteenth century in the Courts of High Commission and Star Chamber, which used torture to compel the taking of the inquisitorial oath. Gradually England moved towards the adversarial system and the High Commission and Star Chamber were abolished in 1641. See generally LANGBEIN, 2003, pp. 277-278.

173 Sometimes, non-adversarial instead of inquisitorial will appear, so both will be used interchangeably. Both terms have their shortcomings when looking at the content. As much as inquisitorial does not cover the procedures in contemporary mixed continental Europe, so does the term non-adversarial.

174 DAMAšKA, 1972-1973, p. 562. In the sense of Max Weber's ideal-types (Idealtypus), defined as: "an ideal type is formed by the one-sided accentuation of one or more points of view" according to which "concrete individual phenomena ... are arranged into a unified analytical construct" (Gedankenbild); in its purely fictional nature, it is a methodological "utopia [that] cannot be found empirically anywhere in reality". WeBER, 1949, p. 90.

175 DAMAŠKA, 1972-1973, p. 562. Connolly talks about "contrast-model", which refers to an idealized system against which we define our own. Connolly, 1969, pp. 22-24 op cit in: Sklansky, 2009 pp. 1635-1636.

176 OrIE, 2002, p. 1440. Black's Law Dictionary, 1999 describes the terms as follows. Adversarial or adversary proceedings involve a dispute between active and unhindered opposing parties contesting each other to put forth a case before an independent decision-maker. By contrast, inquisitorial proceedings involve a judge who conducts the trial, determines what questions to ask and defines the scope and the extent of the inquiry. 
inquiry with that of party contest." 177 These systems are perceived as two contrasting, mutually exclusive parts as the term 'dichotomy' indicates. ${ }^{178}$ As pointed out by Damaška:

[i]t is best to imagine these two contrary procedural structures [adversarial and nonadversarial] as termini of a continuum, with real-life procedures as hybrid mixtures gravitating toward one or the other terminus, and passing at a certain point from the adversarial into the non-adversarial zone. ${ }^{179}$

This one-dimensional methodological framework does not set out the goals or objectives of a criminal process; however, it says something about the possible procedural steps that can be taken to achieve some specific goals.

\subsubsection{A pure adversarial fact-finding model}

Several determinative features of the adversary system are mentioned, including: the roles of the judge and other decision-makers (active or passive); the role of the parties or party representatives in controlling presentations; the manner in which facts are proven; the obligations of the parties towards one another; and informational and decisional side-constraints which directly or indirectly skew final decision-making. ${ }^{180}$

The following elements can constitute the essentialia and the naturalia of the adversarial system: ${ }^{181}$

177 DAMAŠKA, 1972-1973, p. 577. In fact, this perception of the dichotomy between rival models of criminal process is similar from the perspective of continental as well as common law procedural traditions. There is, however, a significant caveat to this contention: 'the question whether the parties can shape proceedings or not is not as central in common law as it is in continental thinking'. DAMAŠKA, 1972-1973, p. 571 [footnote omitted]. The common law scholarship's emphasis is on the active or passive role of the judge.

178 Summers, 2007, p. 98, contending that the 'versions of how criminal procedural systems should look or indeed function' are essentially competing and are incompatible with each other.

179 DAMAšKa, 2003, p. 120. Damaška himself objects to the typology of adversarial and inquisitorial types of procedure as it is used in comparative criminal law. According to him, the typology of adversarial and inquisitorial types as two historically different developed groups 'becomes cumbersome and difficult to employ as an instrument of analysis. It is of very limited use in providing comparativist orientation beyond justice systems in the West'. The other approach which purports to detach the two models from 'contingencies of history' and thus creating 'fictitious creatures' is a better instrument to understand the different forms of justice, however, the juxtaposition of the different concepts that are ascribed to belong to one system or the other must be abandoned because "most features that constitute the essential contrast cannot be captured by them, especially if one's vision extends beyond the narrow area of criminal procedure.' DAMAŠKA, 1986, pp. 4-6.

180 Goodpaster, 1987, 119 [footnote omitted]. These features are not meant to be exhaustive or exclusive, but have a certain descriptive value.

181 DAMAŠKA, 1972-1973, p. 564. Essentialia of the adversarial tradition are the fair contest under the 
- Party-controlled proceedings (the 'two-cases approach').

- A reactive/passive judge with no prior knowledge of the evidence (tabula rasa).

- Partisan proceedings: parties are present and can challenge their versions of the events. $^{182}$

- Parties have the power and means to lead the proceedings, collect, present and challenge evidence, examine and cross-examine their witnesses and experts.

- Confrontational presentation of evidence.

- The focus is on the trial stage where in principle all the evidence has to be presented.

- Bifurcation of trial: establishing guilt, determining the sanction.

\subsubsection{A pure inquisitorial fact-finding model}

The following elements can be considered to constitute the essentialia and the naturalia of the inquisitorial system: ${ }^{183}$

- Judge-controlled proceedings (the 'one-case approach'): Active judge in the collection and presentation of evidence, questioning of the witnesses and experts.

- The sequence follows: the investigation by the prosecutor; then, if appropriate the judicial investigation; then, if enough evidence: examination at trial.

- Investigating judge (Rechter- commissaris / juge d'instruction) - objective, unbiased, impartial investigation, all the necessary materials in case file (dossier).

- Focus on the pre-trial stage: when the dossier is made which forms the basis for the trial and the decision-making of the judge.

In particular, three aspects contrast the adversarial procedure from the inquisitorial: party control, party collection and party presentation of evidence. ${ }^{184}$ The role, powers

conditions of formal equality ... other features, like the jury trial and oral presentation of evidence, are 'not indispensable to the adversary model ... Yet ... the ideological assumptions underlying the model make ... these non-essential features a matter of natural choice', and thus the naturalia of adversary style. Many other features of adversary criminal proceedings, like the jury trial, 'ambushes as a result of lack of discovery, publicity, emphasis on oral testimony' can be seen as 'naturalia rather than essentialia of the adversary style'.

182 For "[ $t]$ he very premise of our adversary system of criminal justice is that partisan advocacy on both sides of a case will best promote the ultimate objective that the guilty be convicted and the innocent go free." U.S. Supreme Court, Herring v. New York, 422 U.S. 853, 862 (1975). (cited in: J. Stevens, dissenting, U.S. Supreme Court, Bell v. Cone, 535 U.S. 685 (2002), 243 F.3d 961).

183 Essentialia of inquisitorial style: an 'official and thorough inquiry' with the goal of establishing true facts. The 'court-controlled pursuit of facts cannot be limited by the mutual consent of the participants'; the court, once having received the case takes its own responsibility in establishing the truth. (DAMAŠKA, 1972-1973, p. 564). Historical preference for documented evidence and decisionmaking by a professional judge are the naturalia of the inquisitorial style.

184 JACKSON, 1988, p. 500 [footnote omitted]. However, these aspects have been criticized. In relation to the adversarial procedure achieving completeness of evidence: (1) the principle of party control 
and rights of the different participants in the proceedings are determinative for the coherence and efficiency of a procedural system. Adversarial is seen as a process that is dominated by two partisan parties that present their versions of truth orally and publicly before a passive 'tabula rasa' trier of fact. In contrast, the inquisitorial process is characterized by an active state investigation in which all the evidence relevant to the case is collected in a dossier, which in turn is publicly verified by an active judge. The active participation of the defence is, especially in the pre-trial process, neither necessary nor expected. Impartiality and objectivity on the part of the investigative authorities guarantees the necessary protection of the accused.

Although the terms adversarial and accusatorial are usually used interchangeably, Goldstein points out that the two words have different meanings. Adversary refers to "a method of resolving disputes and takes its contours from the contested trial." 185 The parties to the process collect and present evidence and shape the legal issues, while the judge is a neutral, passive participant who sees to it that the formal rules of procedure are followed and that the jury are properly instructed on legal issues. An adversary process does not, without more, protect the accused from interrogation or search or use of his body for evidentiary purposes and "for those, we must turn to a normative tradition partially incorporated into constitutional law." 186 This tradition is called accusatorial, which represents 'a classic procedural model that encompasses not only an adversary trial procedure, but also other fundamental premises like the presumption of innocence as it is for the accuser to prove his case and until that time a defendant is to be treated as if he was innocent. ${ }^{187}$ As such, "an accusatorial system assumes a social equilibrium which is not lightly to be disturbed, and assigns great social value to keeping the state out of disputes, especially when stigma and sanction may follow." 188 The accusatorial tradition is a more encompassing concept with the adversarial method as a constituent element. In this light, the typology accusatorial refers more to the victim-prosecutor level, while adversarial refers to the prosecutordefendant relationship. ${ }^{189}$

Goldstein contends that "an accusatorial system is basically reactive, reflecting its origins in a setting in which enforcement of criminal laws was largely confined

means that the court is not concerned with the truth of the material facts of the case, but only with the truth of the facts which are put in issue by the accused; (2) the system of party collection and presentation ensures that much relevant evidence which is considered harmful to the parties is not presented to the court; (3) these restrictions are compounded by the rules of evidence which have been the product of adversarial procedure, JACKSON, 1988, p. 504.

185 Goldstein, 1974, p. 1016.

186 Goldstein, 1974, p. 1017.

187 Goldstein, 1974, p. 1017.

188 Goldstein, 1974, p. 1017.

189 In this traditional understanding, the accusatorial (victim accusers) and inquisitorial (judge prosecutor) systems are considered to be antipodes. Modern criminal proceedings have developed to be hybrids, while leaning more or less towards the one or the other extreme. 
to courts." ${ }^{190}$ The complaining party had to take the initiative to collect evidence and present it at trial, therefore the state's role in this pre-trial phase was minimalist. This divergent role and attitude of officials is a remarkable contrasting point of adversarial and inquisitorial systems. The societal perception of the role the state authorities have to play in the lives of its citizens is determinative for the procedural form that is chosen in adjudication. Should a state be proactive in carrying out the desired state policies, or reactive and, thus, only step in when the parties involved in a conflict request its involvement? This brings the discussion to the ideal-types of procedure developed by Damaška, who linked the adversarial and non-adversarial models of procedure to the political ideology. ${ }^{191}$ Damaška's models provide a sophisticated analytical framework for comparing procedural systems with divergent characteristics and a basis for the discussion of the genesis and function of these characteristics.

\subsubsection{Damaška’s ideal-types}

Damaška's central argument is that all procedural systems are shaped by two fundamental considerations about (1) the form of the officialdom of the legal order, whether it is hierarchical or coordinate; and (2) the goals of justice, whether it is the implementation of policy which fits with an activist state or whether it is conflict resolution which fits with a reactive state. Thus, theoretically four paradigms emerge: ${ }^{192}$

- Hierarchical authority and policy implementation.

- Coordinate authority and policy implementation.

- Hierarchical authority and conflict resolution.

- Coordinate authority and conflict resolution.

Three elements for the determination of the organization of adjudicatory authority are decisive: the "attributes of officials," "their relationship," and "the manner in which they make decisions." ${ }^{193}$ The hierarchical ideal basically corresponds to classical bureaucracy and is characterized by hierarchically organised professional officials who use technical standards for their decision-making. ${ }^{194}$ The coordinate ideal of officialdom is characterized by non-professional decision-makers, organised on a single level and who make "decisions by applying undifferentiated community standards." 195 According to Damaška the extent to which the organization of judicial authority influences the design of the legal process typifies these two ideals

190 Goldstein, 1974, p. 1016.

191 DAMAŠKA, 1986.

192 DAMAŠKA, 1986, p. 181.

193 DAMAŠKA, 1986, p. 16.

194 DAMAŠKA, 1986, pp. 17, 18-23.

195 DAMAŠKA, 1986, pp. 17, 23-28. 
of officialdom which "offer a convenient perspective upon the always intriguing, never fully grasped contrast between Continental and Anglo-American styles of administering justice." 196 From a brief historical survey of these styles, Damaška concludes that the former has a close affiliation with the hierarchical and the latter with the coordinate ideal of officialdom. What specific procedural features can then be attributed to the different structures of authority? Damaška proposes that the hierarchical ideal possesses the following procedural characteristics: episodical trial with the availability of comprehensive hierarchical review; the importance of the case file which condenses and abstracts the cause materials; piecemeal trials, the exclusivity of the official process (no 'private' witnesses or experts); and an ideal of regulating the legal process "by an internally consistent network of unbending rules." 197

Contrasting procedural arrangements of a coordinate ideal are the following: the concentrated trial ("the trial is a proper synecdoche for the legal process as a whole"); the ideal of a single decision-making level and thus relatively minor emphasis on regular appellate review; reliance on oral communication and live testimony (and, thus, not on a written condensed case file) and on the action of private parties for the preparation of materials for the trial, a one-day-in-court trial; and complex technical rules regulating the conduct of the trial and broad discretion to bend these rules for the official presiding over the proceedings. ${ }^{198}$

Considering the function of the government, Damaška proposes two polar visions: a reactive and an activist state. A reactive state provides only a framework that supports its citizens in pursue of their personal goals. State provides for instruments that "set free spontaneous forces of social self-management." 199 There exist no separate state interests or problems, except for social and individual interests and problems. Individual autonomy is the cardinal value. The minimal government does not intervene in social order until its forum is engaged by a private party and the administration of justice in a reactive state thus, by definition, implies dispute resolution. ${ }^{200}$ Out of court settlements are encouraged; however, if legal proceedings are instituted, they have "an extreme combat design" whereby the judge merely functions as the arbiter for the fair disposition of occasional controversies. ${ }^{201}$ Due

196 DAMAŠKA, 1986, p. 17.

197 DAMAŠKA, 1986, pp. 47-56 (citation pp. 54-55).

198 DAMAŠKA, 1986, pp. 57-66.

199 DAMAŠKA, 1986, p. 73.

200 DAMAŠKA, 1986, p. 77.

201 DAMAŠKA, 1986, pp. 79-80: “adjudicators merely preside over the disputation of the adverse parties and intervene in the process only insofar as intervention is required to monitor and to ensure the fair disposition of incidental controversies." 
to the priority given to individual autonomy, parties to the dispute control factual parameters of the lawsuit, which "places significant limits on the quest for truth." 202

In this conflict-solving type of proceeding, which is characterized by a contest between two equal parties, "the perennial problem in regulating the conflict-solving process is to balance the advantage of litigants to provide them with equal weapons." 203 This balancing exercise is specifically problematic when one party is a state official, like in a criminal process, even if the state official, by analogy, represents the private interest of a victim and not the aggregate interests of society. In a criminal trial "full procedural symmetry" between parties is almost unattainable because "the public prosecutor is not laboring under the threat of detention and punishment, conversion into the role of witness (which would imperil his control over the lawsuit), and similar burdens." ${ }^{204}$ Moreover, the prosecutor, as a state organ, has extensively more means and resources to organize his case than a private individual. Consequently, to achieve the basic goal of contest proceedings, "that is, to equalize the contestants' chances to prevail", the initial symmetry has to be deviated from, which "can be a difficult and delicate enterprise." ${ }^{205}$ Consequently, is "another concept of party equality required, other that the 'formal' one emanating from the regulation of a fight with equal procedural weapons?" 206 According to Damaška, in a reactive state with an extreme laissez-fair ideology, the conflict-solving process with mere formal equality between the parties best fits the contours of his ideal-type conflict-solving model for the purposes of comparative study. ${ }^{207}$

The polar vision is the activist state, of which the government "espouses or strives toward a comprehensive theory of the good life and tries to use it as a basis for a conceptually all-encompassing program of material and moral betterment of its citizens." ${ }^{208}$ Law serves as an instrument for the realization of state policies and

202 DAMAŠKA, 1986, p. 123: “ ... since only difficult cases are litigated, the 'truth' - no matter how conceived - tends to appear elusive and ambiguous. Thus, inspired by the ideology of reactive government, the conflict-solving process is indifferent to how it actually was - wie es eigentlich gewesen."

203 DAMAŠKA, 1986, p. 103.

204 DAMAŠKA, 1986, p. 104 [footnote omitted].

205 DAMAŠKA, 1986, p. 104.

206 DAMAŠKA, 1986, p. 106. “ ... parties are treated 'abstractly', in isolation from their personal (substantive) differences, and as equivalent bearers of procedural rights" (p. 107).

207 DAMAŠKA, 1986, p. 109: "A vision of the conflict-solving process that would require something more that formal party equality would provide no place for arrangements that actually exist in the adversarial style. This is a clear indication that this vision, no matter how attractive, is not acceptable for comparative purposes. Only against the background of an extreme laissez-fair ideology - that is, one satisfied with mere formal equality - can one conceive of a more properly drawn polar vision, one in which existing adversarial forms can be included within the termini of the polarity and thus find a place in the total scheme."

208 DAMAŠKA, 1986, p. 80. 
is thus independent of dispute resolution. ${ }^{209}$ The policy-implementing goals are best served by an official inquest as the procedural style of administration of justice. In fact, interpersonal disputes are taken as an opportunity for the state to address the broader social problems that are made visible through the individual dispute. An extremely activist state maintains "a pure investigative model of the legal process", because "the more fully a state realizes its activist potential, the narrower the sphere in which the administration of justice can be understood as dispute resolution, and the more the legal process is pruned of procedural forms inspired by the key image of a party-controlled contest." 210 The fact-finding process is controlled by state officials and obtaining a correct outcome, to uncover the truth, is the prevailing goals of justice. Although there is a readiness to correct substantially defective judgments, substantially correct decisions should not be interfered with even when obtained through a procedural violation. ${ }^{211}$ Although procedural law has mostly an instrumental value, not just any procedure can be employed to achieve an accurate outcome as some procedural rules can disrupt internal procedural order as well as substantive policy. ${ }^{212}$ Individuals are not regarded as the best representatives of their own interests; a party serves as a source of information to come to a right decision, which is considered the best policy to resolve a particular problem in dispute. ${ }^{213}$ The interests of an individual do not par with those of the activist state; "in such a state there is no equality and no mutuality of rights between the individual implicated in proceedings and the state attorney: individual and sate interests are not on the same plane." 214 The state official is superior to the individual and can even have coercive powers over him. The prosecutor is a "powerful watchdog of state policy" and can be distinguished from the adjudicator only because of his special function. ${ }^{215}$

Although more praise has been voiced with regard to Damaška's approach, some insightful criticisms have also appeared. In a lengthy review article, Markovits has worded some strong critique of Damaška's presentation of the ideal-types. ${ }^{216}$ Contending that all law is adversarial, Markovits challenges Damaška's connection of contest and conflict resolution and inquest with policy implementation. ${ }^{217}$ Moreover, these ideal types, according to Markovits, do not reflect any real procedures and serve little normative purposes in terms of practical application. Arguably, ideal-types by definition constitute abstract, simplified "abstractions from reality" that "mainly serve

209 DAMAŠKA, 1986, p. 84.

210 DAMAŠKA, 1986, p. 87.

211 DAMAŠKA, 1986, p. 180.

212 DAMAŠKA, 1986, p. 148.

213 DAMAŠKA, 1986, p. 153.

214 DAMAŠKA, 1986, p. 157.

215 DAMAŠKA, 1986, p. 157.

216 Markovits, 1989.

217 Markovits, 1989, p. 1337. 
heuristic purpose" and are by definition difficult to relate to any real-time approach. ${ }^{218}$ In this case, the ideal-types create a normative analytical framework, to which real procedure can relate only in a more-or-less faction gravitating between some extreme dichotomized propositions.

Vogler criticizes Damaška for his failure to take the social factors into account, and proposes an approach based on the fundamental trinity of the individual, the community and the state. ${ }^{219}$ Through a historical exposé he addresses three modes of procedure, namely adversarial, inquisitorial and popular:

Every system, at different historical epochs, has experienced the gravitational pull of each of the three trial modes and has responded accordingly. Every system, in its current structure and practice, crystallizes their relative influence to a greater or lesser extent. The central argument of this book is that whatever mode of procedure is operated, it should not seek to exclude, significantly limit or disable the participation of any of these three legitimate interests in criminal justice. ${ }^{220}$

Roberts criticises this proposition for its lack of normative value. He considers "[a] threshold response to these assertions is that, without further clarification of the values that each aspect of trial procedure is supposed to instantiate and promote, no amount of historical or comparative exegesis can tell us how criminal procedure should be designed." ${ }^{21}$ Notwithstanding the critiques, Damaška's models have been an inspiration for comparative law scholars, particularly to reach beyond the adversarial-inquisitorial labels. ${ }^{222}$ Moreover, his models have been 'translated' into the international criminal law level. ${ }^{223}$ But before considering the goals, values and procedural challenges of international criminal justice systems, the next subsection will investigate the role of equality of arms in different procedural settings familiar to national criminal justice systems.

\subsection{THE ROLE OF EQUALITY OF ARMS IN ADVERSARIAL AND INQUISITORIAL PROCEDURES}

The concept of equality of arms as such predates its literal use in modern criminal law systems as introduced by the European Commission on Human Rights (see Chapter 2). The principle of equality of arms is said to be an expression of the ancient principle

\footnotetext{
218 SWART, 2008, p. 93.

219 Vogler, 2005, p. 11.

220 VOGLER, 2005, p. 16.

221 Roberts, 2008, p. 375 [emphasis added].

222 See for example the collection of essays in JACKSON, LANGER AND TILLERS, 2008.

223 Some contibutions will be discussed in the last part of this chapter.
} 
audi alteram partem or audiatu et altera pars. ${ }^{224}$ In this sense, the difference with the adversarial principle as interpreted in the case law of the ECtHR seems illusive. ${ }^{225}$ In addition, the Latin proverb libra justa justitiam servat - 'a true weight serves the cause of justice' 226 - has also been mentioned with reference to equality of arms. ${ }^{227}$ As mentioned in the introduction, in the common law tradition the concept of equality of arms arose in the context of the "trial by wager of battle' ...."228 On the continent, in German criminal law writings, reference to 'Waffengleihheit' turns up in the mid-19th century, at a time of discussions surrounding the fundamental reform of the German criminal process towards a more adversarial model. ${ }^{229}$

\subsubsection{The Roman origin: the principle of audi et alteram partem}

The ancient principle of audi alteram partem is considered to be the genesis of the 'modern' principle of equality of arms. The concrete content of audi alteram partem is wide-ranging and to some extent intangible, qualities that are not unknown to principles in general. This principle in its wide sense has two aspects. ${ }^{230}$ Firstly, the court should be bias-free both in respect of substance as well procedure. ${ }^{231}$ Secondly, there is the "right to equal and effective access to the court." 232 The litigants "should be considered by the court as participants in the machinery of the legal procedure, hence as equals before the court, entitled to equal treatment by the court and to equal procedural rights and equally bounded by procedural obligations." 233

In the various classical texts that contain a reference to the principle audi alteram partem a duality of purpose of this principle can be detected. ${ }^{234}$ In the ancient Greek

224 See FawCETt, 1987, p. 154; Also, NowAK, 2005, p. 321. The principle is translated as "hear the other side of the question"- meaning "listen to what each party may be able to advance, otherwise you cannot be sure that your decision will be impartial or just" in Moore, 1831, p. 30.

225 An adversarial trial as interpreted by ECHR means 'in a criminal case, that both prosecution and defence must be given the opportunity to have knowledge of and comment on the observations filed and the evidence adduced by the other party', E.g. ECtHR, Brandstetter v. Austria, App. Nos. 1170/84, 12876/87, 13468/87, Judgment of 28 August 1991, paras. 66-67. In fact, the distinction between the adversarial principle and equality of arms is very much confused in the case law of the ECtHR. See supra Chapter 3.

226 Moore, 1831, p. 205; or 'a just balance preserves justice' in Riley, 1866, p. 205. Stone, 2005, p. 54.

227 See Silver, 1990, p. 1032.

228 BuFFord, 2007, p. 395, footnote 311.

229 Glaser, 1983, Part I, p. 18 et seq. Also Kohlbacher, 1978, pp. 3-7.

230 In French le droit de la défense and in German the right to rechtsliches Gehör, see AssER, 1994, p. 211.

231 Asser, 1994, p. 211: "the court should conduct the procedure with impartiality and detachment in order to guarantee both parties their procedural rights and to see to it that both parties meet their procedural obligations."

232 Asser, 1994, p. 212.

233 Asser, 1994, p. 212.

234 See generally KeLLY, 1964, pp. 103-110. 
and Roman worlds this principle was seen both as a rule of justice and as a rule of wisdom. Although these notions do overlap to some extent in that a correct decision is implied in both, as a rule of justice it "suggests rather the effect of a correct decision seen from the point of view of those affected by it", while as a rule of wisdom it "seems to concentrate on the quality of mind of the person who produces the correct decision." 235 Thus, the principle audi alteram partem incorporates two ideas: "one hears both sides of a case" not only "because if one does not it is unfair to the party unheard", but also "because otherwise one may make a mistake." 236

In modern common law, the principle of audi alteram partem is seen as a principle of natural justice and is understood only in the sense of the idea of providing for a fair approach towards both parties. ${ }^{237}$ This right to be heard is regarded as a natural and fundamental element in the adversarial approach to procedure. In fact, "the principle audi et alteram partem ... is not only self-evident but also - and perhaps for that very reason - valid for all times." ${ }^{238}$ However, on the continent, this principle " ... taken in the wide sense of the right to defend one's interests in court, is much more liable to be neglected" due the very active role of the judge. ${ }^{239}$

The idea of audi alteram partem, basically understood to mean that each side to a conflict should be heard, is also expressed in the principle of adversary argument. ${ }^{240}$ The adversary argument principle is procedural in nature in that is shows how to get to a just outcome, instead of providing for a substantive definition of a just outcome. ${ }^{241}$ As a "general principle of justice" 242 it can be seen to incorporate those "natural and universal procedures and institutions" that exist in almost all societies. ${ }^{243}$ Although the institutions vary according to different cultures, the "necessities of peaceful confrontation of unreconciled enemies entail that the adversary principle is everywhere employed in some accepted conventional clothing." ${ }^{244}$ Adversary thinking or argument is natural for individual reasoning and is duplicated in the form and structure of public procedures and institutions. In the public debate, the adversary

235 Kelly, 1964, p. 103.

236 Kelly, 1964, [emphasis in the original].

237 Kelly, 1964, p. 103.

238 AsSER, 1994, p. 209 [footnote 1 omitted], referring to KeLLy, 1964.

239 ASSER, 1994, p. 212.

240 CEVA, 2008, p. 2.

241 CEVA, 2008, p. 4.

242 CEVA, 2008, p. 4.

243 Hampshire, 2002, p. 637. Referring to institutions and procedures which are indispensable in an organized society: e.g. fair procedures for moral disputes, council of cabinet for discussing policy options, procedures and methods of negotiation with adjacent societies, and procedures of inquiry and prevention of disasters.

244 Hampshire, 2002, p. 637. 
principle is necessitated by the "declared facts of conflict." ${ }^{245}$ In the private sphere, hearing both sides extends to the individual's rationality. ${ }^{246}$

The adversary principle determines fairness between opponents in a wide variety of contexts and situations, but only if both opponents have accepted the procedures as fair. ${ }^{247}$ Although Ceva agrees that the principle of adversary argument lies "at the heart of different existing practices of interaction", she has criticized Hampshire's account of the principle of adversary argument, because the "knowledge of a principle (even familiarity with it) does not necessarily imply its prioritisation over other potentially conflicting principles or values." ${ }^{248}$ She proposes a different foundation for the principle of adversary argument. According to Ceva, it should be endorsed by the idea of procedural equality, meaning that an equal chance "to have their say" should be provided to all parties to a conflict. ${ }^{249}$ Procedural equality should be a procedural and a minimal value. A procedural value because "it qualifies the property of procedures" but says nothing about the substantive outcome of this egalitarian procedure. ${ }^{250}$ To be 'trans-contextual' the concrete realization of this principle should be left for contextual definition. Procedural equality thus "does not necessarily require that material equality between the parties be realized preliminarily." ${ }^{251}$ Procedural equality is a minimal value "in that it is not supported by a specific conception of the good ... but rather [is] an instrument for the construction of a procedure that is capable of addressing value conflicts in a just way." ${ }^{252}$ Ceva defends the principle of adversary argument on the basis of "basic intuition" about the value that it has for different agents involved in a conflict in formulating their arguments. ${ }^{253}$ Procedural equality and the principle of adversary argument are considered "two steps of a single process." Procedural equality ensures that all parties can have their say (active requirement), while the passive requirement that all parties get a fair hearing follows from the principle of adversary argument. ${ }^{254}$ As procedural principles, the overlapping content of the principle of adversary argument and that of participation discussed above is apparent. In fact, one element of the principle of participation, the

245 HAMPSHIRE, 2002, p. 638.

246 HAMPSHIRE, 2002, p. 638.

247 HAMPSHIRE, 2002, p. 639.

248 Ceva, 2008, p. 4.

249 Ceva, 2008, p. 3.

250 CEVA, 2008, p. 7.

251 CEva, 2008, p. 7: 'the compensation for such [material] inequalities is not an issue belonging to the domain of procedural equality'.

252 Ceva, 2008, p. 7.

253 CEva, 2008, p. 8. The defence of procedural equality being a pragmatic rather than intuitionist argument, as it concerns the attitudes of the conflicting parties towards the argument that it is an essential basic requirement that he/she is not given a relatively smaller chance to be heard. Justice 'is conceived here ... as a virtue of institutions rather than of individuals' (p. 9).

254 Ceva, 2008, p. 11. 
opportunity to be heard, is incorporated in the principle of adversary equality, as it demands an equal opportunity to be heard.

\subsubsection{The 'balance of advantages' in the adversarial process}

\subsubsection{Early starting point and ideological underpinnings}

The common law roots of equality of arms, in its literal meaning, goes back to the $12^{\text {th }}$ and $13^{\text {th }}$ centuries. Parties controlled the proceedings and could, to some extent, select a mode of proof. The ancient irrational modes of proof included ordeal, battle and wager of law, and "all employed an oath to invoke the judgment of God." 255 In ordeal, the party having the burden of proof would take an oath and then submit himself to some kind of torturous test, "such as holding a red-hot iron rod for a prescribed time; if the iron did not burn him, his case was proved." 256 In battle, the winning party, also under oath, would prove his case. ${ }^{257}$ And the wager of law "depended on oaths by the litigant and his 'suitors', who swore to the truth of his story" and only by performing the oaths without error did the litigant prove his case. ${ }^{258}$ Gradually, these modes fell into misuse in the $13^{\text {th }}$ century, and only the battle continued in England as duels until they were abolished in 1819..$^{259}$ The weapons used for battles and duels had to be equal between both contestants.

Later, the battle was replaced by the jury and the contemporary adversarial system of justice "is founded on the presumption that the truth is more likely to emerge from the contest between zealous advocates." ${ }^{260}$ The principle of equality of arms is "the single redeeming feature of trial by battle." ${ }^{261}$ Each side needs to be 'equally armed for combat', meaning not the equality in skills or resources but equality in terms of procedural rights to be able to present one's case. ${ }^{262}$ According to Silver "this fundamental requirement of fairness and effectiveness in the adversarial quest for truth has never been clearly articulated or conceptualized in the past." ${ }^{263}$ The following factors contributed to the creation of the adversarial style known today:

[t]he tradition of party control over some aspects of adjudication; the strong legal profession that would naturally gravitate to a system that increased that control, thereby

255 SWARD, 1989, p. 320.

256 SWARD, 1989, p. 320.

257 For a modern defence of this 'irrational' legal institution see LeESON, 2011, pp. 341-375.

258 SWARD, 1989, p. 320.

259 SWARD, 1989, p. 321. As late as 1818, an English court granted a request for a trial by battle, following an acquittal for murder, in the case of Court of King's Bench, Ashford v. Thornton [(1818) 106 ER 149], 16 April 1818.

260 SiLVER, 1990, p. 1008 [footnote omitted].

261 Silver, 1990, p. 1009.

262 SilVER, 1990, p. 1009.

263 Silver, 1990, p. 1009. 
giving the parties and their attorneys more power; the democratic and individualistic ideals that grew in England, which would naturally lead to an individualistic system of dispute resolution, the growing faith in reason and decisionmaking, including faith in the ability of reason to tame the facts; and the growing faith in procedure as a magical substitute for God. ${ }^{264}$

The adversarial style that evolved is highly individualistic: "[i]t gives both control and responsibility to the individuals who are most interested in the result and takes advantage of their self-interest in complete and creative argument." ${ }^{265}$ In a criminal process, the prosecutor is an officer of the court and seeks to assist the court in ascertaining the truth. However, as soon as the prosecutor chooses the, in his sense, most truthful account of the fact underlying the criminal case and steps into the courtroom to defend his vision, he is acting as and is perceived to be one of the parties telling 'his side of the story'. The emphasis on equality in the contest between the state and the individual puts the interests of the state and that of the individual theoretically on the same plane. The passive attitude of the judge fits well with the liberal, laissez-fair state ideology.

\subsubsection{Equality of arms as a corollary of adversarial procedure?}

It is clear from the above discussion that the adversarial process encompasses procedural equality between two parties to the proceedings. When searching the case law of countries which adhere to the adversarial process for the term 'equality of arms' one becomes aware of the origin of the term, namely the jurisprudence of the European Commission/Court of Human Rights. Only a couple of decisions by the lower US courts mention it; the UK courts obviously refer to Article 6 ECHR. In addition, several Australian and Canadian decisions have briefly mentioned equality of arms, either with reference to ECHR or ICCPR. However, some decisions also mention the principle as being part of the national procedural system. ${ }^{266}$

Interestingly, one of the few cases which actually has some more elaborate mention of equality of arms, and surely one of the very few cases from the US, contains this reference:

264 SWARD, 1989, p. 326 [footnote omitted].

265 SwARD, 1989, p. 313: 'It seeks a solution by enabling the litigants to seek their own self-interest without regard for others; indeed, it expects them to argue selfishly'.

266 I have searched the case law (available on the internet through Westlaw International) of the United States, Canada, Australia and the United Kingdom. The total number of hits was 946, including criminal, civil and administrative cases and many cases of which only a summary was available and the term would appear in the keywords attached to the summary of the case. The principle of equality of arms is mostly mentioned with reference to Articles 6 ECHR, 14 ICCPR, in Canadian, Australian and UK case law. 


\begin{abstract}
A criminal prosecution [...] is in no sense a symmetrical proceeding. [...] It is inherent in our criminal justice system that defendants will virtually always be outmatched in investigatory resources, funds, and time to prepare for litigation. This does not offend the Constitution. 'The Bill of Rights does not envision an adversary proceeding between two equal parties.' [...] The principle of equality of arms may apply in certain international criminal law contexts, $[\ldots]$ but it has no place in our constitutional jurisprudence. [...] For better or worse, due process demands only that a criminal defendant receive a constitutionally 'adequate' defense, not that the parties to a criminal prosecution be equally matched.[... $]^{267}$
\end{abstract}

This District judge, as formulated in this passage, seems to deny the relevance of equality of arms in the adversarial process. The passage is a collection of citations which partially distorts the meaning. In Wardius v. Oregon, the United States Supreme Court stated in relation to the 'notice of alibi' rule that:

The growth of such discovery devices is a salutary development which, by increasing the evidence available to both parties, enhances the fairness of the adversary system. As we recognized in Williams, nothing in the Due Process Clause precludes States from experimenting with systems of broad discovery designed to achieve these goals. "The adversary system of trial is hardly an end in itself; it is not yet a poker game in which players enjoy an absolute right always to conceal their cards until played. We find ample room in that system, at least as far as 'due process' is concerned, for [a rule] which is designed to enhance the search for truth in the criminal trial by insuring both the defendant and the State ample opportunity to investigate certain facts crucial to the determination of guilt or innocence." Although the Due Process Clause has little to say regarding the amount of discovery which the parties must be afforded, but cf. Brady v. Maryland, 373 U.S. 83 (1963), it does speak to the balance of forces between the accused and his accuser. Cf. In re Winship, 397 U.S. 358, 397 U.S. 361-364 (1970). [Footnote 6]'.268

In his concurring opinion, Justice Douglas stated that this "salutary development", referring to the reciprocal disclosure obligations of the accused:

has altered the balance struck by the Constitution. The Bill of Rights does not envision an adversary proceeding between two equal parties. If that were so, we might well benefit from procedures patterned after the Rules of the Marquis of Queensberry. But, the Constitution recognized the awesome power of indictment and

267 U.S. v. Tucker, 249 F.R.D. 58, S.D.N.Y., 2008, February 07, 2008. The issue concerned a subpoena issued by the defendants [footnote references omitted].

268 U.S. Supreme Court, Wardius v. Oregon, 412 U.S. 470, 474 (1973), footnote 6: This Court has therefore been particularly suspicious of state trial rules which provide non-reciprocal benefits to the State when the lack of reciprocity interferes with the defendant's ability to secure a fair trial. See, e.g., U.S. Supreme Court, Washington v. Texas, 388 U. S. 14, 388 U. S. 22 (1967); U.S. Supreme Court, Gideon v. Wainwright, 372 U. S. 335, 372 U. S. 344 (1963). Cf. Goldstein, 1960. 
the virtually limitless resources of government investigators. Much of the Bill of Rights is designed to redress the advantage that inheres in a government prosecution. It is not for the Court to change that balance. See Williams v. Florida, supra, at 399 U.S. 111-114 (Black, J., dissenting). ${ }^{269}$

The balance of advantages is thus maintained by the specific rights that the US Constitution provides for. However, in U.S. v. Turkish the Supreme Court has concluded that "[i]n the context of criminal investigation and criminal trial [in which the] accused and accuser have inherently different roles, with entirely different powers and rights, equalization is not a sound principle." 270

It is clearly recognized that in a criminal trial, contrary to the theoretical assumption of a procedurally equally balanced adversarial trial, an inherent inequality between the parties does exist. Not only does this inequality relate to the "awesome power of indictment and the virtually limitless resources of government investigators," ${ }^{271}$ but also to the personal disadvantages for the accused, including the fear about one's own liberty. What can and should be done about this inequality, already from a theoretical perspective, is not entirely clear. The quotes mentioned above imply that it would be sufficient to provide for certain constitutional rights to an individual, no more no less. Goldwasser argued that whereas both sides in a criminal trial should be afforded fairness, equating it with symmetry is untenable in the American criminal justice system. Although adversarial, this system "operates on the premise that fairness can be achieved only by recognizing the differences between prosecution and defence."'272

Brennan has also drawn attention to the difference between the role of the prosecution and the accused. According to Brennan, it is "misleading and dangerous" to regard a criminal trial as a sporting contest because the rules that govern a sporting event are to achieve the outcome that the best skilled team/person wins the contest and a criminal trial should be governed by rules that serve the "basic internal function of the trial - the determination of the truth." ${ }^{273}$ With the application of the same rule to all the participants, their skills are tested. In a criminal trial, however, "[t]his sporting conception of fairness - procedural equivalence in the positions of the participants under the rules, so that skills determine the outcome of the contest - simply has no place." ${ }^{274} \mathrm{He}$ considered there to be no obvious reason to hold that in an adversarial system the truth would best appear when two evenly matched parties playing by the same rules confront each other. The goal of truth finding determines fairness in a criminal trial, not evenly matching the prosecution and the accused. He argued that:

269 U.S. Supreme Court, Wardius v. Oregon, 412 U.S. 470, 480 (1973).

270 United States v. Turkish, 623 F.2d 769, 774-775 (2 ${ }^{\text {nd }}$ Cir. 1980). Cited in Silver, 1990, p. 1039, footnote 170 and accompanying text.

271 U.S. Supreme Court, Wardius v. Oregon, 412 U.S. 470, 480 (1973).

272 Goldwasser, 1989, pp. 825-826.

273 BRENNAN, 1989, p. 18.

274 Brennan, 1989, p. 18. 
procedural rules ought to be designed to maximize the chance that the outcome of the trial will be a verdict that is based on what truly occurred, and it would be mere happenstance if the set of rules thus derived bore any resemblance to a set of rules that would ensure fairness in the sporting sense of fair play between counsel - evenly matched legal gladiators. ${ }^{275}$

Uviller also contended that a literal parity of resources and prerogatives between parties is unattainable in a criminal trial. Instead he talks about the "balanced empowerment" of both parties in a criminal process. ${ }^{276}$ The entitlements should fit the dissimilar role of the parties; and whether these entitlements promote fairness depends on the "rationality of the connection between the supposed advantage and the principle it serves." ${ }^{277}$ It is thus "inescapable" that fairness is related to function. ${ }^{278}$ As such, "it should be obvious that to talk about a 'balance of advantage' as though it were a simple comparison of armament, without taking account of the differing functions of the parties, is foolish." 279 The prosecutor's prerogative is to investigate, charge, prosecute and prove criminal facts beyond a reasonable doubt. The defence is responsible only for discrediting the prosecution's case presentation; it does not have to prove anything. According to Uviller, "the best way to assess fairness in these circumstances is to ... consider the implements accorded by law for the accomplishment of these differing objectives." 280 A disadvantage is thus only unfair if it constitutes "a disabling impediment inappropriate to the task of the party suffering it." ${ }^{281}$

Silver, however, criticized this as being too simplistic an argument. $\mathrm{He}$ acknowledges the unique, non-reciprocal advantages that the prosecutor has which are matched by the unique, non-reciprocal constitutional advantages of the accused. It would be illogical for the principle of equality of arms to intent to alter this balance. ${ }^{282}$ According to Silver, the principle of equality of arms does not apply to these nonreciprocal advantages of both parties, "instead ... it applies to the procedural rights of each advocate to formulate and present her case." 283 The reciprocal procedural devices, such as the ability to cross-examine or to advance evidence, "can and must exist in symmetrical balance." ${ }^{284}$ Following this argument, the principle of equality of arms is based on the fundamental premise of (theoretical) equality between the

275 BrenNAN, 1989, p. 18.

276 UVILLER, 1999, p. 16.

277 Uviller, 1999, p. 19. Cf. Hessler, 2001, p. 1560.

278 UViller, 1999, p. 19.

279 UVILLER, 1999, p. 19.

280 UViller, 1999, p. 21.

281 Uviller, 1999, p. 21.

282 Silver, 2009, p. 1039.

283 SilVER, 2009, p. 1039.

284 Silver, 2009, p. 1039. 
prosecutor and the defence. The function of this principle is thus to maintain formal equality with regard to procedural opportunities. In this sense, only the procedural devices that are suitable for reciprocal application fall within the scope of application of the principle of equality of arms. The non-reciprocal advantages fall outside the scope of applicability of equality of arms. The non-reciprocal constitutional safeguards for the defendant are necessary to offset the superior resources and other advantages of the prosecutor that are inherent in the nature of a criminal process. Thus, it can be observed that to sustain the adversary nature of the proceedings, the 'balance of advantages' or the 'balance of forces' includes the following, nonreciprocal 'advantages' for the defendant: (1) to be informed promptly of the charges against him; (2) to have assistance of a counsel and adequate time and facilities to prepare a defence; (3) to have the right to access and the ability to comment on the evidence against him; and (4) to have the right to secure attendance and examination of witnesses on his behalf under the same conditions as witnesses against him. ${ }^{285}$

From these considerations it becomes clear that the debate is not really 'adversary' in the sense that competing accounts are presented. The main point of controversy seems to revolve around the need and, indeed, the possibility to 'compare' the prosecutor and the defence. What are both parties entitled to, and does it have to be the 'same'? What becomes clear from the different accounts is that (1) the inherent inequality between prosecution and defence is acknowledged; (2) this inequality has to be

285 U.S. Supreme Court, Williams v. Florida, 399 U.S. 78, 112 (1970), Dissenting opinion of Justice Black: 'It is no answer to this argument to suggest that the Fifth Amendment, as so interpreted, would give the defendant an unfair element of surprise, turning a trial into a "poker game" or "sporting contest," for that tactical advantage to the defendant is inherent in the type of trial required by our Bill of Rights. The Framers were well aware of the awesome investigative and prosecutorial powers of government, and it was in order to limit those powers that they spelled out in detail in the Constitution the procedure to be followed in criminal trials. A defendant, they said, is entitled to notice of the charges against him, trial by jury, the right to counsel for his defense, the right to confront and cross-examine witnesses, the right to call witnesses in his own behalf, and the right not to be a witness against himself. All of these rights are designed to shield the defendant against state power. None is designed to make convictions easier, and, taken together, they clearly indicate that, in our system, the entire burden of proving criminal activity rests on the State. The defendant, under our Constitution, need not do anything at all to defend himself, and certainly he cannot be required to help convict himself. Rather, he has an absolute, unqualified right to compel the State to investigate its own case, find its own witnesses, prove its own facts, and convince the jury through its own resources. Throughout the process, the defendant has a fundamental right to remain silent, in effect challenging the State at every point to: "Prove it!" The Bill of Rights thus sets out the type of constitutionally required system that the State must follow in order to convict individuals of crime. That system requires that the State itself must bear the entire burden without any assistance from the defendant. This requirement is clearly indicated in the Fifth Amendment itself, but it is equally apparent when all the specific provisions of the Bill of Rights relating to criminal prosecutions are considered together. And when a question concerning the constitutionality of some aspect of criminal procedure arises, this Court must consider all those provisions and interpret them together. 
compensated to some extent; and that (3) this compensation should be proportionate and should depend on the different roles both parties are expected to assume. Moreover, there seems to be an understanding, or at least an acknowledgment, that the rights of the accused, prescribed to be observed during a criminal process, have been developed to 'equalize' the positions of the parties, in other words to equate the position of the accused to that of the prosecutor. Whether one considers these rights to be enough to serve their function is another question. Indeed, that the balance of advantages in the common law tradition tends to be too much on the defendant's side is a reoccurring statement that does not seem to become outdated. Much depends on the political climate at a particular time and whether there is dissatisfaction with the criminal justice system that brings along more 'crime control' voices that is capable of (temporary) silencing the 'due process' proponenents.

\subsubsection{Parity of information: pre-trial disclosure regime}

As already touched upon in the previous chapter, access to information constitutes a central element in sustaining a meaningful equality of arms between the parties. Following from the burden of proof and the initial resource advantages of the prosecutor, the basic understanding of fairness in a criminal trial is that the defence should have access to the fruits of an investigation. The terminology employed in common law systems usually refers to discovery as a process by which the parties gain access to facts that are then presented to the court. Pre-trial disclosure is one of the elements of criminal discovery. ${ }^{286}$ The connection of discovery to the right to remain silent and the privilege against self-incrimination makes the debate about criminal discovery, including the disclosure obligations, "strong, emotive and polarized."287 In a purely adversarial process the tactical advantage that is gained by a surprise element has an important function. As such, disclosure is seen as a non-adversarial element. ${ }^{288}$ In an ideal adversarial contest the parties are not supposed to provide each other with potential 'arms', the system can only make a fair determination of the victor if "the parties are equal - in resources, analytical skill, creativity, advocacy skill, and information." 289 The disclosure of evidence serves as an 'equalizer' of the inherent unequal nature of the criminal process and, thus, "[d]iscovery is a subtle admission that the system does not do what it is intended to do." 290

286 While discovery is mentioned as a broader term encompassing disclosure obligations in the pre-trial phase of a criminal process, the term disclosure is more commonly referred to in the criminal law context (in the US and UK). Disclosure is considered to be the process of exchanging information between parties (inter partes) and in some instances the court.

287 Moisidis, 2008, p. 2.

288 SWARD, 1989, p. 328.

289 SWARD, 1989 , p. 329.

290 SWARD, 1989, p. 329. 
One argument for limited disclosure "was that broad discovery would put the defendant in too favorable a position." ${ }^{291}$ As Judge Learned Hand, in United States $v$. Garsson, stated:

Under our criminal procedure the accused has every advantage. While the prosecution is held rigidly to the charge, he need not disclose the barest outline of his defense. $\mathrm{He}$ is immune from question or comment on his silence; he cannot be convicted when there is the least fair doubt in the minds of any one of the twelve. Why in addition he should in advance have the whole evidence against him to pick over at his leisure, and make his defense, fairly or foully, I have never been able to see. No doubt grand juries err and indictments are calamities to honest men, but we must work with human beings and we can correct such errors only at too large a price. Our dangers do not lie in too little tenderness to the accused. Our procedure has been always haunted by the ghost of the innocent man convicted. It is an unreal dream. ${ }^{292}$

Other dangers of liberal disclosure in a criminal case have been considered, including the risk of perjury, suppression of evidence, bribery or intimidating witnesses and general interference with the administration of justice. Thus, in Weatherford $v$. Bursey, the US Supreme Court considered that "there is no general constitutional right to discovery in a criminal case." 293

Gradually, under the influence of efficiency, pragmatism and managerial consideration, the attitude changed and some discovery models started to appear in adversarial settings. It was realized that some kind of reciprocal disclosure has to be admitted to make the trial more efficient. In addition, considerations about truthfinding played a role: the adversarial trial had become too much of a partisan contest where truth became stuck in the middle. According to Brennan, "[t]he essential purpose of permitting a criminal defendant to engage in pre-trial discovery of the prosecution's case is to enhance the truth-finding process so as so minimize the danger that an innocent defendant will be convicted." 294 He describes the development of a broader pre-trial discovery process and discusses the arguments that were and are used to promote either the broader or limited disclosure obligations of the prosecutor.

However, most US jurisdictions contain limited and specific regulations with regard to prosecutorial disclosure obligations. The Federal Rules of Criminal Procedure enumerate some specific categories of information that a prosecutor has to disclose upon the request of the accused, such as summaries of the witness

291 BRENnAN, 1989, p. 7. It was seen as unfair to oblige the prosecutor to disclose (most of) his case while the defendant is protected against self-incrimination and, thus, can hide information and 'surprise' the prosecutor with this at trial.

292 United States v. Garsson, 291 Fed. 646, 649 (S.D.N.Y. 1923).

293 Weatherford v. Bursey, 429 U.S. 545, 559 (1977).

294 BRENNAN, 1989, p. 2. Another objective, a subsidiary purpose, of pre-trial discovery is the possibility of a plea bargain for a guilty defendant. 
testimony and materials obtained from and concerning the accused (e.g. statements, criminal records, medical examinations). ${ }^{295}$ Moreover, in Brady v. Maryland (373 U.S. 83 (1963) the UC Supreme Court acknowledged the constitutional right of every criminal defendant to obtain from the prosecution material which is favourable for the defence. The US Supreme Court "held that upon request a prosecutor has a duty to disclose material exculpatory evidence - that is, evidence that might affect the outcome of a trial." The duty to provide the defence with exculpatory evidence even in the absence of a request was further stressed in U.S. v. Agurs ${ }^{296}$ While there is a duty to disclose exculpatory evidence to the defence, there is, however, no duty to investigate exculpatory leads. ${ }^{297}$

In relation to discovery against the accused, there is, of course, a strong (constitutional) impediment to force a defendant to comply with a state's discovery requests. Thus, discovery against the defence can, in principle, be of a limited nature. As a rule, when using an alibi or special defence (such as insanity) the defence is required to give notice to the government. In the case of Wardius v. Oregon (1973), the U.S. Supreme Court considered the notice of alibi rule which was not reciprocal (no requirement to disclose a prosecutorial rebuttal):

\begin{abstract}
Although the Due Process Clause has little to say regarding the amount of discovery which the parties must be afforded, but cf. Brady v. Maryland, 373 U.S. 83 (1963), it does speak to the balance of forces between the accused and his accuser. ... But we do hold that in the absence of a strong showing of state interests to the contrary, discovery must be a two-way street. The State may not insist that trials be run as a 'search for truth' so far as defense witnesses are concerned, while maintaining 'poker game' secrecy for its own witnesses. ... It is fundamentally unfair to require a defendant to divulge the details of his own case while at the same time subjecting him to the hazard of surprise concerning refutation of the very pieces of evidence which he disclosed to the State. ${ }^{298}$
\end{abstract}

The Court suggested that any inequality in disclosure obligations should benefit the accused. ${ }^{299}$ However, many states have formulated disclosure rules against the accused that are more elaborate than the alibi or the insanity defences. ${ }^{300}$

The rules of disclosure in the UK have been developed in common law, and found their way into the statutory regime of the Criminal Procedure and Investigations

\footnotetext{
295 See more generally, SAlzBURG AND CAPRA, 2006, pp. 987 et seq.

296 United States Supreme Court, U.S. v. Agurs, 427 U.S. 97 (1976).

297 SalzBurg AND CAPra, 2006, p. 1024.

298 United States Supreme Court, Wardius v. Oregon, 412 U.S. 470, 474 (1973).

299 Salzburg and CAPra, 2006, p. 1027.

300 On the defence's disclosure obligations see generally Mosteller, 1986.
} 
Act 1996 (CPIA) ${ }^{301}$ The formal duties of disclosure are the result of quite recent developments, ${ }^{302}$ as previously the formal regulation of disclosure was considered unnecessary and "reliance was instead placed on a belief in fair play and the integrity of those acting on behalf of the Crown in criminal cases." 303 There was thus a slow development in the common law of obligations in placing the prosecution under an obligation "to disclose material in its possession which might undermine its case or assist that of the accused." ${ }^{304}$

The present prosecutorial disclosure obligations are regulated by the CPIA in stages "but involves a single test for prosecution disclosure:" 305

1. Initial duty of the prosecutor to disclose to the accused any material, not yet disclosed, that "might reasonably be considered capable of undermining the case for the prosecution against the accused or of assisting the case for the accused ..." (section 3 (1) (a) CPIA);

2. This initial disclosure is followed by "defence statement" to the prosecutor and the court (sections 5 and 6 CPIA). The problem of uninformative defence statements has been tackled by an amendment of the CPIA expanding the defence disclosure obligations; ${ }^{306}$

3. Subsequent and 'continuing duty' of the prosecutor, independent of fulfiment of defence's disclosure obligations, to disclose any materials that might undermine prosecution's case and which have not yet been disclosed (section 7A CPIA); ${ }^{307}$

301 In effect as of 1 April 1997, amended in 2005. See e.g. Sprack, 1997.

302 Review of Disclosure in Criminal Proceedings, Report of The Rt Hon. Lord Justice Gross, September 2011, par. 13 (available at: http://www.judiciary.gov.uk/Resources/JCO/Documents/ Reports/disclosure-review-september-2011.pdf) "Consideration of the prosecution's duty to make disclosure begins with the judgment of Lord Goddard CJ in $R$ v. Bryant and Dickson (1946) $31 \mathrm{Cr}$ App R 146. While the prosecution was not under a duty to supply a copy of a statement obtained from an individual whom it did not intend to call to give evidence, the prosecution did have a duty to make available to the defence a witness whom it knew could give material evidence."

303 Review of Disclosure in Criminal Proceedings, Report of The Rt Hon. Lord Justice Gross, September 2011, par. 12 (available at: http://www.judiciary.gov.uk/Resources/JCO/Documents/ Reports/disclosure-review-september-2011.pdf).

304 ReviewofDisclosureinCriminalProceedings, ReportofTheRtHon.LordJusticeGross, September2011, par. 12 (available at: http://www.judiciary.gov.uk/Resources/JCO/Documents/Reports/disclosurereview-september-2011.pdf) citing CORKER AND PARKInSON, 2009, Chapter 1, par. 1.06.

305 For some critical observations on the operation of the disclosure regime see Plotnikoff and Woolfson, 2001. In 2003 changes to the regulation of the disclosure system were introduced; the Review Report of Justice Gross represents an evaluation of the newly established system. See Review of Disclosure in Criminal Proceedings, Report of The Rt Hon. Lord Justice Gross, September 2011, par. 12 (available at: http://www.judiciary.gov.uk/Resources/JCO/Documents/Reports/disclosurereview-september-2011.pdf).

306 Review of Disclosure in Criminal Proceedings, Report of The Rt Hon. Lord Justice Gross, September 2011, par. 12 (available at: http://www.judiciary.gov.uk/Resources/JCO/Documents/ Reports/disclosure-review-september-2011.pdf).

307 Section 7A(2) CPIA states: "The prosecutor must keep under review the question whether at any given time (and, in particular, following the giving of a defence statement) there is prosecution material 
4. If and only if, the defence has supplied a defence statement, the accused may apply to the court for an order requiring further disclosure of prosecutions materials of which the defence has "at any time reasonable cause to believe that there is prosecution material which is required by section 7A to be disclosed to him and has not been ..." (section $8(2)){ }^{308}$

The Criminal Procedure Rules 2011 (No. 1709, Rules) ${ }^{309}$ specify that their overriding objective is to deal with cases justly (Rule 1.1) which implies "(a) acquitting the innocent and convicting the guilty; (b) dealing with the prosecution and the defence fairly; (c) recognising the rights of a defendant particularly those under Article 6 of the European Convention on Human Rights; (e) dealing with the case efficiently and expeditiously" (Rule 1.1(2)). The prosecutor has the obligation to "service on the defendant ... copies of the documents containing the evidence on which the charge or charges are based, in a case where the defendant is sent for trial." ${ }^{110}$ In addition, the prosecutor is required to provide initial details of his case to the court officer and the defendant "at, or before, the beginning of the day of the first hearing". ${ }^{111}$ Judges have a duty to streamline the disclosure process, primarily to ensure that the trial focuses on the real issues in dispute. ${ }^{312}$ The defence's disclosure obligations are clearly stated

which (a) might reasonably be considered capable of undermining the case for the prosecution against the accused or of assisting the case for the accused, and (b) has not been disclosed to the accused."

308 Review Report of Justice Gross represents an evaluation of the newly established system. See Review of Disclosure in Criminal Proceedings, Report of The Rt Hon. Lord Justice Gross, September 2011, par. 28. See also par. 35: "S.11 of the CPIA addresses the question of sanctions where the accused has failed to give disclosure pursuant to the provisions outlined above. Where this section applies, s.11(5) provides that: '(a) the court or any other party may make such comment as appears appropriate; (b) the court or jury may draw such inferences as appear proper in deciding whether the accused is guilty of the offence concerned.' By way of safeguard, s.11(10) provides that a person shall not be convicted solely on an inference drawn under s.11(5)."

309 Available at http://www.legislation.gov.uk/uksi/2011/1709/part/1/made.

310 Rule 14.1(1)(a) Criminal Procedure Rules 2011.

311 Rule 21.2 Criminal Procedure Rules 2011. Rule 21.3 states that "Initial details of the prosecution case must include - (a) a summary of the evidence on which that case will be based; or (b) any statement, document or extract setting out facts or other matters on which that case will be based; or (c) any combination of such a summary, statement, document or extract; and (d) the defendant's previous convictions.

312 See Rule 3.2 Criminal Procedure Rules 2011. Also Review of Disclosure in Criminal Proceedings, Report of The Rt Hon. Lord Justice Gross, September 2011, available at: http://www.judiciary.gov.uk/ Resources/JCO/Documents/Reports/disclosure-review-september-2011.pdf ("36. The philosophy underlying case management was, with respect, crisply set out by Judge LJ (as he then was) in $R$ v. Jisl [2004] EWCA Crim 696, as follows: 114. The starting point is simple. Justice must be done. The defendant is entitled to a fair trial: and, which is sometimes overlooked, the prosecution is equally entitled to a reasonable opportunity to present the evidence against the defendant. It is not however a concomitant of the entitlement to a fair trial that either or both sides are further entitled to take as much time as they like, or for that matter, as long as counsel and solicitors or the defendants 
and limited. Prosecutorial disclosure does not depend on the fulfilment of disclosure obligations by the defence. As stated in the latest disclosure evaluation Report of Lord Justice Gross:

In our adversarial system, it would neither be appropriate nor realistic to anticipate that the defence will take the lead in disclosure; as already discussed, that lead can only come from the prosecution. It should further be recollected that the prosecution's obligation to give disclosure under the CPIA ... is not linked to the production of a defence statement; the prosecution must do what it can to ensure the fairness of the proceedings, even if the defence, without good reason, does not furnish a defence statement. ${ }^{313}$

However, this does not imply that the defence cannot be approached for a more cooperative attitude on the basis of counsel's professional and ethical obligations. The Disclosure Report considers that "the trigger is the prosecution getting its tackle in order; provided it does so, there can, generally at least, be no excuse for a defence failure to engage and at an early stage in the proceedings." ${ }^{114}$

Accepted as a tenet of fairness in a criminal process, disclosure obligations of the prosecuting authorities in an adversarial process to make available the fruits of the investigation to the defence, and particularly, the materials that might be favourable to the defence case, have been a source of change and development. Challenges particularly revolve around the delineation and distribution of responsibilities between the actors in a criminal process. Whereas the primary responsibility of the prosecution is unquestionable with regard to proper disclosure practice, the additional responsibility for a cooperative and engaging attitude from the defence has been

themselves think appropriate. Resources are limited ... Time itself is a resource ... It follows that the sensible use of time requires judicial management and control. 116. The principle therefore, is not in doubt ... its practical application depends on the determination of trial judges and the co-operation of the legal profession. Active, hands on, case management, both pre-trial and throughout the trial itself, is now regarded as an essential part of the judge's duty ...".

313 Review of Disclosure in Criminal Proceedings, Report of The Rt Hon. Lord Justice Gross, September 2011, (available at: http://www.judiciary.gov.uk/Resources/JCO/Documents/Reports/ disclosure-review-september-2011.pdf), par. 137: "Still further, it should be underlined that there can be no quibbling with a defence attack on prosecution disclosure which does not comply with the prosecution's CPIA regime obligations; no proper criticism can be made of such an approach (regardless of the "merits" in the rest of the case) - and if an attack of this nature is successful, the defendant is entitled to the benefit of it and the prosecution has only itself to blame. Perspective must therefore be retained. However, nothing said here should be taken as encouraging inappropriate abuse of process applications, and we anticipate that all such applications will receive the closest judicial scrutiny."

314 Review of Disclosure in Criminal Proceedings, Report of The Rt Hon. Lord Justice Gross, September 2011, (available at: http://www.judiciary.gov.uk/Resources/JCO/Documents/Reports/disclosurereview-september-2011.pdf), par. 139. 
emphasized time and time again, and has resulted in the formalisation of several disclosure obligations incumbent upon the defence. As stated in the Disclosure Report of Lord Justice Gross, "the prosecution was not there to do the job of the defence." 115 For that purpose, the managerial duties of judges to streamline the disclosure practice, specifically in the context of the UK, are considered an important resource for the improvement of the disclosure regime.

\subsubsection{Equality of arms and inquisitorial process: a missing link?}

It has been said that, by its very nature, the inquisitorial process "does not incline to the principle of 'equality' between the parties." 316 Is the principle a completely foreign element translated into the inquisitorial style? To some extent the answer depends on whether one is looking at the classical 'inquisitorial' secret proceedings or the more evolved modern continental jurisdictions.

During the 'transitional period' of the late 1200s and the first part of the 1300s, two procedures, inquisitorial (written, secret, inspired by Roman and Canon Law) and accusatory (in the domains of the Crown, procedure by inquest or jury ('enquête') for proof by wager of battle) existed alongside each other. ${ }^{317}$ During the Republican time of Rome, a system emerged that would later be considered as typically accusatorial: the private nature of prosecution, the burden of proof on the prosecutor, equality between the parties and their control over the evidence, public and oral proceedings and the passivity of the judge, the arbiter of a dispute. In the Roman Empire, another process was established, initially to better protect the Emperor: ex officio state magistrates investigated crimes in secret, written proceedings where the accused was used as a source of evidence and subjected to torture. The Ordinance of 1670, the "Code of Criminal Examination of the 'Old Régime' codified and even aggravated the existing rules of inquisitorial procedure in France." 318

315 Review of Disclosure in Criminal Proceedings, Report of The Rt Hon. Lord Justice Gross, September 2011, (available at: http://www.judiciary.gov.uk/Resources/JCO/Documents/Reports/disclosurereview-september-2011.pdf), par. 95. This statement is a general inclination of an adversary system. However, note that the statement was made in the context of an evaluation of the US disclosure practice, where US authorities were cited.

316 SAfFerLing, 2001, p. 267. That 'equality of arms' is missing in French criminal process see Pradel, 2008, p. 132.

317 EsMEIN, 1913, pp. 39-40. In accusatorial proceedings, in the case of very serious crimes, when an accusation was brought by the interested party, the procedure began directly by an appeal, or a challenge to the judicial duel. In such cases the detention of both the accuser and the accused was the rule. This was explained, first, by the general character of the accusatory procedure, the object of which was to maintain absolute equality between both parties. But if a wager of battle was given, even in the most serious cases, both parties could be set free on bail, 'for it was very essential that the adversaries should prepare themselves for the combat'. (EsmeIn, 1913, pp. 70-71).

318 Esmein, 1913, pp. 39-40. 
The critical revolutionary spirit grew in the 18th century; English criminal procedure that was inspired by the Roman accusatorial process was looked at with admiration. This procedure, including the grand jury and jury trial, was adopted in France from 1789 to 1792. Napoleon re-established the inquisitorial procedure and some provisions of the 1670 Ordinance found their way into the first part of the Code of Criminal Examination of 1808 (the investigating phase); the second part retained the accusatory procedure and the jury (accusatorial trial). ${ }^{319}$ This code is considered as the fundament of the modern 'mixed' continental criminal procedures.

A double tendency was visible from that time onwards. Strife between the Classical and the Modern School became apparent. The former was individualistic and attempted to increase individual liberty by eliminating the severities inherited from the 1670 Ordinance, to make the proceedings more public, with several forms of protection for the accused. The Modern School,

which is above all collectivist, desires to strengthen the 'social defense', to deprive the prisoner of those safeguards which are summed up in the 'presumption of innocence', to substitute for a humanitarian procedure a scientific procedure, to transform the penal action into a clinical examination and the judges into expert specialists, who must have a very special education in matters of psychology, anthropology, and criminal sociology. ${ }^{320}$

In the course of the $19^{\text {th }}$ century, two major procedural shifts occurred on the Continent. Firstly, the functions of judging and prosecuting were separated in France and Germany. Where it was previously common to have one authority supervise the investigation, to collect and examine evidence and to render a verdict, it was now acknowledged that the functions of an investigative judge and a prosecutor had to be separated to safeguard the objectivity and impartiality of the former. ${ }^{321}$ This development is seen as symptomatic of the embracement of the interests of society as the notion around which a criminal procedural system had to be build. ${ }^{322}$ The impartiality of the investigative judge was a sufficient safeguard to sustain fair and legitimate proceedings, and thus the role of the accused in the pre-trial proceedings was diminished towards a mere object of investigation. ${ }^{323}$ Secondly, the European reforms changed the conception of the trial phase giving it a more adversarial character: the public presentation of evidence by two opposing sides. ${ }^{324}$ In fact, "[a]

319 EsMeIN, 1913, p. 40.

320 EsMEIN, 1913, p. 41 [footnote omitted].

321 Summers, 2007, pp. 31-32.

322 Summers, 2007, p. 32.

323 SuMmERs, 2007, p. 34: "[f]reeing investigative judges of their responsibility to prosecute, however, meant that there was no longer the same need to ensure that the accused was permitted a participatory role in the proceedings."

324 Summers, 2007, p. 29: "In the course of the nineteenth century, then, a conception of the structure 
cceptance of the adversarial conception of truth meant that the accusatorial structure had to be considered as the only satisfactory procedural structure [...]." ${ }^{325}$

Generally, the formal introduction of the principle of equality of arms in Continental criminal procedures took place though constitutional provisions and under the influence of European human rights law. ${ }^{326}$ As discussed previously in Chapter 2, the term equality of arms was 'invented' by the European Commission of Human Rights in the context of civil proceedings, and it was transplanted into criminal proceedings soon afterwards. This initial discussion of the principle of equality of arms was undertaken in the setting of an inquisitorial criminal process. ${ }^{327}$ The application of this principle, as something originating from the 'other', adversarial, system, was not taken without opposition. Some German scholars argue that the reality of a criminal trial does not allow for a real equality of arms Waffengleichheit, but the concept should be interpreted as Chancegleichheit ('the equality of chances') which "implies that all unequal treatment of one party vis-à-vis the other which is not justified by the natural role played by it in the procedure, is forbidden as a breach of the equality requirement." 328 Clearly, this discussion does not differ a great deal from those undertaken in common law systems, as discussed above. However, what is clear from the above is that different process models have a different approach when it comes to the protection of the defence rights in a criminal process. ${ }^{329}$ Hereunder, some critical issues with regard to the meaning and function of the principle of equality of arms in an inquisitorial trial setting will be considered.

of the trial as involving opposing sides (the defence and the prosecution) and an impartial judge with responsibility for determining the charge was accepted in England, France and Germany and became the dominant procedural model across Europe" [footnote omitted].

325 Summers, 2007, p. 58.

326 In French criminal proceedings, for example, '[t]he content of the requirements of a fair and adversarial trial is said to embody the so-called bloc de constitutionnalité, meaning the body of legal principles articulated by the French Constitutional Council (Conseil constitutionnel) on the occasion of its assessments of the constitutionality of legislation immediately following the legislation's passage. These principles have been endorsed, and added to, by the European Court of Human Rights on the occasions when it reviews the conformity to the Human Rights Convention of the national laws and decisions that are referred to it. Finally, the law of 15 June 2000, on the presumption of innocence, introduced into the Code of Criminal Procedure a new preliminary article of some 20 lines affirming the following principles: The procedure must be fair and adversarial, and a balance of rights between the parties must be maintained. ... 'Pradel, 2008, pp. 133-134.

327 Pataki and Dunshirn v. Austria, App. No. 596/59 and 789/60, report of 28 March 1963, Yearbook, volume 6, p. 714.

328 WáseK-Wiaderek, 2000, p. 49 with references in footnotes 191-194. STeiner, 1995, p. 205; Weichbrodt, 2012, p. 315.

329 Prakken and Sponken, 2009, p. 11. 


\subsubsection{1 'Dialogue' in the pre-trial process: defence participation}

One of the major points of critique of the Continental criminal process as often stated in the literature is its lack of protection afforded to an individual in the pre-trial phase. ${ }^{330}$ In these initial stages of investigation, the individual is often considered the object of investigation, lacking any participatory rights. To an important extent under the influence of the European human rights system, several changes on the Continent amounted to better individual protection in the initial stages of the criminal process, such as the better access of defence lawyers to their clients in police custody, ${ }^{331}$ better access to the dossier, ${ }^{332}$ and a stronger position during the judicial pre-trial investigation. ${ }^{333}$

330 E.g. Tomlinson, 1983, pp. 164-165, 167: 'In the abstract, the French and American approaches to protecting the rights of the individual in the criminal process appear to have much in common. Both systems seek to protect what are essentially the same rights. In practice, however, the French approach has proved to be a less effective safeguard of individual liberty, largely because the system is unwilling to recognize an individual's rights at the early stages of the criminal process. Further, the French system's formalism reduces its protection of an individual's rights; the legality of an investigatory practice often depends on whether is satisfies formal criteria rather than on its impact on the individual.'

331 Some examples: in France, the 2000 (Loi no 2000-516, 15 June 2000) reform law introduced the possibility for an interview at the beginning of detention in police custody (with possible follow-up interviews) and the suspect had to be reminded of the right to silence at the start of each interrogation (the right to a lawyer-client interview in pre-trial detention, and thus not a right to have a lawyer present during interrogation). See Field AND West, 2003, p. 285 and 289. In The Netherlands, the ECtHR case law, particularly the judgment in Salduz v. Turkey, App. No. 36391/02, Judgment of 27 November 2008, (GC), has had substantive impact on accused right to legal assistance when arrested by the police. Following the case law of the ECtHR, the Dutch Supreme Court has acknowledged a right to consult a lawyer (but not a general right to have a lawyer physically present at the first police interrogation), when arrested and before the first police interrogation (see e.g. Hoge Raad, 30 June 2009, LJN BH3079, NJ 2009, 349). Following an experiment at several police departments (Kamerstukken II 2006-2007, 30800 VI, nr. 113, for an evaluative report of this experiment see Stevens and Verhoeven, 2010), the Minister of Security and Justice has proposed an amendment to the law involving a right to have a lawyer present during police interrogations, in certain cases and under certain conditions (Conceptwetsvoorstel rechtsbijstand en politieverhoor, submitted on 15 April 2011). In Belgium, new law was introduced on 13 August 2011 (BS 5 September 2011 (56347), in effect from 1 January 2012) that is a direct consequence of the Salduz-case law of the ECtHR, and which contains rules e.g. in regard to the right to consult a lawyer before police interrogation (for a maximum of 30 minutes) and the right to have a lawyer present during the interrogation (but no interference allowed).

332 The French 2000 reform law introduced a formal legal right to be told the nature of the offence and a right to access the dossier during custody. See FiELD AND WeSt, 2003, p. 287, footnote 98 and p. 289. In the Netherlands, amendments to the rules on access to dossier have been introduced recently (Law of 13 December 2011, Stb. 2011, nr. 601) intending to strengthen the position of an accused person in relation to the access to the case file and introducing e.g. a right to access to the case file from the moment of first police interrogation after arrest.

333 In France, a formal right to request investigative acts from the juge d'instruction and to appeal against refusal of such requests was introduced. Loi no. 1993-2 (4 January 1993) and Loi no. 2000-516 
Criticism of the traditional inquisitorial judicial search for the truth with a passive role for the defence, "led to a historic compromise whereby defence rights encapsulated in what the French term le principe du contradictoire - right to a lawyer, to see the dossier of evidence, to make representations, to appeal against adverse decision accrued during the judicial investigation (instruction) phase." ${ }^{334}$ The French 2000 reform actually recognized the vulnerable position of the accused in police custody, but affirmed the "historical and cultural logic" of the "fundamental inquisitorial premise of the primary role of the state - and especially the magistrate - in both the search for the truth and as guarantor of individual liberty." ${ }^{335}$ The same can be observed in the Dutch criminal setting, where the more adversary trial format mostly does not serve any real truth-finding function, but constitutes rather an evaluative and controlling phase of the case as developed during the investigative stage. ${ }^{336} \mathrm{In}$ fact, the principle of equality of arms in an inquisitorial setting is embodied by the contradictory process at trial, which amounts to the possibility for the defence to challenge the evidence collected and adduced at trial, rather than equal investigative opportunities.

The cardinal argument for the minimalist role of the accused in the initial investigative stage of the inquisitorial process is that the magistrates involved in the process, the prosecutor and the investigating judge, are under the obligation to search for the truth, which should not be endangered by any 'obstacles'. In fact, “[t] raditionalist examining magistrates retain a suspicion of the advocat as a mercenary who impeded the search for the truth." ${ }^{337}$ However, this judicial supervision can have a downside, namely it can be "vulnerable to bureaucratic pressures to process large volumes of cases, even if there was a cultural commitment to seek out exculpatory

(15 June 2000), cited in: Field And West, 2003, p. 265, footnote 15. The Delmas-Marty Commission, responsible for recommendations for the 1993 reform, "had found French criminal justice wanting exactly because of the relatively passive role and limited rights of intervention accorded to the defence. It saw dialogue as the key to the historic task of inquisitorial criminal process - the search for truth - and in order to prompt greater dialogue in criminal process, recommended that the defence be given greater capacity to take the initiative." (Id.) In the Netherlands, amendments to the rules on judicial pre-trial investigation have been introduced by the law of 1 December 2011 (Stb. 2011, nr. 600), changing the role of the rechter-commissaris (judge commissioner) from primarily an investigative judge to a 'judge in pre-trial investigation'. The concept judicial pre-trial investigation has been formally abolished; the investigative judge has been assigned a more supervisory role during the pre-trial investigative process and can perform investigatory acts upon request from the prosecution or the defence. Whether the position of the defence in the pre-trial phase in practive will be improved is another point of discussion.

334 Field And West, 2003, p. 285: 'The earlier preliminary investigation (including the police custody phase) remained dominated by the interests of the state search for the truth and a view of the suspect as object of inquiry rather than an active subject'.

335 Field And West, 2003, p. 286.

336 See generaly Prakken and SPonken, 2009.

337 Field and West, 2003, p. 309 [footnote omitted]. Also Prakken and Sponken, 2009, p. 8. 
as well as inculpatory evidence." ${ }^{\prime 38}$ Moreover, the impartial role of the prosecutor as an impartial truth-seeker is easier stated in theory than implemented in practice. For example, there is some fairly recent criticism of the growing tendency of the Dutch public prosecutor to act more as a 'party' to criminal proceedings instead of as a public service official whose task is to serve the public order, including its central responsibility of protecting the innocent from punishment: 'In de strijd om de waarheid is strijd de enige waarheid'. ${ }^{339}$

As concluded by Field and West:

[d]ialogue within the French inquisitorial pre-trail tradition remains an ideal strongly held by those hoping to reconcile that tradition to the challenges of the model of fair trial being established by the European Court of Human Rights and a more modern and active conception of citizenship. But it promises to be a long haul and the most recent developments point - in the name of crime control - in another direction. ${ }^{340}$

\subsubsection{The function of the dossier}

All the evidence collected by the police and by the investigating magistrate (the judge or the prosecutor) is collected into one file, the dossier. ${ }^{341}$ The accused, as well as the prosecutor, can add to the dossier, which can collectively be accessed by the judge, the prosecutor, the defence and the civil party before the trial. This gives the possibility to hold an almost summary trial; everyone is supposed to be familiar with the content of the dossier before the trial, so that at trial only the contentious issues are discussed. ${ }^{342}$ The completeness of the available evidence makes it possible to have a holistic approach thereto, every piece can be merited in light of the whole file. Another advantage is that once the evidence is in the dossier, it is as if it is 'frozen' and cannot 'disappear' ${ }^{343}$ In this regard, it has been argued that "inquisitorial adjudication offers a better balance of tasks than does adversarial adjudication because it gives the parties a significant voice but gives them considerably less opportunity to hide or distort evidence." ${ }^{344}$ One necessity as to the quality of the evidence is that it is reported properly at every instance: the judge will usually have no direct contact with the original source of the information, so the credibility of the evidence

338 Field AND West, 2003, p. 316.

339 'In the contest for the truth contest is the only truth' [translation MF]. KAPTEIN, 2009, p. 58.

340 Field AND West, 2003, p. 316.

341 With the recent reforms, the Italian criminal system has been replaced by a more 'accusatorial' system: the parties conduct their own investigations and prepare their own dossiers, which are not completely open to the judge before the trial (he receives a really thin version of the real dossiers). See generally Pizzi AND MARAFIOTI, 1992.

342 ORIE, 2002, p. 1444.

343 DAMAŠKA, 1972-1973, p. 519.

344 Sward, 1989, p. 316, referring to LangbeIn, 1985. 
has to be tested with the dossier at hand. One argument in favour would be that this provides for a certain detachment for the judge, who can look at the evidence more objectively. However, as for example in the Netherlands, a guilty verdict can only be issued upon the judge's conviction that the defendant has indeed committed the crime. Oral presentation of evidence before a judge can thus be advantageous to ensure that the judge indeed reaches the appropriate level of conviction, towards guilt or innocence, concerning the defendant.

As mentioned, in practice the 'trial amounts to a verification of the record prepared by the investigator'. ${ }^{345}$ The space for defence counsel to challenge the account of reality which is presented in the dossier by prompting further pre-trial investigations is limited in reality. This is not only because of the lawyer's suspicion of the prosecutor's impartiality, but also because of the very practical reason that 'the kind of detailed pre-trial reading of the dossier that is implied often simply did not take place early enough'. ${ }^{346}$ So the examination of the dossier by the defence attorney is limited to searching for elements that are brief and not detailed, and are regarded as a weak point of the dossier; to controlling whether specific factual statements are supported by the necessary routine evidence (for example, with an allegation of drunkenness an alcohol level test), "[b]ut above all the advocate was looking for inconsistency between the accounts of prosecution witnesses or between witness accounts and forensic evidence which could be used to undermine the credibility of the dossier." 347

From the adversarial perspective, the inquisitorial system of the 'disclosure' of evidence before the trial in a communal all-encompassing dossier can be looked upon as a better way to 'equalize' the position of an accused who is substantially disadvantaged in the adversarial collection of evidence. The more open system of reciprocal disclosure already exists in the context of adversarial civil proceedings. ${ }^{348}$ The argument to the contrary is dual in nature: on the one hand, the nature of the adversarial contest trial does allow for the 'surprise' element, especially from the side of the accused; this non-reciprocity, on the other hand, is supported by the strong underlining of the protection against self-incrimination, an accused cannot be forced to provide 'weapons' to the prosecutor. ${ }^{349}$ Of course, from the Continental-

345 DAMAŠKA, 1972-1973, pp. 544-545.

346 Field And West, 2003, pp. 294-295.

347 Field AND West, 2003, pp. 293-294 [footnote omitted].

348 According to Goldstein "This process has as its object the harnessing of the full creative potential of the adversary process, bringing each party to trial as aware of what he must meet as his finances and his lawyer's energy and intelligence permit." Goldstein, 1960, pp. 1197-1198 for some proposed solutions. For a plea to expand the pre-trial discovery obligations of the defendant in an adversary trial, see Moisidis, 2008.

349 E.g. U.S. Supreme Court, Williams v. Florida, 399 U.S. 78, 111-112 (1970), Justice Black dissenting: "The Florida 'notice of alibi' rule, in my opinion, is a patent violation of that constitutional provision, because it requires a defendant to disclose information to the State so that the State can use that 
style perspective the " ... problem of disclosure does not present itself to continental lawyers as one of balancing advantages. Full advanced disclosure is simply viewed as one of the postulates of rational fact-finding." ${ }^{350}$

\subsubsection{Active judge}

In contrast to the adversarial process, the judiciary in inquisitorial process is a central figure in the investigation of crimes and the collection of evidence for trial. The term judiciary is viewed broadly, to include the prosecutor, the investigating judge and the trial judge. The collection of evidence is undertaken in the pre-trial stage of the proceedings by a public prosecutor and/or the investigative judge, with a broad mandate to collect all the material that could lead to the truth. The investigating authorities have the duty to conduct the investigation in an impartial and unbiased manner, and to collect both inculpatory as well as exculpatory evidence. A typical element in inquisitorial procedures is the institution of an investigative magistrate, ${ }^{351}$ which is " ... one of the key divisions between English and Continental practice related to judicial supervision of pre-trial investigations: a generally established practice on the Continent, a relatively little known historical episode in England." 352

Although the role of the investigating judge can differ extensively in different countries, there are some common features that can be mentioned. ${ }^{353}$ The investigating judge starts to play a role in the proceedings where the complexity or seriousness of the case so demands, or if certain coercive measures have to be ordered. The investigating judge is an independent and impartial first-instance bench judge and is not associated with the office of the prosecutor. The investigating judge has the

information to destroy him. It seems to me at least slightly incredible to suggest that this procedure may have some beneficial effects for defendants. There is no need to encourage defendants to take actions they think will help them. The fear of conviction and the substantial cost or inconvenience resulting from criminal prosecutions are more than sufficient incentives to make defendants want to help themselves. If a defendant thinks that making disclosure of an alibi before trial is in his best interests, he will obviously do so. And the only time the State needs the compulsion provided by this procedure is when the defendant has decided that such disclosure is likely to hurt his case. It is no answer to this argument to suggest that the Fifth Amendment, as so interpreted, would give the defendant an unfair element of surprise, turning a trial into a 'poker game' or 'sporting contest', for that tactical advantage to the defendant is inherent in the type of trial required by our Bill of Rights."

350 DAMAŠKA, 1972-1973, p. 535, footnote 64.

351 The French, Belgian or Luxembourg juge d'instruction, the Spanish juez de instruccion, the Portuguese juiz de instruçao, the Dutch rechter-commissaris.

352 FIELD, 2009, p. 380.

353 For example, the role of the rechter-commissaris in the Netherlands is much more limited than that of the juge d'instruction in France. The role of rechter-commissaris depends on the seriousness of the case; it can vary from merely authorizing some coercive measures to also questioning witnesses. He merely collects the evidence that is put into the dossier and does not have to give an opinion as to the sufficiency of evidence to bring the case to trial. 
duty to investigate both à charge and à décharge evidence and has full investigative powers: he can hear the victim, interrogate the suspects, question the witnesses, order an expert opinion, supervise a forensic expert's work at the crime scene and be present at the pathologist's post-mortem investigation, order restraining orders, detention or release on bail, and controls the special investigative measures like searches and seizures and phone-tapping. Investigating judges do not decide on any factual or legal issue of the case, but some have the power to judge the sufficiency of the evidence in order to send the case to trial..$^{354}$ There is a possibility of an interlocutory appeal against the decisions of the investigating judge. The institution of the investigating judge is regularly under attack, with some countries (Germany and Italy) abolishing the institution altogether, while others continuously struggle to determine the exact role of the investigating judge..$^{355}$

Arguably, where the judge controls the pre-trial collection of evidence, the parties need to have less power to collect evidence on their own. During the investigation by the investigating judge, the suspect has the right to be assisted by counsel and has access to (a part) of the dossier. The suspect can call on the investigating judge to investigate certain issues in his or her favour. The presumption of innocence is protected by holding these initial investigations not in an open public trial, but in confidential proceedings.

The trial judge has an active role in the search for the truth. ${ }^{356}$ The presiding judge leads the proceedings. Witnesses are invited to state a narrative, the full story as to their recollection, after which the judge, prosecutor and the defence can pose questions. No institution of cross-examination as in adversarial settings exists here, the partial vision of the accused or even the prosecutor as the sole testimonial basis would be insufficient for a judge to fulfil his obligation to get to the truth. ${ }^{357}$

354 For example, the French juge d'instruction, contrary to the Dutch rechter-commissaris.

355 There is a discussion in the Netherlands about the exact role of the rechter-commissaris: it currently seems to be diminishing, but should it be made stronger again? For a discussion see e.g. Mevis, 2009, chapter 9; VAN DER MEIJ, 2008. On the role of Dutch rechter-commissaris see generally VERREST, 2011, Furthermore, a new Dutch law amending the Code of Criminal Procedure has been intoduced (not yet in effect), which brings significant changes to the institution of pre-trial judicial investigation (Wet van 1 december 2011 tot wijziging van het Wetboek van Strafvordering, het Wetboek van Strafrecht en enige andere wetten tot versterking van de positie van de rechter-commissaris). With the intent of strengthening the role of the investigative judge (rechter-commissaris), the law abolishes the institution of the judicial pre-trial investigation altogether, providing for a different role of the investigative judge: a more supervisory role during the pre-trial investigating, with the power to perform investigatory acts upon request from the prosecution or the defence.

356 E.g. Section 244, par. 2 of the German Code of Criminal Procedure ("Das Gericht hat zur Erforschung der Wahrheit die Beweisaufnahme von Amts wegen auf alle Tatsachen und Beweismittel zu erstrecken, die für die Entscheidung von Bedeutung sind.").

357 DAMAŠKA, 1972-1973, p. 545: “Another factor, seldom discussed, is relevant here. It is well known to experimental psychologists that different people have disparate cognitive needs; they often require different information, or ways of presenting it, in order to be persuaded of, or simply to comprehend a point. The continental trial is in a sense more attuned to this psychological phenomenon. All 
The developments at the level of the European Court of Human Rights have some challenging consequences for many continental procedures. ${ }^{358}$ In fact, it has been argued that the expansion of defence participation has not only influenced the judges' approach to the protection of defence rights, but also set in motion several 'neutralizing' legislative approaches. ${ }^{359}$ The expanding margin for defence participation in a criminal process has resulted in a shift of responsibility for the preservation of defence rights from the judge to defence counsel. In addition, the ruling assumption that expanded defence participation can only be associated with an impediment to truth finding has led, in the Netherlands for example, to the establishment of several 'counter-measures' for the enhancement of the truth-finding function of a criminal process. ${ }^{360}$

The above discussion of the different goals and values, the ideal-type criminal processes, and a glimpse at the function that equality of arms can and should assume in different criminal procedural settings are provided to prepare this study for its further course. Indeed, merely looking at the international criminal institutions and their procedure can only provide a limited or partial understanding of its development. The basis is to be found in theories and practices developed at and for the purpose of the national criminal systems. As eloquently stated by Mégret "[ $t$ ]raditions have played a role, but one could say it is as a means rather than an end, as repositories of certain practices rather than as a real constraint. The susceptibility of international criminal procedure to already existing models is partly a result of international law being largely tradition-less." 361

Before turning to the practice of international criminal tribunals, some reflection is merited upon the discussion about the different goals and values that international criminal justice and its institutions are to endeavour to achieve. The importance is rather obvious, without a clear vision as to what the international community is striving for when creating those institutions, it becomes difficult to create effective and fair criminal justice systems.

continental decisionmakers, lay or professional, are entitled to address questions to witnesses and take an active part during the presentation of evidence. ... One can only surmise that the adversary method of presenting evidence is somewhat more conducive to uncertainties and doubts than the more organized and detached continental method."

358 See Chapter 2 for a more elaborate discussion of ECtHR case law.

359 Prakken and Sponken, 2009, p. 11 et. seq.

360 Prakken and Sponken, 2009, p. 11 et. seq.

361 MÉgret, 2009, p. 48. 
Criminal Process Perspective

\subsection{INTERNATIONAL CRIMINAL PROCEDURE: REASSESSING GOALS, VALUES AND PROCEDURES?}

The balance of values in a criminal procedural system can only be analyzed in its own framework because the different elements all have their fixed place and meaning, thus leading to the completeness and coherence of a system of law. How, then, can the international criminal process be evaluated with regard to a proper balancing of different values? In other words, what is the analytical framework of the contemporary international criminal procedure? An unsatisfactory short answer is that there is none. There is not one system, but the international criminal processes are fragmented; it is also very much in its infancy as the historical roots go back only some 18 years, ${ }^{362}$ the procedural frameworks of international criminal institutions are marked by (political) compromise, ${ }^{363}$ ambiguity and underdevelopment ${ }^{364}$ and a further sophistication of the system is dependent on people from various legal cultures promoting fundamentally different assumptions. ${ }^{365}$

On the face of it, all these factors do not promote the development of a comprehensive and coherent procedural system. The drive for universality has brought about a system that compulsively tries to accommodate the different elements of the major Western systems of criminal procedure, specifically the adversarial and the inquisitorial trial setting. This 'best of two worlds' approach, however, hides a risk of a lethal combination as the particular elements of a coherent system cannot merely be 'copy-pasted' into another without having regard to a system's fundamental ideologies and assumptions, aims, goals and values and overall structure. ${ }^{366}$ Moreover, some natural human resistance, amounting from a misunderstanding of the 'other system' would not seem to promote the smooth development of a coherent procedural system. In this regard, Groome makes the following observation:

Like my colleagues from other systems, I feel the same visceral discomfort each time I ventured out of my own legal culture. ... While core values like fairness serve as a compass, permeating all that we do as lawyers they can also stifle earnest attempts to improve the adjudication process and can impede the healthy and necessary development of legal systems. Changes that implicate these core values, are difficult

362 The predecessors of the contemporary international criminal courts are of course the Nuremberg and Tokyo Military Tribunals, but it is agreed that international criminal procedure as we know it now only 'came to life' with the establishment of the ad hoc international criminal tribunals for the former Yugoslavia and Rwanda.

363 See Kress, 2003, p. 605, who describes the system of the ICC as a 'fundamental compromise formula'.

364 The drafters often had recourse to the 'technique of constructive ambiguity'. KRESs, 2003, p. 606.

365 As remarked by Orie: "The role of the professionals who were responsible for the shaping of the procedural systems in the international administration of criminal justice is often better understood if one takes into account their geographical origin or their legal roots". ORIE, 2002, p. 1440.

366 ORIE, 2002, p. 1442. DAMAŠKA, 1997-c, p. 852. 
not only because they challenge deeply held notions of justice and fairness but because they pose a threat to us - for to consider the merits of another methodology is to critically reflect on whether our own method is truly fair. ${ }^{367}$

However, the adversarial-inquisitorial dichotomy has served extensively as an analytical point of reference and a departure not only in the field of comparative criminal procedure, but specifically for the international criminal justice systems. In addition, particular reference is made to Damaška's models. ${ }^{368}$ Although these models have been created for the sake of domestic legal proceedings, and, thus, cannot merely be transferred to the international level, they have been used extensively as an authoritative source of reference for the typology and analysis of international criminal proceedings, mostly due to the lack of a better analytical framework. ${ }^{369}$ And indeed, as pure or ideal-type criminal process models, the adversarial-inquisitorial dichotomy can serve as an analytical tool to better shape the international criminal process. In this regard it must be emphasized that the particular typology of the different individual rules as adversarial or inquisitorial is less important than the analysis of the underlying balance of values that occurs in different procedural settings depending on procedural goals and objectives. Because the international criminal process is, if it were taken out of a historical, cultural and socio-economic context, a guidance for the analysis of its overall procedural structure can only be sought in the overall objectives these institutions were deemed to achieve. For support one has to turn to the guidance of international human rights law (as a minimum to be achieved) and the insights of comparative scholarship. As Delmas-Marty expresses it, international criminal proceedings call for a 'common grammar' to achieve the coherence of the system. Thus, the "elaboration of a grammar adapted to the hybridization process requires a systematic approach that is in keeping with the specific context of a body of law that is both international and criminal." 370

The problem concerning the analysis and evaluation of the procedure and the performance of the international criminal courts is due, as mentioned, to the lack of a comprehensive analytical framework and particularly because there is much uncertainty and controversy about what goals can be subscribed to international criminal justice. ${ }^{371}$ As discussed above, a particular mix of procedural goals correlates with a particular procedural form that best fits the achievement of these goals. Therefore, it is of paramount importance to determine what goals international

367 GroOMe, 2007, p. 794.

368 DAMAŠKA, 1986.

369 SWART, 2008; also VAN DER WiLt, 2010, pp. 44-58.

370 Delmas-Marty, 2009, p. 101: "Hybridization goes hand in hand with autonomization" meaning "that coherence cannot be borrowed from a pre-existing system".

371 In the eloquent words of Damaška: "As the ancient mariners used to say, no winds are favourable to a ship without a clear destination”. DAMAŠKA, 2009, p. 186. 
criminal justice and process are to achieve and what the underlying philosophy is so that we can establish proper objectives of punishment and procedure.

The ICTY judges have considered that " ... the underlying philosophy for the criminal procedure of the ICTs aims to maintain a sort of balance between the accusatory procedure in common law systems and the inquisitorial procedure in the civil law tradition, whilst ensuring at the same time that justice is done." 372 Of course, in light of the difficulties of political compromise between common and civil law representatives, but also between international and criminal lawyers, it is understandable that international criminal courts want to achieve the best hybrid approach between the two systems. ${ }^{373}$ However, the focus should not be upon the establishment of a system that represents and balances the adversarial-inquisitorial elements in the best way, but rather a system that is autonomous and coherent and is effective in the achievement of its objectives. ${ }^{374}$ In that sense, one should look beyond the procedural adversarial-inquisitorial dichotomy and focus on the complementary power of both systems to achieve the goals of international criminal justice in the best possible way. ${ }^{375}$ This submission might seem quite self-evident; however, in the complexity of the issues at hand, even the most simple things can be lost out of sight and shift one's focus.

One remarkable feature of the goals which international criminal courts are expected to achieve, as well as the goals they have themselves set out to achieve, is that they are extremely broad. In the discussion, the difference between the particular aims, goals and values of the criminal justice system and the criminal process is blurred, which makes it particularly difficult to get a clear understanding of what is meant by what

372 ICTY, Prosecutor v. Delalič et al., Décision relative à la requête de l'accusation aux fins de communication à l'avance de l'identité des témoins à décharge, IT-96-21-T, T. Ch., 4 February 1998, par. 20, op cit. in Delmas-Marty, 2009, p. 98.

373 There is some evidence of 'clashing cultures', see for example PAKES, 2003, p. 309.

374 One example of the attempt to 'escape' the adversarial-inquisitorial labels is the fact that the terminology familiar to common or civil law traditions has been deliberately avoided in the statute of ICC to avoid any association with or preference for one system or another. So is the wording 'admission of guilt' instead of 'guilty plea', see generally LEE, 1999, p. 242.

375 As expressed by Judge Shahabuddeen: 'Judicial traditions vary and the Tribunal must seek to benefit from all of them'. ICTR, Prosecutor v. Barayagwiza, Decision (Prosecutor's Request for Review or Reconsideration), Separate Opinion of Judge Shahabuddeen, ICTR-97-19-AR72, A. Ch., 31 March 2000, par. 68. Of course this does not imply that, in practice, the different legal-cultural views would not determine the outcome of some procedural decision. DANNER AND MARTINEZ, 2005, pp. 77-78: International law "seeks to melt two legal systems into a coherent whole; international criminal tribunals combine aspects of the common law adversarial system with the civil law inquisitorial system. In a formal sense, their rules of procedure and evidence draw on both legal traditions; in a practical sense, judges schooled in the common law or the civil law reflect their system of origin in their approach to various legal problems." However, the solution should be guided by the aims of international criminal justice and not by the legal background and feelings of national superiority of the decision-makers. 
and when. Generally, it is assumed that next to the traditional goals of retribution and deterrence, international criminal courts were established to stop ongoing conflicts, to contribute to the restoration of international peace and security, to produce an accurate historical record of horrific crimes and to provide a venue for reconciliation and satisfaction for the many victims of these crimes, to have an educative role in articulating the era of the end of impunity for gross human rights violations and, thus, to advance international human rights, international humanitarian and international criminal law. ${ }^{376}$

One of the most pressing problems concerning this list of goals is immediately obvious: the list is long. This can be partly explained by the fact that no differentiation is made between the aims of the international criminal justice system, the international criminal sentencing purposes, the goals of the process and the different stages of that process and the underlying values. It is however important to realise and to keep in mind the differences between the aims, goals and values, for a differentiation of the kind can help to properly understand, analyse and evaluate the procedural framework. This is not to say that this differentiation is easy to make. Deterrence, for example, can be regarded as a general aim of the international justice system, but also as a goal to punish an individual perpetrator. Establishing the truth is regarded as a general aim of the criminal justice system in the sense of a record of properly constructed historical facts, but also as a procedural goal and a value underlying the criminal process. Another important value of the criminal process is fairness, which is particularly informed by the aim of protecting an individual from improper political interference. A proper classification is necessary as one general aim of the criminal justice system, such as, for example, the aim of ending impunity for international crimes, in the sense of general deterrence, cannot in itself be a proper sentencing purpose because its generality extends beyond the confines of individual criminal responsibility, an essential principle in criminal law. ${ }^{377}$

However, this overabundance of the aims and goals of international criminal justice is not the only problem. ${ }^{378}$ The nature of these goals as primary or auxiliary and also their hierarchical status are also very much debated. Moreover, finding a proper balance between the different values is not an easy undertaking as the realisation of many of them inevitably leads to mutual tension and one only has to mention the

3762004 Report of the then U.N. Secretary-General Kofi Annan (The Secretary-General, Report of the Secretary-General on the Rule of Law and Transitional Justice in Conflict and Post-Conflict Societies, par. 38, U.N. Doc. S/2004/616, 23 August 2004): objectives of international criminal tribunals include: bringing to justice those responsible for serious violations of human rights and international humanitarian law, putting an end to such violations and preventing their recurrence, securing justice and dignity for the victims, establishing a record of past events, promoting national reconciliation, re-establishing the rule of law, and contributing to the restoration of peace. See also DAMAŠKA, 2009, p. 177.

377 ICTY, Prosecutor v. Krajišnik, Judgment, IT-00-39-T, T. Ch., 27 September 2006, par. 1137.

378 See generally DAMAŠKA, 2008. 
tension between the fairness of the proceedings for the accused and the need of many victims for satisfaction.

To establish a ranking order to the satisfaction of all is a challenging undertaking. Damaška proposes the nomination of one paramount goal that would provide an argumentative advantage in balancing the goals for the determination of the proper procedure to achieve these goals. ${ }^{379} \mathrm{He}$ rejects the idea that international criminal courts are a proper forum for attaining a deterrence, establishing a historical record and satisfying victims as their primary and overarching goal. Instead, he advances the socio-pedagogical goal as 'the heart of international criminal courts' mission'. ${ }^{380}$ International criminal courts are to spread moral and legal disapproval of international criminals, and thus to function as an example for the prosecution of those crimes. Moreover, at the sentencing level of goals, the cardinal value is placed on retribution, which "largely obviates the need to make choices where different goals might conflict with one another; it reduces dissonance." ${ }^{381}$

The goal of deterrence (specific and general), so common in national justice systems, seems to have been lost in the practice of international criminal tribunals: the passion and the conflict situation that usually accompanies the assurance of international crimes and their gravity leads to the conclusion that the remote possibility of criminal accountability has no deterrent or minimal deterrent effect. ${ }^{382}$ The relatively small number of prosecutions, in addition, promises only a small deterrent effect. ${ }^{383}$ As such, "[t]he connection between international prosecutions and the actual deterrence of future atrocities is at best a plausible but largely untested assumption." 384 Moreover, a criminal trial does not strike one as the most appropriate method to achieve satisfaction for victims and to establish a historical record of the

379 DAMAŠKA, 2009, p. 183.

380 DAMAŠKA, 2009, p. 184.

381 SWART, 2008, p. 104.

382 For an interesting deterrent example by the ICC, see the statement of the United Nations Special Envoy on Child Soldiers, Radhika Coomaraswamy, before the ICC Trial Chamber I: "The willingness on the part of the Court to prosecute these cases has sent many armed groups to us - the United Nations - willing to negotiate 14 action plans for the release of children; most recently yesterday in Nepal where the release of 3,000 children is about to begin today. (Transcript, p. 16, 7 January 2010, available at: http://www.icc-cpi.int/iccdocs/doc/doc802628.pdf. See, however, the report of Human Rights Watch that offers some 'nuances' to the statement: "[A]t the time of our field mission there, militia leaders in Ituri appeared to be changing their approach to child soldiers because of the charges against Lubanga. Previously, these leaders openly admitted approximate numbers of children in their ranks and handed children over to the United Nations Mission in the Democratic Republic of Congo (MONUC) and the United Nations Children's Fund (UNICEF) as part of the demobilization process. Following the confirmation of charges against Lubanga, however, many denied having any children under their command. [...] Children were hidden or chased from the ranks, and some were abandoned rather than being brought to the demobilization ceremonies, which is concerning." (Courting History, www.hrw.org/sites/default/files/reports/icc0708_1.pdf, at pp. 68-69).

383 Ku AND NzeLibe, 2006.

384 WipPMAN, 1999-2000. 
atrocities that took place during the conflict and would not seem suited to be the paramount goal of international criminal justice. ${ }^{385}$ It has also been mentioned that international prosecutions, instead of achieving reconciliation, in fact, "can trigger more vengeance ... [so that a] TRC [Truth and Reconciliation Commission] might be preferred." 386

In addition, tensions between the different aims can arise. For example, the implication of the "vast participation of ordinary citizens in the Nazi extermination machine" during the Nuremberg Trial did not advance Germany's future reconciliation. ${ }^{387}$ Another example concerns the avoidance by the ICTR of the issue of the immediate trigger of the genocide, namely the shooting down of the plane of the Hutu President. ${ }^{388}$ Moreover, there might be tensions between domestic goals, on the one side, and the goals of building an historical record and transitional justice on the other. Is it wise to prosecute all sides to the conflict, or in contrast, to allow some (small) fish to escape? The testimony of a witness/victim can contain too many references to general historical events, and that might be prejudicial to the accused (the guilt by association scenario). And "[p]erhaps most significantly of all, there is uncertainty over whether the means of achieving the various aims of international criminal justice complement each other." 389 This discussion emphasises the general aim of ending impunity for international crimes or the goal to punish the perpetrators of international crimes as the primary considerations underlying international criminal justice and process. ${ }^{390}$ As considered by one commentator, fighting impunity "should be approached as an interpretative tool of sources of international criminal law." 391

This may not satisfy those who envision a seemingly greater role for the international criminal courts; however, being the beacon of moral authority on the edge of law and politics where the former still loses time after time to the latter may just be the highest possible aim that these institutions can achieve. ${ }^{392}$ There should be no mistake, achieving the aim of moral authority implies achieving legitimacy,

385 WILSON, 2005 ("even if history writing were desirable, the courts could not fulfill this task anyway, since law and history involve different modes or reasoning altogether.")

386 Minow, 1998.

387 Posner, 2005, p. 140.

388 Galbraith, 2009, p. 96.

389 Galbraith, 2009, p. 95.

390 ARENDT, 2006, p. 253: ' ... the purpose of a trial is to render justice, and nothing else; even the noblest of ulterior purposes - "the making of a record of the Hitler regime which would withstand the test of history," as Robert G. Storey, executive trial counsel at Nuremberg, formulated the supposed higher aims of the Nuremberg Trials - can only detract from the law's main business: to weigh the charges brought against the accused, to render judgment, and to mete out due punishment'.

391 Sluiter, 2010, p. 257.

392 DRUMBL, 2009, p. 44: "The truths told by international criminal law are convenient. They are manageable. By blaming the few for the murder of the many, these truths comfort. They do not embarrass too much or too many. But the origin of atrocity is much more discomfiting and discomforting". 
something that national systems struggle with every day. Moreover, other aims are not dismissed and their realization is very much on the agenda of these institutions. As has been observed, "[w]hile domestic criminal law aims unquestionably dominate our current understanding of international criminal law, most commentators are willing to acknowledge that the historical record aim and the transitional justice aim also have at least theoretical appeal. ${ }^{.393}$ Moreover, transitional justice goals influence the workings of international tribunals most evidently in the way they affect prosecutorial discretion. According to Greenawalt, if the ICTY would have prosecuted only on the basis of the gravity of crimes, no Croat or Muslim crimes would be charged. ${ }^{394}$ The prosecution of all sides was partly to serve appeasement to advance the process of reconciliation in the region. However, even with regard to the traditional, retributive basis of international criminal justice, some commentaries voice concern about its ability to achieve this goal. On the one hand, could the few possible prosecutions even pretend to meet out just deserts? ${ }^{395}$ On the other hand, the victor's justice perception could divert attention from a retributive toward a vindictive perception. ${ }^{396}$

Importantly, and "[p]erhaps most significantly of all, there is uncertainty over whether the means of achieving the various aims of international criminal justice complement each other." ${ }^{397}$ Notably, first, the rules of procedure and evidence of the ICTY clearly adopted a "decidedly adversarial approach." 398 Similarly, at the ICC, "the adversarial-accusatorial process prevails in substance." ${ }^{399}$ Considering the above discussion of truth-finding in a criminal trial, one may argue that, notwithstanding the commitment of adversarial and inquisitorial traditions to truth, the former is at least more inclined to accept procedural truth rather than substantive more easily than the inquisitorial tradition. From this perspective, another emphasis is placed on the aim to realise these goals through procedures that adhere to the minimum international human rights norms. ${ }^{400}$ Indeed, it has been advanced that international

393 Galbraith, 2009, p. 94.

394 Greenawalt, 2007. Carla del Ponte, Address in Bern, 1 September 2005 (http://www.icty.org/ $\mathrm{sid} / 8544)$ all sides are responsible for crimes.

395 DRUMBL, 2007, p. 153: “ ... the operation of international criminal law occasions a retributive shortfall in that too few people or entities receive just deserts [sic].

396 Trial of the Major War Criminals Before the International Military Tribunal, Nuremberg, 14 November 1945-1 October 1946, Vol. 19, p. 432 (1948); available at http://www.loc.gov/rr/frd/ Military_Law/NT_major-war-criminals.html. Justice Robert H. Jackson ended his closing argument at Nuremberg "if you were to say of these men that they are not guilty, it would be as true to say that there has been no war, there are no slain, there has been no crime".

397 Galbraith, 2009, p. 95.

398 Antonio Cassese, Statement by the President Made at a Briefing to Members of Diplomatic Missions, IT/29, 11 February 1994.

399 Bassiouni, 1999, p. 464.

400 JACKSON, 2009-a, p. 22: “Although these purposes [of international criminal justice] continue to be subject to debate, one of its core aims remains the need to determine whether accused persons are guilty of international crimes and there is a consensus that for this purpose there needs to be full 
criminal courts are to perform the function of 'enlightened justice', and "international criminal procedure should strive to satisfy - perhaps even surpass - the highest standards evolved in national justice systems of contemporary liberal societies: it should aspire to be the model and inspiration for national criminal enforcement." 401 Should international criminal procedure strive to implement the highest standards of fairness, or would that be aiming too high? Which endeavour would only damage the reputation and legitimacy of international criminal institutions? ${ }^{402}$ From this perspective, some consider it best to focus:

on the purposes of the international criminal trial and not directly on the purposes of international criminal law more generally. There is a difference. One can believe that war crimes and other crimes against humanity must be punished - for reasons of deterrence and retribution, among others, without taking a position as to precisely how this is to be accomplished in every situation. ${ }^{403}$

Swart talks about the 'micro' and 'macro' levels at which the goals of criminal justice can be realized. At the more general macro level, "the ability of a system of criminal justice to reach its proffered goals depends on such factors as its general ability to investigate and adjudicate cases effectively as well as the perception of its effectiveness by the general public and the degree of confidence it inspires." ${ }^{404}$ The micro level clearly relates to individual cases and it is "[o]nly, or mainly at this level [that] the question arises as to the relationship between the goals a system is supposed to pursue and the shape of the particular legal process for adjudicating individual cases." ${ }^{405}$

Specifically with regard to international criminal justice, Turner makes a distinction between the legal and the political model of international criminal trials, arguing that "the further a trial strays from its focus on the adjudicative function, the more likely it is to disregard the defendant's rights in pursuit of nonlegal purposes." 406 The legal model, in this sense, refers to adjudicating guilt and appropriate punishment, ${ }^{407}$ with the additional goals of punishment being: deterrence, incapacitation, and rehabilitation. While the political model of international criminal trials focuses on promoting peace and reconciliation, compiling an accurate historical record, and providing closure for victims. Indeed, this division might prove helpful as

adherence to international fair trial norms."

401 DAMAŠKA, 2011, p. 1.

402 DAMAŠKA, 2011.

403 Turner, 2008, p. 533.

404 SWART, 2008, p. 101.

405 SWART, 2008, p. 101.

406 TuRnER, 2008, p. 537.

407 The ability of international criminal tribunals to achieve even these objectives have been questioned. See Combs, 2010. 
a division of power and responsibility between different stakeholders. The political decisions, motivations and aims are to be considered by the political bodies that are involved in the establishment, development and institutional changes of these courts. The legal considerations are the prerogative of the people who are involved in the dayto-day business of these courts. To some extent, this might explain judges' reluctance to formulate or elaborate more general goals of international criminal justice, beyond their understanding of the goals of punishment.

The trial-centredness of the international criminal system is supported by many incentives that push towards a full-fledged trial. All the parties involved do not (usually) bear the economic costs of the international criminal process. Moreover, the goals of establishing a more complete historical record of atrocities and giving the victims of those crimes a voice push more towards a trial than towards diversion from the formal process through the dispositive value of a guilty plea. In addition, delaying the proceedings might also be a defence strategy (in the context of ICTY/ICTR) "because the chances of acquittal are not insignificant (which creates incentives to fully litigate the case at trial), and because the longer the proceedings take the more defendants may question the legitimacy of the Tribunal." 408 This tactic might be appropriate for the prosecution as well: the suspects of international crimes are usually not arrested when the prosecution is ready for trial but when the possibility of an arrest arises. ${ }^{409}$ Lastly, one might consider the practice surrounding the initial guilty pleas before the ICTY, such as imposing higher sentences than settled in a plea agreement, which has discouraged plea agreements. ${ }^{410}$

Finally, the 'show' element of the trial might be emphasized. Not as a 'show trial', which has a negative ring to it, but as the climax of the socio-pedagogical role that international criminal courts are to achieve. The fact that the trial is the culmination of a court's absolute jurisdictional power, since the investigation and enforcement of sentences stages are dependant on states, supports this proposition. The moral and legal condemnation of gross human rights violations can only be achieved through the application of substantive criminal provisions by fair and efficient procedures. To some extent, it feels like a paradox. International criminal justice has a magnified vision with magnified intentions, which surpass the mere individuals involved. It is not merely about fact-finding in a criminal act, it is about recoding the history of a violent conflict. It is not merely about retribution, it is about giving the numerous victims a voice. It is not merely about the rehabilitation of an individual in a society, but about the reconciliation of and within societies. However, the only way to achieve all this is through providing a fair trial for that individual. The legitimacy of these institutions indeed "comes not from the shaky political authority that creates them, but from the manifested fairness of their procedures and punishments. Tribunals

408 LANGer AND Doherty, 2011, p. 261.

409 LANGer and Doherty, 2011, p. 261.

410 Langer and Doherty, 2011, p. 261. 
bootstrap themselves into legitimacy by the quality of justice they deliver; their rightness depends on their fairness." ${ }^{411}$

\subsection{CONCLUding REMARKS}

I think systems of law diverge more in methods of trial than in principles of law to be applied in decision. Then too, with lawyers practice becomes a matter of professional habit, and our habits often seem more fixed than our principles. ${ }^{412}$

This chapter attempted to provide a procedural framework for evaluating the principle of equality of arms by tracing the foundations of the principle as a procedural device for upholding the adversarial nature of the proceedings. The theoretical foundations are informed by the concept of procedural fairness which is founded on a broader notion of legitimacy and includes the principles of participation, accuracy and efficiency. The notion of balancing, although contextual in its application, is considered to be central in this consideration of different values, goals and aims that are served by a particular process.

Two possible implementations of this concept of procedural justice were considered: the adversarial and inquisitorial style. For comparative and analytical purposes these styles are best conceptualized as ideal-type models. The cardinal difference is the division of powers of different participants and their respective roles vis-à-vis each other.

From a traditional adversarial perspective, the balance of advantages has to be upheld formally. However, this 'fair rules of the game' approach has been considered inadequate in the criminal law setting. Here, an inherent inequality between the powers of the state and the accused has to be acknowledged. A full procedural symmetry is unattainable in a criminal trial. Fairness is achieved and maintained by a strict observance of certain minimum requirements that an accused has been provided with. In fact, the key to maintaining equilibrium between the parties is to consider a 'balanced empowerment', which implies procedural entitlements measured out of the necessities of a party's role in a criminal setting. ${ }^{413}$ The idea of equalizing positions seems to be abandoned in these arguments, which, at an extreme, could justify the denial of all the procedural opportunities to the defence, as it is the prosecution which is to present and to prove a case. Obviously, this position is impossible in a procedural

411 Luban, 2008, p. 13.

412 JACKSON, 1948-1949, p. 148.

413 See also D. Steiner, Das Fairneßprinzip im Strafproze $\beta$, Peter Lang, 1995, p. 205: "Der Strafprozess folgt nicht den Regeln des Parteiprozesses, sondern denen eines 'Anklageverfahrens mit Ermittlungsgrundsatz.' In diesem Verfahrenstyp bedeutet Waffengleichheit nach richtigem Verständnis, nicht Gleichheit der Rechte, sonderns deren Ausbalancierung under Berücksichtigung der Verschiedenartigheit der Prozeßrollen." [footnotes omitted]. 
setting where truth and fairness are determined by a possibility of both parties to present their antagonistic argument before an impartial decision maker. Thus another idea is to present a separation of the procedural entitlements we are talking about into the non-reciprocal and reciprocal. As the term presupposes, the non-reciprocal entitlements cannot be compared or measured against each other. Simply stated, the state bears the burden of proof, so also the magnitude of investigative powers and resources. The accused does not have to prove anything; however, in order to be able to challenge his adversary's account, an individual is assigned certain rights that 'equalize' his position to that of the prosecution. In fact, according to Silver, the principle of equality of arms, as a procedural device, would not apply to those non-reciprocal entitlements. This principle could only be applicable to the reciprocal entitlements that parties incur in a procedural setting, for example witness (cross-) examination. However, one must keep in mind that many of the non-reciprocal rights an accused is entitled to are based on a principled approach to considerations of fairness. This should be taken into account when determining the appropriate balance between the rights of the parties. For example, the possibility for the prosecution to challenge a defence witness might be limited as the principle of fairness might dictate that an accused should have the last word at his own trial.

As a procedural device, the principle of equality of arms implies reciprocity in procedural possibilities and restrictions. As an inherent element of the adversarial process, the principle of equality of arms implies formal procedural equality between two parties. This equality concerns the reciprocal procedural devices that are given to the parties in an adversarial trial, and does not embody the non-reciprocal advantages that are installed to 'equalize' the inherently unequal criminal process system, as to make a full and meaningful application of the adversarial principle possible. This does not mean that the scope of equality of arms does not overlap with the 'equalizing' advantages. To the extent that the advantages are reciprocal, the principle of equality of arms applies. Indeed, from a procedural perspective the scope of the adversarial principle is broader as it incorporates the principle of equality of arms.

Although adversarial style is the genesis of the principle of equality of arms, the specific context of a criminal trial makes the pure application of an adversarial contest ideology practically unattainable. Conversely, there seems to be no link between the principle of equality of arms and pure inquisitorial style. However, contemporary reformed Continental criminal procedures incorporate several elements that positively influence the application of equality of arms: the principle finds its application also in an inquisitorial criminal process through the interpretation of these inherent procedural elements. It does not suffice to look only at the formal procedural elements (whether both prosecutor and defence have a particular right), the internal procedural arrangements have to be taken into account too, if one is to come to a meaningful interpretation of the principle of equality of arms. 


\section{Chapter 4 \\ Parties' Role During Investigations}

\subsection{INTRODUCTION}

The dependence of international criminal courts on state cooperation has been singled out as one of the most influential 'special circumstances' under which international criminal courts have to operate. In addition, due to this dependant situation, the powers of an international prosecutor in practice cannot be compared to his national equivalent. From the perspective of the defence, many international defence teams have complained about the inadequacy of their investigative efforts to properly prepare for trial. In fact, the inequality of arms between the prosecution's and the defence's investigative powers has often been voiced as an issue of concern. As presented in Chapter 1, this study takes this concern as a point of departure and operates on the assumption of defence's investigative inferiority; the question is how to remedy it.

This chapter will tackle this highly complex and wide-ranging issue from several perspectives. First, it will take a closer look at the role of the prosecutor in the initiation of international criminal proceedings: the function, the framework of legal (and ethical) responsibilities, the practical concerns and complications. The first part zooms in on the pre-charge and the pre-trial stages of the process. It is not intended to compare the role of the prosecutor in the national and international criminal process to make a sound statement on the 'equality' of their positions, but rather to consider how the positions of the prosecutor and the defence in international investigations are 'levelled out' so as to appear equal and, consequently, to respect the principle of equality of arms. ${ }^{1}$ Therefore, I will position the defence in its investigative ability in light of the minimum human rights guarantees and the procedural demands. In this regard, it has been argued that the choice for the procedural model of a "twocase" presentation, and the ensuing necessity for the defence to conduct its own instigations to be able to present its case, jeopardizes equality of arms. As a solution,

1 Knoops And Amsterdam, 2006, p. 261. "Within the proceedings before all these types of tribunals, two procedural pillars are of perennial concern and importance. The first procedural pillar is the element of State cooperation, without which international criminal proceedings cannot effectively function, seen from the perspectives of both the prosecution and the defence" [footnote omitted]. The second procedural pillar is an effective enforcement of the principle of equality of arms, which is decisive for the administration of fair proceedings [footnote omitted]." Without these pillars the international criminal tribunals cannot function. "Consequently, that principle should have a selfexecuting effect on the first pillar: State cooperation." 
the defence has continuously argued for an increase in defence resources and facilities, particularly in the sense of budgeting and institutional support (this will be looked at in Chapter 6). Meanwhile, this problem has been tackled from the other side too: a changed focus by the organs of the international criminal institutions. The ICC prosecutor has been given an explicit assignment to search for the truth by investigating both incriminating and exculpatory evidence. ${ }^{2}$ In addition, judges have been developing a more 'managerial' role in the international criminal process. ${ }^{3}$ In particular, the ICC Pre-Trial Chamber was given a more elaborate mandate to control the pre-trial process. Indeed, these two considerations are determinative for the balance between the parties: (1) the substantive nature of the prosecutor's role in the proceedings and (2) the role of the judges in the process. An investigation into the triangular relationship between the prosecutor, defence, victims and judges can be considered the 'common thread' running through this study.

\subsection{ThE ROLE OF THE INTERNATIONAL PROSECUTOR}

When looking at the 'role' of a prosecutor several intertwined and inter-related factors and perspectives have to be taken into account. The prosecutorial leading ethos is usually considered as twofold:

[t]he prosecutor acts both as an 'administrator of justice', in that he acts in the interests of international justice pursuing the goal of indentifying, investigating and prosecuting the most serious international crimes and, as in common law legal orders, as a party in an adversarial system. ${ }^{4}$

The dialectic tension between these two dichotomised positions is resolved within the confines of the legal institutional position and function of the prosecutor. ${ }^{5}$ On the domestic level, the office of the prosecution can be subordinate to the executive branch and/or be part of the judicial corpus while being separated from the judges. The prosecutorial mandate can be subject to the legality principle implying mandatory prosecution, or be guided by a - wide - prosecutorial discretion in pursuing a case. The concrete tasks that inform the prosecutorial function vary extensively depending on the legal system, although there are some common prosecutorial 'core' tasks that can be identified across systems. ${ }^{6}$ Moreover, the 'hat' that a prosecutor wears changes following a particular phase of a criminal process: at trial the 'zealous partisan'

2 Article 54 ICC Statute.

LANGER AND DOHERTY, 2011.

CASSESE, 1999, p. 162.

Boyne, 2010, pp. 1291, 1300, arguing that "the degree of an individual prosecutor's commitment to the performance of objectivity is shaped by institutional and individual-level factors."

6 JACKSON, 2006-b, p. 2. 
comes to the fore most noticeably, while the pre-trial discretionary function must be executed more dispassionately. The division of power between the prosecutor and the other parties, particularly the judges, is determinative for a concrete delimitation of the prosecutorial role. ${ }^{7}$

\subsubsection{Prosecutorial ethos: a dichotomy?}

From a theoretical perspective, the role of a prosecutor is considered to be informed by a certain neutrality; he represents more than just a party in criminal proceedings. This "obligation of dispassion in a passionate pursuit" gives rise to two seemingly dichotomised role perceptions: a 'quasi-judicial' and 'zealous advocate' ${ }^{8}$ In his quasijudicial role the prosecutor is expected to serve a fair and efficient administration of justice by investigating and prosecuting crimes in an impartial manner leading to the determination of truth (as an impartial truth-seeker). Neither an 'organ of state policy' nor a 'victim's champion' stricto sensu, the prosecutor is considered to act as a 'guardian of the community'. ' In this capacity, the prosecutor is responsible for the protection of victims and witnesses, for safeguarding the integrity of the proceedings, ${ }^{10}$ and for guaranteeing a fair trial to the accused. ${ }^{11}$ This latter responsibility places upon the prosecutor the duty to disclose to the accused any exculpatory or mitigating evidence that he encounters during the investigation. In the context of the ICC, this duty is furthermore expanded to an active search for such evidence. However, it is this latter responsibility that can most noticeably conflict with his other 'face' as a party in a criminal process. In that capacity, the prosecutor has the responsibility to zealously prosecute those responsible for crimes, to 'win' the case by securing a

7 Admittedly, examining the role of the prosecutor and the balance of powers as well as rights and responsibilities between the prosecutor, the judges and the defence from a formal legalistic perspective is an imperfect and one-sided exercise because the cultural and sociological factors that surface in a particular institutional setting are very much determinative for the actual practice within the international criminal tribunals. An in-depth analysis of these issues exceeds the scope of this chapter.

8 UVILLER, 2000 (referring to "adjudicative" and "adversary" processes for a prosecutorial evaluation of a case). See also McMunigal, 2000 (opposing the dichotomised nature of prosecutorial standards as compared to those of other counsel). Gershman, 1992, p. 453 (“ ... prosecutors are guided by higher ethical considerations than those governing attorneys generally. The prosecutor exercises a "quasi-judicial" function" [footnotes omitted].).

9 JACKSON, 2006-a, pp. 49-50.

10 The prosecutor can be directed by the Chamber to prosecute Contempt of Court cases: Rule 77 RPE ICTY and ICTR.

11 It is argued that there is an "inherent tension between the idea of an objective 'minister of justice' presenting evidence to the court dispassionately as part of the overall public interest in pursuing a conviction, whilst at the same time performing any sort of support or protective function in relation to the victims." See DoAK, 2005, p. 306, referring to Ellison, 1997, pp. 281-284 The same tension can be said to exist in ensuring a fair trial for the accused. 
conviction, preferably with the maximum sentence possible being imposed. In the 'combat' between the two parties, the judges are the administrators of justice and are responsible for a fair trial. As argued in Chapter 1, international criminal courts have adopted and extended the notion of fairness by considering that 'the right to a fair trial applies both to the Defence and the Prosecution'. ${ }^{12}$ This approach makes the prosecutor the beneficiary of several fair trial 'rights', including equality of arms that formally targets the accused alone. ${ }^{13}$

These two sides of the prosecutor's role in their pure sense should be seen as two extremes of a continuum; as two pure models, which inform the role of the prosecutor in practice. There, these two theoretical approaches are entwined, correlate and can collide. Thus, in practice, the prosecutor's role is defined by the manner in which the inherent tension between the two approaches is resolved; the extent to which the optimal balance is achieved. This balance is very much dependant upon the philosophical underpinnings of truth-funding as the ultimate goal of the criminal process and procedural roles that are assigned to the different participants in that process. ${ }^{14}$

The perception of a prosecutor as an impartial truth-seeker is central to the systems based on the 'inquisitorial' tradition. In fact, from the theoretical perspective the above-mentioned tension between the 'quasi-judicial' and 'zealous advocate' perceptions does not arise in civil law-based traditions where prosecutors are seen as one pillar of the magistrate, 'standing' as opposed to 'sitting' judges. ${ }^{15}$ Acting as 'a judge before a judge', ${ }^{16}$ the prosecutorial quasi-judicial mandate is clearly informed by the ethical obligation of the judges to establish the truth: the prosecutor's "role is not to obtain a conviction at all events, and as severe as possible, but their role is to

12 ICTR, Prosecutor v. Karemera et al., Decision on Severance of André Rwamakuba and Amendments to the Indictment, ICTR-98-44-PT, T. Ch. III, 7 December 2004, par. 26. Also e.g. ICTY, Prosecutor v. Milutinović et al., Decision on Prosecution's Request for Certification of Rule 73 bis Issue for Appeal, Case IT-05-87-T, T. Ch. III, 30 August 2006, par. 10 (“Although use of the word 'fairness' in the context of a criminal trial might commonly refer to fairness for an accused, the Prosecution undoubtedly is entitled to a fair opportunity to present its case. The Statute of the Tribunal ... and does not provide that only an accused is entitled to be treated equitably.").

13 The headings of the appropriate articles all refer to the 'Rights of the Accused', see Articles 21 and 20 ICTY and ICTR Statute respectively, Article 17 SCSL Statute and Article 67 ICC.

14 See Chapter 3.

15 However, the most continental prosecution offices are hierarchically placed under the authority of the Minister of Justice (see Jehle, Smit And ZiLA, 2008, p. 162) and this can cast some shadow over the independence of the prosecution office (see e.g. Clear as mud. France's Judicial System: The Clearstream case raises new questions of Judicial Independence, 394 Economist, 00130613, 6 February 2010, Issue 8668, pp. 56-58).

16 Kausch, 1980. See also Jehle, Wade And Elsner, 2008, p. 98 ("The Netherlands provide an excellent example of a smaller western European country which is the most advanced in terms of dealing with cases informally, that is without a court hearing. The prosecution service there can be regarded as the 'judge before the judge', due to its role in ending cases."). See also Boyne, pp. 1291, 1288, referring to the function of a prosecutor as a "second judge." 
suggest a just solution to the judges, who are then to decide for themselves." ${ }^{17}$ The goal is to ascertain the truth, even if the truth leads to the acquittal of the accused; "[t]he imagery of 'winning' and 'losing' criminal cases is much more congenial to American than to European prosecutors." 18 The mandate of a continental prosecutor demands not only an active search for all the relevant evidence, inculpatory as well as exculpatory, but also the presentation of such evidence to the court. Thus, "[t]he prosecutor is placed in a position which obliges him as much to protect the accused as to come forward against him." 19

Although the obligation to disclose exculpatory evidence to the defence is not unfamiliar to common law prosecutors, ${ }^{20}$ the emphasis on an adversarial philosophy does make the tension between "the quasi-judicial role of protecting the innocent and the advocate's role of pursuing convictions" ${ }^{21}$ more evident in common lawbased systems. As an officer of the court, the prosecutor is expected to 'seek justice'22 on behalf of the people. ${ }^{23}$ In fact, the prosecutorial mandate is seen as imposing a unique legal and ethical duty to discover the truth and a responsibility to facilitate the truth-finding function of the courts. ${ }^{24}$ However, the trial philosophy of a fair combat

17 Vouin, 1970, p. 492.

$18 C f$. DAmašKa, 1986, p. 223. One striking example is the Wilders case in the Netherlands, where the Amsterdam Public Prosecution Office recommended an acquittal on all charges in its closing speech on 15 October 2010. In this case the prosecution was 'forced' to pursue the case by the Appellate Court which has the power to reverse a prosecutorial decision not to prosecute (Article 12 of the Dutch Code of Criminal Procedure).

19 JESCHECK, 1970, p. 511.

20 In the famous case of Brady v. Maryland (373 U.S. 83), the US Supreme Court in 1963 expanded Constitutional due process rights for criminal defendants by requiring prosecutors to disclose exculpatory material to defence counsel: "[T]he suppression by the prosecution of evidence favorable to an accused upon request violates due process where the evidence is material either to guilt or to punishment, irrespective of the good faith or bad faith of the prosecution." (Brady, 373 U.S. at 87).

21 Melilli, 1992, p. 697.

22 ABA Standards for Criminal Justice: Prosecution and Defense Function, $3^{\text {rd }}$ ed., 1993, American Bar Association (available at http://www.americanbar.org/content/dam/aba/publications/criminal justice_standards/prosecution_defense_function.authcheckdam.pdf): "Standard 3-1.2 The Function of the Prosecutor: (a) ... ; (b) The prosecutor is an administrator of justice, an advocate, and an officer of the court; the prosecutor must exercise sound discretion in the performance of his or her functions; (c) The duty of the prosecutor is to seek justice, not merely to convict." The Code for Crown Prosecutors, CPS, February 2010, available at http://www.cps.gov.uk/publications/docs/ code2010english.pdf, par. 2.4 ... Prosecutors must always act in the interests of justice and not solely for the purpose of obtaining a conviction.

23 ABA Standards for Criminal Justice: Prosecutorial Investigations, 2008 American Bar Association (available at http://www.americanbar.org/content/dam/aba/migrated/moratorium/policy/2000s/2008_ MY_105D.authcheckdam.pdf): "Standard 1.2 General Principles (a) An individual prosecutor is not an independent agent but is a member of an independent institution the primary duty of which is to seek justice; (b) The prosecutor's client is the public, not particular government agencies or victims ...."

24 Gershman, 2001, p. 313 (see the cases cited in footnote 38). On the devastating effect of the method of the adversarial trial on its truth-finding ability, see the extensive critical US literature, e.g. PIzzI, 
between two opposing competent advocates leads to a division of procedural roles between the prosecutor and the defence that imposes an independent responsibility to present one's side to the court. Thus, within the confines of an adversarial trial, the role of an officer of the court is vindicated as soon as the prosecutor has disclosed all the relevant evidence to the defence (inculpatory and exculpatory), any other facilitation of the defence's cause is neither expected nor welcome in an adversarial process. The common law depicts the role of the prosecutor as "a "fair minister of justice' of a 'quasi-judicial kind'. ${ }^{25}$

On the international plane, other than the criminal tribunals, there are different documents adopted that emphasize some common standards and ethical principles governing prosecutorial conduct. ${ }^{26}$ These documents emphasize impartiality and

1999; G. GoOdPaster, 1987; Frankel, 1975.

25 Vasiliev, 2010, p. 13. Devlin, 1960, p. 23: Lord Patrick Devlin considered that a prosecuting counsel "is to act as a minister of justice rather than as an advocate; he is not to press for a conviction but is to lay all the facts, those that tell for the prisoner as well as those that tell against him, before the jury."

26 UN Guidelines on the Role of Prosecutors, Adopted by the Eighth United Nations Congress on the Prevention of Crime and the Treatment of Offenders, Havana, Cuba, 27 August to 7 September 1990 (available at http://www2.ohchr.org/english/law/prosecutors.htm): Role in criminal proceedings

10. The office of prosecutors shall be strictly separated from judicial functions.

11. Prosecutors shall perform an active role in criminal proceedings, including the institution of prosecution and, where authorized by law or consistent with local practice, in the investigation of crime, supervision of the legality of these investigations, supervision of the execution of court decisions and the exercise of other functions as representatives of the public interest.

12. Prosecutors shall, in accordance with the law, perform their duties fairly, consistently and expeditiously, and respect and protect human dignity and uphold human rights, thus contributing to ensuring due process and the smooth functioning of the criminal justice system.

13. In the performance of their duties, prosecutors shall:

(a) Carry out their functions impartially and avoid all political, social, religious, racial, cultural, sexual or any other kind of discrimination;

(b) Protect the public interest, act with objectivity, take proper account of the position of the suspect and the victim, and pay attention to all relevant circumstances, irrespective of whether they are to the advantage or disadvantage of the suspect."

Standards of professional responsibility and statement of the essential duties and rights of prosecutors, adopted by the International Association of Prosecutors on the twenty third day of April 1999 (available at http://www.iap-association.org/ressources/Standards_English.pdf): “1. Professional conduct: Prosecutors shall ... strive to be, and to be seen to be, consistent, independent and impartial; always protect an accused person's right to a fair trial, and in particular ensure that evidence favourable to the accused is disclosed in accordance with the law or the requirements of a fair trial; always serve and protect the public interest; respect, protect and uphold the universal concept of human dignity and human rights."

Recommendation $\operatorname{Rec}(2000) 19$ of the Committee of Ministers to member states on the role of public prosecution in the criminal justice system, adopted by the Committee of Ministers of the Council of Europe on 6 October 2000 (available at https:/wcd.coe.int/wcd/ViewDoc. jsp?id=376859\&Site=COE): " 1 . "Public prosecutors" are public authorities who, on behalf of society and in the public interest, ensure the application of the law where the breach of the law carries a criminal sanction, taking into account both the rights of the individual and the necessary 
independence, effectiveness and respect for the human rights of the defence and the victims, including the duty to make oneself "aware of all relevant circumstances including those affecting the suspect, irrespective of whether they are to the latter's advantage or disadvantage." 27

As mentioned, the ICC prosecutor is invested with a duty to establish the truth and therefore to investigate both incriminating and exonerating circumstances equally. ${ }^{28}$ In fact, Article 54 is a salient example of the insertion of an inquisitorial element and has been described as an attempt 'to build a bridge between the adversarial common law approach to the role of the prosecutor and the role of the investigative judge in certain civil law systems'. ${ }^{29}$ The struggle for 'equalization of arms' in the practice of the ad hoc tribunals had been particularly taken into account when expressly investing the prosecutor with a duty to investigate both incriminating and exonerating evidence at the ICC. Interestingly, when drafting the Rome Statute the German proposal to include an independent obligation to search for truth for the judges was explained

effectiveness of the criminal justice system. ... 26. Public prosecutors should ensure equality before the law, and make themselves aware of all relevant circumstances including those affecting the suspect, irrespective of whether they are to the latter's advantage or disadvantage. 27. Public prosecutors should not initiate or continue prosecution when an impartial investigation shows the charge to be unfounded. 28. Public prosecutors should not present evidence against suspects that they know or believe on reasonable grounds was obtained through recourse to methods which are contrary to the law. In cases of any doubt, public prosecutors should ask the court to rule on the admissibility of such evidence. 29. Public prosecutors should seek to safeguard the principle of equality of arms, in particular by disclosing to the other parties - save where otherwise provided in the law - any information which they possess which may affect the justice of the proceedings."

27 Recommendation $\operatorname{Rec}(2000) 19$ of the Committee of Ministers to member states on the role of public prosecution in the criminal justice system, adopted by the Committee of Ministers of the Council of Europe on 6 October 2000 (available at https://wcd.coe.int/wcd/ViewDoc.jsp?id=376859\&Site=COE), par. 26. See also Explanatory note to the Bordeaux Declaration "Judges and Prosecutors in a Democratic Society", Opinion No. 12 of the Consultative Council of European Judges (CCJE) and Opinion No. 4 of the Consultative Council of European Prosecutors (CCPE) to the Attention of the Committee of Ministers of the Council of Europe on the Relations Between Judges and Prosecutors in a Democratic Society, Strasbourg, 8 December 2009, par. 12: "par. 2 of the Declaration: The fair administration of justice requires that there shall be equality of arms between the prosecution and defence, as well as respect for the independence of the court, the principle of separation of powers and the binding force of final court decisions." "In carrying out their functions, prosecutors rely on either a system of discretionary prosecution (the opportunity principle) or a system of mandatory prosecution (the legality principle), but in both cases prosecutors not only act on behalf of the society as a whole, but also discharge duties to particular individuals, namely the accused person to whom a duty of fairness is owed, as well as the victims of crime to whom a duty is owed to ensure that their rights are fully taken into account. In that sense and without prejudice to the respect for the principle of equality of arms, the prosecutor can not be considered equal to other parties."

28 Article 54(1) (a) ICC Statute.

29 Articles 81(1)(b) and 84(1) ICC Statute. Bergsmo and Kruger, 2008, p. 1078. See also De Smet, 2009, p. 425: "In a way, the Prosecutor, in his function of investigator performs a role very similar to that of the inquisitorial investigating judge." 
by appealing to the 'equality of arms' between the prosecution and the defence. The explanatory remark stated that 'the first step to guarantee a fair trial and equity for both sides is to oblige the prosecutor to extend the taking of evidence to all facts being of importance for the verdict'.$^{30}$ Given the complexity of the cases before the ICC, a suspect or accused who is taken from his social environment, kept in custody far away from the crime scene and who is often struggling with the languages of the court, "will generally have great difficulty to conduct his own investigations in the prior or present war-area." 31 Thus, "equality of arms on par with the public prosecution office can ... only be guaranteed by a court being entitled and bound to clarify all crucial facts, also - should the situation arise - in the interest of the underprivileged or weak defendant' ${ }^{32}$ Although the reference to the duty of the Court was dropped in the final text, the Preparatory Committee made an annotation explaining the independent role of the Court in the 'evaluation of the necessary depth of investigation and determination of the facts' by underlining the 'truth-finding mission of the Court'. ${ }^{33}$ The truth-finding mandate of the ICC prosecutor is thus one important element contributing to equality of arms. This mandate is operationalized through his duty to search for exculpatory evidence and to make it available to the defence.

However, this proposition has been criticized in light of the particular structure of the ICC procedure. As contended by Damaška:

[t]here is also reason to doubt that sufficient room for neutral research under the twocase approach exists if prosecutors, as officers of the court, are invited to assume nonpartisan attitudes and be equally attentive to incriminating and exculpating evidence. This non-partisan posture is easier to postulate in theory than to achieve in practice. For if prosecutors know that at the trial the defense's case follows their own case, a procedural dynamic develops in which it becomes difficult for them to refrain from using evidence selectively. No wonder when truth is expected to emerge from two competing vectors, their sum is skewed whenever one side exaggerates while the other side refrains from doing so. ${ }^{34}$

Although this tension is not unfamiliar to most legal systems, this point touches upon the extent of the prosecutor's duty to search for truth: does it include both the collection and presentation in court of exculpatory evidence? Arguably, the

30 Proposal made by the Delegation of Germany, New York, 23 August 1996, Report of the Preparatory Committee on the establishment of an International Criminal Courts - Vol. II, General Assembly Official Records - Fifty-first Session Supplement No. 22A [A/51/22], 1996, at 207 [German Preparatory Committee Proposal, 1996].

31 German Preparatory Committee Proposal, 1996, at 207.

32 German Preparatory Committee Proposal, 1996, at 208.

33 Decisions taken by the Preparatory Committee at its Session held from 1 to 12 December 1997 (A/AC.249/1997/L.9/Rev.1), Article 44, note 57.

34 DAMAŠKA, 2008, p. 338. 
selective use of the evidence at trial does not directly undermine the requirement of prosecutorial objectivity at the investigation stage. In fact, the prosecutor is expected to bring forward selected evidence that strongly supports the prosecutor's theory of the case.

A reading of Article 54(1) of the ICC Statute indicates that the duty to search for truth only extends to the investigative stage. The fact that the prosecutor is endowed with a statutory right to appeal or apply for a revision of a judgment on behalf of the convicted person indicates that the prosecutor's duty to search for the truth may well extend beyond the literal confines of Article 54(1) ${ }^{35}$ However, the precise implications for the trial stage, in terms of the prosecutor's duty to present exculpatory evidence and actively direct the judges towards the truth, instead of only limiting himself to the presentation of a case for prosecution, as a party to proceedings, are not clear. The legal framework of the ICC leaves it to the judges to design the case presentation. ${ }^{36}$ Theoretically, it would be possible for judges to design the trial as one case presentation, in which it would be more natural for the prosecutor to present all the investigative efforts to the court, including any exculpatory or mitigating evidence. ${ }^{37}$ The practice until now seems more inclined towards a two-case approach to the presentation of the evidence, ${ }^{38}$ where the defence is naturally required to present within its case all the exonerating evidence. In fact, within the structure of the ICC, this more adversarial two-case approach is additionally emphasized by the prosecutorial duty to disclose to the defence "as soon as practicable' the evidence possessed or controlled by the prosecutor that might exonerate or mitigate the guilt of the accused or affect the credibility of prosecution's evidence. ${ }^{39}$ To some extent, the prosecutor has to wear his 'zealous advocate' hat when presenting and arguing a case. As the representative of the international community in general, and the victims of the most serious crimes in particular, the prosecutor has a duty to vigorously pursue the institution's primary objective to prosecute those most responsible for international crimes and, thus, to end impunity. The scarce resources constitute potentially the biggest practical limitation upon prosecutorial discretion in that regard. The complexity of the cases before international criminal courts, and the widespread victimization, will necessarily force all investigation and prosecution efforts to focus upon making the best case against those most responsible for international crimes. However, the prosecutor's 'quasi-

35 Articles 81(1)(b) and 84(1) ICC Statute. Friman ... [et al.], 2003, par. 30.

36 See Articles 64 (3) (a) and 8 (b) ICC Statute, Rule 140 ICC RPE and Regulation 43 ICC Regulations.

37 Defending this procedural model, see e.g. KIRSCH, 2008, pp. 47-62.

38 ICC, Prosecutor v. Katanga and Ngudjolo Chui, Situation in the DRC, Directions for the conduct of the proceedings and testimony in accordance with Rule 140, ICC-01/04-01/07-1665-Corr, T. Ch. II, ICC, 1 December 2009.

39 Article 67(2) ICC Statute. 
judicial' character directs him towards ensuring a fair administration of justice, even at the expense of 'winning' a case. ${ }^{40}$

The duty to disclose favourable evidence to the defence is also known to other international criminal tribunals, ${ }^{41}$ it is the duty to investigate both inculpatory as well as exculpatory evidence that sets the ICC Statute apart. Although the tribunals' legal documents do not refer explicitly to the prosecutorial obligation to search for truth, the case law has affirmed the position of the Prosecution and its staff as "ministers of justice assisting in the administration of justice." ${ }^{42}$ A direct consequence of this status is the duty to disclose exculpatory evidence, which "is as important as the obligation to prosecute." ${ }^{43}$ Although the ICTY has hinted towards a broader responsibility of its prosecutor to disclose and to present exculpatory evidence, ${ }^{44}$ thus expanding the position of a fair minister of justice familiar to common law systems, no support in the legal framework can be found for this aspiration. ${ }^{45}$ While being

40 JACKSON, 1940, p. 6: "The qualities of a good prosecutor are as elusive and as impossible to define as those which mark a gentleman. And those who need to be told would not understand it anyway. A sensitiveness to fair play and sportsmanship is perhaps the best protection against the abuse of power, and the citizen's safety lies in the prosecutor who tempers zeal with human kindness, who seeks truth and not victims, who serves the law and not factional purposes, and who approaches his task with humility."

41 Rule 68 ICTY/ICTR Statute.

42 ICTY, Prosecutor v. Blaškić, Decision on the Appellant's Motions for the Production of Material, Suspension or Extension of the Briefing Schedule, and Additional Filings, IT-95-14-A, A. Ch., 26 September 2000, par. 32: "the Appeals Chamber takes note, with appreciation, of the position of the Prosecution which, in its view, conforms with the mandate of the Tribunal to dispense justice on behalf of the international community and with the status of the Prosecutor and her staff being, as it were, "ministers of justice assisting in the administration of justice." See also: STL, Order Regarding the Detention of Persons in Lebanon in Connection with the Case of the Attack against Prime Minister Rafiq Hariri and Others, CH/PTJ/2009/06, Pre-Trial Judge, 29 April 2009, par. 25: "Pursuant to Article 11 of the Statute, the Prosecutor is responsible for the investigation and prosecution of persons thought to be responsible for the crimes falling within the jurisdiction of the Tribunal. As he rightly points out, in so doing, the Prosecutor must act, not merely as a party to the proceedings, but also as an agent of Justice, representing and safeguarding the public interest. In that capacity, in accordance with Rule 55(C), he shall "assist the Tribunal in establishing the truth and protect the interests of the victims and witnesses. He shall also respect the fundamental rights of suspects and accused."

43 ICTY, Prosecutor v. Kordić and Čerkez, Decision on Motions to Extend Time for Filing Appellant's Briefs, IT-95-14/2-A, A. Ch., 11 May 2001, par. 14.

44 ICTY, Prosecutor v. Kupreškić et al., Decision on the Communication between Parties and their Witnesses, IT-95-19-T, T. Ch. II, 21 September 1998: “ ... (ii) However it should be noted that the Prosecutor of the Tribunal is not, or not only, a Party to adversarial proceedings but is an organ of the Tribunal and an organ of international criminal justice whose object is not simply to secure a conviction but to present the case for the Prosecution, which includes not only inculpatory, but also exculpatory evidence, in order to assist the Chamber to discover the truth in a judicial setting."

45 ZAPPALÀ, 2003, p. 41. The Prosecution's obligation pursuant to Rule 68 is to disclose exculpatory evidence or evidence which may affect the credibility of Prosecution evidence, where such evidence is in its possession. It is not disputed that the requested documents are not within the Prosecution's 
a "lofty pronouncement", this non-binding rhetoric does not reflect the Tribunal's legal framework or its party-controlled process and gives only "cold comfort to the accused." 46 When assessing prosecutorial actions, "it is necessary to have a keen appreciation for the partisan nature of the Office of the Prosecution." "47 The overall position of the ad hoc tribunals' prosecutor is comparable to the common law prosecutor, as stated by Judge Shahabbuddeen in his Separate Opinion in the Barayagwiza case:

The prosecutor of the ICTR is not required to be neutral in a case; she is a party. But she is not of course partisan. This is why, for example, the Rules of the Tribunal require the prosecutor to disclose to the defence all exculpatory material. The implications of that requirement suggest that, while a prosecution must be conducted vigorously, there is room for the injunction that prosecuting counsel 'ought to bear themselves rather in the character of ministers of justice assisting in the administration of justice' ${ }^{48}$

Although the prosecutor's fundamental position is that of a minister of justice, at trial he is a party and must pursue the case with dedication; thereby 'zealously' establishing the truth. ${ }^{49}$ The difficulty of drawing a line between being a 'fair minister of justice' and a 'partisan advocate' particularly in the morally appalling and politically sensitive cases before the international criminal courts can be illustrated by the memoires of the ICTY prosecutor, Carla Del Ponte. Remembering her pleadings in the Brayagwiza case, when she was trying to convince the Appeals Chamber to review its own earlier

possession. Thus, the motion must be dismissed. The Prosecution's disclosure obligations under the Statute and the Rules do not extend to pursuing every possible avenue of investigations into a witness's credibility on behalf of the Defence. ICTR, Prosecutor v. Simba, Decision on Defence Motion to Obtain Judicial Records Pursuant to Rule 68, ICTR-01-76-T, T. Ch., 4 October 2004, par. 8.

46 FAIRLIE, 2004, p. 314.

47 FAIRLIE, 2004, p. 315.

48 ICTR, Barayagwiza v. Prosecutor, Separate Opinion of Judge Shahabuddeen, Decision, ICTR-9719-AR72, A. Ch., 31 March 2000, par. 68, referring in footnote 71 to "R. v. Banks [1916] at 623, per Avory J.." See also ICTR, Prosecutor v. Mpambara, Decision (Defence Motion for Release of the Accused), ICTR-2001-65-1, 22 October 2002, par. 7: "The Trial Chamber notes that Article 15(2) of the Statute provides that the Prosecutor shall act independently as a separate organ of the Tribunal Even though the Prosecution, in this Tribunal, appears to function differently from the prosecuting bodies in the Civil Law inquisitorial systems, that is not sufficient to call into question the Tribunal's independence or impartiality; except if it were to be considered, as the Defence seems to do, that the prosecuting bodies of the Common Law accusatorial systems from which the Statute partly draws inspiration in this regard, fail as such to ensure the independence and impartiality of prosecutions in these systems. Such an argument is unfounded.

$49 C f$. VAsiliev, 2010, p. 15: “ ... the fundamental nature of the prosecutorial function is not to be conflated with the operational modality: the resolute pursuit of justice in an individual case does not per se negate, and can rather be a manifestation of, the prosecutor's impartiality.” Also p. 21: “ ... the trial role of international Prosecutor can be defined by a somewhat oxymoronic term of "impartial advocate' [footnote omitted]". 
decision to dismiss the case against Barayagwiza whose rights had been violated, 'with prejudice'; the prosecutor remarked that: "In hindsight, these words might have gone over the line. I allowed my zeal on behalf of the victims to carry my rhetoric beyond the bounds required by the presumption of innocence and respect for the tribunal's own independence." ${ }^{50}$ The Appeals Chamber did not leave the prosecutor's overzealousness unnoticed and considered that:

The Chamber notes also that, during the hearing on her Motion for Review, the Prosecutor based her arguments on the alleged guilt of the Appellant, and stated she was prepared to demonstrate this before the Chamber. The forcefulness with which she expressed her position compels us to reaffirm that it is for the Trial Chamber to adjudicate on the guilt of an accused, in accordance with the fundamental principle of the presumption of innocence, as incorporated in Article 3 of the Statute of the Tribunal. ${ }^{51}$

At the ICC, an incident in the Lubanga case illustrates the need for the prosecution to consciously be aware of its quasi-judicial role and at least see to the appearance thereof. The incident involved an interview published online, ${ }^{52}$ in which a representative of the OTP made inappropriate comments with regard to 'life' issues that await the Chamber's determination and also made suggestions about both the prosecution and the defence's disclosure practice that are both incorrect and misleading..$^{53}$ This

50 Del Ponte and Sudetic, 2009, p. 82. She pleaded: "I am the only person here to represent the victims, and on their behalf I pray you to allow the prosecutor to institute proceedings against Barayagwiza, who has committed crimes against humanity, who has committed genocide, and his indictment has been confirmed. He is no longer a suspect. He is an accused. This accused is responsible for the death of over 800,000 people in Rwanda, and the evidence is there. Irrefutable, incontrovertible, he is guilty. ... In the name of justice, genuine justice, for the sake of victims, for the sake of the survivors. There are victims who are still suffering for what happened in Rwanda. I will always continue to say that Barayagwiza is guilty."

51 ICTR, Barayagwiza v. Prosecutor Decision (Prosecutor's Request for Review or Reconsideration), ICTR-97-19-AR72, A. Ch., 31 March 2000, par. 35. Judge Shahabuddeen, in his separate opinion, adds to this that: "The prosecution takes the position that it would not prosecute without itself believing in guilt. The point of importance is that an assertion by the prosecution of its belief in guilt is not relevant to the proof. Judicial traditions vary and the tribunal must seek to benefit from all of them. Taking due account to that circumstance, I nevertheless consider that the system of the Statute under which the Tribunal is functioning will support a distinction between an affirmation of guilt and an affirmation of preparedness to prove guilt. In this case, I would interpret what was said as intended to convey the latter meaning, by the strength with which the statements were made comes so close to the former that I consider it right to say that the framework of the Statute is sufficiently stable not to be upset by the spirit of the injunction referred to concerning the role of a prosecutor."

52 www.lubangatrial.org, 15 March 2010, available at: http://www.lubangatrial.org/2010/03/15/ interview-icc-prosecutors-will-refute-allegations-that-intermediaries-manipulated-evidence-inlubanga-case/ (last accessed on 28 December 2011).

53 ICC, Prosecutor v. Lubanga Dyilo, Decision on the Press Interview with Ms Le Fraper du Hellen, ICC-01/04-01/06, T. Ch. I, 12 May 2010 [Lubanga Press Interview Decision]. 
interview took place after the defence had alleged that some intermediaries used by the prosecution in his contact with witnesses had behaved inappropriately. The Chamber reasoned that the OPT representative "seriously intruded on the role of the Chamber in her unequivocally expressed conclusions" about issues that still needed to be decided by the Chamber. ${ }^{54}$ The Chamber considered that the fact that the Lubanga trial had been conducted for a considerable part behind closed doors, for security reasons, "has increased the need for responsible and balanced comments and reporting of the case, an obligation which extends to all those involved in the trial." ${ }_{55}$ Essentially, it is a matter of professional ethics that a party to the proceedings must not misrepresent the evidence or make unfounded accusations about misconduct on the part of another party. The Chamber came to the harsh conclusion that the representative's remarks during her interview prejudiced the public understanding of the trial, "which tends to bring the Court into disrepute." ${ }^{56}$ Moreover, the Chamber took offence at the representative's statement about the intimidating manoeuvres of the accused during a child soldier's testimony in court. This seriously misleading statement, which creates the impression of witness intimidation before the eyes of the trial judges, could critically damage the legitimacy of the ICC and its ability to function, in light of the ongoing investigations in the Democratic Republic of the Congo (DRC)..$^{57}$

The relationship between the parties to the proceedings and the media is not expressly regulated in the legal framework of the ICC. ${ }^{58}$ Whether the power of the Trial Chamber to control the proceedings and see to their fairness extends to cover these kinds of external public statements from the parties is debatable. ${ }^{59}$ However, in light of the prosecutor's quasi-judicial character and his role as an impartial truthseeker envisioned by the ICC Statute, it can be argued that it is perfectly reasonable

54 Lubanga Press Interview Decision, par. 49. The representative stated e.g. that the defence argument is "just talk"; that the Chamber will reject the defence submissions on Prosecutor's abuse of process in relation to intermediaries ("nothing is going to happen"); that the accused will be convicted, and this will be followed by a long sentence ("Mr Lubanga is going away for a long time").

55 Lubanga Press Interview Decision, par. 38.

56 Lubanga Press Interview Decision, paras. 39, 41.

57 Lubanga Press Interview Decision, par. 51.

$58 C f$. Presumption of innocence and statements to media from the prosecutor: see ECtHR, Khuzhin and others v. Russia, 13470/02, Judgment of 23 October 2008, par. 96: “ ... the Court considers that those statements by the public officials amounted to a declaration of the applicants' guilt and prejudged the assessment of the facts by the competent judicial authority. Given that those officials held high positions in the town and regional prosecuting authorities, they should have exercised particular caution in their choice of words for describing pending criminal proceedings against the applicants. However, having regard to the contents of their statements as outlined above, the Court finds that some of their statements could not but have encouraged the public to believe the applicants guilty before they have been proved guilty according to law. Accordingly, the Court finds that there was a breach of the applicants' presumption of innocence."

59 See e.g. William A. Schabas blog, 14 July 2010: http://humanrightsdoctorate.blogspot.com/2010/07/ more-on-intermediaries-from-lubanga.html (last accessed on 28 May 2012). 
to expect the prosecutor to express him or herself in a nuanced way, so as to appear to assist the court "to arrive at the truth and to do justice for the international community, victims and the accused." $" 60$

In fact, the SCSL Code of Professional Conduct for prosecution and defence counsel mentions the impartiality standards for prosecution counsel both in appearance (by respecting the presumption of innocence of all suspects and accused and, thus, by refraining from expressing publicly and outside the framework of proceedings any opinion on the guilt of the accused) and in substance (by assessing the material according to all relevant, inculpatory or exculpatory, circumstances) ${ }^{61}$ With regard to the scope of investigations, the SCSL Code of Conduct provides that the prosecution "shall conduct investigations and analyses with the central aim of providing the factual and evidentiary basis for an accurate assessment of criminal responsibility" and "conduct fair and firm prosecutions of crimes within the jurisdiction of the Special Court, when well-founded upon evidence reasonably believed to be reliable and admissible." ${ }^{\prime 2}$

60 ICTY and ICTR Prosecutor's Regulation No. 2 articulating Standards of Professional Conduct for Prosecution Counsel, signed by Louise Arbour, 14 September 1999, New York, available at: http://www.icty.org/x/file/Legal\%20Library/Miscellaneous/otp_regulation_990914.pdf or http:// www.unictr.org/Portals/0/English/Legal/Prosecutor/reg_05.pdf (last accessed on 28 May 2012). Par. 1: The duties and responsibilities of the Prosecutor differ from, and are broader than, those of defence counsel ... Par. 2 (h): to assist the Tribunal to arrive at the truth and to do justice for the international community, victims and the accused.

The ICC Prosecutor has also been criticized for making exaggerated statements on the Darfur Situation and to some extent misrepresenting the Court's decision on the arrest warrant of Al Bashir (William A. Schabas writes on this in his blog, 16 July 2010: http://humanrightsdoctorate. blogspot.com/2010/07/inappropriate-comments-from-prosecutor.html (last accessed on 28 May 2012). Also: ICC, Situation in Darfur, Sudan, in the Case of Prosecutor v. Omar Hassan Ahmad Al Bashir, Notification of Public Statement by the Prosecutor, ICC-02/05-01/09, 30 July 2010. In the most recent situation in Libya: "The International Criminal Court prosecutor has said he is "one hundred per cent" certain that his investigation will lead to charges of crimes against humanity against Muammar Gaddafi and members of his regime. ... While stating that he remains impartial throughout the investigation, he added that 'Gadhafi's personality helped unite the world against him'." http://www.haguejusticeportal.net/smartsite.html?id=12503\&utm_source=Hague+Justice+Portal\& utm_campaign=79490a60f6-Latest+news+feed\&utm_medium=email (last accessed on 28 May 2012).

61 Code of Professional Conduct for Counsel with the Right of Audience before the Special Court for Sierra Leone, adopted on 14 May 2005, amended on 13 May 2006, available at http:/www.sc-sl.org /LinkClick.aspx?fileticket=IbTonPmXLHk\%3d\&tabid=176 (last accessed on 28 May 2012), Article 24: “(A) Prosecution Counsel shall respect the presumption of innocence of all suspects and accused, and in particular, shall refrain from expressing a public opinion on the guilt or innocence of a suspect or an accused in public or outside the context of proceedings. (B) Prosecution Counsel shall assess the materiality of facts and the probative value of evidence according to all relevant circumstances and irrespective of whether they are to the advantage or disadvantage of the suspect or accused."

62 Article 23 of the Code of Professional Conduct for Counsel with the Right of Audience before the Special Court for Sierra Leone, adopted on 14 May 2005, amended on 13 May 2006, available at http://www. sc-sl.org/LinkClick.aspx?fileticket=IbTonPmXLHk\%3d\&tabid=176 (last accessed on 28 May 2012). 
At the ECCC, the only internationalized criminal court that is rooted in the civil law tradition, the prosecutor has a closer link to the magistrate, familiar to other inquisitorial systems. ${ }^{63}$ The Office of the Co-Prosecutors is an independent office within the ECCC and the prosecutors must execute their mandate independently from any political or other sources within the confines of the material, temporal and personal jurisdiction of the Court. ${ }^{64}$ Being a 'judge before a judge', and in light of the ECCC's 'one-case' approach to the presentation of evidence, it seems more natural for the ECCC prosecutor to assume a more 'quasi-judicial' role when investigating and prosecuting a case as compared to the ad hoc tribunals. However, the ECCC's Internal Rules instruct that the proceedings "shall be fair and adversarial and preserve a balance between the rights of the parties [and] shall guarantee separation between those authorities responsible for prosecuting and those responsible for adjudication." 65 In light of the necessary adversarial nature of the proceedings and the fact that the coinvestigating judges and not the co-prosecutors are endowed with the investigating and charging function, the prosecutor's role could, however, be inclined towards a more adversarial 'minister of justice'.

\subsubsection{Prosecutorial function within the institutional design}

While there is a general agreement about the 'quasi-judicial' role of a public prosecutor, the vagueness of that terminology does not help to delineate "the precise role that prosecutors should play in the criminal process." ${ }_{66}$ Jackson proposes four sets of ethical duties for prosecutors deriving them "from the professional obligation of prosecutors to carry out their responsibility on behalf of the community to call offenders to account for the harm that has been inflicted on the community's interests and values." ${ }^{\prime 67}$ First, prosecutors must "be able to make independent evaluation of the evidence against the defendant." ${ }^{68}$ The second set "concerns the decisions that are

63 The Cambodian co-prosecutor is chosen from Cambodianjudges (while the international co-prosecutor is recommended by the UN), and both co-prosecutors are appointed by the Cambodian Supreme Council of Magistracy, that also appoints judges to the ECCC. See Article 6(5) of the Agreement between the United Nations and the Royal Government of Cambodia Concerning the Prosecution under Cambodian Law of Crimes Committed during the Period of Democratic Kampuchea, 6 June 2003, available at http://www.unhcr.org/refworld/country,,UN,,KHM,,4ba8e2ea9dc,0.html (last accessed on 28 May 2012), further: ECCC Agreement; and Article 18 (new) of the Law on the Establishment of the Extraordinary Chambers in the Courts of Cambodia for the Prosecution of Crimes Committed During the Period of Democratic Kampuchea, as amended on 27 October 2004 (NS/RKM/1004/006), available at http:/www.eccc.gov.kh/sites/default/files/legal-documents/KR Law_as_amended_27_Oct_2004_Eng.pdf (last accessed on 28 May 2012), further: ECCC Law.

64 Rule 13(1) ECCC Internal Rules, Article 6(3) ECCC Agreement, Article 19(2) ECCC Law.

65 Rule 21(1)(a) ECCC Rules (used version of revision on 3 August 2011 (Rev. 8).

66 JACKSON, 2006-a, pp. 38, 47.

67 JACKSON, 2006-a, p. 51.

68 JACKSON, 2006-a, p. 51. 
made in relation to whether it is in the public interest to prosecute." ${ }^{69}$ The third set relates to "prosecutorial treatment of victims in the case." "Fo Fourth is the prosecutor's interaction with the defence. ${ }^{71}$ The extent to which a prosecutor can, in fact, fulfil these ethical duties very much depends on the concrete design of the prosecutor's function within a particular criminal justice system.

A prosecutor's concrete function varies widely per jurisdiction, from rubberstamping the police investigations and prosecution to a much deeper involvement in directing and supervising police investigations. ${ }^{72}$ Obviously, the prevailing prosecutorial ethos and the concrete function of a prosecutor are intertwining and mutually reinforcing factors $;{ }^{73}$ however, there can also be some tension when the ethical/moral expectations are undermined or even negated by the practical possibilities within an institutional design. As mentioned, for example, a party-driven process is not very open to a possibility of an 'inquisitorial' prosecutor whose duty is not only to collect but also to present exculpatory evidence at trial. In that setting, one would not expect a trial to continue, while the authority subject to the responsibility to present an inculpatory case opts for the acquittal of the accused. ${ }^{74}$

\subsubsection{Structural parameters}

Drawing upon the ideal-types presented by Damaška, ${ }^{75}$ Jackson identifies four idealtypes of prosecutorial fact-finding organized upon the different structures of authority and upon different values instilled in prosecutors. ${ }^{76}$ The structures of authority described by Damaška can take the form of a coordinate or a hierarchical ideal, the first referring to horizontally structured, relatively independent decision-making organs that assume the responsibility of a particular function, while the hierarchical ideal represents a professional corps of officials vertically organized where the decision-making is reviewed by higher echelons. The prosecutor in a hierarchically organized system will control all relevant decision making related to the investigation and prosecution of a case, while the different tasks and the decision will be exercised by different independent authorities within a coordinate structure. Although stylizing and exaggerating certain features, the coordinate ideal authority is associated with the Anglo-American legal culture, while Romano-Germanic systems are assumed

69 JACKSON, 2006-a, p. 52.

70 JACKSON, 2006-a, p. 53.

71 JACKSON, 2006-a, p. 54.

72 JACKSON, 2004, p. 131.

73 Boyne, 2010, pp. 1291, 1300: “ ... a prosecutor's ability to function in an objective manner is driven not only by the individual's mindset, but perhaps more importantly by organisational norms, practices, recourses, and institutional relationships."

74 See the example of the Wilders case in the Netherlands.

75 DAMAŠKA, 1986. See Chapter 3.

76 JACKSON, 2004, p. 116. 
to adhere more to the hierarchical ideal. As an ethos instilled in prosecutors Jackson identifies the investigative and the adjudicative extremes. The first is primarily truthoriented and "calls for a crusading zeal in ferreting out evidence so that they [the prosecutors] are in a position to form a judgment about the guilt of the accused." 77 By contrast, the adjudicative approach does not necessitate the prosecutor to form a belief about the evidence as to the guilt of the accused, but to judge whether there is enough evidence to prosecute. ${ }^{78}$

Several cognitive errors and biases arise with certain prosecutorial fact-finding arrangements. Separating the functions of investigation and prosecution in order to ensure the independence of the prosecutor can lead to an artificial division with 'skewed and partisan police investigations' and too little oversight leading to miscarriages of justice. ${ }^{79}$ Moreover, the prosecutor's ability to present a strong indictment and case before a judge may be impaired when the prosecutor has not been able to gain the best knowledge and understanding of the evidence due to a lack of evidence-gathering oversight. ${ }^{80}$ However, when prosecutors have a greater role to play in investigations, their independence and impartiality can be compromised. ${ }^{81}$ The incompatibility of three different roles, namely prosecution, defence and judge, all injected into one investigating judge, is one of the reasons why this magistrate was abandoned in Germany and Italy. ${ }^{82}$

Of course, one has to keep in mind that, notwithstanding the theoretical dichotomy between the ideals of the criminal justice system, there are the realities of pragmatic decision-making, like the administrative demands and informal social relationships that control prosecutorial decision-making. ${ }^{83}$ In practice, the role some continental

77 JACKSON, 2004, p. 117.

78 JACKSON, 2004, p. 117. A matrix of four operating arrangements surfaces: (1) coordinate-investigative, (2) coordinate - adjudicative, (3) hierarchical - investigative, and (4) hierarchical - adjudicative.

79 JACKSON, 2004, p. 118. For this reason, the Public Prosecution in England and Wales was endowed with the power to discontinue a prosecution initiated by the police.

80 JACKSON, 2006-a, p. 39.

81 JACKSON, 2004, p. 126: "When prosecutors become 'masters of the instance', however, and take a leading role in investigation, there is a countervailing danger that they will become so corrupted by the exigencies of the investigation that they will lose the detachments necessary for carrying out the quasi-judicial function of assessing the strength of the prosecution evidence", also p. 127: "Leaving aside any motivational bias that may exist when a prosecutor has become involved in investigations, there is also the cognitive errors that arise when we look for confirming, rather then disconfirming, evidence." See also ABA Criminal Justice Standards, Standards on Prosecutorial Investigations, February 2008, Standards 1.2 (e): Generally, the prosecutor engaged in an investigation should not be the sole decision-maker regarding the decision to prosecute matters arising out of that investigation.

82 SPENCER, 2002, p. 11. In the Netherlands, the role of the investigating judge has been marginalized since the 1980s in light of the powers of the prosecutor. VAN DER MeIJ, 2010, p. 332; De Doelder, 2000. Conversely, the role of the investigating Judge is recently being reassessed in the Netherlands and proposals have been made to strengthen his/her role. See VAN DER MeI, 2010, p. 332.

83 JACKSON, 2004, p. 120, including references in footnotes 64 and 65. Also BoYNE, 2010, pp. 1291, 1306: 
prosecutors play in investigations by the police is rather passive; it is a "kind of (necessarily retrospective) bureaucratic review of the investigation carried out by the police with considerable reliance placed on written evidence and authenticity of form." ${ }^{84}$ In most cases, the inquisitorial prosecutors work with complete files sent to them by the police, thus "their activity is primarily adjudicative rather then investigative - ensuring procedural safeguards have been complied with and ensuring the integrity of the dossier which justifies the decision to prosecute." ${ }_{85}$ Next to the institutional position and the professional ideology, the practical side of the available resources is determinative for the degree of prosecutorial investigative involvement. ${ }^{86}$

On the international level, the ICTY/ICTR, SCSL and the ICC all have an Office for the Prosecution (OTP), a separate and independent organ of the organisation. These offices are made up of lawyers, forensic experts and investigators, who are in charge of investigating and prosecuting activities. Although the investigatory and prosecutorial activities are vested in one and the same organ (there is no independently functioning police force as in the national context), the de facto separation of these activities has been problematic for a proper preparation and presentation of a case. The OTP within the ad hoc tribunals was split into two sections, the Investigation Section with the exclusive responsibility for collecting evidence and based in the crime-site jurisdiction, and the Prosecution Section exclusively responsible for prosecuting all cases and based in The Hague. ${ }^{87}$ This 'Australian' model of criminal investigation and prosecution initially installed at the OTP proved inadequate for complex crimes with high-ranking perpetrators due to a lack of effective oversight concerning the investigative process: "[ $\mathrm{t}]$ he prosecuting attorney has to suffer the results of the investigator's work." "factual minutiae of the specific cases" and "often had to struggle to adjust their arguments to fit evidence collected under misdirected theories they had no hand in fashioning." ${ }^{89}$ Due to its independence, the investigative section "largely drove the

"Despite the fact that prosecutors possess more decision-making discretion than ever before, their decisions are still not completely autonomous because prosecutors remain embedded in institutions with norms, expectations, and resource constraints" [footnote omitted]; and "The most important factor shaping prosecutors' daily choices is not a set of written guidelines, but rather the informal traditions of practice communicated from colleague to colleague." [footnote omitted].

84 Hodgson, 2001, p. 350.

85 JACKSON, 2004, p. 122.

86 Of course perceptions on factors such as the gravity of the crime or publicity should not be neglected. In relation to the Chief Prosecutor's role regarding diplomatic and public relations, David Crane, the former and first Chief Prosecutor of SCSL, eloquently stated: "That's just a reality of being a chief Prosecutor, to keep the world's interest, to keep money coming in, and to ensure you have political buy-in ... you've got to be on the road talking to people or you'll lose the political support and interest that is so crucial in a tribunal." Cited in: VAN TUYL, 2008, p. 7.

87 Due to the tribunal's completion strategy, these two divisions were unified in 2008.

88 Del Ponte and Sudetic, 2009, p. 126.

89 Del Ponte and Sudetic, 2009, pp. 126-127. 
work of the entire office"; thus, "[i]n essence, the investigators held all of the power over the investigations but no accountability for the results, and the prosecuting attorneys who had to try the cases had no power over investigations but all the accountability." ${ }^{90}$

Carla Del Ponte, a prosecutor trained in civil law, had to shift the power from investigators to the prosecuting attorneys, a shift that encountered some resistance from the investigators who were used to the strict separation between investigative and prosecutorial tasks. ${ }^{91}$ In addition, the investigation section was detrimentally affected by the lack of proper skills and experience of the investigators for performing the tasks necessary to collect evidence on high-ranking individuals. ${ }^{92}$ Many of the initially compiled investigative files "suffered from weak linkage evidence" connecting the crime-based evidence to the political or military superiors. ${ }^{93}$ Eventually, the supervision of investigations was placed on the shoulders of senior trial attorneys and out of the hands of senior investigative staff. ${ }^{94}$ However, overseeing complex investigations and being able to sort the necessary raw information and consequently to "distil a prosecutable case" proved problematic too, due to insufficient skills and experience and the lack of background knowledge of the OTP's personnel. ${ }^{95}$ Lack of experience and expertise in international criminal law was also a problem within the OTP at the SCSL. ${ }^{96}$ However, this lack of experience and expertise was partly attributable to the first prosecutor's hiring practice, when " $[\mathrm{t}]$ he founding Prosecutor deliberately eschewed hiring individuals with professional experience in the other tribunals, because he feared personnel recruitment from those institutions would replicate inefficiency [and high cost] at the SCSL." ${ }^{97}$

Mindful of these difficulties encountered at the ad hoc tribunals, "the ICC inquiries and investigations have focused heavily on questions of linkage." ${ }^{98}$ Investigations

90 Del Ponte and Sudetic, 2009, pp. 126-127.

91 Del Ponte and Sudetic, 2009, p. 127. Observing this structure at the ICTY, however, prompted the founding SCSL Chief Prosecutor and Chief of Investigations to take a different approach in the name of efficiency. See VAN TuYL, 2008, p. 12.

92 VAN TUYL, 2008, p. 12. Investigators with "street experience" were preferred, but they lacked the necessary skills and 'sensitivity' to conduct witness interviews with "sensitive-source witnesses."

93 Bergsmo and Wiley, 2008, p. 11.

94 Bergsmo and Wiley, 2008, p. 11. Del Ponte and Sudetic, 2009, p. 131: “ ... I gave the senior trial attorneys supervisory authority over all investigations, making one senior trial attorney responsible for investigating and constructing each new case."

95 Del Ponte and Sudetic, 2009, p. 129.

96 CASSESE, 2006, par. 56.

97 VAN TUYL, 2008, p. 40.

98 Bergsmo And Wiley, 2008, p. 11: "Cognizant of the early investigative shortcomings at the ICTY and the ICTR, the ICC inquiries and investigations have focused heavily on questions of linkage. From the start of any given ICC inquiry, attention is given to the allegations of criminal misconduct made against groups and individuals in open-source reports by IGOs, NGOs, governments and others. Specific allegations against individuals are initially observed in passing." 
proceed in joint teams consisting of staff from the three OTP Divisions, ${ }^{99}$ "to ensure a coordinated approach throughout the investigation." 100 Strategic guidance and coordination of the OTP activities are invested in the Executive Committee, consisting of the prosecutor and the heads of the three divisions, thus introducing a hierarchical element into the largely coordinate structure.

\subsubsection{Prosecutorial discretion}

With regard to prosecutorial discretion to initiate a case, national systems have differences in their approaches that do not always fit neatly into the civil law/common law divide. Generally, common law prosecutors assume wide discretion in initiating a case without any substantial judicial oversight. ${ }^{101}$ While keeping some 'margin of appreciation' in the charging process, some Continental systems traditionally adopt a stricter principle of legality, which leads to mandatory prosecution, inspired by the desire to ensure an uniform and non-arbitrary application of the law. ${ }^{102}$ However, various exceptions to this principle of mandatory prosecution have been recognised, acknowledging, for example, the Opportunitätsprinzip (or 'expediency' principle) for lesser offences or where a trial would not serve the public interest. ${ }^{103}$ In other jurisdictions this principle of 'opportunity' provides the public prosecutor with broad discretion to initiate a prosecution, subject to some exceptions. ${ }^{104}$

On the international level, the mandate to bring to justice those most responsible for international crimes gives international prosecutors a broad discretionary power to choose whom to prosecute, while assuming total prosecutorial independence from political interference with only very limited judicial oversight. ${ }^{105}$ In the words of the former ICTY/R prosecutor Louise Arbour:

99 The ICC OTP consists of, next to the Executive Committee, three Divisions and two Support Sections: the Jurisdiction, Complementarity and Cooperation Division, the Investigation Division, the Prosecution Division, the Services Section and the Legal Advisory Section. ICC OTP Regulations 4 and 5.

100 ICC OTP Regulation 32.

101 Harsh criticism of the American Prosecutor is uttered by DAVIS, 2007. For more references to prosecutorial misconduct in the US see LUNA AND WADE, 2010, p. 1414, footnote 1.

102 For example, following $§ 152$ II German Code of Criminal Procedure (Strafprozessordnung, StPO) the Prosecutor is required to prosecute in all cases in which there is sufficient evidence to believe that a crime has been committed. LANGBEIN, 1974, p. 450: "The dual function of the rule mirrors the dual character of the German prosecutor's office: he is obliged to perform an executive function according to judicial standards of conduct." Next to Germany, the legality principle also dominates in Austria, Finland, Italy, Poland, Portugal, Spain and Switzerland.

103 E.g. $\S 153$ StPO, German prosecutors have greater discretion in handling minor cases. WeIGEND, 2008, pp. 39-64. Also in Austria, Finland, Brazil, Chile and Costa Rica, see AmBos, 2000, p. 100.

104 See e.g. Articles 167 and 242 Dutch Code of Criminal Procedure; Article 40 of the French Code of Criminal Procedure. Amвos, 2000, pp. 99-100 (referring to exceptions to prosecutorial discretion).

105 Cf. ICTR, Prosecutor v. Bagosora et al., Decision on Ntabakuze Petition for a Writ of Mandamus 
Parties’ Role During Investigations

\begin{abstract}
The main distinction between domestic enforcement of criminal law, and the international context, rests upon the broad discretionary power granted to the international Prosecutor in selecting the targets for prosecution. Domestically, the general assumption is that enforcement is universal, i.e. that all crimes beyond the de minimis range will be prosecuted, subject to the determination by the Prosecutor that a charge is appropriate based on a preliminary examination of the facts of the case. In the international context, $(\ldots)$, the discretion to prosecute is considerably larger, and the criteria upon which such prosecutorial discretion is to be exercised are ill-defined and complex. In my experience, based on the work of the two tribunals to date, I believe that the real challenge posed to a Prosecutor is to choose from many meritorious complaints the appropriate ones for international intervention, rather than to weed out weak or frivolous ones. ${ }^{106}$
\end{abstract}

As compared to the ad hoc tribunals, with their limited jurisdictions (temporal as well as to their loci delicti), this challenge is arguably exaggerated in the context of the ICC. When referring to prosecutorial discretion, vague (legal) concepts such as the gravity of crimes, senior leaders, the highest responsibility and the interest of justice have to be applied in practice. Arguably, the exercise of discretion is determined, to a large extent, by "the exercise of common sense and good judgment by responsible professionals." 107 In the political world in which these courts have to operate, the exercise of prosecutorial discretion has led "to a barrage of commentary, second-guessing and [critical] evaluation." 108 This chapter refrains from an in-depth analysis of the exercise of prosecutorial discretion as others have adequately done so. ${ }^{109}$ Suffice it to say that in the context of the ICC, prosecutorial independence "meets undoubtable limitations" and is subject to more extensive judicial control as compared to other international criminal tribunals. ${ }^{110}$

and Related Defence Requests, ICTR-98-41-T, T. Ch., 18 April 2007: the defence requested the Trial Chamber to order the OTP to complete its investigations and to initiate proceedings against RPF leaders. The Trial Chamber rejected this request because the Statute provides that the Prosecutor has independence and unfettered discretion to decide which investigations and prosecutions to pursue (par. 6). Moreover, the Chamber found that it had no jurisdiction to direct the Prosecutor's course of action in conducting investigations or prosecutions (par. 8) or to inquire into the reasons for prosecuting certain individuals and not others (par. 10).

106 Justice Arbour, 1999, p. 213.

107 Schabas, 2008, p. 749.

108 Goldston, 2010, p. 384.

109 See e.g. Stahn, 2009, pp. 239-71; Schabas, 2008; Goldstone, 2008; GreEnawalt, 2007; Côté, 2006; Gallavin, 2006; Jallow, 2005; WebB, 2005; Ntanda Nsereko, 2005; Côté, 2005; Brubacher, 2004; DANNER, 2003.

110 Turone, 2002, p. 1139. 


\subsubsection{Judicial control}

One of the important themes contributing to substantial changes in the international criminal procedural setting has been the development of judicial activity. Langer argues that international criminal courts incorporated a different philosophy of managerial judging into their process. ${ }^{111}$ In fact, better control of the pre-trial process by the judges has been deemed essential to expedite international criminal proceedings. ${ }^{112} \mathrm{At}$ the ICTY the figure of the Pre-Trial Judge plays a central role in preparing the cases for a smooth trial conduct by establishing a work plan, coordinating communication between the parties, recording the points of agreement and disagreement between them and ordering the parties to outline their case in a pre-trial brief. ${ }^{113}$ On the basis of the file submitted by the Pre-Trial Judge, the Trial Chamber may limit both prosecution and defence cases, both temporally and in relation to subject-matter. ${ }^{114}$ The prosecutor has been the primary recipient of the case management efforts of the judges, and has seen his discretionary powers in relation to case presentation shrinking. ${ }^{115}$ This shift is understandable due to the fact that all international criminal tribunals (with the exception of the ECCC) have opted for a two-case approach to case presentation, and in light of the principle of equality of arms, limiting the case of the prosecution almost automatically limits the responsive case of the defence. ${ }^{116}$

111 See LANGER, 2005. In contrast with an 'inquisitorial' ideal judge (or investigative judge) a managerial judge is not invested with an active duty to search for truth.

112 ICTY Manual, 2009, p. 53, par. 1: "Because of the scale and inherent complexity of war crimes trials, active pre-trial management is needed. The pre-trial stage provides an important opportunity to ensure that the trial is conducted in the most fair and expeditious manner while bringing the Prosecution and Defence together to resolve issues that can be disposed of before the trial begins."

113 Rules 65ter ICTY RPE.

114 Rules 73bis and 73ter ICTY RPE (including the power to direct the Prosecutor to select the counts on which to proceed), Rules 73bis and 73ter ICTR and SCSL RPE. See ICTY MANUAL, p. 53, par. 2: "The Objective of the pre-trail stage should be twofold: to dispose of as many issues as possible in order to conserve valuable court time; and to provide a solid platform for the parties and the court to determine how much time is required to present evidence on the matters in dispute."

115 See Chapter 7 of this study.

116 Assessment and Report of Judge Fausto Pocar, President of the International Criminal Tribunal for the Former Yugoslavia, Provided to the Security Council Pursuant to Paragraph 6 of Council Resolution 1534 (2004), Annex I to the Letter dated 29 May 2006 from the President of the International Tribunal for the Prosecution of Persons Responsible for Serious Violations of International Humanitarian Law Committed in the Territory of the Former Yugoslavia since 1991, addressed to the President of the Security Council, S/2006/353, 31 May 2006, par. 28: "The International Tribunal has long been aware that the length of its trials also depends on the complexity and breadth of the indictments. The philosophy behind the Prosecution's pleading practices is its obligation to victims. In practice, the length of the Prosecution case has meant that in order to accord the accused due process, Judges have had to allocate a comparable amount of time to the Defence case. The solution for the Judges, therefore, is to limit the length of the Prosecution's case to require the Prosecution to focus at trial on the strongest part of its case. This in turn will lead to a shorter Defence case." 
Before the rise of managerial pre-trial judging, judicial involvement in the pretrial stage was limited to the confirmation of indictments. ${ }^{117}$ The requirement of a judicial review of the indictments presented by the prosecutor has functioned as "a safeguard against prosecutorial abuse." 118 At the ad hoc tribunals, a relatively low test of the prima facie sufficiency of evidence supporting the case ${ }^{119}$ has been applied at the confirmation stage, which does not require the case to be "trial-ready." ${ }^{20}$ Although a more 'rigorous approach' to the confirmation process might have proved beneficial for an improved management of the pre-trial process, this would also mean more judicial 'intrusion' on prosecutorial independence. ${ }^{121}$

The threshold for the confirmation of an indictment is even lower at the SCSL, where the prosecutor does not have to show the sufficiency of evidence, and the Chamber does not examine the accompanying material. Political pressure to produce immediate results might have played a role for judges to assume this difference in approach to the confirmation stage. ${ }^{122}$ However, this 'pushing' through of the indictments had a detrimental effect on the quality of prosecutions. The defence complained about the prosecutorial 'moulding' of evidence to fit the case when the trial was already underway, through witness-proofing sessions and re-interviewing witnesses, which resulted in a 'rolling disclosure' practice of inculpatory evidence. ${ }^{123}$ The practice of re-interviewing witnesses was "so extensive, and goes so in-depth, that it has given prosecutors a back door mechanism to ameliorate earlier investigative weaknesses and compensate for the lack of specificity in the RUF indictment." 124 As noted by Cassese in his expert report on SCSL, "the breadth of the charges and the lack of particulars in the indictments have opened the door to an expansion of the Prosecution's case during the trial." 125 The degree of specificity of the "simple and direct" indictments ${ }^{126}$ was minimal, to say

117 Articles 19 and 18 ICTY and ICTR Statutes respectively.

118 ICTY MANUAL, p. 39, par. 16.

119 Rule 47 ICTY RPE. E.g. ICTY, Prosecutor v. Kupreškić et al, Decision on the Review of Indictment, IT-96-16-I, 10 November 1995, pp. 2-3: "a prima facie case for this purpose is understood to be a credible case which would (if not contradicted by the defence) be a sufficient basis to convict the accused on the charge." And the review has "two separate and distinct components", first "an assessment of whether, from the face of the indictment, it is alleged that the accused committed acts which, if proven beyond a reasonable doubt, are crimes as charged and are within the subject matter jurisdiction of the International Tribunal" and second, "an examination of the accompanying material."

120 ICTY ManUaL, p. 39, par. 18.

121 ICTY Manual, p. 39, par. 18.

122 VAN TUYL, 2008, pp. 7, 42.

123 SCSL, Prosecutor v. Sesay et al., Decision on Defence Motion to Request the Trial Chamber to Rule that the Prosecution Moulding of Evidence is Impermissible, SCSL-04-15-T, T. Ch., 1 August 2006. VAN TUYL, 2008, p. 45. The $R U F$ defence submits that the accused were convicted on 250 additional charges not as such included in the indictments. JORDASH AND MARTIN, 2010, pp. 596-597.

124 VAN TUYL, 2008, p. 45.

125 CASSESE, 2006, par. 72.

126 Crane, 2006, p. 511. According to David Crane, he "did something that had never been done before" 
the least, ${ }^{127}$ and the Trial Chamber's approach to it perplexing. In the $R U F$ case the Trial Chamber considered "the particular context in which the RUF trial unfolded" as a pertinent factor to determine the level of specificity of the indictment. ${ }^{128}$ Particular relevance was attached to "[t]he fact that the investigations and trials were intended to proceed as expeditiously as possible in an immediate post-conflict environment." 129 The Appeals Chamber did not explicitly address this additional policy factor added by the Trial Chamber, but considered the fact that the Trial Chamber was aware of the prosecutor's obligations in drafting an indictment as developed in the case law of the ad hoc tribunals as sufficient indications that no error of law had been made. ${ }^{130}$ This is unfortunate as it seemingly opens the door for the Prosecution to "rely on its own investigative weaknesses" as long as it is covered by the context in which the prosecution is situated. ${ }^{131}$

As mentioned above, the judicial oversight of the ICC prosecutor in relation to the selection of situations and cases is "considerably more robust." 132 When the prosecutor wants to initiate an investigation proprio motu into a situation, he must obtain authorization from the Pre-Trial Chamber. ${ }^{133}$ Moreover, when charging a suspect, the prosecutor must obtain an arrest warrant (or a summons to appear) from the Pre-Trial Chamber and, after arrest, the Pre-Trial Chamber must confirm the charges against the

by making the indictments "simple and direct."

127 JoRdash AND Martin, 2010, p. 590.

128 SCSL, Prosecutor v. Sesay, Kallon, Gbao, Trial Chamber Judgment, SCSL-04-15-T, 2 March 2009, par. 330 .

129 SCSL, Prosecutor v. Sesay, Kallon, Gbao, Trial Chamber Judgment, SCSL-04-15-T, 2 March 2009, par. 330 .

130 SCSL, Prosecutor v. Sesay, Kallon, Gbao, Appeals Chamber Judgment, SCSL-04-15-A, 26 October 2009, par. 60, referring to the following passage from the Trial Chamber Judgment: "Nevertheless, in an indictment, the Prosecution must 'indicate its best understanding of the case against the accused.' The Prosecution may not rely on weakness of its own investigation to justify its failure to plead material facts in an Indictment. Nor may the Prosecution omit aspects of its main allegations in an Indictment "with the aim of moulding the case against the accused in the course of the trial depending on how the evidence unfolds.' An Indictment must provide an accused with sufficient information to understand the nature of the charges against him and to prepare his defence. Therefore, a Chamber must balance practical considerations relating to the nature of the evidence against the need to ensure that an Indictment is sufficiently specific to allow an accused to fully present his defence." (par. 330).

131 Jordash and Martin, 2010, p. 594.

132 Schabas, 2008, p. 734.

133 Article 15 ICC Statute. The 'situations' were already predetermined for the Prosecutors of the ad hoc tribunals. The ICC Pre-Trial Chamber in the Central African Republic situation, for example, has requested " ... the Prosecutor to provide the Chamber and the Government of the Central African Republic, no later than 15 December 2006, with a report containing information on the current status of the preliminary examination of the CAR situation, including an estimate of when the preliminary examination of the CAR situation will be concluded and when a decision pursuant to Article 53(1) of the Statute will be taken." ICC, Situation in the Central African Republic, Decision Requesting Information on the Status of the Preliminary Examination of the Situation in the Central African Republic, ICC-01/05, PTC III, 30 November 2006. 
suspect. ${ }^{134}$ The objective of the confirmation of charges hearing is "to protect the rights of the Defence against wrongful and wholly unfounded charges." 135

A direct confrontation between the judge and the prosecutor concerning prosecutorial discretion arose at the Lubanga confirmation of charges, when the PreTrial Chamber added, when confirming the charges, the context of international armed conflict to the charges, something the prosecutor himself had deleted. The prosecutor filed a leave to appeal arguing that the issue posed a "vital question of the scope of the Chamber's authority under Article 61(7) [and] the scope of the Prosecution's autonomy to determine, according to its own professional assessment, which crimes should be included in its charging instruments and prosecuted at trial." ${ }^{136}$ The Pre-Trial Judge rejected leave to appeal, proposing that both the prosecution and the defence can in any case request the Trial Chamber to reconsider the legal characterization of the facts as confirmed in the charges. ${ }^{137}$

In addition, the ICC judges found it necessary to limit a party's ability to prepare witnesses for trial by disallowing the practice of witness proofing (but allowing for 'witness familiarization'), so commonly used in the common law-based systems and accepted at the ad hoc international tribunals. The ICC judges found that spontaneity from witnesses giving testimony in court would enhance the truth-finding value of proceedings and, that that, thus, outweighs any practical arguments associated with the proofing practice. ${ }^{138}$ This dictum has led to a heated debate on the ICC stance on witness proofing and the value of this practice more generally. ${ }^{139}$

134 Articles 58 and 61 ICC Statute.

135 ICC, Prosecutor v. Lubanga Dyilo, Decision on Confirmation of Charges, ICC-01/04-01/06-803tEN, PTC I, 29 January 2007, par. 37.

136 ICC, Prosecutor v. Lubanga Dyilo, Application for Leave to Appeal Pre-Trial Chamber I's 29 January 2007 'Décision sur la confirmation des charges', ICC-01/04-01/06, PTC I, 5 February 2007, par. 14.

137 ICC, Prosecutor v. Lubanga Dyilo, Application for Leave to Appeal Pre-Trial Chamber I's 29 January 2007 'Décision sur la confirmation des charges,' ICC-01/04-01/06, PTC I, 5 February 2007, par. 44.

138 ICC, Prosecutor v. Lubanga Dyilo, Decision on the Practices of Witness Familiarisation and Witness Proofing, ICC-1/04-01/06-679, PTC I, 8 November 2006; ICC, Prosecutor v. Lubanga Dyilo, Decision Regarding the Practices Used to Prepare and Familiarise Witnesses for Giving Testimony at Trial, ICC-01/04-01/06-1049, T. Ch. I, 30 November 2007, par. 45: "The ICC Statute has, through important advances, created a procedural framework which differs markedly from the ad hoc tribunals, such as, for example, in the requirement in the Statute that the prosecution should investigate exculpatory as well as incriminatory evidence, for which the Statute and Rules of the $a d$ hoc tribunals do not provide. Also, the Statute seemingly permits greater intervention by the Bench, as well as introducing the unique element of victim participation. Therefore, the Statute moves away from the procedural regime of the ad hoc tribunals, introducing additional and novel elements to aid the process of establishing the truth. Thus, the procedure of preparation of witnesses before trial is not easily transferable into the system of law created by the ICC Statute and Rules. Therefore, while acknowledging the importance of considering the practice and jurisprudence at the ad hoc tribunals, the Chamber is not persuaded that the application of ad hoc procedures, in the context of preparation of witnesses for trial, is appropriate." [footnote reference omitted].

139 VASILIEV, 2010, p. 71, footnote 403, for a general overview of the national and international practice of witness proofing see pp. 69-76. 
In light of the 'two-case' approach to the presentation of evidence at the ICC, in which the proof taking is still party-driven, an unprepared approach to witness testimony could result in a "situation in which the parties do not control evidence and the Chamber's claim of 'ownership' still remains an aspiration more than reality" and " $[t]$ his could engender a vacuum of 'ownership' counterproductive to effective truth-finding." 140 However, the contribution of witness 'spontaneity' to truth-finding may very well outweigh the negative effects on the 'disorder' at trial and the length thereof. Indeed, it obliges the judges to take a more active stance on the leading of evidence at trial ${ }^{141}$ and enhances the perception of truth-finding as led by the judges as opposed to a 'perfect picture' presented by the parties.

\subsection{Prosecutor's ABILITY TO PREPARE FOR TRIAL: THE APPROACH TO INVESTIGATIONS}

The ethical and institutional parameters presented above are determinative for the prosecutorial ability to prepare a case for trial. It would be an understatement to contend that international criminal investigations are difficult to conduct. Undoubtedly, the challenges are immense: (post-)conflict situations, the wide geographical area of crimes, mass-victimization, the complexity and breadth of cases are just a few more general factors to be taken into consideration. This section will reflect on the international prosecutor's approach to investigations and more specifically on the challenges that arise from institutional dependence on state cooperation. A practical caveat is that international investigations mostly proceed out of the public eye and a good insight into the operation of an OTP is practically impossible for an outsider to obtain. However, obtaining empirical data on the concrete operation of an OTP in practice, and evaluating the extent to which the OTP adheres to its standard operating procedures extends the scope of this study. What is of interest for this chapter is the extent of the legally pronounced approach to the investigations of the OTP in light of an international prosecutor's role in investigating and prosecuting crimes before international criminal courts. Thus, this section focuses on the extent to which the prosecutor's commitments to his objective 'quasi-judicial' role can be objectified on the basis of legal documents, OTP pronouncements and reports and other documents.

140 VAsiliev, 2010, pp. 74-75. In Lubanga some prosecution witnesses admitted in court that their prior statements were false (the first witness testified again under more extensive protective measures, and repeated the statements he made before his first recantation in court).

141 The trial judges may question the witnesses in a manner which they determine to be appropriate, and order additional evidence when this is deemed necessary for the determination of the truth. See Articles 64(6)(d) and 69(3) ICC Statute. ICC, Prosecutor v. Lubanga Dyilo, Decision on Judicial Questioning, ICC-01/04-01/06-2360, T. Ch. I, 18 March 2010, paras. 33-49. 


\subsubsection{Yugoslavia and Rwanda Tribunals}

The prosecution can commence an investigation ex officio or on the basis of information obtained from any source once it is satisfied that there is a sufficient basis to proceed. ${ }^{142}$ The ICTY website explains that "once the prosecutor is satisfied that there are reasonable grounds to believe that crimes within the jurisdiction of the Tribunal have been committed, an investigation begins." ${ }^{143}$ For that purpose, a multi-disciplined investigation team is created, comprising of investigators, lawyers, military, criminal and political analysts, research officers and interpreters. Due to limited resources, ongoing conflict situations and a lack of cooperation on the part of key states, the ICTY OTP adopted a so-called "pyramidal investigation strategy", meaning a 'bottom-up' approach to investigations starting with crime-based evidence and low-ranking suspected persons. As explained above, the early focus on crimebased evidence had, as a consequence, a missing link to higher echelons of responsible individuals. As a result, the strategy of later years was top-down, with an emphasis on linking the evidence to top leaders.

Except for the prosecutor's Regulation No. $2,{ }^{144}$ no substantive, procedural or policy guidelines are publically available for the conduct of investigations at the ad hoc tribunals. The ICTY Manual on Developed Practices provides some further insight into the investigative practice of the ICTY OTP, but more from the perspective of 'best practice' advice. It states that it "was a Prosecution strategy to obtain all relevant evidence by use of broad-based search and seizure warrants that authorized the Prosecution to take possession of military records and government archives", which was "necessitated by the need to preserve the integrity of evidence." 145 Moreover, in relation to the selection of targets of investigation, the Manual states that a mixed "top-down" and "bottom-up" approach is preferred as leading towards the best results. ${ }^{146}$ Furthermore, it instructs that:

in the early stages of an investigation, prosecutors and investigators should keep an open mind about the responsibility of individuals, and should be prepared to consider conflicting evidence, alter the direction of an investigation, and avoid focusing on simply trying to build a selective case against a particular individual because of early discovery of some evidence that appears to inculpate that individual. ${ }^{147}$

142 Article 18 ICTY Statute, Article 17 ICTR.

$143 \mathrm{http}: / /$ www.icty.org/sid/97.

144 Mentioned in footnote 60 above.

145 ICTY Manual on Developed Practices, 2009 p. 8, par. 7. This practice inevitably led to a massive amount of materials (about 5 million), which in turn resulted in difficulties in archiving these materials in an accessible manner, particularly in relation to the obligation to disclose all the potentially exculpatory evidence to the defence.

146 ICTY MANUAL, 2009, p. 15.

147 ICTY MaNUAL, 2009, p. 15, par. 17. 
Chapter 4

This approach appears to direct towards objectivity in conducting investigations.

\subsubsection{The Special Court for Sierra Leone}

According to Article 15 of the Statute of SCSL, the OPT is a separate and independent organ of the SCSL invested with the responsibility to investigate and prosecute "persons who bear the greatest responsibility for serious violations of international humanitarian law and crimes under Sierra Leonean law committed in the territory of Sierra Leone since 30 November 1996." 148 The prosecutor has the power to "question suspects, victims and witnesses, to collect evidence and to conduct on-site investigations." ${ }^{149}$ Further rules on the conduct of investigations mirror those of the ad hoc tribunals. ${ }^{150}$ Neither the Statute nor the Rules contain a provision on the modes of triggering an investigation (ex officio or on basis of external information) as one can find in Articles 18 and 17 ICTY/ICTR Statute respectively.

As already touched upon above, the SCSL experienced severe challenges in relation to institutional knowledge and development in the early years. In part, the challenges contributed to the first prosecutor's practice not to involve any experience from the former ad hoc tribunal so as to start with "a clean slate." Moreover, both institutional oversight and training have not been prominent in the OTP's investigative work. ${ }^{151}$ As a result, erroneous steps were inevitable.

Rightly referred to as "one of the most disgraceful incidents known in the history of international criminal investigations", ${ }^{152}$ the investigator's abusive approach during the interrogation of the first accused in the RUF case, Issa Sesay, presents a unique and at the same time troubling view into the kitchen of an "opaque" section of SCSL, the OTP. ${ }^{153}$ Van Tuyl, with the War Crimes Studies Center, University of

148 In the $A F R C$ case on appeal, Kanu argued that the requirement of "greatest responsibility" is a jurisdictional requirement. The Appeals Chamber agreed with the prosecution in that: the "only workable interpretation of Article 1(1) is that it guides the Prosecutor in the exercise of his prosecutorial discretion. That discretion must be exercised by the Prosecution in good faith, based on sound professional judgment ... that it would also be unreasonable and unworkable to suggest that the discretion is one that should be exercised by the Trial Chamber or the Appeals Chamber at the end of the trial." In the opinion of the Appeals Chamber "it is inconceivable that after a long and expensive trial the Trial Chamber could conclude that although the commission of serious crimes has been established beyond reasonable doubt against the accused, the indictment ought to be struck out on the ground that it has not been proved that the accused was not one of those who bore the greatest responsibility. Kanu's interpretation of Article 1 of the Statute is a desperate attempt to avoid responsibility for crimes for which he had been found guilty." See SCSL, Prosecutor v. Brima, Kamara and Kanu, Judgment, SCSL-04-16-A, 3 March 2008, paras. 272-274.

149 Article 15(2) Statute of SCSL.

150 Rules 39-40 SCSL RPE.

151 VAN TUYL, 2008, p. 40.

152 VAsiliev, 2010, at p. 65.

153 VAN TuYL, 2008, p. 3. 
California, Berkley, presented an excellent and detailed report of the inquiry into the investigative practices of the SCSL's OTP. ${ }^{154}$ In 2007, the defence challenged the admissibility of transcripts of several prior statements made by the accused on the basis of an uninformed and unwilling waiver of his rights. The SCSL Trial Chamber initiated a voire dire procedure to further investigate the allegations of investigatory misconduct. The incident involved eleven custodial interviews with Issa Sesay in March and April 2003, who was held incommunicado (no contact with his family), was uninformed about his rights (the investigators continuously stressed the fact that he would be an 'insider' witness if he cooperated), did not have access to a lawyer, was unaware of his status as an accused (investigators kept on referring to him as a suspect), and did not understand that there were charges against him. The Trial Chamber held the statements to be inadmissible because they had been involuntarily obtained out of "fear of prejudice and the hope of advantage." 155

The initial investigative results of the OTP were poor in that they presented poor quality witness statements with little to no corroboration. Many witnesses had to be re-interviewed and facts re-investigated by the trial team, sometimes extending way into the trial. ${ }^{156}$ The extent of this re-interviewing gave rise to concerns of procedural abuse and prejudice towards the accused. ${ }^{157}$ Seemingly, the problems of inefficiency surrounding the ad hoc tribunals, that the founders of SCSL were desperate to avoid, duplicated themselves at the SCSL. ${ }^{158}$ Just as at the ad hoc tribunals, the strict division of two hierarchical structures of Prosecution and Investigation Divisions within the OPT, with limited cross-supervision and coordination, had a detrimental effect on the efficiency of investigations and, more importantly, on the fairness of

154 VAN TUYL, 2008. Other Tribunals know of instances of allegations of improper OTP conduct towards witnesses, where the Chamber considered the allegations to be sufficiently substantiated to initiate a more thorough investigation: See ICTY, Prosecutor v. Šešelj, Redacted Version of the Decision in Reconsideration of the Decision of 15 May 2007 on Vojislav Šešelj's Motion for Contempt against Carla Del Ponte, Hildegard Uertzretzlaff and Daniel Saxon, IT-03-67-T, T. Ch., 29 June 2010; ICC, Prosecutor v. Lubanga Dyilo, Redacted Decision on Intermediaries, ICC-01/04-01/06-2434-Red2, 31 May 2010.

155 SCSL, Prosecutor v. Sesay et al., SCSL-2004-15-T, Transcript, T. Ch. I., 22 June 2007; SCSL, Prosecutor v. Sesay et al., Written Reasons - Decision on the Admissibility of Certain Prior Statements of the Accused Given to the Prosecution, SCSL-2004-15-T, T. Ch., 30 June 2008, par. 66. The accused was persuaded to give self-incriminating evidence while he was under the misapprehension that he was a witness and not an accused, thus his right not to be compelled to testify against himself and his rights to silence had been violated (par. 60).

156 VAn TuYL, 2008, p. 44.

157 The problem of "rolling disclosure" will be discussed in Chapter 5.

158 CASSESE, 2006, par. 54: "As relative newcomers to international criminal law practice, they [Judges, the first Prosecutor, Deputy Prosecutor and Registrar] were not in a position to have learned firsthand from the experiences accumulated by the two tribunals or from the failings in which these other tribunals had admittedly entangled themselves." 
the proceedings. ${ }^{159}$ In this context, talking about prosecutorial objectivity and the necessary breadth and depth of the investigations almost seems superfluous.

The Taylor defence team tried to expose the OTP preliminary investigation irregularities by requesting the Trial Chamber to investigate the alleged prosecutorial abuse of process during the investigations. The defence requested the Trial Chamber to investigate (1) the conduct of the OTP (as a legal entity) in relation to (potential) witnesses, and (2) all payments and benefits offered by the OTP to (potential) witnesses. ${ }^{160}$ The Trial Chamber declined to entertain the defence's request for the appointment of an independent investigator (following Rule 77(C)(iii) RPE), finding that (i) "the request was time-barred due to the fact that the Defence had failed to bring the allegations of contempt to the Court's notice within a reasonably time"; (ii) "the Defence request amounting to an audit of the Office of the Prosecutor from its inception, lacked specificity and was outside the ambit of Rule 77." ${ }^{161}$ The Trial Chamber did grant leave to appeal this decision. The Appeals Chamber, without going into the merits, dismissed the appeal in its entirety, finding itself not competent to render a decision on the subject-matter of the appeal. ${ }^{162}$ However, the Appeals

159 Cf. VAN TUYL, 2008, p. 47: “ ... the parallel hierarchies of authority that the founding prosecutor designed to make the OTP more efficient and effective appear to have hindered rather than facilitated attorney supervision of investigative activities. The resulting lack of meaningful oversight has been detrimental to fairness, efficiency, and efficacy alike."

160 SCSL, Prosecutor v. Taylor, Decision on Public with Confidential Annexes A-J and Public Annexes K-O Defence Motion Requesting an Investigation into Contempt of Court by the Office of the Prosecutor and Its Investigators, SCSL-03-01-T, 11 November 2010, par. 1. The Defence submitted "that there are reasons to believe that the Prosecutor, David Crane and all his successors in title, through their own acts of commission or omission and/or through the acts and conduct of their subordinates and/or agents, have violated the Statute, the Rules and the Code of Conduct in that they have: (i) assaulted a suspect and/or potential witness or source; (ii) exerted undue pressure by threatening, intimidating, or harassing suspects, witnesses, potential witnesses or sources; and (iii) offered and/or provided improper, unjustifiable or undue payments, benefits or other incentives, including relocation, to witnesses, potential witnesses or sources, which acts the Defence submits, amount to misconduct, abuse of process and most importantly, contempt of court." Consequently, the Prosecution's acts cast doubt on the credibility of the prosecution's evidence, and in addition negatively affected the fair trial rights of the accused in that this conduct "has generally poisoned the environment and has made it difficult for the Defence to find witnesses who have not compromised themselves with the Prosecution." (par. 4).

161 SCSL, Prosecutor v. Taylor, Decision on Public with Confidential Annexes A-J and Public Annexes K-O Defence Motion Requesting an Investigation into Contempt of Court by the Office of the Prosecutor and Its Investigators, SCSL-03-01-T, 11 November 2010. SCSL, Prosecutor v. Taylor, Decision on Public Defence Notice of Appeal and Submissions Regarding the Decision on the Defence Motion Requesting an Investigation into Contempt of Court by the Office of the Prosecutor and Its Investigators, SCSL-03-01-T, A. Ch., 21 January 2011, par. 7.

162 SCSL, Prosecutor v. Taylor, Decision on Public Defence Notice of Appeal and Submissions Regarding the Decision on the Defence Motion Requesting an Investigation into Contempt of Court by the Office of the Prosecutor and Its Investigators, SCSL-03-01-T, A. Ch., 21 January 2011, par. 43. The Appeals Chamber underscored the fact that interlocutory appeals are exceptional and that Rule 77 only provides for possible appeals following a conviction under that rule. The Trial 
Chamber emphasized that this procedural impediment does not interfere with the rights of the accused, for two reasons. First, the relief sought by the defence was highly speculative (if the defence would be able to show that any person might be in contempt, if the Trial Chamber would thus appoint an independent investigator, if, following that investigator's report, the Trial Chamber would initiate contempt proceedings, if those would lead to the defence's desired outcome, the finding would be made in separate criminal proceedings where the defence would have no legal standing). Second, the defence was able to bring this allegation of prosecutorial misconduct in their own proceedings for the determination of the Trial Chamber. Principally, and in contrast to this second argument, the first one sounds less persuasive from a legal point of view. As noted by the Trial Chamber when deciding to grant leave to appeal the Impugned Decision, the "Defence allegation of contempt of court could have serious implications on the integrity of the Office of the Prosecutor that may ultimately affect the integrity and/or fairness of these proceedings, [and] the Accused might suffer irreparable prejudice that cannot be easily remedied on final appeal." 163 Not the speculative nature of the potential outcome of the contempt proceedings as such, but rather the decision not to entertain the appeal on purely procedural and efficiency reasons does not seem to interfere directly with the rights of the accused.

\subsubsection{The International Criminal Court}

As mentioned, the ICC Statute explicitly imposes on the prosecutor a duty to conduct objective investigations: according to Article 54(1)(a) the prosecutor should equally investigate both inculpatory and exculpatory evidence. Establishing the truth is thus the ultimate goal of the prosecutor's investigative activities; it "provides a matrix against which the prosecutor should mobilise his or her investigative resources." 164 The prosecutor's obligation to search for the truth is meant to ensure that the proceedings do not reflect a competition between two opposing parties where winning would be the only goal. Arguably, the prosecutor should search for all the necessary evidence that could be relevant to determining the truth. On this basis, it would be possible, in principle, for the defence to request the prosecutor to carry out certain investigatory measures. ${ }^{165}$ Such requests, directed at the prosecutor, would be subject to prosecutorial 'courtesy' but might be prompted by the willingness for an

Chamber's discretionary power to initiate (or rather not to initiate) contempt proceedings is subject to the Trial Chamber's administrative/executive responsibilities, rather than judicial, for the purpose of controlling the proceedings and are not subject to an appeal.

163 SCSL, Prosecutor v. Taylor, Decision on Public Defence Notice of Appeal and Submissions Regarding the Decision on the Defence Motion Requesting an Investigation into Contempt of Court by the Office of the Prosecutor and Its Investigators, SCSL-03-01-T, A. Ch., 21 January 2011, par. 8.

164 Bergsmo and Kruger, 2008, p. 1079.

165 Friman et al., 2003, par. 28. 
ultimate trial preparation so as not to 'lose face' before the judges when confronted with the defence's alternative accounts. Theoretically, assuming that the prosecutor optimally exercises his duties, the role of the defence is arguably limited to directing the judges' attention to an alternative account of the events based on the prosecutorial investigative file. However, the absence of an official 'dossier' which formally transfers pieces of evidence from the pre-trial collecting stage to the evaluation at trial would seem to be an impediment to this approach. Moreover, this primarily 'inquisitorial' approach has not been absorbed into the practice of the ICC. ${ }^{166}$

The standard to initiate an investigation is reflected in Article 53 ICC Statute, which directs the prosecutor to initiate an investigation "unless ... there is no reasonable basis to proceed." To determine that, the prosecutor must take into account that (a) the information available provides reasonable grounds to believe that a crime under its jurisdiction has been committed; (b) the admissibility of the case under Article 17; and (c) notwithstanding the gravity of the crime and the interests of victims, there are substantial reasons to believe that an investigation would not serve the interests of justice. ${ }^{167}$ The OTP Regulations provide guidance as to the prosecutor's approach when preparing a case. Regulation 24 provides substantive criteria for the handling of information and evidence of the alleged crimes: the OTP "shall develop and apply a consistent and objective method for the evaluation of sources, information and evidence." In that regard, the OTP will "take into account inter alia the credibility and reliability of sources, information and evidence, and shall examine information and evidence from multiple sources as a means of bias control." 168 Hereafter, the OTP will determine a provisional case hypothesis (or

166 ICC, Prosecutor v. Lubanga Dyilo, Decision on the Defence Request for Unrestricted Access to the Entire File of the Situation in the Democratic Republic of the Congo, ICC-01/04-01/06-103, 17 March 2006 (the Pre-Trial Chamber rejected the defence's motion for unrestricted access to the Prosecution's investigative file).

167 The ICC OTP has issued a Policy Paper on the Interests of Justice, September 2007, available at: http://www.icc-cpi.int/NR/rdonlyres/772C95C9-F54D-4321-BF09-73422BB23528/143640/ ICCOTPInterestsOfJustice.pdf (last accessed on 29 May 2012). Article 53(2) ICC Statute incorporates the standard of a "sufficient basis" for the initiation of a prosecution upon an investigation.

168 Regulations of the Office of the Prosecutor, ICC-BD/05-01-09, entered into force on 23 April 2009 (ICC OPT Regulations). In the evaluation of the Iraq communications, the prosecutor, next to the communications provided, “ ... conducted an exhaustive search of all readily-available open source information, including media, governmental and non-governmental reports. Significant additional material collected from open sources includes, among others, the findings of Amnesty International, Human Rights Watch, Iraq Body Count and Spanish Brigades Against the War in Iraq ... [and] additional information was sought and received from relevant governmental sources and from other sources that could have independent information and would be affiliated with the perspective of victims. OTP Response on the communication concerning the situation in Iraq, 9 February 2006, pp. 2, 6 (http:// www.icc-cpi.int/NR/rdonlyres/04D143C8-19FB-466C-AB77-4CDB2FDEBEF7/143682/OTP letter_to_senders_re_Iraq_9_February_2006.pdf) (last accessed on 29 May 2012). Although NGOs can be considered reliable sources within the meaning of Article 15(2) ICC Statute, the Prosecutor should give due consideration to their reliability considering the enormous diversity of NGOs as to 
hypotheses), which shall include "a tentative indication of possible charges, forms of individual criminal responsibility and potentially exonerating circumstances." 169 With regard to the preliminary examination of evidence, the Draft Policy Paper on Preliminary Examinations repeats the principle of objectivity laid down in Article 54(1) and states its applicability at the stage before taking the decision to continue with an investigation. ${ }^{170}$ If the information forming the basis for the preliminary examination has been obtained from a third source rather than from the OTP's own investigative efforts, "the Office pays particular care to assess the relevance, reliability, credibility and completeness of such information." ${ }^{171}$ Moreover, the OPT "seeks to ensure due process by providing all relevant parties with the opportunity to submit information they consider important." 172 As to the prosecutor's ethical standards, the Draft Code of Professional Conduct for Prosecutors of the ICC instructs the prosecutor to "ensure that all necessary and reasonable enquiries are made and the result disclosed in accordance with the requirements of a fair trial, whether they point to the guilt or innocence of the suspect"; and to "act with competence and diligence, make impartial judgments based on the evidence and consider foremost the public interest, and not proceed if the evidence does not create a reasonable basis for a charge." 173

As a permanent institution, the ICC encounters a wide range of situations falling within its jurisdiction. To accommodate a selection of - and cases within - the different potential situations, the ICC OTP pursues a strategy of focused investigations and prosecutions, "meaning it will investigate and prosecute those who bear the greatest responsibility for the most serious crimes, based on the evidence that emerges in the course of an investigation." 174 For the selection of cases from specific situations, only a limited number of incidents are selected, which "allows the Office to carry out short investigations; to limit the number of persons put at risk by reason of

their "size, structure, political objectives or financing." JACOBS, 2007, p. 324.

169 Regulation 34 ICC OTP Regulations. Notably, Regulation 10 ('Specific Standards of Truth-Seeking') of the OPT Draft Regulations (3 June 2003) required the "investigation of both incriminating and exonerating circumstances as a matter of equal priority and with equal diligence." This definition of the concept of truth-seeking was deleted in the final text of the OTP Regulations. Text of Draft Regulation 10 cited in Schabas, 2010-a, p. 676.

170 Policy Paper on Preliminary Examinations, Draft, 4 October 2010, available at: http://www.icc-cpi. int/NR/rdonlyres/E278F5A2-A4F9-43D7-83D2-6A2C9CF5D7D7/282515/OTP_Draftpolicypaperonpreliminaryexaminations04101.pdf (last accessed on 29 May 2012), par. 41 (ICC OPT Policy Paper).

171 ICC OPT Policy Paper, par. 43.

172 ICC OPT Policy Paper, par. 44.

173 Draft Code of Professional Conduct for Prosecutors of the International Criminal Court, available at: http://www.amicc.org/docs/prosecutor.pdf (last accessed on 29 May 2012), Article 8, referring to Investigation and Prosecution.

174 Prosecutorial Strategy 2009-2012, ICC OTP, 1 February 2010, available at: http://www.icc-cpi. int/NR/rdonlyres/66A8DCDC-3650-4514-AA62-D229D1128F65/281506/OTPProsecutorialStrategy20092013.pdf (last accessed on 29 May 2012), par. 19 (Prosecutorial Strategy). 
their interaction with the Office; and to propose expeditious trials while aiming to represent the entire range of victimization." 175 Moreover, the prosecutor requests a Pre-Trial Chamber to issue an arrest warrant or a summons to appear, "based on the evidence collected, only when the Office is nearly trial-ready, thus contributing to efficient Court proceedings." ${ }^{\prime 176}$ Implementing these idyllic aspirations is, however, a different matter than postulating them in theory. The drive and necessity for efficiency is understandable, but the important question for this chapter is what room is left for the necessary objectivity and active search for exculpatory evidence, elements which are considered crucial for equality of arms, within these 'focused' and 'short' investigations and prosecutions?

\subsubsection{Confidentiality agreements}

The Lubanga case demonstrates the challenges associated with investigations in the context of an ongoing conflict and puts to the test the legal and ethical obligations of the prosecutor in his quasi-judicial role. Twice, the Trial Chamber has ordered a stay (in pre-trial and during trial) because it could not control the fairness of proceedings as a direct result of the prosecutor's conduct in this case. The first stay was ordered because the prosecutor could not disclose material that he had obtained under the cloak of confidentiality and that contained exculpatory elements. The second stay came when the prosecutor refused to disclose the identity of an intermediary used by the prosecution to contact witnesses, following an explicit disclosure order by the Trial Chamber. Although these decisions to stay the proceedings revolve around the issue of the disclosure of information, which will be discussed in more detail in the next chapter, these decisions provide a glance into the investigative practice of the prosecutor. The Lubanga case is the first case that went to trial at the ICC, and presented for the Prosecution a 'trial case' of implementing the principles and intentions of the OTP into concrete practice as well as a 'trial case' for the prosecutor's objectivity.

Essentially, a power-struggle between the prosecutor and the judges underlies the disclosure crisis in the Lubanga case, which eventually led to the first stay of proceedings. ${ }^{177}$ As one commentator put it, “ “.. one of the most remarkable aspects of this story was its inevitability." ${ }^{178}$ According to the Trial Chamber, the prosecutor had abused Article 54(3)(e) ICC Statute, which provides for an opportunity not to

175 Prosecutorial Strategy, par. 20.

176 Prosecutorial Strategy, par. 21.

177 ICC, Prosecutor v. Lubanga Dyilo, Decision on the Consequences of Non-disclosure of Exculpatory Materials Covered by Article 54(3)(e) Agreements and the Application to Stay the Prosecution of the Accused, together with Certain Other Issues Raised at the Status Conference on 10 June 2008, ICC-01/04-01/06-1401, T. Ch., 13 June 2008 [Lubanga First Stay of Proceedings Trial Decision].

178 Whiting, 2009, p. 209. 
disclose information that has been obtained confidentially and only for the purpose of generating new evidence. ${ }^{179}$ The prosecutor could not disclose most of the confidential materials to the Trial Chamber, notwithstanding the letters of assurance that it would not provide it to the defence without the consent of the information provider. ${ }^{180}$ The context of ongoing hostilities in the DRC, in which the prosecutor had to investigate, contributed to the fact that many information providers agreed to supply information only under confidentiality agreements. ${ }^{181}$ The crux of the matter was that the prosecutor wanted "to obtain these materials as quickly as possible for the sake of the ongoing investigation", and only after the identification of pieces he wished to use as evidence and to seek permission for disclosure. ${ }^{182}$ After repeated orders directed to the prosecutor to ensure the lifting of confidentiality agreements to be able to comply with his statutory obligations in relation to safeguarding the rights of the accused, the Trial Chamber sanctioned the prosecutor's "overzealous" use of confidentiality agreements ${ }^{183}$ by imposing a stay on proceedings. ${ }^{184}$

The prosecutor appealed arguing that the power to secure information under the cloak of confidentiality is a key tool of the Prosecution in fulfilling its mandate. ${ }^{185}$

179 Article 54(3)(e) ICC Statute (the Prosecutor may agree not to disclose, at any stage of the proceedings, documents or information that the Prosecutor obtains on the condition of confidentiality and solely for the purpose of generating new evidence, unless the provider of the information consents). For an overview of the framework of the ICTY in relation to confidential agreements and the disclosure of exculpatory evidence (Rule 70 and 68), see Whiting, 2007, pp. 211-215.

180 Transcript of hearing on 6 May 2008, ICC-01/04-01/06-T-86-ENG, page 35, line 20 to page 36, line 17.

181 The Trial Chamber acknowledged the "good faith" of information providers: "It needs to be stressed, however, that the Chamber fully appreciates that the UN, and possibly other information-providers, were invited by the Court to enter into these agreements, and it unreservedly accepts that they will have approached this issue in good faith, bearing in mind their own particular responsibilities and their respective mandates." Lubanga First Stay of Proceedings Trial Decision, par. 64.

182 Transcript of hearing on 6 May 2008, ICC-01/04-01/06-T-86-ENG, pp. 23, 8-14, the OTP Trial Attorney contended that: "Of course there was never ever any intention on the side of the Prosecutor, and it was also understood as such by the United Nations, that these materials were received only for lead purposes. The point was to obtain these materials as quickly as possible for the sake of the ongoing investigation and then to allow the Office of the Prosecutor to identify the materials it wishes to use as evidence and then seek permission." Later, he corrected this submission by stating that "whenever the Office of the Prosecutor enters into 54(3)(e) agreements, the aim obviously of such agreements is to obtain only lead information", (pp. 35, 15-17). However, "the damage was already done." Ambos, 2009, p. 552.

183 Over $50 \%$ of the DRC materials were obtained on the basis of confidentiality, see ICC, Prosecutor v. Lubanga Dyilo, Decision Regarding the Timing and Manner of Disclosure and the Date of Trial, ICC-01/04-01-06, 9 November 2007, par. 6.

184 Arguably, to take the matter further, the Trial Chamber sanctioned the Prosecutor for 'bypassing' the Chamber, and not consulting as he should have done according to Article 67(2) ICC Statute and Rule 83 ICC RPE.

185 ICC, Prosecutor v. Lubanga Dyilo, Prosecution's Document in Support of Appeal against Decision to Stay Proceedings, ICC-01/04-01/06 OA13, 24 July 2008, par. 10 [footnote reference omitted]. 
This tool is particularly pertinent to providers in the context of armed conflicts, ${ }^{186}$ and "it is also in the interests of the objective and efficient administration of justice for the Prosecution to gather such information at the earliest possible time, in particular to guide its investigations." 187 In response to the Trial Chamber's assessment of the conditionality between the confidential agreements and the disclosure crisis, ${ }^{188}$ the prosecutor, in fact, made a valid point: "if the material had not been received under Article 54(3)(e) it would not have been provided to the Prosecution in the first place, thus could not have been disclosed." 189 This scenario, in fact, would seem to vindicate the 'truth-finding' role of the prosecutor.

This scenario would then be that the prosecutor, being open-minded, unbiased and on a mission to conduct an objective, impartial investigation to establish the truth of what happened in the DRC, sought to collect as much material as possible from a wide range of information providers, which he thought would be used to generate new evidence. The realities of the ongoing conflict precluded the prosecution from gathering evidence without the ability to make confidential agreements. When the international community was eager to see some action from the expensive institution which was taking too long to 'warm up', the prosecutor used these materials obtained under the cloak of confidentiality to substantiate the allegation against the accused. In this scenario, the availability of the exculpatory evidence, that might have been inaccessible to the defence, is the direct consequence of the prosecutor's objective investigations. ${ }^{190}$ In accordance with Article 67(2), the prosecutor is the initial assessor of the material collected and following Article 54(3)(e), ${ }^{191}$ the prosecutor could have presented other, arguably similar, evidence that was found from the lead materials collected under the confidentiality agreements. To some extent, this practice would be contrary to the spirit of Article 54(1) ICC Statute, ${ }^{192}$ and the prosecutor's upfront

186 ICC, Prosecutor v. Lubanga Dyilo, Prosecution's Application for Leave to Appeal "Decision on the Consequences of Non-disclosure of Exculpatory Materials Covered by Article 54(3)(e) Agreements and the Application to Stay the Prosecution of the Accused, together with Certain Other Issues Raised at the Status Conference on 10 June 2008, ICC-01/04-01/06-1407, T. Ch., 23 June 2008, par. 12: "The realities of investigations during ongoing conflicts or in regions of substantial instability reinforce the need for providers to be able to transmit material confidentially, and for the limited purpose of generating new evidence, when necessary."

187 ICC, Prosecutor v. Lubanga Dyilo, Prosecution's Document in Support of Appeal against Decision to Stay Proceedings, ICC-01/04-01/06 OA13, 24 July 2008, par. 9 [footnote reference omitted].

188 Lubanga First Stay of Proceedings Trial Decision, par. 70: "if the exculpatory material was not covered by the agreements, it would have been provided to the defence: non-disclosure is the direct result of the prosecution's use of the Article 54(3)(e) agreements."

189 ICC, Prosecutor v. Lubanga Dyilo, Prosecution's Document in Support of Appeal against Decision to Stay Proceedings, ICC-01/04-01/06 OA13, 24 July 2008, par. 16.

190 Cf. ICC, Prosecutor v. Lubanga Dyilo, Prosecution's Document in Support of Appeal against Decision to Stay Proceedings, ICC-01/04-01/06 OA13, 24 July 2008, paras. 12, 24.

191 Lubanga First Stay of Proceedings Trial Decision, par. 88.

192 There might be differences, however slight, between the 'lead' and the gained evidence, and arguably, the Defence's assessment of the exculpatory value of a material might be different from 
'disclosure' of the 'lead' materials as exculpatory would seem to be in line with this spirit. ${ }^{193}$ In this regard, the Appeals Chamber was critical of the fact that the prosecutor had collected large amounts of materials under the confidentiality agreements, while being aware that exculpatory materials might be included. ${ }^{194}$ Should not this practice actually be applauded in light of the prosecutorial duty to search for truth? The prosecutor, of course, expected the incriminatory materials to outweigh the exculpatory ones and to lift confidentiality if and when it would become necessary. ${ }^{195}$ In light of equality of arms, one would hope that the information providers would not be reluctant to provide potentially exculpatory evidence so as to preserve total confidentiality with regard to the inculpatory evidence. And for that matter, that the prosecutor would not turn away from potentiality exculpatory evidence, if offered under the cloak of confidentiality, so as not to be caught between a rock and a hard place. ${ }^{196}$

Notwithstanding this other scenario, the crux of the matter is that justice has to (be seen to) be done; and "[ $\mathrm{t}]$ he stark fact is that evidential material rending to exculpate the accused, known to the prosecutor, could not be disclosed to defence."197 The Appeals Chamber confirmed the Trial Chamber's interpretation of Article 54(3) (e) ICC Statute, meaning that this Article can only be used for the specific purpose of generating new evidence. ${ }^{198}$ Considering the prosecutorial obligation to find the truth under Article 54(1) the Appeals Chamber argued that:

that of the Prosecutor.

193 The Appeals Chamber did not doubt the Prosecutor's good faith and transparent approach to disclosure challenges; in fact, as is to be expected, however, it emphasised the exclusion of the Trial Chamber from the process. See ICC, Prosecutor v. Lubanga Dyilo, Judgment on the Appeals of the Prosecutor against the decision of Trial Chamber I entitled "Decision on the Consequences of Nondisclosure of Exculpatory Materials Covered by Article 54(3)(e) Agreements and the Application to Stay the Prosecution of the Accused, together with Certain Other Issues Raised at the Status Conference on 10 June 2008, ICC-01/04-01/06-OA 13, A. Ch., 21 October 2008, par. 96. [Lubanga First Stay of Proceedings Appeals Decision]. But see also the Separate Opinion of Judge Pikis, par. 41, contending that the Prosecutor's actions are contrary to Article 54(1) as he had failed to collect exculpatory evidence, of which he was aware, from the lead.

194 Lubanga First Stay of Proceedings Appeals Decision, par. 44: "It appears from the record that when agreeing to receive the material on the condition of confidentiality the Prosecutor was aware that the material could contain exculpatory evidence."

195 Lubanga First Stay of Proceedings Appeals Decision, par. 44: "He relied on the expectation that the information providers would, at a later stage, agree to the lifting of the confidentiality, should this become necessary."

$196 C f$. Whiting, 2007, p. 210, arguing that the lack of clarity as to how to resolve the conflict between confidentiality and disclosure "could inhibit investigation efforts by the Prosecution in the future as well as the willingness of third parties to cooperate with the Prosecution."

197 Separate Opinion of Judge Pikis, Lubanga First Stay of Proceedings Appeals Decision, par. 10.

198 Lubanga First Stay of Proceedings Appeals Decision. 
Chapter 4

It follows from Article 54(1) of the Statute that the investigatory activities of the Prosecutor must be directed towards the identification of evidence that can eventually be presented in open court, in order to establish the truth and to assess whether there is criminal responsibility under the Statute. ${ }^{199}$

Notwithstanding the importance of the confidentiality agreements to conducting investigations into conflict areas, the prosecutor must utilize this tool in accordance with his other functions and obligations under the Statute. In any case, the Chambers must be able to resolve the possible tension between confidentiality and disclosure..$^{200}$

Judge Pikis, in his Separate Opinion to the Appeals Chamber's decision, contended that the prosecutor had done "little, if anything" to conduct any further investigations on the exculpatory leads so as to be able to discharge his disclosure obligations towards the accused. ${ }^{201}$ This, in fact, would amount to a blatant violation of the prosecutor's obligation to search for truth. The other disturbing element is the prosecutor's late revelation of the disclosure dilemma and his late attempt to resolve it. When one of the fundamental rights of the accused is so openly endangered by the conduct of the prosecutor, despite the possible bona fide character of this conduct, the prosecutor is advised not to take chances. The judges are the final arbiters of the fairness of proceedings, something that they made very clear in this first power struggle at the ICC..$^{202}$

199 Lubanga First Stay of Proceedings Appeals Decision, par. 41.

200 The Appeals Chamber rejected the resolution of this tension proposed by the participating victims. They proposed an interpretation that under Article 67(2) ICC Statute only evidence has to be disclosed, while Article 54(3)(e) documents or information does not become evidence unless the providers have consented to the lifting of confidentiality. As a consequence, the Prosecutor would be able to withhold information because it is not yet evidence, which was unacceptable to the Appeals Chamber. See Lubanga First Stay of Proceedings Appeals Decision, par. 43.

201 Lubanga First Stay of Proceedings Appeals Decision, par. 96. But see the Separate Opinion of Judge Pikis, par. 42: "There is nothing to suggest that any consistent effort was made to generate evidence for the material received. On the contrary, the indications are that little, or anything was done in that direction, resting on the hope that the providers would consent to the disclosure of such material to the accused." Single Judge Steiner, in the Katanga/ Chui, case expressed her concern about the "reckless investigative techniques" of the Prosecutor. ICC, Prosecutor v. Katanga and Ngudjolo Chui, Decision on Article 54(3)(e) Documents Identified as Potentially Exculpatory or Otherwise Material to the Defence's Preparation for the Confirmation Hearing, ICC-01/04-01/07, 20 June 2008, par. 123.

202 The Prosecutor managed to reach agreements for the disclosure of all the undisclosed material to the Trial Chamber. Consequently, the Trial Chamber lifted the stay of proceedings on 18 November 2008. By 21 November 2008 the Prosecutor had disclosed all the materials to the defence. ICC, Prosecutor v. Lubanga Dyilo, Reasons for Oral Decision Lifting the Stay of Proceedings, ICC01/04-01/06-1644, 23 January 2009. The trial started on 26 January 2009. 
Parties’ Role During Investigations

\subsubsection{Protection of witnesses}

In light of this situation, one wonders why the prosecutor would engage in yet another power struggle with the judges in the same trial. On 8 July 2010, the Trial Chamber again issued a stay of proceedings because the prosecutor repeatedly did not comply with the Chamber's orders to disclose the identity of an intermediary that the defence wished to call to the stand. ${ }^{203}$ The role of the intermediaries used by the prosecution to "facilitate contact between the Prosecution and a witness or any other source of information" 204 was brought into discredit during trial when several defence witnesses implicated these intermediaries in being engaged in improper conduct. The defence wished to have the issue examined in more detail in court and the Trial Chamber agreed. ${ }^{205}$ Consequently, the Trial Chamber ordered the prosecution to (1) disclose the identity of one intermediary "to enable the defence to conduct necessary and meaningful investigations and to secure a fair trial for the accused", ${ }^{206}$ once the necessary protective measures had been implemented; to (2) call two intermediaries on the stand to testify; and (3) to call an the OTP representative to testify generally on the use of intermediaries. ${ }^{207}$ Arguably acting as a 'minister of justice' (by protecting broader public interests), the prosecutor explained his failure to disclose by referring to his own "autonomous duties of protection that it must honour at all times."208 The

203 ICC, Prosecutor v. Lubanga Dyilo, Redacted Decision on the Prosecution's Urgent Request for Variation of the Time-Limit to Disclose the Identity of Intermediary 143 or Alternatively to Stay Proceedings Pending Further Consultations with the VWU, ICC-01/04-01/06-2517-Red, T. Ch. I, 8 July 2010 [Lubanga Second Stay of Proceedings Trial Decision].

204 ICC, Prosecutor v. Lubanga Dyilo, Prosecution Proposed Procedure for Dealing with Intermediaries, ICC-01/04-01/06-2362, 19 March 2010, introduction.

205 ICC, Prosecutor v. Lubanga Dyilo, Redacted Decision on Intermediaries, ICC-01/04-01/06-2434Red2, 31 May 2010, par. 135: "The precise role of the intermediaries (together with the manner in which they discharged their functions) has become an issue of major importance in this trial. Contrary to the prosecution's argument, the defence submissions are not dependent on speculative assertions: they are, to an important extent, clearly evidence based." [Lubanga Decision on Intermediaries].

206 Lubanga Decision on Intermediaries, par. 143.

207 Lubanga Decision on Intermediaries, par. 150.

208 ICC, Prosecutor v. Lubanga Dyilo, Prosecution's Urgent Request for Variation of the Time-Limit to Disclose the Identity of Intermediary 143 or Alternatively to Stay Proceedings Pending Further Consultations with VWU, ICC-01/04-01/06-2512, T. Ch. I, 8 July 2010, pp. 1-4. ICC, Prosecutor v. Lubanga Dyilo, Prosecution's Urgent Provision of Further Information Following Consultation with the VWU, to Supplement the Request for Variation of the Time-Limit or Stay, ICC-01/0401/06-2516, 7 July 2010, par. 6: "The Prosecution is sensitive to its obligation to comply with the Chamber's instructions. However, it also has an independent statutory obligation to protect persons put at risk on account of the Prosecution's actions. It should not comply, or be asked to comply, with an Order that may require it to violate its separate statutory obligation by subjecting the person to a foreseeable risk. The Prosecutor accordingly has made a determination that the Prosecution would rather face adverse consequences in its litigation than expose a person to risk on account of prior interaction with this Office. This is not a challenge to the authority of the Chamber, it is instead a reflection of the Prosecution's own legal duty under the Statute." 
Trial Chamber was not convinced and found an abuse of process because of the direct non-compliance with the Chamber's orders, and more generally, because of the prosecutor's "clearly evinced intention" not to comply with the orders when he thinks they conflict with his other obligations. ${ }^{209}$

The Appeals Chamber's ruling is straightforward. The prosecutor had obviously and deliberately disobeyed, and any argument to the contrary "is, at best, disingenuous [and] at worst, ... an expression of ... a more profound and enduring concern ....".210 The prosecutor advanced many arguments with regard to the intermediary's security risk and the prosecutor's duty to protect this intermediary. ${ }^{211}$ The Appeals Chamber, however, refused to consider any of these arguments because both orders were not on appeal at the time. ${ }^{212}$ The Appeals Chamber reiterated that the Trial Chamber is "the ultimate guardian of a fair and expeditious trial", a fact which "does not negate any Statutory duties of the prosecutor, but, ... it does mean that when there is a conflict between the prosecutor's perception of his duties and the orders of the Trial Chamber, the Trial Chamber's orders must prevail." ${ }^{213}$ Notwithstanding, the Appeals Chamber reversed the Trial Chamber's stay of proceedings, by considering it as premature in light of the possible tools to bring about compliance. ${ }^{214}$

The prosecutor's obligations vis-à-vis third parties clearly fall within his duties as an officer of the court to ensure proper administration of justice. Intermediaries form an essential element in the prosecution's investigations due to the unstable security situation in the DRC. ${ }^{215}$ It was foreseeable that the prosecutor would be reprimanded for not complying with the Trial Chamber's direct orders. In this regard, his explicit recognition that he would rather face adverse consequences as a party to the proceedings, than fall short of ensuring the protection of broader public interests, can

209 Lubanga Second Stay of Proceedings Trial Decision, par. 31.

210 ICC, Judgment on the Appeal of the Prosecutor against the Decision of Trial Chamber I of 8 July 2010 entitled "Decision on the Prosecution's Urgent Request for Variation of the Time-Limit to Disclose the Identity of Intermediary 143 or Alternatively to Stay Proceedings Pending Further Consultations with the VWU, Prosecutor v. Lubanga Dyilo, ICC-01/04-01/06 OA 18, A. Ch., 8 October 2010, par. 46 [Lubanga Second Stay of Proceedings Appeals Decision]. According to the Prosecutor, "every request by a party that a Chamber reconsider a prior ruling or seeks a variation of a time-limit will present a situation of non-compliance."

211 Prosecution's Appeal of Lubanga Second Stay of Proceedings Trial Decision, par. 48.

212 Lubanga Second Stay of Proceedings Appeals Decision, par. 45.

213 Lubanga Second Stay of Proceedings Appeals Decision, paras. 47-48.

214 Lubanga Second Stay of Proceedings Appeals Decision, par. 59.

215 ICC, Prosecution's Submissions in Response to Trial Chamber's Oral Request of 10 February 2010, Prosecutor v. Lubanga Dyilo, ICC-01/04-01/06-2310-Red, 25 February 2010, par. 12. In fact, "[i]t is not an exaggeration to say that the prosecutions themselves are impossible without the assistance of intermediaries." For instances of harassment for cooperation with the ICC in Sudan, see International Federation for Human Rights, Serious concerns about harassment faced by persons suspected of supporting or cooperating with the International Criminal Court in Sudan, 2 February 2009, available at: http://www.unhcr.org/refworld/docid/49885789c.html (last accessed 28 May 2012). 
be seen as an expression of the 'quasi-judicial' perception of his role. ${ }^{216}$ Whether the prosecutor was prepared to allow the trial be permanently halted, rather than obeying the Chamber's orders, is another, rather speculative question. ${ }^{217}$ Notwithstanding all of this, the prosecutor clearly took the wrong path regarding his assessment of the primacy of the Trial Chamber's evaluation of protective measures.

\subsubsection{Victim participation}

Another complicating factor within the ICC is the extended role of victims as acknowledged participants throughout the proceedings. The ICC Pre-Trial Chamber's acknowledgment of victim participation in the investigative stage $\mathrm{e}^{218}$ had been met with a vigorous protest from the prosecutor. It is in this context that the prosecutor argued for the protection of his objectivity ${ }^{219}$ and equality of arms for the accused. ${ }^{220}$ The possibility for victims to present evidence to the Chamber during the investigation of a situation, outside the protection and guarantees offered by the Statute, "can very easily lead to consideration by the Chamber of unreliable and prejudicial material, and even of material that is forged or fabricated." ${ }^{221}$ In addition, the protection of sensitive information and witnesses could be endangered. ${ }^{222}$ Thus, according to the prosecutor, "the system adopted in the Decision, due to the inherent limitations of the Chamber, the lack of adequate guidelines or regulations, and the broad forms of victim participation envisioned, does not provide sufficient safeguards vis-à-vis the dangers described ...." ${ }^{223}$

In regard to the rights of the defence, the prosecutor contended that extensive victim participation envisioned by the Chamber seriously affects the balance between victims and accused persons "capable of affecting the fairness and integrity

216 Rather than the sole desire to "win" the case, $c f$. VAsiLIEv, 2010, p. 50.

217 Considering the Prosecutor's contention that the stay was imposed on a conditional basis, see Trial Transcript of 15 July 2010, ICC-01/04-01/06-T-314-ENG.

218 ICC, Situation in the Democratic Republic of the Congo, Décision sur les Demandes de Participation á la Procedure de VPRS 1, VPRS 2, VPRS 3, VPRS 4, VPRS 5 et VPRS 6, PTC, ICC-01/04-101, 17 January 2006 (ICC-01/04-10-tEN-Corr), [DRC Victims' Participation Decision].

219 Prosecution's Application for Leave to Appeal Pre-Trial Chamber I's Decision on the Application for Participation in the Proceedings of VPRS 1, VPRS 2, VPRS 3, VPRS 4, VPRS 5 and VPRS 6, ICC-01/04-103, 23 January 2006, par. 14 [Prosecution's Appeal of DRC Victims' Participation Decision]: "These statutory requirements [Article 54(1)(a)] of objectivity and independence demand that the investigation be insulated from any influence not permitted by the Statute and therefore, capable of improperly tainting its objectivity and integrity." [footnote omitted].

220 Prosecution's Appeal of DRC Victims' Participation Decision, paras. 20-22.

221 Prosecution's Appeal of DRC Victims' Participation Decision, par. 16: "In addition, the Chamber, it is respectfully submitted, lacks the investigative tools made available to the Prosecution by the Statute and thus had no means of fully testing the reliability of any such submitted material."

222 Prosecution's Appeal of DRC Victims' Participation Decision, par. 17.

223 Prosecution's Appeal of DRC Victims' Participation Decision, par. 19. 
of proceedings." 224 This is particularly the case in the investigative stage where no individual accused has been named who could effectively counterbalance victims' interventions. ${ }^{225}$ According to the prosecution, the Chamber's solution to appoint ad hoc counsel for the defence is inadequate for the purposes of effectively reacting to the type of participation envisaged by the Decision throughout the entire investigative stage. ${ }^{226}$ Another factor that potentially endangers the fairness of proceedings is the extent of pre-judging required to be made by the Chamber for the purpose of determining victim status eligible for participation. ${ }^{227}$ Lacking the powers of an investigative chamber, the Pre-Trial Chamber might "not only be reaching premature and inappropriate factual conclusions, but also doing so on the basis of information the reliability of which it can only test in an extremely limited fashion." ${ }^{228}$ Lastly, the prosecutor argued that the envisioned victim participation will detrimentally affect the expeditiousness of the proceedings by placing "a serious burden for all organs of the Court." 229

Thus, at stake is the prosecutor's ability to juggle with the different interests involved: the objective, efficient and expeditious investigations, the protection of victims/witnesses and the rights of the defence, within the overseeing power of the Pre-Trial Chamber. The Pre-Trial Chamber denied the prosecutor's application to appeal. ${ }^{230}$ In relation to the presentation by the victim participant of additional information (outside the prosecutor's framework of investigations), the Chamber considered that the prosecution's access to additional evidence could only enhance the impartiality of the investigations. ${ }^{231}$ The Chamber found the prosecutor's arguments in relation to the endangered confidentiality of victims/witnesses and information to be too theoretical at that stage. ${ }^{232}$ This also applied to the equality of arms argument: future accused would be given access to all the relevant information for the preparation of their cases, and in the meantime, ad hoc counsel appointed

224 Prosecution's Appeal of DRC Victims' Participation Decision, par. 21.

225 Prosecution's Appeal of DRC Victims' Participation Decision, par. 21. See DRC Victims' Participation Decision par. 24: "In his memorandum, ad hoc Defence counsel does not challenge either the applicability of Article 68(3) of the Statute to this stage of the investigation or the possibility in legal terms of participation by the victims at this stage of the proceedings."

226 Prosecution's Appeal of DRC Victims' Participation Decision, par. 22.

227 Prosecution's Appeal of DRC Victims' Participation Decision, paras. 23-28.

228 Prosecution's Appeal of $D R C$ Victims' Participation Decision, par. 27.

229 Prosecution's Appeal of DRC Victims' Participation Decision, par. 32: “To begin with, the Decision will impact on the Prosecution, which works with finite resources and must be allowed to conduct its investigation of crimes in an expeditious manner in order to fulfil its mandate."

230 ICC, Situation in the Democratic Republic of the Congo, Decision on the Prosecutor's Application for Leave to Appeal the Chamber's Decision of 17 January 2006 on the Applications for Participation in the Proceedings of VPRS 1, VPRS 2, VPRS 3, VPRS 4, VPRS 5 and VPRS 6, PTC, ICC-01/04135-tEN, 31 March 2006 [Decision on Prosecution's Appeal].

231 Decision on Prosecution's Appeal, par. 45.

232 Decision on Prosecution's Appeal, paras. 48, 51. 
by the Pre-Trial Chamber would "promote the right of the Defence when any issue having direct repercussions on the fairness of the proceedings arises." ${ }^{233}$ In general, the Pre-Trial Chamber considered its role as follows:

The Chamber is of the view that its role is to guarantee and preserve the rights of the Prosecutor, Defence and Victims throughout the entire pre-trial proceedings and in particular to preserve the impartiality and integrity of the Prosecutor's investigation. More specifically, the role of the Chamber, at the investigation stage of a situation, is to ensure that the Prosecutor is able to exercise the powers and fulfil the functions stipulated in Article 54 of the Statute. ${ }^{234}$

Contrary of the prosecutor's 'intrusionist' vision of the Pre-Trial Chamber's role, the Chamber viewed its powers as facilitating and supporting those of the prosecutor with regard to the investigations. The prosecutor kept voicing his rejection of a general right for victims to participate during investigations. ${ }^{235}$ The Pre-Trial Chamber, however, denied the prosecution's requests for appeal. ${ }^{236}$ In 2008, however, the Pre-Trial Chamber in the Darfur case granted leave to appeal the issue of whether victims could be granted general participatory rights in the investigation phase of a situation. Agreeing in part with the prosecutor's contentions, the Appeals Chamber overruled the Pre-Trial Chamber's decisions. ${ }^{237}$ According to the Appeals Chamber, Article 68(3) provides for a possibility for victims to participate in the context of judicial proceedings. It stated that the investigations are not proceedings, but rather prosecutorial inquiries for the identification of the committed crimes and those responsible. ${ }^{238}$ Accordingly, the Statute does not provide for a general right for victims to participate during investigations, and consequently, victims would have to show a specific interest in a specific matter arising at this stage. ${ }^{239}$

233 Decision on Prosecution's Appeal, par. 54.

234 Decision on Prosecution's Appeal, par. 43.

235 See also ICC, Situation in Uganda, No. ICC-02/04-103, 20 August 2007.

236 ICC, Situation in Uganda, ICC-02/04-103, 20 August 2007; ICC, Situation in DRC, ICC-01/04-103, 23 January 2006 and ICC-01/04-141, 24 April 2006.

237 ICC, Situation in Darfur, Pre-Trial Chamber 1 of 3 December 2007 entitled "Decision on the Requests of the OPCD and the Production of Relevant Supporting Documentation Pursuant to Regulation 86(2) of the Regulations of the Court and on the Disclosure of Exculpatory Materials by the Prosecutor" (ICC-02/05-110); and the decision of Pre-Trial Chamber I of 6 December 2007 entitled "Decision on the Applications for Participation in the Proceedings of Applicants a/0011/06 to a/0015/06, a/0021/07, a/0023/07 to a/0033/07 and a/0035/07 to a/0038/07" (ICC-02/05-111).

238 ICC, Situation in DRC, Judgment on victim participation in the investigation stage of the proceedings in the appeal of the OPCD against the decision of Pre-Trial Chamber I of 7 December 2007 and in the appeals of the OPCD and the Prosecutor against the decision of Pre-Trial Chamber I of 24 December 2007", 19 December 2008 (ICC-01/04-556), par. 45.

239 For a more detailed account see McGonigle Leyh, 2011, pp. 267-273. 


\subsection{THE DEFENCE'S ABILITY TO PREPARE FOR TRIAL: DEFENCE INVESTIGATIONS}

Principally, the defence does not have to 'trust' the prosecutor and can initiate its own parallel investigations. ${ }^{240}$ In relation to the scope of the defence's right or responsibility to conduct its own investigations, the ICTY Appeals Chamber has stated that "there is a firm obligation placed upon those representing an accused person to make proper enquiries as to what evidence is available in that person's defence." ${ }^{241}$ Of course, "the Defence's ability to present evidence on its behalf is a fundamental tenant of the right to a fair trial." ${ }^{\prime 242}$ Next to scrutinizing the prosecution's case and disclosure material, the proper inquiries would seem to include conducting their own on-site investigations. ${ }^{243}$ The reactive nature of the defence's case has as a natural consequence that the defence is the last to conduct these investigations. ${ }^{244}$ The prosecutor is better positioned to secure the materials necessary either by negotiations with the state or by relevant Tribunal orders, thus denying the defence the same opportunity to 'fish' through the materials in the same way as the prosecution. ${ }^{245}$ State cooperation with defence investigators has on occasions been "far less forthcoming" as compared to the Prosecution teams. ${ }^{246}$ In fact, " ... many potential witnesses and international experts are reluctant to testify on behalf of the defence even when their testimony is both probative of the actual truth of the events in dispute or necessary for a proper legal interpretation of those events." ${ }^{247}$

The argument of institutional inequality between the positions of the prosecutor and the defence has been advanced to explain the more difficult position of the

240 Friman [et al.], 2003, par. 28: “ ... the Defence cannot be required to rely exclusively on the investigative activities of the Prosecutor, despite its necessary objectiveness."

241 ICTY, Prosecutor v. Aleksovski, Decision on Prosecutor's Appeal on Admissibility of Evidence, IT-95-14/1, A. Ch., 16 February 1999, par. 18; ICTY, Prosecutor v. Brđjanin and Talić, Motion to Dismiss the Indictment, IT-99-36-PT, T. Ch., 2 May 2001, par. 10.

242 ICTR, Prosecutor v. Renzaho, Judgment and Sentence, ICTR-97-31-T, T. Ch., 14 July 2009, par. 70.

243 Turner, 2008, p. 554 (arguing that defence lawyers consider it essential to conduct on-site investigations and that most defence teams do). See also, KAY AND SwArT, 2002, pp. 1423-1424 (arguing that on-site investigations are "necessary to familiarize the lawyer with the areas that feature in the evidence of the case, to check the accuracy of evidence relied upon by the prosecution and to search for evidence that is relevant to the defence").

244 Cf. MCInTyre, 2003, p. 280.

245 McIntyre, 2003, p. 280. The disclosure issues are the subject of discussion in the next chapter.

246 Newton, 2011, p. 390: "The vast bulk of what may become admissible evidence is therefore in the hands of national authorities, who have established detailed mechanisms for providing that information to the Prosecution teams, but have often been far less forthcoming to defence investigators."

247 Newton, 2011, p. 388 [footnote omitted]. Prosecutor v. Renzaho, Judgment and Sentence, ICTR97-31-T, T. Ch., 14 July 2009, par. 76 (the Chamber dismissed the defence's general argument of an "inability to obtain evidence from witnesses from Rwanda given the current political climate of threats and intimidation aimed at those otherwise willing to provide testimony in favour of the Accused"). 
defence in conducting of investigations. Not having the status of an independent entity, an organ of the tribunal, the defence is viewed with different eyes by state authorities. ${ }^{248}$ As an example, Wladimiroff describes his own experience of being denied state cooperation due to a lack of institutional embedding of the defence. ${ }^{249}$ This stance has not changed over time; Germany responded to a recent request from Karadžić to assist in interviewing a witness that "[n]either Article 29 of the ICTY nor Rule 39 of its Rules of Procedure and Evidence provide any basis for the request" and, thus, Germany was "not in a position to grant the request." ${ }^{250}$ Also the treatment of the defence at the crime scene areas has, on occasion, been less then welcoming. ${ }^{251}$

To some extent the difference in approach is attributed to the difference in the legal traditions of the states involved. Wladimiroff contends that in relation to state cooperation in criminal matters, the position of defence lawyers is "totally different" in common law and Continental European civil law. ${ }^{252}$ State cooperation under the mutual assistance conventions operate very much in line with the European civil law 'top-down' approach, which assigns only a marginal role to the defence. ${ }^{253}$ While at the international criminal law level, state cooperation is regulated "along lines similar to those governing general inter-State cooperation in criminal matters, the law and procedures that govern the Tribunals are more common law oriented." ${ }^{254}$ In the same vein, the ICC Assembly of State Parties' Bureau on Cooperation argues in its report that:

Provision of information to defence teams may in some cases pose a particular problem in relation to civil law systems, where the defence may be treated differently to the

248 Felde ... [ET AL.], 1998, p. 1450: "The reality was that the defense was not an entity, not an organ of the Tribunal, and therefore, non-existent for those states. I had no access to any official authority and I had no way to track down the witnesses. In the end, I had to contact the trial chamber and the prosecution to get this support."

249 Wladimiroff, 2002, p. 248: "in requesting state (Germany) assistance in locating certain witnesses, the German initial response was essentially: "No. Who are you?", and was later somewhat modified into: "well, there is no provision under German law, so why should we answer your request?."

250 ICTY, Prosecutor v. Karadžić, Invitation to Germany Regarding Motion for Subpoena of Christoph Von Bezold, IT-95-5/18-T, T. Ch., 8 April 2011.

251 Felde ... [ET AL.], 1998, pp.1450-1451: "For example, local authorities initially denied access to their territory. Later on, they denied access to specific areas, to specific regions. They also ordered officials - policemen and civil servants - not to speak with the defence. They kept people away. They removed people from their houses in order to prevent them from speaking to us. They threatened people if they spoke to us. When we found people and we spoke to them, they were threatened again not to contact the defense ever again. They also harassed and jailed people after we spoke to them. On top of this, we faced problems that witnesses, once located, disappeared, not only because of the threats of local authorities, but also as a result of the ongoing conflict."

252 WladimirofF, 2002, p. 243.

253 WLADIMIROFF, 2002, p. 244.

254 Wladimiroff, 2002, p. 244. 
prosecution with regard to requests for judicial assistance, compared to common law systems. It is burdensome for the defence to approach Chambers for a Court order each time they need a particular piece of information, and in most cases Chambers would request that the defence first approach the authorities in question. This leads to very slow turn-around time for this type of cooperation and States Parties should be mindful of ways in which this process can be made more efficient, having due regard to the principle of equality of arms. ${ }^{255}$

The expected, more active role for defence counsel at the international criminal level actually causes problems in terms of state cooperation arrangements. ${ }^{256}$ In light of scarce defence resources and the difficulties in many cases to conduct proper (if any) on-site investigations, the defence is to a large extent dependant on the investigative efforts of the prosecutor and on the support of judges. ${ }^{257}$ However, the solution Wladimiroff found, namely asking the prosecution to issue a request, which they did, does not generally 'fit in' with the ICTY's procedural system. ${ }^{258}$ A more apparent option for the defence, thus, is to request the court to issue any necessary orders or seek state cooperation in order to assist the defence in its case preparation. ${ }^{259}$ In fact, "[i]f used properly, this function may serve to enhance equality of arms and foster adherence to the statutory requirement of objective investigations and to promote coordination between prosecution and defence cases." ${ }^{260}$ However, this possibility to

255 ICC, Assembly of State Parties, Report of the Bureau on Cooperation, ICC-ASP/6/21, 19 October 2007, par. 33. Adopted by the Assembly of States Parties, Omnibus Resolution, ICC-ASP/6/Res.2, 14 December 2007. In addition, it is argued that "Practical assistance includes logistical support to defence teams, victims and witnesses, staff and suspects, including permission to transfer through national territory, access to communications equipment, meeting facilities and pouch services as well as issuance of visas. The scope for providing such assistance varies with the circumstances of each case. The Court should, however, be mindful of burden sharing to the extent this is at all possible. Again the designation of a contact point at relevant Embassies and diplomatic missions is important, as it enables the Court to explore possibilities for involving more States Parties" (par. 53).

256 Wladimiroff, 2002, p. 244: "The defence lawyer is in almost the same position as the prosecution, and that is where the problems start."

257 E.g the Lubanga Defence argued that Article 54(1)(a) of the Statute imposed a responsibility on the prosecution to investigate exonerating materials. One reason for this was that it did not have the resources, authority or institutional aids which are available to the prosecution. ICC, Prosecutor $v$. Lubanga Dyilo, Réponse de la Défense à la "Prosecution's submissions on undisclosed documents containing potentially exculpatory information" datée du 28 mars 2008, ICC-01/04-01/06-1291, 22 April 2008, par. 6.

258 WladimirofF, 2002, p. 248.

259 Rule 54, 54bis ICTY/ICTR Statute. Article 57(3)(b) ICC Statute. In comparison, the prosecutor formally enjoys an advantage in relation to taking specific investigative steps because the PreTrial Chamber may not only "issue such orders and warrants as may be required for the purposes of an investigation" (Art. 57 (3) (a) ICC Statute), but in addition "[a]uthorize the Prosecutor to take specific investigative steps within the territory of a State Party without having secured the cooperation of that State" upon the determination of an inability to cooperate on the part of the State. Article 57(3)(d) ICC Statute.

260 Friman ... [ET AL.], 2003, par. 36. 
request a formal order for cooperation is subject to various threshold requirements "[t]o minimize both security concerns and the practical burden on states ...." ${ }^{261}$ These requirements will be discussed in more detail below.

In the framework of the ICC, before issuing such an order, the Pre-Trial Chamber may consult with the Prosecution, ${ }^{262}$ a practice which seems to be a sensible one. ${ }^{263}$ Considering this, the ICC Statute seems to promote coordination and even cooperation between prosecutorial and defence investigative efforts. Indeed, this approach seems to be preferred in relation to the efficiency and expeditiousness demands of the investigative/pre-trial stage of proceedings. ${ }^{264}$ On the other hand, consultation with the prosecutor presents an obvious limitation upon the freedom of action for the defence, as it might expose its defence strategy. ${ }^{265}$ However, no judicial control by the Pre-Trial Chamber generally over the investigative efforts and their objectivity is included in the system of the ICC. ${ }^{266}$

Only in relation to a unique investigative opportunity can the Pre-Trial Chamber order, at the request of the parties or on its own initiative, investigative measures that are necessary to preserve essential evidence for the benefit of the defence at trial (Article 56(3) ICC Statute). The rationale for this is "the fear that a defendant is not capable of efficiently collecting his evidence and preparing for trial." ${ }^{267}$ This fear may result from lawyers' lack of experience stemming from the 'inquisitorial'

261 Newton, 2011, p. 417.

262 Rule 116(2) ICC RPE: "Before taking a decision whether to issue an order or seek cooperation under Article 57, paragraph 3 (b), the Pre-Trial Chamber may seek the views of the Prosecutor."

263 Unless an ex parte consideration is warranted, see ICC, Prosecutor v. Katanga and Ngudjolo Chiu, Decision on the "Defences Application pursuant to Article 57(3)(b) of the Statute to Seek Cooperation of the Democratic Republic of Congo (DRC)", ICC-01/04-01/07, PTC I, 25 April 2008. Arguably, the ICC Statute does not give the Pre-Trial Chamber the power to order the Prosecutor to carry out investigations for the benefit of the Defence upon the latter's request. DE SMET, 2009, p. 424. As ICTY practice shows, the Prosecutor may already be in possession of the documents sought by the Defence: in Kordić and Čerkez the defence had obtained a binding order, which was not complied with, addressed to the relevant authorities to produce documents that after the conclusion of the trial were discovered to be in the possession of the Prosecution during the trial. See ICTY, Prosecutor v. Kordić and Čerkez, Order to Bosnia and Herzegovina for the Production of Documents, IT-95-14/2, T. Ch., 18 July 2000; See also Kordić and Čerkez, Status Conference, IT-9514/2, 22 June 2001, T. 28522-28523, 28525-28528. The Defence argued that the Prosecution knew that it was trying to obtain these documents; however, as emphasised by Judge Hunt, the application for a state cooperation order had been made ex parte.

264 FrimAn ... [ET AL.], 2003, par. 24: "Coordination of the defence investigation with the investigation conducted by the Prosecutor may, to some extent, reduce the contrast between "prosecution and defence cases" prepared at the investigation stage. This could, in turn, contribute to a less contradictory - and thus less time-consuming - presentation of the evidence at the trial stage."

265 FRIMAN ... [ET AL.], 2003, par. 28.

266 De Smet, 2009, p. 423. See also Guariglia, Harris and Hochmayr, 2008, p. 1124: “ ... vesting PreTrial Chambers with the authority to instruct the Prosecutor to accomplish investigative acts would undermine the latter's independence".

267 ORIE, 2002, p. 1476. 
systems in the preparation of an 'adversarial' trial, ${ }^{268}$ but also from past experiences at the ICTY/R where the collection of evidence constituted a major challenge for the defence. ${ }^{269}$ The next section will focus on the avenues for parties to obtain state cooperation with regard to collecting evidence.

\subsection{Parties' access to state cooperation}

Having no police force of their own, state cooperation in general is regarded as a sine qua non for the sole existence of international criminal courts. ${ }^{270}$ Connecting this to equality of arms arguments and statements, two premises are fundamental. First, international criminal institutions are intrinsically dependant on state cooperation. In practice, this dependence has created tensions between the judicial dimension of the courts and the political dimension of state interests. Different strategies, 'hard' and 'soft' powers and persuasiveness or pressure/leverage tactics have been used in negotiating an acceptable outcome within the interplay of the tribunal-stateinternational community of states. ${ }^{271}$ Second, the defence, not being an organ of the international criminal courts, creates an institutional vacuum that both in the books as well in practice creates an (appearance) of inequality that has been at the centre of any equality of arms debate from the start.

State cooperation can take several different 'dimensions': (1) political in the sense of recognition, moral, financial and material support; and (2) legal in the sense of 'co-operation in criminal matters'. ${ }^{272}$ Cooperation in the legal sense can be categorized as follows: the "transfer or surrender of the accused, co-operation related to investigations and the production of evidence, and co-operation with regard to the enforcement of sentences." 273 The issue of equality of arms comes most to the fore in cooperation relating to investigations and the collection of evidence, as it particularly plays a role in the 'proceedings' before these courts, thus after a suspect or accused

268 ORIE, 2002, p. 1476. The argument could be made that while to some extent expecting an active fact-finding role for the Prosecutor and the Pre-Trial Chamber, these lawyers might be too 'passive' when it comes to the active collection of defence evidence. For the limited fact-finding role of the ICC Pre-Trial Chamber see De Smet, 2009.

269 In several cases the Defence was not allowed to have access to the crime-site states, see e.g. ICTY, Prosecutor v. Tadić, Judgement, IT-94-1-A, A. Ch., 15 July 1999; ICTR, Prosecutor v. Kayishema v. Ruzindana, Judgment (Reasons), ICTR-95-1-A, A. Ch., 1 June 2001, par. 72; ICTY, Prosecutor v. Milutinović et al., General Ojdanić's Third Motion for Stay of Proceedings, IT-05-87-T, T. Ch., 23 July 2007.

270 Following the infamous metaphor of Judge Cassese: “ ... the ICTY remains very much like a giant without arms and legs - it needs artificial limbs to walk and work. And these artificial limbs are state authorities." CASSESE, 1998, p. 13.

271 PESKIN, 2008.

272 Sluiter, 2002, p. 6.

273 Sluiter, 2002, p. 7. On tribunals' bargaining position in relation to state cooperation in the arrest and surrender of suspects, see ROPER AND BARRIA, 2008, pp. 457-476. 
has been identified and when the involvement of both parties (rather than only the prosecutor) is visible. Certainly, the line is artificial to some extent, especially when it comes to the difference in the political 'game' and strategies that the tribunals as well as the states have to play. Moreover, no 'sure thing' exists when it comes to cooperation in practice. The insistence on and the support for the creation of an international criminal institution does not automatically imply cooperation when it comes to arrest and surrender and evidence gathering. Neither does an arrest and surrender lead to improved cooperation in evidence gathering.

The political considerations that had a detrimental effect on state cooperation towards the ad hoc tribunals had taken several forms and it took almost a decade, a regime change, pressure from world powers like the EU and the US and a clever handling of the available leverage from the side of the prosecutor to get and keep states' attention and cooperation. ${ }^{274}$ According to Article 29 ICTY (Article 28 ICTR) Statute, states have the responsibility to cooperate with the ad hoc tribunals. Being an instrument of the UNSC, the obligation extends towards all the members of the UN. However, having had the executive arm of the UNSC at their disposal has not obviated ad hoc tribunals' problems in relation to state cooperation. ${ }^{275}$

Although one of the advantages of an internationalized court like the SCSL would be its proximity to the crime area, not only with regard to its visibility and

274 For example, Serbia being a ‘villain' but feeling a 'victim' cooperated poorly, not in the least because of the genocide allegations brought against it by Bosnia-Herzegovina before the International Court of Justice; Croatia refusing to acknowledge its wrongdoing in its struggle for liberation; and Rwanda manipulating the ICTR proceedings as soon as the ICTR's investigations into RPF became too pressing. The Balkan states were seducible to (financial) pressure from the West, for a big part because of a regime change within the countries in question. RPF crimes are not, and will probably not be prosecuted before the ICTY, just the way Rwanda wants it. Pressing for RPF investigation did cost Carla Del Ponte her job at the ICTR, see Del Ponte and Sudetic, 2009.

275 Seventh Annual Report of the International Tribunal for the Prosecution of Persons Responsible for Serious Violations of International Humanitarian Law Committed on the Territory of the Former Yugoslavia since 1991, U.N. Doc.A/55/273-S/2000/777, 26 July 2000, paras. 156-157: "Although imperfect and still very problematic, cooperation between States and the Tribunal improved over the reporting period. This improvement can be seen in the fact that much evidence has been forwarded to the Tribunal and arrests of indicted have increased significantly. In one year, a total of 13 individuals were apprehended. This success is first of all the result of improved collaboration on the part of all States which, through actions of NATO, and more specifically those of SFOR and KFOR, have demonstrated their sustained cooperation with the Tribunal. This advance can be accounted for also by the cooperation of the Balkan States, in particular the entities of the Republic of Bosnia and Herzegovina and, more recently, the Republic of Croatia. The Government of Croatia has moreover shown publicly that it wishes to cooperate more in arrests of accused persons and in the search for evidence. When they visited the Tribunal, Prime Minister Dodik and Vice-President Šarović of Republica Srpska also expressed their intention to collaborate with it." The same report mentions that Serbia refused to issue a visa to the Prosecutor to be able to travel there. (Id. par. 165: "The Minister for Foreign Affairs of the Federal Republic of Yugoslavia announced on 16 June 2000 that the Prosecutor of the Tribunal should be deemed a NATO official and that, consequently, she could not enter the sovereign territory of the Federal Republic of Yugoslavia."). 
approachability, but also with regard to the resolution of state cooperation problems encountered at the ICTY/ICTR, the SCSL legal framework is explicitly biased towards the prosecution when it comes to state cooperation. Article 17(1) of the UN and Sierra Leone Agreement on the Establishment of a Special Court states that "[t]he Government shall cooperate with all organs of the Special Court at all stages of the proceedings. It shall, in particular, facilitate access to the Prosecutor to sites, persons and relevant documents required for the investigation." 276 Paragraph 2 states that "[t]he Government shall comply without undue delay with any request for assistance by the Special Court or an order issued by the Chambers ...." ${ }^{277}$ The defence is left to either approach the government through the Registry, ${ }^{278}$ or request the Chamber to issue an order. In the $A F R C$ case, the defence requested "the Chief Registrar ... for a more extensive interpretation of Article 17(1), arguing that it should also apply to potential witnesses for the defense who are not accessible to the defense or against the testimony of whom the domestic authorities create obstacles." 279 The Registrar's response was in the negative; ${ }^{280}$ however, a Designated Judge, drawing guidance from the ICTY Blaškić case on the "rather esoteric area of the law" governing states' cooperation with international criminal tribunals, issued an order for the provision of documents sought by the defence. ${ }^{281}$ Of course, the disadvantage is that this regime only governs the relationship between Sierra Leone and the Court, thus placing no obligation upon third states to cooperate with the Court.

The state cooperation regime at the ICC is legally different as compared to the ad hoc tribunals (representing more a 'horizontal' regime rather than a 'vertical' one), ${ }^{282}$ and this is assumed to have both positive and negative effects on state cooperation with the ICC generally. First, states have to become a party to the Rome Statute to be subjected to its jurisdiction, while becoming a party voluntarily, the pressing obligations flowing from the UN Security Council authority is missing. ${ }^{283}$ Second, at least until now, the policy of state self-referrals can be regarded as advantageous in terms of state cooperation, ${ }^{284}$ however, there is a risk that cooperation would be

276 Emphasis added.

277 Agreement on the SCSL, 16 January 2002 [emphasis added].

278 An official organ of the Court, Article 11 SCSL Statute.

279 Knoops And Amsterdam, 2006, p. 273.

280 Knoops and Amsterdam, 2006, p. 273.

281 SCSL, Prosecutor v. Brima, Kamara and Kanu, Decision on Defence Motion in Respect of Santigie Borbour Kanu for an Order Under Rule 54 with Respect to Release of Exculpatory Evidence, SCSL-04-16-PT, 1 June 2004, par. 19. ICTY, Prosecutor v. Blaškić, Judgement on the request of the Republic of Croatia for review of the decision of Trial Chamber II of 18 July 1997, IT-95-14-A, A. Ch., 29 October 1997.

282 Sluiter, 2002, p. 82.

283 Of course this does not apply in the case of a Security Council referral under Article 13 Rome Statute. Moreover, to some extent, state obligations under international agreements could impair the surrender of suspects to the Court following Article 98(2) ICC Statute.

284 Annex to the "Paper on some policy issues before the Office of the Prosecutor": Referrals and 
one-sided, meaning towards the opposite regime (thus shielding possible governmental misconduct).

A vertical element in the generally horizontal state cooperation regime of the ICC is the "innovative and radical" possibility created by Article 99(4)(a) of the ICC Statute. ${ }^{285}$ In fact, paragraph 4 "made the negotiation of this article difficult, challenging and extremely volatile." ${ }^{286}$ This article allows the prosecutor to carry out certain non-compulsory investigative acts necessary for a successful execution of a cooperation request, without that state's explicit consent, directly on State territory where the crime is alleged to have been committed and when the case has been determined admissible before the ICC. ${ }^{287}$ Thus, under strict conditions, the prosecutor can collect evidence in a state party that received a cooperation request, without the presence of state authorities. In other circumstances (except for a 'failed-state' situation, Article 57(3)(d) ICC Statute), the investigative steps are to be taken by, or under the direct supervision of, the national authorities. The power under Article 99(4) ICC Statute does not in itself interfere with the state sovereignty principles, as the state in question has already agreed on a general basis to cooperation with the ICC by

Communications, ICC Office of the Prosecutor, April 2004, available at: http://www.icc-cpi.int/NR/ rdonlyres/278614ED-A8CA-4835-B91D-DB7FA7639E02/143706/policy_annex_final_210404. pdf. ("Where the Prosecutor receives a referral from the State in which a crime has been committed, the Prosecutor has the advantage of knowing that that State has the political will to provide his Office with all the cooperation within the country that it is required to give under the Statute. Because the State, of its own volition, has requested the exercise of the Court's jurisdiction, the Prosecutor can be confident that the national authorities will assist the investigation, will accord the privileges and immunities necessary for the investigation, and will be anxious to provide if possible and appropriate the necessary level of protection to investigators and witnesses. Even if a referral comes from a third State not involved in the alleged crimes, the referral will indicate support for the involvement of the Court from that part of the international community. Thus, given that under the Statute, the Prosecutor relies on cooperation to carry out his investigations, the Prosecutor will in general seek where possible to make this support explicit through a referral.").

285 Schabas, 2010-a, p. 1049: "It is a departure from the 'horizontal' view of State cooperation, by which the national authorities of the State are responsible for implementing the request, and a manifestation of the 'vertical' approach. The prosecutor acts as a representative of the international community in the conduct of an investigation, as if he is an agent of an international police force."

286 Kress and Prost, 2008, p. 1622: "While no calculation was done, those present would no doubt attest to the fact that this one paragraph consumed the most time and effort of all of Part 9."

287 Art. 99 (4)(a) ICC Statute: "Without prejudice to other articles in this Part, where it is necessary for the successful execution of a request which can be executed without any compulsory measures, including specifically the interview of or taking evidence from a person on a voluntary basis, including doing so without the presence of the authorities of the requested State Party if it is essential for the request to be executed, and the examination without modification of a public site or other public place, the Prosecutor may execute such request directly on the territory of a State as follows: (a) When the State Party requested is a State on the territory of which the crime is alleged to have been committed, and there has been a determination of admissibility pursuant to Article 18 or 19, the Prosecutor may directly execute such request following all possible consultations with the requested State Part." Schabas, 2010-a, p. 1048. For a more elaborate discussion see Sluiter, 2002, pp. 320-325. 
ratifying the Statute. ${ }^{288}$ From the perspective of both the prosecution and the defence, this provision has been criticized. First, due to the conditions imposed, the powers of on-site investigations are too restrictive. Second, the power is only attributed to the ICC Prosecutor, thus raising questions in relation to equality of arms. ${ }^{289}$ What is particularly clear is that the discussion has focused on sovereignty issues of the states and not on any effect of this provision on the position of the accused. Indeed, this inequality between the investigative powers of the prosecution and the defence is rather common and does not in itself lead to a violation of the principle of equality of arms. In any case, states are not inclined to pursue any changes to this provision, one of the hard won compromises of the ICC Statute, either to strengthen the powers of an international prosecutor, at the expense of state sovereignty; or, and that is even more problematic, to provide the defence with the same power. ${ }^{290}$

In relation to the enforcement of state cooperation, the only 'hard' power in the hands of the international criminal courts is the possibility to report to the Security Council about any lack of state cooperation. ${ }^{291}$ As practice has shown, the Security Council is reluctant to act upon the courts' referral of non-cooperation. ${ }^{292}$ Encouraging states

288 SAFFERLING, 2011, p. 657.

289 See Sluiter and Schabas, 2010, p. 10: "First, the powers attributed are too restrictive, subject to too many limitations and conditions. Second, the powers contained in that provision are exclusively attributed to the Prosecutor, leaving defence and chambers empty-handed; from a fair trial perspective, this raises a serious problem in terms of equality of arms. The scope and content of art. 99(4) have been criticized in the literature, and this forms the basis for this question."

290 See Sluiter and Schabas, 2010, p. 11: “ ... there is no strong inclination to improve the powers to conduct on-site investigations. It may be a long term aim for the ICC, possibly in the framework to improve other aspects of the cooperation regime, like enforcement. This position was echoed at the Otzenhausen-meeting. Committee members agreed that Article 99(4) potentially raises an equality of arms - problem and that it is important to draw the attention of the Assembly of States Parties to this matter. However, certain members also indicated that amendments to Article 99(4) are likely to be inconsistent with domestic legislation regulating cooperation with the ICC and may cause significant problems in terms of effective implementation at the national level."

291 Rule 7bis ICTY/ICTR RPE. Article 87(7) ICC Statute. Prosecutor v. Blaškić, Judgement on the Request of the Republic of Croatia for Review of the Decision of Trial Chamber II of 18 July 1997, IT-95-14, A. Ch., 29 October 1997, par. 33. Within ICC, Article 87 (5) and (7) and ICC, Prosecutor v. Hurun ("Ahmad Hurun") and Abd-Al-Rahman ("Ali Kushayb"), the Decision, Public Document Informing the United National Security Council about the lack of cooperation by the Republic of Sudan, Situation in Darfur, Sudan, in the case of the ICC-02/05-01/07, T. Ch., 25 May 2010, (inherent power to refer a case of non-compliance by a non-state party referred to the Court by UN SC; "CONSIDERING that, by virtue of Security Council Resolution 1593 (2005), when the Republic of the Sudan fails to cooperate with the Court, thereby preventing the Court from executing the task entrusted to it by the Security Council, the Court has the inherent power to inform the Security Council of such a failure; ..." ").

292 Bass, 2001, p. 223. Rastan, 2008, p. 438 (referring to MERon, 1999, p. 347). Rastan further argues that "while notifications and reports of non-compliance have not led to the adoption of enforcement measures by the Security Council itself, they have exercised considerable influence on other multi- 
to cooperate through other, political, avenues such as "the threat of exclusion from other areas of international life", might be the only effective power to enforce state cooperation for international criminal courts. ${ }^{293}$

The first ICTY case, Tadic, where the defence complained about a lack of state cooperation with regard to the collection of evidence, bringing about substantial inequality between parties, led to the first discussion of the application of equality of arms in this context. The Appeals Chamber came to the conclusion that "under the Statute of the International Tribunal the principle of equality of arms must be given a more liberal interpretation than that normally upheld with regard to proceedings before domestic courts." ${ }^{294}$ It reached this conclusion after the discussion of the different circumstances under which the Tribunal has to operate, as compared to the national courts. The Tribunal lacks the extensive enforcement powers of a state and is completely dependant on state cooperation without having the power of enforcement. The Chamber submitted that equality of arms implies "that the Prosecution and the Defence must be equal before the Trial Chamber." 295 Consequently, the Trial Chambers shall assist the parties as much as possible in presenting their case. ${ }^{296} \mathrm{In}$ addition, the Appeals Chamber reiterated the fact that Trial Chambers are cognisant of the difficulties that parties face when collecting evidence on the territory of an uncooperative state. ${ }^{297}$ The Appeals Chamber implied that the principle of equality of arms provides for procedural equality between the parties concerning access to the Tribunal's procedures available to facilitate access to evidence. ${ }^{298}$ In this regard, a more liberal interpretation might refer to the application of that principle to both parties, instead of only to the defence as exemplified by the human rights jurisprudence. Not clear are the consequences that should be attached when the Chamber has done all that it could without avail. The Chamber does refer to exceptional circumstances, when the lack of state cooperation would deny the defence the ability to prepare for trial, and its power to issue a stay of proceedings. What these exceptional circumstances

and bilateral processes affecting the states of the former Yugoslavia” (p. 439).

293 RASTAN, 2008, p. 439. Although "[s]uch multilateral support for the work of the Court, however, is, by its nature, both unpredictable and subject to competing priorities" (Id. 439-440), it might just provide enough 'leverage' in relation to more vulnerable states emerging from a conflict situation.

294 ICTY, Prosecutor v. Tadić, Judgement, IT-94-1-A, 15 July 1999, A. Ch., par. 51.

295 ICTY, Prosecutor v. Tadić, Judgement, IT-94-1-A, 15 July 1999, A. Ch., par. 52.

296 ICTY, Prosecutor v. Tadić, Judgement, IT-94-1-A, 15 July 1999, A. Ch., par. 52. See also e.g. ICTR, Prosecutor v. Renzaho, Judgment and Sentence, ICTR-97-31-T, T. Ch. I, 14 July 2009, adding in par. 62: "Provisions under the Statute and the Rules exist to alleviate the difficulties faced by parties by empowering the Chambers to issue such orders, summonses, subpoenas, warrants and transfer orders as may be necessary for the purposes of investigation or for the preparation or conduct of trial. In addition, where such measures have proved to no avail, a Chamber may order that proceedings be adjourned or, if the circumstances so require, that they be stayed" [footnote references omitted].

297 ICTY, Prosecutor v. Tadić, Judgement, IT-94-1-A, 15 July 1999, A. Ch., par. 52.

298 See also, McInTYre, 2003, p. 275. 
would be in practical terms neither becomes clear from this decision, nor can they be observed in subsequent practice. In light of this, it is interesting to see how the defence utilized the Court's powers in that regard, and more specifically how the Chambers have approached their obligation to support the defence in its efforts to obtain sufficient state cooperation.

\subsubsection{State cooperation order requirements}

\subsubsection{Ad hoc tribunals}

Whenever the "avenues of request for voluntary cooperation" have been exhausted without success, recourse to a formal request for cooperation from the Trial Chamber will be necessary. ${ }^{299}$ According to Rule 54bis ICTY RPE, the Chambers can issue binding orders for state cooperation. Before this Rule entered into force in 1999, judges could rely on their general power under Rule 54 for issuing “ ... orders, summonses, warrants and transfer orders as may be necessary for the purposes of an investigation or for the preparation or conduct of the trial", which will be discussed in the section hereunder.

In relation to Rule 54bis, before a Chamber will issue an official order for cooperation, several threshold requirements have to be met. ${ }^{300}$ In Blaškić, the Appeals Chamber identified the following criteria for an order for the production of documents to be met:

(i) identify specific documents and not broad categories. In other words, documents must be identified as far as possible and in addition be limited in number. The Appeals Chamber agreed with the submission of counsel for the accused [46] that, where the party requesting the order for the production of documents is unable to specify the title, date and author of documents, or other particulars, this party should be allowed to omit such details provided it explains the reasons therefore, and should still be required to identify the specific documents in question in some appropriate manner. The Trial Chamber may consider it appropriate, in view of the spirit of the Statute and the need to ensure a fair trial referred to in Rule 89(B) and (D), to allow the omission of those details if it is satisfied that the party requesting the order, acting bona fide, has no means of providing those particulars;

299 ICTR, Prosecutor v. Bagosora et al., Request to the government of United States of America for cooperation, ICTR-98-41-T, T. Ch., 10 July 2002.

300 Rule 54bis

(A) A party requesting an order under Rule 54 that a State produce documents or information shall apply in writing to the relevant Judge or Trial Chamber and shall:

(i) identify as far as possible the documents or information to which the application relates;

(ii) indicate how they are relevant to any matter in issue before the Judge or Trial Chamber and necessary for a fair determination of that matter; and

(iii) explain the steps that have been taken by the applicant to secure the State's assistance. 
Parties’ Role During Investigations

(ii) set out succinctly the reasons why such documents are deemed relevant to the trial; if that party considers that setting forth the reasons for the request might jeopardise its prosecutorial or defence strategy it should say so and at least indicate the general grounds on which its request rests;

(iii) not be unduly onerous. As already referred to above, a party cannot request hundreds of documents, particularly when it is evident that the identification, location and scrutiny of such documents by the relevant national authorities would be overly taxing and not strictly justified by the exigencies of the trial; and

(iv) give the requested State sufficient time for compliance; this, of course, would not authorise any unwarranted delays by that State. Reasonable and workable deadlines could be set by the Trial Chamber after consulting the requested State. ${ }^{301}$

Subsequent case law, mostly referring to this decision, mentions three criteria laid down in Rule 54bis ICTY RPE: specificity, relevance and necessity ${ }^{302}$ First, the request should sufficiently specify the required materials or information for the authorities to be able to indentify them. ${ }^{303}$ The request should provide as many specifications

301 ICTY, Prosecutor v. Blaškić, Judgment on the request of the Republic of Croatia for review of the decision of Trial Chamber II of 18 July 1997, IT-95-14, A. Ch., 29 October 1997, par. 32. For a discussion see e.g. Cogan, 2000, p. 422 (referring to this Appeals Chamber's approach as "realistic" or "pragmatic": "The Chamber delicately balances the need for an effective investigation with a realistic assessment of the means by which an ICTY investigation is likely to succeed."). The binding order may be directed to a State and not to a state official, so as to leave that state "some choice or leeway in identifying the persons responsible for, and the method of, its fulfilments" (Blaškić, par. 43).

302 Although the ICTR RPE do not contain a comparable provision, the judges interpreted Article 28 as including the three criteria laid down in Rule 54bis ICTR RPE (and referring to the Blaškić Appeal Chamber judgement). See e.g. ICTR, Prosecutor v. Bagosora et al., Request to the Government of Rwanda for Cooperation and Assistance Pursuant to Article 28 of the Statute, ICTR-98-41-T, T. Ch., 10 March 2004, par. 4; ICTR, Prosecutor v. Bagosora et al., Decision on Request to the Republic of Togo for Assistance Pursuant to Article 28 of the Statute, ICTR-98-41-T, T. Ch., 31 October 2005, par. 2. ICTR, Prosecutor v. Bizimungu et al., Decision on Nzuwonemeye's Motion Requesting the Cooperation of the Government of Ghana Pursuant to Article 28 of the Statute, ICTR-99-56-T, 13 February 2006, par. 6; ICTR, Prosecutor v. Bizimungu et al., Decision on Casimir Bizimungu's Request for Disclosure of the Bruguiere Report and the Cooperation of France, ICTR-99-50-T, T. Ch., 25 September 2006, par. 25.

303 ICTR, Prosecutor v. Nahimana et al., Decision on the motion to stay the proceedings in the trial of Ferdinand Nahimana, ICTR-99-52-T, T. Ch., 5 June 2003, par. 11: "Hence, a party cannot request hundreds of documents, particularly when it is evident that the identification, location and scrutiny of such documents by the relevant national authorities would be overly taxing and not strictly justified by the exigencies of the trial." 
as possible and should be formulated in precise language ${ }^{304}$ However, the use of categories, as such, is not prohibited. ${ }^{305}$

The second requirement is that of relevancy to the proceedings, and constitutes "the second main reason for denial of orders of cooperation." 306 The materials sought must be relevant to any matter in issue before the Chamber and necessary for a fair determination of that matter. ${ }^{307}$ No 'fishing' expeditions are allowed. ${ }^{308}$ A binding order must not be unduly onerous on the state, taking into "account mainly whether the difficulty of producing the evidence is not disproportionate to the extent that process is 'strictly justified by the exigencies of the trial'. ${ }^{309}$ It requires a balancing of:

the need, on the one hand, for the Tribunal to have the assistance of States in the collection of evidence for the purpose of prosecuting persons responsible for serious violations of international humanitarian law and the need, on the other hand, to ensure that the obligation upon States to assist the Tribunal in the evidence collecting process is not unfairly burdensome. ${ }^{310}$

304 ICTY, Prosecutor v. Milutinović et al., Decision on Second Application of Dragoljub Ojdanić for Binding Orders Pursuant to Rule 54bis, IT-05-87-PT, 17 November 2005; ICTR, Prosecutor v. Bizimungu et al., Decision on Prosper Mugiraneza's Motion Regarding Cooperation with the Republic of Burundi, ICTR-99-55-T, 30 October 2008; ICTR, Prosecutor v. Bagosora et al., Request to the Government of Rwanda for Cooperation and Assistance Pursuant to Article 28 of the Statute, ICTR-98-41-T, T. Ch., 10 March 2008; and ICTY, Prosecutor v. Hadžihasanvić et al., Decision on Defence Access to EUMM Archives, IT-01-47-PT, T. Ch., 12 September 2003.

305 ICTY, Prosecutor v. Kordić and Čerkez, Decision on the Request of the Republic of Croatia for a Review of a Binding Order, IT-95-14/2-AR108bis, 9 September 1999, par. 38: "The underlying purpose of the requirement of specificity is to allow a State, in complying with its obligation to assist the Tribunal in the collection of evidence, to be able to identify the requested documents for the purpose of turning them over to the requesting party. The question is then whether "documents which are only identifiable as members of a class, however clearly defined this may be and however readily the identification of its content may be made" fall foul of the requirement of specificity. The requirement of specificity clearly prohibits the use of broad categories, which, of course, in itself is a relative term. It does not, as correctly asserted by the Prosecution, prohibit the use of categories as such."

306 Newton 2011, pp. 422, 423: "A common trend in these decisions is that of defense attorneys requesting information contained in documents, or known by persons, about events that are physically or temporally distant form the events at issue at the trial."

307 See e.g. ICTR, Prosecutor v. Bagosora et al., Decision on Request for Cooperation of the Government of France, ICTR-98-41-T, 6 October 2006, par. 6: the Trial Chamber denied defence's request to issue a request to the Government of France, pursuant to Article 28 of the Statute, for the disclosure of a report concerning the attack on President Habyarimana's airplane on the night of 6 April 1994 (so- called "Bruguière Report") which allegedly blames the RPF for the attack ... ." The Chamber considered that this report lacked direct relevance to the core issues of the trial.

308 ICTR, Prosecutor v. Nzirorera et al., Decision on the Request to the Governments of United States of America, Belgium, France and Germany for Cooperation, ICTR-98-44-I, 4 September 2003.

309 Prosecutor v. Kordić and Čerkez, Decision on the Request of the Republic of Croatia for a Review of a Binding Order, IT-95-14/2-AR108bis, 9 September 1999, par. 41.

310 Prosecutor v. Kordić and Cerkez, Decision on the Request of the Republic of Croatia for a Review 
The defence is not required to know exactly the content of the documents sought or its potential effects on the outcome of the trial or the admissibility of evidence, however, to obtain a request for cooperation, the defence has to indicate that those documents could be relevant for assessing prosecution's evidence. ${ }^{311}$

Lastly, the party has to show that it has acted with due diligence in trying to obtain the required materials on his own. ${ }^{312}$ In this regard, the Appeals Chamber has considered:

that requiring an applicant to make a showing that he has exhausted all other possible avenues that may provide access to the information is too onerous and could inhibit the right to a fair trial. However, the Appeals Chamber recalls that it has held that a Trial Chamber's binding order to a State to produce documents or information must be 'strictly justified by the exigencies of the trial', in light of the reliance of the International Tribunal on the bona fide assistance and cooperation of sovereign States. Therefore, the Appeals Chamber holds that it is reasonable under the necessity requirement for an applicant to demonstrate either that: 1) it has exercised due diligence in obtaining the requested materials elsewhere and has been unable to obtain them; or 2) the information obtained or to be obtained from other sources is insufficiently probative for a fair determination of a matter at trial and thus necessitates a Rule 54 bis order. $^{313}$

In this regard a party has to show that prior reasonable efforts to gain state cooperation did not lead to success. It is not required to "exhaust all possible mechanisms before seeking intervention by the Chamber." 314 Interestingly, in this case the defence had sent a letter to the Registrar, who in turn transmitted a note verbale to the relevant state asking for assistance with the defence's request, to which no answer was forthcoming. ${ }^{315}$ This single attempt, according to the prosecutor, could not be qualified as a sufficient attempt to obtain state cooperation, and the defence had failed to utilize other options, including a mission to Burundi. ${ }^{316}$ The Chamber disagreed and argued that although there may have been other means available to obtain the

of a Binding Order, IT-95-14/2-AR108bis, 9 September 1999, par. 41.

311 ICTR, Prosecutor v. Karemera et al., Decision on Joseph Nzirorera's Motion to Request the Cooperation of the government of a State, ICTR-98-44-PT, T. Ch. III, 23 February 2005, par. 5.

312 ICTY, Prosecutor v. Milutinović et al., Decision on Second Application of Dragoljub Ojdanić for Binding Orders Pursuant to Rule 54bis, 17 November 2005.

313 ICTY, Prosecutor v. Milutinović et al., Decision on Request of the United States of America for Review, IT-05-87/AR108bis.2, A. Ch., 12 May, 2006, par. 25.

314 ICTR, Prosecutor v. Bizimungu et al., Decision on Proseper Mugiraneza's Motion Regarding Cooperation with the Republic of Burundi, ICTR-99-50-T, 30 October 2008, par. 14.

315 ICTR, Prosecutor v. Bizimungu et al., Decision on Proseper Mugiraneza's Motion Regarding Cooperation with the Republic of Burundi, ICTR-99-50-T, 30 October 2008, par. 12.

316 ICTR, Prosecutor v. Bizimungu et al., Decision on Proseper Mugiraneza's Motion Regarding Cooperation with the Republic of Burundi, ICTR-99-50-T, 30 October 2008, par. 13. 
required documents, the defence had done enough. ${ }^{317}$ In light of the limited resources of the defence, and the potential difficulties in conducting a mission as proposed by the prosecutor, this low-threshold approach adopted by the Chamber concerning the 'due diligence' standard is preferable. ${ }^{318}$

Moreover, with regard to this third requirement of due diligence, an ICTY Trial Chamber has determined that this requirement is fulfilled even when a party refuses to accept materials provided pursuant to a conditional offer of confidentiality. ${ }^{319}$ However, this finding was reversed on appeal where the Appeals Chamber argued that "[a] party may not bypass a State's cooperative efforts to assist it with gaining access to certain confidential information simply because that party does not want the State to be able to utilize the protections afforded to it through Rule 70." ${ }^{320}$ Thus, Ojdanić did not fulfil the due diligence requirement when he failed to accept a conditional offer of confidentiality from the US. The Appeals Chamber did, however, agree with the Trial Chamber's view that "[a] State cannot arrogate to itself the right to limit the request of an applicant to material that it considers to be favourable to the Applicant's case." ${ }^{321}$ Namely, it is for the applicant to determine what he is to use for his case.

317 In fact, in Ngirabatware, the Prosecutor sought a cooperation order from the Trial Chamber after the French Government advised the Prosecution to seek such a cooperation request. No official response was provided, but the Prosecutor gave his word that France indeed wanted a cooperation order from the Chamber. The Defence argued that the Prosecution did not meet the threshold of due diligence, because it could not substantiate this advice. The Chamber considered that an annexed Prosecution request was enough to establish due diligence, and more particularly, that the "apparent lack of a written response from the French government should not prejudice the Prosecution's ability to secure the documents it requires to conduct an effective cross-examination of Defence witnesses." ICTR, Prosecutor v. Augustin Ngirabatware, Decision on Prosecution Motion Requesting a cooperation order directed to France, ICTR-99-54-T, T. Ch. II, 30 March 2011, par. 16.

318 In Naletilić and Martinović, the Trial Chamber declined to issue a subpoena duces tecum to the Deputy Minister of Defence of Bosnia and Herzegovina, for the reason that the defence had not exercised reasonable due diligence. The defence had (1) not followed the advice of the Minister (by a letter of 15 July 2002) to address the request to the Deputy Minister, and (2) waited until 25 September 2002 before requesting the Chamber. ICTY, Prosecutor v. Naletilić and Martinović, Decision on Accused Naletilic Request for issuance of subpoena duces tecum per Rule 54, IT9834-T, T. Ch. 25 October 2002.

319 ICTY, Prosecutor v. Milutinović et al., IT-05-87-PT, T. Ch., 23 November 2005, Decision on Second Application of Dragoljub Ojdanić for Binding orders pursuant to Rule 54bis, par. 24 (par. 23: It should be noted that, although the Applicant at some point accepted the USA's offer to view certain material pursuant to Rule 70, the USA limited its search in relation to paragraph (A) to exculpatory material, thereby failing to satisfy the Applicant's request in its entirety. A State cannot arrogate to itself the right to limit the request of an applicant to material that it considers to be favourable to the Applicant's case. If a specific request is made for the production of material relevant to an issue in the case, then the primary obligation of a State is to co-operate with the Applicant by searching for any material falling within the terms of the Request. It is for the Applicant to determine which documents, if any, of those produced should be used in his case.).

320 ICTY, Prosecutor v. Milutinović et al., Decision on Request of the United States of America for Review, IT-05-87/AR108bis.2, A. Ch., 12 May, 2006, paras. 31, 37.

321 ICTY, Prosecutor v. Milutinović et al., Decision on Request of the United States of America for 
Importantly, the obligation of due diligence is significant for its broader application to procedures before and during trial and on appeal. ${ }^{322}$

Additionally, the defence has an independent duty to take reasonable steps to obtain the necessary materials from a state. In Simba, the defence requested the Chamber to issue a binding order to Rwanda to produce the judicial documents of certain detained witnesses for the prosecution. The Chamber declined to do so because the defence had not satisfied the threshold requirement of due diligence. ${ }^{323}$ In this case, the defence had requested the prosecutor to obtain these documents, and argued later that if even the prosecutor could not obtain the needed documents, the defence would automatically face the same fate. ${ }^{324}$ The Trial Chamber declined to make such an inference, and reasoned that "the Defence is not relieved of its obligation because the prosecution has not yet been successful." ${ }_{325}$ According to the Chamber, the authority to compel state cooperation based on the state's obligations under Chapter VII UN Charter, by issuing a binding order, is not to be used lightly. ${ }^{326}$ Moreover, the Chamber disagreed with the defence's contention that the production of judicial documents relating to the prosecution's detained witnesses falls within the obligation of the prosecutor to disclose evidence that "may affect the credibility of Prosecution evidence" (Rule 68 ICTR RPE). It referred to its earlier decision in the same case where it argued that the prosecution's obligation to disclose exculpatory

Review, IT-05-87/AR108bis.2, A. Ch., 12 May, 2006, par. 27.

322 ICTY, Prosecutor v. Krstić, Decision on Application of Subpoenas, IT-98-33-A, A. Ch., 1 July 2003, par. 5 (Referring to 'due diligence' in the context of the admissibility of additional evidence on appeal. Due diligence meaning that the defence must show that it made use of all the available mechanisms under the Statute and Rules for protection and compulsion and that it brought any difficulties in relation to obtaining evidence on behalf of the accused, including those arising from intimidation or an inability to locate witnesses, to the attention of the Trial Chamber).

323 ICTR, Prosecutor v. Simba, Decision on Matters Related to Witness KDD's Judicial Dossier, ICTR01-76-T, 1 November 2004.

324 ICTR, Prosecutor v. Simba, Decision on Matters Related to Witness KDD's Judicial Dossier, ICTR01-76-T, 1 November 2004, par. 5.

325 ICTR, Prosecutor v. Simba, Decision on Matters Related to Witness KDD's Judicial Dossier, ICTR01-76-T, 1 November 2004, par. 10.

326 ICTR, Prosecutor v. Simba, Decision on Matters Related to Witnesses KDD's Judicial Dossier, ICTR-01-76-T, 1 November 2004, par. 9. In relation to the standing of the state in a state cooperation request procedure, the Appeals Chamber considered that rather than having a right to be heard before the issuance of a binding order, the affected state had the opportunity to challenge that order according to Rule 108bis RPE procedure. In connection to the State's request to be heard beforehand, the Appeals Chamber stressed "that the issuance of a binding order by a Trial Chamber does not indicate a finding of a failure of a State to fulfil its obligations under the Statute and the United Nations Charter." However, it did consider that a binding order might "become necessary whenever co-operation is found to be inadequate for the purpose of obtaining such documents as are required for the conduct of a trial." A binding order is thus one step before finding a failure to cooperate. See ICTY, Prosecutor v. Kordic and Čerkez, Decision on the Request of the Republic of Croatia for Review of a Binding Order, IT-95-14/2, A. Ch., 9 September 1999, paras. 17-18. 
evidence under Rule 68 RPE only extends to material in its possession. ${ }^{327}$ Notably, the Chamber considered that " $[\mathrm{t}]$ he Prosecution's disclosure obligations under the statute and the Rules do not extend to pursuing every possible avenue of investigations into a witness's credibility on behalf of the Defence." 328 The disclosure of judicial documents relating to the prosecution's own detained witnesses, in all fairness, does not seem to extend to cover "every possible avenue" of investigations for the sake of the defence. Interestingly, the Trial Chamber seemed to acknowledge this because it decided to facilitate the defence proprio motu by instructing the prosecutor to make all necessary efforts to obtain the judicial records of witness KDD and to report to the Chamber on the progress and results of these efforts. ${ }^{329}$ The Chamber based this order on its Rule 98 power to order the production of additional evidence. ${ }^{330}$ According to the Chamber, Rule 98 may be invoked to expedite proceedings with respect to the production of the judicial records of detained witnesses "given the importance of these records to the preparation of the parties and given the familiarity of the Prosecution with its witnesses." ${ }_{331}$ Because this is an order to the prosecution, the threshold of due diligence as with state binding orders does not apply.

\subsubsection{International Criminal Court}

In the context of the ICC, Article 57(3)(a) and (b) of the Statute provides a basis for Pre-Trial Chamber's power to issue the necessary orders pursuant to party's request. Thus, Article 57(3)(a) authorizes the Chamber, at the request of the prosecutor, to issue such orders and warrants (involving coercive measures) as may be required for the purposes of an investigation. Moreover, as mentioned above, all the investigative measures deemed necessary by the Prosecution have to be authorized and supervised by national authorities. A possibility for the ICC Prosecutor to perform investigative acts on the territory of a state party without the presence of the national authorities is provided for in Article 99(4) ICC Statute and applies only to non-compulsory measures under strict conditions. The other possibility for the ICC Prosecutor to perform certain on-site investigative steps specifically authorized by the Chamber, is in case of a 'failed state' scenario (Article 57(3)(d) ICC Statute). It is only to this extent that states have to allow direct on-site investigations by the ICC Prosecutor.

327 ICTR, Prosecutor v. Simba, Decision on Matters Related to Witness KDD's Judicial Dossier, ICTR01-76-T, 1 November 2004, par. 12.

328 ICTR, Prosecutor v. Simba, Decision on Matters Related to Witness KDD's Judicial Dossier, ICTR01-76-T, 1 November 2004, par. 12.

329 ICTR, Prosecutor v. Simba, Decision on Matters Related to Witness KDD's Judicial Dossier, ICTR01-76-T, 1 November 2004, paras. 7, 15.

330 Rule 98 ICTR RPE states: “A Trial Chamber may order either party to produce additional evidence. It may proprio motu summon witnesses and order their attendance."

331 ICTR, Prosecutor v. Simba, Decision on Matters Related to Witness KDD's Judicial Dossier, ICTR01-76-T, 1 November 2004, par. 11. 
The horizontal relationship between the ICC and state parties complicates the issue of the scope of state duty to cooperate with the court. From a legal point of view, the ICC cooperation regime has been deemed weaker than that of the ad hoc tribunals. ${ }^{332}$ Potentially, this could affect the defence more negatively than the Prosecution, in light of the absence of a state duty to cooperate with the defence. The following remarks will therefore focus particularly on the possibility of judicial assistance in seeking state cooperation for the performance of on-site investigations.

As mentioned, under Article 57(3)(b) of the ICC Statute the defence can request the Pre-Trial Chamber to issue such orders that may be necessary to assist in the preparation of the defence. ${ }^{333}$ It has been argued that this paragraph "attempts to balance the situations of the accused person and the prosecutor at the pre-trial stage, by providing - even if incompletely - some degree of equality of arms during this procedural phase, rather than obliging the defence to rely solely on his or her right of cross-examination at trial." ${ }^{334}$ Rule 116 further elaborates that an order shall be issued when two cumulative conditions are satisfied: (1) such an order "would facilitate the collection of evidence that may be material to the proper determination of the issues being adjudicated, or to the proper preparation of the person's defence"; and (2) in case of cooperation (Part 9), sufficient information to comply with Article 96(2) has been provided. ${ }^{335}$ This latter article contains the requirement that a written request for state assistance should contain an order to avoid "fishing expeditions". ${ }^{336}$ On its face, these requirements are much more detailed and potentially more demanding on the part of the defence than the requirement of Rule 54bis ICTY and its case law. If

332 SLUiter, 2002, p. 344.

333 In contrast to Article 57(3)(a), which allows the Pre-Trial Chamber to issue, "at the request of the Prosecutor, such orders and warrants as may be required for the purposes of an investigation", sub-paragraph (b) mentions only orders and not warrants for the benefit of the defence. A 'warrant' is defined as "a writ directing or authorizing someone to do an act, especially one directing a law enforcer to make an arrest, a search, or a seizure." An 'order' is defined as "a command, direction, or instruction; a written direction or command delivered by a court or judge." See BLACK's LAW DiCTIONARY, 1999.

334 Guariglia, Harris and Hochmayr, 2008, pp. 1123-1124.

335 ICC, Prosecutor v. Katanga and Ngudjolo Chui, Decision on the "Defence's Application pursuant to Article 57(3)(b) of the Statute to Seek Cooperation of the Democratic Republic of Congo (DRC)", ICC-01/04-01/07-444, 25 April 2008, p. 5 [Katanga and Ngudjolo Chui Decision on Article 57(3) (b) request].

336 Katanga and Ngudjolo Chui Decision on Article 57(3)(b) request, footnote 17. Article 96(2) provides: "The request shall, as applicable, contain or be supported by the following: (a) a concise statement of the purpose of the request and the assistance sought, including the legal basis and the grounds for the request; (b) as much detailed information as possible about the location or identification of any person or place that must be found or identified in order for the assistance sought to be provided; (c) a concise statement of the essential facts underlying the request; (d) the reasons for and details of any procedure or requirement to be followed; (e) such information as may be required under the law of the requested State in order to execute the request; and (f) any other information relevant in order for the assistance sought to be provided. 
not applied as a mere formality, the requirements of Article 96(2) could present an obstacle for the defence in obtaining a cooperation request from the Trial Chamber. It is not yet clear how exactly the Pre-Trial Chamber is to apply these thresholds or what their relationships is, except for the fact that it concerns two cumulative conditions. It has been argued that "[t]he Chamber may ... assist the defence in obtaining the missing information, if the defence meets with disproportional difficulties to obtain it." ${ }^{337}$ This seems to imply a certain degree of due diligence on the part of the defence, a requirement that is not explicit in the relevant legal provisions.

In Katanga \& Ngudjolo Chui the defence requested the Pre-Trial Chamber to issue a cooperation request to the DRC pursuant to Article 57(3)(b) ICC Statute to obtain eight items of information. ${ }^{338}$ Katanga had sought cooperation on his own; however, the DRC authorities informed the defence that they could not cooperate on this matter. ${ }^{339}$ The Pre-Trial Chamber considered it necessary to assist the defence in obtaining some documents but not others. For the first category of documents, the Chamber ordered the Registrar to prepare a cooperation request, containing the necessary Articles 93 and 96 information and to transmit it to the relevant DRC authorities. ${ }^{340}$ With regard to the second category of documents, however, the Chamber considered that these documents were "likely to be in the possession or control of the Prosecution", so the defence was first required to approach the prosecutor through a Rule 77 inspection of his materials. ${ }^{341}$ With regard to one item sought by the defence, the Chamber considered that an intervention was not 'necessary' at this stage because it is the Registrar who is responsible for the execution of arrest warrants, and consequently, “ "... the Defence of Germain Katanga can file a motion requesting the Chamber to order the Registry to provide the relevant information on the execution of the warrant of arrest for Germain Katanga." ${ }^{342}$ It is not clear why the Chamber chose this seemingly cumbersome approach.

Judge Anita Ušaka issued an interesting partly dissenting opinion that directly touches upon the principle of equality of arms in the context of cooperation requests. ${ }^{343}$ Judge Ušaka disagreed with the majority not to seek cooperation for three items due to their 'unnecessary' nature at that stage, because "the conclusion of the majority that the specific information requested could be obtained from another source is not

337 Guariglia, Harris and Hochmayr, 2008, p. 1125.

338 Katanga and Ngudjolo Chui Decision on Article 57(3)(b) request.

339 Katanga and Ngudjolo Chui Decision on Article 57(3)(b) request, pp. 5-6.

340 Katanga and Ngudjolo Chui Decision on Article 57(3)(b) request, p. 10. According to the Chamber, the defence has provided sufficient information to satisfy the Article 96(2) ICC Statute requirements.

341 Katanga and Ngudjolo Chui Decision on Article 57(3)(b) request, p. 6.

342 Katanga and Ngudjolo Chui Decision on Article 57(3)(b) request, p. 7.

343 Partly Dissenting Opinion of Judge Anita Ušaka attached to the Decision on the "Defence's Application pursuant to Article 57(3)(b) of the Statute to Seek Cooperation of the Democratic Republic of Congo (DRC)", Prosecutor v. Katanga, ICC-01/04-01/07-444, 25 April 2008 [Partly Dissenting Opinion to Katanga and Ngudjolo Chui Decision on Article 57(3)(b) request]. 
only not supported by the record, but also sets the threshold too high for granting a cooperation request, and appears to create an unnecessary additional requirement for Article 57(3)(b) requests." ${ }^{444}$ Rule 116 resulted from a balanced negotiation process as to the appropriate threshold for granting the defence's requests for assistance. ${ }^{345}$ According to Judge Ušaka, Rule 116(1) sets a relatively low standard for the Chamber to apply (an order should be issued when it "would facilitate the collection of evidence that may be material to the proper determination of issues or preparation of the defence). ${ }^{346}$ Indeed, the 'necessity to defence preparation' requirement was omitted from Rule 116 in the final draft of that Rule, and accordingly, the "majority's analysis as to whether the information requested is "necessary" for the defence" in Judge Ušaka's view sets too high a threshold.

Although this interpretation of Article 57(3)(b) would indeed set a higher standard than the one elaborated in Rule 116(1) RPE, the majority's view does not seem to do that. The decision did not find the material requested not to be necessary to the defence, something that Judge Ušaka seemed to suggest, but it rather found the Chamber's intervention to assist the defence in obtaining these materials to be unnecessary at this stage. The reason for this was the possibility for the defence to obtain the documents elsewhere. Although not mentioned explicitly, this reasoning seems to support a 'due diligence' requirement on the part of the defence before seeking assistance from the Chamber, as discussed above in the context of the $\mathrm{ad}$ hoc tribunals. Although reading a requirement of due diligence into Article 57(3)(b) would not improperly raise the standard for the issuance of a state cooperation order, this requirement should be interpreted reasonably broadly so as to keep the standard low. In other words, it would not be unreasonable for the defence to try to obtain the materials on their own before addressing the Chamber for assistance, but it would be unreasonable to require the defence to pursue all possible lines of inquiry. ${ }^{347}$ And it is exactly this point that seems to be a weak point in this majority decision as correctly pointed out by Judge Ušaka.

Indeed, Rule 116(2) gives the Pre-Trial Chamber the discretionary authority to consult with the prosecutor before issuing an order according to Article 57(3)(b) and Rule 116(1). As discussed above, this measure seems sensible in light of the prosecutor's duty to search for both inculpatory and exculpatory materials (Article 54) and the demands of efficiency and expeditiousness. Simply stated, the prosecutor might already possess the documents sought by the defence, which would avoid going through the state cooperation channels. However, when the involvement

344 Partly Dissenting Opinion to Katanga and Ngudjolo Chui Decision on Article 57(3)(b) request, par. 3.

345 Partly Dissenting Opinion to Katanga and Ngudjolo Chui Decision on Article 57(3)(b) request, paras. 9-10.

346 Partly Dissenting Opinion to Katanga and Ngudjolo Chui Decision on Article 57(3)(b) request, par. 10 [emphasis added].

347 Cf. Guariglia, Harris and Hochmayr, 2008, p. 1125. 
of the prosecution seems unwarranted in light of the defence's case preparation strategy, the Pre-Trial Chamber should assist the defence without the involvement of the prosecutor. ${ }^{348}$ In fact, in Katanga and Ngudjolo Chui the Pre-Trial Chamber explicitly considered the prosecutor's involvement to be unnecessary considering the nature of some of the requested documents. ${ }^{349}$ In its decision, the Pre-Trial Chamber neither specified the exact items to which ex parte consideration would apply (or why not), or why the defence should approach the prosecutor in relation to two items when it approached the Chamber ex parte. Moreover, with regard to the scope of 'due diligence', the Defence did approach both the DRC and the prosecutor, but to no avail. ${ }^{350}$ The majority decision does not reflect upon this.

In conclusion, this decision unfortunately poses more questions than it provides answers to in relation to the topic of Pre-Trial Chambers' assistance in defence preparation. Clearly, the drafters intended to provide "some degree of equality of arms in the collection of evidence at the Pre-Trial stage" through Article 57(3)(b). ${ }^{351}$ In the Katanga and Ngudjolo Chui decision the Chamber seems to introduce the requirement of 'due diligence' on the part of the defence, without mentioning this explicitly, discussing the parameters, or elaborating on its application in the present case. More generally, the Chamber did not reflect on the right of the defence to prepare a defence, equality of arms, or the Chamber's role in this regard. ${ }^{352}$ No supporting references were made. In light of the fact that this decision touches upon an important issue for the defence's preparations and it concerns the first decision on the application of Article 57(3)(b) and Rule 116(1), some more elaboration would not have been redundant.

There are a couple of more recent decisions on the application of Article 57(3)(b) ICC Statute, and specifically the requirement of 'necessity.' In Banda and Jerbo the defence requested the Pre-Trial Judge to issue a request to the Republic of Sudan to

348 Although the defence could approach the Prosecutor, before requesting the Chamber for assistance, it seems it does not have to do so. "The Chamber has to decide on a case-to-case basis whether to seek the Prosecutor's views. In making this decision, the Chamber must consider all relevant interests, including the interests of the defence, the protection of victims and witnesses, the integrity of the investigations, and, as far as possible, the avoidance of double requests for State cooperation." Guariglia, Harris and Hochmayr, 2008, p. 1125.

349 Katanga and Ngudjolo Chui Decision on Article 57(3)(b) request, p. 4.

350 Katanga and Ngudjolo Chui Decision on Article 57(3)(b) request, pp. 5-6. Judge Ušaka pointed out that the Defence had also requested the same items from the Prosecution, but to no avail. Partly Dissenting Opinion to Katanga and Ngudjolo Chui Decision on Article 57(3)(b) request, par. 13.

351 Partly Dissenting Opinion to Katanga and Ngudjolo Chui Decision on Article 57(3)(b) request, par. 6.

352 As pointed out by Judge Ušaka, the ICC legal framework does seem to support the proposition that the Defence may not seek cooperation from a State when there is another source that can provide this information. The defence should be able to consult different sources to be able to compare or corroborate. Partly Dissenting Opinion to Katanga and Ngudjolo Chui Decision on Article 57(3)(b) request, par. 23 . 
provide various forms of assistance to the defence team to be able to properly prepare the case. ${ }^{353}$

The defence on its own had attempted to persuade Sudan to cooperate in providing access to the defence for on-site investigations; however, these attempts were not successful. ${ }^{354}$ The Pre-Trial Judge considered that the defence had failed to provide sufficient reasons why it was necessary for the Pre-Trial Chamber to assist the defence at this stage, "in particular in light of the strategy pursued by the Defence in respect of the forthcoming confirmation hearing." ${ }^{355}$ The defence agreed, for the purpose of the confirmation hearing, not to contest any of the material facts charged, not to challenge the charges or evidence, or to present evidence. ${ }^{356}$ Consequently, the Pre-Trial Judge considered that "any investigative step which might be taken, as well as any evidentiary material which might be collected, following an order issued pursuant to article 57(3)(b) would serve no purpose for the pre-trial phase of the case, namely in respect of the confirmation hearing which will conclude it." ${ }_{357}$ Moreover, according to the Judge, "[i]t appears significant that the Defence Application (as opposed to the request initially addressed by the Defence to the Registry) only refers to the need to "prepare its case", or to "the proper preparation of the defence", and that no mention is made of the confirmation hearing." 358 The Pre-Trial Judge emphasized that after the confirmation of charges, in the event the charges were confirmed, the Defence could file a new application for a cooperation request with the Trial Chamber assigned to the case. ${ }^{359}$ In effect, this decision makes a somewhat artificial distinction between the pre confirmation of charges stage and post confirmation of charges stage in relation to the defence case preparation, which can

353 ICC, Prosecutor v. Abdallah Banda Abakaer Nourain and Saleh Mohammed Jerbo Jamus, Decision on the "Defence Application pursuant to Article 57(3)(b) of the Statute for an order for the preparation and transmission of a cooperation request to the Government of the Republic of Sudan, ICC-02/05-03/09-95, 17 November 2010, par. 1 [Banda and Jerbo Decision on Article 57(3) (b) request]. See also ICC, Decision on the "Defence Request for an order for State Cooperation Pursuant to Article 57(3)(b) of the Rome Statute, Prosecutor v. Callixte Mbarushimana, ICC-01/0401/10, PTC I (Single Judge), 24 March 2011. The Defence submitted that it was essential for the preparation of a request for interim release that the Chamber sought the cooperation of France in order to obtain confirmation that the French authorities agreed to receive Mr. Mbarushimana onto French territory, should he be released" (p. 3). "Considering that it is for the Chamber to request observation from the State concerned (according to regulation 51) only if and when an application for interim release is made, and that it is not required that such observations should be obtained by the person applying for interim release and included in that person's application (p. 3) ... therefore, the information the defence seeks is not material to the proper preparation of a request for interim release, within the meaning of Rule 116(1)(a) of the Rules (p. 4)."

354 Banda and Jerbo Decision on Article 57(3)(b) request, par. 1.

355 Banda and Jerbo Decision on Article 57(3)(b) request, par. 3.

356 Banda and Jerbo Decision on Article 57(3)(b) request, par. 3.

357 Banda and Jerbo Decision on Article 57(3)(b) request, par. 4.

358 Banda and Jerbo Decision on Article 57(3)(b) request, par. 4.

359 Banda and Jerbo Decision on Article 57(3)(b) request, par. 5. 
neither be found in Article 57(3)(b) nor in Rule 116(1). It might be that the Pre-Trial Judge had in mind that in the event the charges were not confirmed, the case would be terminated and the defence would not have to investigate anything. However, not confirming the charges does not mean a complete dismissal of the case per se, as the prosecutor can always bring the charges anew. Moreover, the defence strategy to remain passive during the confirmation proceedings could slightly increase the chance that the charges in fact would be confirmed.

The defence applied for leave to appeal this decision. It argued that the requested order was "absolutely necessary for it to prudently continue its investigations at the pre-trial phase, with a view to ensuring an effective defence in the event the case proceeds to trial." ${ }^{360}$ The powers of the Pre-Trial Chamber extend beyond issuing orders that are only necessary for the purposes of the confirmation of charges hearing, as evidenced by Rule 116(1). ${ }^{361}$ According to the defence, the denial of assistance at this stage directly disturbs equality of arms that Article 57(3)(b) intends to safeguard. ${ }^{362}$ Moreover, it has a detrimental effect on efficient and expeditious process because (1) defence investigations will be delayed by at least two month (following the time frame for issuing a confirmation decision after the hearing); and (2) the delay may have an adverse impact on the quantity and quality of evidence the defence may be able to collect. ${ }^{363}$

The Pre-Trial Judge rejected the defence's application to appeal because an immediate resolution of this issue by the Appeals Chamber would not materially advance the proceedings. ${ }^{364}$ The Judge considered that even if the Appeals Chamber would be able to issue its decision very expeditiously, even before the confirmation of charges decision, this:

360 ICC, Prosecutor v. Abdallah Banda Abakaer Nourain and Saleh Mohammed Jerbo Jamus, Defence Application for Leave to Appeal the "Decision on the 'Defence Application pursuant to Article 57(3) (b) of the Statute for an order for the preparation and transmission of a cooperation request to the Government of the Republic of Sudan'" of 17 November 2010, ICC-02/05-03/09-105, 19 November 2010, par. 8 [Defence Application for Leave to Appeal], where the defence argued that "[a]n effect of the Decision may be that a defence team that intends to challenge the charges at confirmation (with the arguable effect that confirmation may be less likely) will obtain the assistance requested, whereas a Defence team that does not contest the charges (with the effect that confirmation may be more likely) will be denied the requested assistance and so hampered in its preparation for trial" (footnote 8).

361 Defence Application for Leave to Appeal, paras. 10-11.

362 Defence Application for Leave to Appeal, par. 14.

363 Defence Application for Leave to Appeal, paras.15-17.

364 ICC, Prosecutor v. Abdallah Banda Abakaer Nourain and Saleh Mohammed Jerbo Jamus, Decision on the "Defence Application for Leave to Appeal the 'Decision on the 'Defence Application pursuant to Article 57(3)(b) of the Statute for an order for the preparation and transmission of a cooperation request to the Government of the Republic of Sudan' of 17 November 2010", ICC-02/05-03/09-109, 30 November 2010. 
time-span of few [sic] days or weeks at the most, vis-à-vis proceedings which have already taken more that a year since the issuance of the summonses to appear for both suspects, cannot be regarded as possessing the degree of importance and significance which Article 82(1)(d) unequivocally requires for leave to appeal to be granted. ${ }^{365}$

Notably, the Judge took into account that the failure of the defence to submit the request for assistance earlier "makes the Defence's claims as to the urgency of the requested assistance less compelling." "366 The judge did not take into account the fact that the initial appearance of both suspects took place on 17 June 2010 - five months before the impugned decision was issued, or that the defence attempted to obtain cooperation from Sudan on their own and through the ICC Registry. ${ }^{367}$ Although one could see that the Appeals Chamber's decision would not substantially affect the course of proceedings in terms of the timeline at that moment, the Pre-Trial Judge's remark as to the 'urgency' of the defence's request seems unnecessary and unsubstantiated.

From this decision, it follows that when a defence chooses not to challenge the charges at the confirmation hearing or to present evidence, the right to obtain assistance from the Pre-Trial Chamber for any defence investigations at this stage would be forfeited. This directly interferes with the defence's ability to formulate a strategy with regard to its case. Agreeing not to challenge the charges at the confirmation of charges stage does not mean the defence is conceding the allegations and that it will not challenge the charges when the case goes to trial. In light of the efficiency and expeditiousness of the legal process, it is difficult to grasp why the defence would not get the assistance of the Court to prepare its case, when it has chosen not to contest the charges (for various reasons like expeditiousness or not revealing the defence case before there is a case to challenge). ${ }^{368}$

365 ICC, Prosecutorv. Abdallah Banda Abakaer Nourain and Saleh Mohammed Jerbo Jamus, Decision on the "Defence Application for Leave to Appeal the 'Decision on the 'Defence Application pursuant to Article 57(3)(b) of the Statute for an order for the preparation and transmission of a cooperation request to the Government of the Republic of Sudan' of 17 November 2010", ICC-02/05-03/09-109, 30 November 2010, par. 6.

366 ICC, Prosecutorv. Abdallah Banda Abakaer Nourain and Saleh Mohammed Jerbo Jamus, Decision on the "Defence Application for Leave to Appeal the 'Decision on the 'Defence Application pursuant to Article 57(3)(b) of the Statute for an order for the preparation and transmission of a cooperation request to the Government of the Republic of Sudan' of 17 November 2010", ICC-02/05-03/09-109, 30 November 2010, par. 6: "It is hard to see why waiting for a handful of weeks at the most would now result in irreparable prejudice to investigative activities, when such activities could well have been undertaken (and the appropriate assistance by the Chamber requested) at an earlier stage."

367 Banda and Jerbo Decision on Article 57(3)(b) request, par. 1.

368 Reference to practical / political issues such as the non-cooperative stance of Sudan towards the ICC, or to legal questions and practical restraints with regard to cooperation obligations of non-state parties to the ICC, were purposively omitted in this discussion, as they have not been made explicit in the relevant decisions. 


\subsection{OTHER ISSUES SURROUNDING THE COLLECTION OF EVIDENCE}

This section will discuss the possibility for parties to request the Trial Chamber or a judge to issue orders or subpoenas necessary for trial preparation. In this regard, two questions are interesting to reflect upon. What is the appropriate threshold for the issuance of such an order? And whether (and to what extent?) the Chambers have considered the specific circumstances under which an international criminal institution has to operate and the particular roles and responsibilities of the various parties when issuing such orders.

\subsubsection{Ad hoc tribunals - Rule 54 orders necessary for trial preparation}

Outside the context of state cooperation and before Rule 54bis was added to the ICTY RPE in November 1999, the general power under Rule 54 is of relevance when it comes to issuing " ... orders, summonses, warrants and transfer orders as may be necessary for the purposes of an investigation or for the preparation or conduct of the trial." Although, according to Rule 39(i) RPE, the prosecutor may "summon and question suspects, victims and witnesses and record their statements, collect evidence and conduct on-site investigations", if necessary, he must seek assistance from the judges to issue the necessary orders under Rule 54. ${ }^{369}$ With regard to unwilling witnesses, both the defence and prosecution are, in principle, in the same position before an international criminal court, they must both seek assistance from the Chamber to compel a witness to testify. ${ }^{370}$ Of course, the prosecutorial advantage might lie in its 'persuasive powers' (including the power to issue protective and immunity measures). A Rule 54 order presents the only opportunity for the defence to summon a witness or to provide the necessary protection or immunity to a potential witness. ${ }^{371}$

As such, Rule 54 provides the authority to compel a (unwilling) "prospective witness to attend at a nominated place and time in order to be interviewed by the defence where that attendance is necessary for the preparation or conduct of the

369 Rule 39(iv) ICTY RPE.

370 See ICTY, Prosecutor v. Mrksić, Decision on Defence Interlocutory Appeal on Communication with Potential Witnesses of the Opposite Party, IT-95-13/1-AR73, A. Ch., 30 July 2003: "Where, however, a person for any reason declines to be interviewed, the Prosecution does not have the power to compel the person to attend an interview or to respond to questions posed by the Prosecution. As the Trial Chamber correctly indicated, if the Prosecution or the Defence wishes to compel an unwilling person to submit to a pre-trial interview, then it must seek the assistance of the Chamber pursuant to Rule 54. Only subpoenas and other orders issued by the Tribunal have a legally binding effect that is enforceable by the application of criminal sanctions."

371 E.g. argued by the Krstić defence in the Defence Reply to the Prosecution's Response to Defence Motions for Admission of Additional Evidence under Rule 115, Prosecutor v. Krstić, IT-98-33-A, A. Ch. 20 February 2003, par. 6. 
trial." ${ }^{372}$ The Appeals Chamber in the Krstic case determined that "an order or a subpoena pursuant to Rule 54 would become 'necessary' for the purposes of that Rule where a legitimate forensic purpose for having the interview has been shown." ${ }^{773}$ Thus, when applying for an order or subpoena, the party must demonstrate "a reasonable basis for his belief that there is a good chance that the prospective witness will be able to give information which will materially assist him in his case, in relation to clearly identified issues relevant to the forthcoming trial." ${ }^{374}$ In Karadžić, the Trial Chamber determined that the application for a subpoena should be necessary for the preparation of the trial at this stage. ${ }^{375}$

The Appeals Chamber underlined that although this test would have to be applied "in a reasonably liberal way", the defence is not permitted to engage in a "fishing expedition", meaning a situation "where it [the defence] is unaware whether the particular person has any relevant information, and it seeks to interview that person merely in order to discover whether he has any information which may assist the defence." ${ }^{376}$ In this regard, it is interesting to note that the Krstic defence argued that where a witness has refused to be interviewed, it would be difficult for the defence to show that this witness is 'necessary' for the purposes of obtaining a Rule 54 subpoena. ${ }^{377}$ The Appeals Chamber agreed that where the defence is unaware of the precise nature of the evidence to be given by the prospective witness, it would be unreasonable to require the defence to use all mechanisms of protection and compulsion available to force the witness to give evidence 'cold' in Court. ${ }^{378}$ According to the Appeals Chamber, the defence is mistaken in assuming that Rule 54 only applies to compel

372 ICTY, Prosecutor v. Krstić, Decision on Application of Subpoenas, IT-98-33-A, A. Ch., 1 July 2003, par. 10.

373 ICTY, Prosecutor v. Krstić, Decision on Application of Subpoenas, IT-98-33-A, A. Ch., 1 July 2003, par. 10. Drawing guidance, by analogy, from the standard of legitimate forensic purpose necessary for applications for access to confidential material in other cases.

374 ICTY, Prosecutor v. Krstić, Decision on Application of Subpoenas, IT-98-33-A, A. Ch., 1 July 2003, par. 10. To assess whether this standard has been met, the following factors are considered relevant by the Appeals Chamber: (1) the position held by the prospective witness in relation to the events in question, (2) any relationship he may have (or have had) with the accused which is relevant to the charges, (3) the opportunity which he may reasonably be thought to have had to observe those events (or to learn of those events) and (4) any statements made by him to the prosecution or to others in relation to those events (id., par. 11).

375 ICTY, Prosecutor v. Karadžić, Decision on Motion for Subpoena to Douglas Lute and John Feeley, IT-95-5/18-PT, T. Ch., 8 July 2009, par. 14. A failure by the applicant to establish that the subpoena would be relevant for eventual sentencing led the Chamber to consider that the applicant "has failed to demonstrate a reasonable basis for his belief that there is a good chance that they [potential witnesses] will be able to give information which would materially assist him in his case at this stage."

376 Prosecutor v. Krstić, Decision on Application of Subpoenas, IT-98-33-A, A. Ch., 1 July 2003, par. 11.

377 ICTY, Defence Reply to the Prosecution's Response to Defence Motions for Admission of Additional Evidence under Rule 115, Prosecutor v. Krstić, IT-98-33-A, A. Ch. 20 February 2003, par. 7.

378 ICTY, Prosecutor v. Krstić, Decision on Application of Subpoenas, IT-98-33-A, A. Ch., 1 July 2003, par. 8 . 
witnesses to give evidence before the Chamber; rather "the appropriate mechanisms must also be used in the situation where the defence is unaware of the precise nature of the evidence the prospective witness can give and where the defence is unable to obtain his cooperation by speaking to it." ${ }^{379}$ The Appeals Chamber considers this to be within the determination of the scope of the 'due diligence' standard that has to be fulfilled on appeal. On its face, this statement seems to be contrary to the above prohibition of 'fishing expeditions.' Does the Appeals Chamber imply that in order to satisfy the due diligence requirement on appeal, the defence is advised to bring even the 'fishing' missions to the attention of the Trial Chamber so as to 'cover all the tracks'? The implication is there when the Appeals Chamber considers that drawing the attention of the Trial Chamber to the uncooperative stance of certain witnesses is the first step towards the fulfilment of due diligence and in addition it is "a means of self-protection, in that a contemporaneous record then exists that the cooperation of the prospective witness had not been obtained." 380

In Halilović, the Appeals Chamber underlined the intrusive nature of a subpoena, ${ }^{381}$ and considered that when deciding whether the evidentiary threshold has been met, a Trial Chamber may consider two factors: (1) whether the information sought through a subpoena is necessary for the preparation of the case and (2) whether the information is obtainable through other means. ${ }^{382}$ The focus is thus not only on "the usefulness of the information to the applicant" but also "on its overall necessity in ensuring that the trial is informed and fair." ${ }^{\prime 3} 3$ In this case, the Appeals Chamber determined that

379 ICTY, Prosecutor v. Krstić, Decision on Application of Subpoenas, IT-98-33-A, A. Ch., 1 July 2003, par. 9.

380 ICTY, Prosecutor v. Krstić, Decision on Application of Subpoenas, IT-98-33-A, A. Ch., 1 July 2003, par. 14. The second step it to seek the Trial Chamber's assistance, and if relief is denied by the Trial Chamber or the steps taken prove unsuccessful, the defence would have discharged its due diligence in relation to that witness (id., par.15).

381 ICTY, Prosecutor v. Halilović, Decision on the Issuance of Subpoenas, IT-01-48-AR73, 21 June 2004, par. 6

382 ICTY, Prosecutor v. Halilović, Decision on the Issuance of Subpoenas, IT-01-48-AR73, 21 June 2004, par. 7. As described in Prosecutor v. Delalić et al., Decision on the Motion Ex Parte by the Defence of Zdravko Mucic concerning the Issue of a Subpoena to an Interpreter, IT-96-21-T, T. Ch., 8 July 1997, par. 13: "The gravamen of the Rule ... is whether it is necessary (not merely useful or helpful) for the purpose of the investigation or for the preparation or conduct of the trial. The applicant should demonstrate that there is no other way to obtain the evidence sought."

383 ICTY, Prosecutor v. Halilović, Decision on the Issuance of Subpoenas, IT-01-48-AR73, 21 June 2004, par. 7. See also e.g. ICTR, Prosecutor v. Karemera et al., Decision on Defence Motion for Issuance of Subpoena to Witness T, ICTR-98-44-T, T. Ch. III, 8 February 2006 (the Trial Chamber declined to subpoena a witness to be interviewed by the defence because it would not serve the overall interests of the criminal process (par. 7). The defence argued that the interview would not only allow the defence to sufficiently prepare for an effective cross-examination, which facilitates equality of arms, and would alleviate unnecessary consumption of trial time, but in addition would provide additional information to the defence extending the scope of cross-examination (par. 2). The Chamber considered that this interview would not be necessary or appropriate for the conduct of the proceedings, because the same witness had met twice with defence counsel before providing a 
where the sole rationale for a subpoena is a more effective preparation for crossexamination, this, as such, is not a sufficient basis to issue a subpoena. The Appeals Chamber considered:

Being a mechanism of judicial compulsion, backed up by the threat and the power of criminal sanctions for non-compliance, the subpoena is a weapon which must be used sparingly. While a Trial Chamber should not hesitate to resort to this instrument where it is necessary to elicit information of importance to the case and to ensure that the defendant has sufficient means to collect information necessary for the presentation of an effective defence, it should guard against the subpoena becoming a mechanism used routinely as a part of trial tactics. ${ }^{384}$

Thus, the judicial power to compel should only be used to serve "the overall interests of the criminal process, not where it would merely facilitate a party's task in litigation." ${ }^{385}$ However, the mere fact that a witness will be available for crossexamination does not in itself justify the denial of a request for a subpoena. ${ }^{386}$ The witness might have information which could be valuable to the opposing party in relation to its trial preparation. In fact, the inability to interview these witnesses may give the other party an unfair advantage by being able to frustrate his opponent's ability to interview crucial witnesses merely by placing them on the potential witness list. ${ }^{387}$ If the party later decides not to call the witness at all, and the opposing party

statement to the prosecution. Moreover, relevant statements and documents had been disclosed and the same witness had already testified in other trials before the same Tribunal (par. 5).

384 ICTY, Prosecutor v. Halilović, Decision on the Issuance of Subpoenas, IT-01-48-AR73, 21 June 2004, par. 10.

385 ICTY, Prosecutor v. Halilović, Decision on the Issuance of Subpoenas, IT-01-48-AR73, 21 June 2004, par. 10. See also, ICTY, Prosecutor v. Brđjanin and Talić, Decision on Interlocutory Appeal, IT-99-36-AR73.9, A. Ch., 11 December 2002, par. 31: "The discretion of the Trial Chambers [under Rule 54], however, is not unfettered. They must take into account a number of other considerations before issuing a subpoena. Subpoenas should not be issued lightly, for they involve the use of coercive powers and may lead to the imposition of a criminal sanction.", par. 31 (declining to subpoena a war correspondent because of qualified privilege). Also, ICTY, Prosecutor v. Delalić et al., Decision on the Motion Ex Parte by the Defence of Zdravko Mucic concerning the Issue of a Subpoena to an Interpreter, T. Ch., 8 July 1997 (declining to issue a subpoena to an interpreter requested by the defence as "the interest of justice frowns upon any of the parties being able to call an interpreter as a witness", par. 20).

386 Notably, in Nzirorera et al., the Trial Chamber refused to issue a subpoena, considering e.g. that the witness "has specifically and catergorically refused to meet Defence counsel in this or any other case. This raises questions as to what practical benefit would be derived from the issuance of a subpoena to a non-cooperative witness. In light of Witness G's refusal to meet with the Defence, the Chamber is not satisfied that a subpoena would result in any information being divulged which cannot be gleaned from cross-examination of the witness", ICTR, Prosecutor v. Nzirorera et al., Decision on the Defence Motion for Subpoena to Witness G, ICTR-98-44-I, T. Ch. III, 20 October 2003, par. 22.

387 ICTY, Prosecutor v. Halilović, Decision on the Issuance of Subpoenas, IT-01-48-AR73, 21 June 2004, par. 12 . 
seeks a subpoena to interview that witness, the latter party will experience an unfair disadvantage in relation to the time and ability to prepare for trial. ${ }^{388}$ In this regard, the Trial Chamber should consider whether, when deciding on the issue of a subpoena, the party has presented sufficient reasons that extend beyond the mere need to prepare a more effective cross-examination. ${ }^{389}$

This reasoning is clearly informed by the tribunals' approach to a party's 'ownership' of witnesses. As stated in Mrksić, "witnesses to a crime are the property of neither the Prosecution nor the Defence; both sides have an equal right to interview them." ${ }^{390}$ In this case, the defence argued that the prosecutor's power to summon defence witnesses places "pressure on the witness and endangers the equality between the parties." ${ }^{391}$ The defence references its "inferior position" to that of the prosecution, "because the defence cannot rely on state institutions to convince potential witnesses of the Prosecution to speak with Defence investigators." ${ }^{392}$ According to the defence, the issue only concerns witnesses who have agreed to testify for the defence and have explicitly declined to talk to the prosecutor. ${ }^{393}$ Notably, the defence proposed that the prosecution would be free to cross-examine those witnesses. The Appeals Chamber agreed with the Trial Chamber's decision, and considered that the parties are in the same position when it comes to compelling unwilling witnesses to testify: the only recourse is an order or subpoena pursuant to Rule $54 .{ }^{394}$ Although avoiding the defence's equality of arms argument completely, the Chamber did consider it necessary to emphasise that "particular caution is needed where the Prosecution is seeking to interview a witness who has declined to be interviewed by the Prosecution, since in such a case the witness may feel coerced or intimidated." ${ }^{395}$ Reference to

388 ICTY, Prosecutor v. Halilović, Decision on the Issuance of Subpoenas, IT-01-48-AR73, 21 June 2004, par. 13.

389 ICTY, Prosecutor v. Halilović, Decision on the Issuance of Subpoenas, IT-01-48-AR73, 21 June 2004, par. 15.

390 ICTY, Prosecutor v. Mrksić, Decision on Defence Interlocutory Appeal on Communication with Potential Witnesses of the Opposite Party, IT-95-13/1-AR73, A. Ch., 30 July 2003, par. 15.

391 ICTY, Prosecutor v. Mrksić, Decision on Defence Interlocutory Appeal on Communication with Potential Witnesses of the Opposite Party, IT-95-13/1-AR73, A. Ch., 30 July 2003, par. 5.

392 ICTY, Prosecutor v. Mrksić, Decision on Defence Interlocutory Appeal on Communication with Potential Witnesses of the Opposite Party, IT-95-13/1-AR73, A. Ch., 30 July 2003, par. 6. The Prosecutor notified the witnesses that giving a statement to the Defence team did not relieve them of an obligation to submit to an interview by the Prosecution. ICTY, Prosecutor v. Mrksić, Prosecution's Response to the 'Defence Brief on an Interlocutory Appeal on Trial Chamber's Decision on Defence Motion Requesting the Determination of Rules for Communicating with Potential Witnesses of the Opposite Party', IT-95-13/1-AR73, 16 June 2003, par. 5.

393 ICTY, Prosecutor v. Mrksić, Defence Brief on an Interlocutory Appeal on Trial Chamber's Decision on Defence Motion Requesting the Determination of Rules for Communicating with Potential Witnesses of the Opposite Party, IT-95-13/1-AR73, 4 June 2003.

394 ICTY, Prosecutor v. Mrksić, Decision on Defence Interlocutory Appeal on Communication with Potential Witnesses of the Opposite Party, IT-95-13/1-AR73, A. Ch., 30 July 2003, par. 15.

395 ICTY, Prosecutor v. Mrksić, Decision on Defence Interlocutory Appeal on Communication with 
the prosecution, instead of a 'party', could be indicative of the Appeals Chamber's recognition of the more expansive power of the prosecution to 'persuade' witnesses to testify (and, if needed, to provide directly for protective and immunity measures). The issue is certainly not whether the defence has the right to question a witness (which it has according to Article 21(3)) but whether the witness "is obliged to submit to questioning." ${ }^{396}$ As contended by the prosecution, "equity is achieved not by mirroring or creating identical authorities, but in relation to the responsibilities of the parties." ${ }^{397}$ In this light, reference by the Chamber to the prosecutor's role as a 'minister of justice' (or a quasi-judicial one), endowed with the duty to assist the Court in ascertaining the truth and, therefore, to protect the rights of the accused, would not be misplaced. Indeed, in the Krstić decision on subpoenas, the Appeals Chamber hinted towards explicating this role of the prosecutor by considering that:

In some cases, once the difficulties encountered by the defence have been brought to the attention of the Chamber, it may be that the prosecution, in accordance with its duty to assist the Tribunal to arrive at the truth and to do justice for (inter alia) the accused, will use its own resources and its somewhat more extensive powers (including the power of persuasion) to facilitate and interview directly between the prospective witness and the defence. ${ }^{398}$

More importantly, although the language adopted is optional, the Chamber seems to be inclined to extend the notion of the prosecutorial role of a 'minister of justice' prevalent at the ad hoc tribunals towards a more objective understanding of that role and towards the quasi-judicial character of a civil law tradition-based prosecutor. As discussed above, this role would include not only an obligation to disclose potentially exculpatory evidence to the defence, but also the prosecutor's obligation to facilitate the defence, whenever necessary, to ensure the vindication of the rights of the accused.

Furthermore, the Appeals Chamber in Krstić presented an alternative scenario for when a potential witness has expressed his/her unwillingness to cooperate with

Potential Witnesses of the Opposite Party, IT-95-13/1-AR73, A. Ch., 30 July 2003, par. 16.

396 Dissenting Opinion of Judge Shahabuddeen in the Decision on Application of Subpoenas, ICTY, Prosecutor v. Krstić, IT-98-33-A, A. Ch.,1 July 2003, par. 36: Referring to equality of arms with regard to the question of why the Tribunal should not have the power to authorise the defence to question witnesses, in light of Prosecution's power under Article 18(2), Judge Shahabuddeen contends that the latter provision "was only vesting the Prosecutor, a creature of statute, with a competence to question witnesses that the accused, as an individual, would have without the need for statutory authorisation."

397 ICTY, Prosecutor v. Mrksić, Prosecution's Response to the 'Defence Brief on an Interlocutory Appeal on Trial Chamber's Decision on Defence Motion Requesting the Determination of Rules for Communicating with Potential Witnesses of the Opposite Party', IT-95-13/1-AR73, 16 June 2003, par. 15.

398 ICTY, Prosecutor v. Krstić, Decision on Application of Subpoenas, IT-98-33-A, A. Ch.,1 July 2003, par. 13. 
the defence: it is for the Trial Chamber to consider whether it is "reasonably likely that there would be cooperation if such an order were made." 399 If the Chamber determines that such cooperation would not be forthcoming or an order would not be complied with:

an alternative course could be to make an order or to issue a subpoena pursuant to Rule 54 requiring the prospective witness to appear before the Tribunal, when the judge who issues the order can explain to him the importance of his cooperation to assist in producing a just result in the trial, and how he will be afforded protection by the Tribunal if it is required. ${ }^{400}$

If this alternative route leads to the desired result, the defence can interview the witness in private, "before he is released by the Tribunal." ${ }_{401}$

Considering this point, it is important to pay attention to the dissenting opinion voiced by Judge Shahabuddeen in the Krstić Appeals Chamber decision. Judge Shahabuddeen took issue with the "liberal intent" of the majority decision which was too liberal in his eyes. ${ }^{402} \mathrm{He}$ disagreed with the following two determinations: (1) the majority determination of Appeals Chamber's competence to subpoena a state official to testify as to what he had seen or heard in his official capacity, and (2) the majority determination that individuals could be compelled to attend a nominated place to be interviewed by the Krstić defence team..$^{403}$

In relation to the first issue, the Krstic Appeals Chamber distinguished between the Blaškić Subpoena Decision, which in its view concerned only the impossibility to subpoena a state or its officials for the production of documents in their custody in their official capacity, and not to subpoena (former) state officials to testify in court about what they had seen or heard in their official capacity. ${ }^{404}$ Indeed, this distinction seems somewhat stilted. The rationale for not being able to issue a subpoena against states and their actors was that the Tribunal was in no other position but to respect state sovereignty and could not impose criminal sanctions, which underlie a subpoena, against a state. ${ }^{405}$ Instead, the Tribunal is competent to issue binding

399 ICTY, Prosecutor v. Krstić, Decision on Application of Subpoenas, IT-98-33-A, A. Ch.,1 July 2003, par. 11: "That is not a determination which the defence may safely make for itself."

400 ICTY, Prosecutor v. Krstić, Decision on Application of Subpoenas, IT-98-33-A, A. Ch., 1 July 2003, par. 12.

401 ICTY, Prosecutor v. Krstić, Decision on Application of Subpoenas, IT-98-33-A, A. Ch., 1 July 2003, par. 12 .

402 Dissenting Opinion of Judge Shahabuddeen in the Decision on Application of Subpoenas, Prosecutor v. Radislav Krstic, IT-98-33-A, A. Ch., 1 July 2003, par. 1.

403 Dissenting Opinion of Judge Shahabuddeen in the Decision on Application of Subpoenas, Prosecutor v. Krstić, IT-98-33-A, A. Ch., 1 July 2003, paras. 2, 20.

404 ICTY, Prosecutor v. Blaškić, Judgment on the Request of the Republic of Croatia for Review of the Decision of Trial Chamber II of 18 July 1997, A. Ch., 29 October 1997.

405 ICTY, Prosecutor v. Blaškić, Judgment on the Request of the Republic of Croatia for Review of the 
orders, and in case of non-compliance with that order, the only enforcement measure is to report that behaviour to the Security Council, the 'mother ship' of the tribunal. Notwithstanding this decision, the Krstić Chamber determined that "[t]he [Blaškić] Appeals Chamber did not say that the functional immunity enjoyed by State officials includes an immunity against being compelled to give evidence of what the official saw or heard in the course of exercising his official functions." ${ }^{~} 406$

Concerning the second issue, Judge Shahabuddeen found against the Chamber's competence to issue a subpoena against individuals who are to be interviewed by the defence only (without the presence of the Chamber or the prosecutor) and not under oath. ${ }^{407}$ According to Judge Shahabuddeen, the Appeals Chamber, by moving from facilitating the defence interview (by issuing a binding order against the state) to compelling the witness to answer the defence's questions under the threat of criminal sanctions, has distorted the delicate balance between the public interest in securing information needed for a criminal trial and the public interest in the right to privacy. ${ }^{408}$ This may surely be the case from the perspective of prosecution. However, the specific issue underlying the decision concerns the defence whose interests might not entirely overlap with those of the 'public interest' to secure information for a criminal trial. On the scale of individual interests (defence fair trial rights and witness' right to privacy), the delicate balance might not be distorted at all. In the circumstances in which international criminal tribunals have to operate, the Appeals Chamber's pragmatic approach is a welcoming development from the point of view of defence ability to prepare for trial. This approach, however, is informed by ICTY's 'adversarial' inclination in relation to the roles of the participants in a criminal trial: the parties have a primary responsibility to prepare and present their case, while the judges facilitate a fair preparation and presentation without ever taking the lead in relation to the evidentiary framework from which the truth has to emerge.

Decision of Trial Chamber II of 18 July 1997, A .Ch., 29 October 1997, paras. 26-31.

406 ICTY, Prosecutor v. Krstić, Decision on Application of Subpoenas, IT-98-33-A, A. Ch., 1 July 2003, par. 27. Other Chambers followed this finding.

407 Dissenting Opinion of Judge Shahabuddeen in the Decision on Application of Subpoenas, Prosecutor v. Krstić, IT-98-33-A, A. Ch., 1 July 2003, par. 28: “ ... it is one thing for the Appeals Chamber to use its powers under the Rule [54] to remove any difficulties which might prevent a potential witness from coming forward to the defence [by issuing a binding order against the state to facilitate witnesses cooperation]; it is another thing for the Appeals Chamber to use its powers under the Rule to compel the potential witness to come forward to the defence, and more particularly under the threat of penal sanctions."

408 Dissenting Opinion of Judge Shahabuddeen in the Decision on Application of Subpoenas, ICTY, Prosecutor v. Krstić, IT-98-33-A, A. Ch., 1 July 2003, par. 43. Cf. Dissenting Opinion of Judge Weinberg de Roca in the ICTY, Decision on the Issuance of Subpoenas, Prosecutor v. Halilović, IT-01-48-AR73, 21 June 2004, par. 4, focusing rather on the individual interests involved and considering that "[t]o compel an unwilling witness to submit to a pre-trial interview, absent a clear showing that such measure is necessary to the fair adjudication of the case, would be a grave invasion of privacy indeed." 


\subsubsection{Compellability of witnesses at the ICC}

Importantly, as compared to the framework of the ad hoc tribunals, the ICC does not have the same power to subpoena unwilling witnesses as provided for under Rule 54 ICTY/ICTR RPE. According to the ICC Statute, a Trial Chamber may "require the attendance and testimony of witnesses and production of documents and other evidence by obtaining, if necessary, the assistance of States as provided in this Statute." ${ }^{409}$ Rule 65 ICC RPE specifically elaborates on the compellability of witnesses: "a witness who appears before the Court is compellable by the Court to provide testimony unless otherwise provided for ...". This framework does not leave any room for a power to subpoena witnesses to testify at the ICC. Article 93(1)(e) reassures that conclusion when it talks about "facilitating the voluntary appearance of persons as witnesses or experts before the Court" as one possible measure of assistance the ICC can request from the states. In fact, from this provision it seems to follow that states cannot compel witnesses to appear before the ICC. In addition, Article 93(7)(a)(i) mentions the transfer of a detained witness to the Court only under the condition that "the person freely gives his or her informed consent to the transfer". It would seem that a not detained witness would "have at least the same rights as detained witness" and thus "cannot be compelled in any way to testify." 110 Whereas the principle of voluntary appearance does not affect equality of arms directly, as both the prosecution and the defence might suffer from it, ${ }^{411}$ it "may create hardship for the defence" 412 that could potentially violate the right to a fair trial and jeopardise proper administration of justice before the ICC..$^{413}$

\subsubsection{Ad hoc tribunals - Search and seizure warrants}

In Kordic and Cerkez the defence challenged the authority of the prosecutor to "take direct enforcement action in the form of armed search and seizure within the boundaries of a sovereign state without their [state's] consents and/or participation." 414 As such, the search warrant itself was not disputed, but the manner in which it was issued was. As a proper remedy, the defence argued for the exclusion of the collected

\footnotetext{
409 Article 64(6)(b) ICC Statute.

410 Sluiter, 2009, p. 601.

411 SLuiter, 2009, p. 601.

412 SchabAs, 2008, p. 1265.

413 Sluiter, 2009, pp. 601-606.

414 Kordić and Čerkez, IT-95-14/2-T, Transcript of 31 May 1999, p. 2978. "Neither the Statute, in our judgement, nor the Rules of the Tribunal grant the Prosecutor authority to take direct enforcement action in the form of armed search and seizure operations within the boundaries of a sovereign state without their consent and/or participation, and we start with the proposition that the Tribunal and the Office of the Prosecutor, as an international organisation, is a body of limited and delegated authority." (p. 2979).
} 
documents. The prosecutor argued that it had properly exercised it powers under the Rules of the Tribunal and in accordance with the search warrant issued by the ICTY. The Trial Chamber agreed and found no merit in the defence's motion. It argued that the Tribunal enjoys primacy above national jurisdictions and considered that "that the investigation carried out by the Prosecution, resulting in the seizure of certain materials, was perfectly within the powers of the Prosecution provided for in the Statute." ${ }^{15}$

The Chamber, pursuant to Rule 54, can grant a search and seizure warrant to assist the prosecution in the collection of evidence. The basis for the prosecutor's authority to request a search and seizure warrant lies in Article 18 of the Statue (Rules 39(1) and 54 RPE). These warrants are generally made under seal and ex parte (although some have later been made public following a request for access by the defence ${ }^{416}$ ) and, thus, little guidance can be found as to the relevant threshold for authorizing such an order. In his decision, the Duty Judge issuing such a warrant does not have to refer to the conditions of "necessity" or the "legitimate forensic purpose" underlying Rule 54 orders. ${ }^{417}$ Clearly, access to the search and seizure of material for the prosecutor is broader than that of the defence which would have to establish the specific relevance of the material sought to the defence. ${ }^{418}$ The defence is further disadvantaged, as compared to the prosecutor, in that it does not possess the same opportunity to 'fish' through the materials due to prosecution's practice of securing the original materials from various authorities seized either pursuant to Tribunal's warrant or order or by negotiations. ${ }^{419}$

However, the warrants are not completely form free; the Duty Judge did formulate certain terms and conditions, like the time frame for the execution of the order, authorization for the power of enforced entry when the national entity refuses to cooperate, the obligation of the OTP to provide a receipt for the seized material to the occupants of the searched site ${ }^{420}$ and to the relevant ICTY Trial Chamber and

415 ICTY, Prosecutor v. Kordić and Čerkez, Decision Stating Reasons for Trial Chamber's Ruling of 1 June 1999 Rejecting Defence Motion to Suppress Evidence, IT-95-14/2-T, T. Ch., 25 June 1999.

416 ICTY, Prosecutor v. Krajišnik and Plavsić, Decision on Defence Motion for Access to Certain Search Warrants, IT-00-39 \& 40-PT, T. Ch., 26 April 2002; ICTY, Prosecutor v. Karadžić, Decision on the Accused's Request for Copies of Search Warrants, IT-95-5/81-I, 29 August 2008.

417 ICTY, Decision on Request for Reconsideration of Order of 9 May 2002, OT-02-55-Misc 4, 17 July 2002 (Duty Judge Hunt); ICTY, Prosecutor v. Karadžić, Search Warrant for the Public Security Centre (CJB) Srpsko Sarajevo, IT-95-05/18, 11 September 2003 (Duty Judge May).

418 MCINTYRe, 2003, p. 280, argues: “Although the procedure of granting search and seizure warrants is technically available to an accused, it is unlikely that an accused would be granted the same broad access to search for and seize material as the prosecution. The defence will have to identify the relevance of that material in much the same way as required to obtain an order to produce."

419 MCINTYRe, 2003, p. 280.

420 ICTY, Prosecutor v. Karadžić, Search Warrant for the Public Security Centre (CJB) Srpsko Sarajevo, IT-95-05/18, 11 September 2003 (Duty Judge May). 
to seek directions from it as to the disclosure of the materials to the defence. ${ }^{421} \mathrm{On}$ one occasion, the prosecution complained about the conditions imposed as going beyond the supervision necessary to enforce the lawful execution of the warrant and argued that "accidental" non-compliance could render the search unlawful with the consequence of precluding the admission of the seized material into evidence. ${ }^{422}$ According to Judge Hunt, non-compliance with further orders (and not 'conditions') expressed in the search warrant would not invalidate the search as such, but it would constitute a contempt of court. On a critical note, Judge Hunt expressed the view that these orders were "necessary in order to protect the right of any accused person to whom the document may be relevant." ${ }^{\prime 23}$ According to Judge Hunt:

The power of seizure granted to the prosecution is a very powerful weapon in its hands. By seizing material, the prosecution denies such accused persons access to that material. Experience has demonstrated that the results can be seriously deleterious to the rights of those accused. In one case, in which the accused became aware of the seizure by the prosecution, the prosecution waited over six months before providing the accused with a copy of the documents. In another case, in which the accused was unaware of the seizure by the prosecution, the accused had obtained an order requiring the relevant Bosnian authorities to produce the documents which was not complied with. Only after the trial had ended was it discovered that the documents had been in the possession of the prosecution throughout trial. ${ }^{424}$

Judge Hunt considered that "if the Prosecution is not prepared to institute its own system to protect the rights of accused persons, orders of this type are necessary" and they are "the only way the rights of those accused persons adversely affected by the warrants, can be protected." 425 To protect the rights of the accused Judge Hunt in effect extended the judge's oversight of the conduct of the prosecutorial mandate,

421 ICTY, Decision on Request for Reconsideration of Order of 9 May 2002, OT-02-55-Misc 4, 17 July 2002 (Duty Judge Hunt).

422 ICTY, Decision on Request for Reconsideration of Order of 9 May 2002, OT-02-55-Misc 4, 17 July 2002 (Duty Judge Hunt) referring to Prosecution Motion Seeking Reconsideration of the Terms of Ordered by Judge Hunt of 9 May 2002, Granting Warrants for Search and Seizure of Potential Evidence, paras. 3 and 32.

423 ICTY, Decision on Request for Reconsideration of Order of 9 May 2002, OT-02-55-Misc 4, 17 July 2002 (Duty Judge Hunt).

424 ICTY, Decision on Request for Reconsideration of Order of 9 May 2002, OT-02-55-Misc 4, 17 July 2002 (Duty Judge Hunt), paras. 3-4, referring to Brđjanin and Talić, IT-99-36, Statute Conference, 2 February 2001, T. 268-269 and 271-275; ICTY, Prosecutor v. Kordić and Čerkez, IT-95-14/2, Order to Bosnia and Herzegovina for the Production of Documents, 18 July 2000, Application for Issuance of an Order to Bosnia-Herzegovina Compelling the Production of Documents and Other Materials, 20 June 2001; and ICTY, Prosecutor v. Kordić and Čerkez, IT-95-14/2, Status Conference, 22 June 2001, T.28522-28523, 28525-28528.

425 ICTY, Decision on Request for Reconsideration of Order of 9 May 2002, OT-02-55-Misc 4, 17 July 2002 (Duty Judge Hunt). 
which can only be applauded from the perspective of the fairness of the proceedings. Moreover, this can be considered as an implied reminder of the prosecutor's role as a Minister of justice, whose mandate includes safeguarding the fairness of the proceedings and thus, also, the rights of the accused.

\subsubsection{Functional immunity for defence team members}

One important precondition for the defence to be able to conduct on-site investigations is a degree of functional immunity for the protection from improper interference by national authorities. Functional immunity from national legal processes acknowledges and ensures the independence of counsel and is a necessity when it comes to the political world in which international criminal courts operate. The issue of the immunity of defence counsel practising before international criminal courts has only recently been highlighted in practice. The legal frameworks of the ad hoc tribunals do not explicitly mention defence counsel as beneficiaries of the functional immunity; ${ }^{426}$ however, immunity is provided for in the Headquarters Agreements extending to the host states of the ad hoc tribunals. ${ }^{427}$ In a short time-frame the ICTY-ICTR Appeals Chamber had the opportunity to issue two decisions arising out of proceedings before both tribunals, in the cases of Gotovina et al. and Bagosora et al.

In Gotovina et al., the defence requested the Trial Chamber to issue a permanent restraining order against Croatia "to cease all criminal proceedings and prosecutions, including those against a Gotovina Defence member ... (charged with concealment of Croatian archival materials), that emanate from acts related to the Gotovina Defence's fulfilment of its function before the Tribunal." ${ }^{428}$ In the course of an administrative investigation into missing military documents, upon the request of the ICTY prosecutor, Croatia initiated criminal investigations in relation to current

426 See SLuiter, 2002, p. 337 (expressing his surprise at this important omission). The Statutes do refer to the accused and "other persons ... required at the seat of the International Tribunal." See Articles 29 ICTR and 30 ICTY Statutes.

427 See also Article 14 of the Agreement Between the United Nations and the Government of Sierra Leone on the Establishment of a Special Court for Sierra Leone, 16 January 2002: 1. The Government shall ensure that the counsel of a suspect or an accused who has been admitted as such by the Special Court shall not be subjected to any measure which may affect the free and independent exercise of his or her functions. 2. In particular, the counsel shall be accorded: (a) Immunity from personal arrest or detention and from seizure of personal baggage; (b) Inviolability of all documents relating to the exercise of his or her functions as a counsel of a suspect or accused; (c) Immunity from criminal or civil jurisdiction in respect of words spoken or written and acts performed in his or her capacity as counsel. Such immunity shall continue to be accorded after termination of his or her functions as a counsel of a suspect or accused. (d) Immunity from any immigration restrictions during his or her stay as well as during his or her journey to the Court and back.

428 ICTY, Prosecutor v. Gotovina et al., Decision on Gotovina Defence Appeal Against 12 March 2010 Decision on Request for Permanent Restraining Orders directed to the Republic of Croatia, IT-0690-AR73.5, 14 February 2011, par. 1 [Gotovina Defence Immunity Appeals Decision]. 
and former Gotovina defence team members. In fact, the Gotovina defence argued "that the Prosecution exercised, through coercion, substantial influence on Croatia, thereby directing its actions and using it as the Prosecution's quasi-police force," $" 429$ an assertion that was rejected by the Trial Chamber. ${ }^{430}$

The Gotovina Trial Chamber, after an analysis of Article 30 ICTY Statute, concluded that this provision does not provide for personal or functional immunity for defence team members. ${ }^{431}$ According to the Trial Chamber, no general domestic practice exists with regard to providing immunity from legal process to the defence or prosecution, which is indicative of the fact "that functional immunity is not indispensable for the defence or the prosecution to fulfil their functions in a criminal trial." ${ }^{432}$ Moreover, an obligation to refrain from exercising jurisdiction over defence members could frustrate legitimate State interests in investigating and prosecuting crimes under their jurisdiction. ${ }^{433}$ However, the Chamber did consider it appropriate in the context of an international criminal tribunal to provide some form of protection to the defence in the fulfilment of its function against improper interference from state authorities. ${ }^{434}$ Consequently, the Chamber considered that although no immunity is afforded, "a State may not exercise its jurisdiction by improperly subjecting defence members to legal process, with regard to acts that fall within the defence's fulfilment of its official function before the Tribunals, with the intended or foreseeable result of substantially impeding or hindering the performance by defence members of their functions." ${ }^{435}$ This seems a rather cumbersome and extensively qualified way of formulating something that could rather be called 'functional immunity.'

Accordingly, the Appeals Chamber considered that defence counsel and derivatively defence investigators fall within the category of "other persons" within the meaning of Article 30(4) ICTY Statute. ${ }^{436}$ The Appeals Chamber rejected the Trial Chamber's grammatical interpretation of that article when finding that the defence

429 Gotovina Defence Immunity Appeals Decision, par. 7.

430 ICTY, Prosecutor v. Gotovina, Decision on Request for Permanent Restraining Orders Directed to the Republic of Croatia, IT-06-90-T, 12 March 2010, par. 32 [Gotovina Defence Immunity Trial Decision]. The Croatian investigation was officially prompted by an Article 29 (and Rule 54bis) order from the Trial Chamber following a request by the Prosecution in 2008 for Croatia to produce 'Operation Storm' military documents. According to the Prosecutor, Croatia was not willing to produce these documents. In reply, Croatia initiated the underlying investigation to search for the missing documents. The Prosecutor made suggestions with regard to an administrative investigation directing it towards the defence's investigator.

431 Gotovina Defence Immunity Trial Decision, par. 61.

432 Gotovina Defence Immunity Trial Decision, par. 58.

433 Gotovina Defence Immunity Trial Decision, par. 59.

434 Gotovina Defence Immunity Trial Decision, par. 61.

435 Gotovina Defence Immunity Trial Decision, par. 61.

436 Article 30(4): "other persons, including the accused, required at the seat of the International Tribunals shall be accorded such treatment as is necessary for the proper functioning of the International Tribunal." 
did not enjoy functional immunity due to the lack of any reference in this article to the Vienna Convention on Diplomatic Relations and the UN Convention on Privileges and Immunities. ${ }^{437}$ The Appeals Chamber emphasized a teleological interpretation of the said article and considered that the Trial Chamber should have focused on what is necessary for proper functioning before the Tribunal, and not on whether another treaty or Security Council resolution provide for immunity. ${ }^{438}$

Importantly, the Appeals Chamber considered that the Trial Chamber's comparison to the national setting where no functional immunity is generally afforded to prosecution or defence team members was inappropriate. By concluding that immunity is not "indispensible", the Trial Chamber "failed to properly consider the fundamental difference between a domestic court and an international criminal tribunal." 439 The "different legal environment" prevailing at the tribunal, "finding and interviewing witnesses, conducting on-site investigations, and gathering evidence in a State's territorial jurisdiction may be more difficult without the grant of functional immunity, as there is always a risk that a State could interfere by exercising its jurisdiction in such a way as to impede or hinder the activities of the defence." 440 Thus, according to the Appeals Chamber, members of the defence, including defence investigators, enjoy functional immunity under Article 30(4) of the Statute with regard to acts that fall within the fulfilment of their official functions before the Tribunals due to their functions being "necessary for the proper functioning of the Tribunal." ${ }^{441}$ In refuting the argument advanced by the Prosecution that functional immunity for the defence may lead to impunity for their criminal acts, the Appeals Chamber drew a parallel with the functional immunity of the prosecution and the fact that their members are not permitted to commit crimes with impunity either. ${ }^{442}$ Moreover, the Appeals Chamber emphasized that functional immunity for defence team members does not extend to "actions taken in their personal capacity." "443 In relation to the case at hand, the Appeals Chamber considered that it is not disputed that the investigations, seizures and prosecution relate to acts that fall within the official function of the Gotovina defence. ${ }^{44}$

In between the Gotovina et al. Trial and Appeals Chamber decisions, the Appeals Chamber had the opportunity to pronounce a judgement on defence immunity in the ICTR Bagosora et al. case. Erlinder, a defence counsel in that case, had been arrested on 28 May 2010 on charges of genocide denial, when he arrived in Kigali to prepare

437 Gotovina Defence Immunity Appeals Decision, par. 28.

438 Gotovina Defence Immunity Appeals Decision, par. 28.

439 Gotovina Defence Immunity Appeals Decision, par. 30.

440 Gotovina Defence Immunity Appeals Decision, par. 31 [footnote omitted].

441 Gotovina Defence Immunity Appeals Decision, par. 33.

442 Gotovina Defence Immunity Appeals Decision, par. 34.

443 Gotovina Defence Immunity Appeals Decision, par. 34.

444 Gotovina Defence Immunity Appeals Decision, par. 36. 
the defence of the opposition leader Victoire Ingabire who was being detained on similar charges. ${ }^{445}$ On 3 June 2010 Ntabakuze (Erlinder's ICTR client) filed a motion at the ICTR requesting the Appeals Chamber to order the Registrar "to take immediate action to secure the release of his Lead Counsel ... and order the Government of Rwanda to stop all proceedings against his Lead Counsel." ${ }^{446}$ A day before this, the Prosecutor General of Rwanda had responded to the ICTR Registrar's note verbale for a clarification of the arrest, noting that Erlinder's arrest was unrelated to his work at the ICTR. ${ }^{477}$ The second note verbale (11 June) sent by the Registrar to the Rwandan authorities requested the latter to send a copy of the official charges against the Lead Counsel, while the fourth (15 June) emphasized Erlinder's immunity and requested his immediate release. ${ }^{448}$ Erlinder was provisionally released on health grounds on 17 June 2010, without being formally charged, while the investigation against him was ongoing. ${ }^{449}$ In his motion, Ntabakuze emphasized Erlinder's functional immunity and contended that Rwanda's investigation related to Erlinder's writings arising from his mandate before the ICTR. In its response, the prosecution contended that it was unclear whether the charges against Erlinder related to his work at the Tribunal, and that only in that case would he enjoy immunity from legal process.

From the outset, the Appeals Chamber emphasized "that it will not lightly intervene in the domestic jurisdiction of a state", but under its mandate it would only consider whether Rwanda's exercise of its domestic jurisdiction in Erlinder's case "threatens the fairness of the proceedings in this case." 450 In its deliberations, the Chamber recognized the extension of immunity to defence counsel in order to secure their functioning before the Tribunal. The Chamber stated that:

[...] Defence Counsel benefit from immunity from personal arrest or detention while performing their duties assigned by the Tribunal and also with respect to words spoken or written and acts done by them in the course of the performance of their duties as Defence counsel before the Tribunal, in order to allow for the proper functioning of the Tribunal in accordance with Article 29 of the Statute. ${ }^{451}$

The Chamber reached this conclusion after interpreting the Memorandum of Understanding (MOU) between Rwanda and the ICTR and the Convention on the

445 "Rwanda arrests opposition figure's US lawyer", AFP 28 May 2010, available at: http://www. google.com/hostednews/afp/article/ALeqM5hGynm88rJEH0VqfcosXUbIqtAV4g.

446 ICTR, Bagosora et al v. Prosecutor, Decision on Aloys Ntabakuze's Motion for Injunctions against the Government of Rwanda Regarding the Arrest and Investigation of Lead Counsel Peter Erlinder, ICTR-98-41-A, A. Ch., 6 October 2010, par. 1 [Bagosora et al. Defence Immunity Appeals Decision].

447 Bagosora et al. Defence Immunity Appeals Decision, par. 3.

448 Bagosora et al. Defence Immunity Appeals Decision, paras. 5 and 8.

449 Bagosora et al. Defence Immunity Appeals Decision, par. 13.

450 Bagosora et al. Defence Immunity Appeals Decision, par. 18.

451 Bagosora et al. Defence Immunity Appeals Decision, par. 26. 
Privileges and Immunities of the United Nations (13 February 1946). Applying the latter convention, the Appeals Chamber considered that:

[...] While Defence Counsel are not officials of the Tribunal, some guarantee is necessary for the independent exercise of their Tribunal assigned functions which are integral to its functioning. Accordingly, the nature of their mission, which is to engage in preparations for proceedings before the Tribunal, is the defining factor in granting them such privileges and immunities as granted to experts on mission - not their administrative status with the Tribunal. ${ }^{452}$

Although defence counsel are not mentioned in the MOU, the Chamber considered that:

[...] as the rights of access to undertake investigations are fundamental to the preparation of the Defence case, in concluding the Memorandum of Understanding it was contemplated that it applied to Defence Counsel as well as officials of the Tribunal. Indeed, if the Memorandum of Understanding did not extend to Defence Counsel, the right of equality of arms would be meaningless as the Defence would have no guarantee of access to potential witnesses and evidence to allow them to prepare their case. ${ }^{453}$

The majority of the documents forming the basis for the Rwandan investigation against Erlinder were articles written in his private and academic capacity and, thus, did not fall within the confines of the extended immunity. However, because one document did concern Erlinder's arguments made on behalf of Ntabakuze in the Bagosora et al. case, the proceedings initiated by Rwanda did interfere with the proper functioning of the Tribunal and Erlinder enjoyed immunity in this case. In fact, "Ntabakuze's right to a fair trial cannot be protected where Erlinder faces investigation or prosecution in Rwanda on the basis of words spoken or written in the course of his representation of Ntabakuze before the Tribunal." ${ }^{454}$ Thus, the Appeals Chamber requested the Republic of Rwanda "to desist from proceeding against Erlinder in relation to words spoken or written in the course of his representation of Ntabakuze before the Tribunal." ${ }^{455}$

Just as in Gotovina et al., the extent of the immunity is narrowly tailored to the function performed at the Tribunal. In both cases, the national investigations pertained to the work before the tribunal. The question remains what can be done in a case when the national investigation carefully omits acts directly related to work at the tribunals (if Rwanda excludes the one document connecting Erlinder to ICTR, would the national prosecution be possible?). Principally, it seems that Ntabakuze's

452 Bagosora et al. Defence Immunity Appeals Decision, par. 23.

453 Bagosora et al. Defence Immunity Appeals Decision, par. 21.

454 Bagosora et al. Defence Immunity Appeals Decision, par. 30.

455 Bagosora et al. Defence Immunity Appeals Decision, par. 31. 
case would be prejudiced in a situation in which his lead counsel could not enter Rwanda to investigate on his behalf due to a fear of arrest. The rationale for providing functional immunity would seem to support a more extended reading of immunity (from legal process more generally and extending to at least after the cessation of the case in question). Notwithstanding this approach, the details are obviously casespecific - what kind of criminal act is alleged, does it or does it not relate to the 'official' function before the tribunal? The progressive development is the Appeals Chamber's extension of a positive entitlement for the defence, which directly acknowledges and solidifies the defence's specific position in international criminal proceedings. This institutional commitment to a non-organ of the tribunal can generally be applauded from the perspective of equality of arms..$^{456}$

From the outset immunity for defence counsel within the context of the ICC has found a stronger legal basis as compared to the ad hoc tribunals. Article 48(4) ICC Statute accords the defence counsel, and any other person required to be present at the seat of the Court, such treatment as is necessary for the proper functioning of the Court, in accordance with the agreement on the privileges and immunities of the Court. This agreement provides in Article 18 for immunity for counsel and persons assisting defence counsel from (a) personal arrest and detention and (b) immunity from legal process of every kind in respect of words spoken or written and all acts

456 Further developments in this case are quite remarkable. In a motion to stay the proceedings, Ntabakuze argued that his representation had been intentionally impeded by the Rwandan authorities when they issued "genuine threats to [Lead Counsel's] personal safety." Being deprived of effective legal representation, his right to a fair trial had been violated. According to him, "functional immunity provides no guarantee to effectively ensure that Counsel will not face arrest and prosecution." See ICTR, Bagosora et al. v. Prosecutor, Decision on Alloys Ntabakuze's Motion for Stay of Proceedings, ICTR-98-41-A, 27 January 2011, paras. 7, 9. The Appeals Chamber denied the request, while explicitly expressing its dissatisfaction with the conduct of defence counsel (the following excerpt from a letter from co-counsel to counsel was attached: "I strongly recommend to you to activate the motion to stay proceedings in which we will give the proper and clear message on $[\mathrm{sic}]$ our intention to quit. That will be an appropriate way to respond to the [Appeals Chamber] decision on your limited immunity, and that will be a form of pressure to grant our two motions for disclosure for which I entertain no hope as to the positive outcome."), par. 14. After this, when the lead counsel would not travel to Arusha for the appeals hearing in the case because of the said threats to personal security, the Appeals Chamber denied the motion to hold the hearings through a video-link conference. Finally, only five days before the hearing Lead Counsel informed the Appeals Chamber that he would not attend due to medical reasons. ICTR, Bagosora et al. v. Prosecutor, Decision on Aloys Ntabakuze's Motions for Video-Conference Participation of Lead Counsel in the Appeal Hearing and for the Withdrawals of Registrar's Public Decision, ICTR-98-41-A, 15 March 2011, par. 13. The Appeals Chamber was not amused. It considered this behaviour (non-emergency medical reasons, only five days prior to the hearing, while it was obvious that counsel did not intend to attend the hearing at least until January 2011) to be "an obstruction of the proceedings and [...] contrary to the interests of his client." It consequently sanctioned the Lead Counsel by refusing him audience before the Tribunal and ordered the Registrar to replace counsel. See ICTR, Bagosora et al. v. Prosecutor, Order Imposing Sanctions on Ntabakuze's Lead Counsel, ICTR-98-41A-A, A. Ch., 21 April 2011. 
performed by him or her in official capacity, which immunity shall continue to be accorded even after he or she has ceased to exercise his or her functions. ${ }^{457}$ Clearly, the scope of this provision is broader than that elaborated above in the context of ad hoc tribunals. The ICC thus provides for better protection for defence counsel from improper interference by state authorities and a more equalized position of defence counsel as compared to the prosecutor. ${ }^{458}$

\subsection{CONCLUding REMARKS}

As argued by Newton, "[t]he difference in access to international pressure/leverage arguably represents the most significant structural limitation on equality of arms in the system of international justice." ${ }^{459}$ The prosecutor is assumed to have the power and support of the state community in his mission to bring those most responsible for horrible crimes to the dock before an international criminal court. ${ }^{460}$ This Chapter focused on how these courts have approached this argument, and what has been done to compensate for this (perceived) inequality of arms.

In Nahimana et al., the Trial Chamber was confronted with the defence motion to stay the proceedings because of the violation of the defence's right to a fair trial. ${ }^{461}$ More specifically, the defence argued an inequality of arms arising out of its inability to properly conduct investigations due to poor cooperation by the Rwandan authorities. The Chamber engaged in an extensive discussion of equality of arms and the obligation of state cooperation (adopting the Tadić and Blaškić interpretations). According to the Trial Chamber, the defence did not specify the missing documents or their relevance and the Chamber questioned the existence of these documents. ${ }^{462}$

457 Agreement on the Privileges and Immunities of the International Criminal Court, UN 2002, http://untreaty.un.org/cod/icc/apic/apic(e).pdf.

458 Article 15(1) of the Agreement on the Privileges and Immunities of the International Criminal Court states that the "judges, the Prosecutor, the Deputy Prosecutors and the Registrar shall, when engaged on or with respect to the business of the Court, enjoy the same privileges and immunities as are accorded to heads of diplomatic missions and shall, after the expiry of their terms of office, continue to be accorded immunity from legal process of every kind in respect of words which had been spoken or written and acts which had been performed by them in their official capacity."

459 Newton, 2011, p. 390.

460 See also Jones, 2004, p. 493, wording the arguments as follows: "Moreover, it must be appreciated that obstacles to contacting witnesses pose a greater problem for the defence than for the prosecution. The prosecution begins with a 'head start' over the defence, in that, when it issues an indictment, is has already contacted the relevant witnesses. The defence at that stage still has all its investigations to undertake. Therefore, in order to respect the principle of equality of arms, enshrined in Article 21(4) (e) ICTYSt. as far as obtaining witnesses is concerned, the Trial Chamber should, it is submitted, show itself extremely willing to assist the defence in gaining access to witnesses, wherever possible."

461 ICTR, Prosecutor v. Nahimana et al., Decision on the Motion to Stay the Proceedings in the Trial of Ferdinand Nahimana, ICTR-99-52-T, 5 June 2003.

462 ICTR, Prosecutor v. Nahimana et al., Decision on the Motion to Stay the Proceedings in the Trial of Ferdinand Nahimana, ICTR-99-52-T, 5 June 2003, paras. 12-13. 
The Chamber asserted that it had "acted within the limits of its powers to assist the Defence." ${ }^{463}$ When describing its efforts that Chamber noted:

In one instance, the Chamber relaxed the protection order to enable the Defence to investigate protected Prosecution witnesses in detention in Rwanda and to contact the Rwandan Minister of Justice. On another occasion, Counsel for Ferdinand Nahimana made requests to the Trial Chamber to obtain access to microfiche material in Washington D.C., USA. The presiding Judge, in her capacity as President of the Tribunal, intervened with the US Ambassador-at-Large for War Crimes, who provided copies of the materials. ${ }^{464}$

Moreover, the Chamber observed that the defence "had in fact received some measure of cooperation from the Rwandan authorities both in respect of on site investigations and access to material." 465 The Chamber, however, did not elaborate on the fact of whether this 'measure of cooperation' was sufficient for the defence to prepare for trial in light of the defence's right to have adequate time and facilities for preparation.

The Nahimana decision is illustrative of the approach adopted by international criminal courts towards the defence's claims of inequality of arms with regard to inadequate preparation for trial due to limited pre-trial powers and lacking state cooperation. The liberal approach towards equality of arms, postulated in Tadić, ${ }^{466}$ involves (1) the need for a principally equal position between the parties - often without appropriate reference to the difference in their roles, (2) the Chamber's interventionist obligation to assist with the parties' request for the necessary orders taking its 'equalizing' position seriously; and (3) the Chamber's purely procedural approach towards the perception of the equality of the parties' positions and its own efforts to assist - equal procedural opportunities are enough to satisfy equality of arms (taking little guidance from the inequality of powers and the limitations of the operative context). Although the prosecution and the defence 'must be equal before

463 ICTR, Prosecutor v. Nahimana et al., Decision on the Motion to Stay the Proceedings in the Trial of Ferdinand Nahimana, ICTR-99-52-T, 5 June 2003, par. 14, referring in footnote 10 to the measures taken to assist the defence (access to exculpatory materials in Rwanda, investigations in Rwanda, the transfer of a witness, the request to the Belgian Government, the request to UNICEF, order to disclose the identity of certain witnesses detained in Rwanda).

464 ICTR, Prosecutor v. Nahimana et al., Decision on the Motion to Stay the Proceedings in the Trial of Ferdinand Nahimana, ICTR-99-52-T, 5 June 2003, par. 15.

465 ICTR, Prosecutor v. Nahimana et al., Decision on the Motion to Stay the Proceedings in the Trial of Ferdinand Nahimana, ICTR-99-52-T, 5 June 2003, par. 15.

466 " ... under the Statute of the International Tribunal the principle of equality of arms must be given a more liberal interpretation than that normally upheld with regard to proceedings before domestic courts. This principle means that the Prosecution and the Defence must be equal before the Trial Chamber. It follows that the Chamber shall provide every practicable facility it is capable of granting under the Rules and Statute when faced with a request by a party for assistance in presenting its case." 
the Trial Chamber', principally they are not. This postulate must be approached as a goal set, rather than a status quo.

In practice, however, the Chambers have shown flexibility when approaching requests for assistance. Although both the prosecution and the defence have the power to request Rule 54 and 54bis orders, the latter party in practice has more frequent recourse to those powers. Principally, the Chambers have approached state cooperation from a fairly cooperative stance towards the state: using the power of a binding order only as a last resort when cooperation has not been forthcoming. For this purpose, a certain threshold must be met before such an order can be issued. To accommodate the defence, the Chambers have taken a rather open-minded and flexible approach towards the threshold requirements, keeping the threshold in most cases to a minimum. As such, the condition of due diligence has not been applied too severely: one attempt is enough to constitute a reasonable effort (Bizimungu et $a l)$. Moreover, the Chamber has found an alternative route when confronted with the non-fulfilment of due diligence. In Simba it directed the prosecutor to obtain the documents needed by the defence. In addition, the application of subpoena orders against unwilling witnesses has been quite extensive: (1) the Krstić Appeals Chamber practically invalidated the Blaškić decision for the purposes of witness testimony when it decided that also (former) state officials can be subpoenaed to testify on their experiences during their official position; and (2) the subpoena power has been used for the purpose of ex parte, preparatory witness interviews, arguably making a severe intrusion into the area of an individual's privacy, to facilitate the defence in its trial preparations.

However, as argued by the International Bar Association in a recent report evaluating fairness at the ICC, "[t] he process of securing the cooperation of states on matters concerning the defence needs to be streamlined." ${ }^{\prime 467}$ From the perspective of the substantive requirements for the Chamber's assistance, one outstanding issue in the ICC's practice is the 'due diligence' requirement as developed in the practice of the ad hoc tribunals. What does the defence have to do, or to substantiate, in order be able to receive assistance from the Chamber? It first has to seek state cooperation on its own. If no answer is provided or the request is denied, the defence may request the Registry for assistance. And if the Registrar's efforts are in vain, the defence

467 Fairness at the International Criminal Court, 2011, p. 40: "The IBA urges the Registry to create a standardised protocol governing defence cooperation requests endorsed by the Chambers, similar to the Court Protocol. The protocol should clearly indicate:

- the steps to be taken by Counsel in preparing and transmitting cooperation requests;

- the Registry's role in this process;

- the form that the onward transmission by the Registry will take - whether it will be a cover letter or note verbale; and

- the procedure to be followed before the Chamber pursuant to Article 57(3) of the Rome Statute. The CSS - defence counsel's first point of reference - should ensure that this protocol is included in the standard information packet that is made available to counsel." 
can approach the Chamber. Viewed in this light, this approach does strike one as being a "circuitous approach [that] is recourse intensive and needs to be revisited," if only to save scarce resources. ${ }^{468}$ There is a need for a clear "legal and policy framework" for defence cooperation requests. ${ }^{469}$ Not too lightly resorting to binding orders is understandable, however, to prvide an effective tool for the defence in their investigative efforts, the Chamber's cooperation must reflect a cooperative approach. This does not seem to be reflected in practice when denying a cooperation order before the confirmation of charges hearing on the basis of the defence's presumed lack of interest in an investigation when it does not contest the charges. Or by directing the defence to request the prosecution for certain materials when it has filed an ex parte application before the Chamber.

This does not mean that the Chambers should not take greater issue with the prosecutor's quasi-judicial role. In fact, while paying appropriate attention to their own responsibility to ensure equality between parties, ${ }^{470}$ the Chambers have not paid sufficient (explicit) attention to the shared responsibility of the prosecutor concerning truth finding, fair trial and equality of arms. Arguably, the circumstances under which the international criminal courts must operate demand a more robust approach towards the enforcement of prosecutorial objectivity, particularly in the investigative stage of the proceedings. Without losing sight of the difficulties that may exist when reconciling a 'minister of justice' and a 'partisan advocate' in a role that is quasijudicial in nature, the judges should arguably be more explicit and consistent as to their vision of the prosecutorial role. To some extent, this might be the most appropriate (and visible) route to follow when trying to eradicate any (appearance of) inequality of arms that seems to persist in the area of international criminal investigations.

As argued by Wladimiroff, “... one might wonder whether defence attorneys could just 'play ball through the prosecution' and solve all these problems that way." 471 To some extent, this solution does not generally 'fit in' with the ad hoc tribunals' procedural systems. ${ }^{472}$ On the other hand, it can be argued, this solution was principally intended within the framework of the ICC, as discussed above. Of

468 Fairness at the International Criminal Court, 2011, p. 36.

469 Fairness at the International Criminal Court, 2011, p. 36.

470 E.g. ICTR, Prosecutor v. Renzaho, Judgment and Sentence, ICTR-97-31-T, T. Ch., 14 July 2009, par. 62, referring to Tadić; the Chamber reiterated that "Equality of arms before the Tribunal means that a Chamber shall provide every practicable facility it is capable of granting under the Rules and the Statue when faced with a request by a party for assistance in presenting its case. Provisions under the Statute and the Rules exist to alleviate the difficulties faced by parties by empowering the Chambers to issue such orders, summonses, subpoenas, warrants and transfer orders as may be necessary for the purposes of investigation of for the preparation of conduct of trial. In addition, where such measures have proved to no avail, a Chamber may order that proceedings be adjourned or, of the circumstances so require, that they be stayed."

471 Wladimiroff, 2002, p. 249.

472 Wladimiroff, 2002, p. 248. 
course, realistically, this could not function as a solution in all possible scenarios. The defence might not be willing to disclose to the prosecution certain witnesses or information sources, of which the defence is not sure as to their content, for various reasons. It is difficult to discover a structural view on the threshold that the defence teams have posed for themselves before seeking the Chambers' assistance for trial preparations. What surfaces from the above discussion is that the defence is advised to address the Chamber earlier rather than later as a means of "self-protection" to establish a "contemporaneous record", which would avoid "the inevitable charge by the prosecution - when the defence later seeks to have additional evidence admitted in an appeal against conviction - that there is no support for the claim by the defence that it had attempted but failed to obtain the cooperation of the perspective witness." ${ }^{473}$ It should be noted that this approach arguably 'drives an adversarial wedge' between the parties, by requiring a more proactive approach from the defence. This might be perceived as countervailing the above argument, imposing a more 'trustful' and 'coordinate' environment between the parties. Admittedly, a fair portion of the 'civil law tradition' might be talking when it is argued that a system that upholds prosecutorial objectivity to the highest standards, while providing the defence with an opportunity to have adequate time and facilities to prepare its own line of reasoning, is undeniably one step closer to a meaningful 'equality of arms'. The opportunity to have adequate time and facilities to prepare its case is the subject of examination in the following chapters.

473 ICTY, Prosecutor v. Krstić, Appeals Subpoena Decision, 1 July 2003, par. 14. See also e.g. ICTR, Prosecutor v. Renzaho, Judgment and Sentence, ICTR-97-31-T, T. Ch., 14 July 2009, par. 65: the defence must exhaust the remedies available to seek the assistance of the Chamber to issue necessary orders and subpoenas. With regard to the issue of witness intimidation the Chamber reasoned that the Defence should (1) establish witness intimidation on the balance of probabilities, (2) exhaust all available measures afforded under the Statute and Rules to obtain the presentation of evidence; and (3) show material prejudice (Id., par. 63). 


\section{Chapter 5 \\ DisCLOSURE OF INFORMATION}

\subsection{InTRODUCTION}

Chapter 4 has focused on the role of an international prosecutor and the ability of parties to conduct their investigations. The quasi-judicial requirement of objectivity that characterizes the responsibilities of a prosecutor encompasses, at a minimum, an obligation to disclose all the possibly favourable evidence to the defence. ${ }^{1}$ The principle of equality of arms is central to any discussion of 'disclosure obligations' in the criminal process, which is the focus of this chapter. ${ }^{2}$

In international criminal proceedings, equality of arms is extensively debated in the area of access to information, also referred to as discovery or disclosure process. ${ }^{3}$ 'No trial by ambush' is the underlying rationale of the disclosure obligations, which serves the fairness of the process. The ability to prepare one's case, to a large extent, depends on the defence team's access to the necessary information that forms the basis of the criminal accusation against the accused. ${ }^{4}$ Without this access, a meaningful

1 In th e context of the ICC, this obligation is arguably extended to encompass the duty to conduct proper investigations that cover possibly favourable evidence to the defence.

2 Discovery and disclosure are often used interchangeably to describe the process of collecting information that can be presented as evidence in dispute settlement or a trial and is central to the adversarial mode of dispute resolution. The recent UK Civil Procedure Rules now call this factdeveloping process 'disclosure', while the US uses discovery to indicate a comparable process (Lord Woolf, Access to Justice: Final Report, Chapter 12, paragraph 37 http://webarchive.nationalarchives. gov.uk/+/http://www.dca.gov.uk/civil/final/contents.htm). It seems that in criminal procedure, the term 'disclosure' is in use; as it is in the context of the ad hoc tribunals and the ICC.

3 See Chapter 2 for disclosure obligations within the human rights framework. Also NewTon, 2011, p. 416: "Access to information in the preparation of the defense case is an essential element of equality of arms. On occasion, the lack of fair and timely access to information may even represent the single most troubling aspect of the international criminal justice system". See also JoNES, 2004, p. 489: "Disclosure of documentary evidence poses, however, some of the most complex problems for the defence in their pre-trial preparation. ... common difficulties are: differences is views between the prosecution and the defence as to what constitutes 'exculpatory' material, the relationship between Rules 68 and 70, access to documents on other ICTY cases, in particular so-called ' flip-side' cases (i.e. cases where the prosecution has prosecuted members of the other side to the conflict in the same time and place, and where, therefore, the evidence is of mutual relevance to the defence in each case), and access to UN and government archives in the prosecution's possession."

4 In Lubanga, the Single Judge considered "that the relevant rules on disclosure are a key tool in the Court's criminal procedure to ensure the fundamental right of any person to a fair and expeditious trial, and that they must be interpreted in a way consistent with, inter alia, the rights of the accused to be informed promptly and in detail of the nature, cause and content of the charges and to have 
equality of arms cannot be sustained. In theory, the prosecutorial advantage of being able to initiate an investigation, the principally greater resources and the powers belonging to the state that are associated with a public prosecutor's office necessitate some 'equalizing' of arms between the prosecutor and the defence to provide a fair opportunity for the latter to put forward a meaningful defence. In other words, the defence is very much dependent on prosecutorial disclosure for access to materials and building up its case. As discussed in Chapter 3, different systems adopt different means in facilitating defence access to relevant information and to ensure adequate facilities to prepare for trial. Rather than taking the dossier approach typical in civil law tradition-based systems, almost all international criminal tribunals incorporate the 'disclosure' approach known to the common law tradition. This chapter takes a closer look at this disclosure system and practice in international criminal trials. It is not an overstatement to notice that the disclosure (mal)practice continues to be one great source of frustration for the parties involved and the institutional stability see from the perspective of equality of arms. This chapter, more specifically, delineates how the disclosure regime and practice have affected a meaningful interpretation and application of the principle of equality of arms.

First, the prosecutorial disclosure obligation generally and the exceptions to it made possible in light of the necessary protection of competing interests will be briefly reflected upon. Then, the scope of the prosecutorial obligation to disclose potentially favourable evidence to the defence and the development of this practice will be discussed. This element is particularly important in light of the prosecution's role as an 'impartial truth-seeker', and will be the focal point of this chapter. Next, the disclosure obligations of the defence will be considered as, by definition, they have a somewhat unsettling relationship with the fundamental rights of an accused. It is interesting to reflect on whether equality of arms considerations have played a role in the development of defence disclosure obligations. Lastly, some concluding observations will be made.

\subsection{Prosecutorial disclosure: General Obligations}

Central to procedural fairness and equality of arms is the right to receive the evidence on which the prosecution is planning to rely, in other words equality of arms also entails a duty incumbent upon the prosecution to disclose all evidence for or against the accused. ${ }^{5}$ Nevertheless, in human rights law the duty is not absolute since it can be counterbalanced by fundamental competing individual or public interests,

adequate time and facilities to prepare the defence". See ICC, Prosecutor v. Lubanga Dyilo, Decision on the Final System of Disclosure and the Establishment of a Timetable, ICC-01/04-01/06-102, PTC, 15 May 2006, pp. 4-5.

5 ECtHR, Edwards v. The United Kingdom, App. No. 13071/87, 19 December 1992, par. 36. 
for instance national security interests and the need to protect witnesses. ${ }^{6}$ In such cases, adequate adversarial proceedings must be in place. ${ }^{7}$ The basic rule on the disclosure of evidence is that "in principle ... the prosecution authorities should disclose to the defence all material evidence in their possession for or against the accused." Measures restricting the rights of the accused must be strictly necessary and any difficulties caused by this limitation that the defence has to endure must be sufficiently counterbalanced in order to ensure a fair trial for the accused. ${ }^{9}$ This is so far the guidance provided by human rights case law.

\subsubsection{ICTY, ICTR and SCSL}

In the framework of the ad hoc tribunals, the prosecution must hand over to the defence during the pre-trial stage all materials supporting the indictment, copies of witness statements it intends to rely on, and exculpatory evidence, or "all information which in any way tends to suggest the innocence or mitigate the guilt of an accused or may affect the credibility of prosecution evidence, as well as material which may put an accused on notice that such material exists." 10 Two types of disclosure obligations arise: (1) a positive obligation to disclose certain materials; and (2) an obligation to facilitate the inspection of certain materials by the other party.

In the context of the ad hoc tribunals, there are essentially four categories of disclosure:

(1) Within 30 days of the initial appearance, the prosecutor shall disclose all the supporting material accompanying the indictment, as well as all prior statements obtained by the prosecutor from the accused (Rule 66 (A)(i)). ${ }^{11}$ The term "supporting material" refers to the materials upon which the charges are based. ${ }^{12}$ In Blaškić the ICTY Trial Chamber adopted a very broad definition when it considered that "all the previous statements of the accused which appear in the Prosecutor's file, whether collected by the Prosecution or originating from any other source, must be disclosed to the Defence immediately." ${ }^{13}$ In the decision of

6 ECtHR, Jasper v. The United Kingdom, App. No. 27052/95, 16 February 2000, par. 52.

7 ECtHR, Jasper v. The United Kingdom, App. No. 27052/95, 16 February 2000, paras. 53-54.

8 ECtHR, Rowe and Davis v. United Kingdom, App. No. 28901/95, 16 February 2000, par. 60.

9 ECtHR, Rowe and Davis v. United Kingdom, App. No. 28901/95, 16 February 2000, paras. 60-61.

10 ICTY, Prosecutor v. Krstić, Appeals Chamber, Decision on Prosecution's Motion to Be Relieved of Obligation to Disclose Sensitive Information Pursuant to Rule 66(C), IT-98-33-A, 27 March 2003, par. 4.

11 Rule 66(A)(i) ICTY, ICTR and SCSL RPE.

12 ICTY, Prosecutor v. Kordić and Čerkez, Order on Motion to Compel Compliance by Prosecution with Rule 66(A) and 68, IT-95-14-PT, 26 February 1999, p. 3.

13 ICTY, Prosecutor v. Blaškić, Decision on the Production of Discovery Materials, IT-95-14-PT, 27 January 1997, par. 37: "The same interpretation of Sub-rule 66(A) leads to the Trial Chamber to 
15 July 1998, the Trial Chamber in the same case limited its scope by clarifying that "all prior statements obtained by the Prosecutor from the accused" meant "all statements made by the accused during questioning in any type of judicial proceeding which may be in the possession of the Prosecutor, but only such statements." 14

(2) Within a time limit set by the Pre-Trial Judge or Trial Chamber, copies of the statements of witnesses who the prosecution intends to call at trial must be disclosed (Rule 66(A)(ii)). ${ }^{15}$ This is a positive obligation and it thus does not suffice for the prosecutor to place the materials on the EDS (the Electronic Disclosure System) or to provide the defence with a 'courtesy copy' three days before the witness is to take the stand. ${ }^{16}$ Witness statements under Rule 66(A)(ii) refer to "all previous statements of all Prosecution witnesses, in whatever form." 17 The Appeals Chamber has held that the term "witness statement", in relation to Rule 66(A)(ii), is to be interpreted as the "account of a person's knowledge of a crime, which is recorded through due procedure in the course of an investigation into the

draw no distinction between the form or forms which these statements may have. Moreover, nothing in the text permits the introduction of the distinctions suggested by the Prosecution between "the official statements taken under oath or signed and recognized by the accused" and the others". At that time, Rule 66(A) read: "The Prosecutor shall make available to the defence, as soon as practicable after the initial appearance of the accused, copies of the supporting material which accompanied the indictment when confirmation was sought as well as all prior statements obtained by the Prosecutor from the accused or from prosecution witnesses. The final version of the statement of the accused or a witness audio-recorded at the time of the interview, as well as a translation into one of the working languages of the Tribunal shall be provided to the defence."

14 ICTY, Prosecutor v. Blaškić, Decision on the Defence Motion for Sanctions for the Prosecutor's Failure to Comply with Sub-Rule 66(A) of the Rules and the Decision of 27 January 1997 Compelling the Production of all Statements of the Accused, IT-95-14, 15 July 1998. The Defence argued for a much broader interpretation of "all prior statements of the accused" to include "orders issued freely by the accused himself in the course of his duties", an interpretation which the Trial Chamber rejected.

15 Rule 66(A)(ii) ICTY, ICTR and SCSL RPE. As well as copies of all transcripts and written statements taken in accordance with Rule 92bis, Rule 92ter, and Rule 92quater. Copies of the statements of additional prosecution witnesses shall be made available to the defence when a decision is made to call those witnesses.

16 A 'courtesy copy' does not mitigate the Prosecutor's failure to comply with the disclosure obligations. ICTY, Prosecutor v. Lukić and Lukić, Decision on Milan Lukić's Motion to Suppress Testimony for Failure of Timely Disclosure with Confidential Annexes A and B, IT-98-32/1-T, T. Ch. III, 3 November 2008, par. 17.

17 ICTR, Prosecutor v. Bizimungu et al., Decision on Prosper Mugiraneza's Motion to Require Strict Compliance with Rule 66(A)(ii), ICTR-99-50-I, 5 May 2004, par. 7. However, "only when the Witness is to testify on the same subject matter as his previous testimony that this previous testimony shall constitute a witness statement within the meaning of Rule 66(A)(ii) and is therefore subject to disclosure" (Id., par. 8). 
crime." ${ }^{18}$ The same criteria as those identified in respect of previous statements by the accused under Rule 66(A)(i) are applicable mutatis mutandis to the previous statements of witnesses under Rule 66(A)(ii). ${ }^{19}$ In Karadžić, the Trial Chamber considered that Rule 66(A)(ii) disclosure encompasses all witnesses from the original Rule 65ter witness list, even if later identified as 'reserved witnesses'. This status of witnesses would only be relevant for the assessment of whether the accused had suffered prejudice due to a disclosure violation..$^{20}$

(3) In addition, the prosecution, on request, must permit the defence to inspect the documents in its possession or under its control that "are material to the preparation of the defence," and those that "are intended for use by the Prosecutor as evidence at trial" or "were obtained from or belonged to the accused" (Rule 66(B)). With regard to Rule 66(B) the Appeals Chamber considered that "purely inculpatory material is not necessarily immaterial for the preparation of the Defence"; the prosecution has to consider: "(a) whether the issues to which the material related are subject to a ground of appeal", or "(b) whether the material could reasonably lead to further investigation by the Defence and the discovery of additional evidence admissible under Rule 115 of the Rules." ${ }^{21}$ The defence

18 ICTY, Prosecutor v. Blaškić, Decision on the Appellant's Motion for the Production of Material, Suspension or Extension of the Briefing Schedule, and Additional Filings, IT-95-14-A, 26 September 2000, par. 15. Also SCSL, Prosecutor v. Norman et al., Decision on Disclosure of Witness Statements and Cross-Examination, SCSL-04-14-T, 16 July 2004, par. 10. Under Rule 66(A)(i) witness statements are defined as: "any statement or declaration made by a witness in relation to an event he or she witnessed and recorded in any form by an official in the course of an investigation". These include "statements taken by humanitarian organisations for the purpose of recording allegations of human rights abuses, when these are passed to the Prosecution in order to assist it in identifying potential lines of inquiry which then result in the persons who gave the original statements becoming witnesses in Tribunal proceedings" (see ICTY, Prosecutor v. Milutinović et al., Decision on Ojdanić Motion for Disclosure of Witness Statements and for Finding of Violation of Rule 66(A)(ii), IT05-87, 29 September 2006, par. 14); and statements "taken by national authorities in the course of other judicial proceedings" (see ICTR, Prosecutor v. Gatete, Decision on Defence Motions for Disclosure Pursuant to Rule 66(A)(ii) and Commencement of Trial, ICTR-2000-61-PT, 13 October 2009, par. 19); but not a "transcript of an interview given to a journalist for the purpose of making a documentary" (see ICTY, Prosecutor v. Karadžić, Decision on Accused's Eighteenth to TwentyFirst Disclosure Violation Motions, IT-95-5/18-T, T. Ch., 2 November 2010, par. 40).

19 ICTY, Prosecutor v. Milutinović et al., Decision on Ojdanić Motion for Disclosure of Witness Statements and for Finding of Violation of Rule 66(A)(ii), IT-05-87, 29 September 2006, par. 15, footnote 17.

20 ICTY, Prosecutor v. Karadžić, Decision on Accused's Eighteenth to Twenty-First Disclosure Violation Motions, IT-95-5/18-T, T. Ch., 2 November 2010, par. 35.

21 ICTR, Prosecutor v. Casimir Bizimungu et al., Decision on Prosper Mugiraneza's Motion to Require Strict Compliance with Rule 66(A)(ii), ICTR-99-50-I, T. Ch., 5 May 2004, par. 16, referring to ICTY, Prosecutor v. Krstić, Confidential Decision on the Prosecution's Motion to be Relieved of Obligation to Disclose Sensitive Information Pursuant to Rule 66(C), IT-98-33-A, A. Ch., 27 March 2003, p. 4. Witness statements include: audio or video recorded transcripts (ICTR, Prosecutor $v$. 
needs to establish a legitimate forensic purpose for seeking additional material and that material needs to be in the possession of the prosecutor. ${ }^{22}$

In Karadžić, the Trial Chamber considered that the disclosure of a large volume of Rule 66(B) material shortly before the hearing of a witness was not a valid reason to postpone the commencement of cross-examination by the defence. ${ }^{23}$ The Chamber considered the accused's Rule 66(B) requests and found that "there is a direct correlation between making numerous, and often, large requests for information, some at a relatively late stage, and the disclosure of a considerable quantity of material." ${ }^{24}$ Moreover, Rule 66(B) requests can be made at any time, which makes setting a deadline on Rule 66(B) disclosure impossible, and, thus, there can be no right on the part of the defence to have all such materials reviewed prior to the hearing of evidence in the case ${ }^{25}$ Otherwise, according to the Chamber, the defence would be in a position to delay the commencement of the trial only by holding off its Rule 66(B) requests.

(4) Moreover, the prosecution must disclose to the defence, "as soon as practicable", all exculpatory material, i.e. "material known to the Prosecutor which in any way tends to suggest the innocence or mitigate the guilt of the accused or may affect the credibility of prosecution evidence." (Rule 68). ${ }^{26}$ The duty to hand over

Karemera et al., Decision on the Defence Notification of Failure to Comply with Trial Chamber Order and Motion for Remedial Measures, ICTR-98-44, 20 October 2003, paras. 5, 11); testimony transcript from other cases (ICTR, Prosecutor v. Mpambara, Decision Defence Motion for Disclosure of Documents and Objections Regarding the Legality of Procedures, ICTR-2001-65-1, 28 February 2002, par. 23); witness statements collected from sources other than the Prosecution (ICTY, Prosecutor v. Milutinović et al., Decision on Ojdanić Motion for Disclosure of Witness Statements and for Finding of Violation of Rule 66(A)(ii), IT-05-87, 29 September 2006, par. 15, footnote 17; ICTR, Prosecutor v. Nyiramasuhuko et al., Decision on the Defence Motion for the Disclosure of the Declaration of the Prosecutor's Witnesses Detained in Rwanda and all Other Documents and Information Pertaining to the Judicial Proceedings in their Respect, ICTR-9721-T, 18 September 2001, paras. 6, 9); and interview notes (ICTY, Prosecutor v. Milutinović et al., Decision on Renewed Prosecution Motion for Leave to Amend Its Rule 65ter List to Add Michael Phillips and Shaun Byrnes, IT-05-87-T, 16 January 2007, par. 15).

22 ICTY, Prosecutor v. Delalić et al., Decision on the Motion of the Accused Zejnil Delalić for the Disclosure of Evidence, IT-96-21-T, T. Ch. II, 26 September 1996, paras. 8-9. ICTY, Prosecutor v. Naletilić and Martinović, Decision on Joint Motions for Order Allowing Defence Counsel to Inspect Documents in the Possession of the Prosecution, IT-98-34-T, 16 September 2002.

23 ICTY, Prosecutor v. Karadžić, Decision on Accused's Motion for Additional Time to Prepare CrossExamination of Momčilo Mandić, IT-95-5/18-T, T. Ch., 2 July 2010.

24 ICTY, Prosecutor v. Karadžić, Decision on Accused's Motion for Additional Time to Prepare CrossExamination of Momčilo Mandić, IT-95-5/18-T, T. Ch., 2 July 2010, par. 9.

25 ICTY, Prosecutor v. Karadžić, Decision on Accused's Motion for Additional Time to Prepare CrossExamination of Momčilo Mandić, IT-95-5/18-T, T. Ch., 2 July 2010, par. 9, in footnote 16 referring to ICTR, Prosecutor v. Ngirabatware, Decision on Trial Date, ICTR-99-54-T, 12 June 2009, par. 43. Rule 68 ICTY, ICTR and SCSL RPE. 
exculpatory evidence is a continuous obligation, which continues to apply even in the case of an appeal or after the termination of the trial. ${ }^{27}$

At the ICTY, no less than six weeks before the Pre-Trial Conference, the Prosecution must file, inter alia, "the list of exhibits the Prosecutor intends to offer stating where possible whether the defence has any objection as to authenticity" (Rule 65ter(E)(iii)). ${ }^{28}$ Rule 65ter(E)(iii) was amended in December 2001 to include a second sentence necessitating the prosecutor to disclose to the defence copies of the exhibits that the prosecutor has listed indicating whether the defence has any objection as to their authenticity. ${ }^{29}$ This amendment followed the decision in Krajišnik and Plavšić, where the ICTY Trial Chamber had to resolve conflicting interpretations of that Rule. ${ }^{30}$ The prosecution argued, referring to the finding in the Krstic pre-trial conference, ${ }^{31}$ that Rule 65ter(E)(iii) did not oblige it to disclose the exhibits listed as such. Because this Rule is "purely procedural", the prosecution was only willing to disclose the exhibits if it was triggered by a reciprocal disclosure so as to "increase the efficiency of proceedings, protect equality of arms and protect the integrity of documentary evidence." ${ }^{32}$ The defence also relied on equality of arms to argue that it can only be vindicated when the prosecution discloses the materials to which it has access contrary to the defence. ${ }^{33}$ The Trial Chamber agreed with the defence and stated that

27 ICTY, Prosecutor v. Kordić and Čerkez, Appeals Chamber, Judgment, IT-95-14/2-A, 17 December 2004, section IV.D.

28 There is no comparable rule at the ICTR or SCSL. Although the formal function of a Pre-Trial Judge is absent at the ICTR and SCSL, a designated Judge (the Trial Chamber's Judge, often the president) takes it upon himself to collect the pre-trial filings of the parties, see Rule 73bis ICTR ad SCSL. The SCSL judges have adopted a more progressive - ICTY - stance on the powers of judges to control pre-trial proceedings: contrary to the ICTR, Rule 73bis $(\mathrm{G})$ (introduced in 2006, and was thus only relevant for the Taylor trial) authorises the Trial Chamber to invite the Prosecutor to adduce the number of counts charged in the indictment and to determine the number of sites or incidents representative of the crimes charged. See also Rule $73 b i s(D)$ and (E) ICTY RPE.

29 Rule 65ter(E)(iii): When all the preliminary motions have been disposed of, the Pre-Trial Judge shall set a time-limit (not later than 6 weeks before the Pre-Trial Conference) for the Prosecutor to file ... "(iii) the list of exhibits the Prosecutor intends to offer stating where possible whether the defence has any objection as to authenticity. The Prosecutor shall serve on the defence copies of the exhibits so listed".

30 ICTY, Prosecutor v. Krajišnik and Plavšić, Decision on Prosecution Motion for Clarification in Respect of Application of Rules 65, 66(B) and 67(C), T. Ch., IT-00-39 \& IT-00-40/1, 1 August 2001.

31 ICTY, Prosecutor v. Krstić, Status Conference Transcript, 6 March 2000 (closed session).

32 ICTY, Prosecutor v. Krajišnik and Plavšić, Decision on Prosecution Motion for Clarification in Respect of Application of Rules 65, 66(B) and 67(C), T. Ch., IT-00-39 \& IT-00-40/1, 1 August 2001, par. 4.

33 ICTY, Prosecutor v. Krajišnik and Plavšić, Decision on Prosecution Motion for Clarification in Respect of Application of Rules 65, 66(B) and 67(C), T. Ch., IT-00-39 \& IT-00-40/1, 1 August 2001, par. 5. 
The only way in which the Defence can properly prepare for trial is by having notice in advance of the material on which the Prosecution intends to rely, including exhibits. The Prosecution, by not disclosing the documents prior to trial, places the Defence in a position in which it will not be able to prepare properly; and it is this fact that is likely to lead to a violation of the principle of equality of arms. ${ }^{34}$

Consequently, the Chamber concluded that "the Prosecution must disclose all the exhibits on which it intends to rely, at least, by the time that it files its pre-trial brief." 35

Notably, Krstić argued, on appeal, that the above-mentioned decision of the PreTrial Judge not to order the prosecution to disclose all of its exhibits to the defence had resulted in unfairness that necessitated the remedy of a retrial. ${ }^{36}$ In support of this argument the Krstić Defence relied on the Krajišnik and Plavšić decision discussed above, and the subsequent Rule change. ${ }^{37}$ As formulated by the Appeals Chamber, the "issue is whether the amendment to Rule 65ter reflects a consensus as to the proper interpretation of the former Rule, and whether the Trial Chamber in Krajišnik and Plavšić accurately described that interpretation." 38 The Appeals Chamber adopted a rather peculiar stance on this issue. The Chamber considered that while Rules are frequently amended because they require clarification or modification, and the amendments "may cast light on the ambiguity of the former formulation of the Rule," the amendments do not "necessarily assist in the interpretation of it." 39 The rule change merely suggested that the judges recognized that the practice of nondisclosure of the listed exhibits prior to trial "may lead both the Defence and the Prosecution into difficulties when it comes to contesting the authenticity of exhibits," which in turn could result in delays. ${ }^{40}$ Consequently, the "amendment may have been a matter relevant to the efficient management of the trial itself, and not the result of any perceived unfairness to the Defence." ${ }^{41}$ It is indeed not clear why exactly Rule 65ter (E)(ii) was changed, but following the decision in Krajišnik and Plavšić the 'fairness

34 ICTY, Prosecutor v. Krajišnik and Plavšić, Decision on Prosecution Motion for Clarification in Respect of Application of Rules 65, 66(B) and 67(C), T. Ch., IT-00-39 \& IT-00-40/1, 1 August 2001, par. 7: "In addition, the practice may lead to applications for adjournment during the trial to allow the Defence to deal with exhibits of which they had no prior notice, and given the number of documents concerned in this case, such applications might be frequent." Moreover, the Chamber noted that the reference to the Defence's objections to the authenticity of the prosecution's exhibits in Rule 65ter(E)(iii) would be pointless "since it is difficult to see how the Defence can be in a position to indicate any objections if it has not had the opportunity of viewing the exhibits" (par. 8).

35 ICTY, Prosecutor v. Krajišnik and Plavšić, Decision on Prosecution Motion for Clarification in Respect of Application of Rules 65, 66(B) and 67(C), T. Ch., IT-00-39 \& IT-00-40/1, 1 August 2001, par. 10.

36 ICTY, Prosecutor v. Krstić, Appeal Judgment, IT-98-33-A, 19 April 2004, par. 155.

37 ICTY, Prosecutor v. Krstić, Appeal Judgment, IT-98-33-A, 19 April 2004, paras. 157-158.

38 ICTY, Prosecutor v. Krstić, Appeal Judgment, IT-98-33-A, 19 April 2004, par. 161.

39 ICTY, Prosecutor v. Krstić, Appeal Judgment, IT-98-33-A, 19 April 2004, par. 162.

40 ICTY, Prosecutor v. Krstić, Appeal Judgment, IT-98-33-A, 19 April 2004, par. 163.

41 ICTY, Prosecutor v. Krstić, Appeal Judgment, IT-98-33-A, 19 April 2004, par. 163. 
towards the defence' argument does not seem to be too far-fetched. It is unclear why the prosecutor would experience difficulties with regard to contesting authenticity when this rule only requires the prosecutor to disclose exhibits and indicate the defence's objections to authenticity when possible. Moreover, the Trial Chamber in Krajišnik and Plavšić explicitly considered that " ... to allow a narrow interpretation of the Rules [would be] to override elementary notions of a fair trial, i.e. that the accused, without incurring the obligation of disclosure, should know the case he or she has to meet and should be given adequate opportunity to prepare a Defence." ${ }^{42} \mathrm{Be}$ that as it may, the Appeals Chamber's reasoning seems unnecessary in this context. The Defence argued that the prosecutor's disclosure tactics had led to unfairness, which it did not substantiate in the end..$^{43}$ Indeed, an admission in abstracto that the Rule change was motivated by the necessities of fairness towards the defence would not automatically render Krstić's ground of appeal to be substantiated.

\subsubsection{International Criminal Court}

Pre-trial disclosure at the ICC is divided into two parts: (1) the pre-confirmation hearing and (2) pre-trial disclosure. According to Article 61(3) ICC Statute, within a reasonable time before the confirmation of charges hearing, the suspect must be provided with the charging documents and be informed of the evidence on which the prosecutor intends to rely during the confirmation hearing. The Pre-Trial Chamber may issue additional orders on the disclosure of information for the hearing. ${ }^{44}$ Rule 121(2)(3) provides more details regarding the disclosure: the disclosure of a detailed description of the charges together with a list of supporting evidence should be provided to the suspect and the Pre-Trial Chamber no later than 30 days before the confirmation hearing (Rule 121(2)(3)). The Pre-Trial Chamber, that must receive all disclosures between the parties, plays an important monitoring role and must hold status conferences "to ensure that disclosure takes place under satisfactory conditions." ${ }^{45}$

42 ICTY, Prosecutor v. Krajišnik and Plavšić, Decision on Prosecution Motion for Clarification in Respect of Application of Rules 65, 66(B) and 67(C), T. Ch., IT-00-39 \& IT-00-40/1, 1 August 2001, par. 9.

43 ICTY, Prosecutor v. Krstić, Appeal Judgment, IT-98-33-A, 19 April 2004, paras. 164-165. The defence did not establish that it was prevented from properly investigating the authenticity of the exhibits by the Trial Chamber's ruling at pre-trial, and neither did the defence show that it had suffered prejudice as a result.

44 In Bemba, for example, the Pre Trial Chamber ordered the parties to provide (1) a list of evidence, (2) a list of identified recipients for each item reflecting also the access and the level of confidentiality for each item vis-à-vis any party, and (3) an analysis of each piece of evidence. ICC, Prosecutor v. Bemba, Decision on the Evidence Disclosure System and Setting a Timetable for Disclosure between the Parties, ICC-01/05-01/08-55, 31 July 2008, p. 22. ICC, Prosecutor v. Bemba, Decision on the Evidence Disclosure System and Setting a Timetable for Disclosure between the Parties, ICC01/05-01/08-55, 31 July 2008, p. 22.

45 Rule 121(2) RPE. 
The general pre-trial disclosure is governed by Article 67(2) (disclosure of exculpatory evidence); Rule 76-77 (the Prosecutor's disclosure obligations) and Rules 78-80, governing those of the defence. In the Lubanga case, the Single Judge drew a distinction between two modalities: disclosure stricto sensu (Article 67(2), Rules 76 and 79), which requires the relevant party to provide directly to the other party copies of the evidence and materials subject to disclosure; and inspection (Rules 77-78), which imposes on the relevant party the obligation (i) to allow the other party to inspect the relevant books, photographs, maps, and tangible objects, and (ii) to provide those copies requested during inspection. ${ }^{46}$ The Single Judge rejected the defence's request for full access to the entire investigation file of the prosecutor in that case, considering this request to be "fundamentally contrary to the system of disclosure set out in the Statute and the Rules, and in particular in Articles 61(3), 67(1)(a) and (b) and 67(2) of the Statute and Rules 76 and 77 of the Rules." ${ }^{47}$ Moreover, although the Rules on disclosure seem to imply an inter partes process, "in order to have legal certainty of the content of the requests of the Defence for materials and of the responses of the Prosecution, a copy of any such request and response made since the issuance of the present decision must be filed in the record of the case." 48

\section{Disclosure strictu sensu: Rule 76}

Contrary to Rule 66(A)(i) ICTY RPE, Rule 76 ICC does not envisage the disclosure of all the prior statements of the accused. However, according to Rule 112(1)(e), the copy of the transcript and of the audio or video-recorded tape of an interview with the suspect must be provided to him. Furthermore, the ICC prosecutor has to provide the suspect with the names of the witnesses the prosecution intends to call at trial and the copies of their prior statements. ${ }^{49}$ This obligation is comparable to Rule 66(A)(ii) ICTY RPE.

46 ICC, Prosecutor v. Lubanga Dyilo, Decision on the Final System of Disclosure and the Establishment of a Timetable, ICC-01/04-01/06-102, 15 May 2006, p. 4.

47 ICC, Prosecutor v. Lubanga Dyilo, Decision on the Final System of Disclosure and the Establishment of a Timetable, ICC-01/04-01/06-102, 15 May 2006, p. 5, Annex par. 15.

48 ICC, Prosecutor v. Lubanga Dyilo, Decision on Defence Requests for Disclosure of Materials, ICC01/04-01/06-718, 17 November 2006, PTC I, p. 3.

49 ICC, Prosecutor v. Lubanga Dyilo, Decision on Defence Requests for Disclosure of Materials, ICC01/04-01/06-718, 17 November 2006, PTC I, p. 4: "that in the view of the single judge the notion of 'prior statements' in rule 76 of the Rules includes statements taken by entities other than the Prosecution; that rule 76 of the Rules does not limit the Prosecution's disclosure obligations to prior statements 'in the possession or control of the Prosecutor'; and that, therefore, the Prosecution is under an obligation to make its utmost effort to obtain the prior statements of those witnesses on whom the Prosecution intends to rely at the confirmation hearing which have been taken by other entities." 


\section{Inspection of documents: Rule 77}

Similar to Rule 66(B), Rule 77 ICC RPE requires the prosecutor to permit the defence to inspect any books, documents, photographs and other tangible objects in the prosecutor's possession or control which (1) are material to the preparation of the defence, (2) are intended for use at the confirmation hearing or at trial, or (3) were obtained from or belonged to the suspect/accused..$^{50}$ The prosecutor is required to provide copies or photographs of the pieces of evidence requested during the inspection. ${ }^{51}$ The Lubanga Trial Chamber considered that

the prosecution's disclosure obligations under Rule 77 of the Rules are wide, and they encompass, inter alia, any item that is relevant to the preparation of the defence, and including not only material that may undermine the prosecution case or support a line of argument of the defence but also anything substantive that is relevant, in a more general sense, to defence preparation. This means that the prosecution is to communicate to the defence any material in its possession that may significantly assist the accused in understanding the incriminating and exculpatory evidence, and the issues, in the case..$^{52}$

Notably, in establishing a disclosure regime in Bemba, the Pre-Trial Chamber considered that

In the Chamber's opinion, the most important factor in both safeguarding the rights of the defence and enabling the Chamber to exercise its function is not for Prosecutor to disclose the greatest volume of evidence, but to disclose the evidence which is of true relevance to the case, whether that evidence be incriminating or exculpatory. In fact, disclosure of a considerable volume of evidence for which it is difficult or impossible to comprehend the usefulness for the case merely puts the defence in a position where it cannot genuinely exercise its rights, and serves to hold back the proceedings. ${ }^{53}$

Thus, in protecting the defence from being overburdened with massive disclosure, the Chamber considered that the prosecutor must subject the disclosure material to "a sufficiently detailed legal analysis," which should be presented as a summary table

50 See also ICC, Prosecutor v. Lubanga Dyilo, Decision on the scope of the prosecution's disclosure obligations as regards defence witnesses, ICC-01/04-01/06-2624, 12 November 2010, par. 13.

51 See e.g. ICC, Prosecutor v. Bahr Idriss Abu Garda, Decision Scheduling a Hearing on Issues relating to Disclosure between the Parties, ICC-02/05-02/09-18, 30 May 2009, PTC I, par. 5.

52 ICC, Prosecutor v. Lubanga Dyilo, Decision on the scope of the prosecution's disclosure obligations as regards defence witnesses, ICC-01/04-01/06-2624, 12 November 2010, par. 16.

53 ICC, Prosecutor v. Bemba, Decision on the Evidence Disclosure System and Setting a Timetable for Disclosure between the Parties, ICC-01/05-01/08-55, 31 July 2008, par. 67. 
showing the "relevance of evidence presented in relation to the constituent elements of the crimes with which the person is charged." 54

\section{Arrest warrant disclosure}

Prior to Mbarushimana's surrender to the ICC, the defence petitioned the prosecution for the disclosure of material related to the client's arrest for three purposes: to challenge the validity of the arrest warrant pursuant to Rule 117(3) of the RPE; to apply for interim release; and to challenge the admissibility of the case. The prosecution countered that neither the ICC Statute nor the RPE provided for disclosure in relation to the issuance of an arrest warrant. In support of its petition, the prosecution argued that "such advanced disclosure as sought by the defence created a risk of disseminating highly sensitive information to a person who is not subject to the Court's control." 55 Partially granting the defence request, the Pre-Trial Chamber affirmed the defence right to have access to documents which are essential for the purposes of applying for interim release and challenging the validity of the arrest warrant, but limited the scope of disclosure having regard to the sensitive nature of such disclosure. ${ }^{56}$

In Bemba, the defence appealed against the decision of a Single Judge denying his interim release on the ground that he had not been given access to all the relevant information underlying the decision for the arrest warrant. ${ }^{57}$ The Appeals Chamber, noting that there is no express regime for disclosure in relation to applications for interim release in the ICC's legal framework, considered that this framework does provide for a number of rights and guarantees for the arrested person and "[i]deally the arrested person should have all such information at the time of his or her initial appearance before the Court." ${ }^{58}$

54 ICC, Prosecutor v. Bemba, Decision on the Evidence Disclosure System and Setting a Timetable for Disclosure between the Parties, ICC-01/05-01/08-55, 31 July 2008, paras. 66, 70.

55 Fairness at the International Criminal Court, 2011, p. 21, referring to ICC, Prosecutor v. Callixte Mbarushimana, ICC-01/04-01/10-31, Prosecution Response to the 'Defence Request for Disclosure', 5 January 2011, PTC I, pp. 2, 12.

56 ICC, Prosecutor v. Callixte Mbarushimana, Prosecution Response to the 'Defence Request for Disclosure', ICC-01/04-01/10-31, 5 January 2011, PTC I, p. 17.

57 The decision appealed was: ICC, Prosecutor v. Bemba, ICC-01/05-01/08-14, Decision on the Prosecutor's Application for a Warrant of Arrest against Jean-Pierre Bemba Gombo, 10 June 2008, PTC III.

58 ICC, Prosecutor v. Bemba, ICC-01/05-01/08, Judgment on the Appeal of Mr Jean-Pierre Bemba Gombo against the decision of the Pre-Trial Chamber III entitled 'Decision on application for interim release', 16 December 2008, A. Ch., par. 26. 


\subsection{EXCEPTIONS TO DISCLOSURE: THE PROTECTION OF OTHER INTERESTS}

As discussed in Chapter 3, the right to have access to information which is material to the case is not absolute. Other interests may be involved, which necessitate the weighing of the defence right to have access to information and those other interests. Within the framework of the international criminal courts, the protection of witnesses and national security are essential other interests that have necessitated some substantial measure of 'balancing' on the part of the judges. Although the importance and the scope of the issue are immense, the following discussion can necessarily only be of a limited nature within the scope of this chapter. The goal is primarily to point out several areas of concern challenging the adequate facilities of the defence and, thus, equality of arms.

The ad hoc tribunals' framework, under Rule 66(C) RPE, allows the prosecution to apply to the Trial Chamber in camera to be relieved from the disclosure obligations in respect of information "the disclosure of which may prejudice further or ongoing investigations, or for any other reasons may be contrary to the public interest or affect the security interests of any State." ${ }^{59}$ Moreover, exempted from disclosure is the internal work prepared by a party in connection with the investigation or preparation of the case (Rule 70(A) RPE).$^{60}$ The investigator's notes, although falling under Rule 70(A) RPE, ${ }^{61}$ are disclosable in as far as they refer to witness statements. ${ }^{62}$ To the extent that questions were put directly to a witness and notes were made thereof, they fall outside the ambit of Rule 70(A) RPE. ${ }^{63}$ According to the Appeals Chamber

59 "When making such application the Prosecutor shall provide the Trial Chamber (but only the Trial Chamber) with the information that is sought to be kept confidential". See also Rule 66(C) ICTR and 66(B) SCSL RPE.

60 ICTR, Prosecutor v. Nahimana et al., Public Redacted Version of the Decision on Motions Relating to the Appellant Hassan Ngeze's and the Prosecution's Request for Leave to Present Additional Evidence of Witnesses ABC1 and EB, ICTR-99-52, 27 November 2006, par. 12; SCSL, Prosecutor v. Brima et al., SCSL-04-16-T, Decision on Joint Defence Motion on Disclosure of all Original Witness Statements, Interview Notes and Investigator's Notes Pursuant to Rules 66 and/or 69, 4 May 2005, par. 16.

61 ICTY, Prosecutor v. Blaškić, IT-95-14-PT, Decision on the Production of Discovery Materials, 27 January 1997, par. 40; Also in ICTR, Prosecutor v. Ndayambaje, Decision on Defence Motion for Disclosure, Rules 66, 70(A), and 73 of the Rules, ICTR-96-8-T, 25 September 2001; SCSL, Prosecutor v. Brima et al., Decision on Joint Defence Motion on Disclosure of all Original Witness Statements, Interview Notes and Investigator's Notes Pursuant to Rules 66 and/or 69, SCSL-0416-T, 4 May 2005.

62 SCSL, Prosecutor v. Norman et al., Decision on Disclosure of Witness Statements and CrossExamination, SCSL-04-14-T, 16 July 2004, par. 7, 16; SCSL, Prosecutor v. Brima et al., SCSL-0416-T, Decision on Joint Defence Motion on Disclosure of all Original Witness Statements, Interview Notes and Investigator's Notes Pursuant to Rules 66 and/or 69, 4 May 2005, par. 16.

63 ICTR, Prosecutor v. Niyitegeka, Appeals Judgement, ICTR-96-14-A, 9 July 2004, paras. 30-36. Questions merely noted down and not put to the witness, or any other notes with regard to the questioning of the witness do fall within the internal work product exception. 
in Niyitegeka, questionnaires put to the prosecution's witnesses were disclosable as witness statements. ${ }^{64}$

The protection of victims and witnesses is one of the principal concerns confronting international criminal courts. The disclosure requirement is expressly subjected to Rule 53 (public non-disclosure) and Rule 69 (the protection of victims and witnesses - including inter partes non-disclosure or delayed disclosure). ${ }^{65}$ The most common protective measure applied in the ad hoc tribunals' practice, in relation to disclosure, is the late or redacted disclosure of witness-identifying information. In fact, the "system of redacted disclosure is accepted as a virtually unavoidable consequence of the Tribunal's criminal proceedings." ${ }^{66}$ According to Rule 69 ICTY $\mathrm{RPE}$, the prosecutor can request protective measures, such as the non-disclosure or late disclosure of the identity of a witness in the pre-trial phase. Rule 75 deals with protective measures at trial.

Within the framework of the ICC, Rule 81 deals with restrictions on disclosure: ${ }^{67}$

1. Not subjected to disclosure are the internal documents prepared by a party for the preparation of its case;

2. Where the disclosure of material may prejudice ongoing investigations, the prosecutor shall apply to the Chamber ex parte for a ruling on the matter;

3. The non-disclosure of materials subject to confidentiality agreements, in accordance with Articles 54, 57, 64, 72 and 93, and in accordance with Article 68 , "to protect the safety of witnesses and victims and members of their families, such information shall not be disclosed, except in accordance with those articles. When the disclosure of such information may create a risk to the safety of the witness, the Court shall take measures to inform the witness in advance."

64 ICTR, Prosecutor v. Niyitegeka, Appeals Judgement, ICTR-96-14-A, 9 July 2004, paras. 33-34. In contrast see the Trial Chamber in Ndayambaye which considered the Prosecutor's witness questionnaires to be covered by the Rule 70(A) exception. See ICTR, Prosecutor v. Ndayambaje, Decision on Defence Motion for Disclosure, Rules 66, 70(A), and 73 of the Rules, ICTR-96-8-T, 25 September 2001, paras. 13-16.

65 ICTY, ICTR and SCSL RPE.

66 MCINTYRe, 2003, p. 287.

67 In Lubanga the Single Judge issued a decision laying out the principles of application of Rule 81(2) and (4) ICC RPE. See ICC, Prosecutor v. Lubanga Dyilo, Decision Establishing General Principles Governing Applications to Restrict Disclosure pursuant to Rule 81(2) and (4) of the Rules of Procedure and Evidence, ICC-01/04-01/06-108-Corr, 30 May 2006, par. 13. Hence, the Single Judge considers that, insofar as ex parte proceedings in the absence of the Defence constitute a restriction on the rights of the Defence, ex parte proceedings under Rule 81(4) of the Rules shall only be permitted subject to the Prosecution showing in its application that: i. it serves a sufficiently important objective; ii. it is necessary in the sense that no lesser measure could suffice to achieve a similar result; and iii. the prejudice to the Defence interest in playing a more active role in the proceedings must be proportional to the benefit derived from such a measure. 
4. The non-disclosure of materials subject to confidentiality agreements, in accordance with Article 54, 72 and 93, and in accordance with Article 68, to "protect the safety of witnesses and victims and members of their families, including by authorizing the non-disclosure of their identity prior to the commencement of the trial." ${ }_{68}$

Importantly, the Rule 75 emphasizes that the undisclosed material may not be introduced at trial without adequate prior disclosure to the accused. Rule 81(6) formulates 'equality of arms' with regard to the non-disclosure of information to the defence in relation to the protection of witnesses. Thus, information that is subject to disclosure can be withheld from the prosecution, and instead a summary thereof may be filed; however, that material may not be introduced into evidence without prior disclosure to the Prosecutor. The operation of any protective measures is subject to ultimate control by the Chambers. ${ }^{69}$

As mentioned, the practice of redacted documents has been extensive at the ad hoc tribunals. At the ICC, in the Lubanga case the Single Judge considered the prosecutor's practice of providing the defence with redacted documents, without the authorization of the Pre-Trial Camber, as inappropriate..$^{70}$ The Judge considered that an accused has the right to access unredacted versions of evidence on which the prosecution intends to rely during the confirmation of charges hearing, and all the potentially exculpatory evidence or which might be material to the defence's preparation. ${ }^{71}$ Thus,

68 When making an assessment of whether to authorize non-disclosure of witness identities to the defence, the Chamber has to take into account the following three most important considerations: (1) the endangerment of the witness or of members of his or her family that the disclosure of the identity of the witness may cause; (2) the necessity of the protective measure; and (3) why the PreTrial Chamber considered that the measure would not be prejudicial to or inconsistent with the rights of the accused and a fair and impartial trial. Moreover, an assessment of subsidiarity must be made; if "less restrictive protective measures are sufficient and feasible, a Chamber must choose those measures over more restrictive measures." The analysis should be conducted on a case-by-case basis. ICC, Prosecutor v. Lubanga Dyilo, Judgment on the appeal of Mr. Thomas Lubanga Dyilo against the decision of Pre-Trial Chamber I entitled "First Decision on the Prosecution Requests and Amended Requests for Redactions under Rule 81", ICC-01/04-01/06-773, A. CH., 14 December 2006, paras. 21, 33.

69 ICC, Prosecutor v. Katanga and Ngudjolo, Judgement on the Appeals of the Prosecutor against the "Decision on Evidentiary Scope of the Confirmation Hearing, Preventive Relocation and Disclosure under Article 67(2) of the Statute and Rule 77 of the Rules" of Pre-Trial Chamber I, 26 November 2008, ICC-01/04-01/07-776, par. 93: "The Appeals Chamber finds that any disagreement between the VWU and the Prosecutor about the relocation of a witness should ultimately be decided by the Chamber dealing with the case - and should not be resolved by the unilateral and unchecked action of the Prosecutor."

70 ICC, Prosecutor v. Lubanga Dyilo, Decision on the Prosecution Practice to Provide to the Defence Redacted Versions of Evidence and Materials without Authorization by the Chamber, PTC I. (Judge Steiner), ICC-01/04-01-06-355, 25 August 2006 [Lubanga Decision on the Practice of Redactions].

71 Lubanga Decision on the Practice of Redactions, p. 3. 
redactions can only be made as an exception and not as a general rule and are only permissible on a case-by-case basis subject to the Chamber's approval. The Judge dismissed the prosecutors' proposal that it is up to the defence to show good cause to lift unauthorised redactions. This proposal violated the rights of the accused to a fair trial by reversing the burden of proof: it is the prosecutor who must convince the Chamber that the redactions are needed and not the defence. ${ }^{72}$

In Katanga \& Ngudjolo Chui the Appeals Chamber rejected the Pre-Trial Chamber's ruling that Rule 81(4), in its literal interpretation, does not include third individuals (called by the prosecution as 'innocent third parties' who are named in the statements of prosecution witnesses) other than prosecution witnesses, victims and members of their family. ${ }^{73}$ The Appeals Chamber, referring to the object and purpose of protective provisions in the ICC legal framework, considered that the protection in Rule 81(4) should be extended "to persons who may be placed at risk as a result of the activities of the Court, but 'who are not victims, current or prospective prosecution witnesses or sources, or members of their families'." 74 Referring to the jurisprudence of the ECtHR, the ICC Appeals Chamber reasoned that whether or not a redaction would be appropriate has to be determined on a case-by-case basis, while making a careful assessment so as "to ensure that any measures restricting the rights of the Defence that are taken to protect individuals at risk are strictly necessary and sufficiently counterbalanced by the procedures taken by the Pre-Trial Chamber." 75 In the abstract, the Appeals Chamber reiterated certain factors that have to be taken into account when considering the appropriateness of a redaction in a particular instance:

The Appeals Chamber has had previous occasion to set out those factors that must be addressed by the Pre-Trial Chamber when considering whether to authorise the non- disclosure of the identity of a witness pursuant to rule 81(4). The same general factors apply in the current case, which can be summarised briefly as a thorough consideration of the danger that the disclosure of the identity of the person may cause; the necessity of the protective measure, including whether it is the least intrusive measure necessary to protect the person concerned; and the fact that any protective measures taken shall not be prejudicial to or inconsistent with the rights of the accused and a fair and impartial trial. ${ }^{76}$

72 Lubanga Decision on the Practice of Redactions, p. 4.

73 ICC, Prosecutor v. Katanga and Ngudjolo Chui, Judgment on the appeal of the Prosecutor against the decision of Pre-Trial Chamber I entitled "First Decision on the Prosecution Request for Authorisation to Redact Witness Statements", ICC-01/04-01/07-475, 13 May 2008 [Katanga and Ngudjolo Chui Appeal Decision on Redactions].

74 Katanga and Ngudjolo Chui Appeal Decision on Redactions, paras. 40, 55.

75 Katanga and Ngudjolo Chui Appeal Decision on Redactions, par. 59.

76 Katanga and Ngudjolo Chui Appeal Decision on Redactions, par. 67. See also par. 71. 
In the following paragraphs the Appeals Chamber elaborated the appropriate factors for the Pre-Trial Chamber to consider when faced with such requests for a redaction, so as to provide clear guidance. ${ }^{77}$ One of the additional factors is the following: "in balancing the various interests at stake, the Pre-Trial Chamber must make sure that adequate safeguards are in place to protect the interests of the suspect so as to comply, as far as possible, with the requirements of adversarial proceedings and equality of arms." 78 The addition of 'as far as possible' seems to refer to the particular stage of the proceedings, namely the pre-confirmation of charges phase, where the rights accorded to an accused have a more limited application as compared to the trial proceedings.

\subsubsection{Protection of state interests and other third entities}

\subsubsection{ICTY, ICTR and SCSL}

Rule 70(B) ICTY RPE protects information that has been obtained by the prosecutor on a confidential basis and "solely for the purpose of generating new evidence" from having to be disclosed. Without the consent of the information provider, the prosecutor cannot disclose this evidence to the defence and cannot tender it in evidence without prior disclosure to the defence. ${ }^{79}$ The rule was created to encourage state cooperation after an initially difficult cooperation practice. Thus Rule 70(B) "creates an incentive for such cooperation by permitting the sharing of information on a confidential basis and by guaranteeing information providers that the confidentiality of the information they offer and of the information's sources will be protected." ${ }^{80}$ Without such protection, crucial information could be withheld from the Tribunal and, as such, the Tribunal's ability to fulfil its function would be in jeopardy. ${ }^{81}$ The protection of Rule 70 extents to informant's identity, the general subject of his knowledge and also the substance of the shared knowledge, as presented for example in a witness statement. ${ }^{82}$

77 Katanga and Ngudjolo Chui Appeal Decision on Redactions, paras. 70-73.

78 Katanga and Ngudjolo Chui Appeal Decision on Redactions, par. 73.

79 E.g. ICTR, Prosecutor v. Nahimana et al., Public Redacted Version of the Decision on Motions Relating to the Appellant Hassan Ngeze's and the Prosecution's Request for Leave to Present Additional Evidence of Witnesses ABC1 and EB, ICTR-99-52, 27 November 2006, par. 12.

80 ICTY, Prosecutor v. Milošević, Public Version of Confidential Decision on the Interpretation and Application of Rule 70, IT-02-54-AR108bis \& AR73.3, A. Ch., 23 October 2002, paras. 18ii, 19.

81 ICTY, Prosecutor v. Brđjanin and Talić, Public Version of the Confidential Decision on the Alleged Illegality of Rule 70, IT-99-36-T, 6 May 2002, par. 18.

82 The Appeals Chamber in Milosević corrected the Trial Chamber's finding and found that witness testimony was protected under Rule $70(\mathrm{~B})$, contending that "[w] hen a person possessing important knowledge is made available to the Prosecutor on a confidential basis, not only the informant's identity and the general subject of his knowledge constitute the 'information' shielded by Rule 70, but also the substance of the information shared by the person - often, as in this case, presented in summary form in a witness statement." ICTY, Prosecutor v. Milošević, Public Version of Confidential Decision on the Interpretation and Application of Rule 70, IT-02-54-AR108bis \& AR73.3, A. Ch., 23 October 2002, paras. 22-23. 
The Trial Chambers possess only limited discretion to "police the application of Rule 70 in order to prevent its misapplication." ${ }^{83}$ Applying an objective test, the Trial Chamber may ascertain the confidential basis of information by considering (1) the information itself, (2) accepting the prosecution's assertion; (3) the information provider's confirmation; and (4) any indication from the face of the document itself. ${ }^{84}$

Rule 70(F), which has no equivalent under the Rules of the ICTR or SCSL, makes Rule 70 applicable, in the interests of justice, mutatis mutandis to the information in the possession of the accused. This sub-rule is intended to put the defence on a par with the prosecutor with regard to access to information that can only be obtained under a confidentiality agreement. In Orić, the Appeals Chamber reversed the Trial Chamber's refusal of the defence's application under Rule $70(\mathrm{~F}),{ }^{85}$ by considering that the purpose of this rule is to encourage third parties to provide confidential information to the defence equal to the prosecution. ${ }^{86}$ As such, the reference in that rule to "specific information in the possession of an accused" refers not to the materials that are already in the defence's possession, but to materials that the defence will gain access to if the non-disclosure order is given. ${ }^{87}$

\subsection{Disclosure OF EXCULPATORY EVIDENCE}

The prosecutor's duty to disclose exculpatory evidence to the defence, albeit additional to a duty to search for it, can be seen to have a universal application. ${ }^{88}$

83 ICTY, Prosecutor v. Milošević, Public Version of Confidential Decision on the Interpretation and Application of Rule 70, IT-02-54-AR108bis \& AR73.3, A. Ch., 23 October 2002, par. 26.

84 ICTY, Prosecutor v. Milošević, Public Version of Confidential Decision on the Interpretation and Application of Rule 70, IT-02-54-AR108bis \& AR73.3, A. Ch., 23 October 2002, par. 29.

85 Rule 70 (F): The Trial Chamber may order upon an application by the accused or defence counsel that, in the interests of justice, the provisions of this Rule shall apply mutatis mutandis to specific information in the possession of the accused.

86 ICTY, Prosecutor v. Orić, Public Redacted Version of "Decision on Interlocutory Appeal Concerning Rule 70" issued on March 24, 2004, IT-03-68-AR73, A. Ch., 26 March 2004, paras. 6-7. The Trial Chamber dismissed the defence's application as being premature because the evidence was not in the possession of the defence. However, the information provider was only willing to provide the information under a guarantee of confidentiality.

87 ICTY, Prosecutor v. Orić, Public Redacted Version of "Decision on Interlocutory Appeal Concerning Rule 70" issued on March 24, 2004, IT-03-68-AR73, A. Ch., 26 March 2004, paras. 6-7. "The purpose of Rule $70(\mathrm{~F})$ is to encourage third parties to provide confidential information to the Defence in the same way as Rule 70(B) encourages parties to do the same for the Prosecution ${ }^{8}$, regardless of any further disclosure of that confidential information. Read within the context of the Rule therefore, and with its purpose in mind, the reference in Rule 70(F) to "specific information in the possession of an accused" is not a condition for the making of an order that the Rule applies; it is a reference to what the Rule will apply to after the making of an order that it is to apply." The fact that the accused is no longer in possession of such information is therefore irrelevant.

88 The obligation under Article 67(2) ICC Statute for the Prosecutor to disclose any exculpatory evidence to the defence 'is not known to be disputed anywhere and is generally accepted in both 
It is fundamental to a 'fair trial' and central to the prosecutor's role as a 'minister of justice'. In this sense, the duty to disclose exculpatory evidence is an essential requirement to preserve equality of arms between the parties. ${ }^{89}$ The disclosure of exculpatory material is one of the most litigated areas in international criminal practice. However, Rule 68 ICTY has been adjusted to the realities of war crimes prosecution by limiting the scope of its application. Although Rule 68 ICTR to a large extent reproduces Rule 68 ICTY, one crucial sentence differs: Rule 68 ICTR is not subject to the provisions of Rule 70, as is Rule 68 ICTY. Rule 68 SCSL was adjusted in other respects too. ${ }^{90}$ Article 67(2) ICC Statute, formulated as a right of the defence to receive exculpatory evidence, ${ }^{91}$ is a further guarantee of the prosecutor's obligation under Article 54(1) ICC Statute, and its wording endorses the vision of the neutrality of the prosecutor as an independent truth-seeker. ${ }^{92}$ Throughout the years of existence of the ad hoc tribunals, it has been underscored that that the Prosecution's obligation to disclose exculpatory material "is as important as the obligation to prosecute." ${ }^{93}$

common-law and civil-law systems.' OrIE, 2002, p. 1483.

89 Recommendation $\operatorname{Rec}(2000) 19$ of the Committee of Ministers to member states on the role of public prosecution in the criminal justice system, adopted by the Committee of Ministers of the Council of Europe on 6 October 2000 (available at https://wcd.coe.int/wcd/ViewDoc. jsp?id=376859\&Site=COE), par. 29: "Public prosecutors should seek to safeguard the principle of equality of arms, in particular by disclosing to the other parties - save where otherwise provided in the law - any information which they possess which may affect the justice of the proceedings."

90 See Rule 68 of SCSL RPE.

91 "In addition to any other disclosure provided for in this Statute, the Prosecutor shall, as soon as practicable, disclose to the defence evidence in the Prosecutor's possession or control, which he or she believes shows or tends to show the innocence of the accused, or to mitigate the guilt of the accused, or which may affect the credibility of prosecution evidence. In case of doubt as to the application of this paragraph, the Court shall decide". The Trial Chamber has formulated this as an absolute entitlement, see ICC, Prosecutor v. Lubanga Dyilo, Decision on Disclosure Issues, Responsibilities for Protective Measures and Other Procedural Matters, 24 April 2008, ICC-01/0401/06-1311-Anx2, par. 94.

92 More generally on the ICC disclosure regime from the perspective of the defence, see SwoBOdA, 2008.

93 ICTY, Prosecutor v. Kordić and Čerkez, Decision on Motions to Extend Time for Filing Appellant's Briefs, IT-95-14/2-A. A. Ch. (Pre-Appeal Judge), 11 May 2001, par. 14: There should be no possibility of any misunderstanding in relation to this issue. It would have been very simple for the prosecution to have said, expressly, that it had been and was still searching through the material which it received in relation to the two associated "Lašva Valley" cases and from the Zagreb Archives, and that, so far, no material which could reasonably be considered to fall within the scope of Rule 68 had been identified. The considerable strain which the need to make such searches places upon the resources provided to the prosecution was accepted. However, Rule 68 performs an important function. The prosecution is required to carry out these searches because of its superior access to material which may be exculpatory in character. It forms part of the prosecution's duty as "ministers of justice assisting in the administration of justice", upon which the prosecution relies in another context in relation to these Motions, to assist an accused in this way. The prosecution's obligation under Rule 68 is not a secondary one, to be complied with after everything else is done; it is as important as the obligation to prosecute. See also references in footnote 205 of ICTR, Prosecutor v. Bizimungu et al., Judgment and Sentence, ICTR-99-50-T, T. Ch., 30 September 2011, par. 134. 


\subsubsection{ICTY, ICTR and SCSL}

The 'old' Rule 68, which is comparable to Article 67(2) ICC, stated that "[t]he Prosecutor shall, as soon as practicable, disclose to the defence the existence of evidence known to the Prosecutor which is any way tends to suggest the innocence or mitigate the guilt of the accused or may affect the credibility of prosecution evidence." "94 The rationale for this rule was twofold. Firstly, "the Rule was a means to ensure fair trials, by improving the position of the accused and lessening the burden of defence investigations, whenever exculpatory material is available and has been collected by an organ of the international community: The Prosecutor." ${ }^{\circ 5}$ Secondly, "it was an embryonic recognition of the fact that the role of the Prosecutor as an 'impartial' organ entails additional duties for that party, such as the obligation to gather, record and provide the defence with any exculpatory evidence." 96

This rule was amended in 2003, adding much more details regulating the disclosure of exculpatory materials. ${ }^{97}$ The new Rule 68(i) read: "The Prosecutor shall, as soon as practicable, disclose to the Defence any material which in the actual knowledge of the Prosecutor may suggest the innocence or mitigate the guilt of the accused or affect the credibility of Prosecution evidence. ${ }^{\circ 98}$ Although the amendment was "intended to further the interests of justice, providing safeguards for on-going or future investigations, increasing the expediency of proceedings, and protecting the confidentiality interests of states or other sensitive sources," some question "whether the new Rule 68 is consistent with the right of the accused to a fair trial, with the role of the Prosecutor in international criminal law, and, ultimately, with the proper administration of justice." ${ }^{99}$ The reference to the 'actual knowledge' of the prosecutor narrows the obligation to disclose and makes it easier for the prosecutor to comply with its obligation under the rule. ${ }^{100}$

Notably, in the case law of the ICTY, the requirement of knowledge on the part of the prosecutor has been equated as being 'in possession or control'. ${ }^{101}$ As such,

94 "The Prosecutor shall, as soon as practicable, disclose to the defence the existence of evidence known to the Prosecutor which is any way tends to suggest the innocence or mitigate the guilt of the accused or may affect the credibility of prosecution evidence" (the last part after 'or' was added in February 1995).

95 ZaPPALÀ, 2004, pp. 622-623.

96 ZAPPALÀ, 2004, p. 623.

97 In addition, a system of Electronic Disclosure (EDS) was introduced, which would make accessible to the defence all the material that the Prosecutor identified as relevant under Rule 68. Although intended to facilitate the disclosure of information towards the defence, the EDS has also been a source of problems and frustration. Defence counsel have reported problems as to the utility of EDS and the 'disclosure overload' they were confronted with.

98 Revision 29, 12 December 2003, Emphasis added. Sections ii-v omitted.

99 ZaPPALÀ, 2004, p. 624

100 ZAPPALÀ, 2004, p. 624.

101 ICTY, Prosecutor v. Blaškić, IT-95-14-PT, Decision on the Production of Discovery Materials, 
the new Rule arguably codifies the interpretation adopted before the Rule change. Rule 68 certainly does not impose an obligation on the prosecution to search for material of which it has no knowledge, nor does it entitle the defence to embark on a "fishing expedition". ${ }^{102}$ In Blagojević, the Trial Chamber, moreover, made clear that "Rule 68 in not intended to serve as means through which the Prosecution is forced to replace the Defence in conducting investigations or gathering material that may assist the Defence." 103 The defence, according to the Trial Chamber, is not bound by the prosecutor's characterisation of material as exculpatory, and in fact, it is defence counsel who bears the "primary responsibility for investigating the charges against an accused, including seeking and gathering information related to those charges."104 Interestingly, the Trial Chamber in Bizimungu considered that the obligation following from Rule 68

does not mean that the Prosecution should be forced to hunt for materials that it has no knowledge of. It does mean however that where the Defence has specific knowledge of a document covered by the Rule not currently within the possession or control of the Prosecution, and requests that document in specific terms, the Prosecution should attempt to bring such documents within its control or possession where the circumstances suggest that the Prosecution is in a better position than the Defence to do so, and, once this is successfully done, should be disclosed to the Defence; provided it is shown that the Defence had made prior efforts to obtain such document by its own means. This obligation stems from the Prosecution's inherent duty to fully investigate a case before this court, and applies particularly in relation to obtaining previous statements made by Prosecution witnesses before the Rwandan Authorities, where, as a practical reality, the Prosecution enjoys greater leverage than the Defence. ${ }^{105}$

27 January 1997, paras. 47, 50.

102 ICTR, Nahimana et al. v. Prosecutor, Decision on Motions Relating to the Appellants Hassan Ngeze's and the Prosecution's Requests for Leave to Present Additional Evidence of Witness ABC1 and EB, ICTR-99-52-A, 27 November 2006, par. 11, referring in footnote 38 to: "Bralo 30 August 2006 Decision, par. 30; ICTR, Kajelijeli Appeal Judgement, paras 262-263; ICTY, Blaškić Appeal Judgment, par. 268; ICTY, Prosecutor v. Hadžihasanović et al, Decision on Appeal from Refusal to Grant Access to Confidential Material in Another Case, IT-01-47-AR73, 23 April 2002, p. 3. See also ICTR, Prosecutor v. Bizimungu et al., ICTR-99-50-T, Decision on Bicamumpaka's Motion for Disclosure of Exculpatory Evidence (MDR Files), 17 November 2004, paras 11-14; ICTR, Prosecutor v. Bizimungu et al., ICTR-99-50-T, Decision on Prosper Mugiraneza's Motion Pursuant to Rule 68 for Exculpatory Evidence Related to Witness GKI (TC), 14 September 2004, paras 8-12.

103 ICTY, Prosecutor v. Blagojević et al., Joint Decision on Motions Related to Production of Evidence, IT-02-60-PT, 12 December 2002, par. 26. Moreover, the Trial Chamber emphasized that "Rule 68 also does not translate into a right for the defence to "receive all of the Prosecution's evidence that could be useful in the defence against charges in the Amended Indictments" (Id., footnote reference omitted).

104 ICTY, Prosecutor v. Blagojević et al., Joint Decision on Motions Related to Production of Evidence, IT-02-60-PT, 12 December 2002, par. 26.

105 ICTR, Prosecutor v. Bizimungu et al., Decision on Motion of Accused Biramumpaka for Disclosure 
Clearly, this constitutes a recognition of the prosecutor's more expanded role as an impartial truth-seeker, which incorporates both the duty to disclose potentially exculpatory evidence to the defence, but also to facilitate defence investigations where the defence has been unsuccessful. At the ad hoc tribunals this second responsibility remains 'voluntary'; however, the ICC has taken a step forward in that regard by obliging the prosecutor to search explicitly for both incriminatory and exculpatory evidence (Article 54(1), discussed below).

The other change, namely the reference to 'materials' instead of 'evidence' in the new Rule, was prompted by the desire to include any material that could be or could lead to favourable material for the defence and is thus not limited to admissible evidence only. ${ }^{106}$

Another amendment to Rule 68 ICTY RPE was effected in July 2004, making the application of the rule subject to Rule $70 .{ }^{107}$ This was the final solution offered by the ICTY Judges in relation to the conflict between the confidentiality of sources and information, which the prosecutor has to respect as well as his disclosure obligations. The ICTY Judges initially preferred the precedence of the obligation to disclose exculpatory evidence over protecting confidentiality. ${ }^{108}$ The amendment to Rule 68 in December 2003 offered the necessary steps for the prosecutor to undertake when confronted with conflicting obligations, including making an in camera application to the Trial Chamber in case the prosecutor wanted to withhold exculpatory evidence. ${ }^{109}$ However, this did not solve the question of what should be done when the prosecutor could not disclose the evidence even to the judges. Subjecting the disclosure under Rule 68 to confidentiality agreements under Rule 70(B) ICTY seems to reverse the initial priority and gives the prosecutor some leeway to withhold potentially exculpatory materials that have been provided to him on a confidential basis with the purpose of generating new evidence. Without an obligation to investigate both incriminating and exculpatory information, it remains unclear what the ICTY prosecutor's obligations are with regard to exculpatory elements that were obtained under the cloak of confidentiality, and are unsupported by additional evidence (for

of Exculpatory Evidence, ICTR-99-50-T, 23 April 2004, par. 9.

106 ICTY, Prosecutor v. Krnojelac, Record of Rulings Made in Status Conference, IT-97-25-PT, 14 September 1999, p. 2; ICTY, Prosecutor v. Krstić, Appeal Judgment, IT-98-33-A, 19 April 2004, par. 178

107 No such amendment has been made at the ICTR.

108 ICTY, Prosecutor v. Brdjanin and Talić, Public Version of the Confidential Decision on the Alleged Illegality of Rule 70, IT-99-36-T, 6 May 2002, paras. 19-21.

109 Rule 68 (iv) ICTY RPE: "the Prosecutor shall apply to the Chamber sitting in camera to be relieved from an obligation under paragraph (i) to disclose information in the possession of the Prosecutor, if its disclosure may prejudice further or ongoing investigations, or for any other reason may be contrary to the public interest or affect the security interests of any State, and when making such application, the Prosecutor shall provide the Trial Chamber (but only the Trial Chamber) with the information that is sought to be kept confidential." 
whatever reason). The prosecutor's ethical standards, objective as well as subjective, may play the most crucial role in the resolution of this issue.

Ideally, acknowledging the fundamental importance of the disclosure of exculpatory evidence, two scenarios to resolve a conflict between Rule 68 and Rule 70(B) ICTY RPE would be the following: (1) the prosecutor investigates the potentially exculpatory lead material and discloses the results to the defence, or (2) the prosecutor applies to the Chamber under Rule 68(iv) for relief from the disclosure obligations of the exculpatory material that has been provided to him under the cloak of confidentiality and which was not used to generate new evidence. In this second scenario, the Judges would be the final arbiters of disclosure practice and would be able to impose measures to protect the rights of the accused under the circumstances.

Thus, under Rule 68 the prosecutor has a positive, ${ }^{110}$ ongoing ${ }^{111}$ and continuous obligation $^{112}$ to disclose to the defence any material which (1) may suggest the innocence or (2) mitigate the guilt of the accused; or (3) may affect the credibility of the prosecution evidence. ${ }^{113}$ This duty is not limited to the trial phase but extends to the appellate stage. ${ }^{114}$ The determination of which materials are subject to disclosure

110 ICTY, Prosecutor v. Brđjanin, Decision on "Motion for Relief from Rule 68 Violations by the Prosecutor and for Sanctions to be imposed pursuant to Rule 68bis and Motion for Adjournment while matters affecting Justice and a Fair Trial can be resolved", IT-99-36-T, T. Ch., 30 October 2002, par. 24: "The fair trial concept demands not only that the Prosecution, pursuant to the plain language of the Rule [68], disclose to the Defence in sufficient time "the existence of evidence", but also, as the Prosecution has rightly pointed out, that it actually provide the Defence with all of the exculpatory evidence in questions "as soon as practicable"."

111 The standard established in the jurisprudence of the ad hoc tribunals is that the "ongoing nature of the obligation relates only to the fact that as new material comes into the possession of the Prosecution, it should be assessed as to its potentially exculpatory nature and disclosed accordingly." ICTY, Prosecutor v. Karadžić, Decision on Prosecutor's Request for Reconsideration of Trial Chamber's 11 Novemebr 2010 Decision, IT-95-5/18-T, T. Ch., 10 December 2010, par. 11.

112 ICTY, Prosecutor v. Blaskić, Appeal Judgement, IT-95-14-A, A. Ch., 29 July 2004, par. 267.

113 E.g. ICTR, Prosecutor v. Nahimana et al., Decision on Appellant Jean-Bosco Barayagwiza's Motion Requesting That the Prosecution Disclosure of the Interview of Michel Bagaragaza Be Expunged from the Record, ICTR-99-52-A, 30 October 2006, par. 6; ICTY, Prosecutor v. Bralo, Decision on Motions for Access to Ex Parte Portions of the Record on Appeal and for Disclosure of Mitigating Material, IT-95-17-A, IT-95-17-A, 30 August 2006, par. 29; ICTR, Prosecutor v. Karemera et al., Decision on Interlocutory Appeal Regarding the Role of the Prosecutor's Electronic Disclosure Suite in Discharging Disclosure Obligations, ICTR-98-44-AR73.7, 30 June 2006, par. 9; ICTR, Prosecutor v. Bagosora et al., Decision on Interlocutory Appeals of Decision on Witness Protection Orders, ICTR-98-41-AR73 \& ICTR-98-41-AR73(B), 6 October 2005, par. 44; ICTY, Prosecutor v. Blaškić, Confidential Decision on Prosecution's Application to Seek Guidance from the Appeals Chamber regarding Redaction of the Statement of "Witness Two" for the Purposes of Disclosure to Paško Ljubičić under Rule 68, IT-95-14-A, 30 March 2004, par. 32; ICTY, Prosecutor v. Halilović, Decision on Defence Motion for Identification of Suspects and Other Categories Among its Proposed Witnesses, IT-01-48-PT, 14 November 2003.

114 ICTY, Prosecutor v. Blaškić, Decision on the Appellant's Motions for the Production of Material, 
under this provision is a fact-based enquiry made by the prosecution. ${ }^{115}$ The prosecutor has a discretionary power to determine, acting bona fide, which material falls under Rule $68 .{ }^{116}$ Of course, the Chamber may disagree with that characterization. ${ }^{117}$

In Blaškić, the defence argued that the lack of inculpatory evidence on certain points of the indictment constitutes exculpatory evidence as such. However, the Trial Chamber disagreed and considered that any lack of evidence can only be evaluated at trial. ${ }^{118}$ In addition, the Trial Chamber considered the scope of Rule 68 and ordered the prosecutor to respond to the defence concerning questions about the possession and nature of certain materials. ${ }^{119}$ According to the Trial Chamber, it was not sufficient

Suspension or Extension of the Briefing Schedule, and Additional Filings, IT-95-14-A, 26 September 2000, par. 32 .

115 E.g. ICTR, Nahimana et al. v. Prosecutor, Decision on Appellant Jean-Bosco Barayagwiza's Motions for Leave to Present Additional Evidence pursuant to Rule 115 of the Rules of Procedure and Evidence, ICTR-99-52-A, 8 December 2006, par. 34, referring to inter alia, ICTR, Prosecutor v. Nahimana et al., Decision on Appellant Jean-Bosco Barayagwiza's Motion Requesting that the Prosecution Disclosure of the Interview of Michel Bagaragaza Be Expunged from the Record, ICTR-99-52-A, 30 October 2006, par. 6; ICTR, Prosecutor v. Karemera et al., Decision on Joseph Nzirorera's Interlocutory Appeal, ICTR-98-44-AR73.6, 28 April 2006, par. 16.

116 ICTR, Prosecutor v. Nahimana et al., Decision on Appellant Jean-Bosco Barayagwiza's Motion Requesting that the Prosecution Disclosure of the Interview of Michel Bagaragaza Be Expunged from the Record, ICTR-99-52-A, 30 October 2006, par. 6; ICTY, Prosecutor v. Bralo, Decision on Motions for Access to Ex Parte Portions of the Record on Appeal and for Disclosure of Mitigating Material, IT-95-17-A, 30 August 2006, par. 30; ICTR, Prosecutor v. Kajelijeli, Judgment, ICTR-9844A-A, 23 May 2005, par. 262; ICTY, Prosecutor v. Kordić and Čerkez, Appeal Judgment, IT-9514/2-A, 17 December 2004, par. 183; ICTY, Prosecutor v. Brđjanin, Decision on Appellant's Motion for Disclosure Pursuant to Rule 68 and Motion for an Order to the Registrar to Disclose Certain Materials, IT-99-36-A, 7 December 2004, p. 3; ICTY, Prosecutor v. Blaškić, Appeal Judgment, IT-95-14-A, 29 July 2004, par. 264; ICTY, Prosecutor v. Krstić, Appeal Judgment, IT-98-33-A, 19 April 2004, par. 190; ICTY, Prosecutor v. Blaškić, Decision on Prosecution's Application to Seek Guidance from the Appeals Chamber regarding Redaction of the Statement of "Witness Two" for the purposes of Disclosure to Dario Kordić under Rule 68, IT-95-14-A, 4 March 2004, par. 44; ICTY, Prosecutor v. Blaškić, [confidential] Decision on Prosecution's Application to Seek Guidance from the Appeals Chamber regarding Redaction of the Statement of "Witness Two" for the purposes of Disclosure to Paško Ljubičić under Rule 68, IT-95-14-A, 30 March 2004, paras. 31-32; ICTY, Prosecutor v. Blaškić, Decision on the Appellant's Motions for the Production of Material, Suspension or Extension of the Briefing Schedule, and Additional Filings, IT-95-14-A, 26 September 2000, par. 45.

117 For one explicit example of this situation, see ICTY, Prosecutor v. Karadžić, Decision on Accused's Forty-Ninth and Fiftieth Disclosure Violation Motions, IT-95-5/18-T, T. Ch., 30 June 2011, par. 39.

118 ICTY, Prosecutor v. Blaškić, Decision on the Production of Discovery Materials, IT-95-14-PT, 27 January 1997, T. Ch., paras. 8, 25.

119 ICTY, Prosecutor v. Blaškić, IT-95-14-PT, Decision on the Production of Discovery Materials, 27 January 1997, par. 47: “ ... in respect of all the materials mentioned by the Defence, the Prosecutor must state: - whether the materials are in fact in her possession; - whether the materials contain exculpatory evidence; - whether she believes that although she does possess exculpatory materials, Sub-rule $66(\mathrm{C})$ or any other relevant provision require that their confidentiality be protected." The Defence asked for (1) the disclosure of all exculpatory evidence in the possession 
for the prosecutor to declare that she "recognizes her obligations under the Rule and has complied with them." 120 The Trial Chamber acknowledged "although Rule 68 places the burden of unrestricted obligation on the Prosecutor through the general nature of its wording [...], as a corollary, it grants a right to the Defence which is itself unrestricted." 221 The Chamber did not explain why it considers that both the obligation and the right are in themselves "unrestricted" when Rule 68 refers, in its wording, to a degree of knowledge on the part of the prosecutor as to the exculpatory nature of the materials. Notwithstanding this, the Chamber "chooses not to go down this path", firstly because the Chamber "must ensure balanced respect" for the respective rights of the parties; and secondly, because of the generality of the 'right of inspection' as requested by the accused, "the Trial Chamber must only draw the parallel between Rule 68 and Sub-Rule 66(B) of the Rules." ${ }^{\prime 22}$ The defence, by explicitly excluding its disclosure request from the ambit of Rule 66(B), which at the time would trigger the reciprocal inspection right of the prosecutor under Rule 67(C), "evades its discovery obligation to the Prosecutor." 123 Although the line between materials of an exculpatory nature (Rule 68) and "material to the preparation of the defence" (Rule 66(B)) is "tenuous", and the latter necessarily includes the former, the Trial Chamber sees itself as being obliged to ensure "that the balance of the respective rights of the parties in this matter be honoured." ${ }^{124}$ Hence, when making a request for exculpatory evidence, "after having previously shown that they were in the possession of the Prosecutor, the Defence must present a prima facie case which would make probable the exculpatory nature of the materials sought." 125 From the above discussion, it seems that there is a higher burden on the defence to satisfy when applying for the disclosure of exculpatory materials that according to it are in the possession of the prosecutor than when applying for inspection under Rule 66(B) because the latter triggers reciprocity and, thus, 'balances' out the obligations. ${ }^{126}$ The

of the Prosecution; and (2) the disclosure of the nature and location of all exculpatory materials of which it has knowledge but which are not in its possession.

120 ICTY, Prosecutor v. Blaškić, Decision on the Production of Discovery Materials, IT-95-14-PT, 27 January 1997, par. 47 [Blaškić Decision on the Production of Discovery Materials].

121 Blaškić Decision on the Production of Discovery Materials, par. 48.

122 Blaškić Decision on the Production of Discovery Materials, paras. 48-49.

123 Blaškić Decision on the Production of Discovery Materials, par. 49.

124 Blaškić Decision on the Production of Discovery Materials, par. 49: "[I]f the Chamber notes that the Defence does not wish to honour the need for balanced reciprocal disclosure provided for in Subrules $66(\mathrm{~B})$ and $67(\mathrm{C})$, it must then be particularly vigilant as to limiting the nature and extent of the request for exculpatory evidence from the Prosecution's file because the accused has made such a scrutinising request compelling her to produce evidence.

125 Blaškić Decision on the Production of Discovery Materials, par. 49.

126 ICTY Rule 67 was changed in 2005, when the reciprocal inspection obligation on the part of the defence was deleted. However, in 2008, the inspection of the defence's materials was re-admited under Rule 67(A)(i), without any reference to a triggering mechanism. The ICTR has the 'old' Rule 67(C) which triggers reciprocal inspection obligations in case the defence makes use of Rule 66(B) 
Chamber sees the argument as originating from the tension between "the legitimate concern of the Defence to have disclosed to it all the potentially exculpatory evidence and the protection of the right to proceed with the prosecution." ${ }^{27}$ Unfortunately, the Chamber did not refer to the fundamental nature of the right to the disclosure of exculpatory evidence, the rights of the accused more generally, or elaborate on the way it intends to 'balance' the 'rights' of the parties with regard to disclosure.

Later decisions have emphasized the fundamental nature of the prosecutorial disclosure of exculpatory evidence. ${ }^{128}$ Although the rule itself was limited in its scope to accommodate the burden on the prosecutor, confronted with the growing volume of evidentiary materials and sources, the judges have interpreted the rule to be applicable to the broadest possible category of materials. Mindful of the strain that a broad disclosure obligation places upon the prosecutor, the Chambers, have emphasized the importance of the prosecutor's obligations under Rule 68 to a fair trial. ${ }^{129}$

However, the prosecutorial practice with regard to disclosure generally and disclosure of exculpatory evidence particularly have been frequently challenged by the defence teams at the ad hoc tribunals. Whereas numerous violations of disclosure obligations under Rule 66 and 68 have been found, the consequences were limited to occasional reprimanding of the prosecutor's practice and taking several

and requests to inspect the prosecutor's materials. Rule 67 SCSL RPE does not contain a reference to the reciprocal defence inspection obligation, however Rule 67 (C), contrary to ICTY/ICTR, states that "to assist the Prosecutor with its disclosure obligations pursuant to Rule 68, the defence may prior to trial provide the Prosecutor with a Defence Case Statement. The Defence Case Statement shall: (i) set out in general terms the nature of the accused's defence; (ii) indicate the matters on which he takes issue with the prosecution; and (iii) set out, in the case of each such matter, the reason why he takes issue with the prosecution."

127 Blaškić Decision on the Production of Discovery Materials, par. 52.

128 In later case law, the importance of disclosure obligations to a fair trial has been underscored, see e.g. ICTY, Prosecutor v. Krstić, Appeal Judgment, IT-98-33-A, 19 April 2004, par. 180; ICTY, Prosecutor v. Orić, Decision on Ongoing Complaints About Prosecutorial Non-Compliance With Rule 68 of the Rules, IT-03-68-T, T. Ch., 13 December 2005, par. 20: "[i]n the pursuit of justice, the disclosure of Rule 68 material to the defence is of paramount importance to ensure the fairness of proceedings before the Tribunal"; ICTY, Prosecutor v. Stakić, Appeals Chamber Judgment, IT97-24-A, 22 March 2006, par. 188; Karadzić, Decision on Accused's Motion for Additional Time to Prepare Cross examination of Momčilo Mandić, IT-95-5/18-T, 2 July 2010, par. 4: "Rules 65ter, 66, and 68 of the Rules establish certain Prosecution disclosure obligations vis-à-vis an accused person, and are fundamental to a fair trial."

129 E.g. ICTY, Prosecutor v. Blaškić, Appeals Chamber Judgment, IT-95-14-A, 29 July 2004, par. 302: "The Appeals Chamber emphasizes that the Office of the Prosecutor has a duty to establish procedures designed to ensure that, particularly in instances where the same witnesses testify in different cases, the evidence provided by such witnesses is re-examined in light of Rule 68 to determine whether any material has to be disclosed." 
counterbalancing measures such as providing the defence with extra time to review the late disclosure materials.

The standard established for providing an appropriate remedy for the prosecution's violation of Rule 68 obligations comprises two cumulative elements: the defence must show that (1) the prosecution violated Rule 68 obligations and (2) that this violation resulted in a material prejudice to the defence. ${ }^{130}$ To establish a violation of Rule 68 obligations, the defence must (1) identify specifically the material sought; (2) present a prima facie showing of its probable exculpatory nature; and (3) prove that the material requested is in the custody or under the control of the prosecution. ${ }^{131}$ Whenever the exculpatory nature of the material is established, the Chamber evaluates whether this material has been disclosed "as soon as practicable". If the prosecution does not contest that the material in question has exculpatory value and/or fails to indicate when he has received these materials, the Chambers proceeds to finding a violation of the disclosure obligations under Rule $68 .{ }^{132}$ However, the prosecution may still be relieved of its Rule 68 disclosure obligations "if the existence of the relevant exculpatory evidence is known and the evidence is accessible" to the defence as in this case the defence would not suffer material prejudice from the disclosure violation. ${ }^{133}$

In establishing a Rule 68 violation, particularly the second requirement of establishing the prima facie showing of the potentially exculpatory nature of the material has been subject to extended litigation. In Krstić, the Appeals Chamber rejected the Prosecutor's more restricted interpretation of the scope of Rule 68 meaning

130 ICTY, Prosecutor v. Krstić, Appeal Judgment, IT-98-33-A, 19 April 2004, par. 153 [footnote reference omitted].

131 E.g. ICTR, Prosecutor v. Nshogoza, Decision on Defence Motion for Order to Prosecutor to Comply with his Disclosure Obligations and Motion for Stay of Proceedings die to the on-going Violation of the Prosecutor's disclosure obligations, ICTR-07-91-T, T. Ch., 10 February 2009, par. 16; ICTR, Prosecutor v. Augustin Ndindiliyimana et al, Decision on Defence Motions Alleging Violation of the Prosecutor's Disclosure Obligations Pursuant to Rule 68, ICTR-00-56-T, T. Ch., 22 September 2008 par. 13 [references omitted]; ICTR, Prosecutor v. Karemera et al., Decision on Joseph Nzirorera's Appeals from Decision on Tenth Rule 68 Motion, ICTR-98-44-AR73.13, A. Ch., 14 May 2008, par. 9; ICTY, Prosecutor v. Bralo, Decision on Motions for Access to Ex Parter Portions of the Record on Appeal and for Disclosure of Mitigating Material, IT-95-17-A, 30 August 2006, par. 31; Prosecutor v. Bizimungu et. al, Decision on Justin Mugenzi's Request for Disclosure Order, ICTR99-50-T, T. Ch., 23 July 2008, par. 7 [references omitted]; ICTY, Prosecutor v. Brđjanin, Decision on Appellant's Motion for Disclosure pursuant to Rule 68 and Motion for an Order to the Registrar to Disclose Certain Materials, 7 December 2004, p. 3.

132 See e.g. ICTY, Prosecutor v. Karadžić, Decision on Accused's Thirty-Seventh to Forty-Second Disclosure Violation Motions With Partially Dissenting Opinion of Judge Kwon, IT-95-5/18-T, T. Ch., 29 March 2011, paras. 25, 38.

133 ICTY, Prosecutor v. Blaškić, Decision on the Appellant's Motion for the Production of Material, Suspension or Extension of the Briefing Schedule, and Additional Filings, IT-95-14-A, 26 September 2000 , par. 38 . 
that material should be exculpatory 'on its face' to fall under the ambit of Rule $68 .{ }^{134}$ According to the Appeals Chamber, Rule 68 is not only sufficiently clear in itself, but also in light of the fundamental importance of the disclosure of exculpatory evidence; limiting the scope of Rule 68 in this manner would go against the interests of a fair trial. ${ }^{135}$ In Karemera et al., the Appeals Chamber considered the appropriate standard to be "whether there is any possibility, in light of the submissions of the parties, that the information could be relevant to the defence of the accused." 136 The Appeals Chamber agreed with the defence that Rule 68, "as a rule of disclosure rather than admissibility of evidence, imposes a categorical obligation to disclose any document or witness statement that contains exculpatory material." ${ }^{137}$ As a consequence, "this obligation is not subject to a balancing test." 138 Thus, every document containing a potentially exculpatory element must be disclosed under Rule 68.

In the more recent Kalimanzira judgment, the Appeals Chamber explained that for the purposes of establishing a violation of Rule 68, "the defence need only to show that the material is prima facie or "potentially" exculpatory." 139 In this regard, the Appeals Chamber considered the wording of Rule 68 that refers to material that 'may suggest' the innocence or mitigate the guilt of the accused, and the broad interpretation of Rule 68 obligations adopted in the ad hoc tribunals' jurisprudence. ${ }^{140}$ In this case,

134 ICTY, Prosecutor v. Krstić, Appeal Judgment, IT-98-33-A, 19 April 2004, par. 179.

135 ICTY, Prosecutor v. Krstić, Appeal Judgment, IT-98-33-A, 19 April 2004, paras. 179-180.

136 ICTR, Prosecutor v. Karemera et al., Decision on Joseph Nzirorera's Appeals from Decision on Tenth Rule 68 Motion, ICTR-98-44-AR73.13, A. Ch., 14 May 2008, par. 12, citing ICTR, Prosecutor v. Bagosora et al., Decision on Disclosure of Defence Witness Statements in the Possession of the Prosecution Pursuant to Rule 68(A), ICTR- 98-41-T, 8 March 2006, par. 5.

137 ICTR, Prosecutor v. Karemera et al., Decision on Joseph Nzirorera's Appeals from Decision on Tenth Rule 68 Motion, ICTR-98-44-AR73.13, A. Ch., 14 May 2008, par. 12.

138 ICTR, Prosecutor v. Karemera et al., Decision on Joseph Nzirorera's Appeals from Decision on Tenth Rule 68 Motion, ICTR-98-44-AR73.13, A. Ch., 14 May 2008, par. 12. The Trial Chamber, confronted with both inculpatory and exculpatory information in one document, reasoned that this information should be looked at in context: thus "only information, that, when read in its entirety tends to be exculpatory, must be disclosed under Rule 68(A) of the Rules" (Id. par. 11). According to the Appeals Chamber, "the Trial Chamber by reasoning that exculpatory material in a document could be rendered nugatory by the existence of inculpatory material applied an incorrect legal standard resulting in an abuse of its discretion." (Id. par. 12).

139 ICTR, Prosecutor v. Kalimanzira, Appeals Chamber Judgement, ICTR-05-88-A, A. Ch., 20 October 2010, par. 20.

140 ICTR, Prosecutor v. Kalimanzira, Appeals Chamber Judgement, ICTR-05-88-A, A. Ch., 20 October 2010, paras. 18, 20. (In Renzaho the Trial Chamber considered that while an indictment is "not 'evidence' but procedural necessity in order to prosecute the accused," when it is inconsistent with evidence in another case Prosecutor v. Kalimanzira, Appeals Chamber Judgement, ICTR-05-88-A, A. Ch., 20 October 2010, it should be disclosed under Rule 68. The indictment and some supporting materials in the Munyeshyaka case were considered contradictory to the Renzaho case with regard to the time and circumstances of the killing of one family, and thus fell under the ambit of Rule 68 . See ICTR, Prosecutor v. Renzaho, Trial Chamber Judgment, ICTR-97-31-T, T. Ch., 14 July 2009, par. 48-49). 
the Trial Chamber erred in law when considering that the witness transcripts from another case were not 'in fact' exculpatory, by elevating the relevant standard. ${ }^{141}$ The Appeals Chamber pointed out that the defence only had to raise a reasonable doubt and did not bear the burden of contradicting the prosecution's evidence. ${ }^{142}$

As mentioned, as soon as the exculpatory nature of the materials is established, for the purposed of finding a violation, the judges have to make an assessment of whether this material has been disclosed as soon as practicable. A substantive examination takes place only when the prosecutor indicates when he received this material and makes a submission on the reasons of late disclosure. The judges have recognized that delay may occur due to the enormous amount of documents in prosecution's possession. The assessment has focused on the reasons provided by the prosecutor for his inability to quickly identify and/or access the exculpatory materials, and any indication of a mala fide practice. ${ }^{143}$ The threshold is high for the prosecution to successfully argue that he has disclosed the material as soon as practicable. A delay of over three month has been found to violate 'as soon as practicable' requirement. ${ }^{144}$ Even in case where the prosecutor has received the materials under the cloak of confidentiality (Rule 70) and only recently was given consent to disclose them to the defence, the Chambers were ruthless considering that "this does not excuse the

141 ICTR, Prosecutor v. Kalimanzira, Appeals Chamber Judgement, ICTR-05-88-A, A. Ch., 20 October 2010, paras. 19-20. The Trial Chamber did not consider seven transcripts from the Nyiramasuhoko et al. case, which related to the attack on Kabuye Hill and where the witnesses did not mention seeing Kalimanzira there, as exculpatory. The Trial Chamber reasoned that in this other case no questions were asked about Kalimanzira and thus (1) the transcripts as such did not contradict the evidence in Kalimanzira, and (2) it did not mean that Kalimanzira was not there.

142 ICTR, Prosecutor v. Kalimanzira, Appeals Chamber Judgement, ICTR-05-88-A, A. Ch., 20 October 2010, par. 20. According to the Appeals Chamber, the Trial Chamber focused on the potentially low probative value of the transcripts. The Appeals Chamber concluded that the fact that Kalimanzira was not mentioned in the transcripts was potentially exculpatory. However, the defence did not suffer any prejudice due to the low probative value of the materials (paras. 20-22).

143 E.g. ICTY, Prosecutor v. Krstić, Appeal Judgment, IT-98-33-A, 19 April 2004, par. 197: “The Appeals Chamber is sympathetic to the argument of the Prosecution that in most instances material requires processing, translation, analysis and identification as exculpatory material. The Prosecution cannot be expected to disclose material which - despite its best efforts - it has not been able to review and assess. Nevertheless, the Prosecution did take an inordinate amount of time before disclosing material in this case, and has failed to provide a satisfactory explanation for the delay."

144 ICTY, Prosecutor v. Krstić, Appeal Judgment, IT-98-33-A, 19 April 2004, paras. 196, 198. However, in ICTY, Prosecutor v. Blaškić, Appeal Chamber Judgment, IT-95-14-A, 29 July 2004, paras. 270, 273-275, a delay of almost eight month after Trial Chamber's judgment was not "inordinate amount of time." In footnote 554 the Appeals Chamber explained that "A distinction must be drawn between this case and the Krstic case, where the Appeals Chamber found that the Prosecution did take an inordinate amount of time before disclosing Rule 68 material. In that case, the said material was not always identified as exculpatory; some of the disclosure took place over two years after the Prosecution came into possession of the evidence, material had been discovered while the trial was still ongoing, and discovery occurred before the commencement of the Defence's case in chief. 
original failure by the Prosecution to identify this document and seek the required clearance earlier." 145

The most difficult criterion to effectuate a remedy for the established Rule 68 disclosure violation has been to establish the 'prejudice' suffered from that violation. It concerns a very case specific assessment; thus only several elements relevant for that assessment will be mentioned.

First, for the purposes of assessing whether the defence has suffered any material prejudice, the Appeals Chamber has drawn a distinction between material "of a public character in the public domain" and materials "reasonably accessible to the Defence."146 The prosecution's duty under Rule 68 does not extent to the first category of materials. With regard to the second category, the Chamber emphasized that "unless exculpatory material is reasonably accessible to the accused, namely, available to the Defence with the exercise of due diligence, the Prosecution has a duty to disclose the material itself."'147 From this reasoning it follows, on the one hand, that where the defence would be able to gain access to materials that are not of a public character, but can easily be accessed, no material prejudice could arise. On the contrary, in light of the case law on the subject matter, where the material was not reasonably accessible to the defence and gave rise to a Rule 68 violation, the prejudice suffered by the defence is subject to evaluation and does not automatically follow from the fact that the defence could not access the materials.

Second, the specific nature of the materials has been taken into account to the extent that when "their content is not of such significance that their late disclosure has had a detrimental impact on the Accused's overall preparation for trial or the approach to his defence," not prejudice will be established. ${ }^{148}$

Third, the judges have paid attention to whether the defence has enough time to analyze the materials and whether it has an opportunity to challenge it on crossexamination; ${ }^{149}$ and whether the defence could call to testify. ${ }^{150}$

145 ICTY, Prosecutor v. Karadžić, Decision on Accused's Forty-Ninth and Fiftieth Disclosure Violation Motions, IT-95-5/18-T, T. Ch., 30 June 2011, paras. 42, 44.

146 ICTY, Prosecutor v. Blaškić, Appeal Chamber Judgment, IT-95-14-A, 29 July 2004, par. 296.

147 ICTY, Prosecutor v. Blaškić, Appeal Chamber Judgment, IT-95-14-A, 29 July 2004, par. 296.

148 ICTY, Prosecutor v. Karadžić, Decision on Accused's Forty-Ninth and Fiftieth Disclosure Violation Motions, IT-95-5/18-T, T. Ch., 30 June 2011, par. 47. Cf. ICTR, Niyitegeka v. The Prosecutor, Decision on Third Request for Review, ICTR-96-14-R, A. Ch., 23 January 2008, par. 28, no material prejudice was established because the exculpatory evidence did not warrant review.

149 ICTY, Prosecutor v. Krstić, Appeal Judgment, IT-98-33-A, 19 April 2004, paras. 192, 197. In the decisions on numerous defence motions on disclosure violations, the Trial Chamber often considered there to be no prejudice arising from the established disclosure violation as the late disclosure "did not have a detrimental impact on the Accused's overall preparation for trial or his approach to crossexamination." See e.g. ICTY, Prosecutor v. Karadžić, Decision on Accused's Sixtieth, Sixty-First, Sixty-Third, and Sixty-Fourth Disclosure Violation Motions, IT-95-5/18-T, T. Ch., 22 November 2011. 150 ICTY, Prosecutor v. Blaškić, Appeal Chamber Judgment, IT-95-14-A, 29 July 2004, par. 282. 
Forth, on appeal, no prejudice from a violation of a disclosure obligation would arise when the defence was able to seek the admission of additional evidence, even if that evidence was not admitted. ${ }^{151}$

With regard to the practical aspect of accessing the material, the Krstic Appeals Chamber agreed with the prosecutor "that Rule 68 does not require the Prosecution to identify the material being disclosed to the Defence as exculpatory." 152 The Chamber recognized that some Trial Chambers have considered it fairer for the prosecutor to do so, "there is no prima facie requirement, absent an order of the Trial Chamber to that effect, that it must do so." 153 In connection with the new Electronic Disclosure System (EDS), the downside of this practical solution to the defence is that the Prosecutor, by placing 'relevant' material on the EDS, fulfils Rule 68 obligations and the defence is left to work its way through a magnitude of materials. ${ }^{154}$ This does not mean, however, that the defence could not argue that it had suffered prejudice from this practice on appeal. ${ }^{155}$ In fact, in Karemera et al., the Appeals Chamber considered that "the Prosecution has for all intents and purposes buried the exculpatory materials." 156 According to the Appeals Chamber, an electronic search machine could not replace the prosecutor's individualized assessment of the material. However, the Appeals Chamber did not provide clear guidance on the extent of the prosecution's identification obligation; it did suggest making a separate file with exculpatory material.

151 ICTY, Prosecutor v. Krstić, Appeal Judgment, IT-98-33-A, 19 April 2004, par. 187.

152 ICTY, Prosecutor v. Krstić, Appeal Judgment, IT-98-33-A, 19 April 2004, par. 190. The defence submitted "that the Rule 68 disclosures of 25 June 2000 and 5 March 20001 made during trial were buried beneath other material provided at the time, and that the failure of the Prosecution to identify the disclosed material as being disclosed under Rule 68 breached the spirit and letter of that Rule" (Id., par. 189).

153 ICTY, Prosecutor v. Krstić, Appeal Judgment, IT-98-33-A, 19 April 2004, par. 190, referring to e.g. ICTY, Prosecutor v. Krajišnik and Plavšić, Decision on Motion from Momcilo Krajišnik to Compel Disclosure of Exculpatory Evidence Pursuant to Rule 68, IT-00-39 \& IT-00-40/1, 19 July 2001, par. 2. ICTY, Prosecutor v. Brdjanin, Decision on Motion For Relief from Rule 68 Violations by the Prosecutor and for Sanctions to be Imposed Pursuant to Rule 68bis and Motion for Adjournment while Matters Affecting Justice and Fair Trial Can be Resolved, IT-99-36-T, 30 October 2002, par. 23.

154 E.g. ICTR, Prosecutor v. Karemera et al., Decision on Interlocutory Appeal Regarding the Role of the Prosecutor's Electronic Disclosure Suite in Discharging Disclosure Obligations, ICTR-98-44AR73.7, 30 June 2006, par. 13 (defence challenge to the EDS). As mentioned above, in the Bemba case, the ICC Pre-Trial Chamber considered the problem of overburdening from the outset. See ICC, Prosecutor v. Bemba, Decision on the Evidence Disclosure System and Setting a Timetable for Disclosure between the Parties, ICC-01/05-01/08-55, 31 July 2008, par. 67.

155 ICTY, Prosecutor v. Krstić, Appeal Judgment, IT-98-33-A, 19 April 2004, par. 191.

156 ICTR, Prosecutor v. Karemera et al., Decision on Interlocutory Appeal Regarding the Role of the Prosecutor's Electronic Disclosure Suite in Discharging Disclosure Obligations, ICTR-98-44AR73.7, 30 June 2006, par. 15. 
Moreover, in Krstic the defence complained that it had been refused copies of exculpatory material, and could only view them in the prosecutor's office ${ }^{157}$ According to the Appeals Chamber, the plain reading of Rule 68 requires the prosecutor to disclose the existence of Rule 68 material, and not to provide the material itself. ${ }^{158}$ Any prejudice arising from this practice should have been brought to the attention of the Trial Chamber and, thus, the defence failed to show any prejudice. This aspect has evolved with practice, and the parties subject to inspection are now expected to provide copies of the documents which the other party requests.

Where the evidence is called by the Trial Chamber proprio motu, this does not relieve the prosecution of its obligations under Rule 68 in relation to that evidence. ${ }^{159}$ Due to the continuous nature of Rule 68 obligations, the prosecution is expected to monitor the witness testimony and to disclose material which is relevant to credibility of that witness, both during or after the testimony. ${ }^{160}$ To be sure, the Trial Chamber in Karadžić considered that this continuous nature of the Rule 68 obligations relates "only to the fact that the Prosecution must continue to disclose new material that is generated or comes into its possession throughout the pre-trial, trial, and appeals phases of a case."161 The Trial Chamber rejected the prosecution's practice of searching for Rule 68 material on a 'rolling basis'. ${ }^{162}$ Generally, the prosecution should make its assessment of potentially exculpatory evidence "as early as the initial appearance $[\ldots]$ regardless of what the accused's ultimate defence strategy proves to be." 163 Moreover, compliance with requests for inspection under Rule 66(B) did not constitute a satisfactory explanation for the delayed disclosure of potentially exculpatory evidence, as these two obligations were independent of each other. ${ }^{164}$

157 ICTY, Prosecutor v. Krstić, Appeal Judgment, IT-98-33-A, 19 April 2004, par. 194.

158 ICTY, Prosecutor v. Krstić, Appeal Judgment, IT-98-33-A, 19 April 2004, par. 195.

159 ICTY, Prosecutor v. Krstić, Appeal Judgment, IT-98-33-A, 19 April 2004, par. 204.

160 ICTY, Prosecutor v. Krstić, Appeal Judgment, IT-98-33-A, 19 April 2004, par. 206.

161 ICTY, Prosecutor v. Karadžić, Decision on Prosecution's Request for Reconsideration of Trial Chamber's 11 November 2010 Decision, IT-95-5/18-T, T. Ch., 10 December 2010, par. 11.

162 ICTY, Prosecutor v. Karadžić, Decision on Prosecution's Request for Reconsideration of Trial Chamber's 11 November 2010 Decision, IT-95-5/18-T, T. Ch., 10 December 2010, par. 11. The Prosecution would make witness-specific Rule 68 searches seriatim and disclose the relevant material on a rolling basis before the testimony of a witness.

163 ICTY, Prosecutor v. Karadžić, Decision on Prosecution's Request for Reconsideration of Trial Chamber's 11 November 2010 Decision, IT-95-5/18-T, T. Ch., 10 December 2010, par. 13. In fact, the accused's failure to provide clearly his defences in the Pre-Trial Brief did not "significantly impact" the Prosecution's ability to comply with its Rule 68 obligations in a timely manner.

164 ICTY, Prosecutor v. Karadžić, Decision on Accused's Twenty-Second, Twenty-Fourth and TwentySixth Disclosure Violation Motion, IT-95-5/18-T, T. Ch., 11 November 2010, par. 31. 


\subsubsection{ICC}

Article 67(2) imposes an ongoing duty upon the prosecutor to disclose, as soon as practicable, evidence in the prosecutor's possession or control which he or she believes shows or tends to show (1) the innocence of the accused, (2) or mitigate the guilt of the accused, or (3) which may affect the credibility of prosecution evidence. ${ }^{165}$ Compared to Rule 68, Article 67(2) is formulated as a right of the accused, instead of as the prosecutor's duty; it explicitly refers to material that must be in the prosecutor's possession or control (although the Tribunal case law has adopted this requirement), and instead of 'actual knowledge' the prosecutor's 'belief' about the exculpatory nature of the material triggers the disclosure obligation. Arguably, a 'short-cut' to any debate about what is actually known to the prosecutor within the context of the ICC can be taken by reference to the duty to conduct full investigations, searching for both incriminating and exculpatory material. Although the general rule is for the prosecutor to assess the value of the evidence and to decide upon its relevance to the defence, ${ }^{166}$ the ICC Statute places the ultimate power to decide upon the judges. ${ }^{167}$ This addition follows directly from, and reconfirms, the judges' responsibility to ensure the fairness of proceedings. Rule 83 ICC RPE adds that "[t]he Prosecutor may request as soon as

165 This has been considered as a clear definition of 'exculpatory' evidence, see ICC, Prosecutor v. Lubanga Dyilo, Decision on the Consequences of non-disclosure of Exculpatory Materials covered by Article 54(3)(e) agreements and the application to stay the prosecution of the accused, together with certain other issues raised at the Status Conference on 10 June 2008, 13 June 2008, paras. 88-89.

166 In the Lubanga case, the Prosecutor argued that the material in question would not materially impact the Chamber's determination of guilt or innocence. ICC, Prosecutor v. Lubanga Dyilo, Prosecution's Document in Support of Appeal against Decision to Stay Proceedings, ICC-01/04-01/06 OA13, 24 July 2008, par. 29. The prosecutor suggested that, for example, 46 of the documents relate only to tu quoque material (par. 29). He contended that "The extent to which the material exculpates the Accused is highly relevant, to assess the impact of non-disclosure on the fairness of the proceedings, and therefore also the appropriate remedies, yet the Trial Chamber failed to consider this factor." (Ibid., par. 30). The Trial Chamber rejected the suggestion that the prosecution "is entitled to decide whether or not potentially exculpatory evidence will only impact in principle on the Chamber's decision, rather then having a material impact in fact on the Chamber's determination of the guilt or innocence of the accused". Once the Prosecutor believes that the material in his possession or control is exculpatory or mitigating, he is to disclose this material to the defence, or to put it before the judges to decide. ICC, Prosecutor v. Lubanga Dyilo, Decision on the Consequences of Nondisclosure of Exculpatory Materials Covered by Article 54(3)(e) Agreements and the Application to Stay the Prosecution of the Accused, together with Certain Other Issues Raised at the Status Conference on 10 June 2008, ICC-01/04-01/06-1401, T. Ch., 13 June 2008, par. 87.

167 ICC, Prosecutor v. Lubanga Dyilo, Redacted version of "Decision on the prosecution's filing entitled "Prosecution's provision of information to the Trial Chamber" filed on 3 September 2007", Annex 1, ICC-01/04-01/06, T. Ch. I, 26 September 2007, par. 12: "the test required in Article 67(2) carries two main elements. The first element requires the prosecution to have evidence in its possession or control. Secondly, the Prosecutor must assess whether that evidence may affect the credibility of the prosecution evidence. If these two elements are met, it is the duty of the Prosecutor to disclose as soon as is practicable the information to the defence". 
practicable a hearing on an ex parte basis before the Chamber dealing with the matter for the purpose of obtaining a ruling under Article 67, paragraph 2."

In Lubanga the Trial Chamber considered that an accused has "an absolute entitlement" to the disclosure of exculpatory materials and, thus, it is irrelevant whether these materials might be undermined by other evidence or that a witness can also provide incriminating evidence: "[i]f the real possibility exists that this evidence may contribute to a resolution of material issues in the case in favour of the accused, he is to be provided with it [...]." 168 The disclosure must take place as soon as the prosecutor identifies the material. ${ }^{169}$ Ideally, "it would be desirable for the investigation to be complete by the time of the confirmation hearing", so there would be a stable basis for trial preparation. ${ }^{170}$ However, this is neither a requirement of the Statute, nor does it correspond to the realities of investigations, especially in the context of an ongoing conflict situation. ${ }^{171}$ In this regard, the Pre-Trial Chamber I judge's 'interventionist' ${ }^{\prime} 72$ approach to the prosecutor's investigative powers concerning the conduct of investigations after the confirmation of charges ${ }^{173}$ was halted by the Appeals Chamber. ${ }^{174}$ The Appeals Chamber accepted the prosecutor's argument that ruling out further investigations after the confirmation of charges, especially in the context of an ongoing conflict situation, may deprive the Court of significant and relevant evidence, including potentially exculpatory evidence. ${ }^{175}$ This decision can be seen as "a heavy brake on the PTC's perhaps inadvertent attempt to dictate the

168 ICC, Prosecutor v. Lubanga Dyilo, Decision Issuing a Confidential and a Public Redacted Version of Decision on Disclosure issues, responsibilities for protective measures and other procedural matters, ICC-01/04-01/06, 8 May 2008, par. 94.

169 ICC, Prosecutor v. Lubanga Dyilo, Decision on the Final System of Disclosure and the Establishment of a Timetable, ICC-01/04-01/06-102, 15 May 2006, p. 5, Annex paras. 119, $124-131$.

170 ICC, Prosecutor v. Lubanga Dyilo, Judgment on the Prosecutor's appeal against the decision of Pre-Trial Chamber I entitled "Decision Establishing General Principles Governing Applications to Restrict Disclosure pursuant to Rule 81 (2) and (4) of the Rules of Procedure and Evidence", ICC01/04-01/06, 13 October 2006, par. 54.

171 ICC, Prosecutor v. Lubanga Dyilo, Judgment on the Prosecutor's appeal against the decision of Pre-Trial Chamber I entitled "Decision Establishing General Principles Governing Applications to Restrict Disclosure pursuant to Rule 81 (2) and (4) of the Rules of Procedure and Evidence", ICC01/04-01/06, 13 October 2006, par. 55.

172 Miraglia, 2006, p. 188.

173 Prosecutor v. Lubanga Dyilo, Decision on the Final System of Disclosure and the Establishment of a Timetable, ICC-01/04-01/06-102, 15 May 2006, ICC-01/04-01/06, Pre-Trial Chamber I, 15 May 2006.

174 ICC, Prosecutor v. Lubanga Dyilo, Judgment on the Prosecutor's appeal against the decision of Pre-Trial Chamber I entitled "Decision Establishing General Principles Governing Applications to Restrict Disclosure pursuant to Rule 81 (2) and (4) of the Rules of Procedure and Evidence", ICC01/04-01/06, 13 October 2006.

175 ICC, Prosecutor v. Lubanga Dyilo, Judgment on the Prosecutor's appeal against the decision of Pre-Trial Chamber I entitled "Decision Establishing General Principles Governing Applications to Restrict Disclosure pursuant to Rule 81 (2) and (4) of the Rules of Procedure and Evidence", ICC01/04-01/06, 13 October 2006, paras. 53-54. 
character and temporal nature of investigations in a manner that evoked images of a probing investigating judge rather that a pre-trial judge of limited authority." 176

Thus, the prosecutor can continue his investigations after the confirmation of charges and remains under the obligation to disclose any inculpatory evidence he intends to use at trial or which is exculpatory, sufficiently in advance of the trial so as to give adequate preparation time. ${ }^{177}$ For the purpose of the confirmation hearing, the prosecutor is found to have satisfied his obligations under Article 67(2) when he has disclosed the 'bulk' of the exculpatory evidence. ${ }^{178}$ In addition, the Pre-Trial Chamber considered that "nothing has been presented to contradict these submissions." 179 In light of the prosecutor's duty to search for truth, this second reference should not be taken as a strong indication of the prosecutor's fulfilment of his obligations with regard to exculpatory evidence. Especially at an early stage, such as the confirmation of charges, the suspect cannot be expected to 'contradict' the prosecutor's submission that he has discharged his duties concerning exculpatory evidence, because any substantial defence investigations are yet to be undertaken.

In the Mbarushimana and the Kenya cases, however, the judges departed from the 'bulk rule' in favour of the 'totality rule' - the disclosure of all the potentially exonerating evidence and evidence which is material to the preparation of the defence. ${ }^{180}$ The prosecution opposed the broad scope of disclosure prior to the confirmation of charges, arguing that this 'totality rule' placed an unfair burden on the prosecution. ${ }^{181}$ The Pre-Trial Chamber considered it fair to oblige the prosecution to organise his office to effect total disclosure at the pre-confirmation stage in a timely fashion. ${ }^{182}$ Moreover, the prosecution opposed the Chamber's order to provide the defence with summaries explaining the relevance of all disclosed potentially exculpatory material, ${ }^{183}$ arguing that it is "manifestly unequal to require the prosecution to bear

176 SCHEFFER, 2008, p. 160.

177 Article 64(3)(c) ICC Statute.

178 ICC, Prosecutor v. Lubanga Dyilo, Decision on the Confirmation of Charges, ICC-01/04-01/06-803EN, 29 January 2007, par. 154.

179 ICC, Prosecutor v. Lubanga Dyilo, Decision on the Confirmation of Charges, ICC-01/04-01/06-803EN, 29 January 2007, par. 154.

180 ICC, Prosecutor v. Samoei Ruto, Kiprono Kosgey and Arap Sang, Decision Setting the Regime for Evidence Disclosure and Other Related Matters, ICC-01/09-01/11-44, PTC II, 6 April 2011; ICC, Prosecutor v. Callixte Mbarushimana, Decision on issues relating to disclosure, ICC-01/04-01/10-87, PTC I, 30 March 2011.

181 ICC, Prosecution v. Callixte Mbarushimana, ICC-01/04-01/10-93, Prosecution's Application for leave to Appeal the 'Decision on issues relating to disclosure, ICC-01/04-01/10-87, PTC I, 5 April 2011, par. 4; ICC, Prosecutor v. Samoei Ruto, Kiprono Kosgey and Arap Sang, ICC-01/09-01/11-74, Decision on the Prosecution's Application for Leave to Appeal the "Decision Setting the Regime for Evidence Disclosure and Other Related Matters”, PTC II, 2 May 2011, par. 27.

182 ICC, Prosecutor v. Samoei Ruto, Kiprono Kosgey and Arap Sang, ICC-01/09-01/11-74, Decision on the Prosecution's Application for Leave to Appeal the "Decision Setting the Regime for Evidence Disclosure and Other Related Matters”, PTC II, 2 May 2011, par. 27.

183 ICC, Prosecution v. Callixte Mbarushimana, ICC-01/04-01/10-93, Prosecution's Application for 
its own burden to establish substantial evidence to hold the person for trial and also to bear the burden to affirmatively guide the defence to understand and fashion a responsive case". ${ }^{184}$ Moreover, these summaries "might inadvertently mislead the defence in the preparation of its case." 185 The defence argued that the prosecution's summaries helped to mitigate the inequality of resources between the parties ${ }^{186}$ and were protecting the defence from being "overwhelmed by the disclosure of potentially irrelevant material." 187

As argued by the prosecution, there exists a clear disparity between the different approaches of different Pre-Trial Chambers to pre-confirmation hearing disclosure of exculpatory evidence. In some cases, the 'bulk rule' has been applied, ${ }^{188}$ in others the 'totality rule'. ${ }^{189}$ In some, the prosecution had to produce explanatory summaries of the disclosed exculpatory material, ${ }^{190}$ but not in others. Some Pre-Trial Chambers have required that all disclosed exculpatory material be communicated to the Chamber, irrespective of whether the prosecution intended to rely on that material

leave to Appeal the 'Decision on issues relating to disclosure, ICC-01/04-01/10-87, PTC I, 5 April 2011, par. 17; ICC, Prosecutor v. Samoei Ruto, Kiprono Kosgey and Arap Sang, ICC-01/09-01/1144, Prosecution's Application for Leave to Appeal the "Decision Setting the Regime for Evidence Disclosure and Other Related Matters”, PTC II, 13 April 2011, par. 27.

184 ICC, Prosecution v. Callixte Mbarushimana, ICC-01/04-01/10-93, Prosecution's Application for leave to Appeal the 'Decision on issues relating to disclosure, ICC-01/04-01/10-87, PTC I, 5 April 2011, par. 17.

185 Fairness at the International Criminal Court, 2011, p. 23.

186 ICC, Prosecution v. Callixte Mbarushimana, ICC-01/04-01/10-94, Defence Reponse to the Prosecution's Request for Leave to Appeal Decision ICC-01/04-01/10-87, PTC I, 10 Aprill 2011, par. 9.

187 ICC, Prosecutor v. Samoei Ruto, Kiprono Kosgey and Arap Sang, ICC-01/09-01/11-74, Decision on the Prosecution's Application for Leave to Appeal the "Decision Setting the Regime for Evidence Disclosure and Other Related Matters”, PTC II, 2 May 2011, par. 14.

188 ICC, Prosecutor v. Lubanga Dyilo, ICC-01/04-01/06-102, Decision on the final system of disclosure and the establishment of a timetable, PTC I, 15 May 2006, par. 124; ICC, Prosecutor v. Lubanga Dyilo, ICC-01/04-01/06-803-tEN, Decision on the confirmation of charges, PCT I, 29 January 2007, par. 154; ICC, Prosecutor v. Katanga and Ngudjolo Chui, ICC-01/04-01/07-621, Decision on Article 54(3)(e) Documents Identified as Potentially Exculpatory or Otherwise Material to the Defence's Preparation for the Confirmation Hearing, PTC I, 20 June 2008, par. 8.

189 ICC, Prosecutor v. Callixte Mbarushimana, ICC-01/04-01/10-87, Decision on issues relating to disclosure, PTC I, 30 March 2011, par. 20 and pp. 15-16; ICC, Prosecutor v. Samoei Ruto, Kiprono Kosgey and Arap Sang, ICC-01/09-01/11-74, Decision on the Prosecution's Application for Leave to Appeal the "Decision Setting the Regime for Evidence Disclosure and Other Related Matters", PTC II, 2 May 2011 par. 27; ICC, Prosecutor v. Samoei Ruto, Kiprono Kosgey and Arap Sang, ICC01/09-01/11-44, Decision Setting the Regime for Evidence Disclosure and Other Related Matters, PTC III, 6 April 2011, par. 24.

190 ICC, Prosecutor v. Bahr Idriss Abu Garda, ICC-02/05-02/09-35, Second Decision on issues relating to Disclosure, PTC I, 15 July 2009, paras. 15 and 16; ICC, Prosecutor v. Callixte Mbarushimana, ICC01/04-01/10-87, Decision on issues relating to disclosure, PTC I, 30 March 2011, par. 11 and p. 15. 
at the confirmation hearing; ${ }^{191}$ others have not done so, however. ${ }^{192}$ The prosecutor's applications for leave to appeal have been denied, arguing that the disclosure orders were not so burdensome as to affect the fairness of the proceedings. ${ }^{193}$ The extended burden on the prosecution is undeniable, and it is understandable that the prosecution objects to a heavy burden being imposed in relation to the disclosure of exculpatory material. However, this extended burden could rightly be considered as a mere consequence of the objective role of the ICC prosecutor in light of Article 54(1)(a) and the principle of equality of arms. The practical consideration is, however, still open to discussion: the budget can be divided only once, so is it therefore justifiable to place a heavier burden on the prosecution in relation to the disclosure of exculpatory evidence to the defence, rather than providing the same resources to the defence to "understand and fashion a responsive case"? 194

In the context of the disclosure of exculpatory evidence obtained under confidentiality agreements, in the Lubanga case (discussed in more detail below), the prosecutor proposed a 'cut-off' date for the disclosure of the exculpatory evidence, just as for inculpatory evidence. The OTP reasoned that

[t]his Court has a statutory duty to establish the truth, and the truth is established by assessing both incriminatory and exculpatory evidence. If one would now say there is no cut-off date for the potentially exculpatory material but there's a cut-off date for the incriminatory material, it would be very difficult for the Honourable Bench to establish the truth. ${ }^{195}$

191 ICC, Prosecutor v. Samoei Ruto, Kiprono Kosgey and Arap Sang, ICC-01/09-01/11-44, Decision Setting the Regime for Evidence Disclosure and Other Related Matters, PTC III, 6 April 2011, par. 6.

192 ICC, Prosecutor v. Bahr Idriss Abu Garda, ICC-02/05-02/09-35, Second Decision on issues relating to Disclosure, PTC I, 15 July 2009, at par. 9; ICC, Prosecutor v. Callixte Mbarushimana, ICC-01/0401/10-87, Decision on issues relating to disclosure, PTC I, 30 March 2011, par. 9 subparagraph (c).

193 ICC, Prosecutorv. Callixte Mbarushimana, ICC-01/04-01/10-93, Prosecution's Application for leave to Appeal the 'Decision on issues relating to disclosure' (ICC-01/04-01/10-87), PTC I; 5 April 2011; ICC, Prosecutor v. Samoei Ruto, Kiprono Kosgey and Arap Sang, ICC-01/09-01/11-50, Prosecution's Application for leave to appeal the 'Decision Setting the Regime for Evidence Disclosure and Other Related Matters', ICC-01/09-01/11-44, PTC I, 13 April 2011, par. 5; ICC, Prosecutor v. Callixte Mbarushimana, ICC-01/04-01/10-116, Decision on the Prosecution's application for leave to Appeal the 'Decision on issues relating to disclosure', ICC-01/04-01/10- 87, PTC I, 21 April 2011, par. 29; ICC, Prosecutor v. Samoei Ruto, Kiprono Kosgey and Arap Sang, ICC-01/09-01/11-74, Decision on the 'Prosecution's Application for leave to Appeal the "Decision Setting the Regime for Evidence Disclosure and Other Related Matters”, ICC-01/09-01/11-44, PTC I, 2 May 2011.

194 ICC, Prosecution v. Callixte Mbarushimana, ICC-01/04-01/10-93, Prosecution's Application for leave to Appeal the 'Decision on issues relating to disclosure, ICC-01/04-01/20-87, PTC I, 5 April 2011, par. 17.

195 Transcript of 1 October 2007, ICC-01/04-01/06-T-52-ENG, pp. 87, 18-23. 
The prosecutor suggested that after reviewing all the confidential materials, the prosecutor would send out the necessary requests to information providers to lift the confidentiality. Any evidence, inculpatory or exculpatory, obtained in this manner should then be admitted either for the prosecution or for the defence. ${ }^{196}$ The Trial Chamber did not accept this argument and emphasized the prosecutor's duty to ensure a fair trial without undue delay. ${ }^{197}$ The prosecutor's late request to lift confidentiality is generally not the problem of the defence ${ }^{198}$ and should have no bearing on the rights of an accused to an expeditious trial and adequate trial preparation. ${ }^{199}$ Although the prosecutor refers to the Court's duty (and thus his own) to establish the truth, the suggestion that there should be a deadline after which no additional exculpatory evidence has to be disclosed seems to be courter-instinctive in that regard. The rationale for establishing a deadline for the disclosure of incriminating evidence touches upon the fundamentals of the modern understanding of a fair trial: a person who is presumed innocent should know the accusations against him/her so as to be able to prepare and present a defence. ${ }^{200}$ Indeed, it is up to the OTP, as the organ initiating the proceedings, to provide enough inculpatory evidence before this deadline (otherwise the proceedings should be discontinued). If, in the course of the proceedings, it becomes known that the prosecutor was wrong to bring the accusations against that individual, justice cannot be done if the disclosure of such evidence would be withheld. This suggestion alone, arguably, amounts to disregarding the prosecutor's duties as an 'impartial truth-seeker.'

As to the consequences of the non-disclosure of exculpatory evidence, the Trial Chamber indicated that when non-disclosed exculpatory evidence materially

196 Transcript of 1 October 2007, ICC-01/04-01/06-T-52-ENG, pp. 88, 5-12.

197 ICC, Prosecutor v. Lubanga Dyilo, Decision Regarding the Timing and Manner of Disclosure and the Date of Trial, ICC-01/04-01/06, 9 November 2007, par. 19: "The Trial Chamber believes that from the moment the prosecution entered into the agreements and was thereafter presented with exculpatory materials, it has been under the obligation to act in a timely manner to lift the agreements in order to ensure a fair trial without undue delay".

198 In the words of the Prosecution: "One could take the approach that there should be cut-off date in respect of the incriminatory materials, and one could take the approach by saying it's the problem of the Office of the Prosecutor to not yet have received the lifting of restriction decisions of the respective information providers. I would disagree with such an approach, and I'm going to explain why I would disagree with such an approach". Transcript of 1 October 2007, ICC-01/04-01/06-T52-ENG, pp. 87, 11-17.

199 ICC, Prosecutor v. Lubanga Dyilo, Decision Regarding the Timing and Manner of Disclosure and the Date of Trial, ICC-01/04-01/06, 9 November 2007, par. 19.

200 ICC, Prosecutor v. Lubanga Dyilo, Decision Regarding the Timing and Manner of Disclosure and the Date of Trial, ICC-01/04-01/06, 9 November 2007, par. 16: "While the general nature of the case is already apparent from the proceedings until this point, full disclosure is still necessary in order to gain a thorough understanding of the time required by the parties and participants in order to prepare for trial. Although some significant preparatory work has been possible for a considerable period of time, there is further preparation that the defence, and possibly the participants, must engage in and which can only be completed once there has been full disclosure on the part of the prosecution." 
impacts the Chamber's determinations as to the guilt or innocence of the accused, the prosecutor will have to withdraw any charges. ${ }^{201}$ In fact, the prosecutor relied on this suggestion of 'adverse consequences' when he was not able to disclose potentially exculpatory material to the defence and the Trial Chamber in the Lubanga case.

\subsubsection{The Lubanga disclosure crises}

In the context of investigations, this case was already discussed in chapter 4 . Both instances of stay of proceedings in this case directly revolve around disclosure of evidence on which this sub-section focuses.

The first stay of proceedings was the result of the Trial Chamber's finding that the prosecutor had abused Article 54(3)(e) ICC Statute, which provides for an opportunity not to disclose information that has been obtained confidentially and only for the purpose of generating new evidence. ${ }^{202}$ The prosecutor was unable to disclose many confidential materials even to the Trial Chamber, notwithstanding the letters of assurance that it will not provide it to the defence without the consent of the information provider. ${ }^{203}$ Some of the material, however, contained exculpatory evidence that had to be disclosed to the defence. The Chamber issued orders directing the prosecutor to comply with his statutory disclosure obligations, and after repeated non-compliance, the Chamber stayed the proceedings. According to the Trial Chamber, his use of Article 54(3)(e) was too broad and incorrect. ${ }^{204}$

The prosecutor disagreed with this characterization of his use of Article 54(3)(e) and contended that this Article does not restrict the nature, but merely the purpose of the material in question, it "does not govern or limit all potential uses to which material might be put, but only the uses to which the material can be put without further consent from the provider." 205 In short, when the prosecutor chooses to request the information providers to lift the confidentiality of the material, and he actually

201 ICC, Prosecutor v. Lubanga Dyilo, Decision Regarding the Timing and Manner of Disclosure and the Date of Trial, ICC-01/04-01/06, 9 November 2007, par. 19.

202 Article 54(3)(e) ICC Statute (the Prosecutor may agree not to disclose, at any stage of the proceedings, documents or information that the Prosecutor obtains on condition of confidentiality and solely for the purpose of generating new evidence, unless the provider of the information consents). For an overview of the framework of the ICTY in relation to confidential agreements and the disclosure of exculpatory evidence (Rule 70 and 68), see Whiting, 2009, pp. 211-215.

203 Transcript of hearing on 6 May 2008, ICC-01/04-01/06-T-86-ENG, page 35, line 20 to page 36, line 17.

204 ICC, Prosecutor v. Lubanga Dyilo, Decision on the Consequences of Non-disclosure of Exculpatory Materials Covered by Article 54(3)(e) Agreements and the Application to Stay the Prosecution of the Accused, together with Certain Other Issues Raised at the Status Conference on 10 June 2008, ICC-01/04-01/06-1401, T. Ch., 13 June 2008 [Lubanga First Stay of Proceedings Trial Decision], par. 71.

205 ICC, Prosecutor v. Lubanga Dyilo, Prosecution's Document in Support of Appeal against Decision to Stay Proceedings, ICC-01/04-01/06 OA13, 24 July 2008, paras. 6,7 ('Prosecution's Appeal of the First Stay of Proceeding Trial Decision') [emphasis added]. 
obtains this consent, following Rule 82(1) the prosecutor can introduce this material as evidence. ${ }^{206}$ If no consent is obtained, the prosecutor can only use those materials for the purpose of generating new evidence. ${ }^{207}$ This power to secure information under the cloak of confidentiality is "a key tool of the Prosecution; and goes to the heart of the Prosecutor's ability to fulfill its mandate." ${ }^{208}$ This tool is particularly pertinent to providers in the context of armed conflicts ${ }^{209}$ and "it is also in the interests of the objective and efficient administration of justice for the Prosecution to gather such information at the earliest possible time, in particular to guide its investigations." 210

With regard to the Trial Chamber's contention that "the only purpose of receiving this material should be that it is to lead to other evidence," 211 the prosecutor argued that it would be difficult, if not impossible, to assess the relevance of the evidence prior to its collection. ${ }^{212}$ In fact, in response to the Trial Chamber's assessment of the conditionality between the confidential agreements and the disclosure crisis, ${ }^{213}$ the prosecutor made a valid point: "if the material had not been received under Article 54(3)(e) it would not have been provided to the Prosecution in the first place, thus could not have been disclosed." ${ }^{14}$ The Trial Chamber's reasoning is not very clear:

If Article 54(3)(e) is used appropriately, the apparent tension which exists between this provision and Article 67(2) is likely to be negligible: although exculpatory material may be included in the springboard or lead evidence, in the limited circumstances in which this provision should be used, it is likely that a mechanism can be established which facilitates all necessary disclosure; for instance, the prosecution may need to make arrangements with the information-provider for disclosure of such parts of

206 Rule 82(1) ICC RPE: "Where material or information is in the possession or control of the Prosecutor which is protected under Article 54, paragraph 3 (e), the Prosecutor may not subsequently introduce such material or information into evidence without the prior consent of the provider of the material or information and adequate prior disclosure to the accused".

207 Prosecution's Appeal of the First Stay of Proceedings Trial Decision, par. 8.

208 Prosecution's Appeal of the First Stay of Proceedings Trial Decision, par. 10 [footnote reference omitted].

209 Prosecution's Appeal of the First Stay of Proceedings Trial Decision, par. 12: "The realities of investigations during ongoing conflicts or in regions of substantial instability reinforce the need for providers to be able to transmit material confidentially and for the limited purpose of generating new evidence, when necessary".

210 Prosecution's Appeal of the First Stay of Proceedings Trial Decision, par. 9 [footnote reference omitted].

211 Lubanga First Stay of Proceedings Trial Decision, par. 71.

212 Prosecution's Appeal of the First Stay of Proceedings Trial Decision, par. 8: "The provider imposes the restriction on use, not the Prosecutor. Even if the Prosecutor was able to review the documents in detail prior to collection, the full incriminatory or exculpatory value may only become apparent later, and in connection with other evidence." [footnote reference omitted].

213 Lubanga First Stay of Proceedings Trial Decision, par. 70: "if the exculpatory material was not covered by the agreements, it would have been provided to the defence: non-disclosure is the direct result of the prosecution's use of the Article 54(3)(e) agreements."

214 Prosecution's Appeal of the First Stay of Proceedings Trial Decision, par. 16. 
the Article 54(3)(e) material as will enable it to provide any potentially exculpatory evidence to the accused. ${ }^{215}$

Hence, the Chamber seems to imply that because the confidentiality agreements will be exceptional, disclosure problems of potentially exculpatory evidence would be non-existent because (1) the limited lead evidence obtained confidentially would indeed lead to other potentially exculpatory evidence that can be disclosed and (2) it would be possible to agree on (partial) disclosure of any lead evidence that is potentially exculpatory with the providers. The question remains what to do when the information providers do not consent to disclosure of the potentially exculpatory lead evidence that has not generated new evidence. The Trial Chamber's answer is straightforward: "[i]n any event, if the prosecution is unable to disclose evidence of this kind which is covered by these agreements, the issue should always be raised with the Chamber in accordance with Rule 83."216 However, one of the problems - and arguably going to the heart of the first disclosure crisis - was that the information providers did not even consent to the disclosure of the material to the Trial Chamber. One cannot but notice certain circularity in this reasoning.

The Appeals Chamber confirmed the Trial Chamber's interpretation of Article 54(3)(e) ICC Statute, in the sense that this Article can only be used for the specific purpose of generating new evidence. ${ }^{217}$ Considering the prosecutorial obligation to search for the truth under Article 54(1) the Appeals Chamber argued that "the investigatory activities of the Prosecutor must be directed towards the identification of evidence that can eventually be presented in open court, in order to establish the truth and to assess whether there is criminal responsibility under the Statute." 218 Notwithstanding the importance of the confidentiality agreements to conducting investigations into conflict areas, the prosecutor must utilize this tool in accordance with his other functions and obligations under the Statute. In any case, the Chambers must be able to resolve the possible tension between confidentiality and disclosure. ${ }^{219}$ The Appeals Chamber expressed particular concern regarding the fact that the

215 Lubanga First Stay of Proceedings Trial Decision, par. 76.

216 Lubanga First Stay of Proceedings Trial Decision, par. 76.

217 ICC, Prosecutor v. Lubanga Dyilo, Judgment on the Appeals of the Prosecutor against the decision of Trial Chamber I entitled "Decision on the Consequences of Non-disclosure of Exculpatory Materials Covered by Article 54(3)(e) Agreements and the Application to Stay the Prosecution of the Accused, together with Certain Other Issues Raised at the Status Conference on 10 June 2008, ICC-01/04-01/06-OA 13, 21 October 2008 [Lubanga First Stay of Proceedings Appeals Decision].

218 Lubanga First Stay of Proceedings Appeals Decision, par. 41.

219 The Appeals Chamber rejected the resolution of this tension proposed by the participating victims. They proposed an interpretation that under Article 67(2) ICC Statute only evidence has to be disclosed, while Article 54(3)(e) documents or information do not become evidence unless the providers have consented to the lifting of confidentiality. As a consequence, the Prosecutor would be able to withhold information because it is not yet evidence, which is unacceptable to the Appeals Chamber. See Lubanga First Stay of Proceedings Appeals Decision, par. 43. 
prosecutor had agreed to 'exclude' the judges by not disclosing confidential materials even to the Chamber. ${ }^{220}$ It is the Chamber that bears the final say with regard to "whether the material would have to be disclosed, had it not been obtained under Article 54(3)(e) of the Statute." 221 If the Chamber decides in favour of disclosure but the information providers refuse to lift confidentiality, the judges will then have to decide on potential counter-balancing measures to protect the rights of the accused, including evaluating potential alternative evidence. ${ }^{22}$

Notably, the Appeals Chamber rejected the prosecutor's argument that the Trial Chamber had "incorrectly marginalised or numerically limited the potential use of Article 54(3) (e) of the Statute" by referring to the "highly restrictive circumstances" of its use. ${ }^{223}$ According to the Appeals Chamber, the Trial Chamber did not intend to limit the number of documents, but only their use, namely only to generate new evidence. Trial Chamber's reasoning, however, also refers to possibly partial disclosure of that lead evidence to the accused. ${ }^{224}$ Ideally, if Article 54(3)(e) is used properly to only generate new evidence, all potentially exculpatory leads would generate new evidence that could be disclosed and for the small part they would not, possible (partial) disclosure arrangements with information providers could be made. Of course, this reasoning equally implies that these 'leads' could and would indeed lead to 'disclosable' evidence, thus making the lead material itself redundant. Whether this is practically attainable is debatable. Moreover, the rhetorical nature of the second possibility of arrangements is indeed exemplified by the disclosure crises in this case: no such arrangements were in fact possible at first. ${ }^{225}$

In sum, whenever the prosecutor is confronted with material offered to him on the basis of confidentiality, taking into account specific circumstances such as the expected content and nature of the documents, he will have to decide on the specific conditions under which he can accept these materials considering his other obligations. ${ }^{226}$ It follows that to some extent these decisions subject Article 54(3)(e) to Article 67(2) ICC Statute. Importantly, the conditions under which the materials could be accepted under the cloak of confidentiality do not include the possibility of excluding the judges' assessment power provided for in Article 67(2). A point the ICC judges made very clear in this case. However, many practical concerns, from the perspective of both prosecution and defence, remain unresolved. The prosecutor has received little room for manoeuvre in the context Article 54(3)(e) agreements which

220 Lubanga First Stay of Proceedings Appeals Decision, par. 45.

221 Lubanga First Stay of Proceedings Appeals Decision, par. 48.

222 Lubanga First Stay of Proceedings Appeals Decision, paras. 48 and 95.

223 Lubanga First Stay of Proceedings Appeals Decision, par. 55.

224 Lubanga First Stay of Proceedings Trial Decision, par. 76.

225 Eventually, the stay was reversed because the Prosecutor was able to obtain the consent of providers for most docusments after all.

226 Lubanga First Stay of Proceedings Appeals Decision, par. 51. 
can have negative effects on his ability to collect evidence, particularly in (post)conflict situations. From the perspective of the defence, the judge's approach to the relationship between Articles 54(3)(e) and 67(2) seems rather encouraging. However, one is to hope that both the prosecutor and the information providers would not shy away from respectively collecting and disclosing potentially exculpatory evidence which could only be obtained under the cloak of confidentiality. ${ }^{227}$ Otherwise, this will have a devastating effect on both the truth-finding in and the fairness of the process.

The second disclosure crisis occurred on 8 July 2010 when the Trial Chamber again issued a stay of proceedings because the prosecutor had repeatedly not complied with the Chamber's order to disclose the identity of an intermediary that the defence wished to call to the stand. ${ }^{228}$ Arguably, acting in his 'quasi-judicial' role (by protecting broader public interests), the prosecutor repeatedly failed to comply with the Trial Chamber's orders by referring to his own "autonomous duties of protection that it must honour at all times." ${ }^{229}$ The Trial Chamber felt that it was no longer in a position to ensure a fair trial not only due to the particular non-compliance with the Chamber's order, but more generally because of the prosecutor's "clearly evinced intention not to implement the Chamber's orders that are made in an Article 68 context, if he considers they conflict with his interpretation of the prosecutor's other obligations." ${ }^{230}$

The role of the intermediaries used by the prosecution to "facilitate contact between the Prosecution and a witness or any other source of information" 231 was brought into discredit during trial when several defence witnesses implicated these intermediaries in being engaged in improper conduct. The defence wished to have the issue examined in more detail in court and the Trial Chamber agreed. ${ }^{232}$ Consequently,

227 A reason for the ICTY judges to eventually subject the disclosure obligations under Rule 68 to confidentiality agreements possible under Rule 70(B) ICTY RPE.

228 ICC, Prosecutor v. Lubanga Dyilo, Redacted Decision on the Prosecution's Urgent Request for Variation of the Time-Limit to Disclose the Identity of Intermediary 143 or Alternatively to Stay Proceedings Pending Further Consultations with the VWU, ICC-01/04-01/06-2517-Red, T. Ch. I, 8 July 2010 [Lubanga Second Stay of Proceedings Trial Decision].

229 ICC, Prosecutor v. Lubanga Dyilo, Prosecution's Urgent Request for Variation of the Time-Limit to Disclose the Identity of Intermediary 143 or Alternatively to Stay Proceedings Pending Further Consultations with VWU, ICC-01/04-01/06-2512, T. Ch. I, 8 July 2010, p. 3.

230 Lubanga Second Stay of Proceedings Trial Decision, par. 31.

231 ICC, Prosecutor v. Lubanga Dyilo, Prosecution Proposed Procedure for Dealing with Intermediaries, ICC-01/04-01/06-2362, 19 March 2010, introduction.

232 ICC, Prosecutor v. Lubanga Dyilo, Redacted Decision on Intermediaries, ICC-01/04-01/06-2434Red2, 31 May 2010, par. 135: "The precise role of the intermediaries (together with the manner in which they discharged their functions) has become an issue of major importance in this trial. Contrary to the prosecution's argument, the defence submissions are not dependent on speculative assertions: they are, to an important extent, clearly evidence based". [Lubanga Decision on Intermediaries]. 
the Chamber ordered the prosecution to (1) disclose the identity of one intermediary "to enable the defence to conduct necessary and meaningful investigations and to secure a fair trial for the accused," 233 once the necessary protective measures had been implemented, (2) call two intermediaries to the stand to testify, and (3) call an OTP representative to testify generally on the use of intermediaries. ${ }^{234}$

Later during trial, the Trial Chamber ordered an immediate disclosure of the identity of intermediary 143, but only to limited defence team members and only in order to enable the defence to question a witness (intermediary 321), thus disallowing any investigative measures with regard to intermediary 143.235 The Prosecutor did not comply with this order because he felt that it put the intermediary at risk. The Chamber disagreed and noted that limited disclosure of the identity (to the defence present in court and their resource person) would not increase the security risk of intermediary $143 .{ }^{236}$ The Victims and Witnesses Unit (VWU) came to the same conclusion. ${ }^{237}$ Although it did not attach any explicit consequences to it, the Trial Chamber noted that during trial the cover of intermediary 143 was "blown". ${ }^{238}$

The prosecutor refused to implement the Chamber's orders before being "satisfied that it is acting in compliance with its specific duties under the Statue and the Rules. ${ }^{239} \mathrm{He}$ argued that

233 Lubanga Decision on Intermediaries, par. 143.

234 Lubanga Decision on Intermediaries, par. 150.

235 Lubanga Second Stay of Proceedings Trial Decision, par. 10. No investigative steps by the defence were to be undertaken until protective measures for intermediary 143 had been put in place.

236 Lubanga Second Stay of Proceedings Trial Decision, par. 12. Moreover, the intermediary, after initial acceptance, had questioned the proposed security measures, and no reasons for that were provided to the Chamber. In addition, the fact that the Defence indicated that they wanted this intermediary to be called to testify, "tends to undermine the suggestion by the Prosecution this afternoon that he is likely to be killed because he is thought to be a traitor, presumably by Mr. Lubanga" (Ibid.).

237 Lubanga Second Stay of Proceedings Trial Decision, par. 17. Arguably, the former does not necessarily lead to the latter.

238 Lubanga Second Stay of Proceedings Trial Decision, par. 4: "A little later, in private session, defence counsel put the following name to the witness ..., to which he responded "that's the name of Mr. 143". The prosecution accepted that, at least to a certain extent, adopting the expression of the Presiding Judge, the cover of 143 was "blown" [footnote reference omitted]. However, the Prosecution contended that "the identity of Intermediary 143 was still confidential information and disagreed that the intermediary's cover was "blown", but recognizing that the Chamber's confirmation potentially compromised the confidentiality of the information, it increased its monitoring activities for Intermediary 143". Prosecution's Appeal of Lubanga Second Stay of Proceedings Trial Decision, par. 29. The prosecution emphasized that the identity was still not disclosed: “ ... perhaps part of the cat is out of the bag, but the Defence doesn't know what part of that cat is. It doesn't - if there is anything in the name that was disclosed that is similar or close, it's still not the name. The name was not disclosed and the Defence does not know how close or how different the name is." Transcript of 7 July 2010, ICC-01/04-01/06-T-312-ENG, pp. 13, 6-11.

239 ICC, Prosecutor v. Lubanga Dyilo, Prosecution's Urgent Request for Variation of the Time-Limit to Disclose the Identity of Intermediary 143 or Alternatively to Stay Proceedings Pending Further Consultations with VWU, ICC-01/04-01/06-2512, T. Ch. I, 8 July 2010, pp. 1-4. 


\begin{abstract}
[t]he Prosecution is sensitive to its obligation to comply with the Chamber's instructions. However, it also has an independent statutory obligation to protect persons put at risk on account of the Prosecution's actions. It should not comply, or be asked to comply, with an Order that may require it to violate its separate statutory obligation by subjecting the person to a foreseeable risk. The Prosecutor accordingly has made a determination that the Prosecution would rather face adverse consequences in its litigation than expose a person to risk on account of prior interaction with this Office. This is not a challenge to the authority of the Chamber, it is instead a reflection of the Prosecution's own legal duty under the Statute. ${ }^{240}$
\end{abstract}

Next to the immediate refusal to implement its orders, the Trial Chamber identified a second arguably "more profound and enduring concern" in the prosecutor's expressed autonomy to choose to comply with the Trial Chamber's orders depending on the interpretation of his statutory obligations. ${ }^{241}$ The Chamber reiterated that once seized of a case, the Trial Chamber alone has the power to order and vary protective measures as it has the overarching responsibility to ensure a fair trial. ${ }^{242}$ The prosecutor's claim of a separate authority in that regard is obviously misconceived and "involves a profound, unacceptable and unjustified intrusion into the role of the judiciary." ${ }^{243}$

On appeal, the prosecutor argued that he had not refused to comply with the Chamber's orders. ${ }^{244}$ The Appeals Chamber's ruling is straightforward. The prosecutor obviously and deliberately disobeyed, and any argument to the contrary "is, at best, disingenuous [and] at worst, $[\ldots]$ an expression of $[\ldots]$ a more profound and enduring concern [...]." 245 The prosecutor advanced many arguments with regard to the intermediary's security risk and the prosecutor's duty to protect this intermediary. Accordingly, the prosecutor was "surprised" by the "unilateral" and hasty change in the Trial Chamber's approach to protective measures previously

240 ICC, Prosecutor v. Lubanga Dyilo, Prosecution's Urgent Provision of Further Information Following Consultation with the VWU, to Supplement the Request for Variation of the Time-Limit or Stay, ICC-01/04-01/06-2516, 7 July 2010, par. 6.

241 Lubanga Second Stay of Proceedings Trial Decision, par. 21.

242 Lubanga Second Stay of Proceedings Trial Decision, par. 24.

243 Lubanga Second Stay of Proceedings Trial Decision, par. 27.

244 ICC, Prosecutor v. Lubanga Dyilo, Prosecution's Document in Support of Appeal against Trial Chamber I's Decision of 8 July 2010 to stay the proceedings for abuse of process, ICC-01/0401/06-2544-Red, 30 July 2010, [Prosecution's Appeal of Lubanga Second Stay of Proceedings Trial Decision], par. 5.

245 ICC, Prosecutor v. Lubanga Dyilo, Judgment on the Appeal of the Prosecutor against the Decision of Trial Chamber I of 8 July 2010 entitled "Decision on the Prosecution's Urgent Request for Variation of the Time-Limit to Disclose the Identity of Intermediary 143 or Alternatively to Stay Proceedings Pending Further Consultations with the VWU, ICC-01/04-01/06 OA 18, A. Ch., 8 October 2010, par. 46 [Lubanga Second Stay of Proceedings Appeals Decision]. According to the Prosecutor, "every request by a party that a Chamber reconsider a prior ruling or seeks a variation of a time-limit will present a situation of non-compliance". 
invoked. ${ }^{246}$ The Appeals Chamber refused to consider any of these arguments because both orders were not on appeal at the time. ${ }^{247}$ The Appeals Chamber reiterated that the Trial Chamber is "the ultimate guardian of a fair and expeditious trial" and that, notwithstanding the prosecutor's statutory duties, in any perceived conflict between those duties and the Trial Chamber's orders, the latter must prevail. ${ }^{248}$ However, in the end the Appeals Chamber reversed the Trial Chamber's stay of proceedings, by considering it as premature in light of the other possible tools to bring about compliance. ${ }^{249}$

The prosecutor's obligations vis-à-vis third parties clearly fall within his duties as an officer of the court to ensure the proper administration of justice. Intermediaries form an essential element in the prosecution's investigations due to the unstable security situation in the DRC. In fact, "[i]t is not an exaggeration to say that the prosecutions themselves are impossible without the assistance of intermediaries." 250 It was foreseeable that the prosecutor would be reprimanded for not complying with the Trial Chamber's direct orders. His explicit recognition that he would rather face adverse consequences as a party to proceedings than fall short of ensuring the protection of broader public interests can be seen as an expression of the 'quasijudicial' perception of his role. ${ }^{251}$ Whether the prosecutor was prepared to allow the trial be halted permanently, rather than obeying the Chamber's orders, is another question which is somewhat too speculative. ${ }^{252}$ However, the prosecutor clearly took the wrong path regarding his assessment of the primacy of the Trial Chamber's evaluation of protective measures.

\subsection{RECIPROCAL DISCLOSURE OBLIGATIONS: DEFENCE DISCLOSURE}

A discussion of disclosure obligations of defence clearly reveals the tension between the objectives of expeditiousness and fairness of the process. The choices made with regard to the balance of the practical and the principled arguments determine the scope of defence's disclosure duties in a particular system that is based on this information exchange mode. An important question arises as to what extent an obligation to disclose material relevant to its case can be imposed upon the defence

246 Prosecution's Appeal of Lubanga Second Stay of Proceedings Trial Decision, par. 48.

247 Lubanga Second Stay of Proceedings Appeals Decision, par. 45.

248 Lubanga Second Stay of Proceedings Appeals Decision, paras. 47-48. Contrary to the Prosecutor's contention, a request for a reconsideration of an order in itself does not suspend the effect of that order absent a judicial ruling in that regard (Ibid., par. 49).

249 Lubanga Second Stay of Proceedings Appeals Decision, par. 59.

250 ICC, Prosecutor v. Lubanga Dyilo, Prosecution's Submissions in Response to Trial Chamber's Oral Request of 10 February 2010, ICC-01/04-01/06-2310-Red, 25 February 2010, par. 12.

251 Rather than the sole desire to "win" the case, see VAsiliev, 2010, p. 50.

252 Considering the Prosecutor's contention that the stay had been imposed on a conditional basis, see Trial Transcript of 15 July 2010, ICC-01/04-01/06-T-314-ENG. 
in order to advance the efficient and expeditious course of proceedings, without infringing upon the rights of the accused. The rules of procedure of the international criminal tribunals has undergone the necessary changes in order to maximize the efficiency level without sacrificing the fairness concerns from the perspective of the defence. In addition, this is one area where the prosecution frequently has relied on the principle of equality of arms. To a large extent, the issue is very practical: if the defence chooses to present a case, its must show its materials to the adversary party, and possibly the judges, in order to make the preparation and presentation of a case more efficient. However, there are several principled considerations underlying which may not be lost out of sight. ${ }^{253}$ This section focuses on the way international criminal courts have approached the above question.

\subsubsection{ICTY, ICTR and SCSL}

From the outset, the defence was to notify the prosecution if it intended to offer a defence of alibi or any other special defences, including the lack of or diminished mental responsibility. ${ }^{254}$ Even before the addition of Rule $67 \operatorname{ter}(\mathrm{G})$, which directs the defence before the commencement of its case to disclose to the prosecutor a list of witnesses it intends to call at trial and a list of exhibits it intends to offer, the judges already had to consider the defence's disclosure obligations within the legal framework of the Tribunal.

In Tadic, the Trial Chamber was confronted with this issue for the first time, and the majority decision rejected the prosecution's motion seeking the production of prior statements by defence witnesses. ${ }^{255}$ Judge Stephen considered that the limited disclosure obligations of the defence underlying the Rules of the Tribunal are "in accord with the general pattern of procedure in common law, adversarial system of trial." 256 There is no reciprocity of disclosure obligations and the accused "need not afford the Prosecution any assistance in making out the Prosecution case." ${ }^{257}$ To that, Judge Vohrah added that because the nature of the procedure adopted by the

253 Cf. ICC, Prosecutor v. Lubanga Dyilo, Decision on disclosure by the defence, ICC-01/04-01/06-1235, T. Ch., 20 March 2008, par. 27: "The starting-point for consideration of this issue [defence disclosure] is that the fundamental rights of the accused not to incriminate himself or herself and to remain silent must not be undermined by any obligations imposed on the defence, or in any other way."

254 Rule 67(A) ICTY RPE.

255 ICTY, Prosecutor v. Tadić, Prosecution Motion for Production of Defence Witness Statements, IT94-I-T, 27 November 1996, the Prosecutor argued that the Defence was required to produce prior witness statements of the witnesses who testified for the Defence. The three Judges all delivered a separate opinion and Judge McDonald dissented.

256 ICTY, Prosecutor v. Tadić, Separate Opinion of Judge Stephen on Prosecution Motion for Production of Defence Witness Statements, IT-94-I-T, 27 November 1996, par. 12.

257 ICTY, Prosecutor v. Tadić, Separate Opinion of Judge Stephen on Prosecution Motion for Production of Defence Witness Statements, IT-94-I-T, 27 November 1996, par. 12. 
Tribunal was largely adversarial, "the Defence has organized the preparation of its case on assumptions based upon the adversarial process." ${ }^{258}$ A different ruling would jeopardize not only the fundamental principle of lex certa for the defence, but also have an adverse effect on the witnesses, who might be at risk of self-incrimination and/ or losing confidentiality. ${ }^{259}$ Regarding the prosecution's argument that the principle of equality of arms points towards the prosecution's access to prior statements made by defence witnesses, Judge Vohrah made an important remark about the operating scope of that principle. Referring to different international decisions (by the ECtHR, HRC, Court of the European Communities), Judge Vohrah concluded "that the application of the equality of arms principle especially in criminal proceedings should be inclined in favour of the Defence acquiring parity with the Prosecution ["who enjoys the advantages of the State on its side"] in the presentation of the Defence case before the Court to preclude any injustice against the accused." 260

Judge McDonald strongly disagreed with this view referring to the fact that "it is not appropriate to compare the resources and powers of the Prosecution of the International Tribunal with that of many national entities" because the ICTY Prosecutor is dependant on state cooperation and thus "does not have all of the advantages of a State." ${ }^{261}$ Consequently, Judge McDonald considered that the international human rights norms "would not be violated by an order for the disclosure of the relevant portions of prior statements of witnesses called by the defence." 262 On the 'adversarial roots' argument expressed by the other two judges, Judge McDonald remarked that "[o]ur Rules have already moved beyond the 'adversarial cat-and-mouse' approach and the litigation in the International Tribunals is conducted much more "with cards on the table." ${ }^{263}$ After a review of the authorities referred to by Judges Stephen and Vohrah, Judge McDonald concluded that the "modern approach, and one embraced

258 ICTY, Prosecutor v. Tadić, Separate Opinion of Judge Vohrah on Prosecution Motion for Production of Defence Witness Statements, IT-94-I-T, 27 November 1996, par. 2.

259 ICTY, Prosecutor v. Tadić, Separate Opinion of Judge Vohrah on Prosecution Motion for Production of Defence Witness Statements, IT-94-I-T, 27 November 1996, paras. 1-3.

260 ICTY, Prosecutor v. Tadić, Separate Opinion of Judge Vohrah on Prosecution Motion for Production of Defence Witness Statements, IT-94-I-T, 27 November 1996. Cf. Dissenting Opinion of Judge Jean-Claude Antonetti, Presiding Judge of the Trial Chamber, Concerning the Decision on the Oral Request of the Accused Jadrankon Prlić for Authorisation to Use a Laptop Computer at Hearing or to be Seated Next to His Counsel, ICTY, Prosecutor v. Prlić et al., IT-04-74-T, 29 June 2006, par. 9: "One should remember that the right to equality of arms is more generally a right of the accused because the Judges must ensure that the person being prosecuted, who is the most vulnerable person at trial, is not disadvantaged in the conduct of his defence."

261 ICTY, Prosecutor v. Tadić, Separate and Dissenting Opinion of Judge McDonald on Prosecution Motion for Production of Defence Witness Statements, IT-94-1-T, 27 November 1996, par. 32.

262 ICTY, Prosecutor v. Tadić, Separate and Dissenting Opinion of Judge McDonald on Prosecution Motion for Production of Defence Witness Statements, IT-94-1-T, 27 November 1996, par. 32 [footnote reference omitted].

263 ICTY, Prosecutor v. Tadić, Separate and Dissenting Opinion of Judge McDonald on Prosecution Motion for Production of Defence Witness Statements, IT-94-1-T, 27 November 1996, par. 14. 
by the Rules of the International Tribunal, is to facilitate full disclosure of all relevant facts to enhance the truth-finding process that is at the core of all criminal justice systems." 264

Interestingly, what transpires from Judge McDonald's overview of the US approach, a criminal justice system that has been invaluable for the creation of the ICTY Rules, is that prior defence witness statements could be subject to disclosure. Judge McDonald argued that the US approach is qualified because (1) the work product doctrine is "akin to a privileged immunity from discovery, simply requiring the adverse party to show very good cause before gaining access to these types of items;" "265 (2) the privilege against self-incrimination is considered "personal to the defendant and does not extend to the statements or testimony of third parties, because the witnesses, as third parties, were available to both parties," 266 and (3) US Federal Rules of Criminal Procedure provide for the possibility to order the production of prior witness statements, of either party, "after a witness other than the defendant has testified on direct examination." ${ }^{267}$ The later division between pre-trial and trial stage discovery form the basis of Judge McDonald's argument that the pre-trial system of limited defence disclosure does not undermine the ability of the Trial Chamber to order the disclosure of prior statements after the testimony of a witness at trial, and this fact, in turn, does not endanger the principle of lex certa referred to by Judge Vohrah. ${ }^{268}$ In addition, this makes the defence's claim of a loss of confidence among witnesses without foundation because witnesses who testify at trial should not have the expectation that their testimony would not be challenged. ${ }^{269}$ In conclusion, Judge McDonald stated that although a pre-trial disclosure of defence witness statements is precluded by the Tribunal's Rules, the disclosure of these statements after the testimony of the witness at trial should be allowed as it would be "consistent with the purpose of our Rules to put the parties 'on the same footing' at trial."270

264 ICTY, Prosecutor v. Tadić, Separate and Dissenting Opinion of Judge McDonald on Prosecution Motion for Production of Defence Witness Statements, IT-94-1-T, 27 November 1996, par. 6.

265 ICTY, Prosecutor v. Tadić, Separate and Dissenting Opinion of Judge McDonald on Prosecution Motion for Production of Defence Witness Statements, IT-94-1-T, 27 November 1996, par. 25.

266 ICTY, Prosecutor v. Tadić, Separate and Dissenting Opinion of Judge McDonald on Prosecution Motion for Production of Defence Witness Statements, IT-94-1-T, 27 November 1996, par. 27.

267 ICTY, Prosecutor v. Tadić, Separate and Dissenting Opinion of Judge McDonald on Prosecution Motion for Production of Defence Witness Statements, IT-94-1-T, 27 November 1996, par. 29, referring to Rule 26.2

268 ICTY, Prosecutor v. Tadić, Separate and Dissenting Opinion of Judge McDonald on Prosecution Motion for Production of Defence Witness Statements, IT-94-1-T, 27 November 1996, par. 35.

269 ICTY, Prosecutor v. Tadić, Separate and Dissenting Opinion of Judge McDonald on Prosecution Motion for Production of Defence Witness Statements, IT-94-1-T, 27 November 1996, par. 36.

270 ICTY, Prosecutor v. Tadić, Separate and Dissenting Opinion of Judge McDonald on Prosecution Motion for Production of Defence Witness Statements, IT-94-1-T, 27 November 1996, par. 43. Also par. 50: "The International Tribunal should not disregard new and progressive rules that aid in the receipt of all relevant facts. As an international tribunal, rather than ignoring trends towards more 
Later, Judge McDonald's considerations were heard and were gradually reflected in the amended Rules on defence disclosure. In Delalić, the prosecutor argued for the advanced disclosure of the names of defence witnesses intended to be introduced at trial in order to ensure an effective cross-examination and, thus, fairness between the parties, and the Trial Chamber allowed this. ${ }^{271}$ The Trial Chamber explicitly disagreed with Judge Vohrah's above-discussed argument in Tadić in relation to equality of arms and considered that "procedural equality means what it says, equality between the Prosecution and the Defence." 272 Responding to Judge Vohrah, the Chamber stated that an inclination in favour of the defence results in inequality of arms for the prosecution and "[ $\mathrm{t}]$ his will be inconsistent with the minimum guarantee provided for in Article 21 paragraph 4(e), of the Statute". ${ }^{273}$ Explaining this, it argued that "[i]n the circumstances of the International Tribunal, the Prosecutor and the Defence rely on State co-operation for their investigation, so, prima facie, the basis for the inequality argument does not arise." ${ }^{274}$

Notwithstanding the merit of this latter argument, the Chamber did not explain how a possible inequality of arms for the prosecutor could be inconsistent with the minimum rights afforded to the accused. Even presuming that due to the special circumstances of the Tribunal the inherent inequality of a domestic criminal process does not exist, an unsubstantiated contention at best, Article 21(4)(e) clearly provides for a minimum right of the accused to examine witnesses on his behalf under the same conditions as witnesses against him. It does not provide the same right to the prosecutor. The Chamber itself concedes that equality of arms is one of the minimum guarantees for the accused laid down in Article 21(4)(e) of the ICTY Statute and "the most important criteria of a fair trial." ${ }^{275}$ According to the Trial Chamber, the issue of defence disclosure of a witness list at trial is "not a matter of reciprocity but a

fair, efficient and effective litigation procedure, it should lead the way. Justice can not be served if every rule and decision must be justified on the basis of a tally of all legal systems".

271 ICTY, Prosecutor v. Delalić, Decision on the Prosecution's Motion for an Order Requiring Advance Disclosure of Witnesses by the Defence, IT-96-21-T, 4 February 1998. The Defence was ordered to provide the Prosecution with the names of the witnesses that the Defence intended to call at trial, in writing at least seven working days prior to the testimony of each witness.

272 ICTY, Prosecutor v. Delalić, Decision on the Prosecution's Motion for an Order Requiring Advance Disclosure of Witnesses by the Defence, IT-96-21-T, 4 February 1998, par. 49.

273 ICTY, Prosecutor v. Delalić, Decision on the Prosecution's Motion for an Order Requiring Advance Disclosure of Witnesses by the Defence, IT-96-21-T, 4 February 1998, par. 49.

274 ICTY, Prosecutor v. Delalić, Decision on the Prosecution's Motion for an Order Requiring Advance Disclosure of Witnesses by the Defence, IT-96-21-T, 4 February 1998, par. 49.

275 ICTY, Prosecutor v. Delalić, Decision on the Prosecution's Motion for an Order Requiring Advance Disclosure of Witnesses by the Defence, IT-96-21-T, 4 February 1998, par. 45. Par. 22: "The Trial Chamber is of the view that the object of Article 21 paragraph (4) (e) of the Statute is to ensure, except as otherwise provided, procedural equality between the accused and the accuser, namely the Prosecution [reference to Neuwrister (sic) v. Austria (1979-80) I EHRR 1991]". 
matter of the concept of fair trial. ${ }^{276}$ Clearly, it suggests that a fair trial is not only a right of the defence, but should be extended to encompass the prosecution too. This position could be defended, however, as a plain reading of the decision suggests that the Chamber had, erroneously, based the principle of equality of arms solely on Article 21(4)(e) Statute, which it explicitly referred to as a minimum guarantee which an accused is entitled to. ${ }^{277} \mathrm{~A}$ broader embedding of equality of arms into Articles 20 and 21 would be in line with the approach taken by the human rights bodies towards fair trial generally and equality of arms in particular. As such, it could even be defended that any 'rights' of the prosecutor in the criminal process, such as the entitlement to equality of arms, arises from the general right to a fair trial that belongs to an individual only. Stated differently, an accused's right to a fair trial includes a fair and equal presentation of the prosecution's case against him so as to establish a truthful evidentiary record on which to base a final decision. If the prosecutor would be denied a fair and equal opportunity to present his case, the verdict could not be rendered in a fair manner and that would amount to a violation of the right of the accused. ${ }^{278}$

From the perspective of this study, the issue underlying the decision (the disclosure of the defence witness list at trial) is a matter of 'reciprocity,' which could be based on the principle of equality of arms as a corollary of an adversarial trial. It could be reasoned that the disclosure would not jeopardize the rights of the accused, but would rather serve an efficient and expeditious course of proceedings. From that perspective, there would be nothing against an 'equalizing' of the positions between

276 ICTY, Prosecutor v. Delalić, Decision on the Prosecution's Motion for an Order Requiring Advance Disclosure of Witnesses by the Defence, IT-96-21-T, 4 February 1998, par. 45. The Prosecutor, on the contrary, argued that "the Motion has nothing to do with a fair trial. It is aimed at the orderly conduct of proceedings [and] ... has nothing to do with assisting the Prosecution to discharge its burden in the case" (par. 9). This would seem to apply to the right of the defence to a fair trial, as the Prosecution does rely on Article 20 and the fairness of the trial when arguing for its need to be able to effectively cross-examine defence witnesses (par. 5).

277 But see ZAPPALÀ, 2010, p. 149: "Despite some perplexing claims according to which the right to a fair trial is seen as a sort of general public interest - which would imply that the proceedings must be fair towards the Prosecution of society at large - it is important to stress that only the accused has a right to a fair trial. Fairness is not a broad 'one size fits all' notion. Fairness is the standard for assessing the behaviour of public authorities towards the individual against whom criminal charges are laid and who is then subjected to criminal prosecution ... Another fundamental misunderstanding must be clarified concerning the principle of equality - this principle is intended to allow the individual who is brought before a court to be assisted by public authorities in the best possible way to ensure that he or she is not disadvantaged compared with the Prosecution. To consider that equality implies that all parties to the trial must be treated on an equal footing is to misinterpret the requirements of fairness and equality."

278 See VAsiliev, 2010, p. 49, defending this "more inclusive paradigm of fairness", and concluding that "for an international Prosecutor, the 'equality of arms' is not a primordial entitlement by an emanation and direct consequence of such an entitlement of the accused". 
the parties in relation to the disclosure of the list of witnesses before the start of their case so as to facilitate effective cross-examination, and thus an expeditious trial.

In a later decision in the Delalić et al. case, the Trial Chamber considered that the intention of Article 21(4)(e) Statute "is to ensure that the accused is placed in a position of complete equality with respect to the calling and examination of witnesses with the Prosecution." ${ }^{279}$ This is exactly the direction in which the disclosure Rules were developed. As mentioned, the Rules on reciprocal disclosure obligations have been adjusted on several occasions. Before the Rule change of 12 December 2003, Rule 67 on "Reciprocal Disclosure", read in paragraph $C$ that "if the defence makes a request pursuant to Rule 66(B), the Prosecutor shall be entitled to inspect any books, documents, photographs and tangible objects which are within the custody or control of the defence and which it intends to use as evidence at the trial." ${ }^{280}$ By requesting the prosecution to inspect materials in his possession that might be relevant to the preparation of the defence, including materials that would be used at trial or were obtained from or belonged to the accused, the defence triggered the reciprocal disclosure obligations according to Rule 67(C) RPE. Thus, by refusing to subject itself to reciprocal disclosure under Rule $67(\mathrm{C})$, the defence would waive the use of Rule 66(B) and, thus, not be able to inspect the prosecutor's materials. ${ }^{281}$

From 12 December 2003, Rule 67 was renamed as "Additional Disclosure", and paragraph $\mathrm{C}$ on the reciprocity of inspection was deleted altogether. ${ }^{282}$ The revision of 28 February 2008 reorganised the rule once more, by adding two important paragraphs relating to the reciprocity of disclosure obligations. Rule 67(A) now states that within the time-limit prescribed by the Trial Chamber - not before a 'no case to answer' ruling under Rule 98bis, but no later than one week before the commencement of the defence case - the defence shall: (1) permit the prosecutor to inspect materials in possession or control of the defence, which are intended for use as evidence at trial; and (2) provide the prosecutor with copies of statements of all the defence witnesses to testify at trial. Both obligations mirror those of the prosecutor under Rule 66(A), and the reference to the triggering mechanism of reciprocity has been deleted. As

279 ICTY, Prosecutor v. Delalic et al., Decision on the Motion of the Joint Request of the Accused Persons regarding the Presentation of Evidence, dated 24 May 1998, IT-96-21-T, T. Ch. II quarter, 12 June 1998, par. 33.

280 ICTY RPE, Version of 28 July 2003.

281 E.g. ICTY, Prosecutor v. Blaškić, Decision on the Defence Motion for Sanctions for the Prosecutor's Failure to Comply with Sub-Rule 66(A) of the Rules and the Decision of 27 January 1997 Compelling the Production of all Statements of the Accused, IT-95-14, T.Ch, 15 July 1998.

282 The Annual Report of 2004 (A/59/215 S/2004/627, 16 August 2004) states in par. 36: "At the 29th session of the plenary, held in December 2003, the judges approved amendments to the following rules: Rule 44, Rule 65ter(c)(f), Rule 67, Rule 68 and Rule 77. The most significant amendments were to Rules 67 and 68, allowing for the introduction of a system of electronic disclosure of exculpatory and other relevant documents by the prosecution to the defence and removing the reciprocal obligation of disclosure by the defence to the prosecution when seeking access to certain classes of material held by the prosecution." 
such, the defence cannot avoid the prosecution's inspection of its materials by not requesting to inspect the materials in the possession of the prosecutor. ${ }^{283}$ In the meantime, Rule 65 ter $\mathrm{G}$ was added in 2001, which states that:

After the close of the Prosecutor's case and before the commencement of the defence case, the pre-trial Judge shall order the defence to file the following: (i) a list of witnesses the defence intends to call at trial ${ }^{284}$ and (ii) a list of exhibits the defence intends to offer in its case, stating where possible whether the Prosecutor has any objection as to authenticity. The defence shall serve on the Prosecutor copies of the exhibits so listed. ${ }^{285}$

As late as mid-2007, the Trial Chamber in the Dragomir Milošević case noted that "there appears to be no consistent practice within the Tribunal regarding a minimum amount of information that is to be included in Rule 65ter summaries. ${ }^{286}$ Considering that "a party should be able to properly prepare for cross-examination based on the other party's Rule 65ter summaries," the Trial Chamber granted the prosecution's motion and ordered the defence to provide more detailed information. Interestingly, the Judges considered that the insufficient level of detail provided by the defence not only impaired the prosecutor in preparing cross-examinations and had a negative effect on the expediency of the trial, but also that judges encountered difficulties "in preparing to hear the witnesses." ${ }^{287}$ In Milutinović et al., the Trial Chamber considered that "it is in the interest of justice for the Prosecution to be afforded adequate opportunity to prepare for cross-examination and the Defence's Rule 65ter filings are

283 However, the scope of prosecutorial inspection is limited to "books, documents, photographs, and tangible objects in the Defence's custody or control, which are intended for use by the Defence as evidence at trial", and not which are material to the preparation of its case (as stated in Rule 66(A)).

284 Including (a) the name or pseudonym of each witness; (b) a summary of the facts on which each witness will testify; (c) the points in the indictment as to which each witness will testify; (d) the total number of witnesses and the number of witnesses who will testify for each accused and on each count; (e) an indication of whether the witness will testify in person or pursuant to Rule 92bis or Rule 92 quarter by way of written statement or use of a transcript of testimony from other proceedings before the Tribunal; and (f) the estimated length of time required for each witness and the total time estimated for presentation of the defence case.

285 This was 'imported' from Rule 73ter on Pre-Defence Conference. In Blaškić, the Trial Chamber considered that "the present wording of Rule 73ter demonstrates the extent of the obligations the Judges intended to impose upon the Defence vis-à-vis the Prosecution; that the Trial Chamber therefore cannot grant the Prosecutor's Motion insofar as it seeks the disclosure of prior statements from the Defence witnesses". ICTY, Prosecutor v. Blaškić, Decision on the Prosecutor's Motion for Seven (7) Days Advance Disclosure of Defence Witnesses and Defence Witness Statements, IT-9514-T, T. Ch., 3 September 1998.

286 ICTY, Prosecutor v. Dragomir Milošević, Decision on the Prosecution's Motion for Defence Compliance with Rule 65ter (G), IT-98-29/1-T, T. Ch. III, 26 June 2007.

287 ICTY, Prosecutor v. Dragomir Milošević, Decision on the Prosecution's Motion for Defence Compliance with Rule 65ter (G), IT-98-29/1-T, T. Ch. III, 26 June 2007. 
an important means by which to accomplish this procedural fairness." ${ }^{288}$ To effectuate that, the Chamber considered itself competent to "order [the] Defence disclosure in addition to that detailed in Rule 65ter (G)." ${ }^{289}$ In this context, the Trial Chamber has sometimes referred to its duty to "ensure that the right of the Prosecution to a fair trial is respected and that it has the possibility to prepare the cross-examination of Defence witnesses. ${ }^{290}$ Notably, pursuant to its power to impose sanctions in a party who does not comply with its Rule 65ter obligations, ${ }^{291}$ the Trial Chamber in the

288 ICTY, Prosecutor v. Milutinović et al., Decision on Prosecution Request for Disclosure of Further Information Regarding Witnesses to be Called by Lazarević and Lukić Defences, IT-05-87-T, T. Ch., 5 October 2007, par. 6.

289 ICTY, Prosecutor v. Milutinović et al., Decision on Prosecution Request for Disclosure of Further Information Regarding Witnesses to be Called by Lazarević and Lukić Defences, IT-05-87-T, T. Ch., 5 October 2007, par. 6. In Stanišić and Simatović, the Trial Chamber considered the Prosecutor's application for an earlier and more expansive disclosure of defence witnesses' personal information (than provided according to a Rule 67ter (G) filing). See ICTY, Prosecutor v. Stanišić and Simatović, Decision on Urgent Prosecution Motion for Disclosure of Witness details and for Modification of the Scheduling Order of 1 April 2011, IT-03-69-T, 27 May 2011. The Prosecutor argued for equality of arms so as to be able to prepare effectively for cross-examination. In this regard, the Defence submitted that "due to differing disclosure obligations between the Prosecution and the Defence, arguments on strict equality are misplaced" (par. 5). In its deliberations, the Trial Chamber did not consider the argument of equality of arms explicitly. The Trial Chamber considered the differing disclosure obligations of the parties and concluded that the defence does not have disclosure obligations for information on the Personal Details of the witnesses not covered by Rules 65 ter $(\mathrm{G})$ or 67(A) RPE. However, it considered this more extensive disclosure not prejudicial to the Defence, and ordered, in the interest of an expeditious trial, the Stanisic Defence to disclose the requested Personal Details together with its Rule 67(A) disclosure (par. 13). In relation to the timing of the defence disclosure, the Trial Chamber was mindful of possible difficulties encountered by the Prosecutor in preparing effective cross-examination for the first witnesses appearing for the Defence (in the first 4 weeks), but it still considered not granting earlier disclosure (before the set Rule 65ter list disclosure, scheduled 9 days before the beginning of the Defence case), because the Prosecution should have been able to prepare in this short time for the limited number of witnesses who were scheduled to testify within the first weeks of the defence's case (par. 12). Also in ICTY, Prosecustor v. Simić et al., Order in respect of Pre-Defence Filings and Scheduling, IT-95-9-T, 23 October 2002, the Trial Chamber ordered a more elaborate disclosure of defence witnesses (65ter), TC Order in respect of Pre-Defence Filings and Scheduling, 23 October 2002, IT-95-9-T.

290 ICTY, Prosecutor v. Prlić et al., Decision on Motion for Extension of Time for the Commencement of the Defence Case and Adopting a New Schedule, IT-04-74-T, 28 January 2008, p. 6. The Defence requested a postponement of 3 months for the start of the Defence case. The Defence argued that the Trial Chamber's order to postpone the closing date of the Prosecution case by more then a month, as a consequence, shortened the time allotted to the Defence to prepare its case and thus infringed the right of the accused to a fair trial (p. 3). The Trial Chamber was mindful of the enormous amount of exhibits admitted at the request of the prosecution which constituted a 'heavy workload' for the Defence, but found a postponement by 3 months to be excessive, and instead allowed for a shorter postponement (of almost two months). By considering the final date for the filing of Rule 65ter (G) lists, the Chamber once more emphasized the right of the Prosecution to a fair trial and its entitlement to have sufficient time between the filing of these lists and the commencement of the Defence case (p. 7).

291 Rule 65ter (N) ICTY RPE (added in April 2001): "Upon a report of the pre-trial Judge, the Trial 
Naletilic and Martinovic case, has ordered the defence to supplement inadequate summaries of witnesses testimonies and postponed the testimony of these witnesses until at least one week after the filing of properly supplemented summaries to allow the prosecution to prepare for cross-examination. ${ }^{292}$

In sum, "[w]hile the Prosecution has a duty to prove its case, the accused does not have to prove his defence [and] [u]ntil the end of the Prosecution case therefore, the Prosecution needs to establish its case independently, without requiring the Defence to reveal anything." ${ }^{293}$ Thus, although the defence's disclosure obligations have been expanded over time, these obligations apply only before the start of the defence's case and not before (inter partes disclosure under Rule 67 and Rule 67ter filings that are communicated to the judges too). The limited defence pre-trial disclosure concerns a Pre-Trial Brief that states in general terms the nature of the defence's case (Rule $65 t e r(f)(i)$ ) and the notification of any special defences (like an alibi or diminished or lack of mental responsibility - Rule 67(B(i)). This latter responsibility is common to many other adversarial systems and seems to be based on requirements of efficiency of proceedings rather than providing the prosecution with a right to a fair trial.

\subsubsection{International Criminal Court}

At the ICC defence disclosure is covered by Rules 121(6), 78 and 79 RPE. Rule 121(6) covers the pre-confirmation of charges hearing disclosure and instructs the suspect, in case he decides to present evidence under Article 61(6), to provide the Pre-Trial Chamber with a list of that evidence no later than 15 days before the hearing. For reasons of expediency, the Pre-Trial Chamber shall provide the list to the Prosecutor. ${ }^{294}$

Rule 79 directs the defence to give notice of an alibi defence and other special defences under Article 31(1) ICC Statute. Comparable to the rules of the ad hoc tribunals the timely disclosure of special defences is regarded as enhancing the fairness and efficiency of the proceedings, and provides the prosecutor with a

Chamber shall decide, should the case arise, on sanctions to be imposed on a party which fails to perform its obligations pursuant to the present Rule. Such sanctions may include the exclusion of testimonial or documentary evidence."

292 ICTY, Naletilić and Martinović, Decision on the Prosecution Motion to preclude Defence Witnesses Damir Zorić and Milan Kovać from testifying, IT-98-34-T, T. Ch., 15 April 2002.

293 ICTY, Prosecutor v. Halilović, Decision on Motion for Prosecution Access to Defence Documents Used in Cross-Examination of Prosecution Witnesses, IT-01-48-T, T. Ch. I, 9 May 2005, par. 9. In this case, the Trial Chamber dismissed the Prosecutor's request to be provided with the documents the Defence intended to use during cross-examination beforehand. The Trial Chamber considered that the principle of equality of arms, although interpreted in favour of both parties, does not entail an obligation upon the defence to provide, in advance (not even at the beginning of the crossexamination), the Prosecution with the documents or a list of the documents which it intended to use during cross-examination.

294 Rule 121(6) RPE. See also Brady, 2001, p. 410. 
possibility to respond to such defences adequately. ${ }^{295}$ Rule 79(4) furthermore provides the Chamber with the authority to order additional disclosure. The ICC provisions on defence disclosure do not direct the defence to disclose the statements of witnesses it intends to call at trial as provided for in Rule 67(A)(ii) ICTR RPE. However, the Single Judge in Lubanga considered it necessary for the parties to communicate the evidence they intend to present, in its original format, to the Pre-Trial Chamber prior to the beginning of the confirmation of charges hearing so as to enable the Chamber to establish an order and the conditions under which the evidence contained in the record of the proceedings is to be presented (Rule 122(1)). ${ }^{296}$

Rule 78 contains the provision on defence obligations concerning inspection by the prosecutor of materials which the defence intends to use at the confirmation of charges hearing or the trial. The defence is required to provide the prosecution with copies of any documents requested during the inspection. ${ }^{297}$ There is no reciprocal triggering as known under the regime of the ad hoc tribunals before the amendment in 2003. Just as Rule 77 on inspection of the prosecutor's materials, Rule 78 does not refer to 'a request' from the other party for inspection (as does Rule 66(B) ICTY/ICTR/SCSL for defence inspection). The implication is that either party must make available to the other the materials falling under Rules 77 and 78, without the necessity of a formal request. ${ }^{298}$

The ICC rules on defence disclosure do not dictate the timing of that disclosure (as does Rule 67 ICTY, not less than one week prior to the commencement of defence case), and seem more limited to those of the ICTY. Next to the obligation to allow inspection of the materials to be used at the confirmation of charges hearing or the trial, the defence must notify the prosecutor of any special defence it intends to submit. In addition, Rule 79(4) instructs that the Chamber may order disclosure of any other evidence. ${ }^{299}$ Thus, the practical modalities of disclosure have been decided on a case-by-case basis, setting out the mode and timing of inter partes disclosure and the subsequent filling in the record of the case.

In Lubanga, at the pre-confirmation of charges stage, the Pre-Trial Chamber ordered the defence to file its list of evidence it intended to use at the confirmation of charges hearing ten days after the prosecutor has fulfilled his obligations and two weeks in advance of the confirmation hearing. Moreover, the defence was ordered to

295 Rule 79(2) RPE. BRADY, 2001, pp. 415-416.

296 ICC, Prosecutor v. Lubanga Dyilo, Decision on the Final System of Disclosure and the Establishment of a Timetable, ICC-01/04-01/06-102, 15 May 2006, p. 5, Annex paras. 44-45, 135-136.

297 ICC, Prosecutor v. Bahr Idriss Abu Garda, Decision Scheduling a Hearing on Issues relating to Disclosure between the Parties, ICC-02/05-02/09-18, 30 May 2009, PTC I, par. 6.

298 ICC, Prosecutor v. Lubanga Dyilo, Decision on the Final System of Disclosure and the Establishment of a Timetable, ICC-01/04-01/06-102, 15 May 2006, parties must allow inspection and provide copies of the requested materials.

299 Rule 79(4) ICC RPE: "This rule does not prevent a Chamber from ordering disclosure of any other evidence. Thus not summaries of witness statements or other evidence. 
allow the prosecution to inspect the materials it intends to present at the hearing no later than one week prior to the hearing. ${ }^{300}$ At the pre-trial stage, the Lubanga Trial Chamber issued a decision elaborating on the principles and the use of discretionary powers in relation to defence disclosure. ${ }^{301}$ It emphasized the Chamber's absolute duty to ensure a fair trial for the accused. ${ }^{302}$ In order to ensure a fair trial, the Chamber considered, "only proportionate disclosure obligations" can be imposed on the defence with regard to the evidence it wants to present at trial. ${ }^{303}$ This conclusion followed the Chamber's consideration that " $\mathrm{t}]$ here is often likely to be a link between the disclosure obligations to be imposed on the defence, on the one hand, and the proximity of the start date of the trial and the extent to which the prosecution has fulfilled its own disclosure obligations, on the other." ${ }_{304}$ Considering the context of the case and the prosecution's disclosure results, the Trial Chamber found that the defence disclosure "should be of an appropriately restricted nature." ${ }^{305}$ Hence, the defence was ordered to (1) inform the prosecution and the Chamber of any special defences; to provide three weeks before the trial (2) a document setting out in general terms the defences it intends to raise; and (3) details of any applications it intends to raise with regard to admissibility or relevance or other substantive point that need to be resolved before the trial; (4) to submit, after the presentation of prosecution's evidence, the personal details of any defence witnesses; and (5) provide the evidence it intends to present three days in advance of that presentation. ${ }^{306}$

The prosecution was not satisfied and applied to the Chamber seeking an order extending defence disclosure obligations (supplemental summaries or witness statements, make available for inspection all the evidence defence intents to use at trial and providing photographs of defence witnesses). ${ }^{307}$ The Chamber considered that

300 ICC, Prosecutor v. Lubanga Dyilo, Decision on the Final System of Disclosure and the Establishment of a Timetable, ICC-01/04-01/06-102, 15 May 2006, pp. 11-12.

301 ICC, Prosecutor v. Lubanga Dyilo, Decision on disclosure by the defence, ICC-01/04-01/06-1235, T. Ch., 20 March 2008.

302 ICC, Prosecutor v. Lubanga Dyilo, Decision on disclosure by the defence, ICC-01/04-01/06-1235, T. Ch., 20 March 2008, par. 33.

303 ICC, Prosecutor v. Lubanga Dyilo, Decision on disclosure by the defence, ICC-01/04-01/06-1235, T. Ch., 20 March 2008, par. 34.

304 ICC, Prosecutor v. Lubanga Dyilo, Decision on disclosure by the defence, ICC-01/04-01/06-1235, T. Ch., 20 March 2008, par. 34.

305 ICC, Prosecutor v. Lubanga Dyilo, Decision on disclosure by the defence, ICC-01/04-01/06-1235, T. Ch., 20 March 2008, par. 34.

306 ICC, Prosecutor v. Lubanga Dyilo, Decision on disclosure by the defence, ICC-01/04-01/06-1235, T. Ch., 20 March 2008, par. 41.

307 ICC, Prosecutor v. Lubanga Dyilo, Redacted Second Decision on disclosure by the defence and Decision on whether the prosecution may contact defence witnesses, ICC-01/04-01/06-2192-Red, T. Ch., 20 January 2010. 
[t]he overall positions of the prosecution and the defence are not the same - there are self-evident differences in their roles, in the length of their respective investigative involvement in the case and in the resources available to each of them. Although this divergence does not ipso facto lead to unequal or different disclosure obligations, it is an important factor that the Court must bear in mind, so as to ensure that the requirements which a Chamber imposes are fair and proportionate. ${ }^{308}$

When deciding that it would not be proportionate to extent defence disclosure obligations, the Chamber took into account two factual elements. First, the defence due to limited time spend with each witness was not able to take any formal witness statements. Second, the defence already disclosed, as a courtesy, summaries of defence witnesses testimony, which the Chamber considered "prima facie, extremely helpful." ${ }^{309}$ As to the inspection, the Chamber rejected prosecutor's contention that defence should make available the totality of its evidence for inspection as too broad. Referring to the different disclosure and inspection duties of the parties, the Chamber reasoned that from the perspective of defence it is enough to present to the prosecution those books, documents, photographs or other tangible objects that defence counsel decided to use at trial. ${ }^{310}$

In the Katanga and Ngudjolo case, the Trial Chamber took over the assessment of the different responsibilities of the parties and consequently, the limited extent of defence disclosure provided for in Lubanga. ${ }^{311}$ The Trial Chamber considered that "[a] $t$ least after the Prosecution's case, the defence is not under any obligation to provide the Prosecution with any information that could reveal its strategy." ${ }^{12}$ Excluded from the consideration were the defences under Rules 79(10 and 80, and "the material that the Defence intends to use in cross-examination of Prosecution witnesses." ${ }^{1313}$ This latter material is an addition as compared to the Lubanga disclosure practice.

308 ICC, Prosecutor v. Lubanga Dyilo, Redacted Second Decision on disclosure by the defence and Decision on whether the prosecution may contact defence witnesses, ICC-01/04-01/06-2192-Red, T. Ch., 20 January 2010, par. 54.

309 ICC, Prosecutor v. Lubanga Dyilo, Redacted Second Decision on disclosure by the defence and Decision on whether the prosecution may contact defence witnesses, ICC-01/04-01/06-2192-Red, T. Ch., 20 January 2010, par. 58.

310 ICC, Prosecutor v. Lubanga Dyilo, Redacted Second Decision on disclosure by the defence and Decision on whether the prosecution may contact defence witnesses, ICC-01/04-01/06-2192-Red, T. Ch., 20 January 2010, par. 64.

311 ICC, Prosecutor v. Katanga and Ngudjolo Chui, Decision on the Public Document "Prosecution's Application Concerning Disclosure Pursuant to Rules 78 and 79(4)" by the Defence, ICC-01/0401/07-2388, T. Ch., 14 September 2010, par. 37.

312 ICC, Prosecutor v. Katanga and Ngudjolo Chui, Decision on the Public Document "Prosecution's Application Concerning Disclosure Pursuant to Rules 78 and 79(4)" by the Defence, ICC-01/0401/07-2388, T. Ch., 14 September 2010, par. 49.

313 ICC, Prosecutor v. Katanga and Ngudjolo Chui, Decision on the Public Document "Prosecution's Application Concerning Disclosure Pursuant to Rules 78 and 79(4)" by the Defence, ICC-01/0401/07-2388, T. Ch., 14 September 2010, par. 49. 
In Bemba, at the pre-confirmation of charges stage, both parties were required to provide (1) a list of evidence, (2) a list of identified recipients for each item reflecting also the access and the level of confidentiality for each item vis-à-vis any party, and (3) an analysis of each piece of evidence. ${ }^{314}$

In sum, the defence disclosure obligations at ICC model the adversarial approach taken by the ad hoc tribunals. The defence is only required to disclose materials as soon as it decides to use it at trial and no substantial disclosure obligations incur before the close of prosecution's case.

\subsection{REMEDYING DISCLOSURE VIOLATIONS}

In light of the importance of strict adherence to the disclosure obligations for the fairness of proceedings, an important question concerns how to remedy disclosure violations. Moreover, sanctioning these violations could be considered an appropriate method to prevent any reoccurrence of the damaging behaviour. This section considers the legal framework to remedy and sanction disclosure violations and takes a closer look at how international criminal courts have approached this issue.

Before any remedies or sanctions can be considered, a violation of the disclosure obligation and an ensuing prejudice has to be established. Particularly the practice of disclosure of exculpatory evidence, partly due to the continuous nature of this obligation, the vast amount of disclosable material and the prosecutorial discretion, has been receptive to violations. In addition, establishing material prejudice has not been an easy undertaking for the defence. Speculatively, the opposing interests of the prosecution and the defence may have contributed to the extensive litigation in this area. To be sure, any violation in this area potentially undermines the rights of the accused and endangers the fairness of proceedings. Moreover, inefficient disclosure practice has had a detrimental effect on the expeditiousness of the proceedings. ${ }^{315}$

In several cases disclosure violations have led to remedial actions. ${ }^{316}$ In Bizimungu et al., the ICTR Trial Chamber, on the basis of the existing case law of the ad hoc tribunals, summarized the available remedial options for disclosure violations. They

314 ICC, Prosecutor v. Bemba, Decision on the Evidence Disclosure System and Setting a Timetable for Disclosure between the Parties, ICC-01/05-01/08-55, 31 July 2008, p. 22.

315 Letter dated 29 May 2006 from the President of the International Tribunal for the Prosecution of Persons Responsible for Serious Violations of International Humanitarian Law Committed in the Territory of the Former Yugoslavia since 1991, addressed to the President of the Security Council, ANNEX I Assessment and Report of Judge Fausto Pocar, President of the International Criminal Tribunal for the Former Yugoslavia, Provided to the Security Council Pursuant to Paragraph 6 of Council Resolution 1534 (2004), S/2006/353, 31 May 2006, par. 25: "One of the fundamental areas, which has negatively impacted on expeditiousness of proceedings at the International Tribunal, concerns problems surrounding the efficient disclosure of evidence."

316 For an overview, see ICTR, Prosecutor v. Bizimungu et al., Judgment and Sentence, ICTR-99-50-T, T. Ch., 30 September 2011, paras. 170-174. 
include "recalling relevant Prosecution witnesses for further cross-examination, ${ }^{317}$ allowing the Defence to call additional witnesses, drawing a reasonable inference in favour of the Accused from the exculpatory material, excluding relevant parts of the Prosecution evidence, ordering a stay of proceedings and dismissing charges against the Accused." ${ }^{\prime 18}$ In this case, the Trial Chamber concluded that the defence suffered material prejudice because the prosecutor's late disclosure of exculpatory material prevented the defence from exercising its right to call and examine witnesses. ${ }^{319}$ This prejudice was further enhanced because of the clearly exculpatory nature of the evidence with regard to the charges, and because the delay in disclosure occurred during the drafting of the judgment. ${ }^{320}$ As a remedial action, the Chamber considered it appropriate to draw a reasonable inference in favour of the Accused from the exculpatory material, as this would "strike an appropriate balance between remedying the material prejudice caused to the Accused by the Prosecution's late disclosure of exculpatory material, and respecting the quality of the evidence adduced by all parties as it relates to the affected allegations." ${ }^{321}$ These inferences were not based on a positive evaluation of the evidence, but the Chamber did not enter findings on incriminating evidence that was affected by the exculpatory evidence because of the prosecutorial disclosure violations. "On a final note," the Chamber reprimanded the Office of the Prosecution for its "inexcusable" conduct and its failure to design adequate procedures for the re-examination of evidence in light of Rule 68 from different cases. ${ }^{322}$

Another notable example is the Karadžic case, where the accused seems determined to expose every prosecutorial misstep in relation to disclosure. In fact, Karadžić has filed at least 64 motions for the finding of prosecutorial disclosure violations and for remedial action. In many instances, the ICTY Trial Chamber has found that the prosecution has indeed violated its disclosure obligations under Rules 66 and 68 ICTY RPE. In one of its decisions, the Chamber remarked that " $[\mathrm{t}]$ he reasons proffered by the Prosecution for the failure to identify and disclose the

317 E.g. ICTR, Prosecutor v. Renzaho, Judgment and Sentence, ICTR-97-31-T, T. Ch., 14 July 2009, par. 50.

318 ICTR, Prosecutor v. Bizimungu et al., Judgment and Sentence, ICTR-99-50-T, T. Ch., 30 September 2011, par. 143, referring in footnote 224 to ICTR, The Prosecutor v. Ndindiliyimana et al., Decision on Defence Motions Alleging Violation of the Prosecutor's Disclosure Obligations Pursuant to Rule 68, ICTR-00-56-T, T. Ch., 22 September 2008, paras. 61-62; ICTY, Prosecutor v. Orić, Decision on Ongoing Complaints about Prosecutorial Non-Compliance with Rule 68 of the Rules, IT-03-68-T, T. Ch., 13 December 2005, par. 35.

319 ICTR, Prosecutor v. Bizimungu et al., Judgment and Sentence, ICTR-99-50-T, T. Ch., 30 September 2011, par. 166.

320 ICTR, Prosecutor v. Bizimungu et al., Judgment and Sentence, ICTR-99-50-T, T. Ch., 30 September 2011, par. 167.

321 ICTR, Prosecutor v. Bizimungu et al., Judgment and Sentence, ICTR-99-50-T, T. Ch., 30 September 2011, par. 174.

322 ICTR, Prosecutor v. Bizimungu et al., Judgment and Sentence, ICTR-99-50-T, T. Ch., 30 September 2011, par. 175, 177. 
Rule 68 documents have often been completely inadequate." 323 In another decision, the Chamber considered that the cumulative effect of the disclosure violations was "likely to have placed a strain on the resources of the Accused in the preparation of his defence." 324 As a remedial action, the Trial Chamber postponed the testimony of the witnesses affected by the disclosure violations, ${ }^{325}$ and suspended the proceedings to give the defence adequate time to deal with the voluminous disclosure. ${ }^{326}$ Not explicitly considered in the disclosure violations decision, but clearly connected to this issue are the President's orders for additional funding to be provided to the accused, particularly for the delay and the voluminous disclosure in this case. ${ }^{327}$

In many other cases, the Judges have found the prosecutor to be in violation of Rule 68 disclosure obligations; however, the applications for some sort of remedy have usually been dismissed on the ground that the defence has suffered no material prejudice from the disclosure violation. ${ }^{328}$ Relying on the prosecutor's good faith, in the absence of prima facie evidence from the defence to the contrary, ${ }^{329}$ the Judges have been reluctant to impose any material sanctions for disclosure violations. In fact, "[t]he tribunals have operated a presumption that the prosecution is able to and will discharge its obligation faithfully, despite the fact that there have been a number of cases in which materials that the prosecutor claimed not to have in its possession were subsequently shown to have been in its possession. ${ }^{330}$ The first step usually taken is to request/order the prosecution to file a (progress) report on disclosure. ${ }^{331}$

323 ICTY, Prosecutor v. Karadžić, Decision on Accused's Forty-Ninth and Fiftieth Disclosure Violation Motions, IT-95-5/18-T, T. Ch., 30 June 2011, par. 53. Notably, the Trial Chamber did not any prejudice towards the accused in this decision, however, it did order the Prosecution to file a "detailed report on the measures taken to ensure compliance with its disclosure obligations" (see paras. 53-54).

324 ICTY, Prosecutor v. Karadžić, Decision on Accused's Eighteenth to Twenty-First Disclosure Violation Motions, IT-95-5/18-T, T. Ch., 2 November 2010, par. 43. ICTY, Prosecutor v. Karadžić, Decision on Accused's Twenty-Second, Twenty-Fourth and Twenty-Sixth Disclosure Violation Motion, IT-95-5/18-T, T. Ch., 11 November 2010, paras. 40-41.

325 ICTY, Prosecutor v. Karadžić, Decision on Accused's Eighteenth to Twenty-First Disclosure Violation Motions, IT-95-5/18-T, T. Ch., 2 November 2010, par. 43. ICTY, Prosecutor v. Karadžić, Decision on Accused's Twenty-Second, Twenty-Fourth and Twenty-Sixth Disclosure Violation Motion, IT-95-5/18-T, T. Ch., 11 November 2010, paras. 40-41.

326 Postponement of proceedings for 3 months. Also, ICTY, Prosecutor v. Karadžić, Oral Decision, IT95-5/18-T, TCh, 3 November 2010, T.8907-8908.

327 See Chapter 6.

328 E.g. ICTR, Prosecutor v. Renzaho, Judgment and Sentence, ICTR-97-31-T, T. Ch., 14 July 2009, paras. 36-51.

329 E.g. ICTY, Prosecutor v. Brdjanin, Decision on "Motion for Relief from Rule 68 Violations by the Prosecutor and for Sanctions to be imposed pursuant to Rule 68bis and Motion for Adjournment while Matters Affecting Justice and a Fair Trial can be resolved", IT-99-36-T, T. Ch., 30 October 2002, par. 30; ICC, Prosecutor v. Bemba, Decision on the Defence Request for disclosure of preinterview assessments and the Consequences of non-disclosure (ICC-01/05-01/08-750-Conf), ICC01/05-01/08-750-Red, T. Ch., 9 April 2010, par. 37.

330 JACKSON, 2009-a, p. 27.

331 E.g. ICTY, Prosecutor v. Orić, Decision on Urgent Defence Motion Regarding Prosecutorial Non- 
From the outset the judges considered the sanction approach not a primary option as "the possible violation of Rule 68 are governed less by system of 'sanctions' than by Judges' definitive evaluation of the evidence presented by either of the parties and the possibility which opposing party will have to contest it." 332

When it did come to taking remedial action, postponements have been the preferred approach to disclosure violations. This is understandable. In a criminal context, "more is at stake, so sanctioning the parties (even the prosecutor) with preclusion becomes more difficult. There also is the right of the defendant to keep his evidence close to the vest. Inevitably, then, a party-driven criminal process is less predictable and harder to manage than a party-driven civil process. ${ }^{\prime 333}$ In international criminal trials, moreover, the massive amount of documents that might be subject to disclosure can interfere and offset even the most bon a fide intentions of the parties in relation to disclosure. In addition, the importance of the prosecution of international crimes and the judges' flexible approach to the admission of evidence are factors that point towards a modest use of sanctioning powers. ${ }^{334}$

Although the sanctioning approach has not been the primary course of action, mindful of the problems associated with disclosure practice, in 2001 the ICTY judges adopted Rule 68bis to address the failure to comply with disclosure obligations. This rule states that the "pre-trial Judge or the Trial Chamber may decide proprio motu, or at the request of either party, on sanctions to be imposed on a party which fails to perform its disclosure obligations pursuant to the Rules." 335 Although providing the legal basis for remedial actions, in practice, this Rule has largely remained nearly a dead letter rule. Indeed, as late as 2006 the ICTY judges, have expressed their intention to change that practice and to make "wherever necessary, full use ... of the power to sanction parties for failures to comply with time limits." ${ }^{\prime 36}$

Compliance With Rule 68, IT-03-68-T, T. Ch., 27 October 2005; ICTY, Prosecutor v. Karadžić, Decision on Accused's Forty-Ninth and Fiftieth Disclosure Violation Motions, IT-95-5/18-T, T. Ch., 30 June 2011, par. 53.

332 ICTY, Prosecutor v. Blaškić, Decision on Defence's Motion for Sanctions for Prosecutor's Continuing Violation of Rule 68, IT-95-14-T, T. Ch., 28 September 1998, p. 3. Also ICTY, Prosecutor v. Brđjanin, Decision on "Motion for Relief from Rule 68 Violations by the Prosecutor and for Sanctions to be imposed pursuant to Rule 68bis and Motion for Adjournment while matters affecting Justice and a Fair Trial can be resolved", IT-99-36-T, T. Ch., 30 October 2002, par. 23.

333 Langer and Doherty, 2011, p. 296.

$334 C f$. Gershman, 1992, p. 439: “Thus, by avoiding any inquiry into the prosecutor's culpability, and focusing entirely on the materiality of the evidence, the Court encourages prosecutors, even ethical prosecutors, to withhold evidence. It is not an understatement to say that prosecutorial suppression of evidence presents perhaps one of the principal threats to a system of rational and fair fact-finding. It skews the ability of the adversary process to function properly by denying important evidence to the defense." [footnote omitted].

335 ICTR and SCSL RPE do not contain a comparable Rule 68bis. Nether does the framework of the ICC.

336 Letter dated 29 May 2006 from the President of the International Tribunal for the Prosecution of Persons Responsible for Serious Violations of International Humanitarian Law Committed in the Territory of the Former Yugoslavia since 1991, addressed to the President of the Security Council, 
Interestingly, Rule 68bis, which did not find an equivalent under the Rules of ICTR and SCSL, refers to 'sanctions' that could be imposed rather then 'remedies'. Clearly, any measure addressing disclosure violations has to strike an appropriate balance between the interests involved: those of the defence, prosecution and victims of international crimes. ${ }^{337}$ The prominent statement that has been repeated in the practice of ad hoc tribunals that the prosecution's obligation to disclose exculpatory material "is as important as the obligation to prosecute," does not imply a hierarchy between the two goals for the purpose of striking the right balance when it comes to taking remedial actions. ${ }^{338}$ 'Sanction' mentioned in Rule 68bis directs the attention to the punitive, deterrent effect of the measures taken. In light of the importance of the prosecution of international crimes and the practice of avoiding measures that could undermine the case of the prosecution, this choice is remarkable. Moreover, tribunals' decisions mostly refer to remedial actions when addressing disclosure violation. In fact, judges' hesitation, almost unwillingness to sanction prosecutorial disclosure violations constitutes a source of frustration for many defence teams. Arguably, neglecting the sanctioning element of remedial actions in the context of disclosure violations could create a perception of implied tolerance on the part of judges towards a rather serious, improper practice. This does not in any way imply a mala fide conduct on the part of the prosecution. However, and notwithstanding many practical concerns the prosecutor is facing with regard to proper disclosure implementation, a lack of sanctioning measures provides little 'encouragement' to

ANNEX I Assessment and Report of Judge Fausto Pocar, President of the International Criminal Tribunal for the Former Yugoslavia, Provided to the Security Council Pursuant to Paragraph 6 of Council Resolution 1534 (2004), S/2006/353, 31 May 2006, par. 25: “The Working Group recommended that greater use should be made of the power to sanction a party for failure to comply with its disclosure obligations pursuant to Rule 68bis where that failure hampers the pre-trial process. This should ensure that the parties and their counsel understand that time limits are to be strictly adhered to."

337 Clearly, the most extreme measures such as exclusion of evidence, ordering a stay of proceedings or dismissing the charges against the accused, have a reparative as well as punitive nature.

338 ICTY, Prosecutor v. Kordić and Čerkez, Decision on Motions to Extend Time for Filing Appellant's Briefs, IT-95-14/2-A. A. Ch. (Pre-Appeal Judge), 11 May 2001, par. 14: There should be no possibility of any misunderstanding in relation to this issue. It would have been very simple for the prosecution to have said, expressly, that it had been and was still searching through the material which it received in relation to the two associated "Lašva Valley" cases and from the Zagreb Archives, and that, so far, no material which could reasonably be considered to fall within the scope of Rule 68 had been identified. The considerable strain which the need to make such searches places upon the resources provided to the prosecution was accepted. However, Rule 68 performs an important function. The prosecution is required to carry out these searches because of its superior access to material which may be exculpatory in character. It forms part of the prosecution's duty as "ministers of justice assisting in the administration of justice", upon which the prosecution relies in another context in relation to these Motions, to assist an accused in this way. The prosecution's obligation under Rule 68 is not a secondary one, to be complied with after everything else is done; it is as important as the obligation to prosecute. See also references in footnote 205 of ICTR, Prosecutor v. Bizimungu et al., Judgment and Sentence, ICTR-99-50-T, T. Ch., 30 September 2011, par. 134. 
reconsider the disclosure practice; thus, changing any (systemic) flaws that might have been prompted by the practical concerns in the first place.

An interesting point to consider in one of the more recent decisions on Karadžić's disclosure violation motions, is the dissenting opinion of the presiding Judge Kwon. ${ }^{339}$ Judge Kwon took issue with Chamber's declaratory finding of a violation of Rule 68 by the prosecution. He considered it "unnecessary, moot or even frivolous" to issue such a finding in the absence of any material prejudice to the accused. ${ }^{340}$ Judge Kwon considered that in a case of the size and scope as this one, issuing the declaratory finding of Rule 68 violation is unwarranted as "it would only encourage the Accused to continue filing unnecessary motions." 341 Thus, he proposed a different assessment of a Rule 68 disclosure violation; this finding could only be made when the defence has suffered prejudice from the belated disclosure of exculpatory evidence.

The merit of this approach could be practical, in the sense that the defence would be discouraged to file motions alleging disclosure violations, and it could avoid creating a perception of tolerance as mentioned above. Simply by declaring that the prosecution has repeatedly violated his disclosure obligations, does not send a right sign to the defence or the general public that the judges are willing and able to address improper disclosure practice.

Conversely, discouraging the defence from addressing the disclosure violations might bring us a step back from addressing and improving serious (systemic) shortcomings. Moreover, explicitly identifying disclosure violations even without taking remedial action directly might have an ancillary remedial effect. A cumulative effect of several declaratory findings of disclosure violations could deter any further malpractice, at least in that particular case. In addition, the findings of disclosure violations could cumulate to a prejudicial effect of another violation thus prompting immediate action on the part of the judges. In the case of Bizimungu et al., mentioned above, the Chamber explicitly took into account the repeated nature of prosecutorial disclosure violations when deciding on an appropriate measure. ${ }^{342}$

The rather short practice of the ICC has exposed the Trial Chamber judges' willingness to take even the most drastic measures (a stay of proceedings and the release of

339 ICTY, Prosecutor v. Karadžić, Decision on Accused's Thrity-Seventh to Forty-Second Disclosure Violation Motions with Partially Dissenting Opinion of Judge Kwon, IT-95-5/18-T, T. Ch., 29 March 2011.

340 ICTY, Prosecutor v. Karadžić, Decision on Accused's Thrity-Seventh to Forty-Second Disclosure Violation Motions with Partially Dissenting Opinion of Judge Kwon, IT-95-5/18-T, T. Ch., 29 March 2011, par. 4.

341 ICTY, Prosecutor v. Karadžić, Decision on Accused's Thrity-Seventh to Forty-Second Disclosure Violation Motions with Partially Dissenting Opinion of Judge Kwon, IT-95-5/18-T, T. Ch., 29 March 2011, par. 7.

342 ICTR, Prosecutor v. Bizimungu et al., Judgment and Sentence, ICTR-99-50-T, T. Ch., 30 September 2011. 
the accused) in order to ensure the prosecutor's compliance with his disclosure obligations (Lubanga disclosure crises). ${ }^{343}$ Whereas the Lubanga Trial Chamber used its ultimate power to control the fairness of the proceedings, thus delineating the responsibilities and putting the prosecutor in his place, the Appeals Chamber proved to be the 'gatekeeper'. While keeping the accused within the system, it emphasised the importance of the ICC's mandate to prosecute the most serious crimes.

\subsection{INTER PARTES DISCLOSURE AND THE ROLE OF THE JUDGES}

At the ad hoc tribunals, the role of the Pre-Trial Judge or the Trial Chamber with regard to disclosure varies between managing a proper and timely disclosure regime and deciding on some specific issues, such as protective measures and instances of non-(or delayed or redacted)disclosure of certain materials. ${ }^{344}$ Still, these powers do not put the judges in a position to review the whole evidentiary file of the prosecutor before the start of the trial. ${ }^{345}$ This was the defence's contention in Blagojevic et $a l$. when the Trial Chamber ordered the prosecutor to disclose to it all the witness statements and exhibits it intended to present at trial. ${ }^{346}$ The defence appealed that decision arguing that (1) the legal framework of the Tribunal did not allow for the Trial Chamber to receive the prosecutor's disclosure materials; (2) the Trial Chamber, by reviewing the disclosure materials before their admission into the trial evidentiary record, assumes or facilitates the investigative role of the prosecution, something that is not contemplated by the adversarial system of the Tribunal; (3) by reviewing the disclosure materials, the Trial Chamber would improperly consider the merits of the case before the trial; and that (4) consequently, this would violate the accused's rights under Article 21(3)(4) of the Statute. ${ }^{347}$

The Appeals Chamber dismissed all the grounds of appeal. With regard to the first ground, the Appeals Chamber considered that although "the terms of Rule 65ter may be clear [they are] not intended to be exhaustive." ${ }^{348}$ Importantly, "[t]he pre-

343 The legal framework of the ICC does not provide for a provision similar to Rule 68bis ICTY RPE.

344 Rules 65ter, 66(C), 70, 92bis, 94bis.

345 The ICTY RPE do not contain a Rule similar to Rule 73bis ICTR RPE which authorizes the Trial Chamber to order the Prosecution to provide copies of the written statements of witnesses it intends to call at trial. Rule 65 ter (E)(ii) ICTY RPE merely requires e.g. a summary of the facts on which each witness will testify.

346 ICTY, Prosecutor v. Blagojević et al., Decision on Joint Defence Motions for Reconsideration of Trial Chamber's Decision to Review all Discovery Materials Provided to the Accused by the Prosecution, IT-02-60-PT, 21 January 2003.

347 ICTY, Prosecutor v. Blagojević et al., Decision, IT-02-60-AR73, IT-02-60-AR73.2 and IT-02-60AR73.3, A. Ch., 8 April 2003, (Appeals Chamber presents the overlapping appeals of the accused in an consolidated manner).

348 ICTY, Prosecutor v. Blagojević et al., Decision, IT-02-60-AR73, IT-02-60-AR73.2 and IT-02-60AR73.3, A. Ch., 8 April 2003, par. 17. 
trial Judge's powers are not confined to what is specified in the rule, as long as his powers are exercised consistently with the provision of Rule 65ter (B)" ICTY RPE. ${ }^{349}$ With reference to Blagojevićs fear that the Trial Chamber would assume a "quasiinvestigative role in search for material truth, not assigned to it by the Statute and the Rules," the Appeals Chamber emphasised the Trial Chamber's role as both a trier of fact and an arbiter of questions of law, and its authority under the Statute and the Rules "to make factual findings on the basis of evidence presented by the parties." ${ }^{350}$ As such, the Trial Chamber's "factual findings, subject to appeal and review, are parts of the truth proved beyond reasonable doubt." ${ }^{351}$ Nothing in the Trial Chamber's decision, according to the Appeals Chamber, suggested that it has to pursue further investigations after it has received the disclosure material from the prosecutor. Moreover, the Appeals Chamber referred to the Trial Chamber's authority to put forward questions to a witness called by either party (Rule 85(B) RPE), and considered that this authority does not in itself help the prosecution in discharging its burden of proof, as "the answers may be to the advantage of the accused." ${ }^{352} \mathrm{On}$ this point, the Appeals Chamber could have been more principled in referring to the overall duty of the judges to come to the truth. As pointed out by the accused, a Trial Chamber may call additional evidence proprio motu (Rule $98 \mathrm{RPE}$ ), an authority which suggests that it can make factual findings not only on the basis of the evidence presented by the parties. ${ }^{353}$ In dismissing the third ground of appeal the Appeals Chamber stated that " $[\mathrm{t}]$ he professionalism of the judges of the Trial Chamber is a guarantee that the presumption of innocence will be respected", and emphasised the Trial Chamber's consideration that the "Disclosure Material[s] are not evidence unless and until submitted and admitted in the course of trial in accordance with the Rules." ${ }^{354}$ This last point formed a central basis for dismissing the last ground of appeal (a violation of the accused's fair trial rights). In addition, the Appeals Chamber considered it "notable, that at this moment the Disclosure Materials are not formally filed with the Registry as part of the trial record." 355

349 ICTY, Prosecutor v. Blagojević et al., Decision, IT-02-60-AR73, IT-02-60-AR73.2 and IT-02-60AR73.3, A. Ch., 8 April 2003, par. 17. Notably, the Appeals Chamber emphasized that the Trial Chamber did not issue its decision pursuant to Rule 65ter, but on the basis of other provisions.

350 ICTY, Prosecutor v. Blagojević et al., Decision, IT-02-60-AR73, IT-02-60-AR73.2 and IT-02-60AR73.3, A. Ch., 8 April 2003, par. 22.

351 ICTY, Prosecutor v. Blagojević et al., Decision, IT-02-60-AR73, IT-02-60-AR73.2 and IT-02-60AR73.3, A. Ch., 8 April 2003, par. 22 [footnote reference omitted].

352 ICTY, Prosecutor v. Blagojević et al., Decision, IT-02-60-AR73, IT-02-60-AR73.2 and IT-02-60AR73.3, A. Ch., 8 April 2003, par. 23.

353 ICTY, Prosecutor v. Blagojević et al., Decision, IT-02-60-AR73, IT-02-60-AR73.2 and IT-02-60AR73.3, A. Ch., 8 April 2003, par. 20.

354 ICTY, Prosecutor v. Blagojević et al., Decision, IT-02-60-AR73, IT-02-60-AR73.2 and IT-02-60AR73.3, A. Ch., 8 April 2003, paras. 29, 28.

355 ICTY, Prosecutor v. Blagojević et al., Decision, IT-02-60-AR73, IT-02-60-AR73.2 and IT-02-60AR73.3, A. Ch., 8 April 2003, par. 33. 
The practice of ordering the prosecution's disclosure materials to be provided to the Trial Chamber "in order to be prepared to make decisions that effect preparations for the trial and decisions during trial including those on admissibility of evidence" has also been adopted in other cases (no complaints from the parties). ${ }^{356}$

Under the ICC regime, the Single Judge in Lubanga considered that inter partes disclosure should be distinguished from the Rule 121(2)(c) communication of disclosure to the Pre-Trial Chamber. ${ }^{357}$ According to the Judge, disclosure through the Registrar would not be fully consistent with the legal framework of the ICC or the nature of the confirmation of charges hearing. ${ }^{358}$ Disclosure between the parties would be most effective and expeditious in the view of the Single Judge:

\begin{abstract}
the consistency of the disclosure process and the need to safeguard the Court's unique criminal procedure require that disclosure be carried out inter partes with regard to (i) the evidence that subsequently must be communicated to the Pre-Trial Chamber by filing it in the record of the case, that is the evidence on which the parties intend to rely at the confirmation hearing; and (ii) the other materials that the Prosecution must disclose to the Defence before the confirmation hearing but that neither party intends to present at that hearing. ${ }^{359}$
\end{abstract}

In Bemba, the Pre-Trial Chamber also drew a distinction between 'disclosure' which happens between the parties, and 'communication' to the Chamber. However, the Chamber took a broader view of the evidence that needs to be communicated to the Chamber, namely not only evidence on which the parties intend to rely during the confirmation hearing, but also evidence that was previously inspected by the parties. ${ }^{360}$ As such, the Chamber determined that all the disclosure material under Article 67(2) and Rules 76, 77, 78 and 79 must be communicated to the Chamber for it to be able to fulfil the principal objective of truth-finding. ${ }^{361}$ The Chamber ordered

356 ICTY, Prosecutor v. Blagojević et al., Decision on Joint Defence Motions for Reconsideration of Trial Chamber's Decision to Review all Discovery Materials Provided to the Accused by the Prosecution, IT-02-60-PT, 21 January 2003, footnote 7.

357 ICC, Prosecutor v. Lubanga Dyilo, Decision on the Final System of Disclosure and the Establishment of a Timetable, ICC-01/04-01/06-102, 15 May 2006, paras. 61-66.

358 ICC, Prosecutor v. Lubanga Dyilo, Decision on the Final System of Disclosure and the Establishment of a Timetable, ICC-01/04-01/06-102, 15 May 2006, par. 64: “ ... insofar as it would require filing (no matter whether the parties intend to rely on them at the hearing) all evidence and materials subject to disclosure in the record of the case, maintaining all such materials and evidence accessible to the Pre-Trial Chamber, and presenting them at the confirmation hearing, under Rule 122(1) of the Rules".

359 ICC, Prosecutor v. Lubanga Dyilo, Decision on the Final System of Disclosure and the Establishment of a Timetable, ICC-01/04-01/06-102, 15 May 2006, paras. 65-66.

360 ICC, Prosecutor v. Bemba, Decision on the Evidence Disclosure System and Setting a Timetable for Disclosure between the Parties, ICC-01/05-01/08-55, 31 July 2008, paras. 43, 47.

361 ICC, Prosecutor v. Bemba, Decision on the Evidence Disclosure System and Setting a Timetable for 
the Registry to establish a record of the case containing all the disclosed materials, which should be freely electronically accessible to both parties. ${ }^{362}$

\subsection{CONCLUding REMARKS}

The ad hoc tribunals and the ICC have established a disclosure system more associated with a common law-based system. However, the realities of international criminal prosecution clearly demanded several adjustments to the system that was envisioned initially at the ad hoc tribunals. These adjustments were driven by considerations of fairness, equality of arms, access to evidence for both the prosecution and the defence, and the expeditiousness and efficiency of proceedings. The ad hoc tribunals grew to acknowledge the fundamental importance of the disclosure of (exculpatory) evidence to the defence and have taken a broad approach towards disclosable evidence. However, the demands of expeditiousness and efficiency, fuelled by the realities of the prosecution of mass atrocity crimes, have left their undeniable imprint on disclosure rules and practices.

Overall, both the rules and practice have changed considerably over time. Even now, in the final years of the tribunals' functioning, the disclosure rules cannot be pinned down to a clear and unequivocal regime. Although the Judges have strengthened their grip on controlling and coordinating the proper course of the pre-trial disclosure, much depends on the approach taken in individual cases by the parties. The role of the prosecutor has been described as that of a 'minister of justice', helping the court to arrive at the truth, but these voices have been irregular. Little principled rhetoric has been used to emphasize the objective role of the prosecutor or the ultimate goal of the court to arrive at the truth. From the perspective of developed national criminal systems, these rhetorical utterances might seem superfluous; however, in the development of international criminal institutions in their infancy, proper rhetoric represents the needed perceptions, next to the practice as such. It cannot be overstated, 'justice has to be seen to be done.'

More specifically, the equalizing of arms between the prosecutor and the defence would have benefited from a more principled approach towards the prosecution's disclosure practice. Although the burden on the prosecutor may not be underestimated, so may not the difficulties encountered by the defence with regard to investigations and access to evidence. Having regard to the principally different roles and positions is the key to a proper application of equality of arms in disclosure practice. This principle has played a vital role in 'equalizing' the disclosure rules over the years. The end-result at the moment is that the disclosure obligations of

Disclosure between the Parties, ICC-01/05-01/08-55, 31 July 2008, paras. 51, 11, 16.

362 ICC, Prosecutor v. Bemba, Decision on the Evidence Disclosure System and Setting a Timetable for Disclosure between the Parties, ICC-01/05-01/08-55, 31 July 2008, par. 53. 
the evidence that a party wants to use in its case are very much aligned. The main justification has been found in the demands of expeditiousness and efficiency. To a minor extent, the justifications were based on the 'rights' of the prosecutor to be able to prepare adequately for the defence's case, thus extending equality of arms in favour of the prosecution. The principally different positions of the parties were considered to be respected by the fact that the disclosure obligations of the defence in the pre-trial phases are still very limited. When the reciprocal disclosure rule was deleted in 2003, limiting considerably the disclosure obligations of the defence, the prosecution criticised this development. The prosecution argued that efficiency and expeditiousness in preparing and presenting a case would suffer severely when the Defence has such a limited disclosure obligation as to the content of its case. The reintroduction of the more elaborate disclosure obligations of the defence in 2008 largely did not affect the concern of the prosecution, because defence disclosure is effectuated only at the close of the prosecution's case. ${ }^{363}$ However, one might remark that the reintroduction was not so much intended to facilitate the case preparation of the prosecutor, who arguably bears the burden of proving his case, but to facilitate the judges in better coordinating and preparing the cases for trial and to promote efficiency and expeditiousness in trial proceedings.

However, due and principled regard must be had to the fundamental differences in the roles and responsibilities of the parties. Too much 'equality' between parties is neither necessary nor principally attainable. The prosecutor's objective role and the defence's necessarily subjective role have to guide the regime of access to information in a criminal case, whether it is a disclosure or an open-file approach.

At the ICC, the legal regime of disclosure builds further on the developments from the ad hoc tribunals. Although the regime envisioned is formally a twoparty disclosure practice, the legal regime and practice of the ICC clearly shows the influence of the civil law dossier approach. Two structural elements are of paramount importance: (1) the enhanced monitoring role of the Pre-Trial Chamber on the disclosure practice; and (2) the objective role of the prosecutor. Promoting the cooperative approach but extending vigorous oversight over the disclosure practice has characterized the ICC approach to disclosure. To some extent, this can be seen to inject a somewhat paradoxical effect. On the one hand, the prosecutor is seen as an impartial truth-seeker, more equal to the Judges, with the duty to establish the truth while protecting the rights of the victims and accused. On the other hand, the supervisory approach taken by the Chambers leaves little independent room for the prosecutor for his ministerial role. It brings the prosecutor 'down' to the mere level of a party, so to say. From the perspective of equality of arms, the prosecutor's impartial attitude towards the prosecution must be emphasized and developed to better protect and equalize the rights of the accused. The first practice of the ICC shows that 
the prosecutor has not reached the necessary level with regard to this objectivity requirement, subjectively as well as objectively. More emphasis should be placed on a more inclusive, positive and cooperative approach to collecting and disclosing evidence. Clear ethical standards should be in place and guide the OTP in its search for the truth. It is the prosecutor's responsibility to ensure a fair administration of justice generally and a fair trial for the accused in particular.

The next chapter will take a closer look at another vital element in ensuring meaningful equality of arms: resources that are needed to be able to effectively prepare a defence. 


\section{Chapter 6 \\ Institutional Support for the Defence}

\subsection{InTRODUCTION}

The discrepancy between the resources and material support for the prosecution and the defence, or the appearance of inequality in this regard, has been a persistent argument in international criminal proceedings. Challenges from the defence perspective usually relate to alleged inequality of arms. ${ }^{1}$ The institutional imbedding of the defence has been a source of frustration; nevertheless, there have been a number of developments concerning their institutional position. The defence's dissatisfaction with the availability of resources and funding has been expressed by almost all the defence teams at one point or another. This is not surprising, given the fact that most accused before international criminal courts are indigent and, thus, have to operate within the confines of the legal aid system provided by these courts. ${ }^{2}$ Legal aid systems around the world have been and are continuously criticized for their inability to properly allocate the scarce resources for the support of indigent accused. ${ }^{3}$ Taking into account the coming of age of the international criminal system, the persistence of the defence's arguments towards an alleged inequality of arms caused by the inadequacy of material support in itself justifies a deeper evaluation of the matter. Moreover, any structural inconsistencies and inequalities will have to be uncovered.

The issue is, however, not as simple as to say that the prosecution and the defence must have the same resources in order for the principle of equality of arms to be vindicated. The differing powers and obligations make a direct comparison difficult. Nor can it be asserted, in principle, that since the resources of the prosecution and the defence cannot be directly compared that any argument based on equality of

1 Motions requesting the dismissal of indictments or a stay of proceedings because the Tribunals have been unable to provide 'equality of arms' between the prosecutor and the defence have been on the docket continuously. See e.g. ICTY, Prosecutor v. Brđjanin and Talić, Motion to Dismiss the Indictment, IT-99-36-PT, T. Ch., 2 May 2001. The defence has also submitted motions expressing its dissatisfaction with the resources and time available for preparation, without requesting concrete measures from the Court, see for example: ICC, Prosecutor v. Bemba Gombo, Defence Application for Appropriate Decisions by Trial Chamber III Prior to Commencement of the Trial Scheduled for 22 November 2010, ICC-01/05-01/08, 1 November 2010 (Trial Chamber's Decision to that Motion dated 16 November 2010).

2 "Since December 2000 and as of end 2009, the registry has found that 39 [out of 161 persons indicted] of the Tribunal's accused (including one accused of contempt) were able to contribute to their defence costs." See ICTY website: http://www.icty.org/sid/163.

3 E.g. Simon, 2008, pp. 581-594. 
arms has to fail. As one of the founding principles, equality of arms is intrinsically connected to any system of legal aid because its rationale amounts to a safeguard against a procedural imbalance between the prosecutor and the accused. Brđjanin's motion to dismiss the indictment as a remedy for inequality of arms exemplifies the problem. The Pre-Trial Judge considered that "[w]hen stripped of its rhetoric and unsubstantiated assumptions, the Motion is indeed concerned only with the sufficiency of the resources made available to Brđjanin in his defence." According to the Judge, Brđjanin should firstly exhaust the available "avenues of redress" under the Directive on Assignment of Defence Counsel. ${ }^{5}$ In addition, the Pre-Trial Judge added that "the Trial Chamber is not indifferent to the difficulties faced by the defence in preparing a case of this complexity." When the defence can demonstrate "that the resources necessary to ensure a fair trial are not available", the Trial Chamber would be obliged to avoid the occurrence of a miscarriage of justice. ${ }^{7}$ Although the dismissal of the indictment could only be appropriate in exceptional circumstances, in the event of the absence of necessary resources the Trial Chamber has "the inherent power and the obligation to stay the proceedings until the necessary resources are provided, in order to prevent the abuse of process involved in such a trial."

This chapter examines the development of institutional support for the defence at international criminal courts and the "avenues of redress" available to the defence when facing inadequate resources. ${ }^{9}$ However, neither the case assessment of the sufficiency of the resources nor of the whole legal aid system is intended or is visible in light of the scope of this chapter. ${ }^{10}$ The main intention is to zoom in on several main challenges with regard to the defence's institutional position so as to come to an understanding of how the courts have interpreted and applied equality of arms in this area. Thus, this Chapter will take a closer look at the 'margin of appreciation'

4 ICTY, Prosecutor v. Brđjanin and Talić, Decision on Second Motion by Brđjanin to Dismiss the Indictment, IT-99-36-PT, T. Ch., 16 May 2001, par. 3 [emphasis added, MF], [Brdjanin and Talić Equality of Arms Decision, 16 May 2001].

5 Brojanin and Talić Equality of Arms Decision, 16 May 2001, par. 3.

6 Brđjanin and Talić Equality of Arms Decision, 16 May 2001, par. 4.

7 Brđjanin and Talić Equality of Arms Decision, 16 May 2001 par. 5. As to the burden upon an accused, the Pre-Trial Judge considered that "[i]t may be sufficient if it is demonstrated that the absence of such resources is likely to result in a miscarriage of justice" (footnote 11).

8 Brđjanin and Talić Equality of Arms Decision, 16 May 2001, par. 5.

9 The overview is mostly based on the decisions of the Presidency and the Trial Chamber reviewing administrative decisions made by the registrar. These latter decisions are only sparsely published on the website of the ICTY, and mostly relate to assignment of defence counsel. The decisions taken in the context of the legal aid are case specific and mostly unpublished.

10 Clearly, the provision of financial means to defence teams is very case specific and it is difficult, if not impossible, for an 'outsider' to assess whether those means were sufficient as a whole for the preparation and presentation of a particular case. Moreover, the meta-analysis of sufficiency of the overall budged assigned to legal aid of those tribunals, which very much depends on the overall budget of these institutions and the political-economic considerations associated with establishing that budget, cannot be undertaken in this legal study. 
which the registrar has concerning his decision-making in the context of the legal aid system; at the threshold the defence has to meet in order to qualify for additional funding; and at the way the Chambers have dealt with these issues. Moreover, the challenging issue of self-represented accused and the availability of legal aid will be considered, as it is in this situation that the gist of equality of arms is exposed to its very limits. But first the connection between equality of arms and the adequacy of resources necessitates some more reflection.

\subsection{EQUALITY OF ARMS, ADEQUATE FACILITIES AND THE LEGAL AID SYSTEM}

Before looking at the institutional position of and the support available for the defence at several of the international criminal courts, several definitional issues have to be considered. As discussed in Chapter 2, the right to have adequate time and facilities is one of the essential corollaries of the principle of equality of arms. This right can be considered to function as a 'safety net' provision, covering issues that do not exactly fall under the heading of other minimum rights. Moreover, the right to legal assistance is a crucial part of equality of arms. Although this study does not evaluate the adequacy of legal assistance before international criminal courts as such, ${ }^{11}$ the system of legal aid falls within the confines of this right. ${ }^{12}$ A strict division will not always be easy to make and notably, has not been made in the case law of international criminal courts.

Copied from the human rights conventions, all the statutes of international criminal tribunals contain a provision on the minimum right of an accused to have adequate time and facilities to prepare his defence. ${ }^{13}$ The 'two limbs' of the guarantee, namely adequate time and facilities, "are not entirely unrelated: the more 'adequate' the facilities for the preparation of the defence are, the longer the defence will need to use them effectively." 14 This could, of course, also be argued the other way around: the more adequate the facilities provided for the defence, the less time it will need to prepare. ${ }^{15}$

In the Krajišnik decision, the ICTY Trial Chamber contended that "[i]t would be unacceptable [...] if the time granted so far to Defence should fall below the

11 See $e . g$. Temminck Tuinstra, 2009.

12 Cf. ICTY, Prosecutor v. Milutinović et al., Decision on Interlocutory Appeal on Motion for Additional Funds, Dissenting Opinion of Judge Hunt, IT-99-37-AR73.2, A. Ch., 13 November 2003, par. 24:

"The reference in Article 21(4)(b) to facilities is not a reference to legal aid, as that issue is dealt with independently in Article 21(4)(d) ...".

13 See also Article 20(4)(b) ICTR Statute, 17(4)(b) SCSL Statute, 67(1)(b) ICC Statute, 14(3)(b) ICCPR, 6(3)(a) ECHR, 8(2)(b) ACHR.

14 TReChsel, 2005, p. 208.

15 Cf. ICTY, Prosecutor v. Slobodan Milošević, Decision on the Interlocutory Appeal by the Amici Curiae against the Trial Chamber Order Concerning the Presentation and Preparation of the Defence Case, IT-02-54-AR73.6, 20 January 2004, par. 13. 
minimum necessary to make the trial fair for the Accused." 16 This seems to imply that the Trial Chamber is only to ensure that no violation of the defence's rights takes place "without really trying to determine whether it [the Chamber] should go further to vindicate them." ${ }^{17}$ From a human rights perspective this implication does not strike one as being particularly inappropriate. The specific rights of the accused are formulated as 'minimum rights' and whether the right to adequate time and facilities to prepare a defence is not the same as 'the right to the minimum necessary defence' can thus be questioned. ${ }^{18}$ However, the manner in which the right to a fair trial applies "clearly depends upon the special features of the proceedings." 19 The exploration of whether the 'special features' of international criminal proceedings require a somewhat different application of minimum human rights constitutes an underlying rationale of this research endeavour.

In addition, the adequacy of facilities and even more of time is obviously very much case-specific. ${ }^{20}$ From the case law, only very general standards can be drawn which will be looked at more closely hereunder. The corollary of the relative nature of these rights is the required due diligence on the part of the defence. ${ }^{21}$ As stressed by the Trial Chamber in the Čelebići case, "the Rules are not designed to hide inefficiencies in trial strategy, but to ensure the smooth operation of the judicial process." 22 The degree of the required diligence again depends on the special circumstances of the case, for example more diligence might be expected from a defendant who is a lawyer than in a case where he is not. Moreover, there should be "a reasonable prospect of success" when applying the requirement of due diligence. Naturally, if no realistic

16 ICTY, Prosecutor v. Krajišnik, Decision on Defence Motion for Adjournment (written reasons), IT00-39-T, T. Ch. I, 21 September 2004, par. 16 [emphasis added].

17 Moesenthin, 2010, p. 214.

18 Moesenthin, 2010, p. 214. In any case, in the second decision on adjournment and the following appeal, the Trial and Appeals Chamber did not elaborate on this point any further. See ICTY, Prosecutor v. Krajišnik, Decision on (second) Defence Motion for Adjournment, IT-00-39-T, T. Ch. I, 4 March 2005, and ICTY, Prosecutor v. Krajišnik, Decision on Interlocutory Appeal of Decision on Second Defence Motion for Adjournment, IT-00-39-AR73.1, A. Ch., 25 April 2005.

19 ECtHR, Vacher v. France, App. No., 20368/92, Judgment of 16 December 1996, par. 24.

20 Cf. ICTY, Prosecutor v. Karadžić, Decision on Appeal from Decision on Motion for Further Postponement of Trial, IT-95-5/18-AR73.7, 31 March 2010, par. 23: “ ... a Trial Chamber's assessment of the time and resources requirement to prepare for trial is such a "fact-intensive exercise" that Karadžić's comparison to other cases are of limited assistance and limited relevance." [footnote omitted].

21 E.g. HRC, Harward v. Norway, Comm. No. 451/1991, Views of 15 July 1994, par. 9.5.

22 ICTY, Prosecutor v. Delalić et al., Decision on the Application for Adjournment of the Trial Date, IT-96-21-T, T. Ch. I, 3 February 1997, par. 24. Cf. Milošević case where the Trial Chamber did not grant the accused additional time to present his case considering that he had not made a genuine effort to present his case efficiently within the time allocated to him and it was the "[t]he Trial Chamber's fundamental obligation [...] to bring this trial to a fair and expeditious conclusion", ICTY, Prosecutor v. Slobodan Milošević, Decision in relation to Severance, Extension of Time and Rest, IT- 02-54-T, T. Ch. I, 12 December 2005, par. 25. 
effect can be expected from a request for time and/or facilities, no such request can be required for the sake of assessing due diligence. ${ }^{23}$

International criminal defence teams have found creative ways to bring the issue of (the appearance of) resource inequality to the attention of the judges. In Perišić, ${ }^{24}$ for example, the defence requested the appointment of an amicus counsel to investigate and report to the Chamber on the possible imbalance created by the allocated resources to both parties. ${ }^{25}$ The Perišić defence advanced that "the inequality of resources in this case is now at a crisis point" and offered several examples of manifestations of this inequality. ${ }^{26}$ The defence argued that although it was very cautious in stretching its overall budget to the limit, as the available pre-trial funds would soon be exhausted, the defence staff would "need to be terminated" bringing the defence of Momčilo Perišić "to a grinding halt." ${ }^{27}$ This inequality is extended by the length of the pretrial process, which means "more trips need to be conducted on a pro bono basis, overhead costs accumulate without reimbursement, and staff defections cause lost knowledge and increased start up costs for replacement personnel." ${ }^{28}$ Moreover, the amount of disclosed material which is relevant to the case and/or is exculpatory is such that by using all the pre-trial funds the defence "would not be able to look at $75 \%$ of the printed relevant materials" let alone at the video/audio disclosure. ${ }^{29}$ The defence also alleged a severe discrepancy in the quality of the investigative staff and expert resources between the defence and prosecution. According to the defence, the "OPT's investigative staff in this case includes doctorates in history and philosophy, professional accountants and high ranking military personnel" ${ }^{30}$ while "[t]he hard truth is defence teams at this tribunal are staffed by a single overwhelmed attorney and a single case manager until shortly before trial." ${ }^{31}$ The defence thus invited the Chamber to appoint an amicus curiae to investigate the issue neutrally and provide the Chamber with the opportunity to objectively determine whether any inequality of arms existed in the case. ${ }^{32}$ Although the defence did not seek a specific remedy because the extent of the inequality had not yet been established, it did request the

23 Trechsel, 2005, p. 215.

24 ICTY, Prosecutor v. Perišić, Decision on Motion to Appoint Amicus Curiae to Investigate Equality of Arms, IT-04-81-PT, T. Ch. III, 18 June 2007 [Perišić Decision on Inequality of Arms, 18 June 2007].

25 ICTY, Prosecutor v. Perišić, Motion for Appointment of Amicus Counsel to report to Chamber on Inequality of Arms afforded the defence, IT-04-81-PT, T. Ch. III, 1 February 2007, par. 1 [Perišić Motion on Inequality of Arms, 1 February 2007].

26 Perišić Motion on Inequality of Arms, 1 February 2007, par. 3.

27 Perišić Motion on Inequality of Arms, 1 February 2007, par. 4 (a).

28 Perišić Motion on Inequality of Arms, 1 February 2007, par. 4 (b).

29 Perišić Motion on Inequality of Arms, 1 February 2007, par. 4 (c).

30 Perišić Motion on Inequality of Arms, 1 February 2007, par. 4 (d).

31 Perišić Motion on Inequality of Arms, 1 February 2007, par. 4 (e).

32 Perišić Motion on Inequality of Arms, 1 February 2007, par. 5. 
Chamber, "at a minimum ... to increase defence resources to a level which allows the defence team to continue working on the case during the remainder of the Pre-Trial period." ${ }_{33}$

According to the Chamber, the argument of the general appearance of inequality between parties before the Tribunal "does not amount to anything more than a complaint that he [the accused] does not have the same material resources than the Prosecution. ${ }^{\prime 34}$ In that regard, the ad hoc tribunals have frequently repeated the dictum of the Appeals Chamber in the Kayishema and Ruzindana case stating that "equality of arms between the defence and the prosecution does not necessarily amount to the material equality of possessing the same financial and/or personal resources. ${ }^{35} \mathrm{Next}$ to a rather obscure foundation of this observation, the meaning of this statement was not elaborated upon any further. ${ }^{36}$ Equality of arms does not necessarily reflect equality of resources between prosecution and defence, but could there be instances where it does? Common sense teaches us that a mathematical parity between the staff and resources of the prosecution and the defence, especially in the pre-trial phase, is principally and practically unattainable. Equality of arms cannot be assessed on the basis of comparing the available pre-trial resources between the prosecution and defence; it would be like comparing apples and oranges. There is no reciprocity on the issue of resources due to the differing roles of the prosecution and the defence in the proceedings. Yet, the principle of equality of arms will be violated if the defence or the prosecution is put at a disadvantageous position when presenting its case as compared to each other. This reasoning would imply that resources, both material and personnel, as such, fall outside the operating scope of the principle of equality of arms, simply stated because resources cannot be compared and the principle of equality of arms implies a comparison.

However, this reasoning seems to be defective to the extent that equality of arms is one of the fundamental principles of the legal aid system that secures 'equality of arms' by providing quality defence to indigent accused. ${ }^{37}$ The 'playing field' would

33 Perišić Motion on Inequality of Arms, 1 February 2007, par. 7.

34 Perišić Decision on Inequality of Arms, 18 June 2007, par. 10.

35 ICTR, Prosecutor v. Kayishema v. Ruzindana, Judgment (Reasons), ICTR-95-1-A, A. Ch., 1 June 2001, par. 69.

36 The Appeals Chamber refers in footnote 84 to the European Court of Human Rights case of Hentrich as an example ("See, for example, Hentrich v. France, Eur. Court H.R., Judgment of 22 September 1994, para. 56"); however, this case concerns an civil case and the particular passage from the judgment does not seem to provide any support for the Appeals Chamber's assumption.

37 ICTY, Prosecutor v. Milutinović et al., Decision on Interlocutory Appeal on Motion for Additional Funds, IT-99-37-AR73.2, 13 November 2003, par. 3: "The international Tribunal's Legal Aid System ... bears the costs of a defence for indigent accused; it is not in dispute that the system is designed to give the defence quality representation to secure equality of arms with the Prosecution". See also: ICTY, Prosecutor v. Karadžić, Decision on Accused Motion for Adequate Facilities and Equality of Arms: Legal Associates, IT-95-5/18-PT, 28 January 2009 par. 29: “The Tribunal has a fully funded, flexible scheme for the provision of legal aid through counsel and associated staff for indigent 
undeniably be tilted in a case where an indigent accused would not be afforded legal assistance; our understanding of a fair trial does not envisage a criminal trial where a poor individual has to face a powerful prosecutor alone. Thus, the legal aid system is established to provide for equality of arms, but following the Kayishema and Ruzindana reasoning defence counsel cannot appeal to that principle when requesting additional funds.

It follows that in Perišić, rather than arguing general inequality of arms based on the difference in resources between the prosecution and the defence, the latter in this case should have focused its submissions on the (minimum) rights of the accused. The important question remains whether the defence was objectively able to adequately prepare for trial and not whether an unequal distribution of resources between prosecution and defence had created an - appearance of - inequality of arms. The issue at hand concerns a non-reciprocal advantage for the prosecution, ${ }^{38}$ and an argument of inequality based on a comparison between prosecution and defence is bound to be dismissed as an inappropriate request for additional funding. ${ }^{39}$

The adequacy of resources for the defence can only be made within the framework of a particular procedural system having due consideration to the difference in functions that prosecution and defence are to assume in different stages of a criminal trial. Regarding this aspect, the Trial Chamber reiterated the Tadic formula that "equality of arms obliges a judicial body to ensure that neither party is put at a disadvantage when presenting its case." ${ }^{40}$ It furthermore added that "[t]he principle also must be viewed with respect to the different functions which the

accused. Thus is equality of arms with the Prosecution generally secured." See also Report to the Assembly of States Parties on options for ensuring adequate defence counsel for accused persons, International Criminal Court, ICC-ASP/3/16, Third Session, 17 August 2004, par. 16: “ ... Equality of arms: The payment system must contribute to maintaining equilibrium between the resources and means of the accused and those of the prosecution. In this respect, the fees of the members of the defence team are based on the salaries paid in the Office of the Prosecutor (OPT) of the ICC and at the ad hoc Tribunals, increased by $40 \%$ to compensate for the increment in professional charges resulting from an appointment".

38 According to Trechsel " ... it is rather obvious that the prosecuting authority will always have an advantage over the suspect, with the exception of those parts of the investigation in which the defence assists. As a counter-weight, the defence enjoys the presumption of innocence", TRECHSEL, 2005 , p. 223.

39 In the sense that request for additional funding would have to be directed to the appropriate body, the registrar. This decision could be reviewed by the Chamber. See ICTY, Prosecutor v. Perišić, Decision on Motion to Appoint Amicus Curiae to Investigate Equality of Arms, IT-04-81-PT, T. Ch. III, 18 June 2007, par. 10 and 11 . To be allowed additional funds the defence has to demonstrate exceptional circumstances or circumstances beyond its control which would warrant additional resources during a particular stage of the proceedings. See ICTY, Prosecutor v. Milutinović et al., Decision on Interlocutory Appeal on Motion for Additional Funds, IT-99-37-AR73.2, A. Ch., 13 November 2003, par. 21.

40 Perišić Decision on Inequality of Arms, 18 June 2007, par. 6. 
parties have in various systems." ${ }^{41}$ Obviously, the only system which is relevant to this decision is the ICTY system, and, in that regard, the Trial Chamber repeats the decision from the Aleksovski Appeals Chamber that the role of the prosecution is to represent not only the victims of the charged offences but also the whole international community. ${ }^{42}$ To equalize the powerful position of the prosecutor, the Tribunal's legal system, "in accordance with internationally recognized human rights instruments", affords the accused substantial rights. ${ }^{43}$ This is evidenced by the presumption of innocence which an accused enjoys, in contrast with the burden of proof resting upon the prosecution; by the "extensive burden on the Prosecution for discovery and disclosure of exculpatory material to the Defence"; and by the fact that proceedings before the Tribunal were designed to "adhere to internationally recognized principles of fair trial." ${ }^{44}$

\subsection{INSTITUTIONAL SUPPORT FOR THE DEFENCE}

While the right to competent defence counsel and legal aid have been enshrined in the legal system of the ad hoc Tribunals, "it is fair to say" that both have been the "Achilles' heel" of the courts. ${ }^{45}$ As stated, equality of arms amounts to one of the fundamental principles of the legal aid system: "[t]he international Tribunal's Legal Aid System ... bears the costs of a defence for indigent accused; it is not in dispute that the system is designed to give the defence quality representation to secure equality of arms with the Prosecution." 46 The point of departure is that equality of arms with the prosecutor is "generally secured" by the availability of "a fully funded, flexible scheme for the provision of legal aid through counsel and associated staff for indigent accused." ${ }^{47}$ However, as already noted, the Appeals Chamber seems to have

41 Perišić Decision on Inequality of Arms, 18 June 2007, par. 6.

42 Perišić Decision on Inequality of Arms, 18 June 2007, par. 7, referring to ICTY, Prosecutor $v$. Aleksovski, Decision on Prosecutor's Appeals on Admissibility of Evidence, IT-95-14/1-AR73, A. Ch., 16 February 1999, par. 25.

43 Perišić Decision on Inequality of Arms, 18 June 2007, par. 7, referring to ICTY, Prosecutor $v$. Aleksovski, Decision on Prosecutor's Appeals on Admissibility of Evidence, IT-95-14/1-AR73, A. Ch., 16 February 1999, par. 25.

44 Perišić Decision on Inequality of Arms, 18 June 2007, par. 7, referring to ICTY, Prosecutor v. Aleksovski, Decision on Prosecutor's Appeals on Admissibility of Evidence, IT-95-14/1-AR73, A. Ch., 16 February 1999, par. 25 [emphasis in the original].

45 Tolbert, 2003, p. 975.

46 ICTY, Prosecutor v. Milutinović et al., Decision on Interlocutory Appeal on Motion for Additional Funds, IT-99-37-AR73.2, 13 November 2003, par. 3: "The international Tribunal's Legal Aid System ... bears the costs of a defence for indigent accused; it is not in dispute that the system is designed to give the defence quality representation to secure equality of arms with the Prosecution".

47 ICTY, Prosecutor v. Karadžić, Decision on Accused Motion for Adequate Facilities and Equality of Arms: Legal Associates, IT-95-5/18-PT, 28 January 2009 par. 29: "The Tribunal has a fully funded, flexible scheme for the provision of legal aid through counsel and associated staff for indigent 
excluded resources from the operative scope of the principle of equality of arms by considering that "equality of arms between the defence and the prosecution does not necessarily amount to the material equality of possessing the same financial and/or personal resources." 48 This leads to the conclusion that the existence of a legal aid system already fully vindicates equality of arms, and, thus, the operation of this legal aid system is excluded from the scope of this principle. Instinctively, this conclusion seems insufficient. The legal aid system of the ad hoc tribunals has been subject to continuing review and some remarkable changes.

\subsubsection{Legal aid arrangements}

\subsubsection{Ad hoc tribunals}

An effective legal aid system is a fundamental element for ensuring the right to legal representation. ${ }^{49}$ At the ad hoc tribunals, most accused have been found (partly) indigent, and rely on legal aid arrangements. ${ }^{50}$ The Office for Legal Aid and Detention Matters (OLAD) of the registry makes determinations about whether an accused is indigent, makes payment arrangements to the defence teams and employs financial investigators to ensure the effective functioning of the legal aid system. At the ICTR, the Defence Counsel Management Section is responsible for administering the legal aid arrangements.

The ICTY's legal aid system has been subject to radical change since 2002, from a ceilings system (the maximum allotment of hours) to a lump-sum system. The "famous fee-splitting scandals" are considered partly responsible for this change. ${ }^{51} \mathrm{~A}$

accused. Thus equality of arms with the Prosecution is generally secured."

48 ICTR, Prosecutor v. Kayishema and Ruzindana, Judgment (Reasons), ICTR-95-1-A, A. Ch., 1 June 2001, par. 69.

49 For a comparison of the legal aid arrangements at international criminal institutions (ICTY, ICTR, SCSL, ECCC and ICC) see Report on different legal aid mechanisms before international criminal jurisdictions, ICC-ASP/7/23, 23 October 2008, available at http://www.icc-cpi.int/iccdocs/asp_ docs/ASP7/ICC-ASP-7-23\%20English.pdf.

50 Out of 133 accused (as of June 2011), 79 were found indigent, 37 received partial legal aid, 10 did not request legal aid and only one was found to have sufficient means; 6 are under a financial means inquiry. See http://www.icty.org/sid/163: "The legal aid system accounts for approximately $11 \%$ of the Tribunal's yearly budget." United States Institute of Peace, Special Report 122, Building the Iraqi Special Tribunal: Lessons from Experiences in International Criminal Justice, 2004, p. 7: " ... the provision of gratis counsel consumed some ten percent of the ICTY budget, to the sum of 10-13 million per year ...".

51 Newton, 2011, p. 397-398: "The famous fee-splitting scandals also mark an inescapable watershed in the ethical and procedural evolution of the tribunals. In the early years of the ICTY and ICTR, defence counsel would often agree to share a portion of the funds paid by the registrar with the defendant or defendant's family members, a practice that became known as "fee-splitting". See also De Bertodano, 2004, p. 504: "But it is also true that dishonest practices, such as overbilling and feesplitting, have played a part and a lack of proper caps and controls has resulted in an inflated defence 
lump-sum system was also considered to provide for a more effective legal aid system "designed to give counsel maximum flexibility in the use of resources and to allow Lead Counsel to use the lump-sum to hire members of the defence team in a manner that best suits the needs of the team." 52 Moreover, it also distinguished between the level of complexity of different cases and replaced the monthly invoices with the end of stage work reports to alleviate the administrative burden on the defence. ${ }^{53}$

Based on Article 21(d) ICTY Statute, the main principles of the legal aid system are considered to be the following:

(a) the accused is entitled to legal aid if he is partially or fully incapable of paying for his defence;

(b) only necessary and reasonable expenses for the criminal defence are remunerated;

(c) the legal aid system requires the defence to be efficient in its management of cases;

(d) the legal aid system must be able to attract defence counsel of good quality and standing, and with skills at a level comparable to the senior trial attorneys working in the Tribunal's Office of the Prosecutor; and

(e) the accused and the prosecutor must have equality of procedural arms, supported by an appropriate level of resources. ${ }^{54}$

Moreover, the Report states that an accused receiving legal aid "may challenge relevant aspects of the legal aid system of the Tribunal where the system is perceived by the defence not to provide adequate resources and therefore affect the principles of fair trial and equality of arms as enshrined in the Tribunal's Statute." ${ }_{55}$ However, as the above discussion has made clear, the judges seemingly excluded framing the inadequacy of resources in terms of an 'equality of arms' challenge.

The lump-sum is divided into pre-trial, trial and appeals stages and is provided in "monthly stipends which is not meant to represent a monthly allotment of hours or a monthly salary." 56 The exact amount is determined by the complexity of the

budget." Referring to the Report of the Office of Internal Oversight Services on the Investigation into Possible Fee-Splitting Arrangements between Defence Counsel and Indigent Detainees at the ICTR and ICTY, UD Doc A/55/759, 1 February 2001, par. 60 and the Follow-up Investigation, UN Doc. A/56/836, 26 February 2002.

52 http://www.icty.org/sid/163.

53 http://www.icty.org/sid/293.

54 Comprehensive report on the Progress Made by the International Criminal Tribunal for the Former Yugoslavia in Reforming its Legal Aid System, Report of the Secretary-General, A/58/288, 12 August 2003, par. 4.

55 Comprehensive report on the Progress Made by the International Criminal Tribunal for the Former Yugoslavia in Reforming its Legal Aid System, Report of the Secretary-General, A/58/288, 12 August 2003, par. 5.

56 Comprehensive report on the Progress Made by the International Criminal Tribunal for the Former Yugoslavia in Reforming its Legal Aid System, Report of the Secretary-General, A/58/288, 12 August 2003, par. 5. 
case (level 1, 2 or 3), which is evaluated according to a number of factors, such as the accused's position within the political and military hierarchy; the number and nature of counts in the indictment; the number and type of witnesses and documents involved; whether the case involved crimes committed in a number of municipalities; and the novelty and complexity of legal and factual arguments the case will deal with.

The pre-trial stage covers three phases: (1) initial appearance, (2) preliminary motions and work plan; and (3) trial preparation per se. The trial stage is divided into prosecution and defence phases, and the allotment is determined upon consultation with the Trial Chamber and the parties and upon an evaluation of the estimated duration of the trial stage and the complexity of the case. The importance of the managerial powers of the judges to set the time for a party's case presentation (discussed in the next chapter) is expressed by the fact that it constitutes the determinative factor for the estimation of the duration of the trial within the legal aid system. Due to the protracted duration of cases before the tribunals, the distribution of the lump-sum is phased throughout the trial:

The defence team will receive an up-front payment at the commencement of trial (representing 10 per cent of the lump-sum), a monthly stipend, and a final End of Phase distribution (normally comprising approximately 20 percent of the lumpsum). The up-front payment and monthly stipends are considered advance payments towards the lump-sum rather than an allotment of hours. ${ }^{57}$

The appeals stage is structured differently: for this phase a maximum number of hours are allotted, billed through hourly invoices. ${ }^{58}$

As to the combination of a team, depending on the size of the case, each team is allowed a lead and a co-counsel, a case manager, legal assistants, investigators and consultants. ${ }^{59}$ Payment to the accused's defence team covers all aspects of preparing

57 http://www.icty.org/sid/163.

58 http://www.icty.org/sid/163. "As of June 2011, lead counsel is paid between $€ 71$ and $€ 97$ per hour, depending on how many years of experience they have. Co-counsel is paid a fixed rate of $€ 71$ per hour. Payment for support staff ranges according to experience from $€ 15$ an hour to $€ 25$. The Appeals Payment Scheme is as follows: whenever a Notice of Appeal is filed against a trial judgement, the case is preliminarily ranked as a Level 1 (difficult) case. The Level 1 case is then allotted a maximum of 1,050 hours for counsel and up to 450 hours for the work of support staff (which may include legal assistants, investigators, translators, and interpreters). Upon request, a case may be upgraded in its complexity level. A Level 2 case (very difficult) is allotted 1,400 hours for counsel and 600 hours for support staff. A Level 3 case (extremely difficult) is allotted 2,100 hours for counsel and 900 hours for support staff. Additional payments are made for all hours spent in the courtroom by Defence counsel."

59 http://www.icty.org/sid/163. ICTR: http://www.unictr.org/Portals/0/English/Forms/New_Lump_ Sum_System_of_ICTR.pdf (pre-trial and trial stages provided for a lead and co-counsel and three legal assistants and/or investigators). This is clearly a positive development since the first Directive on the Assignment of Defence Counsel, IT/1/94, Article 16: A suspect or accused shall only be entitled to have one counsel assigned to him and that counsel shall deal with all stages of the 
and presenting the defence case, including reviewing the indictment, the supporting materials and all other documents provided by the prosecution or gathered through the defence investigation, filing motions, interviewing witnesses, research, and arguing the case in court.

The ICTR system was based on an hourly-rate system, and since 2005 it is based on a lump-sum system per phase. In 2006, some changes were made to this system, in order to adapt it to the completion strategy of the ICTR to "address the real needs of the Defence, at the appropriate time;" to estimate "with greater precision, the cost of defending accused persons before the International Criminal Tribunal for Rwanda, and thus align budgetary projections with the actual budget;" and to simplify and render more attractive the existing lump-sum system. ${ }^{60}$

Defence teams before the SCSL are paid differently than the Court's staff or even the independent contractors, which has proved problematic. ${ }^{61}$ Defence counsel, entering into a legal services contract with the SCSL, receive a lump-sum payment of $\$ 400,000$ USD for an estimated trial length of eight months. ${ }^{62}$ This was an all-in payment including travel costs and daily living allowance expenses. Each defence team was expected to consist of 1 lead counsel, 2 co-counsel and a legal assistant, although variations to this composition have been common. ${ }^{63}$ Teams are provided support by a Sierra Leonian investigator and sometimes a short-term international investigator. The reality of a protracted and interrupted trial has led to the rapid exhaustion of the available funds, and although the contracts were extended for three months ( $\$ 25,000$ USD per month), the insufficiency of resources for the defence has

procedure and all matters arising out of the representation of the suspect or accused or of the conduct of his defence. Payment was set at US \$200 per day (Id., Article 25). The expectations of the trial length had to be drastically adjusted.

60 See New Lump Sum System for the Remuneration of Defence Teams at ICTR, http://www.unictr. org/Portals/0/English/Forms/New_Lump_Sum_System_of_ICTR.pdf.

61 Report on the Special Court for Sierra Leone, submitted by the Independent Expert Antonio Cassese, 12 December 2006, par. 138. "Staff receive monthly salary plus a daily living allowance and certain other benefits. Contractors within the Court receive a salary calculated on a daily rate plus the living allowance".

62 Report on the Special Court for Sierra Leone, submitted by the Independent Expert Antonio Cassese, 12 December 2006, par. 139. The sum could be used at a rate of $\$ 25,000$ USD per month or $\$ 75,000$ USD per three-month period. Cassese suggested a separation of travel costs and daily allowances from the legal aid lump sum provided for each team "so as to increase the money available for the legal fees of the defence and to remove the travel disincentive" (Id., par. 141).

63 Report on the Special Court for Sierra Leone, submitted by the Independent Expert Antonio Cassese, 12 December 2006, par. 137. 
plagued the SCSL. ${ }^{64}$ In addition, as a consequence of this all-in arrangement defence counsel were discouraged from travelling to Freetown. ${ }^{65}$

In the context of the ICC one has to keep in mind the infancy of the institution, which makes it difficult to set up a benchmark. ${ }^{66}$ The legal aid system is based on a monthly lump-sum system, instead of per phase as arranged at the ICTY. There rests an obligation upon counsel to submit detailed action plans to the Registrar before each phase of the proceedings (and six months afterwards if the phase still continues) and a final report on its implementation. ${ }^{67}$ As a controlling mechanism, the Registrar verifies these plans and final reports against the defence team's monthly time sheets. ${ }^{68}$ The monthly lump-sum payments remain constant during the proceedings, including in time of limited court activity. ${ }^{69}$ The following reasons for this approach are mentioned:

(a) To make defence teams feel part of the Court by making their payment structure similar to that used for Court staff members;

(b) To regularize defence team members' payments;

(c) To lessen the burden on counsel for remuneration of team members and to avoid payment disputes between counsel and team members; and

(d) To simplify management of the periodical payments to the different team members, who also benefit, inter alia, from receiving a fixed amount each month. ${ }^{70}$

A core defence team is comprised of three components: counsel, a legal assistant and a case manager. During proceedings, additional resources can be provided, either

64 Report on the Special Court for Sierra Leone, submitted by the Independent Expert Antonio Cassese, 12 December 2006, par. 140.

65 Report on the Special Court for Sierra Leone, submitted by the Independent Expert Antonio Cassese, 12 December 2006, par. 139.

66 Report on different legal aid mechanisms before international criminal jurisdictions, ICCASP/7/23, 23 October 2008, par. 9, available at http://www.icc-cpi.int/iccdocs/asp_docs/ASP7/ICCASP-7-23\%20English.pdf.

67 Regulation 134 of the Regulations of the Registry, ICC-BD/03-01-05-Rev.1. ICC-BD/03-0106-Rev.1, 6 March 2006, (revision 25 September 2006). See also, Report on different legal aid mechanisms before international criminal jurisdictions, ICC-ASP/7/23, 23 October 2008, par. 27 available at http://www.icc-cpi.int/iccdocs/asp_docs/ASP7/ICC-ASP-7-23\%20English.pdf.

68 For a comparison of the legal aid arrangements at international criminal institutions (ICTY, ICTR, SCSL, ECCC and ICC) see Report on different legal aid mechanisms before international criminal jurisdictions, ICC-ASP/7/23, 23 October 2008, par. 28, available at http://www.icc-cpi.int/iccdocs/ asp_docs/ASP7/ICC-ASP-7-23\%20English.pdf.

69 Report on different legal aid mechanisms before international criminal jurisdictions, ICC-ASP/7/23, 23 October 2008, par. 29, available at http://www.icc-cpi.int/iccdocs/asp_docs/ASP7/ICCASP-7-23\%20English.pdf.

70 Report on different legal aid mechanisms before international criminal jurisdictions, ICC-ASP/7/23, 23 October 2008, par. 29, available at http://www.icc-cpi.int/iccdocs/asp_docs/ASP7/ICCASP-7-23\%20English.pdf. 
automatically or through a defence request. ${ }^{71}$ Interestingly, in the context of the ICC, the principle of equality of arms is taken quite literally in the legal aid scheme:

The payment system must contribute to maintaining equilibrium between the resources and means of the accused and those of the prosecution. In this respect, the fees of the members of the defence team are based on the salaries paid by the Office of the Prosecutor (OTP) of the ICC and at the ad hoc Tribunals, increased by $40 \%$ to compensate for the increment in professional charges resulting from an appointment. $^{72}$

Contrary to the ICTY and ICTR systems, the ICC provides for an investigation budget based on 90 days of work conducted by an investigator and a resource person. ${ }^{73}$ The Defence Support Section handles the budget of the legal aid system, while the Office of the Public Defence Counsel (considered in more detail below) is primarily responsible for legal representation, external and internal, and for providing substantive assistance to defence teams.

Both the ECCC and the STL will escape attention at this time, but will be considered in more detail below when discussing the institutional arrangements for the defence.

\subsubsection{Avenues of redress for challenging the inadequacy of resources}

In the context of the ICTY an accused may challenge "relevant aspects of the legal aid system of the Tribunal where the system is perceived by the defence not to provide adequate resources and therefore affect the principles of fair trial and equality of

71 Report on different legal aid mechanisms before international criminal jurisdictions, ICC-ASP/7/23, 23 October 2008, par. 20, available at http:/www.icc-cpi.int/iccdocs/asp_docs/ASP7/ICCASP-7-23\%20English.pdf.

72 ICC, Report to the Assembly of States Parties on options for securing adequate defence counsel for accused persons, ICC-ASP/3/16, 17 August 2004, par. 16. ("It should be noted that different contingencies were taken into account in setting the appropriate salary step for defence team members, which is set at step $\mathrm{V}$, as they have to arrange and pay for their own insurance and pension. Also, they may work for a team for several years without any increment in salary entitlements." See Report on different legal aid mechanisms before international criminal jurisdictions, ICCASP/7/23, 23 October 2008, par. 28, available at http://www.icc-cpi.int/iccdocs/asp_docs/ASP7/ ICC-ASP-7-23\%20English.pdf.

73 Report on different legal aid mechanisms before international criminal jurisdictions, ICC-ASP/7/23, 23 October 2008, par. 44: "At the Court, the budget limits investigations to 90 days of work for an investigator (paid at P-4 level) and a resource person (paid at P-1 level) for a case where other participants in the proceedings present up to 30 witnesses, plus a further $€ 33,970$ for travel and subsistence purposes. The total investigation budget allocated to each team is currently set at $€ 73,000$. The adjustments proposed by the Court in 2007 , which were endorsed by the Committee, included an increase in the number of witnesses among the criteria which could allow the allocation of additional resources to a defence team." 
arms as enshrined in the Tribunal's Statute." ${ }^{\prime 74}$ Being primarily responsible for administering the legal aid system, the registrar has a certain margin of discretionary power. When looking at the standard of review of an administrative decision, the following passage from an Appeals Chamber's reasoning is considered authoritative:

Judicial review of such an administrative decision is not a rehearing. Nor is it an appeal, or in any way similar to the review which a Chamber may undertake of its own judgment in accordance with Rule 119 of the Rules of Procedure and Evidence. A judicial review of an administrative decision made by the Registrar in relation to legal aid is concerned initially with the propriety of the procedure by which Registrar reached the particular decision and the manner in which he reached it. The administrative decision will be quashed if the Registrar has failed to comply with the legal requirements of the Directive. This issue may in the particular case involve a consideration of the proper interpretation of the Directive. The administrative decision will also be quashed if the Registrar has failed to observe any basic rules of natural justice or to act with procedural fairness towards the person affected by the decision, or if he has taken into account irrelevant material or failed to take into account relevant material, or if he has reached a conclusion which no sensible person who has properly applied his mind to the issue could have reached (the "unreasonableness" test). These issues may in the particular case involve, at least in part, a consideration of the sufficiency of the material before the Registrar, but (in the absence of established unreasonableness) there can be no interference with the margin of appreciation of the facts or merits of that case to which the maker of such an administrative decision is entitled. These standards for judicial review of administrative decisions rest on general principles of law derived from the principal legal systems. ${ }^{75}$

Thus, central to the marginal review of an administrative decision are the following standards which are said to have the status of general principles derived from principle legal systems: incorrect interpretation and application of legal provisions, failure to observe 'any rules of natural justice' or 'procedural fairness,' and the unreasonableness test. What the rules of natural justice constitute or what procedural fairness requires is left to be determined in the context of a particular review.

The registrar's decision allocating resources under the legal aid system is first of all open to a review by the President. Only when the matters touch upon the fairness

74 Comprehensive Report on the Progress Made by the International Criminal Tribunal for the Former Yugoslavia in Reforming its Legal Aid System, Report of the Secretary-General, A/58/288, 12 August 2003, par. 5.

75 ICTY, Prosecutor v. Kvočka et al., Decision on Review of Registrar's Decision to Withdraw Legal Aid from Zoran Žigić, IT-98-30/1-A, A. Ch., 7 February 2003, par. 13. Moreover, in legal aid cases "it is clear, from the implicit restriction that only the Registrar may determine the extent to which the accused has the means partially to remunerate counsel, that the power of the Chamber to substitute its own decision for that of the Registrar is limited" (par. 14). 
of proceedings can the decision be subjected to a Trial Chamber's review. In fact, the President has stated that the "review of a decision by the Registrar on allocation of funds in terms of its impact upon the right of an accused to 'equality of arms' with the Prosecution lies with the relevant Chamber." 76

From the case law of the ad hoc tribunals, it seems that the registrar's 'margin of appreciation' has been applied very broadly. ${ }^{77}$ The Appeals Chamber's decision in Milutinović et al. is instructive in this regard. It endorsed the Trial Chamber's decision backing the registrar in not providing additional funds. Repeating Kayishema and Ruzindana, the Appeals Chamber considered that equality of arms does not necessarily imply material equality of possessing the same financial and/or personal resources between defence and prosecution and that " $[\mathrm{t}]$ he principle of equality of arms would be violated only if either party is put at a disadvantage when presenting its case." ${ }^{78}$ Considering the circumstances of the case, the Appeals Chamber concluded that the defence "cannot rely on the alleged inadequacy of funds during the pre-trial stage to establish such disadvantage", thus excluding the subjective evaluation of the adequacy of resources from the scope of equality of arms. ${ }^{79}$ This reasoning seems to imply that the principle of equality of arms is to be applied only at the trial stage when presenting evidence. As considered in Chapter 2, this is rather at odds with the case law of the ECtHR. One would assume, though, that an established inadequacy of resources at the pre-trial stage of the process would interfere with the right of an

76 ICTY, Prosecutor v. Stanišić and Simatović, Decision on Stanišić Defence Motion for Equality of Arms and Immediate Suspension of the Trial and on Association of Defence Counsel (ADC-ICTY) Motion for Leave to Appear as Amicus Curiae, IT-03-69-T, T. Ch. I, 10 March 2011, par. 14: Where the power to review a decision of the Registrar is specifically conferred on the President of the Tribunal, the Trial Chamber cannot appropriate that power for itself. However, a Trial Chamber otherwise has an inherent power to ensure that the trial of an accused person is fair and expeditious. Further, the President has stated that a "review of a decision by the Registrar on allocation of funds in terms of its impact upon the right of an accused to 'equality of arms' with the Prosecution lies with the relevant Chamber". When a Trial Chamber uses its inherent power to intervene in the decision making powers of the Registrar, it must ensure that the person has first exhausted all available remedies." [footnotes omitted].

77 Comprehensive Report on the Progress Made by the International Criminal Tribunal for the Former Yugoslavia in Reforming its Legal Aid System, Report of the Secretary-General, A/58/288, 12 August 2003, par. 20: "However, the implementation of the payment ceiling system has its own drawbacks. Some defence teams exhaust their full allotment at the beginning of the pre-trial and appeal stages through heavy billing in the initial stages of the proceedings. In such cases, it is not unusual for defence counsel to approach the registry, and often the Chambers, requesting additional resources. In most instances, the registry has firmly refused the granting of additional resources. The defence consistently challenge its decisions."

78 ICTY, Prosecutor v. Milutinović et al., Decision on Interlocutory Appeal on Motion for Additional Funds, IT-99-37-AR73.2, 13 November 2003, par. 24 [Milutinović et al. Additional Funds Appeal Decision 13 November 2003].

79 Milutinović et al. Additional Funds Appeal Decision 13 November 2003, par. 24. 
accused to have adequate time and facilities to prepare his case, a right which is a corollary of the principle of equality of arms.

To be allowed additional funds, the defence has to demonstrate exceptional circumstances, or circumstances beyond its control, which would warrant additional resources during a particular stage of the proceedings. ${ }^{80}$ This implies that the registrar "is open to certain flexibility in considering requests for additional resources;" however, this flexibility is limited by the institutional arrangements of the legal aid system. Notably, the Milutinović et al. Trial Chamber reasoned in this context that

counsel who have agreed to represent indigent accused before the Tribunal are fully aware of the system of remuneration for assigned counsel, including the basis for calculating the costs of legal representation, the billing arrangements, and the maximum allotment for the pre-trial stage according to the particular circumstances of the case." ${ }^{\prime 2}$

This reasoning was endorsed on appeal. The Appeals Chamber dismissed the defence's argument that an ethical consideration would require counsel to withdraw from representation because no adequate defence can be provided due to the lack of resources, by considering that counsel was aware of the remuneration systems when accepting the case, which agreement is binding. ${ }^{83}$

Notably, Judge Hunt issued a strong dissenting opinion in the Appeals Chamber's decision in this case. He specifically criticized the registrar's flexibility with regard to additional funding for the defence. ${ }^{84}$ According to Judge Hunt, the application of the legal aid system in this case makes the registrar's claim that the legal aid system ensures equality of arms indeed "very hollow." 85 In relation to the registrar's contention that it is counsel's responsibility to assess within the provided lump-sum payment "what is reasonable and necessary in the interest of the [client], which requires a degree of prioritisation", ${ }^{86}$ Judge Hunt considered that "[a] system of legal aid which requires defence counsel to select only that part of the work which is necessary as can reasonably be done with the funds granted does not ensure such [quality] representation." ${ }^{87}$ Article 22(A) of the Directive on Assignment of Counsel leaves room for the adjustment of the maximum allotment for the pre-trial phase in a

80 Milutinović et al. Additional Funds Appeal Decision 13 November 2003, par. 21.

81 Milutinović et al. Additional Funds Appeal Decision 13 November 2003, p. 5.

82 Milutinović et al. Additional Funds Appeal Decision 13 November 2003, p. 5 [emphasis in the original].

83 Milutinović et al. Additional Funds Appeal Decision 13 November 2003, par. 22.

84 Milutinović et al. Additional Funds Appeal Decision 13 November 2003, par. 22.

85 Milutinović et al. Additional Funds Appeal Decision 13 November 2003, par. 36.

86 Milutinović et al. Additional Funds Appeal Decision 13 November 2003, par. 13.

87 Milutinović et al. Additional Funds Appeal Decision 13 November 2003, par. 36. 
case where the actual amount of work exceeds the estimation. ${ }^{88}$ Judge Hunt rejected the registrar's contention that the defence's arguments for additional funding (such as the amount of material disclosed and discovery processes) were "foreseeable" in leadership cases before the Tribunal and, thus, were already taken into consideration when upgrading the case to Level 3. According to Judge Hunt, the relevant criterion is not what is "foreseeable", such as problems caused by the continuous discovery process, which is included in the maximum allotment to the case, but what is "foreseen" as being necessary for an adequate preparation of the defence because the extent of those problems may not be foreseen at all. ${ }^{89}$ Judge Hunt concluded that "[t]he difference between the two words is substantial, and the use by the Registrar of the words placing the greater burden on the defence is but another indication of how the legal aid system is misunderstood by those who administer it." ${ }^{90}$ It must be noted, however, that the registrar in its Comment on Defence Motion for Additional Funds does not consider the arguments advanced by the defence "as an unforeseen circumstance" that can justify additional funding, thus not making any distinction between "unforeseen" and "unforeseeable."

Moreover, Judge Hunt found no merit in the registrar's assertion that his 'flexibility' with regard to additional funding is limited by the defence showing of exceptional circumstances. No basis can be found for the imposition of such a strict limitation in the Directive; ${ }^{92}$ and serving only the ease of the system's administration, this limitation imposes "impossible barriers." " However, the Appeals Chamber endorsed the Trial Chamber's acceptance of the "exceptional circumstances" limitation, and neither Chamber provided for any reasoning regarding this acceptance.

The Chambers seem to have implicitly accepted the registrar's contention that according additional funding in this case would establish a dangerous precedent and

88 Milutinović et al. Additional Funds Appeal Decision 13 November 2003, par. 37. Article 22(A) Directive states: "The Registrar establishes maximum allotments for each defence at the beginning of every stage of the procedure taking into account his estimate of the duration of the phase. In the event that a stage of the procedure is substantially longer or shorter than estimated, the Registrar shall make a decision, after consulting the Chamber and, if necessary, the Advisory Panel".

89 Milutinović et al. Additional Funds Appeal Decision 13 November 2003, par. 40.

90 Milutinović et al. Additional Funds Appeal Decision 13 November 2003, par. 40.

91 Milutinović et al. Additional Funds Appeal Decision 13 November 2003, par. 8.

92 Also considered in ICTY, Prosecutor v. Karadžić, Decision on Appeal of OLAD Decision in Relation to Additional Pre-Trial Funds, IT-95-5/18-T, President Decision, 17 December 2009, par. 20. In relation to the asserted discretion of the registrar "to authorize a reasonable amount of additional funds where an unforeseeable circumstance or any other extraordinary reason arises which warrant a departure from the Remuneration Scheme", the President argued that the Remuneration Scheme does not make such reference on its face and that the source of this discretion is unclear. However, the President accepted it as this was not contested by either party.

93 ICTY, Prosecutor v. Milutinović et al., Dissenting Opinion of Judge David Hunt to the Decision on Interlocutory Appeal on Motion for Additional Funds, IT-99-37-AR73.2, 13 November 2003, par. 41 . 
a 'free ride' for other defence teams to "systematically request and expect addition allotments." ${ }^{94}$ Moreover, the responsibility of defence counsel to conduct necessary and effective investigations that would amount to an 'adequate defence' is clearly underlined in this case. In this respect the registrar referred to the 'inadequate' allocation of funding by the Ojdanic defence team, ${ }^{95}$ something that has been endorsed by Judge Hunt who considered that "[i]n the present case, the defence does appear to have proceeded according to a programme which, although appropriate where there is a bottomless purse to pay for representation, should more appropriately have entered the investigation stage far earlier than was contemplated here." 96 The main defence argument for additional funding was based on the amount of continuously disclosed material that needed to be reviewed. Although ideally it might be 'more comfortable' for the defence to go through the whole disclosure before conducting its own investigations, in the far from ideal system administered by the Tribunal "the prosecution continues to seize more and more documents and to issue more and more indictments, and in most cases there will inevitably be a continuous discovery process as a result of what is learnt in other cases." 97 Whereas this situation "is inevitable because of the failure of various States to provide the cooperation which the Tribunal's Statute demands of them", "defence counsel must face up to that situation and do everything which they can by way of investigating as they go along, even if it may require revisiting some witnesses." 98 This flexibility provided by the new lump-sum legal aid system, as argued by the registrar, seems quite limited in light of the defence's dependence on the way the prosecutor's case unfolds. It is "the responsibility of the lead counsel to plan the utilization of the allotment granted under the legal aid system in order to ensure that it covers the whole pre-trial stage." 99 This planning must be done and adjusted 'as they go along'.

Judge Hunt's approach seems reasonable in light of the fact that he argues for a more lenient approach towards the allocation of additional recourses while not disregarding defence counsel's own responsibility for the conduct of his case. Realistically, at the moment of that decision, the parameters for allocating additional funding still had to be 'negotiated' in light of the Tribunal's recent radical change

94 ICTY, Prosecutor v. Milutinović et al., Registry Comments on Defence Motion for Additional Funds, IT-99-37-PT, 16 June 2003, par. 12 [Milutinović et al. Registry Comment on Additional Funds, 16 June 2003].

95 Milutinović et al. Registry Comment on Additional Funds, 16 June 2003, par. 20: “ ... the Registry would like to emphasize that the lead counsel in Ojdanić case requested the assignment of both cocounsel and a legal consultant at the early pre-trail stage". This was not allowed under the old legal aid system.

96 Milutinović et al. Registry Comment on Additional Funds, 16 June 2003, par. 39.

97 Milutinović et al. Registry Comment on Additional Funds, 16 June 2003, par. 39.

98 Milutinović et al. Registry Comment on Additional Funds, 16 June 2003, par. 39.

99 Milutinović et al. Registry Comment on Additional Funds, 16 June 2003, par. 19. 
in the legal aid system. What is 'foreseeable' and what has been 'foreseen' will necessarily be determined as the proceedings before the tribunal proceed.

In this light, in Karadžic the amount and timing of the prosecutorial disclosure has led to a successful revision of the registrar's decision denying the allocation of additional funding. The President considered that the late disclosure of a high percentage of relevant materials and the fact that this case has a higher number of prosecution witnesses than average, had not been taken sufficiently into consideration by the registrar. ${ }^{100}$ Notably, this is exemplified by the small number of allocated additional hours, which was challenged by the accused. ${ }^{101}$ After the commencement of the trial, the accused once again challenged the registrar's decision denying the allocation of additional funding. The President again considered it inappropriate for the registrar to decline additional funding in light of the fact that some 300,000 documents, normally considered as pre-trail disclosure, were disclosed by the prosecution only after the commencement of the trial. ${ }^{102}$ It seems that in this case the President allowed for less 'margin of appreciation' for the registrar to consider what a 'reasonable' request for additional funding actually entails.

Karadžić defence's submissions on the inadequacy of time and resources have plagued the whole process to the point that the self-represented accused refused to appear when the trial commenced. The Chamber was required to find other solutions and chose for the imposition of a standby counsel and granted him a four-month preparation time before proceeding with the trial. ${ }^{103}$ While, on the one hand, the Chamber refused to postpone the trial any further because of the accused's assertion that he was not ready to proceed, the problematic 'sabotaging' of his own trial by a self-representing accused who continually contended that the available resources and facilities provided for such a complex case were inadequate was 'smoothened', on the other hand, by the President's decisions granting additional funding to the accused. Essentially, this is one of the last 'big fish' cases which the Tribunal will prosecute before shutting down completely. And although the self-representing accused is not making a mockery of the trial, as was the case in Milošević, he seems to be determined to expose the challenges that the Tribunal is facing. ${ }^{104}$

In the context of the ICC, Regulation 83 of the Court stipulates (where relevant) that a parson who receives legal assistance can request the registrar for additional

100 ICTY, Prosecutor v. Karadžić, Decision on Appeal of OLAD Decision in Relation to Additional Pre-Trial Funds, IT-95-5/18-T, President Decision, 17 December 2009, par. 25.

101 Ibid., par. 21.

102 ICTY, Prosecutor v. Karadžić, Decision on Request for Review of OLAD Decision on Trial Phase Remuneration, IT-95-5/18-T, President Decision, 19 December 2010.

103 For background see ICTY, Prosecutor v. Karadžić, Decision on Request for Review of OLAD Decision on Trial Phase Remuneration, IT-95-5/18-AR73.7, paras. 3-5.

104 Next to inadequacy of resources, the problems related to disclosure (see Chapter 5). 
funding "which may be granted depending on the nature of the case." Moreover, the relevant Chamber is competent to review decisions of the registrar on the scope of legal assistance paid by the Court. As such, the scope of judicial review exceeds those of the ad hoc tribunals where the Trial Chamber is only competent to review decisions that potentially affect the fairness of proceedings. One of the challenging issues with regard to the allocation of pre-trial resources has been responding to the numerous applications filed by the victims' participants. That problem has been acknowledged in the report on the evaluation of the legal aid system. ${ }^{105}$ This report made some proposals for amendments to that system, particularly providing for parameters for the allocation of additional resources dependent on the number of victim applications. ${ }^{106}$ The defence, however, continues to struggle with the multitude of victim applications and the proper allocation of scarce resources. ${ }^{107}$

\subsubsection{Defence Support Sections}

Undeniably, when the ICTY came into existence the defence was forgotten about institutionally; as such, initial defence support was rightly called "rudimentary." 108 The attention for defence issues has been growing gradually since then. In fact, "[t]he shock of the fee splitting scandals highlighted the need for a coordinated organizational response that would galvanize the rhetoric of equality of arms and fundamental fairness into a lasting reality." 109 Although not a proper organ of these institutions, the defence was afforded a section within the administrative organ, the registry. The actual support provided by these sections to the satisfaction of the defence teams has been proportionally increasing too. Much depends on the balance that such support sections are capable of striking between their institutional restraints and the independent and substantive support they can provide.

105 Report on the operation of the Court's legal aid system and proposals for its amendment, ICCASP/6/4, Sixth session, New York 30 November to 14 December 2007, par. 20: "In the case of The Prosecutor v. Thomas Lubanga Dyilo, there were 74 requests to participate in the proceedings, and the defence was required to comment on those applications within 10-15 days. The time required to prepare these observations is an additional burden on the defence, which also has to observe time limits imposed in relation to other issues."

106 Report on the operation of the Court's legal aid system and proposals for its amendment, ICCASP/6/4, Sixth session, New York 30 November to 14 December 2007, par. 35. For each person submitting an application for participation in the proceedings.

107 ICC, Prosecutor v. Bemba Gombo, Defence Application for Appropriate Decisions by Trial Chamber III Prior to Commencement of the Trial Scheduled for 22 November 2010, ICC-01/0501/08, 1 November 2010 (Trial Chamber's Decision to that Motion dated 16 November 2010), (“... defence is significantly handicapped by the multitude of applications for victim participation.").

108 Hocking, 2010, p. 6.

109 Newton, 2011, pp. 408-409. 


\subsubsection{ICTY/ ICTR}

In the early years the defence was treated with mistrust: there was no free entrance for defence members into the ICTY building, security had to escort the defence from and to the courtrooms, and even the cafeteria was off-limits. ${ }^{110}$ These "well documented examples of institutional hostility" undermined "the idea of any level playing field as between the defence and prosecution and strike at the heart of professional effective representation." 111 As considered by one commentator, "... in its very physical layout, with prosecutor and Court located "cheek by jowl" and defense counsel situated generally off site, there is perhaps a metaphor for where the defense fits into the scheme of things." "112

Things changed later on, especially since the official recognition of the Association of Defence Counsel (ADC) in 2002 and the improvement of cooperation between the ADC and the Registry. The ADC was created as "an effort to offset some of the disadvantages of the defence not being institutionally represented. It was also intended to compensate for the absence of a bar association at the international level." 113 Within the structure of the ad hoc Tribunals a special office within the registry was created to deal with defence issues - the Office for Legal Aid and Detention Matters (OLAD). ${ }^{114}$

Access to office facilities and office equipment has been a source of great frustration for defence teams. ${ }^{115}$ As with other defence matters, practical support improved with the tribunal's 'growing up'; these seemingly petty problems exemplify once more the extent to which the 'defence' has been an after-thought of these tribunals more generally. ${ }^{116}$ However, as the expression goes, 'better late than never,' the defence's factual position "has improved significantly over the last years." 117 OLAD provided logistical and communication support to the defence teams (over 500 defence counsel

110 HockIng, 2010, p. 6.

111 MORRISON, 2002, p. 45.

112 TOLBERT, 2003, p. 976.

113 HockING, 2010, p. 7. See the Constitution of the ADC at http://adc-icty.org/Documents/adcicty_ constitution.pdf.

114 Defence Counsel Unit, renamed the Office of Legal Aid and Detention Matters (OLAD) in 2002. ICTY, Seventh Annual Report of the International Tribunal for the Prosecution of Persons Responsible for Serious Violations of International Humanitarian Law Committed on the Territory of the Former Yugoslavia since 1991, U.N. Doc. A/55/273-S/2000/777, 26 July 2000, par. 229.

115 Hocking, 2010, p. 6.

116 An anecdote presented by Kevin Jon Heller is illustrative: an email sent by the ICTR to one of the coming interns about Useful Information in preparation for your internship at the Tribunal explicates that "Remember, you are not obliged to bring a laptop except if you work for the Defence. The Office should be able to provide you a computer to work on." See Opinio Juris blog at http:// opiniojuris.org/2008/04/22/have-laptop-will-defend/.

117 "Legal Aid and Defence Support at the ICTY", Address of Mr John Hocking, registrar, United Nations International Criminal Tribunal for the Former Yugoslavia, Meeting of Registrars of Final/ Appellate, Regional and International Courts, Ottawa, Canada, 14-16 April 2010, p. 6. 
now), including travel arrangements to and from the Court, field investigations, meetings with the accused at the United Nations Detention Unit (UNDU) and liaising with other sections of the Tribunal. ${ }^{118}$ The duality of OLAD's responsibilities, supporting the defence while also administering it (legal aid, assessing indigency, assignment of counsel) has led to tension with defence counsel about the Office's unbiased support nature. ${ }^{119}$ The Defence Counsel and Detention Management Section at the ICTR is also housed at the registry.

Information technology support for the defence has also entered the twentyfirst century, and the defence now has remote access to the ICTY's intranet, Judicial Database, Electronic Disclosure System and E-Court, next to having access to a safe IT environment. The defence IT resources now equal those of ICTY staff members. ${ }^{120}$

Over the years, the registry "has made a real effort" to include the ADC in the Tribunal's life and "[i]t is very fair to say that the ADC is now the de facto fourth organ of the Tribunal," 212 with the main purpose of supporting the "function, efficiency and independence of Defence Counsel ... officially established in September 2002." "122 The RPE were amended to require membership of ADC-ICTY for any counsel appearing before the tribunal. ${ }^{123}$ The ICTR counterpart of the ADC-ICTY was established in March 2002 as the "Association des Advocats de la Défence" (ADAD); ${ }^{124}$ however, it is less formal and less well funded. ${ }^{125}$ Both organizations, however, are financially independent from the tribunals. The most important functions performed by these organizations have been (1) overseeing the conduct and performance of defence counsel and (2) being a source of knowledge, support and professional training. ${ }^{126}$ The formalization of the organizational structures for the defence also helps to ensure a level of institutional memory, something that is quite important for a profession that is ad hoc in nature at the international level. ${ }^{127}$

\footnotetext{
118 Hocking, 2010, p. 7.

119 Mettraux and Cengic, 2007, p. 402.

120 HockING, 2010 , p. 7.

121 Hocking, 2010, p. 8.

122 Article 2 ADC-ICTY Constitution, http://adc-icty.org/Documents/adcicty_constitution.pdf.

123 Rule 44(A) RPE.

124 http://adadictr.org/.

125 Newton, 2011, p. 409.

126 Newton, 2011, pp. 409-410.

127 For a comparison of the legal aid arrangements at international criminal institutions (ICTY, ICTR, SCSL, ECCC and ICC) see Report on different legal aid mechanisms before international criminal jurisdictions, ICC-ASP/7/23, 23 October 2008, available at http://www.icc-cpi.int/iccdocs/asp_ docs/ASP7/ICC-ASP-7-23\%20English.pdf.
} 


\subsubsection{SCSL}

In contrast to ICTY/ICTR where defence issues are managed by an administrative body within the structure of the tribunal and substantive support is provided by an external independent professional association, the SCSL legal framework is intended to combine the two within the structure of the court. Modelled after public defenders offices in national systems, the SCSL Defence Office was intended to function as the "fourth pillar" of the Court with the aspiration of "providing a counterbalance for the Prosecution." 128 By attracting "only experienced, competent and honest counsel" the Office envisioned that it would "comply with the human rights principle that adversarial trials should manifest an equality of arms (i.e. reasonable equivalence in ability and resources of Prosecution and Defence)." 129 According to Rule 45(B) SCSL RPE, the Public Defender Office is responsible for (i) initial legal advice and assistance by duty counsel, (ii) legal assistance in case of indigency, and (iii) adequate facilities for counsel in the preparation of the defence.

However, the fourth pillar vision was not realized at the SCSL. Such an institutional arrangement was not supported by either the registrar or the prosecution; and according to the Appeals Chamber, the defence was "not an independent organ of the Special Court." ${ }^{130}$ Next to this formalistic proclamation, practice also proved the Chamber right. The independence of the Office was corrupted by its dependence on the registry's financial will and oversight. Importantly, the constant struggle for (and the lack of) appropriate funding plagued the operation of the Court to the extreme. ${ }^{131}$ As stated by the Principal Defender in the Taylor case "the crux of the matter, [is] the need to provide adequate Defence, the need to ensure that a team is put together, and we cannot do that on our own because we do not have the resources. Everything boils down to whether or not the resources are adequate, and it is only the registry that can provide that." 132

The Defence Office's first Principal Defender arrived at the SCSL in April 2003; the legal aid scheme was barely one month old. Only a year later did the UN

128 SCSL President, First Annual Report of the President of the Special Court for Sierra Leone for the Period 2 December 2002 - 1 December 2003, 2003, p. 16.

129 SCSL President, First Annual Report of the President of the Special Court for Sierra Leone for the Period 2 December 2002 - 1 December 2003, 2003, p. 16.

130 SCSL, Prosecutor v. Brima et al., SCSL-04-16, Decision on Brima-Kamara Defence Appeal Motion, AC, 8 December 2005, par. 83.

131 JALLOH, 2011, p. 458: “ ... the lack of stable funding severely hampered the work of the Court. Crucially, among other areas, the lack of a stable source of funds manifested itself in the form of limited institutional and budgetary support for the Defense Office and, more importantly, the defense counsel. Despite the best efforts of committed and fair-minded judges and other professionals throughout the institution, there persisted a general if not gross inequality between the Prosecution and the Defense until the completion of the Freetown trials."

132 SCSL, Prosecutor v. Taylor, Transcript, T. Ch. II, SCSL-2003-01-T, 25 June 2007, p. 359. 
Secretary-General appoint the Court's first permanent Principal Defender. The office was not adequately staffed at the time of 'Operation Justice' on 10 March 2003, a first multi-suspect coordinated arrest effort by the OTP together with the Sierra Leone Police. The shameful incident of not providing legal representation and the coercive interrogation techniques involving Sesay, one of the convicted persons of SCSL, was already touched upon in Chapter 4.

The Defence Office, intended as an "institutional counterbalance" against the OTP, was meant to centralize some vital defence functions into one office and, as such, to "bolster the value of equality of arms, fairness and efficiency." 133 In the assessment of Cassese, "[i]n some ways this project has proven successful by giving the various defence teams an institutional voice that is not present at the ICTY and ICTR." ${ }^{134}$ However, the high expectations remained unrealized for the most part. As a subordinate office of the registry and lacking budgetary independence, the Defence Office in practice has been "caught between the administration and the demands of the accused and defence counsel." 135 Generally, the Office proved unable "to fulfil its role as the guarantor of equality of arms" by not being able "to provide sufficient remuneration, logistical resources, administrative assistance, or substantive legal support to the defence teams." 136 The effort of the financial management of the defence, instead of substantive legal support, led to recurring tensions between the Defence Office and some of the teams which "have been exacerbated by financial, bureaucratic, and resource constraints." 137

Moreover, defence support with regard to infrastructure and access to equipment and materials has been lacking. A room which was the size of a "shipping container" as office space, with two desks and one single computer were supposed to accommodate a defence team of approximately five people. ${ }^{138}$ In contrast to the OTP, all the defence teams were expected to utilize one or two vehicles, which practically made it impossible to conduct investigative missions on short notice. ${ }^{139}$ Another "petty" example of a day-to-day struggle encountered by the defence in the preparation

133 CASSESE, 2006, par. 52.

134 CASSESE, 2006, par. 52.

135 CASSESE, 2006, par. 136. Cf. JALLOH, 2011, p. 443: “Thus, the office would often be caught in between a rock and a hard place: on the one hand, the bosses in the Registry that direct its major decisions, and on the other hand, the privately contracted defense counsel."

136 CASSESE, 2006, par. 136.

137 CASSESE, 2006, par. 53. JALlOH, 2011, p. 441: "At the SCSL, the inequality of resources between the two sides led to tangible differences in terms of access to offices, equipment, and money for local and international investigators and experts to assist the various defense teams." [footnote omitted].

138 While elsewhere in the Court such rooms are intended to accommodate one or two people. CASSESE, 2006, par. 143.

139 CASsese, 2006, par. 144. 
of their case was the access to a photocopier, which seems to have constituted an "ongoing struggle for defence teams." 140

In relation to administrative issues, the defence teams were subjected to the same - bureaucratic - administrative regime as other organs of the court, although the teams did not constitute Court staff or ordinary contractors. ${ }^{141}$ It takes an inordinate amount of time for defence counsel to prepare detailed advance work plans and expenditures for assessment by the Defence Office, which "takes a strict view of any deviation from the work plan, even when justified."'142

Substantive legal support from the Defence Office to the defence teams has been rather "reactive"; and when it has occurred, the initiative to make an explicit request was taken by defence counsel. In his report, Cassese proposed several substantive support tasks that could be undertaken by the Defence Office with a view to effectuating an effective defence preparation for the defence teams. ${ }^{143}$

The Taylor trial cumulated the above-mentioned challenges, but has eventually "become the model of fairness" and "probably the smoothest running trial of a former head of state in modern international criminal tribunal history." 144 Next to the financial and logistical problems of moving the trial to The Hague due to security concerns, the Taylor trial has put SCSL to the test in many respects to the extreme. In relation to the objective of this chapter it is interesting to note that the prosecution, like the defence,

140 CASSESE, 2006, par. 145: "The Defence Office has a photocopier, but it is locked in a room and the defence teams are only allowed unsupervised access and cannot use the copier after 5:30 p.m. when the attendant is off duty. The Principal Defender has responded that the photocopier has been misused by defence teams and that he is hiring a reproduction assistant to supervise photocopying for longer hours and on Saturdays". The first assigned counsel for Charles Taylor pointed out that the defence team had to work in cafes and restaurants due to inadequate facilities (from June 2006-March 2007). SCSL, Prosecutor v. Taylor, Transcript, T. Ch. II, SCSL-2003-01-T, 4 June 2007, p. 256. The acting registrar challenged that contention as "The Defence has always had the opportunity of using office space in Freetown and in The Hague as of February of this [2007] year". (Transcript p. 338).

141 CASSESE, 2006, par. 147: "For example, travel must be justified by the lead counsel to the Defence Office, which must approve the request. Then the travel request is raised by the Defence Office and it is sent to Personnel for signature. Once approved, the request goes to the Registrar for signature and is then sent back to the travel unit for implementation. This process is time-consuming and frustrating for counsel who are not accustomed to these procedures and who are not always in Freetown to supervise the process. The Principal Defender had indicated that there is no other way to manage the movement of personnel and that this should not be an obstacle if the defence counsel would follow the required procedure and submit their travel requests at least 14 days in advance of their travel dates." However, the management of the registrar and the practice of the delegation of authority (non-existent for some matters) could prove problematic for defence teams in case the registrar is on leave (paras. 188-189).

142 CASsese, 2006, par. 148.

143 CASSESE, 2006, paras. 151-152. For example, making compilations of relevant authorities on different legal issues common to all defence teams, such as aggravating and mitigating factors for sentencing, the standard of appellate review and the admission of evidence; and making neutral witness summaries from the transcripts of the hearing. See also Thompson AND STAGgs, 2007.

144 JaLLOH, 2011, pp. 458-459. 
have encountered several obstacles in their trial preparation and presentation. The appointment of the prosecutor and the Senior Trial Attorney were delayed and the budget for the Taylor case has been very "tight." 145

The Taylor case started off dramatically with Taylor effectively boycotting the trial and dismissing his legal counsel due to the reason that there was no equality of arms between the prosecution and the defence and because he was denied adequate time and facilities to prepare his defence. ${ }^{146}$ After a heated debate with the Presiding Judge about the order to represent a client who declined to be represented, Karim A.A. Khan, the first assigned counsel for Taylor, marched out of the courtroom. ${ }^{147}$ The defence has since complained, continuously, about the inadequacy of time and facilities to prepare. ${ }^{148}$ Moreover, the Principal Defender has been precluded from travelling to The Hague to speak to Taylor at the latter's explicit request. ${ }^{149}$ Overseeing the situation, the acting Registrar contended that after discussion and the pulling of additional funds, the Taylor defence team received comparable support as in other tribunals, like the ICTY; in fact, better support. ${ }^{150}$ The Principal Defender recommended the assignment of one new lead counsel at the rank of Queen's Counsel or its equivalent, one experienced senior counsel, two co-counsel, and two

145 CASsese, 2006, paras. 231, 233.

146 Letter from Charles Taylor to the Trial Chamber judges, read out by the assigned counsel on the first trial day. See SCSL, Prosecutor v. Taylor, Transcript, T. Ch. II, SCSL-2003-01-T, 4 June 2007, pp. 246-251.

147 SCSL, Prosecutor v. Taylor, Transcript, T. Ch. II, SCSL-2003-01-T, 4 June 2007, p. 267.

148 As stated by the duty counsel: "The key issue has been the overriding funding concern. This has affected the ability of the Principal Defender's Office to assemble a good legal Defence team to meet the size and complexity of Mr Taylor's case. That is the first point. Secondly, the level of financing available for Defence investigations was a matter of concern to $\mathrm{Mr}$ Taylor. Thirdly, the status of composition of the team, or lack thereof, as we got closer and closer to the opening of trial. Mr Khan at the last occasion made mention of the fact that at least up to 12 QCs have been approached by the Defence seeking their involvement in the case and all of them had declined to represent Mr Taylor because of the funding that is available through the Defence Office from the Registry. Of course, we've done all we can within the mandate of the office to address the issues, to bring them up to the Registry so that the Registry would be engaged. And I'm happy that the Acting Registrar is here. He may be able to clarify from that point of view why there is, as your Honour put it, a bottle-neck. In short, in my respectful submission, the Defence team has faced a number of difficulties, ranging from the adequacy of the funding that our office could provide from the Registry to them, our inability to assist them to compose the team because of that lack of funding, and the hampering of the role of the Defence Office in facilitating the rights of the accused to the extent - to the extent that the Principal Defender's direct involvement could result in resolution of some of the problems."

149 The Acting Registrar stated that he did not indeed provide funding to the Principle Defender to Travel to The Hague, because in his view, the issues could be adequately addresses by the duty counsel as the representative of the Defence Office. The Presiding Judge noted that it is a right of the accused to speak to the Principal Defender about concerns arising from his ability to mount a defence. In fact, the Defence Office was set up to accommodate precisely issues such as these. See SCSL, Prosecutor v. Taylor, Transcript, T. Ch. II, SCSL-2003-01-T, 4 June 2007, p. 340.

150 SCSL, Prosecutor v. Taylor, Transcript, T. Ch. II, SCSL-2003-01-T, 4 June 2007, p. 337. 
legal assistants. The acting Registrar objected to this proposal arguing that it goes far beyond the number and standards provided by the Court. Before instructing the registrar to facilitate a meeting between the Principal Defender with Charles Taylor to sort out his defence problems and to provide all the necessary (logistical) facilities to the accused, presiding Judge Sebutinde stated "And, really, if we are to pretend that this trial is going to be fair, as indeed we hope it will be fair, then there's got to be some kind of equality of arms." 151 The judge's almost ironic expression in this sentence was accompanied by a proactive approach towards the problems at hand. As Taylor's lead counsel later himself asserted in an interview, his client undeniably received the best resourced team in international criminal law history. ${ }^{152}$

\subsubsection{ICC}

Whereas Article 43(6) ICC Statute instructs the registrar to set up a Victims and Witnesses Unit within the registry, it does not contain any reference to the defence. This had been perceived as a shortcoming, especially in light of the fact that the defence, as an independent and important player, has been struggling for more attention within international criminal institutions. ${ }^{153}$ However, an independent defence office was created within the ICC, modelled after the SCSL, but provided with better institutional and financial support. Thus, the defence at the ICC is supported through two divisions: the administrative support is provided by the Counsel Support Section (CSS), a unit within the registry, and the Office of Public Counsel for the Defence (OPCD), an independent office that has been created pursuant Regulation 77 of the Court Regulations and under the auspices of the registry.

Under the RPE, the registrar is mandated to promote "the rights of the defence, consistent with the principle of fair trial as defined in the Statute" and to "ensure the professional independence of defence counsel." ${ }^{54}$ His unique set of responsibilities includes i.e. (i) providing support, assistance and information to all defence counsel appearing before the Court, and support for professional investigators necessary for

151 Statement by the Presiding Judge Sebutinde in SCSL, Prosecutor v. Taylor, Transcript, T. Ch. II, SCSL-2003-01-T, 4 June 2007, p. 252.

1527 March 2010, http://www.charlestaylortrial.org/2010/03/19/charles-taylors-defense-counsel-courtenaygriffiths-answers-your-questions-part-ii/ In an interview with an NGO covering the Taylor trial, the lead counsel Mr Courtenay Griffiths stated: "I think we have the best resourced team that perhaps there has ever been in the international criminal justice arena. And I think, from when I was brought on board, there was a degree of equality of arms between the parties. But prior to that, it was totally unequal, which is why Mr Taylor sacked his initial team. It was totally unfair and unequal. And indeed, such inequality is something which is exploited by the prosecution in all of these international tribunals. In most cases before these tribunals the defence just do not have the resources to compete on a level playing field."

153 Filling the Gap, 2005, p. 3.

154 Rule 20(1) heading and (2) ICC RPE. 
the efficient and effective conduct of the defence; (ii) assisting arrested and accused persons in obtaining legal advice; (iii) advising the prosecutor and the Chambers on relevant defence-related issues; (iv) providing the defence with necessary facilities; and (v) facilitating the dissemination of information and case law of the Court to defence counsel, and, as appropriate, cooperate with national defence and bar associations ... to promote the specialization and training of lawyers in the ICC's legal framework. ${ }^{155}$

The OPCD is mandated to implement "equality of arms", and its role has been compared to that of the "legal advisory section of the Office of the Prosecutor and is an important step in ensuring equality of arms for the defence." ${ }^{156}$ Moreover, the OPCD is to represent and protect the rights of the defence during the initial stages of an investigation. ${ }^{157}$ In addition, the office

promotes, examines and raises awareness on defence-related issues, participates in working groups, attends training courses, seminars or conferences at the seat of the Court and elsewhere, contributes to "equality of arms" for the Defence at all stages of an investigation or trial, and advocates for the respect of the presumption of innocence and the principle of a fair trial. ${ }^{158}$

In May 2011, a select committee of ICC judges together with the deputy registrar started a review of the functioning of the OPCD. This review of both OPCs, for victims and defence counsel, was initiated following "concerns expressed by relevant stakeholders concerning the manner in which the respective mandates were being implemented." 159 The main issues concerned (1) the difference in the interpretation of mandates by both offices; and (2) the lack of clear mechanisms to ensure governance and accountability for these independent offices. ${ }^{160}$ The mandate of the OPCD was intended to provide "hands-on, case-focused help to individual defendants and to the Court." ${ }^{161}$ Specifically, the OPCD was intended to reduce legal aid costs and to expedite the proceedings. ${ }^{162}$ Contrary to this view, the OPCD interpreted its mandate

155 Rule 20(1)(b)-(f) RPE.

156 First Challenges, 2009, p. 31.

157 Situation in Darfur, Sudan, Decision on the Ad hoc Counsel for the Defence's Request for leave to Appeal the Decision of 2 February 2007, No. ICC-02/05, 21 February 2007: “ ... the Office for the Public Counsel for Defence (the OPCD) - and not the Ad hoc Counsel appointed for the purpose of specific proceedings under Rule 103 - is, as per Regulation 77(4) of the Regulations of the Court, the body of the Court which has been assigned the task of representing and protecting the rights of the Defence during the initial stages of an investigation".

158 FAQ "How does the Office of Public Counsel for the Defence (OPCD) assist in ensuring respect for the rights of the Defence and equality of arms?" at http://www.icc-cpi.int/.

159 Fairness at the International Criminal Court, 2011, p. 30.

160 Fairness at the International Criminal Court, 2011, p. 30.

161 Fairness at the International Criminal Court, 2011, p. 30.

162 Fairness at the International Criminal Court, 2011, p. 30, referring to Fulford, 2011. 
differently, not as an equivalent of a public defender's office per se, but more as behind the scenes support and not as replacing defence counsel. ${ }^{163}$ Thus, next to representing the interests of the defence during the investigation stage, the OPCD focused on strengthening institutional knowledge for the benefit of the defence through conducting research and providing legal advice to different defence teams. Moreover, the OPCD has been "advocating to the general interests of the defence in connection with internal and external policies and agreements." 164 Judge Fulford, who initiated the creation of the OPCD, stated that it is "wholly uncertain whether this sufficiently justifies the costs involved." 165

\subsubsection{ECCC}

Although this court has been plagued by institutional corruption allegations and political interference, strikingly, the Defence Support Section (DSS) established the Office of Administration, which generated much content among the defence teams for their institutional independence and material support provided to the defence at the ECCC. ${ }^{166}$ The DSS is responsible for defence counsel lists, for providing legal and administrative support including payments fees. Moreover, the DSS represents the defence in outreach programs, provides training courses to staff, conducts legal research and analysis. ${ }^{167}$

\subsubsection{STL}

To ensure equality of arms, the first independent defence office as a separate organ of the court was established at the Special Tribunal for Lebanon in 2007. ${ }^{168}$ The Defence Office intends to provide support and assistance to the defence teams practising before the STL. The Head of the Defence Office (Rule 57 F) "at the request of the Pre-Trial Judge, a Chamber, the Registrar, the Defence or where the interests of justice so require, proprio motu, shall have rights of audience in relation to matters of general interest to defence teams, the fairness of the proceedings or the rights of a suspect or accused ..." 169 In September 2011, the Defence Office published the

163 Fairness at the International Criminal Court, 2011, p. 30.

164 Fairness at the International Criminal Court, 2011, p. 30.

165 FulFord, 2011, p. 222.

166 Generally positive attitude towards the operation of the Defence Support Section was experienced (trough formal and informal interviews) during the research visit at the ECCC conducted in November 2009.

$167 \mathrm{http}: / / w w w . e c c c . g o v \cdot k h / \mathrm{en} / \mathrm{dss} /$ defence-support-section-dss.

168 UN Security Council, Report of the Secretary-General on the establishment of a special tribunal for Lebanon, UN Doc. S/2006/893, 15 November 2006, par. 30.

169 STL, Practice Direction on the Role of the Head of Defence Office in Proceedings before the Tribunal, Issued by the President, Antonio Cassese, STLIPO/20 11104, 30 March 2011, par. 1. 
Defence Counsel List and Adopted its Legal Aid Policy. ${ }^{170}$ Particular emphasis in this policy is placed on the right of the defence to equality of arms, which is implemented through paying the defence counsel the equivalent net salary to senior trial attorneys for the prosecution. ${ }^{171}$

\subsection{LEGAL AID AND SELF-REPRESENTATION: TO HAVE ONE'S CAKE AND TO EAT IT TOO?}

In the framework of the ad hoc tribunals, no arrangements were made concerning legal aid for indigent accused who choose not to be represented by legal counsel. To date, several accused before the ICTY have chosen to represent themselves; ${ }^{172}$ this practice, however, has brought an immensurable amount of problems and challenges to the fore. In Milošević, self-representation caused tensions within the parameters of the expeditiousness of the proceedings and the right to have adequate time and facilities to prepare and present one's case. In addition, the right to be present at trial had to be qualified albeit first and foremost in relation to medical problems, while in Šešelj it was the obstructionist behaviour of the self-representing accused which caused problems in that regard. In Krajišnik the issue of self-representation on appeal had to be addressed for the first time. And Karadžić cumulates the previous developments, attitudes and challenges concerning self-representation in a case of extreme proportions, with one of 'the biggest fishes' for accused who seems rather up to the challenge of representing himself in Court that is plagued by the imposed Completion Strategy and retrieving financial and personnel resources. ${ }^{173}$

The issue of legal aid and self-representation first arose in the $\breve{S}$ ešelj case where the pre-trial Judge examined defendant's request legal aid in light of his indigency. ${ }^{174}$ In a detailed discussion of the issue, the Pre-Trial Judge "established the principle of the absolute need to constitute a team in order to assist the Accused, who has

170 http://www.stl-tsl.org/en/about-the-stl/structure-of-the-stl/defence.

$171 \mathrm{http}: / /$ www.stl-tsl.org/en/about-the-stl/structure-of-the-stl/defence: "Each accused, presumed innocent until proven guilty, has the right to equality of arms. In this respect, a fair trial requires that sufficient resources be provided to the Defence so as not to place them at a procedural disadvantage vis-à-vis the Prosecution with regard to the preparation and presentation of their case. The Legal Aid Policy seeks to effectively implement this right by paying defence counsel the equivalent net salary of that accorded to a senior trial attorney for the Prosecution, and by making available to the defence counsel adequate human and financial resources."

172 Milošević, Šešelj, Krajišnik, Karadžić and Tolimir.

173 An in-depth discussion of the challeges associated with self-representing accused is not intended, and the focus of this section is on how ICTY has approached the problem of legal aid and selfrepresenting accused. For a general overview of self-representation before international criminal tribunals, see Boas et. Al., 2011, pp. 156-163; Kay and Higgins, 2010; Scharf, 2006; Jørgensen, 2006; TEMMINCK Tuinstra, 2006;

174 ICTY, Prosecutor v. Šešelj, Decision on the Financing the Defence of the Accused, IT-03-67-PT, 30 July 2007 [Šešelj Financing Defence Decision, 30 July 2007]. 
chosen to represent himself, in the preparation and presentation of his defence." 175 It is, thus, "incumbent upon the Registry to take the specific steps to apply the principle after pre-trial Judge has recalled certain guidelines." 176 These guidelines include the requirement for the accused to cooperate fully with the Registrar in the investigation establishing accused's indigency; the legal associates the accused wants to work with must (at east one person) possess the qualifications required under Rule 45 ICTY RPE; and the Registrar is expected to "set, depending on the resources of the Tribunal, the reasonable and necessary amounts to be allocated to the Accused for the preparation and presentation of his defence." 177

In coming to this conclusion, the pre-trial judge elaborated on the underlying rights and principles, by looking at the judge's duty to ensure a fair trial, equality of arms and the proper administration of justice. Due to accused's detention situation and thus, impossibility to conduct on-site investigations, a defence team should be constituted for the purpose of ensuring the fairness of the proceedings. Although the principle of equality of arms does not envision equality of resources, it would be "inconceivable" in the eyes of the pre-trial judge, "that the financial situation of an accused should result in an inequality of arms." ${ }^{178}$ Interestingly, the judge considered that "in order to restore balance to the situation of a self-represented accused and to guarantee him 'procedural equality', it may be necessary to grant him more facilities and financial resources than to those afforded to an accused who is represented by counsel." "179 The pre-trial judge seems to apply the principle of equality of arms between represented and self-represented accused rather than the latter and the prosecution. Moreover, it does not become clear why a self-representing indigent accused would be entitled to more resources than a represented one. In any case, as will be seen later, the Appeals Chamber did not go this way of possibly providing for more facilities to an self-representing accused than to those accused represented by a counsel; rather the opposite is true. Lastly, the pre-trial judge agreed with the Registrar that a self-representing accused, by choosing so, "accepts at a minimum the burden of drafting his submissions, as he has stated that he is qualified to carry our these tasks." 180 However, the written submissions that were drafted by the legal assistants were clearly much better than those filled by the accused; thus, according to the Judge, the interests of proper administration of justice demand that the legal associates, "who undeniably play a positive role in his defence, may be decently paid

175 Šešelj Financing Defence Decision, 30 July 2007, par. 56.

176 Šešelj Financing Defence Decision, 30 July 2007, par. 56.

177 Ššelj Financing Defence Decision, 30 July 2007, paras. 56, 59, 60, 63.

178 Šešelj Financing Defence Decision, 30 July 2007, par. 52.

179 Šešelj Financing Defence Decision, 30 July 2007, par. 52.

180 Šešelj Financing Defence Decision, 30 July 2007, par. 55. 
for the services they perform." ${ }^{181}$ Before any further action was taken in this case, the Appeals Chamber issued an important decision on the issue.

In Krajišnik the problem arose on appeal. The Appeals Chamber considered that Article 21(4)(d) ICTY Statute does not provide for legal aid to a self-represented accused. According to the Appeals Chamber, the option to defend oneself stands in "binary opposition" with the option to have legal assistance for representation. ${ }^{182}$ It amounts to an 'either or' choice, and consequently, the subsidiary right of legal aid in case of indigence is not applicable when the accused chooses to represent himself. The Appeals Chamber, furthermore, did not accept the accused's contention that the principles of equality and fair trial (Article 21(1) and 21(2) ICTY Statute) provide an indigent self-representing accused with funded legal aid. By making the choice for self-representation the accused accepts any disadvantages that this choice may bring, in this respect no legal aid on an equal footing with other represented accused. ${ }^{183}$ To decide otherwise, and, thus, to provide full legal aid to a self-represented accused, would "let him have his cake and eat it too." 184

However, to avoid any perception of injustice, the Appeals Chamber sought another solution to the problem. Although the reference to "facilities" in Article 21(4)(b) ICTY Statute does not normally cover legal aid, ${ }^{185}$ the Appeals Chamber considered it appropriate to provide some funding for legal assistance to the extent the registry "requires or encourages indigent self-representing accused to coordinate their defences through designated legal associates" by way of giving effect to Article 21(4)(b). ${ }^{186}$ This reimbursement of legal associates for their coordinating work and for related legal consultation, while not comparable to that of represented accused, was thought nevertheless to be adequate. ${ }^{187}$ In this light, to have 24 -hour access to a telephone, scanner, fax, and photocopier in the UNDU (in a case of self-representing accused) "goes far beyond what is necessary to ensure the provision of adequate facilities." ${ }^{88}$ Consequently, the registrar created a policy for financial support for self-

181 Šešelj Financing Defence Decision, 30 July 2007, par. 55.

182 ICTY, Prosecutor v. Krajišnik, Decision on Krajišnik's Request and on Prosecution Motion, IT-0039-A, A. Ch., 11 September 2007, par. 40 [footnote reference omitted].

183 ICTY, Prosecutor v. Krajišnik, Decision on Krajišnik's Request and on Prosecution Motion, IT-0039-A, A. Ch., 11 September 2007, par. 41.

184 ICTY, Prosecutor v. Krajišnik, Decision on Krajišnik's Request and on Prosecution Motion, IT-0039-A, A. Ch., 11 September 2007, par. 41.

185 Cf. Prosecutor v. Milutinović et al., Decision on Interlocutory Appeal on Motion for Additional Funds, Dissenting Opinion of Judge Hunt, IT-99-37-AR73.2, A. Ch., 13 November 2003, par. 24: "The reference in Article 21(4)(b) to facilities is not a reference to legal aid, as that issue is dealt with independently in Article 21(4)(d) ...".

186 ICTY, Prosecutor v. Krajišnik, Decision on Krajišnik's Request and on Prosecution Motion, IT-0039-A, A. Ch., 11 September 2007, par. 42.

187 ICTY, Prosecutor v. Krajišnik, Decision on Krajišnik's Request and on Prosecution Motion, IT-0039-A, A. Ch., 11 September 2007, par. 42.

188 ICTY, Prosecutor v. Krajišnik, Decision on Krajišnik’s Request and on Prosecution Motion, IT-00- 
representing accused. The remuneration scheme provides for funding to detained selfrepresented accused who are found to be indigent or partially indigent are eligible for remuneration of their defence teams by the Tribunal. ${ }^{189}$ The scheme does not provide for a lump-sum payment system, but is rather "based on a maximum allocation of hours to the accused's support team depending on the stage of the proceedings and the complexity of the case." ${ }^{\prime 190}$ The defence team members can exist out of a legal associate, a case manager, investigator, and language assistant. ${ }^{191}$

While the issue of financial support for self-representing accused seemed to be settled in general, in Šešelj, the issue of accused's indigency remained unresolved. ${ }^{192}$ Consequently, the Trial Chamber decided to assign a funding opportunity (up to $50 \%$ ) to the self-representing defendant proprio motu in anticipation of the registrar's decision on his indigence. Considering the long detention of the accused (eight years), the Tribunal's Completion Strategy and the interest of justice, the Chamber, being responsible for expeditious proceedings, did "not allow the matter of funding the Accused's defence to have a negative impact upon the status of the proceedings or to slow the progress of the trial." 193

Where the Appeals Chamber has shut the door on relying on the right to legal assistance (Art. 21(4)(d) ICTY Statute) by an accused who chooses to represent himself, it opened a window in Article 21(4)(b) for the self-represented accused to have an entitlement a limited financial support, not being legal aid. While from the perspective of equality of arms, and in light of the specificities of international criminal proceedings, this approach can be justified and applauded, the reasoning behind both the decision of the pre-trial judge and the Appeals Chamber, although opposed, both seem inadequate. ${ }^{194}$ While calling the right to self-representation an "indispensable cornerstone of justice," 195 confronted with the many obstacles this cornerstone provides, the Appeals Chamber seems rather willing to discourage the

39-A, A. Ch., 11 September 2007, par. 42.

189 Remuneration Scheme for Persons Assisting Indigent Self-Represented Accused, application since 1 April 2010, Section A, http:/www.icty.org/x/file/About/Defence/self_rep_remuneration_scheme_ may2010.pdf.

190 Funding for self-represenbted accused, http://www.icty.org/sid/163.

191 Remuneration Scheme for Persons Assisting Indigent Self-Represented Accused, application since 1 April 2010, Section B(2) http://www.icty.org/x/file/About/Defence/self_rep_remuneration_scheme may2010.pdf. Upon a reasoned request the registrar may assign expert(s), see section B(5).

192 Š ešelj refused to cooperate any further with the Registrar on establishing his indigency. ICTY, Prosecutor v. Šešelj, Decision on Implementing the Financing of the Accused, IT-03-67-PT, T. Ch., 30 October 2007; ICTY, Prosecutor v. Šešelj, Decision on Financing of Accused's Defence, IT-0367-PT, T. Ch., 23 April 2009.

193 ICTY, Prosecutor v. Šešelj, Redacted Version of Decision on Financing of Defence, Filed on 29 October 2010, IT-03-67-T, T. Ch. III, 2 November 2010, paras. 26-27.

194 For a very critical discussion See SLUITER 2007, ZAHAR 2008.

195 ICTY, Prosecutor v. Milošević, Decision on Interlocutory Appeal of the Trial Chamber's Decision on the Assignment of Defence Counsel, IT-02-54-A, A. Ch., 1 November 2004, par. 11. 
defendants from picking up this stone by limiting their financial privileges (through the 'either-or' reasoning). The question remains who is to bear the consequences of accused's choices that might undermine a fair trial, when the accused is determined to conduct his own defence in circumstances where he does not rise to the challenge. Although unsatisfyingly reasoned, the pragmatic decision of the Appeals Chamber clearly tries to accommodate a middle road, a compromise between the interests involved. From the perspective of equality of arms and in light of the complexity of the cases and proceedings before the international tribunal, it is only fortunate that the Appeals Chamber did not stop after its first, very principled, consideration that appeal to self-representation automatically implies a waiver of the right to have legal assistance with the provision of financial aid.

\subsection{OTHER FACILITIES}

A very practical application of equality of arms is illustrated by the decision of the ICTY Trial Chamber in the case of Prlic et al. ${ }^{196}$ where the Trial Chamber rejected the request of the accused for an authorization to use his laptop computer at hearings or, alternatively, to be seated next to his defence in the courtroom. The Chamber referred to security reasons [confidential information, the protection of witnesses] advanced by the registrar against the use of a laptop computer by the accused during hearings. The accused had a laptop at the Detention unit and his lawyer in the courtroom, and so the Chamber reasoned that there was no need for the accused to have a laptop in the courtroom. To give more weight to its consideration, the Chamber referred to the principle of equality of arms that as "set out in Article 21(4) of the Statute requires that the parties to the trial must be able to present their case without a manifest disadvantage." However, this principle must not be taken literally "as evidenced by the fact that a person accused before the Tribunal is presumed innocent whereas the prosecution must prove that person's guilt beyond all reasonable doubt." Thus, the Chamber concluded that equality of arms did not require the same financial or technical resources, and "therefore ... the right of the Accused set out in Article 21(4)(b) of the Statute and the principle of equality of arms have been respected and that there is no reason to grant the first request of the Accused [the use of a laptop]." 197

Although the Chamber did make a concise reference to the different roles of the parties to the proceedings, its justification for the decision with reference to the nonliteral application of equality of arms is not entirely convincing. Because equality of arms cannot be taken literally, the prosecutor's right to have a computer in the

196 ICTY, Prosecutor v. Prlić et al., Decision on the Oral Request of the Accused Jadranko Prlić for Authorization to use a Laptop Computer at Hearing or to be seated next to his Counsel, IT-04-74-T, T. Ch. III, 29 June 2006 [Prlić et al. Decision on the Use of a Laptop, 29 June 2006].

197 Prlić et al. Decision on the Use of a Laptop, 29 June 2006, p. 4. 
courtroom does not have to be counterbalanced by the same right of the accused. But, if the lawyer representing the accused has a computer, does that mean that the principle of equality of arms is respected (implying literally the same facilities)? The more principled issue concerns the right of an accused to communicate freely with his lawyer. By denying the second request to be seated next to his lawyer, the Chamber touched upon this right in the sense that it advised the accused to communicate with his counsel through written notes.

The presiding judge, Judge Antonetti, in his dissenting opinion exposed the problematic core of this decision: "[a]lthough new technologies for the exercise of the rights of the defence are available at the Tribunal, at present, the accused do not enjoy them in the courtroom." ${ }^{198}$ In his deliberations, he emphasized the nonexhaustive nature of Article 21(4) and argued that "if necessary, in the name of the principle of equality of arms, and consequently, of a fair trial, the Judges must add guarantees which the Statute does not mention in order to adjust the balance, if so required, between the resources available to the parties." 199 He shared the opinion advanced by Judge Vohrah in the Tadić case "that the right to equality of arms is more generally a right of the accused because the Judges must ensure that the person being prosecuted, who is the most vulnerable person at the trial, is not disadvantaged in the conduct of his defence." 200

It is clear that the practical reasons and obstacles have obscured the more fundamental issues in this decision to some extent. The Trial Chamber took over the registrar's indication of security risks. Moreover, the configuration of the courtroom did not allow for the six accused to sit next to their lawyers. These are both valid and important practical considerations. However, the accused intended to use the laptop to facilitate making his own references during the presentation of his case by his counsel in order to facilitate his case presentation as much as possible. ${ }^{201}$ This consideration touches upon the implementation of the rights of the accused. As reflected upon in Chapter 3, the practical considerations cannot assume the same weight as the considerations of principle when it comes to balancing the various

198 ICTY, Prosecutor v. Prlić et al., Dissenting Opinion of Judge Jean-Claude Antonetti, Presiding Judge of the Trial Chamber, Concerning the Decision on the Oral Request of the Accused Jadranko Prlić for Authorization to use a Laptop Computer at Hearing or to be seated next to his Counsel, IT04-74-T, T. Ch. III, 29 June 2006, par. 14 [Prlić et al. Dissenting Opinion to Decision on the Use of a Laptop, 29 June 2006].

199 Prlić et al. Dissenting Opinion to Decision on the Use of a Laptop, 29 June 2006, par. 6.

200 Prlić et al. Dissenting Opinion to Decision on the Use of a Laptop, 29 June 2006, par. 9.

201 Hearing Transcript, 4 May 2006, p. 1216: "The idea was that we would bring it in every day for Mr Prlić to use. At the end of the day, he would burn the CD of what he had typed so he could take it and download it in the computer that is provided to him at the UNDU. We would take the computer back, the laptop back every day. That way there is no security risk whatsoever. Then Mr Prlić, if he has any notes from the night before, he would bring the $\mathrm{CD}$, we would then download that material and that way we could have his input since we don't have e-mail". 
interests involved. In this light, principled considerations, at a minimum, require explicit justifying reasoning from the decision-maker.

With regard to this consideration, another decision in the same case is interesting to consider. One accused complained of a too rigid limitation of the translation services. The accused referred to the principle of equality of arms by arguing that the evaluation of his need to translation services must proceed against the background of "the extremely broad, complicated and amorphous indictment to which the Accused must respond within an extremely limited period of time." ${ }^{202}$ Moreover, he also argued that a similar "procedural bar" was not imposed upon the prosecution as he "does not have to prove the worth of its evidence before being able to receive facilities for translation." 203

The Appeals Chamber considered that the accused had misunderstood the principle of equality of arms. According to the Chamber "equality of arms does not mean equality of resources, but rather that each party must have a reasonable opportunity to defend its interest under conditions which do not place him at a substantial disadvantage vis-à-vis his opponent." ${ }^{204}$ The Appeals Chamber was "not persuaded that the 1500 standard United Nations pages limitation on additional translation resources places Prljak at a disadvantage vis-à-vis the Prosecution such as to violate this principle." ${ }^{205}$ However, the Appeals Camber did emphasise that it is important for the Trial Chamber, when limiting the translation pages by 1500 pages, to explicitly consider whether the accused still has an opportunity to effectively present his case, while it would not be appropriate to limit his translation resources only on the basis of capacity restraints. ${ }^{206}$ In other words, practical considerations alone cannot negate a principled argument. Why the Appeals Chamber did not refer to the two-pronged test for equality of arms as developed in Oric (basic proportionality and objective adequacy) is unclear. In fact, the accused seems to have been referring to the test of basic proportionality, rather than misunderstanding that equality of arms does not imply that the prosecution must also be subjected to the same translation limitation.

At the ICC, an interesting decision on equality of arms and practicalities of a trial setting has been issued in the Lubanga case. There the defence complained about the unavailability of real life transcripts in French during hearings, which situation "placed it at a significant disadvantage vis-à-vis the prosecution, violating Article 67(1)(f) of

202 ICTY, Prosecutor v. Prlić et al., Decision on Slobodan Praljak's Appeal of the Trial Chamber's 13 October 2008 Order Limiting the Translation of Defence Evidence, IT-04-74-AR.73.12, 5 December 2008, par. 29 [Prlić et al. Decision on Translation, 5 December 2008].

203 Prlić et al. Decision on Translation, 5 December 2008, par. 29 [footnote omitted].

204 Prlić et al. Decision on Translation, 5 December 2008, footnote 86: "Decision of 4 September 2008, para. 29, and the references cited therein."

205 Prlić et al. Decision on Translation, 5 December 2008, par. 30.

206 Prlić et al. Decision on Translation, 5 December 2008, par. 22. 
the Statute" ${ }^{207}$ The Chamber considered that Article 67 encompasses the principle of equality of arms; and reasoned that:

This provision (and in particular the phrase "in full equality") suggests that the minimum guarantees must be generously interpreted, so as to ensure the defence is placed insofar as possible on an equal footing with the prosecution, in order to protect fully the right of the accused to a fair trial. [...] An assessment of the adequacy of the facilities for the defence will clearly be influenced by the extent of those at the disposal of the prosecution, since it will in general be necessary and desirable to rectify significant disparities. However, a fact-sensitive evaluation will be required whenever unfairness is alleged, since it will be impossible to create a situation of absolute equality of arms. ${ }^{208}$

Without referencing the two-pronged test for the application of equality of arms introduced in the Orić case (reasonable proportionality and objective adequacy), ${ }^{209}$ the Trial Chamber's reasoning is clearly comparable: the defence should have adequate facilities, which should be proportional to those of the prosecution. Importantly, the ICC Trial Chamber seems to have merged the two prongs of the Orić-test, when incorporating the comparative element into the assessment of 'adequacy' of the facilities. However, the reasoning seems to limit the application of this comparative element to situations whenever 'unfairness is alleged' that follows from 'significant disparities' between defence's and prosecution's facilities.

\subsection{Concluding Remarks}

This chapter considered more in-depth defence challenges to the adequacy of resources and facilities provided by international criminal courts, in light of equality of arms. Clearly an afterthought at the creation of the ICTY, the defence has struggled for recognition and improved financial and institutional support. Framing their arguments in terms of equality of arms, many defence teams have challenged the resources provided, often with reference to the legal aid arrangements. However, all international criminal tribunals have consistently declined to make a direct comparison between the financial, technical or personnel resources of the prosecution and the defence. $^{210}$ The arguments advanced by the defence and based on the connection

207 ICC, Prosecutor v. Lubanga Dyilo, Decision on defence's request to obtain simultaneous French transcripts, ICC-01/04-01/06-1091, 14 December 2007, par. 10 [Lubanga Decision on Real Life Transcripts, 14 December 2007].

208 Lubanga Decision on Real Life Transcripts, 14 December 2007, par. 18-19.

209 ICTY, Prosecutor v. Orić, Interlocutory Decision on Length of Defence Case, IT-03-68-AR73.2, A. Ch., 20 July 2005.

210 ICTY, Prosecutor v. Tolimir, Decision on the Accused's Information and Requests for the Trial Chamber, IT-05-88/2-T, T. Ch. I, 4 March 2010, par. 14: “The Trial Chamber considers that it would 
between equality of arms and inadequacy of resources have not been accepted by the Chambers. Although all the institutional developments for the support of the defence have been framed in terms of supporting equality of arms, the case law is governed by a rather whimsical application of this principle. The judges have taken over the Kayishema and Ruzindana case reference to the non-literal application of equality of arms: it does not imply equality of means or resources. Thus, the scope of application of equality of arms in this area is rather limited; in fact, this principle seems to have no independent meaning in the context of defence's challenges of inequality in relation to financial means and resources.

However, in light of the rhetoric advanced in relation to other issues, such as the time available for case presentation at trial, where a rather literal, almost mathematical understanding of equality of arms governs, the defence's reference to equality of arms is understandable. And indeed, 'maintaining equilibrium' between the prosecution and the defence has been taken quite literally in legal aid arrangements, where the salaries of prosecution and defence counsel have been equalized. Also, it has been argued that at least an "approximate equality in financial terms" is needed to vindicate equality of arms. ${ }^{211}$ Although this approach does seem to appease the rhetoric of inequality of arms, it, in fact, says little about a defence's ability to adequately prepare for trial. On the contrary, this rather mathematical approach to equality of arms might actually distort the understanding of that principle. By providing a superficial satisfying perception, it diverts attention from the more underlying issues that need a (principled) resolution. This attention is much needed in the judges' approach to understanding equality of arms, also within the realm of financial and institutional resources.

be inappropriate to grant the Accused's request for information on the staffing levels and the allocation of funds to the Prosecution team. The Trial Chamber in Prosecutor v. Naletilić and Martinović held that even though it was apparent that the parties did not have identical amounts of time and resources with which to prepare their respective cases, the real issue was not whether they had equal time and facilities but whether either party, and in particular the Accused, was at a disadvantage when presenting its case. The Trial Chamber does not consider that in the circumstances of the instant case the Accused has been disadvantaged in the time and resources available to him with the result that he will not be able adequately to present his case. The information sought by the Accused on the resources of the Prosecution will not be of assistance to him and the Trial Chamber, therefore, does not deem it appropriate that it be provided."

211 KNOOPS, 2005, p. 1587, referring to MAY AND WIERDA, 2002. 


\section{Chapter 7 \\ Case Presentation}

\subsection{INTRODUCTION}

This chapter focuses on the trial phase in international criminal proceedings and purports to delineate the way judges have interpreted and applied the principle of equality of arms in that context. In this phase, the parties assume their most adversary roles and present their view of events before the panel of judges. Except for the ECCC, all the other international criminal tribunals have chosen for a case presentation scheme that is more aligned with an 'adversarial' mode of proceedings whereby the presentation of evidence is structured primarily as two cases. In this setting, the prosecutor presents his case first, (followed by victims if permitted by the relevant court), and then the defence may present its case if it chooses to do so. On the face of it, the parties seem most equal in this phase of the proceedings, considering that both must be given an equal opportunity to present their version of events. As mentioned in Chapter 4, the procedures of the ad hoc tribunals have evolved steadily, providing for a more active and controlling role for the judges in the area of case preparation and presentation. As a consequence of the 'two-case' approach preferred by the international criminal courts, the case of the prosecutor, which is presented first, stands as an example for the case of the defence. As such, the limits set by the judges on the prosecution's case directly affect the case of the defence from the perspective of equality of arms. Several measures have been taken to expedite the proceedings that are inherently protracted, some of which have exposed fundamental challenges to and tensions between 'expeditiousness' and 'fairness'; rights of the accused and rights of the prosecutor and participating victims. ${ }^{1}$ This chapter purports to trace these challenges and tensions and to evaluate to what extent the interpretation and application of equality of arms have effectively promoted the fairness of the trial proceedings.

1 ICTY, Prosecutor v. Prlić et al., Decision on Adoption of New Measures to Bring the Trial To an End Within a Reasonable Time, IT-04-74-T, 13 November 2006, par. 14: "Furthermore, the Chamber holds that the Accused are not the only ones to have the right to an expeditious trial and, consequently, cannot renounce it." 


\subsection{Shaping The CASE BEFORE TRIAL}

Chapters 4 and 5 have already touched upon the power of the judges with regard to shaping the case pre-trial: limits upon indictments and managing disclosure. Before discussing the modes of evidence presentation at trial, this chapter will examine the way the judges have used their power to determine the scope and length of prosecution and defence cases just before or during trial. These managerial powers of the judges that were incurred as part of the development of the procedures towards more efficient and speedy trial control the scope and length of the parties' case presentation. In addition, they control the triangular relationship between the judges, the prosecution and the defence. It is, thus, important to investigate how 'equality of arms' has been interpreted and applied in this context.

\subsubsection{ICTY, ICTR and SCSL: Pre-Trial and Pre-Defence Conferences}

As mentioned, soon after the ad hoc tribunals were fully functioning, the judges were forced to reconcile the procedure with the realities of war crimes trials: the complexity of the cases, the magnitude of the potential evidence, and the consequential prolongation of the proceedings. Status conferences, ${ }^{2}$ pre-trial Judges, ${ }^{3}$ pre-trial and pre-defence conferences ${ }^{4}$ were institutionalized. ${ }^{5}$ The pre-trial process "culminates in a pre-trial conference" ${ }^{\prime \prime}$ usually held on the eve of the trial. ${ }^{7}$ The Pre-Trial Conference constitutes the single most important event before the trial proceedings start; it determines, in large part, the scope and time allotted to the prosecution's case, which in turn benchmarks the defence case (pre-defence Conference). ${ }^{8}$ The importance of Rule 73bis and Rule 73ter ICTY RPE witness lists is emphasized by ICTY Rule 90(G)

2 Rule 65bis ICTY, ICTR and SCSL RPE.

3 Only at the ICTY, Rule 65ter ICTY RPE. The ICTR and the inheritor of its Rules, the SCSL, did not introduce a Pre-Trial Judge officially, but the functions of pre-trial management were fulfilled by a designated Judge, often the President of the relevant Trial Chamber.

4 Rule 73 bis and 73ter ICTY, ICTR, SCSL RPE.

5 Before these figures, the pre-trial management was limited to the confirmation of indictments.

6 BONOMY, 2007, p. 354.

7 ICTY MANUAL, 2009, p. 60, par. 29.

8 See ICTY Completion Strategy Report, Annex I, Assessment and Report of Judge Fausto Pocar, President of the International Criminal Tribunal for the Former Yugoslavia, Provided to the Security Council Pursuant to Paragraph 6 of Council Resolution 1534 (2004), S/2006,353, 31 May 2006, par. 28: "I now turn to a second important series of proposals made by the Working Group on Speeding Up Trials, which have been implemented by the Judges. The International Tribunal has long been aware that the length of its trials also depends on the complexity and breadth of the indictments. The philosophy behind the Prosecution's pleading practices is its obligation to victims. In practice, the length of the Prosecution case has meant that in order to accord the accused due process, Judges have had to allocate a comparable amount of time to the Defence case. The solution for the Judges, therefore, is to limit the length of the Prosecution's case to require the Prosecution to focus at trial on the strongest part of its case. This in turn will lead to a shorter Defence case." 
which authorizes the Trial Chamber to refuse to hear a witness whose name is not included on the pre-trial witness lists. These two conferences constitute the primary focus of this section. The following overview and discussion focus mostly on the ICTY because the judges' pre-trial management of the cases has been far more robust and proactive compared to the ICTR and SCSL, both in law and litigation. ${ }^{9}$

\subsubsection{Pre-trial conference}

As stated, the pre-trial conference is of paramount importance for the actual conduct of the trial because is delimitates, to an important extent, its scope and length. ${ }^{10}$ The pretrial conference serves as a tool for controlling the extent to which the prosecution's case is trial-ready, to prevent an excessive and unnecessary consumption of time by the prosecution and to ensure that only those issues that are disputed and necessary for the determination of the case are litigated. ${ }^{11}$ According to Rule 73bis ICTY RPE, the Trial Chamber may call upon the prosecutor to shorten the estimated length of the examination-in-chief for some witnesses and determine the number of witnesses the

9 Exemplary is the power of the ICTY Trial Chamber to direct the prosecutor to select the counts in the indictment on which to proceed (absent from ICTR and SCSL). Moreover, Rule 73bis directs the judges to determine the number of witnesses and the time available to the prosecution for its case presentation at the Pre-Trial Conference, while the pre-trial collection of parties' filings and communications is effectuated before the Pre-Trial Conference (Rule 65ter ICTY RPE). At the ICTR, this latter collection is intended to be made at the Pre-Trial Conference (Rule 73bis(B)). The SCSL judges can order the prosecutor to make the pre-trial filings before the Pre-Trial Conference (Rule 73bis(B) SCSL RPE). Moreover, Rule 73 bis $(\mathrm{G})$ SCSL PRE, which authorizes the Trial Chamber to invite the prosecution to reduce the number of counts charged and determine the number of sites or incidents comprised in charges, was introduced in 2006, and makes it relevant for the last Taylor case. In this case, the Trial Chamber did not impose any managerial fetters on the prosecution case. Interestingly, when the prosecution sought an order from to Trial Chamber to impose an "end date" for the Defence case, which was then ongoing, the Trial Chamber denied the request reasoning it "would not serve either the interest of justice nor the importance of a fair trial." SCSL, Prosecutor v. Taylor, Decision on Prosecution Request for Orders in Relation to the Scheduling of the Remainder of the Case, SCSL-03-1-T, 29 March 2010, p. 7. The Trial Chamber considered that the defence had acted in good faith with regard to the presentation of its case and had not caused any undue delay; that the prosecution "significantly contributed to lengthening the trial proceedings by introducing a large number of documents containing "fresh evidence" after the close of its case-in-chief; and that from February 2010 onwards the Chamber was sitting a reduced number of hours resulting from having to share the courtroom with the ICC (Id. p. 6).

10 Bonomy, 2007, p. 354. More generally on the development of Rule 73bis see Higgins, 2009.

11 ICTY, Prosecutor v. Halilović, Decision on Defence Appeal for the Pre-Trial Conference to be Postponed, IT-01-48-PT, T. Ch. I, 4 July 2003, p. 2: "that one of the primary purposes of the pre-trial conference to be held under Rule 73 bis of the Rules of Procedure and Evidence of the International Tribunal ("Rules") is to ensure that the Prosecution's case is ready for trial and where possible, to schedule the commencement of trial after taking into consideration the reasonable requirements of the Defence." ICTY, Prosecutor v. Perišić, Decision on Application of Rule 73 bis and Amendment of Indictment, IT-04-81-PT, T. Ch. III, 15 May 2007, par. 9. The Pre-Trial Conference allows the Trial Chamber "to address any last-minute issues on the even of trial." See ICTY MANUAL, 2009, p. 60 , par. 29. 
prosecutor may call and the time available to the prosecutor for presenting evidence; may invite the prosecutor to reduce the number of counts charged in the indictment and may fix a number of crime sites or incidents comprised in one or more of the charges in respect to which evidence may be presented; and may direct the prosecutor to select the counts in the indictment on which to proceed. ${ }^{12}$ The rule was introduced in 1998, and was amended on several occasions in 1999, 2001, 2003 and 2006, gradually expanding the pre-trial management powers of the judges. ${ }^{13}$

The practice under this rule, although somewhat hesitant in the beginning, was expanded with the protraction of trials. The prosecutor was not too pleased with the judge's power to control his case, and felt it intruded upon his independence, discretionary power and authority. ${ }^{14}$ Three reasons have been mentioned for the prosecutor's unwilling attitude to voluntarily reduce the number of charges in the indictment: (1) denying justice to victims by indictments that do not represent the complete range of harms suffered; (2) less than comprehensive charges would not lay out the whole truth of what happened thus impeding reconciliation in the affected region; and (3) by including more charges and more modes of responsibility the prosecution increases the possibility of a conviction. ${ }^{15}$ All these reasons are hardly unreasonable or difficult to understand. Another important consideration is the 'adversarial' setting chosen for the conduct of trials. As considered by Judge Bonomy, "A fundamental difficulty that will continue to pose problems for the conduct of large complex trials in the international arena" is "the adoption of an adversarial format for the proceedings." 16 To be able to discharge the burden of proving the case beyond a reasonable doubt, the prosecution needs the power and authority to present its case as

12 ICTY MANUAL, 2009, p. 60, par. 30: "The judge that conducts the Pre-Trial Conference has discretion to ask the Prosecution to shorten the length of examination for some witnesses, to determine the number of witnesses the Prosecution may call, and to regulate the time available to the Prosecution for presentation of its evidence."

13 See ICTT RPE, IT/32/Rev.45, 8 December 2010.

14 ICTY Completion Strategy Report, Annex II, Assessment of Carla Del Ponte, Prosecutor of the International Criminal Tribunal for the Former Yugoslavia, Provided to the Security Council Pursuant to Paragraph 6 of Security Council Resolution 1534, S/2006,353, 31 May 2006, par. 26: "The third and final leg of the strategy is to take all possible remaining steps to ensure that the Tribunal's own process is as efficient as possible without taking shortcuts that would render prosecutions unfair, and without cutting corners that would place at risk prosecutions for crimes such as genocide and crimes against humanity, which are by their very nature extensive undertakings. The Prosecutor considers that the breadth of remaining indictments cannot be further reduced without beginning to imperil the prospects of their successful prosecution. She regards the decision not to proceed with any count on a confirmed indictment as being within her exclusive authority, but, especially having regard to the interests of victims, she would not consider it to be a proper exercise of her discretion to reduce the scope of an indictment for reasons simply of lack of time, and in the absence of any reason connected to the merits of the case or the availability of evidence."

15 Kwon, 2007, p. 373.

16 Bonomy, 2007, p. 348. 
"it deems fit (absent a demonstration of abuse)." "Thus, "[t]he proper use of the Rule [73bis] requires a comprehensive and intimate understanding of the prosecution's case," 18 which could not always be obtained by the usually rather late involvement of the trial judges in the case. ${ }^{19}$ Overall, the 'making an offer one cannot refuse' method adopted by the judges in relation to the limitation of the prosecution's case seems rather apt. ${ }^{20}$ The judges 'invite' the prosecution to limit its case first. Considering the scope of victimology and the resources spent on investigations, the prosecutor cannot but express his discomfort with limiting the case and thus decline this 'invitation'. However, having in mind the judge's power of a final say in determining the scope and time schedule for the prosecution's case, the prosecution determines the most appropriate ways in which the case could be limited. The judges then accept this proposal. As such, the prosecution is not 'losing' face before the affected communities and victims, and the judges control the proceedings without having the intimate knowledge of the case as, for example, an investigative judge would have. Hereunder follows a discussion of the relevant cases in which the judges limited the time and/or the scope of the prosecution case.

\section{Limiting the time}

In Galić, the prosecution appealed against the Trial Chamber's order restricting the prosecution's case-in-chief to 280 hours. The bench of three judges of the Appeals Chamber considered that setting time limits for a case "is a powerful tool for preventing excessive and unnecessary time being taken by the prosecution, and it is intended to ensure that the prosecution litigates only those issues which are really in dispute and which are necessary to determine for the purposes of its case." ${ }^{21}$ Indeed, the introduction of this tool "followed serious excesses by prosecution teams in the past." ${ }^{22}$ However, a Trial Chamber is required to consider carefully the real issues

17 ICTY, Prosecutor v. Slobodan Milošević, Reasons for Refusal of Leave to Appeal from Decision to Impose Time Limit, IT-02-54-AR73, A. Ch., 16 May 2002, par. 3 [Milošević, Time Limit Decision, 16 May 2002].

18 Kwon, 2007, p. 375.

19 According to Judge Kwon, only when a Trial Chamber judge has also served as a pre-trial judge can this intimate knowledge be obtained. KwON, 2007, p. 375.

20 The ICTY Working Group on Speeding Up Trials concluded, "after consultations with the Prosecutor and her staff, also arrived at the conclusion that the Prosecutor was unwilling voluntarily to reduce the size of her indictments, and recommended that if any serious attempt was to be made to focus trials properly, it would enable it to be undertaken by the judges of the Tribunal." Moreover, the Working Group advised using Rule $73 b i s(\mathrm{D})$ to set the limits to a case "in a number of imaginative ways." Kwon, 2007, p. 374, referring to the Final Report of the Working Group on Speeding Up Trials, 13 February 2006, pp. 5, 13.

21 ICTY, Prosecutor v. Galić, Decision on Application by Prosecution for Leave to Appeal, IT-98-29AR73, A. Ch., 14 December 2001, par. 7 [Galić 14 December 2001].

22 Galić 14 December 2001, par. 7. 
in dispute between the parties so that it is able to properly assess the time that the prosecution needs to present its case. ${ }^{23}$ In this case, the final issues in dispute were far from clear at the time the Trial Chamber set the time limit, and thus the Trial Chamber had erred in the exercise of its discretion. ${ }^{24}$

In Milošević, the Trial Chamber limited the prosecution's case to 14 months, considering that "no prosecution case should continue for longer than fourteen months," while recognizing the prosecution's duty "to put forward its case, that it must be given a reasonable opportunity to do so, and that it was not for the Trial Chamber to dictate to the prosecution in any arbitrary way how it should do so." 25 The prosecution argued before the bench of three judges of the Appeals Chamber that the power of the Trial Chamber to control the proceedings could not justify improper interference with the prosecution's case presentation. ${ }^{26}$ The Trial Chamber's time limitation on the prosecution's case was an invasion on the prosecution's autonomy, her independence provided by Article 16(2) of the Statute "as well as her right to a fair and expeditious trial under Article 20." ${ }^{27}$ The prosecution has the right, "as an independent and separate organ of the Tribunal," to present its case in a way that it "deems fit (absent a demonstration of abuse)." ${ }^{28}$ The judges considered that "the true intent, and the extent, of Article 16.2 of the Statute" is that it leaves the authority to investigate and initiate prosecution against certain individuals solely in the hands of the prosecution, and as such "it is the source of the "largely adversarial" nature of Tribunal's proceedings. ${ }^{29}$ Once the indictment is confirmed and filed, the prosecutor becomes a party to the proceedings which are subjected to the managing powers of the judges, just as any other party. ${ }^{30}$ In fact, it would be "erroneous" to assume that the prosecutor has any more independence with regard to its case presentation than the accused. ${ }^{31}$ In explaining this latter point, the Bench referred to Article 21(1), which states that all persons shall be equal before the Tribunal, and it emphasized "that equality is fundamental to the fairness of the trials which are conducted before the Trial Chambers." ${ }^{32}$ Although this article specifically refers to the rights of the accused, the bench intentionally (or unintentionally) ignored this heading and expanded the application of this article beyond the equal treatment of individual accused prosecuted before the Tribunal to cover the treatment of the prosecutor and the accused in their mutual relationship.

23 Galić 14 December 2001, par. 7.

24 Galić 14 December 2001, par. 7.

25 Milošević, Time Limit Decision, 16 May 2002, par. 3.

26 Milošević, Time Limit Decision, 16 May 2002, par. 11.

27 Milošević, Time Limit Decision, 16 May 2002, par. 11.

28 Milošević, Time Limit Decision, 16 May 2002, par. 11.

29 Milošević, Time Limit Decision, 16 May 2002, par. 12.

30 Milošević, Time Limit Decision, 16 May 2002, par. 13.

31 Milošević, Time Limit Decision, 16 May 2002, par. 13.

32 Milošević, Time Limit Decision, 16 May 2002, par. 13. 
In Prlić, rather than limiting the prosecution's case on a more detailed level by, for example, setting the number of witnesses or specific geographic locations and incidents on which evidence can be called, the Trial Chamber opted for setting a more general limit to the time available for the presentation of all the evidence..$^{33}$ This 'macro' management is understandable because it is immensely difficult to limit the prosecution's case on substance beforehand in light of the complexity of the Tribunal's cases. However, the other side of the coin is that general time limitations, without properly considering the specificities of the case, might set a somewhat artificial boundary to the case. All the limitations on a case have a direct influence on the strategy of case presentation a party wishes to adopt. And it might be difficult to later change that strategy even if one has the option of presenting additional evidence in the interest of justice.

Setting the amount of time for cross-examination in advance in a complex trial involving several accused is a particularly difficult task for the Trial Chamber. In light of this, the Chamber in the Prlić case opted for not setting the exact time for defence cross-examination of the prosecution's witnesses, but rather for the 'equality of time' approach: all the defence teams would get the amount of time for cross-examination equal to the time taken by the prosecution for its examination-in-chief. ${ }^{34}$ The same approach was taken when making the same determinations with regard to the defence case (see hereunder).

The concrete calculation of time seems to be rather arbitrary at times. In Prlić, the Trial Chamber considered that the trial proceedings could be conducted for 20 hours per week; based on a maximum of 46 working weeks per year, these amounted to 920 in-court hours available per annum. ${ }^{35}$ The Trial Chamber took the view that "it would be unreasonable for this trial to continue for longer that three years," without going into the criteria of a reasonable length of a mega-trial of six accused. ${ }^{36}$ The Chamber thus concluded that "it is reasonable to require the prosecution to complete its presentation of evidence within one year." ${ }^{37}$ Accordingly, the prosecution was allocated

33 ICTY, Prosecutor v. Prlić et al., Revised Version of the Decision Adopting Guidelines on Conduct of Trial Proceedings, IT-04-74-PT, T. Ch. II, 28 April 2006, par. 4 [Prlić et al., Trial Proceedings Guidelines Decision, 28 April 2006].

34 Prlić et al., Trial Proceedings Guidelines Decision, 28 April 2006, par. 5. The Trial Chamber left it up to the individual defence teams to divide the time among themselves, depending on the nature of the witness and the content of the testimony.

35 Prlić et al., Trial Proceedings Guidelines Decision, 28 April 2006, par. 7.

36 Prlić et al., Trial Proceedings Guidelines Decision, 28 April 2006, par. 2. Eventually, the trial lasted from 26 April 2006 to 2 March 2011, with the Prosecution presenting between 26 April 2006-24 January 2008, and the Defence between 5 May 2008-17 May 2010.

37 Prlić et al., Trial Proceedings Guidelines Decision, 28 April 2006, par. 7. The time was later reduced to 293 hours. See ICTY, Prosecutor v. Prlić et al., Decision on Adoption of New Measures to Bring the Trial to an End Within a Reasonable Time, 13 November 2006. Finally, 23 additional hours were added bringing the total number of hours for the Prosecution to 316. See ICTY, Prosecutor v. Prlić et al., Decision Allocating Additional Times for Completion of Case-in-Chief, IT-04-74-T, T. Ch., 22 August 2007. 
a maximum of 400 hours to present its case (examination-in-chief and re-examination but not including evidence in rebuttal, judges' questioning the witnesses or procedural matters). ${ }^{38}$

In light of the size and nature of the Prlic et al. case, the Trial Chamber continued to emphasize that "it would not facilitate the completion of the trial within a reasonable amount of time to set limits on the amount of time available for in-court testimony and then to flood the Chamber with documentary evidence, which must be carefully analysed and assessed in order for a proper determination of the case." ${ }^{39}$ Indeed, the Trial Chamber expected the parties to "be selective in their tendering of documents and other exhibits," while the Chamber itself "will be rigorous in its application of Rule $89(\mathrm{C})$ and the requirements of relevance and probative value." ${ }^{\prime 4}$

Approximately six months into the presentation of the prosecution's evidence, the Trial Chamber reassessed the time available to the prosecution and decided to limit it further to be able to finish the prosecution's case within 15 months. ${ }^{41}$ The prosecution appealed against that decision, generally arguing that the limitation upon its time was unreasonable and unfair and interfered with the prosecution's ability to present its case fairly and effectively; that it was arbitrary and capricious, and penalized and prejudiced the prosecution unreasonably. ${ }^{42}$ The Appeals Chamber first recalled the Orić ruling "that in setting time limits for the presentation of evidence, a Trial Chamber is required to consider whether the amount of time allocated is objectively adequate to permit the relevant party to fairly set forth its case. ${ }^{\prime 43}$ Although that ruling was made in the context of the defence case presentation, the Appeals Chamber considered it applicable to the prosecution case as "the requirement of the fairness of a trial is not uniquely predicated on the fairness accorded to any one party." 44 In fact, "the principle of equality of arms, falling within the fair trial guarantee under the Statute, applies to the prosecution as well as the Defence." ${ }^{45}$ Consequently, the question before the Appeals Chamber concerned whether the Prlić Trial Chamber, "in reducing the Prosecution's case by 107 hours, took into consideration the complexity of the remaining issues to be addressed and determined that the remainder of the time allotted to the Prosecution was sufficient for allowing it a fair opportunity to present

38 Prlić et al., Trial Proceedings Guidelines Decision, 28 April 2006, par. 7.

39 Prlić et al., Trial Proceedings Guidelines Decision, 28 April 2006, par. 8.

40 Prlić et al., Trial Proceedings Guidelines Decision, 28 April 2006, par. 8.

41 ICTY, Prosecutor v. Prlić et al., Decision on Adoption of New Measures to Bring the Trial to an End within a Reasonable Time, 13 November 2006, reducing the number of available hours by 107 .

42 ICTY, Prosecutor v. Prlić et al., Decision on Prosecution Appeal Concerning the Trial Chamber's Ruling Reducing Time for the Prosecution Case, IT-04-74-AR73.4, A. Ch., 6 February 2007, par. 13 [Prlić et al., Reduction of Prosecution Case Appeal Decision, 6 February 2007].

43 Prlić et al., Reduction of Prosecution Case Appeal Decision, 6 February 2007, par. 14 [footnote omitted].

44 Prlić et al., Reduction of Prosecution Case Appeal Decision, 6 February 2007, par. 14 [footnote omitted].

45 Prlić et al., Reduction of Prosecution Case Appeal Decision, 6 February 2007, par. 14 [footnote omitted]. 
its case. ${ }^{46}$ Notably, the Appeals Chamber did not mention that the Orić test was a twostep approach: (1) basic proportionality and (2) objective adequacy, and it neglected to consider that this first step was derived from the principle of equality of arms, while the second step was based on Article 21 ICTY Statute containing the rights of the accused. ${ }^{47}$ While it is understandable that the first step would not automatically seem applicable to the first case to be presented, the prosecution case, the Appeals Chamber in Prlić broadened the scope of the application of the second step by basing it on the principle of fairness (Article 20(1) ICTY Statute). In fact, in a later decision on the prosecution's appeal against the Trial Chamber's decision following this remand from the Appeals Chamber, the Appeals Chamber in fact considered that "[w] hen the proceedings reach that [defence] stage, the Appeals Chamber recalls that under the jurisprudence of the International Tribunal, the Trial Chamber will be bound to apply the longstanding principle of equality of arms to ensure that a basic proportionality will govern the relationship between the time and number of witnesses allocated to all sides." 48 As such, although 'basic proportionality' does not directly apply to the prosecution's case presentation, the principle of equality of arms also implicitly limits the prosecution's case: the Trial Chamber assesses the adequacy of time for the prosecution's case presentation bearing in mind that the defence, when the time comes, will have to be given approximately the same time as the prosecution, depending, of course, on the circumstances of the case.

When applying this test in the Prlić case, the Appeals Chamber found that the Trial Chamber had failed, when it only stated that "the considerations of economy should never violate the right of the Parties to a fair trial," to actually consider whether a further limitation of the prosecution case would still allow for a fair opportunity to present the case..$^{49}$ Importantly, the Appeals Chamber deliberated that a Trial Chamber, based on its general obligation to provide reasoning in support of its findings on the substantive considerations, must specifically consider whether a reduction of case presentation time would still permit a party a fair opportunity to present its case..$^{50}$ It thus remanded the Trial Chamber to reassess its time allocation decision, while stressing that "this is in no way a determination that the Trial Chamber abused its discretion in its original determination that three years is a reasonable timeframe for the conduct of this trial." ${ }^{51}$

46 Prlić et al., Reduction of Prosecution Case Appeal Decision, 6 February 2007, par. 14 [footnote omitted].

47 ICTY, Prosecutor v. Orić, Interlocutory Decision on Length of Defence Case, IT-03-68-AR73.2, A. Ch., 20 July 2005, paras. 7-8.

48 ICTY, Prosecutor v. Prlić et al., Decision on Prosecution Appeal Following Trial Chamber's Decision on remand and Further Certification, IT-04-74-AR73.4, A. Ch., 11 May 2007, paras. 20-21.

49 Prlić et al., Reduction of Prosecution Case Appeal Decision, 6 February 2007, par. 16, referring to ICTY, Prosecutor v. Prlić et al., Decision on Adoption of New Measures to Bring the Trial to an End Within a Reasonable Time, 13 November 2006, par. 16.

50 Prlić et al., Reduction of Prosecution Case Appeal Decision, 6 February 2007, par. 16.

51 Prlić et al., Reduction of Prosecution Case Appeal Decision, 6 February 2007, par. 17. 
Although the Appeals Chamber thought it unnecessary to consider the other prosecution's arguments in detail, it still mentioned a couple of points. Notably, it considered that the "true intent and extent of the independence accorded to the Prosecutor under Article 16 of Statute" is to ensure that no one can direct the prosecution as to whom to investigate or prosecute, and that the prosecutor's contention that its independence extended to the case presentation at trial was rather erroneous. ${ }^{52}$ Moreover, the Appeals Chamber dismissed the prosecution's appeal as to the inappropriateness of the Trial Chamber's mentioning of the Completion Strategy as a translation mistake..$^{53}$

Subsequently, the Trial Chamber maintained its time allocation while having reconsidered that it would give the prosecution a fair opportunity to present its case. ${ }^{54}$ The prosecutor appealed, taking issue once again with the reasoning provided by the Trial Chamber as to why it considered limiting the prosecution case would still leave the latter objectively with adequate time to present the case.${ }^{55}$ According to the Appeals Chamber, "the Prosecution overstates the Trial Chamber's burden in this respect," when in fact, the Trial Chamber had acted within its discretion taking into account all the relevant elements for the assessment of the adequacy of time. ${ }^{56}$

In Delić, the prosecution requested the Trial Chamber to suspend the commencement of the trial arguing that a consequence of the decision to limit the prosecution's case according to Rule 73 bis $(\mathrm{C})$ was that the prosecution was unable to lead evidence on a particular crime site and thus the limited scope of the case made it eligible for transfer pursuant to Rule 11bis. ${ }^{57}$ The Trial Chamber considered that rather than limiting the scope of the prosecution's case according to Rule 73bis(D), it merely reduced "the number of witnesses and hours in light of the considerable cumulation [...]." 58 Furthermore, the Trial Chamber emphasized that the prosecution was at liberty to choose the witnesses from its 65 ter witness list, and there was no reason why no witnesses would be able to testify on that particular site. ${ }^{59}$

52 Prlić et al., Reduction of Prosecution Case Appeal Decision, 6 February 2007, par. 20.

53 Prlić et al., Reduction of Prosecution Case Appeal Decision, 6 February 2007, par. 22.

54 ICTY, Prosecutor v. Prlić et al., Decision Following the Appeals Chamber Decision of 6 February 2007 Concerning Appeal Against Reducing Time for the Prosecution Case, IT-04-74-T, T. Ch. III, 1 March 2007.

55 ICTY, Prosecutor v. Prlić et al., Decision on Prosecution Appeal Following Trial Chamber's Decision on remand and Further Certification, IT-04-74-AR73.4, A. Ch., 11 May 2007, paras. 20-21.

56 ICTY, Prosecutor v. Prlić et al., Decision on Prosecution Appeal Following Trial Chamber's Decision on remand and Further Certification, IT-04-74-AR73.4, A. Ch., 11 May 2007, paras. 25, 30.

57 ICTY, Prosecutor v. Delić, Decision on Prosecution Motion for Suspension of the Commencement of Trial and All Related Proceedings, IT-04-83-PT, 5 July 2007, p. 2.

58 ICTY, Prosecutor v. Delić, Decision on Prosecution Motion for Suspension of the Commencement of Trial and All Related Proceedings, IT-04-83-PT, 5 July 2007, p. 2: "55 witnesses and 170 hours is ample for the Prosecution to present its entire case." Ibid., p. 3. 
In Stanišić and Zupljanin, the Trial Chamber, using its power under Rule 73 bis $(\mathrm{C})$, decided to limit the time and the number of witnesses for the prosecution's case. ${ }^{60}$ The prosecution challenged the Chamber's order limiting the number of witnesses as being "premature and arbitrary." ${ }^{61}$ Moreover, forcing the prosecution to reduce its witness list would "significantly diminish the Prosecution's ability to meet t[he] burden" of "telling an entire story, of putting together a coherent narrative and proving every necessary element of the crimes charged beyond a reasonable doubt." ${ }_{62}$ While recognizing this burden, the Trial Chamber considered that in a case of this size limiting the case presentation by the parties is necessary and justified; "[n]ot every witness to every incident can be called." ${ }^{63}$ Importantly, the Trial Chamber considered that as the trial proceeded, the prosecution would be able to request a variation of the decision on the number of witnesses and it is this "interplay between Rule 73bis (C) and $(\mathrm{F})$ [that] creates the necessary balance between the prosecution's right to prove beyond a reasonable doubt its case against the accused and the accused's right to, and the Trial Chamber's duty to ensure, a fair and expeditious trial." ${ }^{64}$ Finally, it was still up to the prosecution to select the witnesses, the Trial Chamber only indicated which ones it considered reluctant by way of an example. ${ }^{65}$

\section{Limiting the scope of the case}

Rule 73bis(D) ICTY RPE, introduced in July 2003, allows the Trial Chamber (1) to "invite the Prosecutor to reduce the number of counts charged in the indictments" and (2) to "fix a number of crime sites or incidents comprised in one or more of the charges in respect of which evidence may be presented by the Prosecutor." The amendment of the Rule in 2006 gave the judges the power to direct the prosecution to select the counts on which to proceed (Rule 73 bis $(\mathrm{E})$ ). This amendment was inspired by the long-held awareness that the complexity and breadth of the indictments are also to blame for the protraction of trials before the Tribunal. ${ }^{66}$ The prosecution

60 ICTY, Prosecutor v. Stanišić and Župljanin, Decision Denying the Prosecution Motion for Reconsideration of the Order Limiting the Number of Witnesses it May Call at Trial, IT-08-91-T, T. Ch. II, 21 October 2009, par. 2 [Stanišić and Župljanin Decision on the Number of Prosecution's Witnesses].

61 Stanišić and Župljanin Decision on the Number of Prosecution's Witnesses, par. 7.

62 Stanišić and Župljanin Decision on the Number of Prosecution's Witnesses, par. 9.

63 Stanišić and Župljanin Decision on the Number of Prosecution's Witnesses, par. 16.

64 Stanišić and Župljanin Decision on the Number of Prosecution's Witnesses, par. 17: “As these decisions relating to the admission of evidence [judicial notice of adjudicated facts, Rule 92ter and Rule 92quarter] are issues and the strategies of the Defence emerge, the Prosecution's evidentiary needs may evolve. It is for this reason that Rule $73 b i s(\mathrm{~F})$ provides a means for the Prosecution to request, inter alia, variation of the decision as to the number of witnesses that are to be called."

65 Stanišić and Župljanin Decision on the Number of Prosecution's Witnesses, par. 18.

66 ICTY Completion Strategy Report 2006, Annex I, Assessment and Report of Judge Fausto Pocar, President of the International Criminal Tribunal for the Former Yugoslavia, Provided to the Security 
"strongly opposed" this amendment and was less than cooperative in implementing the Trial Chamber's requests in this regard. ${ }^{67}$ In several cases the Trial Chamber 'invited' the prosecutor to limit the indictment (by approximately one-third) and after this invitation was declined, the Chamber ordered reductions to the case, usually following proposals by the prosecution in this regard. ${ }^{68}$

In Mulitinovic et al., the prosecution disagreed with the Trial Chamber's decision prohibiting it to present evidence on three particular crime sites. ${ }^{69}$ The prosecution argued that "Rule 73bis(D) merely enables the Trial Chamber to set the number of crime sites, not to determine in respect of which particular crime sites evidence is to be presented, [because this] determination can only properly be made by the Prosecution." 70 Moreover, the judges' determination as to what evidence not to present not only intruded on the prosecutor's power, but also denied the prosecution a fair trial. ${ }^{71}$ The Trial Chamber addressed the issue of the prosecution's fair trial:

Although use of the word 'fairness' in the context of a criminal trial might commonly refer to fairness for an accused, the Prosecution undoubtedly is entitled to a fair opportunity to present its case. The Statute of the Tribunal obliges each Trial Chamber to 'ensure that a trial is fair and expeditious ..., with full respect for the rights of the accused', and does not provide that only an accused is entitled to be treated equitably. ${ }^{72}$

Council Pursuant to Paragraph 6 of Council Resolution 1534 (2004), S/2006/353, 31 May 2006, paras. 28-29. HigGins, 2009.

67 Thirteenth annual report of the International Tribunal for the Prosecution of Persons Responsible for Serious Violations of International Humanitarian Law Committed in the Territory of the Former Yugoslavia since 1991, UN Doc. A/61/271-S/2006/666, 15 August 2006, par. 10: "Calls for cooperation from the Prosecution to reduce its lengthy cases have been less than satisfactory. Aware that the length of trials begins with the breadth of the Prosecution's indictments, the judges adopted an amendment to rule 73 bis to allow a Trial Chamber to invite and/or direct the prosecution to select those counts in the indictment on which to proceed. This amendment is necessary to ensure respect for an accused's right to a fair and expeditious trial and to prevent unduly lengthy periods of pretrial detention. The Prosecutor strongly opposed this amendment, even though focusing indictments is part of the trial management commonly used in national jurisdictions and does not impact on prosecutorial prerogatives."

68 Thus, the 'invitation' pursuant to Rule 73bis(D) was an invitation that the Prosecutor could not refuse due to the imminent "threat" of the Chamber's order pursuant to Rule 73 bis $(\mathrm{E})$.

69 ICTY, Prosecutor v. Milutinović et al., Decision Denying Prosecution's Request for Certification of Rule 73bis Issue for Appeal, IT-05-87-T, 30 August 2006, par. 1. The Trial Chamber eliminated "those crime sites or incidents that are clearly different from the fundamental nature or theme of the case." ICTY, Prosecutor v. Milutinović et al., Decision on Application of Rule 73bis, IT-05-87-T, 11 July 2006, par. 10.

70 ICTY, Prosecutor v. Milutinović et al., Decision Denying Prosecution's Request for Certification of Rule 73bis Issue for Appeal, IT-05-87-T, 30 August 2006, par. 6 [footnote omitted], [Milutinović et al. Decision on Rule 73 bis Issue, 30 August 2006].

71 Milutinović et al. Decision on Rule 73bis Issue, 30 August 2006, par. 6.

72 Milutinović et al. Decision on Rule 73bis Issue, 30 August 2006, par. 10. 
The Chamber considered that the prosecutor's arguments asserted "unfairness more as a matter of principle than of fact," and thus refused to certify the appeal. ${ }^{73}$

In Šešelj and Dragomir Miloševic, the Trial Chamber, following proposals by the prosecution, removed several counts while focusing on incidents and crime sites that were reasonably representative of the crimes charged. ${ }^{74}$ In Haradinaj, the Trial Chamber decided to accept the prosecutor's reasoning for declining the invitation to reduce the scope of the indictment. The prosecution argued that reducing the charges or incidents "would jeopardise the core of the prosecution's case, thereby violating the prosecution's right to a fair trial." 75 The Trial Chamber agreed and considered that the removal of the counts or incidents "may (i) result in an indictment that is no longer reasonably representative of the case as a whole and (ii) may affect the Prosecutor's ability to present evidence on the scope of the alleged widespread or systematic attack and joint criminal enterprise. ${ }^{\prime 76}$

In Stanišic and Simatović, the prosecutor declined the invitation to reduce the indictment submitting that the case was hardly reducible and the indictment was "already minimalist." "77 However, the prosecution did propose ways by which to reduce the scope of the indictment "while doing the least possible damage to the Prosecution's ability to present its case" if the Trial Chamber decided to act proprio motu. ${ }^{78}$ The Trial Chamber considered that only in very exceptional circumstances a case could not be reduced in line with Rule 73 bis(D). ${ }^{79}$ It followed the prosecution's proposals with regard to the possible reduction of the scope of the indictment and reasoned that the "remaining incidents are reasonably representative of both the geographical areas covered in the Indictment, and of the three key phases of the wars in Croatia and BiH." ${ }^{80}$

73 Milutinović et al. Decision on Rule 73bis Issue, 30 August 2006, par. 11: "Most of the Prosecution's arguments on this point [of unfairness] mistakenly concern the merits of the Decision rather than the requirements of Rule 73(B). The Prosecution does not explain how, and thus has not shown, that the Chamber's action will significantly affect the fair and expeditious conduct of these proceedings or the outcome of this particular trial."

74 See e.g. ICTY, Prosecutor v. Šešelj, Decision on the Application of Rule 73bis, IT-03-67-T, 8 November 2006, par.10; ICTY, Prosecutor v. Dragomir Milošević, Decision on Amendment of the Indictment and Application of Rule 73bis(D), IT-98-2911-PT, 12 December 2006, paras. 38-39.

75 ICTY, Prosecutor v. Haradinaj et al., Decision Pursuant to Rule 73bis(D), IT-04-84-PT, 22 February 2007, par. 7.

76 ICTY, Prosecutor v. Haradinaj et al., Decision Pursuant to Rule 73bis(D), IT-04-84-PT, 22 February 2007, par. 9.

77 ICTY, Prosecutor v. Stanišić and Simatović, Decision Pursuant to Rule 73bis(D), IT-03-69-PT, T. Ch. III, 4 February 2008, paras. 11, 16 [Stanišić and Simatović, Decision on Rule 73bis(D), 4 February 2008].

78 Stanišić and Simatović, Decision on Rule 73bis(D), 4 February 2008, par. 4.

79 Stanišić and Simatović, Decision on Rule 73bis(D), 4 February 2008, par. 11.

80 Stanišić and Simatović, Decision on Rule 73bis(D), 4 February 2008, par. 28. The indictment would be reduced by 10 out of 28 counts. The reduction would reduce the quantity and not the quality of the circumstantial evidence. 
In Perisić, the Trial Chamber noted the prosecution's efforts to streamline its case, but was not satisfied with the proposed reductions as the estimated length of the trial in total would still amount to approximately three years. ${ }^{81}$ The Trial Chamber thus 'invited' the prosecutor to limit its case even further while emphasizing that it would be the Trial Chamber that would make the final determination on the number of witnesses and hours. ${ }^{82}$ After an initial reduction from 907 to 480 hours for examination-in-chief, the prosecution was able to whittle the number of witnesses down to 150 , needing 355 hours to present its case-in-chief, a proposal which was accepted by the Trial Chamber at the Pre-Trial Conference. ${ }^{83}$

In Karadžić, the Trial Chamber, being "gravely concerned" about the scope of the prosecution's case and the time it would take to conclude the trial, invited the prosecution to propose limitations to its case. ${ }^{84}$ The prosecution proposed measures limiting its case in chief to approximately 251 hours from a first estimation of 490 hours, but declined to limit it any further "arguing that the removal of additional counts, crime sites, or incidents would have an adverse impact on its ability to fairly present its case." ${ }^{85}$ The Chamber was disappointed by the prosecution's refusal to limit its case further, and decided to accept all the proposed limitations on the scope of the case by deleting certain crime sites and incidents. ${ }^{86}$ In addition, the Chamber set a time limit on the prosecution's case, allocating it 300 hours in total for the presentation of its case (including direct examination, re-examination and the reserve witness list). ${ }^{87}$

In Milošević the Trial Chamber emphasized that varying a decision instructing the prosecutor not to present certain evidence would only be possible in special circumstances "in the interests of justice where there are compelling reasons for it." ${ }^{\circ 8}$ Permitting the Prosecutor to present evidence on dropped sites would not only

81 ICTY, Prosecutor v. Perišić, Ruling in Relation to Report on Reduction of Length of Prosecution Case, IT-04-81-PT, 27 June 2008, p. 2. No longer than 14 months was considered reasonable for the Prosecution's case. See ICTY, Prosecutor v. Perišić, Decision on Application of Rule 73 bis and Amendment of Indictment, IT-04-81-PT, 15 May 2007, par. 18.

82 ICTY, Prosecutor v. Perišić, Ruling in Relation to Report on Reduction of Length of Prosecution Case, IT-04-81-PT, 27 June 2008, p. 3.

83 Transcript of 2 October 2008, p. 343, accepting Prosecutor's proposal of 26 September 2008. This final number of hours allowed is greater than the number initially allowed by the Pre-Trial Judge (540 for the Prosecution case in total, 220 for direct examination, 220 for cross-examination and 100 for re-examination). ICTY, Prosecutor v. Perišić, Ruling in Relation to Report on Reduction of Length of Prosecution Case, IT-04-81-PT, 27 June 2008, p. 2.

84 ICTY, Prosecutor v. Karadžić, Decision on the Application of Rule 73bis, IT-95-5/18-PT, T. Ch. I, 8 October 2009, par. 5 [Karadžić, Decision on Rule 73bis, 8 October 2009].

85 Karadžić, Decision on Rule 73bis, 8 October 2009, paras. 3, 5.

86 Karadžić, Decision on Rule 73bis, 8 October 2009, par. 5.

87 Karadžić, Decision on Rule 73bis, 8 October 2009, par. 7.

88 ICTY, Prosecutor v. Dragomir Milošević, Decision on Prosecution's Motion Pursuant to Rule 73bis(F), IT-98-29/1-T, 3 April 2007, par. 12. 
disturb the balance of the decision as to the representative nature of the crime sites and incidents selected, but would also have consequences for accused's right to have notice of the case he has to answer. As to the consequences of an order not to present evidence on particular crimes sites and incidents, the prosecution argued in Mulitnovic et al., that the decision to limit the case presentation in fact deleted the charges covered by these sites and incidents and thus no conviction could be entered. ${ }^{89}$

In sum, it can be noted that an expansion of judges' managerial powers and their application met with considerable, and understandable, obstinacy from the prosecutor's side:

Tribunal judges have placed time constraints upon the prosecution, and too often they have done this in an [sic] seemingly whimsical manner with no apparent appreciation for the time, money, and labor expended before the cases have appeared for trial. A tribunal's trial chamber should refrain from unilaterally shrinking complex leadership cases; judicial decisions to remove one or several counts artificially may seriously undermine the case against high-ranking individuals. ${ }^{90}$

Considering the, at times, 'whimsical' nature of the judge's limits on the prosecutor's case, the limitations on the defence's case are usually based on the prosecutor's case. Having knowledge of the prosecution's case gave the judges greater assertiveness in limiting the defence case.

\section{Pre-Defence Conference}

Compared to its sister Rule 73bis, Rule 73ter ICTY RPE contains some minor differences in structure and substance..$^{91}$ For example, according to Rule $73 \operatorname{ter}(\mathrm{A})$, the Trial Chamber may hold a Pre-Defence Conference, instead of the more compelling shall in Rule 73bis(A). Rule 73ter gives the Trial Chamber the authority to call upon the defence to shorten the estimated length of the examination-in-chief for some witnesses (73bis $(\mathrm{B}))$; set the number of witnesses the defence may call $(73 b i s(\mathrm{C})$ ) and determine the time available to the defence for presenting evidence (73bis $(\mathrm{E})$ ). Moreover, Rule 73 bis $(\mathrm{F})$ provides that, during trial, the Chamber may grant the defence additional time to present evidence if the interests of justice so require.

89 ICTY, Prosecutor v. Milutinović et al., Order Regarding Prosecution's Submission with Respect to Rule 73bis(D), IT-05-87-T, 7 April 2009, par. 4. Thus only after the judgment did the Trial Chamber delete the outstanding charges against the accused.

90 Del Ponte and Sudetic, 2009, p. 376.

91 Before the Revision of 17 July 2003 the Rules were identical. This revision added some more details to Rule 73bis, while leaving Rule 73ter untouched. 
One of the first defence challenges to the Trial Chamber's power to limit the defence's ability to call certain witnesses arose in Delalić et al. The defence challenged the Trial Chamber's power to restrict the number of witnesses which the defence was allowed to call due to the possibility of an unnecessary duplication of evidence. ${ }^{92}$ From the similarity between the cases, the Chamber was wary of the possible duplication of witness testimony between the cases of the four co-accused. The Chamber warned the defence teams regarding "the need to adhere strictly to the principles of avoiding the duplication of its witnesses, and the repetition of such testimony, otherwise, the Trial Chamber would be left with the choice of drawing up its own witness lists for each of the accused persons." ${ }^{93}$ The defence challenged this statement. According to the defence, "the actions of the Trial Chamber has the effect of denying the accused persons their right to assistance by counsel, in that they are prevented from presenting evidence under the same conditions as the Prosecution presented evidence against them." 94 Importantly, the defence submitted that the Trial Chamber was not in a position to determine which witnesses each defence team should be called and in what order. ${ }^{95}$ Moreover, in the defence's view "the Prosecution was not subjected to the same scrutiny and control in the presentation of their evidence and calling of their witnesses," which violated the principle of equality of arms. ${ }^{96}$

Relying on the Trial Chamber's general obligation to ensure a fair trial with full respect for the rights of the accused, the Chamber concluded there to be ample legal basis enabling the Chamber to control the calling and examining of witnesses. ${ }^{97} \mathrm{In}$ relation to the right to examine and call witnesses, the Trial Chamber stated that "[t]he intention of Article 21(4)(e) is to ensure that the accused is placed in a position

92 ICTY, Prosecutor v. Delalić et al., Decision on the Motion of the Joint Request of the Accused Persons Regarding the Presentation of Evidence, Dated 24 May 1998, IT-96-21-T, T. Ch., 12 June 1998, par. 22 [Delalić et al. Decision on Defence Presentation of Evidence, 12 June 1998]. At a status conference, the Presiding Judge stated: "Now, as I said, what the Trial Chamber intends to do is to come out with our own list of witnesses, which are not to (sic) materially different from what has been handed in. And we'll cover all the cases, but trimmed down in such a way as to avoid repetition, duplication and irrelevances, which are not necessary for the purposes of this trial. This is what the Trial Chamber has decided to do." Redacted Transcript of 21 May 1998, p. 9, 15-24, cited in ICTY, Prosecutor v. Delalić et al., Joint Request by the Defendants Delalić, Mucić, Delić and Landžo Regarding Presentation of Evidence, IT-96-21-T, 24 May 1998, p. 5.

93 Delalić et al. Decision on Defence Presentation of Evidence, 12 June 1998, par. 25.

94 Delalić et al. Decision on Defence Presentation of Evidence, 12 June 1998, par. 3.

95 Delalić et al. Decision on Defence Presentation of Evidence, 12 June 1998, p. 5.

96 Delalić et al. Decision on Defence Presentation of Evidence, 12 June 1998, par. 39. Consequently, the defence called upon the Trial Chamber to refrain from interfering "with the presentation of the Defence case, save and except to give effect to the provisions of Rule 89(C) and (D) and Rule 95 which govern the admissibility of evidence." (p. 6).

97 Delalić et al. Decision on Defence Presentation of Evidence, 12 June 1998, par. 28. Basing this on Articles 20(1) and 21 and Rules 54 and 89, which provide for general powers to issue such orders as necessary for the conduct of the trial and the power to admit any relevant evidence that the Chamber deems to have probative value, or to exclude other. 
of complete equality with respect to the calling and examination of witnesses with the Prosecution." 98 The Trial Chamber did not elaborate how this statement related to both the treatment of the prosecution and the defence case presentation, but continued to argue that the defence was not disadvantaged, that it "is entitled and have exercised their right under Article 21(4)(e)" and that "[t]his is consistent with the principle that their right to call witnesses is not unlimited." 99 Thus, "[i]t is erroneous to accuse the Trial Chamber of a violation of the right of the Defence."100

In several puzzling passages, the Trial Chamber explained that " $[t]$ he fact that Article 20(1) vests in the Trial Chamber the power to protect the right of the accused is usually ignored." "101 The Chamber further reiterated that in case the counsel errs in calling witnesses and leading witnesses at the trial which error would amount to undue delay that would prejudice the defence, the Trial Chamber "should exercise its power proprio motu to avert any injustice that will result if it did not intervene."102 Was the Chamber implying that in order to protect the accused from a violation of his right to a trial without undue delay, the Chamber had to step in and limit the accused's right to examine witnesses? According to the Chamber, adherence to "the guidelines formulated by the Trial Chamber in calling of witnesses and leading of evidence at trial will in no way deprive the accused of assistance of Counsel to discharge a different burden," while "[e]ach accused is expected to discharge his or her burden of proof in presenting evidence." 103 What burden of proof exactly the Trial Chamber was referring to is far from clear, and this seems a rather cumbersome way to state that defence "Counsel is free to call its witnesses bearing in mind the guidelines." 104 Lastly, and in addition to protecting the expeditiousness of the proceedings, the Chamber found it necessary to emphasize that the guidelines can be usefully applied by the parties "to save cost in time and expense." 105 Touching upon equality of arms, the Chamber considered that the defence's argument that the guidelines had only been imposed when the defence was to present their cases was "not a valid criticism."106

However puzzling and incoherent the argumentation of the Trial Chamber might be at times, the crux of the matter is that the defence, indeed, does not possess an "unrestricted right to lead evidence irrespective of their relevance to the issues before the Trial Chamber." 107 And the Trial Chamber possesses the power to streamline the presentation of the case by directing the defence to present a relevant and non-

98 Delalić et al. Decision on Defence Presentation of Evidence, 12 June 1998, par. 33.

99 Delalić et al. Decision on Defence Presentation of Evidence, 12 June 1998, par. 41.

100 Delalić et al. Decision on Defence Presentation of Evidence, 12 June 1998, par. 41.

101 Delalić et al. Decision on Defence Presentation of Evidence, 12 June 1998, par. 42.

102 Delalić et al. Decision on Defence Presentation of Evidence, 12 June 1998, par. 42.

103 Delalić et al. Decision on Defence Presentation of Evidence, 12 June 1998, par. 42.

104 Delalić et al. Decision on Defence Presentation of Evidence, 12 June 1998, par. 39.

105 Delalić et al. Decision on Defence Presentation of Evidence, 12 June 1998, par. 46.

106 Delalić et al. Decision on Defence Presentation of Evidence, 12 June 1998, par. 46.

107 Delalić et al. Decision on Defence Presentation of Evidence, 12 June 1998, par. 48. 
repetitive witness list. Notwithstanding this fact, one interesting issue was ignored: to what extent is the Trial Chamber empowered to substitute the defence's witness list with its own and how does this relate to equality of treatment between the parties? From the context, it might be clear that during the prosecution case, the Chamber did not consider the evidence irrelevant and repetitious to the same extent as with the defence case. One wonders, however, how the prosecution would have reacted if the Trial Chamber would have extended its power to rewrite the prosecution's witness list when and how it saw fit. From the above discussion of the limitations imposed on the prosecution's case it is clear that the Trial Chamber never deemed it necessary to set out the exact list of witnesses the prosecution was allowed to call. The limitations upon time and the number of witnesses were imposed following an 'invitation' to limit the case which the prosecution could not refuse. However, this is not the way the Trial Chamber chose to proceed in the Delalic et al. defence case.

The following discussion addresses other ICTY cases where the defence case has been limited. Importantly, the discussion focuses on the standard that the Trial Chamber has chosen for the practical limitation of the defence's case and its connection with equality of arms. The method considered appropriate to limit defence case was elaborated upon in Milošević where the Trial Chamber considered "that the Accused should have the same time as the Prosecution had to present his case in chief."108 Thus, the same method would apply as in case of limiting the length of prosecution case, by fixing the number of days (hours) for the presentation in chief.

The Appeals Chamber reinterpreted 'equality of arms' in later decisions by providing a more qualified test based on the different roles of the prosecutor and the defence. ${ }^{109}$ Introduced in Orić, ${ }^{110}$ and picked up in Stakić, ${ }^{111}$ the Appeals Chamber introduced a two-pronged test. It reasoned that equality of arms is governed by

108 ICTY, Prosecutor v. Slobodan Milošević, Order Rescheduling and Setting the Time Available to Present the Defence Case, IT-02-54-T, T. Ch., 25 February 2004, p.3. The same method was applied in Lukić and Lukić, where the Trial Chamber determined "that the interests of a fair and expeditious trial, as mandated by Article 20 of the Statute, are in the circumstances of this case, served by allowing the Defence of Milan Lukić to call the same number of witnesses as the Prosecution and to present its evidence-in-chief within the same amount of time as allotted to the Prosecution, that is 60 hours, even though the Prosecution actually used less time." ICTY, Prosecutor v. Lukić and Lukić, Order Pursuant to Rule 73ter of the Rule of Procedure and Evidence, IT-98-32/1-T, 26 November 2008 , p. 3. The Prosecution used approximately 50 hours for its examination-in-chief.

109 ICTY, Prosecutor v. Orić, Interlocutory Decision on Length of Defence Case, IT-03-68-AR73.2, A. Ch., 20 July 2005, par. 7 [Orić Length of Defence Case Appeal Decision, 20 July 2005].

110 Orić Length of Defence Case Appeal Decision, 20 July 2005.

111 ICTY, Prosecutor v. Stakić, Appeals Chamber Judgment, IT-97-24-A, A. Ch., 22 March 2006, par. 149: "In assessing an equality of arms challenge by an accused, a judicial body must ask two basic questions: (1) was the Defence put at a disadvantage vis-à-vis the Prosecution, taking into account the "principle of basic proportionality" and (2) was the accused permitted a fair opportunity to present his case." 
"the principle of basic proportionality, rather than a strict principle of mathematical equality" due to the differing roles of the parties. ${ }^{112}$ Additionally, the Trial Chamber "must also consider whether the amount of time is objectively adequate to permit the Accused to set forth his case in a manner consistent with his rights" as laid down in Article 21 of the ICTY Statute. ${ }^{113}$ In this case, the question of 'adequate time' arose in the context of even-handedness between the prosecutor and the defence. The defence in Orić appealed against the Trial Chamber's decision to restrict the defence case regarding (1) the subject matter and (2) the number of witnesses and time. After the Rule 98bis judgment, the defence proposed to call 73 defence witnesses and estimated that it would need 249 hours for its examination-in-chief. ${ }^{114}$ The Orić Trial Chamber rejected this proposed framework by finding that certain "areas of evidence" had been "sufficiently addressed during the Prosecution case in a manner and to an extent which, in the Trial Chamber's opinion, did not require any further evidence on the part of the defence." 115

The Appeals Chamber considered that some of these topical restrictions "such as those on evidence regarding the general historical and political background of the Balkan conflict" can be regarded as reasonable in light of Rule 73ter RPE. Nonetheless, in its view others were clearly unreasonable because some subjects could play a central role in the defence. ${ }^{116}$ The Appeals Chamber, anticipating the defence's argument, took into account that the defence of military necessity might play a central role. This led the Chamber to conclude that "unless the Trial Chamber is prepared to reconsider its Rule 98bis ruling and grant partial judgment of acquittal, it must give Orić a reasonable opportunity to present reliable and relevant evidence [...]." 117 This conclusion, however, does not entail a free rein for Orić "to present unnecessary repetitive or irrelevant evidence just because it arguably fits within these

112 Ibid. Cf. ICTY, Prosecutor v. Slobodan Milošević, Decision in relation to Severance, Extension of Time and Rest, IT- 02-54-T, T. Ch. I, 12 December 2005 where the Trial Chamber took a more stringent approach by granting the accused the same time allocated to the prosecution for the presentation of his case (although restricting the number of defence witnesses).

113 Ibid., par. 8 [emphasis added].

114 Orić Length of Defence Case Appeal Decision, 20 July 2005, par. 3. The prosecution called 50 witnesses and used some 260 hours to present its case.

115 Orić Length of Defence Case Appeal Decision, 20 July 2005, par. 4. The Trial Chamber referred to 11 areas of evidence.

116 Orić Length of Defence Case Appeal Decision, 20 July 2005, par. 6: at a minimum Orić should be allowed to present information on: (1) the military situation, broadly construed, throughout the Srebrenica region ..., (2) the allegedly desperate situation of the region's Bosnian Muslim population, (3) the alleged reliance of Bosnian Muslims on weapons that could be captured from Bosnian Serb forces. And (4) any facts that could cast non-trivial doubt on the credibility of Prosecution witnesses.

117 Orić Length of Defence Case Appeal Decision, 20 July 2005, par. 6. KNoops, 2005, p. 1581: "Examining the Orić Decision, one can say that in this way, Rule 98bis may provide the defence an important procedural mechanism to limit the exercise and applicability of judicial economy pursuant to Rule 73ter." 
categories," leaving it, thus, for the Trial Chamber to determine what would qualify as such repetitive or irrelevant evidence. ${ }^{118}$

With regard to restrictions on witnesses and time the Appeals Chamber emphasized the principle of equality of arms, ${ }^{119}$ which "at a minimum ... obligates a judicial body to ensure that neither party is put at a disadvantage when presenting its case." ${ }^{120}$ Regarding the allocation of time and witnesses, just as resources, ${ }^{121}$ to both the prosecutor and the defence, procedural equity is governed by "the principle of basic proportionality, rather than a strict principle of mathematical equality." "122 This is explained by the difference in the roles that both the prosecutor and defence play at trial. The former has the burden of proving its case beyond a reasonable doubt, while the defence's strategy "often focuses on poking specifically targeted holes in the Prosecution's case." 123 Clearly, the question of whether this "endeavour [of the defence] ... may require less time and fewer witnesses" 124 can be subject to debate and is obviously case-specific. In addition to the governing principle of equality of arms, in terms of reasonable proportionality between the defence and the prosecutor, the Trial Chamber "must also consider whether the amount of time is objectively adequate to permit the Accused to set forth his case in a manner consistent with his rights" as laid down in Article 21 of the ICTY Statute. ${ }^{125}$

In considering the allocation of time and witnesses to the defence, the Appeals Chamber concluded that it is "not remotely proportional to the time that was allocated to the Prosecution." 226 Notably, the Appeals Chamber considered, in light of its rejection of most of the subject-matter restrictions imposed by the Trial Chamber, a disproportion that was so great that the defence did not need to show specific prejudice

118 Orić Length of Defence Case Appeal Decision, 20 July 2005, par. 6.

119 A principle that "goes to the heart of the fair trial guarantee", Orić Length of Defence Case Appeal Decision, 20 July 2005, par. 7.

120 Orić Length of Defence Case Appeal Decision, 20 July 2005, par. 7, in footnote 18 referring e.g. to the Tadić Appeal Judgment, paras. 48, 50, 52.

121 ICTR, Prosecutor v. Kayishema and Ruzindana, Judgment (Reasons), ICTR-95-1-A, A. Ch., 1 June 2001, par. 69: "The Appeals Chamber observes in this regard that equality of arms between the Defence and the Prosecution does not necessarily amount to the material equality of possessing the same financial and/or personal resources."

122 ICTR, Prosecutor v. Kayishema and Ruzindana, Judgment (Reasons), ICTR-95-1-A, A. Ch., 1 June 2001, par. 69. Cf. ICTY, Prosecutor v. Slobodan Milošević, Decision in relation to Severance, Extension of Time and Rest, IT- 02-54-T, T. Ch. I, 12 December 2005 where the Trial Chamber took a more stringent approach by granting the accused the same time allocated to the prosecution for the presentation of his case (although restricting the number of defence witnesses).

123 Orić Length of Defence Case Appeal Decision, 20 July 2005, par. 7.

124 Orić Length of Defence Case Appeal Decision, 20 July 2005, par. 7.

125 Orić Length of Defence Case Appeal Decision, 20 July 2005, par. 8 [emphasis added].

126 Orić Length of Defence Case Appeal Decision, 20 July 2005, par. 9. This conclusion is based on Orićs mathematical analysis which was not seriously contested by the Prosecutor and which came down to 30 witnesses and 27 days of testimony for Orić, compared to 50 witnesses and 100 days of testimony for the Prosecution. 
arising out of the disparity to be able to challenge the Trial Chamber's decision. ${ }^{127}$ Because the defence case in Oric "has proceeded under a cloud of uncertainty," 228 due to the fact that the Trial Chamber declined to stay the proceedings while this appeal was pending, the Appeals Chamber instructed the Trial Chamber to provide Oric defence with the opportunity to present its case anew if it so wished. According to the Appeals Chamber, this opportunity would only seem fair, given the fact that its witness presentation strategy might have been very different if the Trial Chamber had allocated more time to the defence in the first place. ${ }^{129}$

Because the assessment was based on the first element of basic proportionality, the Appeals Chamber did not have an opportunity to consider more explicitly the 'objective adequacy' step of the test. Implicitly, the Appeals Chamber obviously considered the time allocated to the defence to be inadequate. The two-step consideration presented by the Appeals Chamber has, as a consequence, that whenever the basic proportionality requirement is not fulfilled the consideration of objective adequacy becomes irrelevant. As a result, an interesting question arises: what should be considered as objectively (in)adequate in a case where the time allocated to the defence is reasonably proportional to that of the prosecutor?

In Krajišnik, the defence requested additional time for the purpose of calling additional witnesses arguing that the defence had only been allocated 60 per cent of the time taken by the prosecution case, which was insufficient, and that the time allocation should have constituted, at a minimum, 70 per cent of the prosecution's time. ${ }^{130}$ The Trial Chamber considered that "[ $\left.t\right]$ he adequacy of time allocation is not a question of finding the correct mathematical formula" and "[ $t]$ he fact that a defence case took 60 or 70 or a greater percentage of the time taken by the Prosecution does not of itself answer the question whether time was adequately allocated to the Defence." ${ }^{\prime 31}$ However, although an automatic or mathematical calculation of allocated time was rejected in Orić, the 'basic proportionality' test clearly envisions a comparative element (between the prosecution and the defence), followed by the step of considering the element of objective adequacy. Moreover, according to the Trial Chamber,

127 Orić Length of Defence Case Appeal Decision, 20 July 2005, par. 9 [emphasis added].

128 Orić Length of Defence Case Appeal Decision, 20 July 2005, par. 10.

129 Orić Length of Defence Case Appeal Decision, 20 July 2005, par. 10.

130 ICTY, Prosecutor v. Krajišnik, Reasons for Decision Denying Motion for Time to Call Additional Witnesses, IT-00-39-T, 16 August 2006, par. 3 [Krajišnik Decision on Additional Time, 16 August 2006].

131 Krajišnik Decision on Additional Time, 16 August 2006, par. 32. However, the Chamber allocated time to the defence on the basis of the Chamber's "experience [that] an allocation of time to the Defence of 60 per cent of the time taken by the Prosecution was a reasonable guideline" (par. 38). The Chamber actually "proceeded to allot an amount of time closer to 70 per cent of the time taken by Prosecution." 
[t]he arguments of the Defence that only time actually spent by the Defence on examination-in-chief may be considered when assessing the adequacy of allocated time is without merit. The actual consumption of time in court is one factor to consider. Other factors to consider are the overall allocations of time to the Defence in which to prepare and present its case, and the actual time spent out of court on the preparation of the Defence case. ${ }^{132}$

This consideration is correct when applied to the determination of adequate time for the preparation of the defence under Article 21(4)(b) ICTY Statute. However, the problem presented in the defence motion is the inadequacy of the actual in-court time for defence case presentation, which was allocated under Rule 73ter. Indeed, the Chamber further considered the relevance of the additional evidence as a factor determining the application for additional time. ${ }^{133}$ In this sense, the relevance of the evidence proposed by the defence, and additional to what was initially intended, determines, in part, the 'adequacy' of time for presentation. If the evidence is sufficiently relevant, without its presentation the defence would then not have had 'adequate' time to present its case. As referred to by the Orić Appeals Chamber, determining the appropriate time with precision beforehand might be an impossible task, and thus the possibility of allowing for additional time to be granted in the 'interest of justice' should be left open. ${ }^{134}$

Another element which the Krajišnik Trial Chamber considered relevant to determine the defence application for additional time was the "interests of the proper administration of justice." According to the Trial Chamber the proper administration of justice is "not served by excessive postponements of the proceedings," and thus, the "Chamber shall not allow unnecessary further time at the expense of other accused awaiting trial." 135 Here, the Trial Chamber seemed to go overboard with this consideration. Of course, "excessive postponements" and "unnecessary further time" would not serve a fair administration of justice due to the consequential interference with the right of the accused to an expeditious trial. If the Chamber refers to this right of other accused, how, then, can this right of other accused, not joined in the Krajišnik trial, be taken into account when determining Krajišnik's application for additional time to present evidence? It seems like taking into account the systemic failure to expeditiously prosecute those arrested and detained when determining one accused application to present additional evidence. Intuitively this does not fit well with the fair trial concept.

132 Krajišnik Decision on Additional Time, 16 August 2006, par. 33.

133 Krajišnik Decision on Additional Time, 16 August 2006, par. 34: "The Chamber must also consider the relevance of the additional evidence that the Defence wishes to present. In particular, it must consider whether the evidence is of such relevance as to support a grant of additional time."

134 Orić Length of Defence Case Appeal Decision 20 July 2005, par. 8, footnote 19, referring to the Trial Chamber decision in that case.

135 Krajišnik Decision on Additional Time, 16 August 2006, par. 35. 
Of "minor significance in the present context" the Trial Chamber further considered the accused's failure to pay his assessed contribution to his defence team, as a factor for determining the adequacy of the time allotted to the defence. Again, in this regard, the place of this consideration for the determination of the allocation of time for the defence under Rule 73ter is somewhat puzzling.

However confusing some of the mentioned factors are for determining adequate time for defence case presentation, the final decision takes the relevant factors into account. In the end, the Trial Chamber rejected the defence's application for additional time because of five considerations. First, the Chamber showed flexibility before the start of the defence case and during it as to the time allotted to the preparation and presentation of the defence case. ${ }^{136}$ Although this seems to concern the time for preparation, the Trial Chamber emphasized that it had granted several postponements and additional time and, importantly, "left it to the Defence to decide how to divide this additional time between preparation and presentation of evidence" only setting an ultimate deadline for the defence case. ${ }^{137}$ Second, the Chamber considered that it had been flexible with regard to defence disclosure obligations under Rule 65ter RPE by giving the defence "unprecedented and ample leeway" to determine which witnesses it considered important and relevant and in what order it wanted to present its case. ${ }^{138}$ Third, the Chamber did not consider the fact that the accused testifying himself consumed a lot of presentation time and was now entitled to present corroborative evidence, as being relevant for the determination of the adequacy of time. The organization of the presentation of evidence is a task for the defence, and it should have divided the time available in a different manner. ${ }^{139}$ This position is similar to the one taken when limiting the prosecution's case: the Trial Chamber sets general limits on the total time available, and leaves it to the party to determine how and when to present their evidence. Last, but surely not least, the Chamber considered that the additional witness testimony was not necessary in light of the large amount of evidence received on the topics on which these additional witnesses were expected to testify. ${ }^{140}$ What remains unclear from the decision is whether this

136 Krajišnik Decision on Additional Time, 16 August 2006, paras. 38-44.

137 Krajišnik Decision on Additional Time, 16 August 2006, par. 40.

138 Krajišnik Decision on Additional Time, 16 August 2006, par. 47. See e.g. ICTY, Prosecutor v. Krajišnik, Order on Prioritizing Defence Witnesses, IT-00-39-T, T. Ch. I, 9 February 2006, p. 2. (Considering the Chamber's preference for hearing the most important and "most highly relevant witnesses", and considering that "in accordance with Rule 98 of the Rule of Procedure and Evidence, Defence witnesses not called by the time the Defence case closed may be contacted by the Chamber at its own discretion and scheduled to appear as Chamber witnesses", the Trial Chamber ordered "that the Defence file on or before ... a list, in order of preference based on importance and relevance, of all the witnesses it intends to call, with the expected necessary measures, if any, that the Chamber should undertake to ensure their attendance.").

139 Krajišnik Decision on Additional Time, 16 August 2006, par. 49.

140 Krajišnik Decision on Additional Time, 16 August 2006, par. 50. 
large amount of evidence received also came from the defence. In fact, the Chamber considered defence witness summaries to be "largely inadequate" and "unrealistic and unhelpful as a planning instrument." 141 However, the Chamber decided, after a careful analysis of the defence witness list summaries, that these summaries did "not reveal unexplored fields of evidence of high relevance." ${ }^{142}$ Although the defence was critical about this point when requesting to appeal that decision, ${ }^{143}$ this consideration emphasized the importance of the witness lists and the summary of witness testimony for the proper planning of the case presentation. ${ }^{144}$

In Prlic et al., when deciding on the time available to the six defence teams to present their evidence, the Trial Chamber was guided by the Orić and the Prlic (prosecution case) decisions. ${ }^{145}$ The Trial Chamber considered that the prosecution had 316 hours but actually only used 296 hours for its case presentation. In this context, it noted that the prosecution had "to retrace the full and coherent history of the case and to establish beyond reasonable doubt each of the constitutive elements of the crime" ascribed to the six accused, while the defence "had to try and find loopholes, flaws in the Prosecution case, which required both less time and fewer witnesses." 146 Recalling Orić, the Trial Chamber emphasized that the principle of basic proportionality determines the allocation of hours to the defence. Hence, it considered, "the present Decision is the result of a thorough examination of each

141 Krajišnik Decision on Additional Time, 16 August 2006, par. 45.

142 Krajišnik Decision on Additional Time, 16 August 2006, par. 51.

143 ICTY, Prosecutor v. Krajišnik, Defence Application for Certification Pursuant to Rule 73(B) of the Rules of Procedure and Evidence to Appeal Against Decision on Defence Motion for Time to Call Additional Witnesses, IT-00-39-T, 23 August 2006, par. 5(b), arguing that the Trial Chamber was mistaken when it used the summaries as a planning instrument de facto, after analyzing them carefully, while at the same time arguing that it thought these summaries were inadequate and not helpful as a planning instrument.

144 As mentioned, Rule $90(\mathrm{G})$ authorizes the Trial Chamber to refuse to hear witnesses whose name is not included on the pre-trial witness lists. Cf. ICTY, Prosecutor v. Prlić, Decision on Defendants Appeal Against "Décision Portant Attribution du Temps à la Défence pour la Présentation des Moyens à Décharge”, IT-04-74-AR73.7, A. Ch., 1 July 2008, par. 59: “ ... the Appeals Chamber does not accept the argument that the Trial Chamber could not make an evaluation of the existence of redundant evidence based on the "relatively short summaries" provided by the Petković Defence in its 65ter list [footnote omitted]. First, the Appeals Chamber notes that Rule 73ter of the Rules expressly provides that a Trial Chamber is to determine the duration of a party's case based on its review of the 65ter Lists and the representations of the party. Second, the Appeals Chamber considers that one of the purposes of the submission of the 65ter list, is for a party to show the relevance of the evidence it proposes to present."

145 ICTY, Prosecutor v. Orić, Interlocutory Decision on Length of Defence Case, IT-03-68-AR73.2, A. Ch., 20 July 2005. ICTY, Prosecutor v. Prlić et al., Decision on Prosecution Appeal Concerning the Trial Chamber's Ruling Reducing Time for the Prosecution Case, IT-04-74-AR73.4, A. Ch., 6 February 2007.

146 ICTY, Prosecutor v. Prlić et al., Decision Allocating Time to the Defence to Present its Case, IT-0474-T, T. Ch. III, 25 April 2008, par. 9 [Prlić et al. Decision on Defence Case Presentation, 25 April 2008]. 
65ter List by the Defence and not of a strictly mathematical calculation of time allocation." 147

The Trial Chamber then continued by determining the precise amount of time for each of the accused so that the defence had "sufficient time to present its case and not be prejudiced." 148 In this mega-trial of six accused, the Chamber considered it necessary to take into account the fact that some witnesses had also been called to appear by other Defence teams. ${ }^{149}$ The Praljak defence was the only one to base its argument explicitly on the principle of equality of arms and the rights of the accused, and compared his case to the Orić case stating that it would be unacceptable for the Trial Chamber to grant him 17 per cent of the total prosecution time, while the Appeals Chamber in Orić considered an allocation of 25 per cent of the prosecution's time to be disproportionate. ${ }^{150}$ The Trial Chamber disagreed and decided to allocate 55 hours instead of the requested 112 to the Prljak defence, because it considered that "an excessive number of witnesses has been called to testify on events that fall outside the frame of the Indictments or that relate only very loosely to them or are totally repetitive." ${ }^{151}$ Without explicitly considering this, the Trial Chamber ended up allocating a total of 336 hours and 30 minutes to the defence, thus exceeding the total number of the prosecution's hours by 20.5. ${ }^{152}$

Notably, the Presiding Judge Antonetti issued a Separate opinion to this decision. ${ }^{153}$ He emphasized that he had sufficient in-depth knowledge of the case, being the Confirming, Pre-Trial and the Presiding Judge, to be able to determine the amount of time required by the Defence to present its case. ${ }^{154}$ His initial estimate would be to divide a total of 300 hours (a number which was approximate to the prosecution's time) equally among the six accused, although he expressed agreement with Trial Chamber's final determination. Moreover, he made it perfectly clear that the Completion Strategy in no way affected the time determination for the Defence. ${ }^{155}$ Almost as if expressing his regret about the current way of proceeding, Judge Antonetti concluded that "[a]bsolute control by the judges of the proceedings in a

147 Prlić et al. Decision on Defence Case Presentation, 25 April 2008, par. 12.

148 Prlić et al. Decision on Defence Case Presentation, 25 April 2008, paras. 24, 28.

149 Prlić et al. Decision on Defence Case Presentation, 25 April 2008, par. 31.

150 Prlić et al. Decision on Defence Case Presentation, 25 April 2008, par. 32.

151 Prlić et al. Decision on Defence Case Presentation, 25 April 2008, par. 33.

152 Prlić et al. Decision on Defence Case Presentation, 25 April 2008, par. 44. Notably, the Trial Chamber decided to certify this decision immediately and proprio motu for a possible appeal by the parties (par. 46).

153 ICTY, Prosecutor v. Prlić et al., Separate Opinion of Judge Jean-Claude Antonetti on the Length of the Presentation of Evidence by the Defence, IT-04-74-T, T. Ch. III, 25 April 2008 [Prlić et al. Separate Opinion Judge Antonetti, 25 April 2008].

154 Prlić et al. Separate Opinion Judge Antonetti, 25 April 2008, par. 13.

155 Prlić et al. Separate Opinion Judge Antonetti, 25 April 2008, paras. 16, 25. 
different framework, with real control of discussion effected by the judges rather than the parties would, in my opinion, have led to a much earlier end to the trial." 156

On appeal, the Petkovic defence complained that the Trial Chamber's allocation of time "is based on an arithmetic division of the time used for the Prosecution case between the six Accused" and that such calculation "constitutes 'a spurious application of the equality of arms' principle." 157 Although the Appeals Chamber agreed that a "purely arithmetical calculation" of the time for a party's case presentation might constitute an abuse of the Trial Chamber's discretion, the appellate Chamber disagreed that this was the method that had been adopted by the Trial Chamber. ${ }^{158}$ The Praljak defence, moreover, argued that there was no 'reasonably proportionality' between the allocation of time to the prosecution or the defence. Comparing the Orić case, where the Appeals Chamber found that an allocation to the defence of 27 per cent of the prosecution's time was unreasonably disproportional, the allocation of only 17.4 per cent of the prosecution's time to the Praljak defence violated that standard. The Appeals Chamber rejected the Orić determination as a substantive guideline for assessing basic proportionality in time in other cases, as "the determination of the time to be granted to the Defence to present its case is the result of a highly contextual analysis." 159 So in a multiple accused case "the issue of proportionality [...] [was] affected not only by the burden of proof upon the Prosecution, but also by the circumstance that not all of the evidence presented by the Prosecution is directed to prove the responsibility of one individual Accused." 160 In this case, the Appeals Chamber did not consider the allocation of time to be unreasonably disproportionate. With regard to the Praljak defence's argument that "a case involving multiple Accused should not have the effect of legitimizing a disproportionate reduction of the defence case for the single Accused, as 'the presence of other accused is at least as much a burden as a benefit," the Appeals Chamber considered that "the eventuality" of contrasting evidence between the accused was "counterbalanced" by the possibility to cross-examine the witnesses and to request additional time if needed. ${ }^{161}$ In addition, the Appeals Chamber emphasized, referring to the decision on the prosecution's appeal on time allocation, that a Trial Chamber has to justify its time

156 Prlić et al. Separate Opinion Judge Antonetti, 25 April 2008, par. 25.

157 ICTY, Prosecutor v. Prlić, Decision on Defendants Appeal Against "Décision Portant Attribution du Temps à la Défence pour la Présentation des Moyens à Décharge”, IT-04-74-AR73.7, A. Ch., 1 July 2008, par. 18 [Prlić et al. Appeal Decision on Defence Case Presentation, 1 July 2008].

158 Prlić et al. Appeal Decision on Defence Case Presentation, 1 July 2008, par. 19.

159 Prlić et al. Appeal Decision on Defence Case Presentation, 1 July 2008, par. 35.

160 Prlić et al. Appeal Decision on Defence Case Presentation, 1 July 2008, par. 39.

161 Prlić et al. Appeal Decision on Defence Case Presentation, 1 July 2008, par. 36: "The Appeals Chamber notes that the eventuality that co-accused present evidence against other accused in the same trial, is counterbalanced by the guarantee, for each accused, to cross-examine witnesses presented by other co-accused and by the fact that each accused may request additional time in due course should good reasons exist." 
allocation decision by indicating what factors were considered for the assessment and what documents and information it had taken into account. ${ }^{162}$ What a Trial Chamber does not have to do is "to itemise and justify the time reduction in respect of each piece of evidence proposed by a party." 163

One day prior to the above-discussed decision allocating time to the defence for the case presentation, the Trial Chamber issued a Decision Adopting Guidelines for the Presentational of Defence Evidence. ${ }^{164}$ Petkovic's defence appealed certain points in that decision, notably the Trial Chamber's ruling to allow the prosecution, for the purpose of cross-examination, 100 per cent of the time allocated for the direct examination. ${ }^{165}$ According to Petkovic the Trial Chamber erred when it made this allocation of time thus violating his rights, notably the principle of equality of arms. ${ }^{166}$ In this respect, the defence submitted that each of the six accused was granted only one sixth of the time used for examination-in-chief for their crossexamination. ${ }^{167}$ This disparity violated the right of the accused to examine witnesses under the same conditions and "although a strict arithmetical equality of the time allocated to each party is not required, it is impossible to see how the Prosecution cross-examination needs to be six times as long as the time which the Trial Chamber regarded as generally sufficient for the cross-examination of Prosecution witnesses

162 Prlić et al. Appeal Decision on Defence Case Presentation, 1 July 2008, par. 56.

163 Prlić et al. Appeal Decision on Defence Case Presentation, 1 July 2008, par. 56 [footnote omitted].

164 ICTY, Prosecutor v. Prlić et al., Decision Adopting Guidelines for the Presentation of Defence Evidence, IT-04-47-T, 24 April 2008.

165 ICTY, Prosecutor v. Prlić et al., Decision on Petković Defence Motion for Certification to Appeal the Decision of 24 April 2008, IT-04-74-T, T. Ch. III, 29 May 2008, p. 4. The same approach was taken during the prosecution case where the Trial Chamber established that: (1) the total time limit of crossexamination by the Defence of the six accused shall not in principle exceed that of the Prosecution's direct-examination and, if the Defence fails to reach an agreement, shall be allocated equally among the Defence Counsel; (2) the Defence Counsel shall rotate their order of cross-examining witnesses; and (3) the testimony of a witness concerns the responsibility of one of the accused in particular, the time for cross-examination may be allocated differently. ICTY, Prosecutor v. Prlić et al., Decision on Defence Request Filed Jointly by the Six Accused for Certification of Interlocutory Appeal Against the Oral Decision of 8 May on time Allocated for Cross-Examination by Defence, IT-04-74-T, 29 May 2006, p. 2. The Defence appealed, but the Appeals Chamber emphasized the Trial Chamber's "considerable discretion in setting the parameters of cross-examination and in outlining the exercise of this right by the Defence" and found that "the Trial Chamber adopted a sufficiently flexible approach, which preserves the rights of cross-examination by each of the Defence counsels and complies with the rights to cross-examine witnesses as stipulated under Article 21(4) of the Statute." See ICTY, Prosecutor v. Prlić et al., Decision on Joint Defence Interlocutory Appeals Against the Trial Chamber's Oral Decision of 8 May 2006 Relating to Cross-Examination by Defence and on Association of Defence Counsel's Request for Leave to File an Amicus Curiae Brief, IT-04-74-AR73.2, 4 July 2005, pp. 3-4.

166 ICTY, Prosecutor v. Prlić et al., Decision on Petković's and Praljak's Appeals against the Trial Chamber's Decision Adopting Guidelines for the Presentation of Defence Evidence, IT-04-47AR73.8, A. Ch., 18 July 2008, par. 8 [Prlić et al., Decision on Petković's and Praljak's Appeals, 18 July 2008].

167 Prlić et al., Decision on Petković's and Praljak's Appeals, 18 July 2008, par. 9. 
by each individual Accused." 168 Interestingly, the prosecution argued "its own right to equality of arms would actually suffer if the 73bis Appeal is allowed and if the Prosecution is only granted one sixth of the time used for its examination-in-chief for its cross-examination of defence witnesses." 169 A disparate allocation of time for cross-examination "would not only violate the well-established practice of the Tribunal that the Prosecution and the Defence collectively are to be accorded roughly equal time but it would also fail to take into account the different burden placed on the Prosecution by the Statute and the Rules." ${ }^{170}$ Repeating the Orić formula and emphasizing the different roles assigned to the parties, the Appeals Chamber reiterated its finding in the decision on appeal of the Trial Chamber's allocation of time, that in a multi-accused trial, the basic proportionality is also affected by the circumstance that not all of prosecution's evidence is presented as proof of the responsibility of one accused. ${ }^{171}$ This is principally applicable to allocating time for cross-examination: while each defendant only challenges his own criminal responsibility when crossexamining prosecution's witnesses, the prosecution when cross-examining defence witnesses challenges all the evidence presented by those witnesses. ${ }^{172}$ The Appeals Chamber considered that this was in fact "a logical outcome of the circumstance that the Prosecution represents the only adversary of each individual accused in a joint trial." 173 With regard to the defence's concern that the defence strategies in a joint trial might differ and possibly conflict with each other, ${ }^{174}$ the Appeals Chamber noted that the "eventuality" that co-accused present evidence against each other would be "counterbalanced" by the possibility to cross-examine each others witnesses and to request additional time of necessary. ${ }^{175}$

The above discussion makes clear that the two-pronged test adopted in Orić has been accepted by other Chambers as leading for the interpretation of 'equality of arms' in the context of defence case presentation. The first step of establishing 'basic proportionality' of time and number of witnesses between prosecution and defence

168 Prlić et al., Decision on Petković's and Praljak's Appeals, 18 July 2008, par. 10 [footnote omitted]. 169 Prlić et al., Decision on Petković's and Praljak's Appeals, 18 July 2008, par. 15 [footnote omitted].

170 Prlić et al., Decision on Petković's and Praljak's Appeals, 18 July 2008, [footnote omitted].

171 Prlić et al., Decision on Petković's and Praljak's Appeals, 18 July 2008, par. 20 [footnote omitted].

172 Prlić et al., Decision on Petković's and Praljak's Appeals, 18 July 2008, par. 20.

173 Prlić et al., Decision on Petković's and Praljak's Appeals, 18 July 2008, par. 20. In the same vein the Trial Chamber allocated $50 \%$ of the time used for direct examination to other defence teams for cross-examination, because the other defence teams in an joint trial are not adversaries of the team presenting a witness, and the purpose of cross-examination is to safeguard the right to a fair trial in case the witness provides incriminating evidence. ICTY, Prosecutor v. Prlić et al., Decision Adopting Guidelines for the Presentation of Defence Evidence, IT-04-47-T, 24 April 2008, 15.

174 ICTY, Prosecutor v. Prlić et al., Decision Adopting Guidelines for the Presentation of Defence Evidence, IT-04-47-T, 24 April 2008, par. 15.

175 ICTY, Prosecutor v. Prlić et al., Decision on Petković's and Praljak's Appeals against the Trial Chamber's Decision Adopting Guidelines for the Presentation of Defence Evidence, IT-04-47AR73.8, A. Ch., 18 July 2008, par. 36. 
has clearly played a principal role when determining the scope of defences case at the pre-defence conference. Although a mathematical approach has been explicitly rejected as guiding the determination of time allocated for defence case, nevertheless, many Chambers adopted exactly this approach. This seems logical for anticipating the case of the defence and mainly practical for allocating time for case presentation and cross-examination beforehand. Considering the two-cases structure of court's trial proceedings, this arithmetical approach to allocation of time follows the logic of prosecution's case, and in addition, established an overall appearance of 'equality of arms' between the parties. The question remains whether the time allocated to defence is objectively adequate to provide for an equitable opportunity to present its case.

\section{Article $73 \operatorname{ter}(D)$ : varying the witness list}

In Gotovina et al., different defence teams requested the Trial Chamber to amend their Rule 65ter list by adding witnesses to it. ${ }^{176}$ According to Rule $73 \operatorname{ter}(\mathrm{D})$ a Trial Chamber may vary the witness list if it finds it necessary in the interests of justice. For this purpose, the Trial Chamber is required to "balance the accused's right to present the available evidence during his or her defence case with the rights of the Prosecution and the co-accused to have adequate time and facilities to prepare their cases." 177 Considering that the prosecution is regarded as the only adversary to each individual defendant (and not the other accused) and the prosecution as such is not entitled to "have adequate time and facilities to prepare" its case as of right, this balancing with a right of an accused to be able to present all the favourable evidence in his defence seems rather inappropriate. This approach undermines the principled nature of the considerations involved.

176 ICTY, Prosecutor v. Gotovina et al., Decision on Čermak's Defence Motion to Add a Witness to Its Rule 65ter $(G)$ Witness List, IT-06-90-T, 17 July 2009, par. 1; ICTY, Prosecutor v. Gotovina et al., Decision on Čermak Defence's Fourth Motion to Amend the Rule 65ter(G) Witness List, IT-0690-T, 15 October 2009, par. 1; ICTY, Prosecutor v. Gotovina et al., Reasons for Granting Markać Defence's Motion to Add Witness MM-28 (Renamed from MM-26) to its Rule 65ter(G) Witness List, IT-06-90-T, 15 January 2010, par. 1.

177 ICTY, Prosecutor v. Gotovina et al., Decision on Čermak's Defence Motion to Add a Witness to Its Rule 65ter $(G)$ Witness List, IT-06-90-T, 17 July 2009, par. 3; ICTY, Prosecutor v. Gotovina et al., Decision on Čermak Defence's Second and Third Motions to Add a Witness to its Rule 65ter $(G)$ Witness List, IT-06-90-T, 22 September 2009, par. 7; ICTY, Prosecutor v. Gotovina et al., Decision on Čermak Defence's Fourth Motion to Amend the Rule 65ter(G) Witness List, IT-06-90-T, 15 October 2009, par. 3; ICTY, Prosecutor v. Popović et al., Redacted Version of “ Decision on Motion on Behalf of Drago Nikolić Seeking Admission of Evidence Pursuant to Rule 92 Quarter", Filed Confidentially on 18 December 2008, IT-05-88-T, 19 February 2009, par. 36; ICTY, Prosecutor v. Gotovina et al., Reasons for Granting Markać Defence's Motion to Add Witness MM-28 (Renamed from MM-26) to its Rule 65ter(G) Witness List, IT-06-90-T, 15 January 2010, par. 3. 
Further elements that need to be considered are (i) the burden on other parties by the late admission of a witness; (ii) the prima facie relevance and probative value of the evidence; (iii) whether a good cause is shown for why the witness was not added at an earlier stage of proceedings, whereby good cause may exist where the witness or the relevant evidence has only recently become apparent. ${ }^{178}$ With regard to the Cermak defence, the Chamber considered that he had shown good cause for not having included the additional witness at an earlier stage due to continuing investigations. ${ }^{179}$ Deciding on Cermak's second and third motions to add more witnesses, the Chamber considered that the burden on the other parties by the admission of these witnesses would be limited because (i) the relevant evidence was already in the possession of all the parties; (ii) the beginning of Cermak's case was not imminent; (iii) all the parties were put on notice about the addition; and (iv) neither party had argued that the addition would be particularly burdensome. ${ }^{180}$ In other decisions, the Chamber concluded that the burden placed on the other parties would only be limited, concluding this on the basis of the fact that the admission of the additional witnesses was not challenged by the prosecution. ${ }^{181}$ In light of the prima facie relevance and probative value of the evidence this witness was to present, the Chamber found it in the interest of justice to add this witness to the list. ${ }^{182}$

As mentioned, the Trial Chamber's authority to reject the hearing of witnesses who are not mentioned on the pre-trial witness list of the party (Rule 90(G) ICTY) provides an extra dimension as to why it is important to compile such a list with due care. Not only can a witness list which is not carefully compiled impair the defence in its presentation of the case, it also violates the prosecutor's entitlement to equality of arms, according to the Chamber. In Stakić, the Trial Chamber allowed only two expert witnesses to be called by the defence, instead of the proposed seven.

178 ICTY, Prosecutor v. Gotovina et al., Decision on Čermak's Defence Motion to Add a Witness to Its Rule 65ter(G) Witness List, IT-06-90-T, 17 July 2009, par. 3; Prosecutor v. Gotovina et al., Decision on Čermak Defence's Second and Third Motions to Add a Witness to its Rule 65ter(G) Witness List, IT-06-90-T, 22 September 2009, par. 7; Prosecutor v. Gotovina et al., Reasons for Granting Markać Defence's Motion to Add Witness MM-28 (Renamed from MM-26) to its Rule 65ter $(\mathrm{G})$ Witness List, IT-06-90-T, 15 January 2010, par. 3.

179 ICTY, Prosecutor v. Gotovina et al., Decision on Čermak Defence's Fourth Motion to Amend the Rule 65ter(G) Witness List, IT-06-90-T, 15 October 2009, par. 5.

180 ICTY, Prosecutor v. Gotovina et al., Decision on Čermak Defence's Second and Third Motions to Add a Witness to its Rule 65ter(G) Witness List, IT-06-90-T, 22 September 2009, paras. 9, 12. ICTY, Prosecutor v. Gotovina et al., Decision on Čermak's Defence Motion to Add a Witness to Its Rule 65ter(G) Witness List, IT-06-90-T, 17 July 2009, par. 6.

181 ICTY, Prosecutor v. Gotovina et al., Decision on Čermak Defence's Fourth Motion to Amend the Rule 65ter(G) Witness List, IT-06-90-T, 15 October 2009, par. 6; ICTY, Prosecutor v. Gotovina et al., Reasons for Granting Markać Defence's Motion to Add Witness MM-28 (Renamed from MM26) to its Rule 65ter(G) Witness List, IT-06-90-T, 15 January 2010, par. 6.

182 ICTY, Prosecutor v. Gotovina et al., Reasons for Granting Markać Defence's Motion to Add Witness MM-28 (Renamed from MM-26) to its Rule 65ter(G) Witness List, IT-06-90-T, 15 January 2010, par. 7. 
This decision found approval on appeal, where the Appeals Chamber considered that due to the fact that the "Defence failed [...] to specify either the names of the proposed experts or an explanation as to what fact and point in the Indictments to which each expert would testify" the Trial Chamber's conclusion that his request for experts was unsubstantiated was in fact correct. ${ }^{183}$ Inadequacy of defence witness list has been considered to have other (negative) consequences for the defence since "[...] the absence of a well-developed schedule for presentation of evidence might impact on the possibility to deviate from a previously set schedule." 184 Moreover, the Trial Chamber considered that the "extremely succinct and summary nature of defence witness statements" in fact violates equality of arms because the prosecution has provided much more detailed witness statements which allowed the defence to prepare for cross-examination. ${ }^{185}$ Assuming the Chamber means that inadequate defence witness statements preclude the prosecution from adequate preparation of cross-examination, it is puzzling why the Chamber finds that equality of arms is violated. In this context, it is important to keep in mind the prosecution's burden and the disclosure obligations and the rights of the accused in this regard (discussed in Chapter 5).

\subsubsection{ICC}

As mentioned, confirmation of charges proceedings is an innovative element at the ICC, as compared to the ad hoc tribunals. After the confirmation of charges, the Presidency assigns a Trial Chamber to a case for the conduct of the trial proceedings and transmits the Pre-Trial Chamber's decision and the record of the proceedings to the Trial Chamber. ${ }^{186}$ However, before the trial begins, the Trial Chamber is responsible for all the outstanding issues that might stand in the way of proceeding to trial. ${ }^{187}$ In particular, the Trial Chamber, "upon assignment of a case for trial," is to

183 ICTY, Prosecutor v. Stakić, Appeals Chamber Judgment, IT-97-24-A, A. Ch., 22 March 2006, paras. $151,153$.

184 ICTY, Prosecutor v. Krajišnik, Decision on Defence Motion Pursuant to Rule 85(A) (vi) - Including Reasons for Denial in Part, IT-00-39-T, T. Ch. I, 24 August 2006, par. 13. In this decision the Trial Chamber denied the hearing of two defence witnesses after the close of the Defence's case because (1) the defence did not indicate the relevance of that testimony, (2) the schedule for the closing of the defence's case was set beforehand and notably was subject to many adjustments, and as such the defence had the opportunity to call these witnesses during its case but opted not to do so; neither did the defence indicate that these two witnesses were not available during the presentation of its case.

185 ICTY, Prosecutor v. Kupreškić et al., Decision, IT-95-16-T, T. Ch., 11 January 1999, p. 2. In this case the Trial Chamber ordered the Defence to provide to the Prosecution more detailed witness statements (upon the latter's request). And in case the defence fails in this, the Prosecution will have the opportunity to interview the witness from whom more detailed statements have not been received.

186 Article 61(11) ICC Statute, Rule 130 ICC RPE.

187 Article 64 lays down the functions and powers of the Trial Chamber. The proper commencement 
confer with the parties and to adopt the necessary procedures that facilitate a fair and expeditious trial, to determine the language(s) to be used at trial and provide for the disclosure between the parties "sufficiently in advance of the commencement of the trial to enable adequate preparation for trial." 188 Rule 132(1) determines that a status conference should be held immediately after a Trial Chamber is constituted to set the date for trial, while paragraph 2 provides for a discretionary authority for the Trial Chamber to hold status conferences to confer with the parties in order to facilitate the fair and expeditious conduct of proceedings. ${ }^{189}$ Although neither the Statute nor the Rules envisage managerial powers comparable to Rules 73bis and 73ter ICTY RPE, the Regulations of the Court provide for a broad spectrum of 'managerial' powers for the Trial Chamber to be exercised at a status conference. Regulation 54 details Article 64(3)(a) and provides a non-exhaustive list:

At a status conference, the Trial Chamber may, in accordance with the Statute and the Rules, issue any order in the interests of justice for the purposes of the proceedings on, inter alia, the following issues:

(a) The length and content of legal arguments and the opening and closing statements;

(b) A summary of the evidence the participants intend to rely on;

(c) The length of the evidence to be relied on;

(d) The length of questioning of the witnesses;

(e) The number and identity (including any pseudonym) of the witnesses to be called;

(f) The production and disclosure of the statements of the witnesses on which the participants propose to rely;

(g) The number of documents as referred to in Article 69, paragraph 2, or exhibits to be introduced together with their length and size;

(h) The issues the participants propose to raise during the trial;

(i) The extent to which a participant can rely on recorded evidence, including the transcripts and the audio- and video-record of evidence previously given;

(j) The presentation of evidence in summary form;

(k) The extent to which evidence is to be given by an audio- or video-link;

(l) The disclosure of evidence;

of the trial is with the opening statements prior to the calling of witnesses. See ICC, Prosecutor v. Lubanga Dyilo, Decision on the Status Before the Trial Chamber of the Evidence heard by the PreTrial Chamber and the decision of the Pre-Trial Chamber in Trial Proceedings, and the Manner in which evidence shall be submitted, ICC-01/04-01/06-1084, 13 December 2007, par. 39. The Trial Chamber considers that the exception to the powers of the Trial Chamber to govern the preparation phase of the trial (proceedings subsequent to the confirmation of the charges) is the power to amend the charges as confirmed by the Pre-Trial Chamber: Article 61(9) invests this power solely upon the Pre-Trial Chamber (Id., paras. 40-41).

188 Article 64(3) ICC Statute.

189 Biтti, 2008, p. 1206. 
(m) The joint or separate instruction by the participants of expert witnesses;

(n) Evidence to be introduced under rule 69 as regards agreed facts;

(o) The conditions under which victims shall participate in the proceedings;

(p) The defences, if any, to be advanced by the accused.

Accordingly, the ICC Trial Chamber can determine the case presentation, including the time and the number of witnesses, analogous to the Pre-Trial and Pre-Defence conferences of the ICTY, ICTR and SCSL. ${ }^{190}$ These case management powers of the judges have a steering effect on the factual inquiry to be conducted during the trial. In fact, "in order to play a meaningful role in establishing the truth, the Trial Chamber may employ its regulatory power under Article 64(3)(a) and Rule 134 to require the parties to submit information disclosed to the other party, as well as additional information relevant to the management of the proceedings, to the Chamber, before the commencement of the Trial." ${ }^{191}$ Knowing what issues are in dispute constitutes a necessary prerequisite for an effective exercise of managerial powers. ${ }^{192}$

In the context of the confirmation of charges scheduling, in the Bemba confirmation of charges proceedings the defence requested additional time to present its case (12 instead of 6 hours). ${ }^{193}$ The Single Judge recalled "the principle of fairness which encompasses the notion of equality of arms and inter alia requires that the parties be placed on equal footing and that the Defence always has the final word as prescribed under Rule 122(8) of the Rules." ${ }^{194}$ However, "with due consideration to the principle of equality of arms," the Single Judge decided to deny the defence's request for additional time for the opening and closing statements. ${ }^{195}$ The defence "should not have more than one hour for each of these statements, bearing in mind that this is the amount allotted for the prosecutor, who concurred with the Proposed Schedule on this particular point." 196 Moreover, the Judge also considered "that it is inappropriate to allow the Defence to have twelve hours to present its case as it would

190 Gallmetzer, 2008, p. 508.

191 BiтTI, 2008, p. 1205 (referring to the power of the Trial Chamber to consult the record of the proceedings as "the condition sine qua non" to the power under Article 69(3) to search for the truth); GALLMETZER, 2008, p. 505.

192 ICTY, Prosecutor v. Lubanga Dyilo, Decision on Agreements between the Parties, ICC-01/04-01/061179, T. Ch. I, 20 February 2008, par. 11: "In order effectively to exercise its case-management powers under Regulation 54(n) of the Regulations of the Court and, in particular, to ensure that witnesses are not needlessly brought to court when their evidence is not in dispute, the Chamber orders the parties to prepare a draft schedule of agreed facts to be considered by the Chamber eight weeks before the commencement of the trial."

193 ICTY, Prosecutor v. Bemba, Decision on the Schedule for the Confirmation of Charges Hearing, ICC-01/05-01/08-336, 29 December 2008, par. 3 [Bemba Confirmation of Charges Schedule, 29 December 2008].

194 Bemba Confirmation of Charges Schedule, 29 December 2008, par. 12.

195 Bemba Confirmation of Charges Schedule, 29 December 2008, par. 15.

196 Bemba Confirmation of Charges Schedule, 29 December 2008, par. 15. 
unduly disrupt the equality between the parties without sufficient justification."197 However, the Judge considered it appropriate to give the defence some "additional time to respond and present its evidence as this part represents the core of the proceedings." 198

There are minimal directions for the trial proceedings proper: according to Article 64(8)(b) the Presiding Judge may give instructions for the conduct of proceedings, but if he does not, the prosecutor and the defence shall agree on the order and manner of the presentation of evidence to the Trial Chamber (Rule 140(1)). If no agreement is reached, the presiding judge must give directions (Rule 140(1)). Exemplary of the use of managerial powers under Rule 140 are the detailed directions for the conduct of proceedings issued by the Presiding Judge in Katanga and Ngudjolo Chui. ${ }^{199}$ At the outset, the prosecution indicated that it needed approximately 200 hours for the examination-in-chief of 26 witnesses it intended to call. ${ }^{200}$ The Chamber calculated that this would amount to almost 8 hours per witness, which it considered far too much. Being aware of "the structural and technical differences between the Court's proceedings and those of the ad hoc tribunals, most notably with regard to the issue of witness proofing" the Chamber considered that on average four and a half hours per witness for examination-in-chief would suffice. ${ }^{201}$ Thus, being allotted in total 120 hours for examination-in-chief, the prosecution remained free to divide the available time among witnesses. Unfortunately, the Chamber does not indicate how it arrived at the average hour per witness or how and what cases it compared from the ad hoc tribunals' practice. It is to be assumed that by reference to the ad hoc tribunals the Chamber considered a higher average of hours per witness at the ICC to be more appropriate, because of the parties' inability to 'proof' witnesses before the sessions, thus being less prepared for the actual way in which the witness may react and answer in court. If one considers an average of two to two and a half hours examinationin-chief per witness at the ICTY (for example, in the Orić and Perišić cases), the Chamber indeed increased that number substantially. Interestingly, the Chamber indicated that for the purpose of cross-examination, each defence team "will be allocated roughly 60 per cent of the time used by the Prosecution for examination-in-

197 Bemba Confirmation of Charges Schedule, 29 December 2008, par. 16.

198 Bemba Confirmation of Charges Schedule, 29 December 2008, par. 16. The Single Judge decided to allot 7 hours to the defence. Because the Prosecution did not apply for additional time, the Single Judge assumed it was satisfied with the allocated time.

199 ICC, Prosecutor v. Katanga and Ngudjolo Chui, Directions for the Conduct of the Proceedings and Testimony in Accordance with Rule 140, ICC-01/04-01/07-1665, 1 December 2009 [Katanga and Ngudjolo Chui Proceedings Directions, 1 December 2009].

200 Katanga and Ngudjolo Chui Proceedings Directions, 1 December 2009, par. 7. This was a revised proposal following the judges' order to 'radically reduce the number of hours envisaged for examination-in-chief" (Idem., par. 6).

201 Katanga and Ngudjolo Chui Proceedings Directions, 1 December 2009, par. 8. 
chief." ${ }^{202}$ As discussed above, the ad hoc tribunals were allocating the same amount of time for examination-in-chief and cross-examination.

At the drafting process concerns about the trial judges' power to view the complete record of proceedings were expressed, particularly from the common law corner: to preserve impartiality, judges should be as "untainted" as possible. ${ }^{203}$ The defence from the civil law corner is usually phrased in terms of enhancing the expeditiousness of the process in a case where the trial judges have an extensive knowledge of the case file before the trial. In fact,

it will be essential for the Trial Chamber to consult the record of the proceedings in order to have sufficient knowledge of the case to fully control over the proceedings: it may be a question of survival for the International Criminal Court to follow the evolution of both ad hoc Tribunals where the Judges have increased their control over the proceedings in order to shorten the trials; it is indeed absolutely vital for the Court not to leave the trial in the hands of the parties to avoid lengthy trials which affect the credibility of international justice. ${ }^{204}$

Arguably, the use of the pre-trial management powers is necessary for streamlining and focusing the trial proper, and acquiring in-depth knowledge of the case file, without making any (final) decisions regarding the guilt or innocence of the accused, helps in that task. In this regard, it is important to observe that the Trial Chamber is not bound by the decisions of the Pre-Trial Chamber on evidential or procedural issues, except with regard to the latter's decision on the confirmation of charges. ${ }^{205}$

\subsubsection{ECCC}

The uniquely 'inquisitorial' model underlying the procedure of the ECCC creates a different outlook at the pre-trial process and the managerial powers of the judges. Indeed, the Co-Investigative Judges completely control the investigative process and assemble a case file with evidence to support the charges that is then transferred to the Trial Chamber for the trial. At trial, the trial judges lead the presentation of evidence, a responsibility which places the parties in a secondary position with regard to prooftaking. According to Rule 87(2) ECCC IR “[a]ny decision of the Chamber shall be based only on evidence that has been put before the Chamber and subjected to

202 Katanga and Ngudjolo Chui Proceedings Directions, 1 December 2009, par. 10.

203 Biтt, 2008, p. 1205 [footnote reference omitted].

204 BiтTi, 2008, p. 1205.

205 ICC, Prosecutor v. Lubanga, Decision on the Status Before the Trial Chamber of the Evidence heard by the Pre-Trial Chamber and the decision of the Pre-Trial Chamber in Trial Proceedings, and the Manner in which evidence shall be submitted, ICC-01/04-01/06, T. Ch. I, 13 December 2007, paras. 43,5 . 
examination." ${ }^{206}$ Paragraph 3 of the same Rule explains that "[t]he Chamber bases its decision on evidence from the case file provided it has been put before it by a party or if the Chamber itself has put it before the parties. Evidence from the case file is considered put before the Chamber or the parties if its content has been summarised, read out, or appropriately identified in court." ${ }^{207}$ This ability 'to put evidence before the Chamber' provides the parties with participation which is substantially in line with the principle of adversarial proceedings contained in Rule 21(1)(a) ECCC IR.

In preparation of the trial, some managerial powers seem unavoidable in order to streamline the trial hearings. ${ }^{208}$ First, Rule 79(7) states that "[i]n order to facilitate the fair and expeditious conduct of the proceedings" the Trial Chamber can hold a trial management meeting to confer with the parties. The purpose of such a meeting is to, inter alia, allow exchanges between the parties thus facilitating the setting of a date for trial and to review the status of the case by giving the accused an opportunity to raise issues in regard to that, including issues in relation to his health. In this format, the trial management hearing is comparable to a status conference at the ad hoc tribunals.

Second, Rule 80 ECCC IR contains an extensive list of pre-trial filings the parties are expected to provide. Thus, the Co-Prosecutors must submit a list to the Greffier (the Registrar) of all the witnesses they intent to summon, which list is placed on the case file and forwarded to the other parties, subject to protective measures. ${ }^{209}$ If the accused or the civil parties wish to summon witnesses who are not on prosecution's list, they should submit an additional list. ${ }^{210}$ In addition, the Trial Chamber may order the submission, before the Initial Hearing, of (1) a summary of the facts each witness is expected to testify on, which should be sufficiently detailed to allow the Chamber and the other parties to understand fully the nature and content of the proposed testimony; (2) the specific points of the Indictment to which each witness is expected to testify; and (3) the estimated length of each witness' testimony. ${ }^{211}$ Moreover, the Chamber may order the parties to file a list of exhibits with a short description of their nature and content, an indication of the legal issues to be raised, any new documents they intend to offer and a list of uncontested facts with a reference to the relevant evidence. $^{212}$

206 ECCC IR (Rev. 7), 23 February 2011.

207 Ibid.

208 The trial preparation stage starts when a Trial Chamber is seized by an indictment from the CoInvestigating Judges or the Pre-Trial Chamber (Rule 79(1)). Although the trial officially starts with an initial hearing (Rule 80bis(1)), the substantive managerial powers can be transferred to the trial stage proper (e.g. Rule 80(4), Rule 80bis(2)).

209 Rule 80(1) ECCC IR (Rev. 7), 23 February 2011.

210 Rule 80(2) ECCC IR (Rev. 7), 23 February 2011. The Greffier puts the list on the case file and forwards it to the other parties.

211 Rule 80(3)(a)(i)-(iii) ECCC IR (Rev. 7), 23 February 2011.

212 Rule 80(3)(b) - (e) ECCC IR (Rev. 7), 23 February 2011. 
At the Initial Hearing, the Chamber shall consider the above-mentioned lists and has the power to reject to summon any proposed witness or expert if their testimony "would not be conductive of the good administration of justice." ${ }^{13}$ For example, in the first case to go to trial, Duch, the Co-Prosecutors proposed to call 35 witnesses and experts (needing 40 trial days), including two civil parties, who were included in case they decided to abandon their civil party status. ${ }^{214}$ The defence proposed only 13 witnesses it wished the Trial Chamber to summon, needing 4 and a half trial days (23 hours and 15 minutes) for their testimony. ${ }^{215}$ The civil parties proposed approximately 17 witnesses. ${ }^{216}$ For the assessment of the witness lists, the Trial Chamber, in closed session, considered whether the witness or expert would not be conducive to the good administration of justice. For this purpose, the Chamber evaluated the proposed witness testimony in light of the Rule 87 criteria for the admissibility of evidence, thus looking at whether the testimony would be (a) irrelevant or repetitious, (b) impossible to obtain within a reasonable time, (c) unsuitable to prove the fact it purports to prove, (d) not allowed under the law. ${ }^{217}$ In addition, "in order to avoid unnecessary repetition and lengthy hearings," the Chamber can take into account whether several witnesses will give evidence on the same facts, whether there are any agreed facts between the parties, and whether there are complete contact details for each witness in order to be able to summon them. ${ }^{218}$ Considering these factors, the Chamber decided to accept 38 witnesses, and to postpone its decision in relation to 17 other witnesses. ${ }^{219}$ One witness would be called by the Chamber, while 3 witnesses (proposed by the civil parties) were rejected: two were considered unnecessary because the facts on which they were to testify were uncontested by the defence, and 1 because she was impossible to contact and no indication of the relevance of her

213 Rule 80bis(2) ECCC IR (Rev. 7), 23 February 2011.

214 ECCC, Prosecutor v. Kaing Guek Eav, Transcript of Proceedings, Initial Hearing Day 1, 001/18-072007-ECCC/TC, T. Ch., 17 February 2009, pp. 71-72 [Duch Initial Hearing, 17 February 2009]. In respect of the two Civil Parties, the Chamber considered that "any civil party whose testimony can be conducive to the ascertainment of the truth may nonetheless be summoned to appear in court. At the time they appear in the court to testify, their status as a civil party will be taken into account. If they do not renounce their civil party status, the prohibition on taking the witness oath under Rule 23(6) will apply."

215 Duch Initial Hearing, 17 February 2009, p. 104.

216 Duch Initial Hearing, 17 February 2009, pp. 82-83.

217 Duch Initial Hearing, 17 February 2009, p. 2.

218 ECCC, Prosecutor v. Kaing Guek Eav, Transcript of Proceedings, Initial Hearing Day 2, 001/1807-2007-ECCC/TC, T. Ch., 18 February 2009 [Duch Initial Hearing, 18 February 2009], p. 2: "It is for the party which requests a witness to be summoned to provide the exact address, or enough information for the Chamber to be able to locate him or her."

219 Duch Initial Hearing, 18 February 2009, p. 3. 
testimony was provided. ${ }^{220}$ The Chamber did emphasize that during trial, the need to hear a witness may change. ${ }^{221}$

Compared to the practice of the ad hoc tribunals, where the Chambers have indicated in general terms the time and/or the number of witnesses available for case presentation, thus leaving it up to the parties to decide on the particulars, the Trial Chamber at the ECCC clearly exercised a more substantial management of the case by pinpointing concrete witnesses the parties were allowed to call or not to call. This seems understandable in light of the familiarity of the judges with the case through the case file. However, a caveat is in order. The Duch case is quite limited in scope, as compared to Case 002, and more importantly, the accused did not challenge many of the factual allegations. Pinpointing exactly the witnesses that may be called might constitute a more challenging task for the Chamber in Case 002, which revolves around five accused who all contest the charges. The defence can be expected to more vigorously challenge any rejection to hear witnesses on the basis of its fundamental right to present favourable evidence in an adversarial setting. The Chambers might be advised to follow the line of the ad hoc tribunals more closely in relation to setting the time and the number of witnesses in that case.

\subsection{Trial Issues}

Having considered the managerial powers of the judges to control the case presentation before the trial by setting limits on the time and the number of witnesses that can be presented, this section will focus on several other issues that arise during trial with regard to equality of arms. The most prominent, in this regard, relate to the calling and questioning of witnesses (including expert witnesses) and the participation of victims in the trial proceedings. But before delving into these matters some general remarks on the case presentation scheme adopted at the ad hoc tribunals, SCSL, ICC and ECCC are in order.

\subsubsection{Case presentation scheme}

The way evidence is to be presented before international and hybrid courts largely accords with the 'adversarial' and 'inquisitorial' models of criminal process. As a principal point of distinction the level of confrontation that regulates the truth-finding in a trial can be mentioned. Whether a tribunal adopts an adversarial 'two cases' or the inquisitorial judge-led approach to the presentation of evidence is to some extent predisposed by the roles and the division of powers between the judges and the parties in the pre-trial process and the actual proof-taking at trial. It should be 
noted that these qualifications are based on both the legal framework and the practice adopted by the tribunals and represent only the general models. The ultimate power to design the case presentation at the ad hoc tribunals, the SCSL and ICC is in the hands of the judges and could potentially vary on a case-by-case basis.

\subsubsection{ICTY, ICTR and SCSL: The 'two-case' approach}

In light of their historical establishment and their procedural and evidentiary roots, the 'adversarial' model can be seen as the driving force of the case presentation scheme for the ad hoc tribunals and the SCSL. ${ }^{222}$ Rule 85(A), common to all the tribunals, established the sequence of the presentation of evidence. According to this Rule, both parties have an opportunity to present their case in one bulk, allowing only for cross-examination by the other party and the judges as 'interruptions' thereto. In accordance with the prosecutor's burden of proof, she presents her case first. Following a judgment against a motion for 'no case to answer', ${ }^{223}$ the defence is to present its case, after which both parties have a possibility to respond to their cases respectively by way of rebuttal and rejoinder. ${ }^{224}$ These latter stages are more limited in character than the examination-in-chief. Lastly, the Chamber is to order any additional evidence it might need and the parties are to present relevant information that may assist the Trial Chamber in determining an appropriate sentence in case the accused is found guilty. This sequence is representative for the practice adopted by the ad hoc tribunals; however, one should keep in mind that the sequence of case presentation laid down in Rule 85 can be deviated from as the judges have the discretion to direct otherwise if it would serve the interests of justice. ${ }^{225}$

222 See e.g. ICTY, Prosecutor v. Delalić et al., Decision on the Prosecution's Alternative Request to Reopen the Prosecution's Case, Case No. IT-96-21-T, T. Ch. II., 19 August 1998, par. 20 [Delalić et al. Decision on Fresh Evidence, 19 August 1998], where the Trial Chamber considered that "the order for presentation of evidence clearly portray the philosophy of the total."

223 Rule 98bis ICTY (Judgment of Acquittal): “After the close of Prosecutor's case, the Trial Chamber shall, by oral decision and after hearing the oral submissions of the parties, enter a judgement of acquittal on any count if there is no evidence capable of supporting conviction." Rule 98 SCSL contains similar wording. Rule 98bis ICTR contains the older version of the ICTY's rule (before the amendment of 8 December 2004) and states: "If after the close of the case for the prosecution, the Trial Chamber finds that the evidence is insufficient to sustain a conviction on one or more counts charged in the indictments, the Trial Chamber, on motion of an accused filed within seven days after the close of Prosecutor's case-in-chief, unless the Chamber orders otherwise, or proprio motu, shall order the entry of judgement of acquittal in respect of those counts."

224 Except at the SCSL, where Rule 85(A) only talks about (i)evidence for the prosecution, (ii) evidence for the defence; (iii) Prosecution evidence in rebuttal, with leave of the Trial Chamber, and (iv) evidence ordered by the Trial Chamber.

225 See the heading of Rule 85. See ICTR, Prosecutor v. Semanza, Decision on the Prosecutor's Motion for Leave to Call Rebuttal Evidence and the Prosecutor's Supplementary Motion for Leave to Call Rebuttal Evidence, ICTR-97-20-T, T. Ch. III, 27 March 2002. ICTY, Prosecutor v. Lukić and Lukić, Decision on the Prosecution's Appeal Against the Trial Chamber's order to Call Alibi Rebuttal 
Rule 85(B) further stipulates the details of each stage: "examination-in-chief, cross-examination and re-examination shall be allowed in each case." Although the party calling the witness is responsible for the examination-in-chief, a judge can put a question before the witness at any stage. Where, in principle, a party is free to choose which and how many witnesses it wants to present to the Trial Chamber, the above discussion has shown that the managerial fetters imposed by the judges at the pretrial stage have gradually qualified this freedom. ${ }^{226}$

The possibility to reopen a case is subject to stringent requirements, which will be discussed hereunder. It is a fundamental right of an accused person to hear clearly the allegations against him and to be provided with an opportunity to defend himself against those accusations. As such, "there should be a point where accusation ends and answering the allegations begins," 227 a notion that underlies the 'two-case' approach as adopted by the ad hoc tribunals.

\subsubsection{ICC: 'Open-ended'approach}

The evidence presentation scheme at the ICC has no specific reference to either a party or a judge-dominated case presentation. The legal framework is open-ended and leaves it to the judges to adopt a model of case presentation on a case-by-case basis. ${ }^{228}$ In theory, the sequence may include the model where the prosecution and the

Evidence During the Prosecution's Case in Chief, IT-98-32/1-AR73.1, 16 October 2008, par. 23: " ... the only justification under the Rules for a change to the normal sequence of the presentation of evidence is where the Trial Chamber finds that it is in the "interest of justice." In this case the Appeals Chamber considered that Trial Chamber had "erred by (1) failing to distinguish between evidence relevant to the Prosecution case in chief and evidence going to rebuttal of an alibi; (2) relying on the Delalic et al. case in order to determine the timing of the hearing of rebuttal evidence concerning an alibi; and (3) requiring the Prosecution to present evidence rebutting the alibi in its case in chief where notice of alibi has been given" (Id. par. 25).

226 Notably, Rule 90(G) ICTY RPE which states that a Trial Chamber has the power to refuse to hear a particular witness whose name does not appear on the Rule $73 \operatorname{bis}(\mathrm{C})$ and $73 \operatorname{ter}(\mathrm{C})$ witness lists.

227 ICTY, Prosecutor v. Blagojević and Jokić, Decision on the Prosecution's, to Admit Evidence in Rebuttal and Incorporated Motion to Admit Evidence Under Rule 92bis in its Case on Rebuttal and to Re-Open its Case for a Limited Purpose, IT-02-60-T, T. Ch., 13 September 2004, par. 6.

228 Article 64(8)(b), Rule 140(1). ICC, Prosecutor v. Lubanga Dyilo, Decision on the "Requête de la Défense sollicitant l'autorisation d'interjeter appeal de la decision orale du 4 mars 2010 autorisant l'utilisation et le depot en prevue de trios photographies", ICC-01/04-01/06-2404, 29 April 2010, par. 26: "The Chamber did not determine that as a matter of general policy, no additional incriminating evidence is to be permitted following the close of the "prosecution case." It is to be noted that the expressions the "prosecution case" and "defence case" are not to be found in the relevant provisions. The Rome Statute framework does not apply fixed stages for the presentation of evidence during the trial, and in this the ICC differs from the position in some other courts or tribunals (see, for instance. Rule 85 of the Rules of Procedure and Evidence of the ICTY). Article 64(8)(b) of the Statute and Rule 140(1) of the Rules of Procedure and Evidence essentially leave it to the Chamber to determine the model to be followed instead of applying a mechanistic formula." [footnote omitted]. 
defence are the first to present their whole cases, or where the judges direct the prooftaking by determining a topical approach to the examination of evidence. ${ }^{229}$

In Lubanga, the prosecution argued for an opportunity to present all the incriminating evidence at the beginning of the trial in order to provide the defence with an opportunity to decide on the exercise of the right under Article 67(1)(g) and (i). ${ }^{230}$ Moreover, this mode would best serve the administration of justice and the expeditiousness of the trial process. ${ }^{231}$ After the prosecution's presentation, the defence should present its evidence, should it decide "to rebut the incriminating evidence and to present his own defence." 232 Lastly, evidence in rebuttal and rejoinder might be accepted by the Chamber on a case-by-case basis. ${ }^{233}$ The examination of witnesses, according to the prosecution, should start with the party who is submitting the evidence as it is most familiar with the witness and its testimony, which in turn best serves trial fairness and expediency. ${ }^{234}$ Because there was "broad agreement on [...] the manner in which evidence shall be submitted," the Trial Chamber tacitly accepted the prosecution's proposal. ${ }^{235}$ Because the parties did not explicitly detail the mode of evidence examination by the judges or the Legal Representatives, the actual trial scheme appears as follows: (1) prosecution case; (2) Trial Chamber's expert witnesses; ${ }^{236}$ (3) victims' evidence, ${ }^{237}$ and (4) defence case.

In the Katanga and Nudjolo Chui and Bemba cases, Trial Chambers II and III issued directions on the conduct of proceedings for the sake of clarity. ${ }^{238}$ The

229 GallmetZer, 2009, p. 506. Kirsch, 2008, pp. 47-62, defending the procedural model of one-case presentation.

230 ICC, Prosecutor v. Lubanga Dyilo, Prosecution's submission regarding the subjects that require early determination: status of the evidence heard by the Pre-Trial Chamber; status of decision of the Pre-Trial Chamber; and the manner in which evidence shall be submitted, ICC-01/04-01/06-953, 12 September 2007, par. 30 [Lubanga Dyilo Prosecution's Submission on Several Issues, 12 September 2007].

231 Lubanga Dyilo Prosecution's Submission on Several Issues, 12 September 2007, par. 30.

232 Lubanga Dyilo Prosecution's Submission on Several Issues, 12 September 2007, par. 30. Rebuttal evidence was later admitted by the Trial Chamber, see ICC, Prosecutor v. Lubanga Dyilo, Redacted Decision on the Prosecution's Application to Admit Rebuttal Evidence from Witness DRC-OTPWWWW-0005, ICC-01/04-01/06-2727-Red, T. Ch. I, 28 April 2011, par. 65.

233 Lubanga Dyilo Prosecution's Submission on Several Issues, 12 September 2007, par. 31.

234 Lubanga Dyilo Prosecution's Submission on Several Issues, 12 September 2007, par. 32.

235 ICC, Prosecutor v. Lubanga Dyilo, Decision on the status before the Trial Chamber of the evidence heard by the Pre-Trial Chamber and the decisions of the Pre-Trial Chamber in trial proceedings, and the manner in which evidence shall be submitted, ICC-01/04-01/06-1084, 13 December 2007, par. 2.

236 ICC, Prosecutor v. Lubanga Dyilo, Transcript of 9 December 2009, ICC-01/04-01/06-T-222-ENG, p.1-2; 7 January 2010, ICC-01/04-01/06-T-223-ENG, p. 6; and 8 January 2010, ICC-01/04-01/06-T224-ENG, p. 2.

237 ICC, Prosecutor v. Lubanga Dyilo, Decision on the request by victims a/0225/06, a/0229/06 and $\mathrm{a} / 0270 / 07$ to express their views and concerns in person and to present evidence during the trial, ICC-01/04-01/06-2032-Anx, T. Ch. I, 29 June 2009.

238 Katanga and Ngudjolo Chui, Proceedings Directions, 1 December 2009, paras. 4-7. See also ICC, 
directions indicate the different phases of the trial: first the prosecution case, then the case for the Defence and lastly any additional witnesses the Chamber may decide to call, including the witnesses suggested by the Victims' Legal Representatives. However, the "Chamber may intervene at all times and order the production of all evidence that it considers necessary for the determination of the truth, in accordance with Article 64(6)(d) and 69(3) of the Statute. ${ }^{239}$ Following the line of Lubanga, any participating victims who wish to testify in person may do so with the permission of the Chamber after the close of the prosecution phase, but before the defence phase has been started. ${ }^{240}$ The directions do not encompass a specific phase of the presentation of evidence in rebuttal and rejoinder; however, the Trial Chambers have considered that in certain circumstances evidence in rebuttal can be admitted. ${ }^{241}$

Notably, Pre-Trial Chamber III in the Bemba case adopted a somewhat different approach to structure the confirmation of charges hearing. While keeping in line with the more adversarial mode of presenting evidence, the Single Judge requested the parties to present (and to react to) the evidence by subject-matter. ${ }^{242}$ Replying to the defence's argument that the prosecution should present its whole case so that the burden of proof is not reversed, the Judge considered that "the order in which the parties give their presentations does not reverse the burden of proof" and that the right of the defence "is safeguarded since, at the end of each session, it will be given the opportunity to respond to the Prosecutor's arguments and to speak last." 243 In fact, the Judge considered the defence's argument to be purely of an organizational nature

Prosecutor v. Bemba, Decision on Directions for the Conduct of the Proceedings, ICC-01/05-01/08, 19 November 2010, par. 5 .

239 Katanga and Ngudjolo Chui Proceedings Directions, 1 December 2009, par. 3; ICC, Prosecutor v. Bemba, Decision on for the Conduct of the Proceedings, ICC-01/05-01/08, 19 November 2010, par. 5.

240 Katanga and Ngudjolo Chui Proceedings Directions, 1 December 2009, par. 5; ICC, Prosecutor v. Bemba, Decision on Directions for the Conduct of the Proceedings, ICC-01/05-01/08, 19 November 2010, par. 5. However, compared to Lubanga, both Katanga and Bemba use a more 'common lawinspired' terminology.

241 ICC, Prosecutor v. Lubanga Dyilo, Redacted Decision on the Prosecution's Application to Admit Rebuttal Evidence from Witness DRC-OTP-WWWW-0005, ICC-01/04-01/06-2727-Red, T. Ch. I, 28 April 2011, par. 43. The Prosecution has to show that: (1) an issue of significance has arisen ex improvisio, (2) the evidence on rebuttal satisfies the admissibility criteria, and (3) admission will not undermine the accused's rights, in particular under Article 67 of the Statute.

242 ICC, Prosecutor v. Bemba, Annex to Decision on the Schedule for the Confirmation of Charges Hearing, ICC-01/05-01/08-336, 29 December 2008. Per subject, the Prosecution is to present first, followed by the arguments of the defence. Having reminded the parties that Rule 122(1) directs the Presiding Judge to determine how the hearing is to be conducted, the Single Judge considered that the proposed schedule for case presentation by charge should not be adjusted.

243 ICC, Prosecutor v. Bemba, Decision on the Schedule for the Confirmation of Charges Hearing, ICC01/05-01/08-336, 29 December 2008, par. 20. 
and "which is not supported in law by any provision of the Statute, the Rules or in international law and internationally recognized norms and standards." 244

\subsubsection{ECCC: A 'Judge-led'approach}

Due to the 'inquisitorial' roots and its imbedding, the ECCC evidence presentation scheme differs from the ad hoc tribunals and SCSL in that is does not reserve an opportunity for the parties to present two distinct cases. The primary role and responsibility for proof-taking is reserved for the judges, and the parties have a secondary role in leading evidence at trial. Although the trial officially starts with the Initial Hearing (Rule 80bis(1) ECCC IR), the Substantive Hearing marks the beginning of the examination of the evidence. ${ }^{245}$ Rule 89 bis stipulates that "[b]efore any accused is called for questioning, the Co-Prosecutors may make a brief opening statement of the charges against the Accused" to which the defence may briefly respond. While questioning the accused, "the judges have a duty to raise all pertinent questions, whether these would tend to prove or disprove the guilt of the Accused" (Rule 90(1)). With the permission of the President, the Co-Prosecutors and all the other parties and their lawyers have the right to question the accused, civil parties, witnesses and experts (Rules 90(2) and 91(2)). However, only the Co-Prosecutors and the lawyers have the ability to pose questions directly, the rest can only ask questions through the President (Rules 90(2) and 91(2)). Objections from the parties to testimony which they consider to be not conducive to ascertaining the truth are allowed (Rule 91(3)). Although the President can determine the order in which the judges and the parties question the accused and other witnesses (Rule 91bis), the primary obligation rests clearly with the judges, and only after their exhaustive examination can the parties purport to provide their input.

In the first case, Duch, the Trial Chamber adopted a thematic approach to the examination of evidence ${ }^{246}$ and this distinct topic-by-topic approach was deemed rather "unexpected." 247 Although "[t]he decision to hear the evidence by topic

244 ICC, Prosecutor v. Bemba, Decision on the Schedule for the Confirmation of Charges Hearing, ICC01/05-01/08-336, 29 December 2008, par. 20.

245 Upon the order of the President, the Greffier will read out the counts against the accused and may be ordered to read the factual analysis in the indictment (Rule 89bis(1)).

246 Dividing the hearing of the witnesses into seven broad topical sets, such as "Issues relating to M-13" "Establishment of S-21 and the Takmao prison", "Implementation of CPK Policy at S-21", "Armed Conflict", etc. See ECCC, Prosecutor v. Kaing Guek Eav, Direction on the Scheduling of the Trial, 001/18-07-2007/ECCC/TC, 20 March 2009, par. 9.

247 See the critical contribution by GiBSON AND RUDY, 2009, p. 1007. In case 002, the Trial Chamber ordered a separation of the case into a series of smaller trials that will be tried separately, including the final verdict and sentence. The expeditiousness of the proceedings in such a complex case prompted this decision. In addition, one of the accused, Ieng Thirith, was found to be unfit to stand trial. 
finds no obvious support in the Internal Rules," ${ }^{248}$ these in turn do not forbid this approach. Being able to focus on one specific topic might "prompt more focused and effective questioning," which in turn might serve judicial expediency. ${ }^{249}$ However, the downside of this approach is that it might be difficult to pigeon-hole witnesses, particularly those with a broad area of expertise. ${ }^{250}$ And a broad approach, allowing the witness to testify on a broad spectrum of issues, to some extent undermines the topical structure in the first place. The order of questioning as determined by the Trial Chamber, to be repeated in relation to each topic, is (1) accused, (2) civil parties, (3) witnesses and (4) experts. ${ }^{251}$ Questioning is first of all conducted by the judges, and only thereafter may the (1) Co-Prosecutors, (2) civil parties and (3) defence pose additional and non-repetitive questions to the person taking the stand. ${ }^{252}$

Although this approach does not necessarily provide the parties with less procedural opportunity in proof-taking, the holistic rather than party-led approach to the presentation of evidence and the changed sequences of its examination has as a consequence a diminished autonomous stance of the parties towards the evidence and the trial. Discharging the burden of proof, which formally belongs to the CoProsecutors, is clearly a different exercise at the ECCC than at the ad hoc tribunals, due to the limited autonomy to make crucial trial decisions such as which witnesses to call and in what order. However, it is the Trial Chamber that bears the final truthfinding duty and responsibility.

\subsubsection{Examination and cross-examination of witnesses}

This section takes a closer look at issues that have arisen with regard to the examination and cross-examination of witnesses that are particularly relevant to the application of equality of arms in international criminal proceedings. ${ }^{253}$ Although a separate section will touch upon issues with regard to the admissibility of evidence, a strict line between examination and admissibility issues is difficult to draw. Many issues considered in this section also touch upon the admissibility of documents (witness statements). The division may seem arbitrary, and is derived mostly from the central provision/subject-matter that underlines a particular decision.

248 Gibson AND Rudy, 2009, p. 1008.

249 GiBSON AND Rudy, 2009, pp. 1008-1009.

250 Gibson and Rudy, 2009, pp. 1008-1009.

251 ECCC, Prosecutor v. Kaing Guek Eav, Direction on the Scheduling of the Trial, 001/18-07-2007/ ECCC/TC, 20 March 2009, par. 9.1.

252 CC, Prosecutor v. Kaing Guek Eav, Direction on the Scheduling of the Trial, 001/18-07-2007/ ECCC/TC, 20 March 2009, par. 9.2.

253 ICTY, Prosecution v. Delalić et al., Decision on the Motion on Presentation of Evidence by the Accused, Esad Landžo, IT-96-21-T, 1 May 1997, par. 22 [Delalić et al. Presentation of Evidence Decision]. Re-examination "is the process whereby the party who had examined a witness-in-chief is allowed to put questions to correct matters or new facts arising out of cross-examination." 


\subsubsection{ICTY, ICTR and SCSL}

\section{Examination-in-chief and re-examination}

As mentioned, Rule 85(B) stipulates the details of each stage: "examination-in-chief, cross-examination and re-examination shall be allowed in each case." By definition, "examination-in-chief is the process whereby a party who has called a witness to give evidence in support of his case elicits from such witness through questions evidence relevant to the issues favourable to his case. ${ }^{254}$ Although the party calling the witness is responsible for the examination-in-chief, a judge can put a question to the witness at any stage. ${ }^{255}$

Notably, in Hadžihasanović and Kubura, the defence requested clarification from the Trial Chamber with regard to the Chamber's questioning of the witnesses. Emphasizing the Trial Chamber's impartiality, the Chamber considered that "it is sometimes difficult for the parties to deduce the purpose sought by the Chamber when questioning witnesses" and that "this purpose can only be the search for the truth [...]. ${ }^{{ }^{256}}$ However, in accordance with the principle of inter partes hearings, the Chamber allowed the parties to present their evidence and the accused to be the last to argue the case, by posing the Chamber's questions to the witnesses first. This practice also allowed the parties to correct or supplement the responses provided by the witnesses to judges' questions. ${ }^{257}$ Although this approach is in line with the Rules, is also clearly ignores the rationale of a confrontational presentation of evidence in an adversarial trial and potentially undermines any strategy employed by the parties in this regard.

In Delalić et al., an interesting issue arose in the context of hearing evidence on re-examination by the prosecution of a witness leading the defence to request the possibility to present further evidence by re-cross-examining these witnesses. ${ }^{258}$ The defence argued that this possibility to re-cross-examine the witness arises from the right of the defence to "examine the witnesses against him." ${ }^{259}$ Considering the issue at hand, the Trial Chamber first positioned Rule 85(A) in the general scheme of the Tribunal's legal system and concluded that this rule "without doubt belongs to the adversarial legal system [...][it] is clearly not inquisitorial [...][and] it is therefore useful to rely on the practice of common law legal systems for interpretation of its

254 Delalić et al. Presentation of Evidence Decision, 1 May 1997, par. 22.

255 Rule 85(B).

256 ICTY, Prosecutorv. Hadžihasanović and Kubura, Decision on Defence Motion Seeking Clarification of the Trial Chamber's Objective in its Questions Addressed to Witnesses, IT-01-47-T, T. Ch. II, 4 February 2005, p. 4.

257 Ibid., p. 4.

258 Delalić et al. Presentation of Evidence Decision, 1 May 1997, Introduction, par. 2.

259 Delalić et al. Presentation of Evidence Decision, 1 May 1997, paras. 1-2. 
scope and meaning if there is any ambiguity." 260 Second the Trial Chamber reiterated the method of legal interpretation of the "literal or golden rule of construction." 261 The Trial Chamber concluded that Rule 85 is "clear and unambiguous" and that Counsel's importing of other terms such as direct examination and re-direct examination is "a wrong thing to do." ${ }^{262}$ Third, the Trial Chamber pointed out that the Defence's contention that a re-cross-examination is a right that derives from the formulation of "in each case" was "misunderstood and misconceived." 263 The phrase "in each case" in Rule 85(B) refers to the presentation of evidence, which sequence is expressed in Rule 85(A) and not to an additional right to examine witnesses. ${ }^{264}$ Importantly, the Trial Chamber considered that "Rule 85(A) illustrates a clear equality of arms in the presentational of evidence" and "[t]his is because the Defence is entitled to present its case in an identical manner to the Prosecution." ${ }^{265}$ Although in special circumstances further cross-examination after re-examination might be merited, the general rule is that each "party has the last word with his own witness." 266

In a later motion in the same case, the Delalic defence challenged the sequence of case presentation in a multiple accused trial. In fact, Delalić argued for a literal application of Rule 85(A)(i)-(v). After having presented evidence for his defence, the first accused, while others were presenting their evidence, sought an order from the Trial Chamber to conclude the presentation of his case. ${ }^{267}$ Referring to Rules 86 and 87 the Delalić defence relied on Articles 20 and 21 in support of the proposed procedure. Specifically, the Delalic defence argued that he had already been subjected to nearly a year of prosecution case presentation, which for a large part did not pertain to his case. Now that his case was almost complete, requiring him to await the presentation of the case of other accused would violate his right to be tried without undue delay. ${ }^{268}$ Although the Delalić defence did not argue for a separation of the trial, it indicated to

260 Delalić et al. Presentation of Evidence Decision, 1 May 1997, par. 16.

261 Delalić et al. Presentation of Evidence Decision, 1 May 1997, par. 17.

262 Delalić et al. Presentation of Evidence Decision, 1 May 1997, paras. 19, 21.

263 Delalić et al. Presentation of Evidence Decision, 1 May 1997, par. 28.

264 Delalić et al. Presentation of Evidence Decision, 1 May 1997, par. 28.

265 Delalić et al. Presentation of Evidence Decision, 1 May 1997, par. 29.

266 Delalić et al. Presentation of Evidence Decision, 1 May 1997, par. 30.

267 ICTY, Prosecution v. Delalić et al., Decision on the Motion by Defendant Delalić Requesting Procedures for Final Determination of the Charges Against Him, IT-96-21-T, 1 July 1998, paras. 3-4. Seeking (1) for the Prosecution to indicate whether it intended to call evidence in rebuttal of the first accused, to be able to present evidence in rejoinder and the Chamber to call its own evidence in regard to the first accused; (2) following (1) for the Prosecution and the first accused to present their closing arguments; and (3) for the trial chamber to proceed to the final determination of the charges against the first accused.

268 ICTY, Prosecution v. Delalić et al., Decision on the Motion by Defendant Delalić Requesting Procedures for Final Determination of the Charges Against Him, IT-96-21-T, 1 July 1998, paras. 7-9 [Delalic et al. Final Determination of Charges Decision, 1 July 1998]. 
rely upon Rule 82(A), which invests each accused in a joint trial with the same rights as if such accused were being tried separately.

Referring to Rule 86 and 2(B), the Trial Chamber relied on the following construction: "an accused person in a joint trial, though vested individually with all the rights of an accused person in a single trial, is subject to the collective rights of the group in the overall interests of justice for ensuring an expeditious and fair trial." ${ }^{269}$ This means that the presentation of closing arguments proceeds after all the evidence has been presented: for the prosecution and for all the accused. ${ }^{270}$ Severance at any stage of the process of a joint trial is not allowed unless the conditions of Rule 82(B) are fulfilled. In relation to a possible violation of the right to be tried without undue delay, the Chamber found it "important to appreciate that the provisions of Article 20 vest in the Trial Chamber, not the accused person, the responsibility" to ensure a fair and expeditious trial with full respect for the right of the accused. ${ }^{271}$ Thus, in a joint trial each of the accused is entitled to be tried without undue delay and it is up to the Trial Chamber "to protect the equal competing rights of the accused persons in a joint trial to an expeditious and fair trial by a strict application of the Rules." 272

\section{Cross-examination}

Cross-examination is "the examination of a witness by questions by the adversary against whom the witness has testified." 273 The two-fold object of cross-examination is (1) "to elicit information concerning facts in issue, or relevant to the issue that is favourable to the party on whose behalf the cross-examination is conducted;" and (2) "to cast doubt upon the accuracy of the evidence-in-chief given against such party." 274 At the ad hoc tribunals, cross-examination shall be limited to "the subject-matter of the evidence-in-chief and matters affecting the credibility of the witness and, where the witness is able to give evidence relevant to the case for the cross-examining party, to the subject-matter of that case" and well as into additional matters with the

269 Delalić et al. Final Determination of Charges Decision, 1 July 1998, par. 41.

270 Delalić et al. Final Determination of Charges Decision, 1 July 1998, par. 42.

271 Delalić et al. Final Determination of Charges Decision, 1 July 1998, par. 48 [emphasis in the original].

272 Delalić et al. Final Determination of Charges Decision, 1 July 1998, par. 48: "As there is no rule prohibiting severance at this stage, so there is none permitting it."

273 ICTY, Prosecution v. Delalić et al., Decision on the Motion on Presentation of Evidence by the Accused, Esad Landžo, IT-96-21-T, 1 May 1997, par. 22. Cf. ICTY, Prosecutor v. Prlić et al., Decision on Prosecution Motion Concerning Use of Leading Questions, the Attribution of Time to the Defence Cases, the Time Allowed for Cross-Examination by the Prosecution, and Associated Notice Requirements, IT-04-73-T, T. Ch. III, 4 July 2008, par. 14 (addressing various definitions of cross-examination).

274 ICTY, Prosecution v. Delalić et al., Decision on the Motion on Presentation of Evidence by the Accused, Esad Landžo, IT-96-21-T, 1 May 1997, par. 22. 
permission of the Chamber. ${ }^{275}$ This clearly amounts to a rather broad approach to cross-examination. ${ }^{276}$

The SCSL does not contain a rule on cross-examination and the practice of an open system of cross-examination has been established. ${ }^{277}$ In Norman et al., for example, Fofana's defence objected to the prosecution's cross-examination aimed at eliciting evidence incriminating the Second Accused from a witness called by the Third Accused. ${ }^{278}$ The context of the motion was as such: after the examination-inchief of one witness, who was not a common witness, called by the third accused, the other accused declined the invitation to cross-examine that witness, and the prosecution started its cross-examination. ${ }^{279}$ During its course, the prosecution tried to elicit incriminating evidence in relation to the second accused; the defence objected. Primarily, Fofana's defence argued a violation of his rights, more specifically his right to adequate time and facilities to prepare those issues and the right to examine witnesses against him since it would not be possible to cross-examine this witness as he would have done had the witness been called by the prosecution. ${ }^{280}$ In this context it was the prosecutor who argued that "re-cross-examination" would be an appropriate remedy for the second accused.

The Trial Chamber reiterated that "the 'real issue' of what constitutes adequate time and facilities to prepare a defence has been characterized as 'not whether the parties have equal time and facilities but rather if either party, and in particular the

275 Rule 90(H)(i) and (iii) ICTY RPE, Rule 90(G)(i) ICTR RPE.

276 ICTY, Prosecutor v. Prlić et al., Decision on Scope of Cross-Examination Under Rule 90(H) of the Rules, IT-04-74-T, T. Ch. III, 27 November 2008, par. 4.

277 SCSL, Prosecutor v. Norman et al., Decision on the Impermissibility of Eliciting Evidence Involving the Second Accused Through Cross-Examination of Witness Called by the Third Accused, SCSL04-14-T, T. Ch. I, 10 November 2006 [Norman et al. Decision on Prosecution Cross-Examination, 10 November 2006], paras. 17-18: "With respect to the scope of cross-examination, the established and consistent practice of the Trial Chamber has been to allow an open system of cross-examination. The cross-examining party, whether the Prosecution or co-Accused, is not strictly limited to addressing questions that arise from the direct examination of the witness, but may also cross-examine on matters of joint criminal enterprise and credibility." There are limits, however, to the questions that may be asked during cross-examination. The Chamber recalled its explicit instructions to this effect: "The exact extent and manner of questioning permitted [...] will depend on the nature of the testimony which has been given by the witness and the purpose of the questioning. This will be decided on a case by case basis" [emphasis in the original, footnotes omitted].

278 Norman et al. Decision on Prosecution Cross-Examination, 10 November 2006, p. 2.

279 Norman et al. Decision on Prosecution Cross-Examination, 10 November 2006, par. 1. In Bagosora et al., the Trial Chamber discussed the fact that the ambit of cross-examination by a co-accused is not limited to "adverse" evidence, and "to some extent, Defence teams other than the one calling a witness will be allowed to elicit evidence in its favour, even if this is not "cross-examination" in the narrow sense of the word." This evidence will only be admitted if it is relevant, if it contributes to the ascertainment of the truth and does not lead to the needless consumption of time. See ICTR, Prosecution v. Bagosora et al., Decision on Modalities for Examination of Defence Witnesses, ICTR-98-41-T, T. Ch. I, 26 April 2005, paras. 5-6.

280 Norman et al. Decision on Prosecution Cross-Examination, 10 November 2006, par. 7. 
accused, is put at a disadvantage when presenting their case." ${ }^{281}$ Recalling the fact that during the direct examination of the witness in question, no evidence relating to the second accused was adduced, the Chamber differentiated between, on the one hand, "attempts to elicit direct evidence relating to an Accused who has not called the witness in question" and, on the other, "attempts to elicit evidence relating to the alleged participation of that Accused in a joint criminal enterprise." ${ }^{\prime 28}$ The Chamber concluded that without a notice and the opportunity to conduct investigations or prepare an effective cross-examination, the second accused would indeed be placed in a seriously disadvantageous position by the first attempt. ${ }^{283}$

An interesting challenge to the scope of prosecution's cross-examination arose at the ICTY in the Prlić case. Here two accused argued that "by putting questions to witnesses in cross-examination regarding issues not raised in direct examination, the Prosecution is in fact continuing to present its case." ${ }^{284}$ Cross-examination on issues that were not raised during the direct examination is not cross-examination stricto sensu and not taking the time spent on this 'cross-examination' into account amounts to unfairness towards the defence. ${ }^{285}$ According to the Trial Chamber, Rule 90(H)(i) "leaves no room for ambiguity" as it authorizes the parties to ask questions which are relevant to their own case even if those matters were not raised in direct examination. ${ }^{286}$ Notably, this rule serves the principle of judicial economy as it prevents the calling of a witness which can be relevant for both parties twice. ${ }^{287}$ With regard to the defence's claim of unequal treatment, the Trial Chamber emphasized that Rule $90(\mathrm{H})$ applies to both parties equally and "a systemic interpretation of the Rules through a combined reading of Rules $85(\mathrm{~A})$ and $90(\mathrm{H})(\mathrm{i})$ enshrined the recognized right of each party to ask questions in cross-examination which relate to its case even though that party has concluded its case." 288 Moreover, not subtracting time for 'cross-examination', which is in fact examination-in-chief, from the time allotted to the latter does not amount to unfairness as both parties were treated equally. ${ }^{289}$

This issue, according to the Presiding Judge Antonetti, "poses the fundamental problem of equality of arms and the expeditiousness of the trial." ${ }^{290}$ In relation to

281 Norman et al. Decision on Prosecution Cross-Examination, 10 November 2006, par. 20 [footnote omitted].

282 Norman et al. Decision on Prosecution Cross-Examination, 10 November 2006, paras. 21-22.

283 Norman et al. Decision on Prosecution Cross-Examination, 10 November 2006, par. 23.

284 ICTY, Prosecutor v. Prlić et al., par. 4 [Prlić et al. Scope of Cross-Examination Decision, 27 November 2008].

285 Prlić et al. Scope of Cross-Examination Decision, 27 November 2008, par. 4.

286 Prlić et al. Scope of Cross-Examination Decision, 27 November 2008, par. 10.

287 Prlić et al. Scope of Cross-Examination Decision, 27 November 2008, par. 10.

288 Prlić et al. Scope of Cross-Examination Decision, 27 November 2008, par. 12.

289 I Prlić et al. Scope of Cross-Examination Decision, 27 November 2008, par. 15.

290 ICTY, Prosecutor v. Prlić et al., Dissenting Opinion of Presiding Judge Jean-Claude Antonetti Regarding the Decision on the Scope of Cross-Examination Under Rule 90(H) of the Rules, IT04-74-T, T. Ch. III, 27 November 2008, p. 2 [Prlić et al. Dissenting Opinion to Scope of Cross- 
equality of arms, Judge Antonetti argued in his dissenting opinion, that the ability of the prosecution to elicit information which is relevant to its case on cross-examination, in fact provides the prosecution with "indefinite authority to put its case during the appearance of defence witnesses." ${ }^{291}$ Effectively, this approach "seriously handicaps the Defence" by doubling the time for the prosecution to present its case. ${ }^{292}$ Moreover, Judge Antonetti seemingly takes issue with Chamber's trial management as he concluded that the excessive protraction of the trial is due to parties' case presentation methodology, and that in the context of the Tribunal's system (a compromise of two systems), judges should more effectively control questioning by the parties. ${ }^{293} \mathrm{He}$ advocated a strict approach to Rule $90(\mathrm{H})$; the scope of cross-examination "must permit the other party to undermine the case put forward, but only on the basis of what a witness says." 294 Thus, the time spent on "excesses" should be subtracted from the time allocated to the presentation of the case for both parties equally. ${ }^{295}$

Notably, Judge Antonetti's argument seems to reflect the compromise-system used by the tribunal. On the one hand he argues for a more limited scope of crossexamination to ensure equality of arms for the defence. This approach advocates a stricter, more 'common law' application of the relevant rule whereby the parties primarily control in testing the evidence. On the other hand he argues for more control of witness examination by the judges to ensure expeditiousness. Where the Trial Chamber accepts that an equal application of the rule on cross-examination ensures procedural equality between the parties, Judge Antonetti seems to accept defence's argument of ensuing disadvantage. No principled considerations precede either argument, which indeed are not easy to state. To some extend, the common law practice of cross-examination and judges' control of witness examination at trial seem incompatible. From the perspective of defence's rights, particularly the right to timely notice and proper ability to prepare its answer to prosecutions case, a more strict approach to prosecution's cross-examination, as advocated by Judge Antonetti, seems preferable. Questioning on issues beyond the scope of direct examination

Examination Decision, 27 November 2008].

291 Prlić et al. Dissenting Opinion to Scope of Cross-Examination Decision, 27 November 2008, p. 3.

292 Prlić et al. Dissenting Opinion to Scope of Cross-Examination Decision, 27 November 2008, p. 3. The defence may be caught by surprise by a cross-examination that subjects the witness to a different set of questions unrelated to witness's primary testimony.

293 Prlić et al. Dissenting Opinion to Scope of Cross-Examination Decision, 27 November 2008, p. 6. It is not the length but the quality of witness-examination that is relevant to the case (p. 7).

294 Prlić et al. Dissenting Opinion to Scope of Cross-Examination Decision, 27 November 2008, p. 7. The scope of Rule $90(\mathrm{H})$ should be strictly limited to "[t]he questions asked may concern only the matters raised by the witness." (pp. 2-3).

295 The "excess" on the prosecution side is the excessive elaboration of issues that were not raised during direct examination, while the Defence took up a great deal of time raising elaborate (commentary-like) objections. Prlić et al. Dissenting Opinion to Scope of Cross-Examination Decision, 27 November 2008, pp. 4-5. 
should require judges' leave. ${ }^{296}$ In this light, the Chamber did emphasize its intention to take a flexible approach towards allowing additional time for re-examination of witnesses in case new issues would be raised on cross-examination. ${ }^{297}$ However, a more limited approach to cross-examination could be seen as rather cumbersome from the perspective of efficiency of the trial, as it eventually 'invites' the parties to dispute the application of the rule. ${ }^{298}$ Notwithstanding this, the rule clearly allows for less stricter application than advocated by Judge Antonetti, because a purely adversarial approach to cross-examination is unattainable at the level of international criminal proceedings, particularly in light of undesirability of recalling witnesses.

In line with this argument another relevant decision was issued in Prlić et al. case on the same day as the decision discussed above. The defence had requested the Trial Chamber to formulate guidelines on the presentation and admission of prosecution's evidence during cross-examination of defence witnesses. ${ }^{299}$ The defence argued that the prosecution should be prohibited from introducing 'new documents' that were not admitted during the prosecution case to defence witnesses during cross-examination, "except for the purposes of impeaching a witness's credibility or refreshing his/her memory." 300 It further argued that the fundamental principle established by the Tribunal that the prosecution should present all the incriminating evidence in his case would be violated if the prosecution would be allowed to continue putting its case after it has been concluded. ${ }^{301}$ The prosecution objected to the motion and argued that no blanket prohibition on presenting incriminating evidence during the defence case exists, but that the Chamber should assess on a case-by-case basis whether a specific document or the way it is presented infringes upon the rights of the accused..$^{302}$

The Chamber agreed with the defence's argument that, in principle, all the incriminating evidence should be presented during the prosecution's case-in-chief. ${ }^{303}$

296 Cf. Rule 611 U.S. Federal Rules of Evidence (as amended 1 December 2011): “[...] (b) Scope of Cross-Examination. Cross-examination should not go beyond the subject matter of the direct examination and matters affecting the witness's credibility. The court may allow inquiry into additional matters as if on direct examination."

297 Prlic et al. Scope of Cross-Examination Decision, 27 November 2008, par. 11.

298 From this perspective, punishing the parties for their 'excesses' as proposed by Judge Antonetti seems as inappropriate as punishing proper behaviour natural in a procedural system. Prlic et al. Dissenting Opinion to Scope of Cross-Examination Decision, 27 November 2008, p. 4-5.

299 ICTY, Prosecutor v. Prlić et al., Decision on Presentation of Documents by the Prosecution in Cross-Examination of Defence Witnesses, IT-04-74-T, T. Ch. III, 27 November 2008, par. 1 [Prlić et al. Decision on Prosecution Evidence in Cross-Examination, 27 November 2008].

300 Prlić et al. Decision on Prosecution Evidence in Cross-Examination, 27 November 2008, par. 4.

301 Prlić et al. Decision on Prosecution Evidence in Cross-Examination, 27 November 2008, par. 5.

302 Prlić et al. Decision on Prosecution Evidence in Cross-Examination, 27 November 2008, par. 6.

303 Prlić et al. Decision on Prosecution Evidence in Cross-Examination, 27 November 2008, par. 10, see footnote 31 for further references. Cf. ICTY, Prosecutor v. Delić, Reasons for Oral Decision on Admission of Exhibits 1316 and 1317, IT-04-83-T, 24 April 2008. The Trial Chamber excluded 
Thus, presenting documents during the cross-examination of defence witnesses has a limited purpose of "testing the credibility of the witness or refreshing his/her memory." 304 However, Rule 90(H) provides an exception to this principled approach. This exception is, inter alia, derived from the fact that the prosecution has no knowledge of defence witnesses and the exhibit list during its case-in-chief. ${ }^{305}$ The order of case presentation presented in Rule 85(A) is not absolute and, in fact, the defence had an opportunity to introduce documents during the cross-examination of prosecution witnesses. ${ }^{306}$ Implying equality between the parties, the Chamber further observed that "it would be difficult to justify having a different arrangement for the Prosecution which, after all, bears the burden of proof." ${ }^{307}$ Interestingly, in explanation, the Chamber considered that international human rights law "does not lay down sharp divisions for the presentation of evidence" and the principle of a fair trial is respected "whenever the Defence has the opportunity of effectively presenting its own evidence in response to any evidence offered by the Prosecution." ${ }^{308}$ Moreover, the Chamber referred to its own duty to ascertain the truth, for which purpose it is authorized to admit any relevant evidence that has probative value. ${ }^{309}$

However, only in limited circumstances can derogations from Rule 85(A) be allowed at an advanced stage of the proceedings. When seeking to admit new incriminating evidence, the prosecution would need to explain on a case-by-case basis: (1) when and by which means it obtained these documents; (2) when it disclosed them to the defence; and (3) why they are being offered only after the conclusion of its case. ${ }^{310}$ Should the

2 exhibits introduced during the cross-examination of defence witnesses. As these exhibits were "tendered for the truthfulness of their contents" and "disclosed to the Defence shortly before the commencement of cross-examination, such admission resulted in prejudice to the fair trial rights of the Accused" (Id., par. 10). The remedy of providing additional time to the defence and recalling some witnesses for further examination would not be in the interest of a fair and expeditious trial at this advanced stage of proceedings. (Id.) Dissenting, Judge Harhoff considered this decision not to be in accordance with the established practice of the Tribunal. "[I]n light of the nature of the trials before this Tribunal, including the length of our proceedings, the number of witnesses, the enormous amount of evidence and the hybrid mixture of our procedures", Judge Harhoff considered, "the 65 ter-lists cannot ... be ultimately binding on the Prosecution to the effect that non-listed evidence can never be tendered under any circumstance." (Dissenting opinion, par. 13).

304 Prlić et al. Decision on Prosecution Evidence in Cross-Examination, 27 November 2008, par. 10.

305 Prlić et al. Decision on Prosecution Evidence in Cross-Examination, 27 November 2008, par. 15.

306 Prlić et al. Decision on Prosecution Evidence in Cross-Examination, 27 November 2008, par. 19.

307 Prlić et al. Decision on Prosecution Evidence in Cross-Examination, 27 November 2008, par. 19.

308 Prlić et al. Decision on Prosecution Evidence in Cross-Examination, 27 November 2008, par. 19.

309 Prlić et al. Decision on Prosecution Evidence in Cross-Examination, 27 November 2008, par. 19.

310 Prlić et al. Decision on Prosecution Evidence in Cross-Examination, 27 November 2008, par. 20. These criteria were adopted by the SCSL in the Taylor case. The Prosecution sought to introduce fresh documents during the cross-examination, not of a witness, but of the accused. The Trial Chamber agreed with the Defence's argument that the accused is not in the same position as other witnesses, due to the protection of his rights offered by the Statute (Article 17). Recognizing the important distinction between "fresh evidence" going towards the credibility of a witness or the guilt of the accused, the Chamber considered that this distinction is particularly "difficult if not impossible" 
Chamber admit these new documents, it will then decide on any countervailing measures to safeguard the rights of the defence. ${ }^{311}$

Notably, the Presiding Judge attached a critical opinion to this decision as well. Judge Antonetti took a very principled stance on the issue and argued that the prosecutor should not be allowed to tender new evidence that has not been on its 65ter list during the cross-examination of defence witnesses. ${ }^{312}$ Evidence must be collected before the trial and not during, and the prosecutor took years to prepare the case. ${ }^{313}$ So "at some point a decision must be made to stop building it [the case]" and that point is marked by the Pre-Trial Conference where the Chamber sets the time and the number of witnesses to be presented. ${ }^{314}$ In addition, the accused must be in a position to know the case against him before the trial so as to prepare his defence, and the Rule 65er list serves that purpose and allows the Defence to prepare its case.

to draw with regard to the cross-examination of the accused. This necessitates that the Chamber is "particularly cautious" when exercising its discretion as to whether to admit "fresh evidence" from the Prosecution. Thus, the Chamber concluded that (1) fresh evidence going towards credibility does not have to be disclosed beforehand; however, (2) fresh evidence going towards guilt is subject to disclosure and its use will not be permitted unless it is in the interest of justice and it does not violate the rights of the accused. Admission of the latter category will only take place in exceptional circumstances and the Prosecution would have to explain the three points mentioned in Prlić. SCSL, Prosecutor v. Taylor, Decision on Prosecution Motion in Relation to the Applicable Legal Standards Governing the Use and Admission of Documents by the Prosecution During Cross-Examination, SCSL-03-1-T, T. Ch. I, 30 November 2009, paras. 25-27. The Prosecution later challenged the application of this two-pronged test, which sets out an unduly high standard for using documents while cross-examining the accused and places the Prosecution in a unequal and unfair position, see e.g. SCSL, Prosecutor v. Taylor, Decision on Urgent Applications for Leave to Appeal Oral Decisions of 18, 21, 25 and 26 January 2010 on Use of Documents in Cross-Examination, SCSL-031-T, 9 February 2010 (leave to appeal was denied). Judge Doherty argued in her dissenting opinion that the application of the test in some decisions places "too onerous" a duty on the Prosecution who must "anticipate detailed aspects of a witness's evidence, in particular evidence that does not go directly to issues in the Indictment." Separate and Partially Dissenting Opinion of Justice Teresa Doherty, Decision on Urgent Applications for Leave to Appeal Oral Decisions of 18, 21, 25 and 26 January 2010 on Use of Documents in Cross-Examination, SCSL-03-1-T, 9 February 2010, par. 7. Later, the Trial Chamber did note that in the Taylor case, the Prosecution "contributed significantly to lengthening the trial proceedings by introducing a large number of documents containing "fresh evidence" after the close of its case-in-chief." SCSL, Prosecutor v. Taylor, Decision on Prosecution Request for Orders in Relation to the Scheduling of the Remainder of the Case, SCSL-03-1-T, 29 March 2010, p. 6.

311 Prlić et al. Decision on Prosecution Evidence in Cross-Examination, 27 November 2008, par. 26.

312 ICTY, Prosecutor v. Prlić et al., Partially Dissenting Opinion of Presiding Judge Jean-Claude Antonetti Regarding the Decision on Presentation of Documents by the Prosecution in CrossExamination of Defence Witnesses, IT-04-74-T, T. Ch. III, 27 November 2008, p. 2 [Prlić et al. Dissenting Opinion to Decision on Prosecution Evidence in Cross-Examination, 27 November 2008].

313 Prlić et al. Dissenting Opinion to Decision on Prosecution Evidence in Cross-Examination, 27 November 2008, p. 2.

314 Prlić et al. Dissenting Opinion to Decision on Prosecution Evidence in Cross-Examination, 27 November 2008, p. 3. 
New evidence may only be admitted under very strict conditions when reopening a case, and new evidence during cross-examination can only serve the purpose of impeaching a witness, without being admitted into evidence. ${ }^{315}$

The majority decision did not clearly explain the relationship between 'new evidence' in the sense of material that only came to the attention of the prosecution after the close of its case, evidence in rebuttal and 'new documents' in the sense of "documents that have not yet been admitted" as used in this decision. ${ }^{316}$ The criteria mentioned by the Majority for the admission of new incriminating evidence do not correspond to the criteria established in relation to "fresh evidence.' 317 In this regard, Judge Antonetti's approach is more straightforward: the admission of new documents (not on the 65ter list) is only allowed when the criteria for admitting "fresh evidence" are satisfied, and any other evidence that has not been admitted during the prosecution's case and which is not on its Rule 65ter list can only be used for the purpose of impeaching the witness's credibility and without requesting the admission of that document. ${ }^{318}$ On a final note, where the approach of the Majority seems less principled in addressing this matter, Judge Antonetti's approach seems 'too principled' as it does not seem to take account of the realities and practicalities of the Tribunal's existence (e.g. dependence on state cooperation which can impede the collection of evidence).

On appeal, the Appeals Chamber first of all clarified the definition of "new documents" to which it chose to refer as "fresh evidence", and which implies "material that was not included in the prosecution Rule 65ter list and not admitted during the prosecution's case-in-chief, but that is tendered by the prosecution when cross-examining Defence witnesses" and which is "not limited to the material that was not available to the Prosecution during its case-in-chief." 319 This definition differs from the meaning established in the context of review and reconsideration of decisions and reopening of cases, where 'fresh evidence' implies material that was not known nor could have been known to the prosecution during the presentation of its case. Reiterating that the sequence of case presentation established in Rule 85(A) may be deviated from "in the interest of justice," the Appeals Chamber conferred with the Trial Chamber's approach that this deviation would only take

315 Prlić et al. Dissenting Opinion to Decision on Prosecution Evidence in Cross-Examination, 27 November 2008, p. 4. Judge Antonetti mentioned a witness's criminal history as the perfect example.

316 Prlić et al. Decision on Prosecution Evidence in Cross-Examination, 27 November 2008, par. 13.

317 See the discussion hereunder.

318 Prlić et al. Dissenting Opinion to Decision on Prosecution Evidence in Cross-Examination, 27 November 2008, p. 4.

319 ICTY, Prosecutor v. Prlić et al., Decision on the Interlocutory Appeal Against the Trial Chamber's Decision on Presentation of Documents by the Prosecution in Cross-Examination of Defence Witnesses, IT-04-74-AR73.14, A. Ch., 26 February 2009, par. 15 [Prlić et al. Appeal Decision on Prosecution Evidence in Cross-Examination, 26 February 2009]. 
place in exceptional circumstances and in accordance with the Rules of Procedure and Evidence. ${ }^{320}$ In fact, the Trial Chamber's careful approach in establishing a high threshold for the admission of fresh evidence while being duly mindful of Rule 89(C) and (D) was, according to the Appeal Chamber, justified, depending of course on the specific circumstances of the case. ${ }^{321}$ The Trial Chamber needs to balance the rights of the accused and the necessity to admit such evidence, by considering "the mode of disclosure of the documents in question, the purpose of their admission, the time elapsed between disclosure and examination of the witness, the languages known to Counsel and the accused, as well as any other relevant factual considerations." ${ }^{22}$ In addition, the Trial Chamber must consider possibilities to address the prejudice to the accused. The high threshold for admissibility of 'fresh evidence' only applies to evidence that goes towards the guilt of the accused and not that merely seeks to impeach the witness. This latter evidence is freely admissible during the defence case. Thus, the Chamber took a rather pragmatic approach to the argument that one and the same document can contain information going both to the guilt of the accused and to the credibility of a witness. According to the Appeals Chamber it poses no problems for the application of the above admissibility test: "[i]ndeed, it is not the contents of the document that the Trial Chamber is required to assess, but the purpose of its admissibility." 323 The authority to limit the purpose for which a document can be used lies within the Trial Chamber's discretion. ${ }^{324}$ Tribunal's flexible approach to

320 Prlić et al. Appeal Decision on Prosecution Evidence in Cross-Examination, 26 February 2009, par. 24.

321 Prlić et al. Appeal Decision on Prosecution Evidence in Cross-Examination, 26 February 2009, par. 24. Indeed, in an older decision in Milošević the Trial Chamber did not admit evidence presented during the cross-examination of the defence's witnesses because it lacked any probative value (the witnesses rejected or did not respond in any meaningful way to that evidence). Thus, the "exhibition of documents used in cross-examination should only be permitted if they contain material which has actually become part of the evidence in the case." ICTY, Prosecution v. Slobodan Milošević, Decision on Prosecution Motion for Reconsideration Regarding Evidence of Defence Witnesses Mitar Balević, Vladislav Jovanović, Vukasin Andrić, and Dobre Aleksovski and Decision Proprio Motu Reconsidering Admission of Exhibits 837 and 838 Regarding Evidence of Defence Witness Barry Lituchy, IT-02-54-T, T. Ch., 17 May 2005, paras. 9,11.

322 Prlić et al. Appeal Decision on Prosecution Evidence in Cross-Examination, 26 February 2009, par. 25. The Appeals Chamber considered that "if, on balance, the fresh evidence is found to be inadmissible during the presentation of the Defence case, the Prosecution may still, under certain conditions, seek its admission as evidence in rebuttal."

323 Prlić et al. Appeal Decision on Prosecution Evidence in Cross-Examination, 26 February 2009, par. 29.

324 Prlić et al. Appeal Decision on Prosecution Evidence in Cross-Examination, 26 February 2009, par. 30. In Delić the Appeals Chamber considered that the Trial Chamber had erred when not specifying the purpose for which some exhibits were admitted while being introduced at the cross-examination of a defence witness and only shortly before that disclosed to the defence. In fact, the Appeals Chamber considered that "[i]n situations where the accused opposes the admission of evidence during cross-exmiantion due to alleged breach of his right to a fair trial, a Trial Chamber must consider how it intends to strike the appropriate balance between the need to ensure the rights of 
evidentiary issues is reflected well in this decision. While the adversarial trial setting was taken as a starting point, the judges have emphasized their discretionary power to control the course of the presentation of evidence by the parties. ${ }^{325}$

\subsubsection{ICC}

In the context of the ICC, Rule 140(2)(b) explicitly states that both the prosecution and defence have the right to question a witness about relevant matters related to the witness's testimony and its reliability, the credibility of the witness and other relevant matters. Comparable to the ad hoc tribunals, 'cross-examination' at the ICC can go beyond matters raised in the direct examination and include matters relevant to the case of the cross-examining party even if not raised during the examination-in-chief, as long as this party states clearly to the witness the contradictory part of his or her testimony. ${ }^{326}$ This latter element serves trial economy to avoid recalling witnesses unnecessarily. ${ }^{327}$

In Katanga, the Trial Chamber provided elaborate guidelines as to the nature and content of the questions and assured that it would disallow attacks on the dignity of a witness, any exploitation of a witness's vulnerability and "unwarranted insinuations or questions that are concealed speeches." 328 The Trial Chamber used a very "common law' vocabulary when setting out the order of questioning of witnesses: examinationin-chief, cross-examination, re-examination. Two issues stand out when looking at the order of questioning that the Trial Chamber has imposed and differ from the approach taken by the ad hoc tribunals. First, it concerns the right to re-examine own witness. The Trial Chamber determined that the prosecution "will have the opportunity to re-examine the witness in relation to matters that were raised for the first time during cross-examination:" while the defence "shall seek permission" to

the accused and its decision to admit such evidence. ICTY, Prosecutor v. Delić, Decision on Rasim Delić's Interlocutory Appeal Against Trial Chamber's Oral Decisions on Admission of Exhibits 1316 and 1317, IT-04-83-AR73.1, 15 April 2008, paras. 22-23. Following this decision, the Trial Chamber decided to exclude the exhibits in question. See ICTY, Prosecutor v. Delić, Reasons for Oral Decision on Admission of Exhibits 1316 and 1317, IT-04-83-T, 24 April 2008.

325 For a critique of this approach, see e.g. Murphy, 2010.

326 ICC, Prosecutor v. Lubanga Dyilo, Decision on various issues related to witness' testimony during trial, ICC-01/04-01/06-1140, T. Ch. I, 29 January 2008, par. 32; Katanga and Ngudjolo Chui Proceedings Directions, 1 December 2009, paras. 69-70.

327 Katanga and Ngudjolo Chui Proceedings Directions, 1 December 2009, par. 73: "Cross-examination allows the party not calling the witness to elicit all further relevant evidence as may be useful for the case of that party or necessary for the determination of the truth."

328 Katanga and Ngudjolo Chui Proceedings Directions, 1 December 2009, paras. 71, 74-75, e.g. questions may be leading and closed and must be reasonable in light of the witnesses' knowledge, they must state the contextual purpose and any challenges to credibility are limited to factors that objectively influence reliability. 
ask further questions after the Prosecution's cross-examination. ${ }^{329}$ These questions will be limited to matters raised on cross-examination and pertain to defence's case. Secondly, in conformity to Rule 140(2)(d) the accused has the right to be the last to question a witness. ${ }^{330}$ This allows for re-cross-examination by the defence of a prosecution's witness, something that the ICTY has rejected because there each "party has the last word with his own witness" (given there are no special circumstances). ${ }^{331}$ In light of the right of the defence to have the last word with each witness in the context of the ICC, the instruction that the defence should ask for permission to re-examine its own witnesses seems redundant. This 'last word'-rule constitutes a notable departure from the procedural framework of the ad hoc tribunals. ${ }^{332}$ This rule is associated with (derives from) the maxim in dubio pro reo and the notions of presumption of innocence and proof beyond the reasonable doubt. The modern understanding of these notions intends to protect innocent accused, and the practice of having the last word can be said to provide the defendant with the advantage of presenting a convincing argument, to spread doubt, at the end of the trial just before the decision-maker retrieves to deliberate. ${ }^{333}$

With regard to introducing incriminating evidence during the cross-examination of defence witnesses relating to issues on which the witness did not testify, the Lubanga Trial Chamber observed that "[s]o long as the witness can give evidence about additional matters and [...] those matters are relevant to our inquiry in this trial, it is open to counsel to open up new issues." ${ }^{334}$ The test employed by the Chamber is "whether the evidence that the prosecution seeks to adduce from the witness is

329 Katanga and Ngudjolo Chui Proceedings Directions, 1 December 2009, paras. 16-17, 35.

330 Katanga and Ngudjolo Chui Proceedings Directions, 1 December 2009, paras. 36, 79.

331 Delalić et al. Presentation of Evidence Decision, 1 May 1997, par. 30.

332 Next to Rule 140(2)(d), Rule 141(2) ICC RPE provides that "the defence shall always have the opportunity to speak last." This rule seems more compelling in 'inquisitorial' traditions (France, Germany, The Netherlands, see e.g. Article 311(4) Dutch Code of Criminal Procedure states that the accused shall have the last word) than in adversarial systems, see e.g. U.S. Federal Rules of Criminal Procedure, Rule 29.1: "Closing arguments proceed in the following order: (a) the government argues; (b) the defense argues; and (c) the government rebuts." This sequence is in fact based on the idea that the prosecution has the burden to proof the allegations 'beyond a reasonable doubt'.

333 Englich, Mussweiler and Strack, 2005, p. 706. Interestingly, this study done in an experimental setting, suggests that "the standard procedural sequence in court may place the defense at a distinct disadvantage." (p. 718). The study explains that "[t]he reason for this is that this sequence deprives the defense of the opportunity to set an initial sentencing recommendation." (p. 706). The researchers conclude, "looking at the various legal system [...] the following: whatever the specific sequence in the different law systems, the present studies suggest that "going first" constitutes a strong advantage. And this message is applicable to almost every legal system." (p. 718).

334 ICC, Prosecutor v. Lubanga Dyilo, Decision on the "Requête de la Défense sollicitant l'autorisation d'interjeter appeal de la decision orale du 4 mars 2010 autorisant l'utilisation et le depot en prevue de trios photographies", ICC-01/04-01/06-2404, 29 April 2010, par. 3, referring to the transcript of a confidential session, ICC-01/04-01/06-T-252-CONF-ENG CT, p. 27, lines 4-6. 
relevant and admissible and, of course, whether it is fair to allow the prosecution at this stage to elicit evidence based on the photographs." ${ }_{335}$ The admission of the three photographs in question which the prosecution wished to use during the crossexamination of a witness was based on the Trial Chamber's assessment that these photographs "may add a fresh dimension to evidence or issues that have already been canvassed during the course of this trial." 336 Concerning the question of fairness, a relevant point is that these photographs had been disclosed as incriminating evidence to the defence beforehand. ${ }^{337}$

\subsubsection{ECCC}

To expedite the proceedings in the Duch case, which was proceeding too slowly, the Trial Chamber decided to impose rather strict time limits upon the parties in relation to the questioning of witnesses. With regard to the questioning of Duch, the defence objected to the precise amount of time allocated to the parties: 4 hours for the prosecution, 45 minutes per civil party team and 4 hours for the defence. ${ }^{338}$ It argued that the defence should principally be accorded the same time as allocated to all the adversary parties together. ${ }^{339}$ The Chamber did not entertain this objection, but continued to enforce precisely the time limits set for the parties, cutting the examination short when necessary. Moreover, requests for an extension of time were routinely denied. ${ }^{340}$ This practice has a potential adverse effect on truth-finding.

\subsubsection{Admissibility of evidence}

\subsubsection{ICTY/ICTR and SCSL}

The rules of evidence at the ad hoc tribunals are concise, providing a general framework rather than detailed rules on admissibility of evidence. ${ }^{341}$ The courts

335 Ibid., p. 31, lines 8-11.

336 Ibid., par. 3, referring to the transcript of a confidential session, ICC-01/04-01/06-T-252-CONFENG CT, p. 32, lines 4-6.

337 Ibid., par. 1.

338 ECCC, Prosecutor v. Kaing Guek Eav, Transcript of Trial Proceedings, 001/18-07-2007-ECCC/TC, T. Ch., 16 June 2009, pp. 2-3.

339 ECCC, Prosecutor v. Kaing Guek Eav, Transcript of Trial Proceedings, 001/18-07-2007-ECCC/TC, T. Ch., 16 June 2009, p. 8: "I don't think I can understand that if the Co-Prosecutors and the civil parties have six hours to question, in turn, the accused, why then the defence would have only four hours, that is to say, slightly more than half of the overall time allotted to the Co-Prosecutors and civil parties. The defence should at the very least, and by way of principle, have the same speaking time as all its opponents together."

340 E.g. ECCC, Prosecutor v. Kaing Guek Eav, Transcript of Trial Proceedings 001/18-07-2007-ECCC/ TC, T. Ch., 1 July 2009, pp. 86-87.

341 Rule 89 and 95 RPE. 
have taken a flexible approach towards admissibility, which has been described as "admit everything, determine weight later" approach associated with the inquisitorial tradition of criminal process. ${ }^{342}$ All evidence that is prima facie relevant and has probative value that is not outweighed by the need to ensure a fair trial is admitted. Questions of reliability, which are best tested at cross-examination, are considered primarily a matter of 'weight' to be assigned to the particular evidentiary piece at the stage of assessment of the evidence rather than admissibility stage. The choice for this inclusive system of admission of evidence, that stands in salient contrast to the roots of a common law tradition on which the ad hoc tribunals are based, is usually justified on the basis of the special trademarks of international criminal courts, namely (1) the adjudication proceeds before a panel of professional judges instead of lay jury, and (2) the truth-telling mission of the courts. Not only are international judged considered to be better equipped to value the evidence tendered, an inclusive approach towards admissibility is conductive of truth. ${ }^{343}$ The introduction of documents can take place through a witness or from the bar table. ${ }^{344}$

The Aleksovski Appeals Chamber decision extensively discussed the principle of equality of arms in the context of the admissibility of hearsay evidence. ${ }^{345}$ More specifically, it touched upon the prosecutor's right to equality of arms. The prosecutor initiated the appeal against two decisions by the Trial Chamber. The first decision concerned the admission into evidence for the defence the testimony of an expert witness from another case without the possibility for the prosecutor to cross-examine that expert. The second decision denied the prosecution's motion to tender evidence (confidential witness testimony in the Blaskić case) to rebut that expert evidence because it would amount to a violation of equality of arms for the defence not to have an opportunity to cross-examine this witness. It is with regard to this second decision that the Appeals Chamber considered that the Trial Chamber had erred.

According to the Appeals Chamber, Article 21(1) of the Statute ("all persons shall be equal before the International Tribunal") "has been interpreted [...] as having been based upon the well-known international law principle of "equality of arms." Endorsing the view of the Trial Chamber in the Delalic et al. case, the Appeals Chamber considered the concept of a fair trial to be applicable to both parties because the prosecutor acts on behalf of the international community, including the victims

342 Zahar And Sluiter, 2008, p. 384.

343 For a critique see e.g. Murphy, 2010.

344 ICTY, Prosecutor v. Prlić et al., Decision on Admission of Evidence, 13 July 2006, Decision Amending the Decision on Admission of Evidence Dated 13 July 2006, IT-04-74, 29 November 2006.

345 ICTY, Prosecutor v. Aleksovski, Decision on Prosecutor's Appeal on Admissibility of Evidence, IT-95-14/1-A, A. Ch., 16 February 1999 [Aleksovski Admissibility of Evidence Appeal Decision, 16 February 1999].

346 Aleksovski Admissibility of Evidence Appeal Decision, 16 February 1999, par. 23. 
of the crimes. ${ }^{347}$ As such, "this principle of equality does not affect the fundamental protections given by the general law or Statute to the accused, and the trial proceeds against the background of those fundamental protections." ${ }^{348}$ From this perspective, the Appeals Chamber reasoned, "it is difficult to see how a trial could ever be considered to be fair where the accused is favoured at the expense of the Prosecution beyond a strict compliance with those fundamental protections." ${ }^{349}$ Thus, the prosecution was treated unfairly when it was denied the advantage granted to the defence, namely an opportunity to call rebuttal witnesses. ${ }^{350}$ With regard to the disadvantage arising out of the fact that the defence could not cross-examine this witness, the Chamber stressed that the 'rebuttal evidence' witness had been extensively cross-examined in the Blaskić case and that the defence had a common interest in both cases. As such, the disadvantage arising out of the non-availability of cross-examination, which is common to any admission of hearsay evidence, "is tempered in this case by crossexamination in Blaskić, and, in any event, any residual disadvantage to the accused is outweighed by the disadvantage which would be occasioned to the Prosecution by the exclusion of the evidence in the circumstances of this case." ${ }^{351}$ What the Appeals Chamber did not question is to what extent this 'residual disadvantage' can and does affect the "fundamental protections" to which an accused is entitled and against which background the trial proceeds.

With regard to the admissibility of hearsay evidence, the Appeals Chamber reiterated that where this evidence is admitted, the opposing party loses the opportunity to cross-examine the witness. The Chamber concluded that "[j]ust as Rule 89(D) does not deny the admissibility of the transcript and video-recording of the hearsay statements made by Admiral Domazet in favour of the accused, so it does not deny the admissibility of the transcript of the hearsay statements made by the confidential witness in favour of the Prosecution, given the need for equality between the parties." ${ }^{352}$ Rule 89(D) provides for a discretionary power for the Chambers to exclude evidence if its probative value is substantially outweighed by the need to ensure a fair trial. The Appeals Chamber seemed to consider a contrario that evidence that, if admitted, would disadvantage the defence would nonetheless have to be admitted because its exclusion would be a greater disadvantage to the prosecution's right to a fair trial. This would indeed seem fair in a situation where the position of the parties would be equal, if the prosecutor would also run the risk

347 Aleksovski Admissibility of Evidence Appeal Decision, 16 February 1999, par. 25. Also, ICTY, Prosecutor v. Halilović, Decision on Motion for Prosecution Access to Defence Documents, IT-0148-T, T. Ch. I, 9 May 2005, par. 8.

348 Aleksovski Admissibility of Evidence Appeal Decision, 16 February 1999, par. 25 [footnote omitted].

349 Aleksovski Admissibility of Evidence Appeal Decision, 16 February 1999, par. 25.

350 Aleksovski Admissibility of Evidence Appeal Decision, 16 February 1999, par. 26.

351 Aleksovski Admissibility of Evidence Appeal Decision, 16 February 1999, par. 27 [footnote reference to Rule 89(D)].

352 Aleksovski Admissibility of Evidence Appeal Decision, 16 February 1999, par. 27. 
of being imprisoned for international crimes. The Chamber applied equality of arms literally and did not consider the respective positions of the accused and prosecutor before the Tribunal from a more principled perspective.

Inequality of arms with regard to the treatment of the prosecution's and defence's documents for admission into evidence was argued by the defence in Prlic et al. case on appeal. ${ }^{353}$ The defence presented three grounds of appeal and argued that the Trial Chamber had committed an error by refusing to reconsider its decision not to admit several defence documents in that it applied a higher standard for the admissibility of defence documents as compared to the prosecution. The Appeals Chamber denied the first two grounds, but accepted the third and remitted it to the Trial Chamber to decide anew. It concerned several video exhibits which the Trial Chamber decided not to admit into evidence due to the defence's failure to provide dates and source information regarding these videos. ${ }^{354}$ However, the Trial Chamber had admitted prior prosecution videos lacking the same information and conceded to having committed an error in that regard. The Appeals Chamber considered that "the practical though unintended result is that a lower standard of admission was applied to the Prosecution's videos," which amounted to the Trial Chamber's abuse of discretion. ${ }^{355}$ Judge Robinson disagreed. While expressing "concern at the apparent inequity resulting form the Trial Chamber's inadvertent application of a lower evidentiary standard to the Prosecution's videos," he argued against the Majority reasoning "as it suggests that a means of curing what the Trial Chamber regards as an error would be for the Trial Chamber to deliberately repeat that error." 356 Although this decision did not lead to substantially severe consequences as the defence had "effectively cured its error" by providing additional information regarding the dates and sources of the videos, it illustrated the Court's commitment to provide 'full equality' between the parties, even with regard to errors which had been made.

\section{Rebuttal}

An exception to the obligation to present all the incriminating evidence in the prosecution's case-in-chief is the rebuttal phase, which is directed towards refuting

353 ICTY, Prosecutor v. Prlić et al., Decision on Jadranko Prlić's Interlocutory Appeal Against the Decision on Prlić Defence Motion for Reconsideration of the Decision on Admission of Documentary Evidence, IT-04-74-AR73.16, 3 November 2009 [Prlić et al. Admissibility of Evidence Decision, 3 November 2009].

354 Prlić et al. Admissibility of Evidence Decision, 3 November 2009, par. 44.

355 Prlić et al. Admissibility of Evidence Decision, 3 November 2009, par. 44.

356 ICTY, Prosecutor v. Prlić et al., Dissenting Opinion of Judge Patrick Robinson to Decision on Jadranko Prlić's Interlocutory Appeal Against the Decision on Prlić Defence Motion for Reconsideration of the Decision on Admission of Documentary Evidence, IT-04-74-AR73.16, 3 November 2009, par. 1. 
some of the evidence presented by the accused during his case-in-chief. ${ }^{357}$ Admitting evidence in rebuttal must be "limited to the matters that arise directly and specifically out of defence evidence" ex improviso and that could not reasonably be foreseen by the prosecution. ${ }^{358}$ As such, evidence that was available to the prosecution but was not deemed relevant cannot be used in rebuttal to rectify defects or reinforce the prosecution case only because some contradicting evidence was presented by the accused. ${ }^{359}$ Moreover, the fact that the evidence was not available at the time of the prosecution case "does not render it admissible as rebuttal evidence," but merely "puts it into the category of fresh evidence, to which a different basis of admissibility applies." ${ }^{360}$ For assessing admissibility, the Chamber has looked at the high probative value (evidence should not be "circumstantial to the proof required of the Prosecution," but "the injustice of rejecting it should be irresistible") and the delay in proceedings that would be caused by the admission of that evidence in light of the right to an expeditious trial. ${ }^{361}$

357 Delalić et al. Decision on Fresh Evidence, 19 August 1998, par. 22: "This exception is of limited scope, and must not be construed as a carte blanche for the Prosecution to adduce evidence at a later stage in the proceedings which should properly have been presented as part of its original case."

358 ICTY, Prosecutor v. Halilović, Decision on Prosecution Motion to Call Rebuttal Evidence, IT-0148-T, T. Ch. I, Section A, 21 July 2005. ICTR, Prosecutor v. Ntagerura et al., Decision on the Prosecutor's Motion for Leave to Call Evidence in Rebuttal Pursuant to Rules 54, 73, and 85(A) (iii) of the Rules of Procedure and Evidence, ICTR-99-46-T, T. Ch., 21 May 2003, par. 34; ICTR, Prosecutor v. Semanza, Decision on the Prosecutor's Motion for Leave to Call Rebuttal Evidence and the Prosecutor's Supplementary Motion for Leave to Call Rebuttal Evidence, ICTR-97-20-T, T. Ch. III, 27 March 2002, paras. 8-10. ICTY, Prosecutor v. Delalić et al., Judgment, IT-96-21-A, A. Ch., 20 February 2001, par. 273.

359 ICTY, Prosecutor v. Delalić et al., Judgment, IT-96-21-A, A. Ch., 20 February 2001, par. 273; ICTY, Prosecution v. Slobodan Milošević, Decision on Prosecution Motion for Reconsideration Regarding Evidence of Defence Witnesses Mitar Balević, Vladislav Jovanović, Vukasin Andrić, and Dobre Aleksovski and Decision Proprio Motu Reconsidering Admission of Exhibits 837 and 838 Regarding Evidence of Defence Witness Barry Lituchy, IT-02-54-T, T. Ch., 17 May 2005, par. 14: "It would plainly undermine the Chamber's control of the trial through careful allocation of time to the Prosecution and Defence to present their cases, if the Prosecution were permitted to lead its own evidence during the Defence case in order to respond to the particular points raised by Defence witnesses who are simply answering the case or charges made against the Accused that emerged in the course of the Prosecution evidence. It is, therefore, distinctly possible that the evidence of a defence witness may be left "in the air" without any specific contradictory evidence. In such circumstances it will be for the Trial Chamber to evaluate the evidence against the background of all other relevant evidence in the case." The Delalic et al. criteria were adopted by the SCSL, see e.g. SCSL, Prosecutor v. Brima et al., Decision on Confidential Motion to Call Evidence in Rebuttal, SCSL-04-16-T, 14 November 2006.

360 ICTY, Prosecutor v. Delalić et al., Judgment, IT-96-21-A, A. Ch., 20 February 2001, par. 276.

361 Delalić et al. Decision on Fresh Evidence, 19 August 1998, paras. 34-37. ICTY, Prosecution v. Kordić and Čerkez, IT-95-14/2-T, oral decision of 18 October 2000, T. 26647: "only highly probative evidence on a significant issue in response to Defence evidence and not merely reinforcing the Prosecution case in chief will be permitted." 
In Krstic, the Trial Chamber considered that while it would normally admit evidence in rebuttal "if it is significant and if it arises directly out of Defence evidence which could not reasonably have been anticipated," evidence with "low probative value or relating to a fundamental part of the Prosecution's case-in-chief" would not fall under that category. ${ }^{362}$ During the trial, the prosecution used some taped evidence while cross-examining the accused that had not been disclosed to the accused until both cases-in-chief were closed. Moreover, the prosecution possessed this evidence for some time and only disclosed it to the defence one day before using it at trial, while the defence did not object to the playing of the evidence at that time. ${ }^{363}$ On appeal, the defence agued that the prosecution had employed a "sharp" trial technique with regard to this evidence that amounted to prosecutorial misconduct. ${ }^{364}$ The Appeals Chamber considered that the Trial Chamber's decision to exclude this evidence, "together with the nature of the evidence in question and the amount of time in which the prosecution possessed it, supports the defence's submission." ${ }^{365}$ The Chamber found that there were "sufficient grounds in the circumstances to question the propriety of the Prosecution as regards the disclosure of evidence." ${ }^{366}$ While it did not grant a retrial, it considered that the prosecution's conduct could correctly be dealt with under Rule $46 .{ }^{367}$

\subsubsection{ICC}

In the legal framework of the ICC the admissibility of evidence is governed by Article 64(9)(a), which gives the Trial Chamber the discretionary power to rule on the admissibility or relevance of evidence, and Article 69(4) ICC Statute, which states that "the Court may rule on the relevance or admissibility of any evidence, taking into account, inter alia, the probative value of the evidence and any prejudice that such evidence may cause to a fair trial or to a fair evaluation of the testimony of a witness [...]." Thus, the Chamber may rule on the relevance and/or admissibility of each submitted piece of evidence and determine the weight later; but it may also defer the

362 ICTY, Prosecutor v. Krstić, Decision on the Defence Motion to Exclude Exhibits in Rebuttal Evidence and Motion for Continuance, IT-98-33-T, 25 April 2001 (confidential), 4 May 2001 (public version), par. 11. Although the evidence subject to this motion was not available at the Prosecution's case-in-chief, it was of high probative value and could directly rebut specific parts of the Defence case, and would thus fall into fresh evidence following the Delalić criteria, and so the Krstić Trial Chamber decided to consider it as rebuttal evidence, thus dispensing of the "formality" to reopen the case due to the advanced stage of proceedings (Idem., par. 13).

363 ICTY, Prosecutor v. Krstić, Judgment, IT-98-33-A, A. Ch., 19 April 2004, par. 167 [Krstić Appeal Judgment].

364 Krstić Appeal Judgment, par. 172.

365 Krstić Appeal Judgment, par. 174.

366 Krstić Appeal Judgment, par. 174.

367 Krstić Appeal Judgment, par. 174. 
decision to assess the relevance and/or admissibility, probative value and potential prejudice of each piece of evidence until the end of the proceedings when it has to evaluate the guilt or innocence of the accused. ${ }^{368}$

An interesting issue with regard to the admissibility of evidence arose in the Bemba case. Although the decision does not directly touch upon the application of the principle of equality of arms, some considerations of the Appeals Chamber with regard to admissibility of evidence, the principle of orality and the right of the accused to examine witnesses are particularly interesting. In order to expedite the proceedings, the Trial Chamber decided to admit prima facie for the purpose of the trial all the materials that were disclosed to the defence and which form part of prosecution's Revised List of Evidence. ${ }^{369}$ Whereas the Trial Chamber considered that an assessment of admissibility is not a pre-condition for the admission of evidence, it appears to have made a prima facie ruling on the admissibility of evidence, without an actual assessment of each item. ${ }^{370}$ Both the prosecution and defence challenged this approach. The accused submitted, inter alia, that Trial Chamber's decision cannot be reconciled with the principle of orality and violated several of his rights. ${ }^{371}$ The prosecution argued that the Trial Chamber denied the parties the opportunity to challenge the admissibility of that evidence, circumvented the statutory principle of orality and failed to provide a reasoned decision for admitting evidence in an individualised manner.

At that point in time, the prosecution has not yet "submitted" all the pieces of evidence from its list that served merely as a "case management tool", which meant that the Trial Chamber considered the items admissible even before they were actually submitted into evidence. ${ }^{372}$ The Appeals Chamber considered this decision

368 ICC, Prosecutor v. Bemba Gombo, Judgment on the appeals of Mr Jean-Pierre Bemba Gombo and the Prosecutor against the decision of Trial Chamber III entitled "Decision on the admission into evidence of materials contained in the prosecution's list of evidence", ICC-01/05-01/08-1386, A. Ch., 3 May 2011, paras. 36-37. [Bemba Appeal Decision on Admission of Evidence from Prosecution's List, 3 May 2011].

369 ICC, Prosecutor v. Bemba Gombo, Decision on the admission into evidence of materials contained in the prosecution's list of evidence, ICC-01/05-01/08-1022, T. Ch., 19 November 2010, par. 35 [Bemba Trial Chamber Decision on Admission of Evidence, 19 November 2010].

370 Bemba Appeal Decision on Admission of Evidence from Prosecution's List, 3 May 2011, par. 39. The Trial Chamber referenced to ICC, Prosecutor v. Lubanga Dyilo, Decision in the Admissibility of Four Documents, ICC-01/04-01/06-1399, T. Ch., 13 June 2008, paras. 27-28, where the judges made a prima facie assessment of the relevance and probative value of the documents for the purposes of admissibility of that evidence.

371 Bemba Appeal Decision on Admission of Evidence from Prosecution's List, 3 May 2011, paras. 2127. The right to be informed of the charges against him, the right to have adequate time and facilities to prepare his defence, the right to be tried without undue delay and the right to question witnesses.

372 Bemba Appeal Decision on Admission of Evidence from Prosecution's List, 3 May 2011, par. 44. The items are 'submitted' when they are "presented to the Trial Chamber by the parties on their own initiative or pursuant to a request by the Trial Chamber for the purpose of proving or disproving the fact in issue before the Chamber." (par. 43). 
to admit all the evidence "without an item-by-item evaluation or giving reasons," to be "outside the legal framework of the Court." 373 The Trial Chamber's approach infringed on the parties' right to challenge the admissibility or relevance of evidence under Rule 64(1) RPE, and consequently placed an "additional burden of disproving the admissibility of items on which the Chamber has already ruled" on the defence. ${ }^{374}$

With regard to alleged violation of the right of the accused, the Appeals Chamber found merit in the allegation of a violation of the right to examine witnesses to the extent that by admitting all prior witness statements into evidence the Trial Chamber circumvented the principle of orality, Article 69(2) ICC Statute and Rule 68 ICC RPE. ${ }^{375}$ Previously recorded witness statements can be admitted into evidence under the strict conditions set out in Rule 68, if (i) the witness is not present at trial but the parties were able to examine the witness during the recording of the testimony, or (ii) the witness is present at trial, does not object to the admission of the prior statement and the parties and the judges have an opportunity to examine the witness during trial. According to the Appeals Chamber, when admitting prior recorded witness testimony, the Trial Chamber has to make sure that this "is not prejudicial to or inconsistent with the rights of the accused or with the fairness of the trial generally." ${ }^{376}$ To ensure this, the Trial Chamber has to make a "cautious assessment" taking into account factors such as whether (1) the evidence relates to issues materially in dispute; (2) it relates to core issues or provides only for background information; and (3) there is any corroborative evidence. ${ }^{377}$ This assessment was lacking and the Appeals Chamber concluded that the Trial Chamber's approach "had the potential effect of depriving Mr Bemba of his right "to examine, or have examined the witnesses against him." 378 This conclusion seems somewhat speculative. The right to examine, or have examined witnesses would be violated only when the accused would be denied an opportunity to challenge witness' statement at one point in the process, either pre-trial or at trial. This clearly constitutes the basis for the criteria as laid down in Rule 68. In Bemba, the witnesses on the prosecution's list were all to be called to give evidence in trial and available for cross-examination.

373 Bemba Appeal Decision on Admission of Evidence from Prosecution's List, 3 May 2011, par. 2.

374 Bemba Appeal Decision on Admission of Evidence from Prosecution's List, 3 May 2011, paras. 47 $50,73$.

375 Article 69(2) states: "The testimony of a witness at trial shall be given in person, except to the extent provided by the measures set forth in Article 68 or in the Rules of Procedure and Evidence. The Court may also permit the giving of viva voce (oral) or recorded testimony of a witness by means of video or audio technology, as well as the introduction of documents or written transcripts, subject to this Statute and in accordance with the Rules of Procedure and Evidence. These measures shall not be prejudicial to or inconsistent with the rights of the accused."

376 Bemba Appeal Decision on Admission of Evidence from Prosecution's List, 3 May 2011, par. 78.

377 Bemba Appeal Decision on Admission of Evidence from Prosecution's List, 3 May 2011, par. 78.

378 Bemba Appeal Decision on Admission of Evidence from Prosecution's List, 3 May 2011, par. 79. 
Furthermore, one of Trial Chamber's arguments in support of its approach concerned the fact that all witnesses' written statements on the prosecutions' list for trial have been used at the confirmation of charges hearing; and thus, the Trial Chamber could not find any "compelling reasons" not use it at trial. ${ }^{379}$ The Appeals Chamber found this link between pre-trial and trial stages "unpersuasive" considering that different evidentiary rules regarding orality apply and are more relax at the pretrial stage..$^{380}$

The Appeals Chamber's strict division between the different stages and the emphasis on the trial and the principle of orality seems to reflect a preference for the Anglo-American procedural set-up. Generally, the 'common law' approach to evidence has a stronger admissibility test than the more flexible civil law approach. The former scrutinizes more closely the pieces of evidence tendered to determine their relevance and probative value, while the latter rather emphasizes a 'wholesale' approach to evidence looking at the weight to be given to the evidence at the end of the trial. The Trial Chamber clearly chose for the flexible approach to "admit everything, determine weight later," ${ }^{381}$ while emphasizing the procedural compromise underlying the ICC, judges' duty to search for the truth and their power to request additional evidence. ${ }^{382}$ Moreover, the evidence was used at the confirmation of charges hearing (thus already part of the 'case-record'), disclosed to the defence and intended by the prosecution to be used at trial.

However, with regard to the admission of evidence, the Appeals Chamber seems not to take a strong position, but leaves it to the Trial Chamber to determine the best approach on a case-by-case basis pursuant to Article 69(4). A Trial Chamber can either rule on the relevance or admissibility of evidence when it is submitted, taking into account the probative value of the items, and determine the weight later; or alternatively, it can defer making a decision on admissibility until the end of the trial when it deliberates on the guilt or innocence of the accused. ${ }^{383}$ Whatever option is chosen, the Appeals Chamber opined, the Trial Chamber "will have to consider the relevance, probative value and the potential prejudice of each item of evidence at some point in the proceedings - when evidence is submitted, during trial, or at the end of the trial." ${ }^{384}$ In light of this 'margin of appreciation,' the Bemba Trial Chamber

379 Bemba Trial Chamber Decision on Admission of Evidence, 19 November 2010, par. 27.

380 Bemba Appeal Decision on Admission of Evidence from Prosecution's List, 3 May 2011, par. 80: "Pursuant to Article 61(5) of the Statute, for the purposes of the confirmation hearing, the Prosecutor "may rely on documentary or summary evidence and need not call the witnesses expected to testify at the trial." At the trial, however, the Trial Chamber must respect Article 69(2). Witness statements may only be introduced under rule 68 of the Rules of Procedure and Evidence if the strict conditions of that rule are met."

381 Zahar And Slutter, 2008, p. 384.

382 Bemba Trial Chamber Decision on Admission of Evidence, 19 November 2010, paras. 17, 27-28.

383 Bemba Appeal Decision on Admission of Evidence from Prosecution's List, 3 May 2011, par. 37.

384 Bemba Appeal Decision on Admission of Evidence from Prosecution's List, 3 May 2011, par. 37. 
seems to have taken a too compromised approach: there should be no intermediary step of prima facie admissibility of all purported evidence; the Chamber can choose to admit, not to admit, or postpone the decision on admissibility. If it chooses to admit, the evidence deserves an item-for-item assessment. Notwithstanding this fact, the Appeals Chamber voiced a preference (a 'common law' approach) for determination at an early stage if a party challenges the admissibility or relevance of the evidence. ${ }^{385}$

On a final note, the Appeals Chamber did not agree with Trial Chamber's view that "the Statute only envisages a presumption in favour of oral testimony, but no prevalence of orality of the procedures as a whole." 386 Taking a more strict approach to the principle of orality is clearly beneficial to the assessment of testimonial evidence, as the judge gets the information 'first hand' and can observe and assess witnesses' demeanor in court. However, a clear lesson from the ad hoc tribunal's practice is that orality equals duration. In fact, the tribunal's judges have struggled for years to find an appropriate (acceptable) balance between the principle of orality and expeditiousness, gravitating more and more towards the more 'inquisitorial' practice of relying on written evidence, just to keep the duration of the proceedings within somewhat acceptable confines.

From this perspective it is interesting to note Judge Fulford's proposal on how to approach witnesses statements and testimony in order to expedite the process. In his view, both parties should be obliged to identify, for each witness they intend to call, the parts of witness statement that parties agree upon, and that are disputed. ${ }^{387}$ The agreed upon parts would then enter into the trial record as a written document, rather than having a witness rehearse elements of the testimony that are accepted. ${ }^{388}$ Although theoretically appealing, a practical relevance of this proposal is not yet clear. It would necessitate the defence to be willing to stipulate to parts of witness testimony before having had a chance to examine the witness. In addition, the role of participating victims would have to be considered; the extent to which victims would have to agree on the specific parts agreed by the parties and the consequences of non-agreement. Due to its obligatory format, this proposal is more far-reaching than the similar Rule 69 ICC RPE, which provides for a possibility for parties to agree on certain facts for the Chamber to consider as proven. The Chamber has a discretionary power in this respect and can order a more complete presentation of evidence on the agreed

385 Bemba Appeal Decision on Admission of Evidence from Prosecution's List, 3 May 2011, par. 37.

386 Bemba Trial Chamber Decision on Admission of Evidence, 19 November 2010, par. 14 [emphasis in original].

387 FulFORD, 2011, p. 221.

388 FULFORD, 2011, p. 221: "This proposal would need to be considered very carefully in advance of its implementation, because it might be said that it constitutes a qualification to the statutory right of an accused to remain silent under Article $67(1)(\mathrm{g})$. It would be useful, indeed arguably necessary, to have this method of admitting evidence resolved in advance (perhaps by way of an amendment to the Statute), given that it is undesirable for the results of criminal trials to be put at risk because of uncertain procedural experimentation." 
facts in the interests of justice in general, and the interests of victims in particular. In case the defence is unable to comply with this Rule's intention, it has to notify the Chamber on time. ${ }^{389}$ Victims must be notified of the agreed facts and they can file submissions " $[\mathrm{t}] \mathrm{o}$ the extent that the views and concerns of participating victims are affected by agreements as to evidence." ${ }^{390}$ In Katanga and Ngudjolo, parties agreed on seven out of 149 proposals for agreement initially filed by the prosecution. ${ }^{391}$ The Chamber took note of these agreements considering that no further substantiation of these facts was necessary and admitted the exhibits the parties agreed upon. Clearly, specific circumstances of the case will play a crucial role in whether parties (defence) are wiling to stipulate to certain fact or parts of witness testimony.

\section{Rebuttal}

In agreement with the jurisprudence of the ad hoc tribunals, the ICC Trial Chamber considered three criteria to be relevant to admit evidence in rebuttal: (1) the issue of significance has arisen eximproviso; (2) evidence on rebuttal satisfies the admissibility criteria; and (3) the admission of this evidence would not undermine the rights of the accused. ${ }^{392}$

\subsubsection{ECCC}

At the ECCC, the guiding principle is that all evidence is admissible unless the Rules provide otherwise. ${ }^{393}$ According to Rule 87(2) ECCC Rules, "any decision of the Chamber shall be based only on evidence that has been put before the Chamber and subjected to examination." The Rules mention several reasons for which the Chamber may reject a request for evidence, namely when the evidence is (a) irrelevant or repetitious, (b) impossible to obtain within a reasonable time, (c) unsuitable to prove the facts it purports to prove, (d) not allowed under the law, and (e) intended to prolong proceedings or is frivolous. ${ }^{394}$ In line with other tribunals, the ECCC judges have a broad discretion in admitting evidence. The heading of Rule 87(3) states that

389 ICC, Prosecutor v. Lubanga Dyilo, Decision on agreements between the parties, ICC-01/04-01/061179, T. Ch., 20 February 2008, par. 12.

390 CC, Prosecutor v. Lubanga Dyilo, Decision on agreements between the parties, ICC-01/04-01/061179, T. Ch., 20 February 2008, par. 13.

391 ICC, Prosecutor v. Katanga and Ngudjolo, Decision on Agreements as to Evidence, ICC-01/0401/07-2681, 3 February 2011, par. 2. In addition, agreement was reached on five cartographic exhibits (par. 3).

392 ICC, Prosecutor v. Lubanga Dyilo, Redacted Decision on the Prosecution's Application to Admit Rebuttal Evidence from Witness DRC-OTP-WWWW-0005, ICC-01/04-01/06-2727-Red, T. Ch. I, 28 April 2011, par. 43.

393 Rule 87(1) ECCC Rules.

394 Rule 87(3) ECCC Rules. 
"[t]he Chamber bases its decision on evidence from the case file provided is has been put before it by a party or if the Chamber itself has put it before the parties. ${ }^{395}$ Thus, material on the case file is not yet evidence unless it has been produced at trial. ${ }^{396}$ Moreover, "[i]n order to be used as evidence, material on the case file must [...] satisfy minimum standards of relevance and reliability necessary for it to be produced before the Chamber [following which] the probative value of this evidence, and hence the weight to be accorded to it will then be assessed." ${ }^{397}$ Evidence from the case file is considered put before the Chamber or the parties if its content has been summarized, read out, or appropriately identified in court (Rule 87(3)). This latter element ('appropriately identified') was added with fourth amendment of the Rules, because the application of this provision as it was initially formulated posed severe challenges to the effectiveness of the system. ${ }^{398}$

The practice arising from the first trial, Duch case, with regard to the admission of evidence has been appropriately characterized as "trial and error." 399 Although the Rules are more detailed as compared to the ad hoc tribunals, the judges have clearly struggled to find a proper balance between the letter of the law and the efficient administration of justice. Exemplary is the first application of Rule 87(3), when the prosecution intended to introduce many documents attached to an expert report. The Trial Chamber chose for a literal interpretation of the Rule and required the prosecution to read out or summarize each item of evidence, considering the fundamental importance of this Rule to a fair trial. ${ }^{400}$ When the prosecution took approximately 30 minutes to read out just a handful of exhibits (out of 148), the Trial Chamber reversed its decision and allowed the prosecution to proceed to identify and summarize the type of the document, which course of action was initially proposed by the prosecution. ${ }^{401}$ As mentioned, after this incident the Rule was amended to include the phrase appropriately identified.

During the trial, the Trial Chamber can proprio motu or at request summon or hear witnesses and admit new evidence in order to ascertain the truth. ${ }^{402}$ The Chamber may reject a request for evidence according to the criteria of Rule 87(3) and if the party cannot satisfy the Chamber that the evidence was not available before the

395 Following a Closing Order, the Co-Investigative Judges seal and forward the case file to the Trial Chamber (Rule 69).

396 ECCC, Prosecutor v. Kaing Guek Eav, Decision on Admissability of Material on the Case File as Evidence, 001/18-07-2007/ECCC/TC, T. Ch., 26 May 2009, par. 6 [Duch Admissibility of Evidence Decision, 26 May 2009].

397 Duch Admissibility of Evidence Decision, 26 May 2009, par. 7.

398 Review 4 of the ECCC Internal Rules, 11 September 2009.

399 GiBSon AND Rudy, 2009, p. 1010.

400 Duch Transcript Trial Hearing of 20 May 2009, pp. 5-6.

401 Duch Transcript Trial Hearing of 17 June 2009, pp. 57, 95-96. For an elaborate discussion see GiBSON AND RUDY, 2009, pp. 1010-1014.

402 Rule 87(4) Internal Rules. 
commencement of the trial. The practice suggests that the Trial Chamber does not take the latter factor too literally. In fact, no considerations of whether evidence was or was not available before the trial are included in the decisions on admissibility of evidence at trial. ${ }^{403}$ Rather, two factors determine the Trial Chamber's decision to admit a certain piece of evidence: (1) whether the defence objected to admission of that evidence, and (2) the potential prejudice to the accused. ${ }^{404}$ The assessment of the latter factor is reflective if the approach taken by the ad hoc tribunals.

The next section will take a closer look at how the ad hoc tribunals have handled admissibility of evidence after the closed of the defence case in chief.

\subsubsection{Admissibility of additional evidence after the close of the case in chief}

Although neither the ICTY Statute nor the Rules provide for the possibility to reopen the case of either party, it has been accepted in the Tribunal's practice that a Trial Chamber can use its discretionary power to reopen a case in certain limited circumstances. ${ }^{405}$ One possibility is based expressly on Rule 85 RPE and concerns the presentation of evidence in rebuttal. ${ }^{406}$ Moreover, there could be a possibility to reopen a case "to adduce evidence of a purely formal and non-contentious nature after the close of the case of the parties." ${ }^{407}$ Another possibility is to reopen a case "in order to present new evidence not previously available." 408 According to the Trial Chamber in the Čelebici $i$ case, "[s] uch fresh evidence properly defined not merely as evidence that was not in fact in the possession of the Prosecution at the time of the conclusion of its case, but as evidence which by the exercise of all reasonable diligence could not have been obtained by the Prosecution at that time." 409

As stated, in principle all the incriminating evidence must be submitted during the prosecution case; however, this might prove difficult to achieve in practice due to the circumstances under which the tribunal operates, and specifically its dependence on state cooperation. Exemplary is the Kordić and Čerkez case, where due to Croatia's capricious cooperation, the prosecution could only obtain certain key documents after

403 Duch Admissibility of Evidence Decision, 26 May 2009; GiBSOn AND Rudy, 2009, footnotes 46 and 47 and accompanying text.

404 Gibson and Rudy, 2009, p. 1013.

405 Delalić et al. Decision on Fresh Evidence, 19 August 1998, par. 21.

406 Delalić et al. Decision on Fresh Evidence, 19 August 1998, par. 22: "This exception is of limited scope, and must not be construed as a carte blanche for the Prosecution to adduce evidence at a later stage in the proceedings which should properly have been presented as part of its original case."

407 Delalić et al. Decision on Fresh Evidence, 19 August 1998, par. 25: "This may be the case, for example, where the Prosecution has omitted to tender a material statutory instrument in evidence. In such circumstances, no prejudice is caused to the accused by allowing the Prosecution to re-open its case, and the Trial Chamber will therefore admit such evidence."

408 Delalić et al. Decision on Fresh Evidence, 19 August 1998, par. 26

409 Delalić et al. Decision on Fresh Evidence, 19 August 1998, par. 26. 
the close of its and the defence's cases. ${ }^{410}$ When arguing for the admissibility of the "Zagreb materials", the Prosecution also argued that the Tribunal's case law takes "an inclusive approach" towards evidence and that the Chamber must take into account the "peculiarities and difficulties of unearthing and assembling material for war crimes prosecutions." 411 Moreover, from the beginning of this trial, the prosecution "has attempted to obtain and provide to the Trial Chamber the best evidence available" and it should "not be prejudiced or penalised for any obstruction or delay on the part of Croatia." ${ }^{412}$ The prosecution thus argued for the application of the same standard for the admission of evidence at this stage as during the trial. ${ }^{413}$ The accused argued in the same vein, they should also not be penalized for Croatia's inaction by the admission of evidence at this late stage in the proceedings. ${ }^{414}$ Although, technically speaking, the prosecution never closed its case in relation to the Zagreb materials, with permission from the Chamber, the Trial Chamber considered that this "technicality" did not stand in the way of the reality that the admission of the materials was being sought after the close of the defence case. ${ }^{415}$ The test as formulated by the Chamber contains the following elements: (1) "the material must be new in the sense of not having been available to Prosecution with due diligence, before the end of its case;" (2) "material should not be cumulative [...] and it must be of significant relevance to the core issues in the case such as those relating to the conduct of the accused;" and (3) "the admission of the evidence must be in the interest of justice, that is in the interests of assisting the Court in determining the guilt or innocence of the accused and not be contrary to Rule 89(D)." ${ }^{\prime 416}$

In Hadžihasanović and Kubura, the prosecutor applied to reopen its case for the purpose of tendering 24 new documents. ${ }^{417}$ Referring to the Čelebići Appeals Chamber

410 ICTY, Prosecutor v. Kordić and Čerkez, Decision on Prosecutor's Submissions Concerning “Zagreb Exhibits" and Presidential Transcripts, IT-95-14/2, T. Ch., 1 December 2000 [Kordić and Čerkez Decision on Fresh Evidence, 1 December 2000].

411 Kordić and Čerkez Decision on Fresh Evidence, 1 December 2000, par. 13 [footnote omitted].

412 Kordić and Čerkez Decision on Fresh Evidence, 1 December 2000, par. 14.

413 Kordić and Čerkez Decision on Fresh Evidence, 1 December 2000, par. 15.

414 Kordić and Čerkez Decision on Fresh Evidence, 1 December 2000, par. 18.

415 Kordić and Čerkez Decision on Fresh Evidence, 1 December 2000, par. 36.

416 Kordić and Čerkez Decision on Fresh Evidence 1 December 2000, par. 36. The Chamber excluded many of the documents for various reasons, and admitted some, on a piece by piece basis. Although the SCSL Rules do not contain a Rule 89(D), its content was adopted as falling under the general discretion of the Trial Chamber. See SCSL, Prosecutor v. Brima et al., Decision on Confidential Prosecution Motion to Reopen the Prosecution Case to Present an Additional Prosecution Witness, SCSL-04-16-T, 28 September 2006 (adopting the Delalić criteria for reopening the case and admitting fresh evidence and finding that the Prosecution had not discharged its due diligence obligation).

417 ICTY, Prosecutor v. Hadžihasanović and Kubura, Decision on the Prosecution's Application to Re-Open its Case, IT-01-47-T, T. Ch. II, 1 June 2005 [Hadžihasanović and Kubura Decision on Reopening Prosecution's Case, 1 June 2005]. The application is dated 22 April 2005, while the Prosecution's case was closed on 23 July 2004 and the defence presented its case from 18 October 
decision, ${ }^{418}$ the Trial Chamber stipulated a two-step procedure to be followed when reviewing the appropriateness of reopening the prosecution's case. First, the party has to demonstrate that despite due diligence it was not able to identify and produce evidence during its case-in-chief. Only then can the Trial Chamber, as a second step, decide on the admissibility of advanced evidence by considering its relevance and probative value. ${ }^{419}$ The two steps are strictly and unconditionally separate and this differentiates this test from most national legal systems. ${ }^{420}$

With regard to the principle of due or reasonable diligence, the prosecution had to prove to the satisfaction of the Trial Chamber that despite its reasonable diligence it was unable to obtain the evidence during the presentation of its case in chief. ${ }^{421}$ The proposed evidence must be "fresh", meaning not in the prosecution's possession before the closure of the case. As such, items not identified or presented due to "some inadvertence or administrative oversight on the part of the Prosecution," or not admitted by the Chamber during the presentation in chief are excluded from constituting a basis for reopening the case..$^{422}$

The Hadžihasanović and Kubura Trial Chamber considered four elements to be relevant in the interpretation of the due diligence principle. These are: (1) the identification of principal and secondary questions of fact and law underlying the case which would guide the appropriate investigations; (2) the identification of all the potential sources of evidence through an in-depth analysis of the indictment; (3) an evaluation of the need and appropriateness to obtain additional evidence before the close of the case-in-chief, even if the existence of the evidence has not been established beforehand; and (4) every effort must be made to obtain all the evidence the party believes it needs before commencing its case, and if this is not possible, further investigations must proceed without undue delay, and the party should inform

2004 to 11 April 2005 (Hadžihasanović) and from 11 April 2005 to 19 May 2005 (Kubura).

418 ICTY, Prosecutor v. Delalić et al., Judgment, IT-96-21-A, A. Ch., 20 February 2001, KLIP AND Sluiter, 2003, p. 369, par. 283: "The Appeals Chamber agrees that the primary consideration in determining an application for reopening a case to allow for the admission of fresh evidence is the question of whether, with reasonable diligence, the evidence could have been identified and presented in the case in chief of the party making the application. If it is shown that the evidence could not have been found with the exercise of reasonable diligence before the close of the case, the Trial Chamber should exercise its discretion as to whether to admit the evidence by reference to the probative value of the evidence and the fairness to the accused of admitting it late in the proceedings. These latter factors can be regarded as falling under the general discretion, reflected in Rule 89(D) of the Rules, to exclude evidence where its probative value is substantially outweighed by the need to ensure a fair trial."

419 Hadžihasanović and Kubura Decision on Reopening Prosecution's Case, 1 June 2005, par. 35.

420 Hadžihasanović and Kubura Decision on Reopening Prosecution's Case, 1 June 2005, par. 35.

421 Hadžihasanović and Kubura Decision on Reopening Prosecution's Case, 1 June 2005, par. 36.

422 ICTY, Prosecutor v. Slobodan Milošević, Decision on Application for a limited Re-Opening of the Bosnia and Kosovo Components of the Prosecution Case with Confidential Annex, IT-02-54-T, T. Ch. I, 13 December 2005, par. 23. 
the Chamber as promptly as possible about any hindrance/obstacles in obtaining the evidence before the close of its case. ${ }^{423}$

The basis for the Trial Chamber's discretion to admit any evidence that has probative value that is not substantially outweighed by the need to ensure a fair trial lies in Rule 89(C) and (D) of the RPE. ${ }^{424}$ The Trial Chamber identified several factors, taken from the Čelebici $i$ Trial Chamber decision and reiterated by the Appeals Chamber, which must be taken into account when considering whether it would be fair to admit new evidence: (1) the advanced stage of the trial; (2) the delay that will be caused by reopening the case; (3) the probative value of the proposed evidence; and (4) in a joint trial, the effect that this new evidence will have on the trial of another accused. ${ }^{425}$ The probative value of the proposed evidence must outweigh any prejudice caused to the accused by the admission of the evidence. ${ }^{426}$ Therefore, the discretion to reopen a case in order to adduce new evidence after the parties have closed their case will only be exercised in "exceptional circumstances where the justice of the case so demands." ${ }^{27}$ In the decision at hand, the Trial Chamber did not proceed with evaluating the admissibility of the proposed evidence because the prosecution had not discharged its due diligence obligation in obtaining the proposed evidence.

The prosecution argued that all the evidence it sought to be admitted was 'fresh' in the sense that it had not been in its possession during its presentation of the case in chief. ${ }^{428}$ With regard to discretionary factors, the prosecution contended that it had made it clear to the defence since early 2005 that it intended to apply to have the case reopened and as such did not 'ambush' the defence with its application. Moreover, the defence had enough time to prepare since the filing of the application because the originals of the proposed evidence had been disclosed to it even before the prosecution's application to reopen its case. ${ }^{429}$ With regard to a possible delay in the proceedings, the prosecution submitted in very general terms that any delay, which was in fact not anticipated, would not violate "the principle of fairness or international norms" and "would be warranted in order to determine the truth."

The defence submitted that the admission of additional evidence after the close of the prosecution's case clearly infringed upon the right of the accused to be informed promptly and in detail of the charges against him, to be tried without undue delay and

423 Hadžihasanović and Kubura Decision on Reopening Prosecution's Case, 1 June 2005, paras. 39-42.

424 Hadžihasanović and Kubura Decision on Reopening Prosecution's Case, 1 June 2005, par. 43.

425 Hadžihasanović and Kubura Decision on Reopening Prosecution's Case, 1 June 2005, paras. 45-46. ICTY, Delalić et al. Decision on Fresh Evidence, 19 August 1998, par. 27.

426 Delalić et al. Decision on Fresh Evidence, 19 August 1998, par. 27, affirmed in ICTY, Prosecutor $v$. Delalić et al., Judgment, IT-96-21-A, A. Ch., 20 February 2001, KLIP AND SLuiter, 2003, par. 288.

427 Ibid.

428 Hadžihasanović and Kubura Decision on Reopening Prosecution's Case, 1 June 2005, par. 10.

429 Hadžihasanović and Kubura Decision on Reopening Prosecution's Case, 1 June 2005, par. 20.

430 Hadžihasanović and Kubura Decision on Reopening Prosecution's Case, 1 June 2005, par. 21. 
to have adequate time and facilities for the preparation of his defence (Articles 21(4) $a, b$ and c ICTY Statute). According to the defence, the proposed documents could have been obtained and presented at a much earlier stage. In any case, in its view the prosecutor had not indicated that there were any problems regarding the cooperation of Bosnia and Herzegovina in obtaining these documents. This advance notice would be indicative of reasonable diligence on the part of the prosecutor. As to the probative value of the proposed evidence, the defence submitted that the proposed additional evidence did not directly extend to proving one of the essential elements of the charges against the accused, and as such the evidence could not be afforded sufficient probative value to outweigh the need to guarantee a fair trial and to be admitted at this late stage. ${ }^{431}$

In analyzing the prosecutor's application, the Chamber considered that "a diligent prosecution must conduct a systematic, assiduous investigation of any evidence which might indicate whether the Mujahedin [foreign Muslim combatants and their local sympathizers] were in fact under the command and control of the Accused." 432 Moreover, a diligent prosecution should attempt to identify several national institutions that would logically closely monitor the movements and activities of foreigners that arrive in a territory for the purpose of lending military assistance, and search their archives. According to the Chamber, "it is obvious that by deciding not to search the archives which might provide that information, the prosecution limits its chances of obtaining key elements to support its case."433

Clearly the mistake of not being able to locate the nine documents coming from the OSA [the Intelligence and Security Agency of the Federation of Bosnia and Herzegovina] archives was fully attributable to the prosecution. In this regard the Chamber noted that due diligence "concerns not only the procedures used for obtaining information in support of a party's case but also how that information is handled," and in respect of the second factor, the prosecution "should and could have reasonably" avoided the committed errors. ${ }^{434}$ Although commendable for its elaborateness, this consideration seems unnecessary in light of the Chamber's consideration that these nine documents were in the possession of the prosecution before the close of its case-in-chief. ${ }^{435}$ This finding in itself would be sufficient to

431 Hadžihasanović and Kubura Decision on Reopening Prosecution's Case, 1 June 2005, par. 28.

432 Hadžihasanović and Kubura Decision on Reopening Prosecution's Case, 1 June 2005, par. 51.

433 Hadžihasanović and Kubura Decision on Reopening Prosecution's Case, 1 June 2005, par. 53.

434 Hadžihasanović and Kubura Decision on Reopening Prosecution's Case, 1 June 2005, par. 74. Although the Prosecution provided several explanations to justify the fact that it was unable to present the documents to the Chamber before the close of its case, it was unable to say which of the explanations was the most likely. [The reasons relate to the technical impossibility of searching the relevant CD-ROM, the mistaken assumption of the investigator that the CD-ROM was merely an electronic version of 796 other documents, the late realization of the importance of the information on the CD-ROM, and the heavy workload of the investigators at the time].

435 Hadžihasanović and Kubura Decision on Reopening Prosecution's Case, 1 June 2005, par. 70. 
reject the prosecution's submission on its due diligence exercise, as its application clearly did not concern 'fresh' evidence that the prosecutor was not able to obtain before the close of its case. ${ }^{436}$

In relation to other documents (concerning Ramo Durmis) that were indeed obtained after the close of the prosecution's case, the prosecution submitted that "it did not realize the precise importance of Ramo Durmis before the completion of its case." ${ }^{437}$ According to the Chamber, the prosecution had failed to analyze, in a timely fashion, the facts available before the end of its case and thus it had acted without due diligence. The same reasoning applied in respect of the other documents the prosecution sought to admit. These other documents had been obtained by the prosecution during its search of the relevant archives after the closure of its case. Although the request to the national authorities to search the archives was made in the context of another case, it was made one day before the closing of the case at hand. In this respect, the Chamber considered it important that the prosecution did not inform the Chamber of its intention to make a search of the archives in respect of this other case, which showed a clear subject-matter overlap with this case, so the Chamber would have had the opportunity to consider any procedural consequences of such an investigative step before the start of the defence case. ${ }^{438}$ This last consideration is particularly important in the assessment of the prosecution's due diligence. In light of the limited subject-matter, the temporal and territorial jurisdiction of the ICTY, some 'extended oversight' on the part of the prosecution does not seem to be an unreasonable demand, particularly because this 'demand' extends only to a timely notification of the Trial Chamber which would provide for the opportunity to consider some procedural consequences.

In cases of such complexity and magnitude as those presented before the ICTY, it is not surprising, to a certain extent, that some relevant evidence might come late to - or escape - the attention of the prosecutor. As held by the Trial Chamber, due diligence is not only expressed in the manner in which the evidence was obtained, but also handled. The prosecution bears the responsibility to prove its case beyond a reasonable doubt against a defendant who enjoys the presumption of innocence. The stringent approach to the admission of evidence after the close of the case is

436 Hadžihasanović and Kubura Decision on Reopening Prosecution's Case, 1 June 2005, par. 36. Cf. ICTY, Prosecutor v. Slobodan Milošević, Decision on Application for a limited Re-Opening of the Bosnia and Kosovo Components of the Prosecution Case with Confidential Annex, IT-02-54-T, T. Ch. I, 13 December 2005, par. 23: "Application of the reasonable diligence standard - indeed, the entire exercise of re-opening a party's case - is reserved for 'fresh' evidence, which by definition excludes any evidence already in the possession of the moving party during its case in chief."

437 Hadžihasanović and Kubura Decision on Reopening Prosecution's Case, 1 June 2005, par. 76.

438 Hadžihasanović and Kubura Decision on Reopening Prosecution's Case, 1 June 2005, par. 42. Also SCSL, Prosecutor v. Brima et al., Decision on Confidential Prosecution Motion to Reopen the Prosecution Case to Present an Additional Prosecution Witness, SCSL-04-16-T, 28 September 2006, par. 37. 
dictated by the nature of the proceedings before the ICTY and the Rules related to the presentation of evidence. The predominating features of the common law system "clearly portray the philosophy of the total" as there should be a point where the "accusation ends and answering the allegations begins." 439 As such it is "consistent with justice not to interfere with the Defendant answering the allegations made by continuing with further accusations." ${ }^{440}$

\subsubsection{Expert witnesses}

\subsubsection{ICTY, ICTR and SCSL}

Due to the complexity of the cases expert evidence has played a paramount role in international criminal proceedings. ${ }^{441}$ Before the expert evidence is deemed admissible, several requirements must be satisfied: (1) the individual must qualify as an expert witness; ${ }^{442}(2)$ the statement or report of the expert must meet the minimum standard of reliability; ${ }^{443}$ (3) the evidence is relevant and has probative value, which value is not outweighed by the need to ensure a fair trial;444 and (3) the evidence falls within the accepted area of witnesses' expertise. ${ }^{445}$ In line with Rule 94bis, the Chamber sets a time-limit for the disclosure of the full statement and/or report of the expert (A), after which, within 30 days, the opposing party must file a notice indicating whether (B) (i) it accepts the experts evidence, or (ii) wishes to crossexamine the witness; and (iii) it challenges either the qualifications of the witness or the (parts of the) statement/report. If the opposing party does not challenge the expert evidence, the Trial Chamber may admit it without calling the witness to testify $(94 b i s(\mathrm{C}))$. The opposing party, while accepting the qualifications of the expert and

439 Delalić et al. Decision on Fresh Evidence, 19 August 1998, par. 20.

440 Delalić et al. Decision on Fresh Evidence, 19 August 1998, par. 20.

441 KLINKNer, 2009, p. 102.

442 ICTY, Prosecutor v. Galić, Decision Concerning the Expert Witnesses Ewa Tabeau and Richard Philipps, IT-98-29-T, T. Ch., 3 July 2002, p. 2, an expert is an individual who "by virtue of some specialized knowledge, skill or training can assist the trier of fact to understand or determine an issue in dispute."

443 See e.g. ICTY, Prosecutor v. Galic, Decision on the Prosecution Motion for Reconsideration of the Admission of the Expert Report of Professor Radinović, IT-98-29-T, 21 February 2003, T. Ch., par. 9. "Minimum standards of reliability" means that the expert report must contain sufficient information as to the sources used in support of it and/or the conclusions contained in it. This information must be clearly set forth and accessible in order to allow the opposing party and the Trial Chamber a basis upon which to test or assess the information the expert relied upon when reaching the opinions in the report.

444 ICTY, Prosecutor v. Perišić, Decision on Expert Report by Richard Philipps, IT-04-81-T, T. Ch., 10 March 2009, par. 10.

445 ICTY, Prosecutor v. Lukić and Lukić, Decision on Second Prosecution Motion for the Admission of Evidence Pursuant to Rule 92bis (Two Expert Witnesses), IT-98-32/1-T, T. Ch., 23 July 2008, par. 15. 
the relevance of the statement/report, retains the right to cross-examine the witness and has to file a submission in reply to Rule 94bis motion. ${ }^{446}$ Challenges related to expert witness' independence and impartiality do not directly affect the admissibility of the expert evidence but go towards the weight to be assigned to that evidence. ${ }^{447}$ In fact, these challenges are deemed appropriate areas for cross-examination at trial. Affiliation with a party, such as being employed by the prosecution, does not in itself constitute a ground to disqualify the expert witness. Only on very rare occasions did the Chamber exclude expert evidence in its entirety. ${ }^{448}$ The Nahimana et al. Appeals Chamber concurred with an earlier ICTY Trial Chamber decision, which held that employment or payment by a party does not disqualify an individual from testifying as an expert witness for that party. Subsequently, the Appeals Chamber in Popović et al. adopted a similar position, holding that the mere fact that an expert witness is employed by, or has connections to, the calling party does not disqualify him or her as an expert. ${ }^{449}$ As long as there are sufficient prima facie indications of reliability so that the evidence of the proposed expert has probative value, then concerns related to connections between the witness and the calling party can be explored in crossexamination. ${ }^{450}$

Introduction of expert evidence is controlled by the parties; as well as the testing the reliability of an expert through cross-examination. This is a natural consequence of a primarily adversarial set-up of proceedings. ${ }^{451}$ In the case of Milutinović et al. the defence challenged this approach arguing in favour of a continental practice of court appointed expert witnesses. The Ojdanić defence (joined by the Pavkovic defense) requested the Trial Chamber to "preclude all parties from calling expert witnesses, and to call as Trial Chamber witnesses at the end of the case those experts who it believes will assist it in coming to a fair determination of the live issues in the case." ${ }^{452}$ The Ojdanić defence argued that the judges should follow the

446 ICTY Defence Manual, 2011, p. 104.

447 ICTY, Prosecutor v. Perišić, Decision on Expert Report by Richard Philipps, IT-04-81-T, T. Ch., 10 March 2009, par. 18. ICTY, Prosecutor v. Galić, Decision Concerning the Expert Witnesses Ewa Tabeau and Richard Phillips, IT-98-29-T, t. Ch., 3 July 2002, pp. 2-3: "The fact that the witness has been involved in the investigation and preparation of the Prosecution or Defence case or is employed or paid by one party does not disqualify him or her as an expert witness or make the expert statement unreliable. Concerns relating to the witness's independence or impartiality do not necessarily affect the admissibility of the witness' statement or report pursuant to Rule 94bis of the Rules, but may affect the weight to be given to the witness's evidence."

448 For several references see ICTY Defence Manual, 2011, p. 105.

449 ICTY, Prosecutor v. Popović et al. Decision on Joint Defence Interlocutory Appeal Concerning the Status of Richard Butler as an Expert Witness, IT-05-88-AR.73.2, A. Ch., 30 January 2008.

450 ICTY, Prosecutor v. Popović et al., Decision on Joint Defence Interlocutory Appeal Concerning the Status of Richard Butler as an Expert Witness, IT-05-88-AR.73.2, A. Ch., 30 January 2008, par. 31.

451 Although the Court may appoint its own witnesses, the general expectation is that the parties are responsible for tendering and challenging expert evidence.

452 ICTY, Prosecutor v. Milutinović et al., Decision on Ojdanić Motion to Preclude Parties from Calling 
inquisitorial model on this issue, notwithstanding the primarily adversarial nature of the Tribunal's proceedings, because it would better serve the rights of all parties to a fair and expeditious trial and to equality of arms. ${ }^{453}$ By retaining an adversarial approach to expert witnesses, equality of arms might be endangered according to the Ojdanić defense, due to "the gross inequity in resources afforded to the prosecution and defence to retain expert witnesses." ${ }^{454}$ Moreover, much of the expert testimony proposed in this case "is unnecessary, or to be presented by unnecessary partisan witnesses," and would take up much of the trial time. ${ }^{455}$ Rather than observing the experts and the parties "slugging it out," the Trial Chamber should call those experts it considers indispensable after the close of parties' presentation of evidence. ${ }^{456}$ The Ojdanic defence further submitted that the ICTY RPE are silent on the right of a party to call an expert witnesses, and emphasized the Trial Chamber's discretion in admitting expert testimony, and its power to limit the number of witnesses under Rule 73 bis and 73 ter $^{457}$ Notably, the other accused disagreed asserting their right to present "a full and complete defence in response to the allegations made by the Prosecution and the evidence adduced at trial by the Prosecution." 458 The prosecution did not contest the Trial Chamber's authority in this regard, but argued that the Ojdanic defence motion ignored the parties' ability to determine whether, and which, expert evidence would best assist the Trial Chamber in better understanding the party's theory of the case and its evidence. ${ }^{459}$ Moreover, the prosecution contended that it bore the burden of proving the allegations against an accused, and that the proposal would lead to unfairness towards the prosecution within the procedural model of the Tribunal: if it failed to present sufficient evidence, the Trial Chamber could acquit the accused of all or some charges after the close of the prosecution's case, without ever hearing any expert testimony. ${ }^{460}$

Considering the issue in dispute, the Trial Chamber emphasized that it had already considered the expert witness evidence and testimony at the pre-trial stage, and had made several determinations on some evidence, while postponing final determinations until the time prior to the expert testimony. Thus, according to the

Expert Witnesses, IT-05-97-T, 16 November 2006, par. 1 [Milutinović et al. Decision on Expert Witnesses, 16 November 2006].

453 Milutinović et al. Decision on Expert Witnesses, 16 November 2006, par. 3.

454 Milutinović et al. Decision on Expert Witnesses, 16 November 2006, par. 19, the Ojdanić defence estimated that "the amount of funds that the Tribunal will allocate for defence experts will result in a greater than 10:1 ratio of resources between the prosecution and the organizations with whom it works on the one hand, and the defence on the other."

455 Milutinović et al. Decision on Expert Witnesses, 16 November 2006, paras. 13-14. It would take up almost 40 trial days to hear expert witnesses, according to the defence's calculation.

456 Milutinović et al. Decision on Expert Witnesses, 16 November 2006, par. 15.

457 Milutinović et al. Decision on Expert Witnesses, 16 November 2006, par. 3.

458 Milutinović et al. Decision on Expert Witnesses, 16 November 2006, par. 6.

459 Milutinović et al. Decision on Expert Witnesses, 16 November 2006, par. 7.

460 Milutinović et al. Decision on Expert Witnesses, 16 November 2006, par. 9. 
Trial Chamber, the defence had ample time pre-trial or at the beginning of the trial to propose new methodology with regard to the selection and admission of the expert witnesses, which it failed to do. ${ }^{461}$ Moreover, not all the accused supported the motion, and thus revising the course after the trial had been underway for four months would be counter-productive to the interests of a fair trial. ${ }^{462}$ Denying the motion, the Trial Chamber did reassure the Ojdanić defence that when determining the admissibility of expert evidence not yet admitted, it would indeed consider the necessity of that expert evidence or testimony. ${ }^{463}$ Although leaving a possibility for a new, 'inquisitorial' approach to expert testimony open, the Chamber unfortunately did not elaborate on this methodology any further.

In Bizimungu et al., the prosecution sought to object to a defence expert's qualifications and report seven months after the deadline under Rule 94bis(B) ICTR RPE by including the prosecution's objections in its response to a defence motion to admit the expert's report without calling the expert to testify. ${ }^{464}$ The Trial Chamber deemed the prosecution's response to be an 'extremely untimely' Rule 94bis(B) notice, rather than a proper Rule 73 ICTR RPE response, and refused to consider it. ${ }^{465}$ The Trial Chamber then assessed whether the prosecution's failure to file a notice pursuant to Rule 94bis constituted a tacit acceptance of the expert's qualifications and report. Because the right to cross-examine is fundamental to the fairness of the proceedings, the Trial Chamber held that 'actual acceptance' is required before the Trial Chamber may exercise its discretion pursuant to Rule 94bis(C) to admit an expert's report without cross-examination. ${ }^{466}$

\subsubsection{ICC}

In the context of the ICC, the regulation of expert testimony is less explicit compared to the ad hoc tribunals, although experts are mentioned on several occasion in the ICC Statute and RPE. ${ }^{467}$ Most clearly, Regulation 44(1) instructs the Registrar to

461 Milutinović et al. Decision on Expert Witnesses, 16 November 2006, par. 18.

462 Milutinović et al. Decision on Expert Witnesses, 16 November 2006, par. 18.

463 Milutinović et al. Decision on Expert Witnesses, 16 November 2006, par. 19.

464 ICTR, Prosecutor v. Bizimungu et al., Decision on Motion of Jérôme-Clément Bicamumpaka to Admit the Report of Expert Dr Bernard Lugan into Evidence, ICTR-99-50-T, T. Ch., 21 February 2008, par. 14. Rule 94bis ICTR RPE provides that a party must, within 14 days of receipt of an opposing party's expert's qualifications and report, file a notice stating whether it accepts that expert's qualifications and report and whether it wishes to cross-examine the expert.

465 ICTR, Prosecutor v. Bizimungu et al., Decision on Motion of Jérôme-Clément Bicamumpaka to Admit the Report of Expert Dr Bernard Lugan into Evidence, ICTR-99-50-T, T. Ch., 21 February 2008, par. 8.

466 ICTR, Prosecutor v. Bizimungu et al., Decision on Motion of Jérôme-Clément Bicamumpaka to Admit the Report of Expert Dr Bernard Lugan into Evidence, ICTR-99-50-T, T. Ch., 21 February 2008, paras. 11-16.

467 Most elaborate provision within the Statute or the Rules is Rule 113(2) states: "The Pre-Trial 
"create and maintain a list of experts accessible at all times to all organs of the Court and to all participants." ${ }^{468}$ According to Regulation 44(4) the Chambers may proprio motu instruct an expert and Regulation 55(m) states that at a Status Conference the Chamber may make an order on "the joint or separate instruction by the participants of expert witnesses."

In the Lubanga case, the Trial Chamber emphasized its preference for appointing joint experts, either jointly or separately instructed, from the list of experts the Registrar is responsible for. ${ }^{469}$ Joint instruction of experts would not only safe time and costs, but also would be of great assistance to the Court "because through the exercise of identifying with precision the real areas of disagreement between the parties, the expert will be placed in the best possible position to achieve a balanced and comprehensive analysis." ${ }^{470}$ Two considerations are particularly important. First, the expert would not be influenced by the viewpoint of one party, and second, any potential challenges on the qualifications and impartiality of the expert would be avoided by a joint instruction, thus improving smooth operation of trial proceedings. ${ }^{471}$ If the parties fail to agree on a joint instruction of a joint expert, separate instructions should be made. In case the appointment of a joint expert is out of reach, the parties should inform the Chamber, as a matter of urgency, of the reasons why an agreement could not be reached, and present the names of the separate expert witness. ${ }^{472}$

Judge Fulford, the Presiding Judge in Lubanga and Katanga and Ngudjolo cases, made an interesting suggestion to expand the role of the experts and consequently to expedite the proceedings by eliminating the need to call many individual witnesses to testify in court. He contended that it should be considered:

Whether some substantial areas of evidence (such as context, background, the general circumstances of the alleged offences and the less central, more peripheral facts) can

Chamber shall appoint one or more experts from the list of experts approved by the Registrar, or an expert approved by the Pre-Trial Chamber at the request of a party."

468 The list of qualifications required to be admitted to the list are available on the website of ICC (http:// www.icc-cpi.int/Menus/ICC/Structure+of+the+Court/Registry/Experts/). To receive instruction, an expert does not have to be on the Registrar's list of experts, as long as the admission to the list is confirmed prior to expert's testimony. In case the Registrar refuses to add the expert to the list, the Chamber would resolve the issue further. See ICC, Prosecutor v. Bemba Gombo, Decision on the Prosecution's Request for Approval of a Proposed Expert and for Extension of Time for the Submission of the Expert Report, ICC-01/05-01/08-928, 7 October 2010, T. Ch., par. 12.

469 ICC, Prosecutor v. Lubanga Dyilo, Decision on the Procedures to be adopted for Instructing Expert Witnesses, ICC-01/04-01/06-1069, 10 December 2007 [Lubanga Decision on Instructing Experts, 10 December 2007].

470 Lubanga Decision on Instructing Experts, 10 December 2007, par. 15.

471 Lubanga Decision on Instructing Experts, 10 December 2007, par. 15.

472 Lubanga Decision on Instructing Experts, 10 December 2007, par. 17. The same considerations were made in ICC, Prosecutor v. Bemba Gombo, Decision on the Procedures to be adopted for Instructing Expert Witnesses, ICC-01/05-01/08-695, T. Ch., 12 February 2010. 
be dealt with by submitting reports from court-appointed experts (rather than by a host of individual witnesses), with the parties contributing to the methodology and subject matter to be covered in the reports, and with the authors giving evidence during the trial; this would ensure that a balanced approach is taken, with the issues being investigated and reported on by someone with real expertise in the area, from a position of appropriate neutrality. ${ }^{473}$

Considering the above, the ICC approach seems to depart from the two partisan party presentation of expert evidence, a setting familiar to the ad hoc tribunals, towards a more integrated, cooperative approach to expert witnesses. Although the parties remain the right to call their own experts, the explicit preference goes towards appointing joint experts (either jointly or separately instructed). This rhetoric is particularly prompted by the concerns of trial economy and trial management. Many issues are still unresolved. For example, how the judges would approach tensions in relation to the appointment of a 'partisan' expert who has not been admitted to the Registrar's list on experts and the need to ensure the rights of the accused to call and examine witnesses in his defence.

\subsection{VICTIMS' PARTICIPATION IN THE TRIAL: FACING MULTIPLE ACCUSERS?}

An important issue that merits separate discussion is the possibility for victims to participate directly in the proceedings before the ICC and ECCC. Although an elaborate discussion of the issues arising out of victim participation would not be realistic in the framework of this chapter, some consideration cannot be avoided as this third party/participant has brought many challenges to the understanding and practice of a 'fair trial' before these institutions. ${ }^{474}$ This section takes a closer look at the role of victims during trial, and more specifically, upon the right afforded to the victims to lead and challenge evidence going to the guilt of an accused.

Both at the ICC and the ECCC, in different capacities, victims have an opportunity to participate in the proceedings affecting their personal interest. ${ }^{475}$ Although the systems differ significantly in their set-up and practice with regard to victim participation, one criticism coming from the corner of the defence has been common to both courts, namely that victims are effectively acting like a second prosecutor,

473 Fulford, 2011, p. 219: "So far the areas dealt with by expert witnesses have been somewhat limited, such as the relevant history to the area of the conflict, and the psychological and other effects of having been used as a child soldier. I believe the role of experts could be significantly expanded, thereby removing the need to call a substantial number of individual witnesses."

474 For an elaborate discussion of victim participation in international criminal proceedings, see the dissertation by McGonigle LeyH, 2011.

475 Article 68(3) ICC Statute, vitims are participants in the proceedings before the ICC. At ECCC victims are Civil Parties, Rule 23 ECCC Internal Rules. 
which not only causes severe practical problems for the defence, but touches upon the fundamental rights of the accused in a criminal trial.

At the ICC, the general legal framework for victim participation does not set out the specific modalities for participation. ${ }^{476}$ This leaves the Trial Chambers the discretionary power to adopt its own approach to participation, which may differ on a case-by-case basis depending on the specificities of a particular case. ${ }^{477}$ It had been contented, with regard to the Lubanga case, that victim participation is "a victory for victims' rights" that has nonetheless "proved to be a tortuous path marred by controversial due process issues." 478 Broad participatory rights have been afforded to victims to give them an opportunity to express their views and concerns. Thus, victims have the right to notification and to attend all public and closed hearings, ${ }^{479}$ have access to both public and confidential filings, ${ }^{480}$ are allowed to question witnesses, ${ }^{481}$ to make submissions orally and in writing on various issues ${ }^{482}$ as well as opening and closing statements, ${ }^{483}$ and introduce and challenge evidence (will be discussed hereunder).

476 Article 68(3) generally provides that "Where the personal interests of the victims are affected, the Court shall permit their views and concerns to be presented and considered at stages of the proceedings determined to be appropriate by the Court and in a manner which is not prejudicial to or inconsistent with the rights of the accused and a fair and impartial trial. Such views and concerns may be presented by the legal representatives of the victims where the Court considers it appropriate, in accordance with the Rules of Procedure and Evidence."

477 ICC, Prosecutor v. Katanga and Ngudjolo Chui, Decision on the Modalities of Victim Participation at Trial, ICC-01/04-01/07-1788-tENG, T. Ch., 22 January 2010, par. 54 [Katanga and Ngudjolo Victim Participation Trial Decision, 22 January 2010]. The Trial Chamber mentioned "for example, the nature and scope of the charges, the number of victims taking part in the proceedings and the degree of similarity between their respective interests, as well as the manner in which they are represented."

478 JOUET, 2007, pp. 259, 262.

479 But not ex parte hearings. See Katanga and Ngudjolo Victim Participation Trial Decision, 22 January 2010, par. 71; Lubanga and Bemba Trial Chambers took the same approach.

480 Katanga and Ngudjolo Victim Participation Trial Decision, 22 January 2010, par. 121; ICC, Prosecutor v. Bemba Gombo, Decision on the participation of victims in the trial and on 86 applications by victims to participate in the proceedings, ICC-01/05-01/08-807-Corr, T. Ch.,12 July 2010, par. 47 [Bemba Victim Participation Trial Decision, 12 July 2010]. In Lubanga victims can have access to confidential filings when they can show that those filings are material to their personal interests, ICC, Prosecutor v. Lubanga Dyilo, Decision on Victim Participation, ICC-01/04-01/06-1119, T. Ch. I, 18 January 2008, par. 106 [Lubanga Victim Participation Trial Decision, 18 January 2008].

481 After submitting a request in that regard. The Trial Chambers in ICC, Prosecutor v. Katanga and Ngudjolo (ICC-01/04-01/07-1665, 20 November 2009, paras. 84-89) and Prosecutor v. Bemba (ICC-01/05-01/08-807-Corr., 12 July 2010, par. 102) follows the Appeals Chamber ruling from Lubanga Dyilo, Judgment on the appeals of The Prosecutor and The Defence against Trial Chamber I's Decision on Victims' Participation of 18 January 2008, ICC-01/04-01/06-1432, A. Ch., 11 July 2008 [Lubanga Victim Participation Appeal Decision, 11 July 2008].

482 Including the admissibility or relevance of evidence. The submissions can be made following a Chamber's request or on their own initiative after requesting the Chamber.

483 Lubanga Victim Participation Trial Decision, 18 January 2008, paras. 108, 117. Victims cannot 
At the ECCC, Rule 23(1)(a) states that the purpose of civil party action before the ECCC is to participate in proceedings by supporting the prosecution. More generally, the Rules require that the proceedings before the ECCC "must be fair and adversarial and preserve a balance between the rights of the parties." The most important participatory rights that the civil parties could exercise in the first trial, Duch, were: accessing the case file, attending public and closed hearings, making oral and written submissions, leading and challenging evidence (by proposing witnesses and documentary evidence to the Court and questioning witnesses), making closing statements and seeking reparations. ${ }^{484}$ Although the legal framework of participatory rights is more elaborate than that of ICC, ECCC judges have struggled delineating the "exact parameters of participation", particularly in light of "expediency and efficiency concerns." ${ }^{485}$

\subsubsection{Lead and challenge evidence}

If a Chamber so allows, victims' representatives may question witnesses according to Rule 91(3), ${ }^{486}$ a practice that has slowly expanded to "become one of the most significant rights exercised by victims through their legal representatives." 487 Arguably, allowing victims to lead and challenge the evidence pointing to the guilt or innocence of the accused interferes with the prosecutor's sole burden of proof. ${ }^{488}$ Principally, the issue of multiple prosecutors is related to equality of arms as "[h]olding the scales even between the parties with the burden of proof cast upon the Prosecutor rules out a second accuser." $\$ 89$

In Lubanga the Trial Chamber considered, that the right to introduce evidence does not belong to parties only. ${ }^{490}$ This conclusion was drawn on the basis of Article 69(3),

make opening statements at the ECCC.

484 McGonigle Leyh, 2011, p. 193.

485 McGonigle Leyh, 2011, pp. 193-193.

486 Originally intended to be limited to elicit evidence related to reparations, see McGonigLE LEYH, 2011, p. 315 and references in footnote 555.

487 McGonigle Leyh, 2011, pp. 315-317 (on the procedure for authorising questions).

488 ICC, Prosecutor v. Lubanga Dyilo, Separate Opinion of Judge Pikis, Decision of the Appeals Chamber on the Joint Application of Victims a/0001/06 to a/0003/06 and a/0105/06 concerning the "Directions and Decision of the Appeals Chamber" of 2 February 2007, ICC-01/04-01/06-925, A. Ch., 13 June 2007, par. 16; ICC, Prosecutor v. Lubanga Dyilo, Partly Dissenting Opinion of Jugde Pikis, Judgment on the Appeals of the Prosecutor and the Defence against Trial Chamber I's Decision on Victims' Participation of 18 January 2008, ICC-01/04-01/06-1432, A. Ch., 11 July 2008, paras. 6-15. In the same case: Partly Dissenting Opinion of Judge Philip Kirsch, paras. 18-24. To tender evidence relates to wither oral or written sentence.

489 ICC, Prosecutor v. Lubanga Dyilo, Decision of the Appeals Chamber on the Joint Application of Victims a/0001/06 to a/0003/06 and a/0105/06 concerning the "Directions and Decision of the Appeals Chamber" of 2 February 2007, ICC-01/04-01/06-925, A. Ch., 13 June 2007.

490 Lubanga Victim Participation Trial Decision, 18 January 2008, par. 108. 
which gives that court discretionary power "to request the submission of all evidence that it considers necessary for the determination of the truth," ${ }^{491}$ and Rule 91(3), which authorizes the Chamber to allow legal representatives of victims to question witnesses in court. Victims, where their interests are engaged, are also allowed to challenge the relevance or admissibility of evidence. ${ }^{492}$ Thus, participating victims may tender and examine evidence to assist the Chamber in the determination of the truth and if the Chamber has "requested" this evidence. ${ }^{493}$ Both prosecution and defence argued against victims' right to lead and challenge evidence, a right that belongs to parties only and appealed the decision. The defence contended that "[a]uthorising victims to submit evidence or to express their opinion on the evidence would mean forcing the defendant to confront more than one accuser, which would violate the principle of equality of arms, one of the necessary elements of a fair trial." 494 The Appeals Chamber (majority) endorsed Trial Chamber's findings in this regard, arguing that generally precluding victims from tendering evidence relating the guilt or innocence of the accused and from challenging the relevance or admissibility of evidence in all instances would make their right to participation potentially "ineffectual." 495 Reiterating that the primary responsibility to tender and challenge evidence lies with the parties, the prosecution and defence, the Appeals Chamber considered that Trial Chamber's approach "did not create an unfettered right for victims to lead or challenge evidence, instead victims are required to demonstrate why their interests are affected by the evidence or issue, upon which the Chamber will decide, on a case-by-case basis whether or not to allow such participation." 496

491 Determination of the truth is expressed as a power rather than an obligation of the judges, which was proposed by the German delegation (German Preparatory Committee Proposal, 1996, at 208). Although the reference to the duty of the Court was dropped in the final text, the Preparatory Committee made an annotation explaining the independent role of the Court in the "evaluation of the necessary depth of investigation and determination of the facts' by underlining the 'truth-finding mission of the Court." See Decisions taken by the Preparatory Committee at its Session held from 1 to 12 December 1997 (A/AC.249/1997/L.9/Rev.1), Article 44, note 57.

492 Lubanga Victim Participation Trial Decision, 18 January 2008, par. 109.

493 Lubanga Victim Participation Trial Decision, 18 January 2008, par. 108.

494 ICC, Prosecutor v. Lubanga Dyilo, Defence Appeal against Trial Chamber I's 18 January 2008 Decision on Victims' Participation, ICC-01/04-01/06-1220-tENG, 10 March 2008, par. 48 [Lubanga Defence Appeal against Victim Participation Trial Decision, 10 March 2008].

495 Lubanga Victim Participation Appeal Decision, 11 July 2008, par. 97. Considering that "Evidence to be tendered at trial which does not pertain to the guilt or innocence of the accused would most likely be considered inadmissible and irrelevant." Judge Pikis dissented on this issue contending that victims cannot tender evidence on the guilt or innocence of the accused or challenge the admissibility of evidence. The prosecutor has the exclusive responsibility to "proof or disproof of the charges," and it is "not vicitm's domain either to reinforce the prosecution or dispute the defence." Victims can only express their views and concerns to the extent the personal interests of the victims are affected by the proceedings.

496 Lubanga Victim Participation Appeal Decision, 11 July 2008, paras. 93, 99. 
This 'case-by-case' approach has varied considerably between the Chambers. ${ }^{497}$ The Lubanga and Bemba approached victim participation from a broad perspective, continuously linking it to the truth-finding role of the court. Thus, legal representatives were allowed to ask questions going beyond the charges against the accused for the purpose of establishing the guilt of the accused, almost on the same footing as the prosecution. ${ }^{498}$ In contrast, in Katanga and Ngudjolo the Trial Chamber considered that "the only legitimate interest the victims may invoke when seeking to establish the facts which are the subject of the proceedings is that of contributing to the determination of the truth by helping the Chamber to establish what exactly happened." ${ }^{499}$ Thus, this Chamber kept the scope of victim participation in relation to tendering and changing evidence reasonably limited; the legal representatives were not there to support Prosecutions case. However, the practice of broadly approaching victims" "views and concerns," 500 including tendering and challenging evidence that points towards the guilt or innocence of the accused, has generated a lot of resistance and many challenges both from a principled and practical perspective.

In another attempt to limit legal representative's involvement in questioning witnesses at trial, the Lubanga defence submitted that the conditions under which victims are allowed to question prosecution witnesses should not be the same in the case of defence witnesses. ${ }^{501}$ The latter witnesses "would otherwise face successive examinations carried out by multiple accusers thereby undermining the fair balance of the proceedings." ${ }^{502}$ Moreover, the defence argued for a restrictive interpretation of 'personal interests' that need to be shown if a victim is to question a defence witness, because a broad interpretation "could seriously affect the fairness of the trial." ${ }^{03}$ Thus, to avoid "an imbalance between the prosecution and the defence, in this context, the notion of 'personal interests' should be restricted to those who are personally, indeed

497 For an elaborate discussion see McGonigle LeyH, 2011, pp. 298-300.

498 McGonigle LeyH, 2011, pp. 298-299.

499 Katanga and Ngudjolo Victim Participation Trial Decision, 22 January 2010, par. 60.

500 Katanga and Ngudjolo Victim Participation Trial Decision, 22 January 2010, par. 59: "The Chamber is mindful of the fact that there may be many such interests. In light of the information contained in the applications for participation which have been submitted in this case, it notes that the victims are seeking not only to obtain reparations, but that they also mention other grounds, such as seeking determination of the truth concerning the events they experienced, or wishing to see the perpetrators of the crimes they suffered being brought to justice."

501 ICC, Prosecutor v. Lubanga Dyilo, Decision on the Defence Observations Regarding the Right of the Legal Representatives of Victims to question defence witnesses and on the notion of personal interest and Decision on the Defence Application to exclude certain representatives of victims from the Chamber during the non-public evidence of various defence witnesses, ICC-01/04-01/06-2340, T. Ch., 11 March 2010 [Lubanga Decision on the Questioning of Defence Witnesses by Victims, 11 March 2010].

502 Lubanga Decision on the Questioning of Defence Witnesses by Victims, 11 March 2010, par. 7.

503 Lubanga Decision on the Questioning of Defence Witnesses by Victims, 11 March 2010, par. 8. 
specifically, affected by the evidence." ${ }^{504}$ In reply, the legal representatives suggested "that the interests of victims are distinct from those of the prosecution, and that, in the main, participating victims have raised matters that have not been addressed by the prosecution." ${ }^{505}$ The Trial Chamber rejected the defence's proposition and argued that

[...] the proper safeguard for the defence lies not in attempting to apply varying standards or definitions to the concept of the victims' personal interests based on the party or participant calling a particular witness, but instead in ensuring that the manner and the timing of the questioning is not prejudicial to, or inconsistent with, the rights of the accused and a fair and impartial trial. This is a quintessentially factbased issue, which cannot be determined in advance, absent a detailed examination of the proposed manner of questioning of all the participating victims who have applied to examine the witness in question. The Chamber must take a global view for each witness, to ensure that the overall effect of the questioning by victims does not undermine the rights of the accused and his fair and impartial trial. ${ }^{506}$

In addition, during trial, victims have already been granted opportunities to examine several witnesses, following approval by the Chamber to that extent, and the "Chamber has consistently confined their questions to the particular issues and evidence which engage their personal interests." 507 With regard to the issue of anonymity, the Chamber considered that if an anonymous victim wishes to question defence witnesses "it is likely that the Chamber will require anonymity to be lifted as regards the defence." 508 With regard to the mode of questioning, there is a "presumption in favour of a neutral approach to questioning on behalf of victims" and they "are less likely than the parties to need to resort to the more combative techniques of 'cross-examination."' 509

504 Lubanga Decision on the Questioning of Defence Witnesses by Victims, 11 March 2010, par. 11.

505 Lubanga Decision on the Questioning of Defence Witnesses by Victims, 11 March 2010, par. 22.

506 Lubanga Decision on the Questioning of Defence Witnesses by Victims, 11 March 2010, par. 35.

507 Lubanga Decision on the Questioning of Defence Witnesses by Victims, 11 March 2010, par. 33.

508 Lubanga Decision on the Questioning of Defence Witnesses by Victims, 11 March 2010, par. 36. The Chamber referred to a previous ruling: "However, the Trial Chamber is of the view that extreme care must be exercised before permitting the participation of anonymous victims, particularly in relation to the rights of the accused. While the safety and security of victims is a central responsibility of the Court, their participation in the proceedings cannot be allowed to undermine the fundamental guarantee of a fair trial. The greater the extent and the significance of the proposed participation, the more likely it will be that the Chamber will require the victim to identify himself or herself. Accordingly, when resolving a request for anonymity by a victim who has applied to participate, the Chamber will scrutinise carefully the precise circumstances and the potential prejudice to the parties and other participants. Given the Chamber will always know the victim's true identity, it will be well placed to assess the extent and the impact of the prejudice whenever this arises, and to determine whether steps that fall short of revealing the victim's identity can sufficiently mitigate the prejudice."

509 ICC, Prosecutor v. Lubanga Dyilo, Decision on the Manner of Questioning Witnesses by the Legal Representatives of Victims, ICC-01/04-01/06-2127, T. Ch. I, 16 September 2009, par. 28. See also Katanga and Ngudjolo Chui Proceedings Directions, 1 December 2009, paras. 82-91. 
In Katanga and Ngudjolo, the defence stated its objection in respect of the questioning of the witnesses by the victim representatives on several occasions. The objections particularly concerned the scope of the questioning. So as not to behave as 'substitute or ancillary prosecutors,' victims should not pose questions going towards establishing the guilt of the accused or touching upon broader issues than those considered during the examination-in-chief. Often, objections have been raised out of principle: the defence has not objected to the question itself, but to the fact that a victim representative was posing that question. ${ }^{510}$ The Katanga and Ngudjolo Trial Chamber, as well as other Chambers, have shown flexibility in allowing legal representatives to ask questions different to the ones submitted beforehand when victims applied for leave to question witnesses. Moreover, questions going beyond the issues arisen on examination-in-chief were occasionally allowed, "so long as the questions are not duplicative or repetitive and are limited to matters in controversy between the parties or are directly relevant to the interests of victims represented." ${ }^{511}$

Generally, although at times helpful to the judges and sometimes contravening prosecutions' strategy, the defence had been most "disadvantaged by an overly active victims' bench." ${ }^{512}$ Legal representatives questioning has been leading, repetitive, touching upon broader issues that arguably fall within the realm of prosecutions' responsibility and going towards establishing the guilt of the accused. The extent of this practice, however, has varied among the different Trial Chambers. ${ }^{513}$

At ECCC, the possibility of civil parties to question witnesses "made a significant impact on proceedings." 514 In Duch, the Trial Chamber decided that civil parties could pose questions 'in support of the prosecution,' as long as those are not repetitious, 'long-winded' or outside the topic. ${ }^{515}$ This decision followed the defence's objection to the scope of questioning by civil party lawyers. ${ }^{516}$ The defence "urged [the civil parties] to concentrate on what is of direct relevance to the victims and not to merely act as a second prosecutor." ${ }^{17}$ However, this initially broad approach to victims' role as supporters of the prosecution was soon restricted. In a later decision, the civil

510 Katanga and Ngudjolo, Transcript of 30 November 2009, p. 32.

511 McGonigle Leyh, 2011, pp. 317-318, footnote 573 references.

512 McGonigle Leyh, 2011, p. 319.

513 McGonigle Leyh, 2011, pp. 319-320.

514 McGonigle Leyh, 2011, p. 208.

515 ECCC, Prosecutor v. Kaing Guek Eav, Transcript of Trial Proceedings, Day 31, 001/18-07-2007ECCC/TC, T. Ch., 22 June 2009, p. 98.

516 ECCC, Prosecutor v. Kaing Guek Eav, Transcript of Trial Proceedings, Day 31, 001/18-07-2007ECCC/TC, T. Ch., 22 June 2009, pp. 91-92, 94-96.

517 ECCC, Prosecutor v. Kaing Guek Eav, Transcript of Trial Proceedings, Day 31, 001/18-07-2007ECCC/TC, T. Ch., 22 June 2009, p. 92. 
parties were prevented from posing questions to the accused or the expert witnesses on issues related to the accused's character and related to sentencing. ${ }^{518}$

The practice generally shows that civil parties' questioning was often irrelevant, repetitive and "off topic", forcing the judges to impose very strict time limits in the name of expediency (and the right of the accused to an expeditious trial). ${ }^{519}$ Extension of time limit to question witnesses were often denied or granted only after long debates. ${ }^{520}$ As mentioned, this approach potentially has an adverse effect on truthfinding, as the judges would not hear possibly relevant information. Moreover, the imposed time-limits were a constant source of objection by the defence; the time allotted to both the prosecution and civil parties would always exceed the time allotted to defence (though not by doubling it), thus potentially violating 'equality of arms'. ${ }^{521}$ Because the defence rarely exceeding the allotted time and did not request for extensions, this objection seem more of a principled than practical nature. McGoningle Leyh, however, considers this practice of giving the defence less time than prosecution and civil parties combined, "potentially dangerous" not least in light of the perception of fairness. ${ }^{522}$ Notwithstanding, the above discussion clearly illustrates that the judges of international criminal courts explicitly rejected this mathematical approach; the guiding principle should rather be whether the defence has had enough time to present its case. In addition, the interests of civil parties with regard to reparations exceed those of the prosecutions, which might count for some extra time for the purposes of prosecution-civil parties side.

\subsubsection{Victims' applications and testimony}

Another challenging issues relate to the combination of victim participation and leading evidence: when a victim participant intends to testify at trial. This dual status (victim-witness) is problematic because (1) the extended access to materials on the case record (including confidential issues) could potentially constitute a source of modification of victim's intended testimony; and (2) there is at least a perception of partiality on the side of a victim-witness (whose financial an other goals may conflict). ${ }^{523}$

The evidentiary nature of victims' applications is that they do not officially constitute evidence. ${ }^{524}$ However, both Lubanga and Katanga and Ngudjolo Trial

518 ECCC, Prosecutor v. Kaing Guek Eav, Transcript of Trial Proceedings, Day 66, 001/18-07-2007ECCC/TC, T. Ch., 27 August 2009, p. 74. The Chamber made this decision proprio motu.

519 McGonigle Leyh, 2011, pp. 208-209. See also section 7.3.2.3 above.

520 McGonigle Leyh, 2011, p. 210.

521 E.g. ECCC, Prosecutor v. Kaing Guek Eav, Transcript of Trial Proceedings, 001/18-07-2007-ECCC/ TC, T. Ch., 16 June 2009, p. 11.

522 McGonigle Leyh, 2011, p. 211.

523 McGonigle Leyh, 2011, p. 312.

524 ICC, Prosecutor v. Katanga and Ngudjolo Chui, Decision on the Confirmation of Charges, ICC- 
Chambers considered that excluding "highly relevant and probative" testimony of a victim participant would be contrary to Chamber's obligation to determine the truth. ${ }^{525}$ For participating victims to provide evidence in person is to testify in court under oath. ${ }^{526}$ Although mindful that domestic legal system, when allowing a dual status of victim-witness do not allow for testifying under oath, the Trial Chamber considered that "the fact that a victim gives evidence under oath - which in itself gives him or her the status of a witness - allows the Defence to cross-examine him or her, which acts as a safeguard and makes the said victim liable to prosecution under Article 70(1)(a) of the Statute if he or she gives false testimony." ${ }^{27}$ This my generally be allowed only if the victim's testimony "can make a genuine contribution to the ascertainment of the truth;" thus, the legal representatives must clearly indicate in what way the testimony is relevant and will help the judges to better understand the facts. ${ }^{528}$ The dual status of victim-witness does not provide for more rights than granted to either a witness or a victim participant. The possibility to testify in person is subject to three limitations, namely (1) victim participation may not infringe on the right of the accused to be tried without undue delay; (2) the testifying victims do not effectively become auxiliary prosecutors; and (3) anonymous testimony vis-à-vis the defence is not allowed. ${ }^{529}$ In addition, "the Chamber must ensure that the Defence has adequate time to prepare, which implies that the participation by a victim may not be the cause of unfair surprise for the Defence, to which it is not able to respond adequately." ${ }^{330}$

As criteria for evaluating applications to give testimony by victims, the Chamber considered, inter alia, whether (1) the proposed testimony would be unnecessary repetitive in light of prosecutions submissions or the evidence already tendered by the parties; (2) the proposed topic of the testimony are "sufficiently closely related" to the issues under consideration of the Chamber; (3) the testimony "is typical of a larger group of participating victims" or comes from a victim who "is uniquely apt to give evidence about a particular matter;" and (4) the testimony would provide "substantial new information" relevant for the determination of the charges. ${ }^{531}$

01/04-01/07-717, PTC II, 30 September 2008, paras. 229-232; ICC, Prosecutor v. Lubanga Dyilo, Decision on the defence application for dislosure of victims' applications, ICC-01/04-01/06, T. Ch. I, 21 January 2009.

525 Katanga and Ngudjolo Victim Participation Trial Decision, 22 January 2010, par. 88.

526 ICC, Prosecutor v. Lubanga Dyilo, Order issuing public redacted version of the "Decision on the request by victims a/ 0225/06, a/0229/06 and a/0270/07 to express their views and concerns in person and to present evidence during the trial", ICC-01/04-01/06-2032, T. Ch., 9 July 2009, Annex, par. 25; Katanga and Ngudjolo Victim Participation Trial Decision, 22 January 2010, par. 86.

527 Katanga and Ngudjolo Victim Participation Trial Decision, 22 January 2010, par. 88.

528 Katanga and Ngudjolo Chui Proceedings Directions, 1 December 2009, par. 20.

529 Katanga and Ngudjolo Chui Proceedings Directions, 1 December 2009, par. 22.

530 Katanga and Ngudjolo Chui Proceedings Directions, 1 December 2009, par. 23.

531 Katanga and Ngudjolo Chui Proceedings Directions, 1 December 2009, par. 30. 
In principle, victims should be questioned in "a neutral fashion", although the Chamber may allow cross-examination by the prosecution or the defence, on a caseby-case basis. ${ }^{532}$ The same neutrality is expected in respect of questioning witnesses called by the Chamber proprio motu, unless the Chamber determines otherwise. ${ }^{533}$ The legal representatives can call only the victims whom they represent, but they could draw Chamber's attention to other material witnesses. ${ }^{534}$

At ECCC, civil parties who wanted to testify in Court could not do so under oath. Whereas generally this kind of testimony is to be afforded less weight than sworn testimony, the Duch Trial Chamber judgment did not contain any indication for that to be the case..$^{535}$ In light of the fact that civil parties have the right to attend all the hearings, public and closed, adjusting of the testimony to fit the case, intentionally and unintentionally, can be seen as potentially great concern. ${ }^{536}$ The practice shows that civil party testimony often "strayed from the relevant facts," and exceeding the time allotted, but importantly added many emotions to the legal process because the civil parties "sought, through the judicial process, broad notions of truth and justice [...] desperately [wanting] answers to help explain how and why their loved ones were killed." 537

\subsection{CONCLUding REMARKS}

This chapter purported to trace the interpretation and to evaluate the application of equality of arms at the stage of case presentation before the international criminal courts. Arguably, at this stage the parties assume their most adversary roles and can be regarded as most 'equal' as compared to the pre-trial stage of proceedings. Achieving this full equality between the parties was stated to be the purpose of the protection offered by the right to call and examine witnesses under the same conditions. This right is considered to be the most explicit manifestation of this further implicit constitutive concept of the fair trial.

Thus, a general point of departure has been the objection to sustain full equality between parties in their case presentation. To accommodate this, particularly from the perspective of the prosecution, the right to a fair trial generally, and the minimum rights particularly, were interpreted to apply to both the defence and the prosecution. Although recognizing the fundamental protections afforded to an accused in a criminal trial, the Appeals Chamber in the Aleksovski case considered that it would

532 Katanga and Ngudjolo Chui Proceedings Directions, 1 December 2009, par. 32.

533 Katanga and Ngudjolo Chui Proceedings Directions, 1 December 2009, par. 44.

534 Katanga and Ngudjolo Chui Proceedings Directions, 1 December 2009, par. 45 [footnote omitted].

535 McGonigle Leyh, 2011, p. 206.

536 McGonigle LeyH, 2011, p. 206.

537 McGonigle Leyh, 2011, p. 216. 
be difficult to conceive of how a trial could be fair when the defence is favoured at the expense of the prosecution, of course beyond a strict compliance with the fundamental protections accorded to the accused. Other Chambers have considered in their decisions the 'right of the prosecution to have adequate time to present its case' and balanced it against a right of the defence. Against this background, the nature of the 'fundamental protections' afforded to the accused has been more qualified to allow a balancing with the 'rights' of the prosecution to the extent that any residual disadvantage to the accused resulting from a particular application of the rules has been found to be counterbalanced by the potentially greater disadvantage suffered by the prosecution if another application would be adopted.

Considering the interpretation of the principle of equality of arms the Chambers strongly opposed a mathematical approach, but were rather guided by the two-pronged test developed in the Orić case: when allocating time and witnesses to the defence, the Chamber should take into account (1) the principle of reasonable proportionality resulting from equality of arms, and (2) objective adequacy to effectively present one's case. This two-step approach implicates that whenever the first element is not complied with, the second implicitly fails. There are no decisions that consider explicitly a situation where the first element was complied with, but not the second. There are, however, instances (like the Prlić case) where the court decided to grant the defence slightly more time for their case presentation than accorded to the prosecution.

However, the Chambers generally followed a rather arithmetical approach for delineating the time for case presentation. For obvious reasons, the element of basic proportionality did not serve as such when allocating time and witnesses to the prosecution. In this respect, the judges explicated that the key to limiting the defence's case is the limitation of the prosecution case, through the operation of equality of arms. This principle thus implicitly delineates the prosecution case, when the judges consider the need to afford approximately equal time to the defence as afforded to the prosecution. Moreover, the application of the second element, objective adequacy, has been extended to apply to delineating the prosecution case, notwithstanding the fact that this second element has been explicitly based on the 'rights of the accused'. Thus, when evaluating the time and the number of witnesses to be provided to the prosecution, the chambers have been taking into account the element of objective adequacy.

With regard to witness examination, cross-examination, and the admissibility of evidence, the relevant provisions have been applied broadly and flexibly, taking into account the specific characteristics of the court's functioning. The primary 'adversarial' set-up of proceedings was supplemented with judges extending control of parties' presentation of evidence. While terminology such as 'ensuring fair trial' and 'in accordance with the rights of the defence' has been prominently present in every relevant discussion, an in-depth consideration of the fundamental questions 
with regard to the rights of the accused has often been absent/inadequate. In this sense, the Chambers have barely considered the right to be informed of the charges against one, the right to examine witnesses and, more generally, the right to present evidence in one's defence, except for an occasional mentioning of the terms. Even less consideration has been given to principled matters such as what is the basis for the prosecutor's right to a fair trial and several other guarantees, formally accorded to the defence. When managing the trial process, the judges particularly focused on a rather formal procedural 'equality' between parties to the extent that in this setting the principle of equality of arms is considered vindicated as soon as the defence has been afforded exactly the same numerical value or a procedural opportunity as the prosecution. Thus, is remains unclear whether the application of equality of arms to the prosecution precludes a more than strict application of the fundamental protections afforded to the accused, in case the inequality is justified on the basis of the difference in the respective roles of the parties.

Lastly, the novelty of victim participation in the proceedings has presented many principled and practical challenges to all participants in the proceedings. From the perspective of equality of arms, the biggest challenge is how to reconcile victim participatory rights, specifically the right to lead and challenge inculpatory and exculpatory evidence, with the right of the defence not to be confronted with multiple accusers. The insufficiencies of the legal framework have been complemented with a rather broad and flexible approach to the practice of victim participation. Whereas in principle victim participation in itself does not pose an obstacle to a meaningful 'equality of arms' between parties, in practical terms the judges have to be particularly vigilant of the different rights and interest accorded to parties in a criminal setting and capable of separating "the relevant from the irrelevant." 538

538 ICC, Prosecutor v. Lubanga Dyilo, Trial Transcript of 7 January 2010, ICC-01/04-01/06-T-223, p. 39. The Presiding Judge Fulford stated, in the context of questioning a witness by a legal representative, that "In due course the Chamber will very carefully separate out what is relevant from what is irrelevant and, rather than interrupting counsel in every question, unless you have strenuous objections, I think it would be better to let this run. But I undertake and reassure you that we will separate, as I say, the relevant from the irrelevant." 


\section{Chapter 8 Conclusions}

\subsection{InTRODUCTION}

The opening of the trial of the former Liberian president, Charles Taylor, at the SCSL reached a dramatic level when the accused refused to be present and his lawyer walked out of the courtroom after reading out Taylor's letter sent to the court. In the letter, the accused explained that the circumstances under which his defence has been conducted violated equality of arms. Specifically, the letter emphasized that the inadequacy of resources and facilities he was facing denied him any possibility of receiving a fair trial. Where the prosecution constituted a team fully composed of nine lawyers, the defence was provided with only one. The defence lacked any office facilities that initially forced counsel to operate from a cafeteria. Moreover, the lack of manpower prevented the defence from going through the many disclosed materials in a timely manner so as to properly prepare for trial. Taylor dismissed his lawyer and opted to conduct his own defence. When the judges decided to continue the trial without the accused being present, his lawyer felt he had no other choice than to leave the courtroom. Subsequently, the judges instructed the Registrar to facilitate a meeting of the Principal Defender with Charles Taylor to sort out his defence problems and to provide all the necessary (logistical) facilities to the accused. In this context, the presiding Judge Sebutinde stated: "And, really, if we are to pretend that this trial is going to be fair, as indeed we hope it will be fair, then there's got to be some kind of equality of arms." ${ }^{\prime \prime}$ This incident in not unique in international criminal

1 Statement by the Presiding Judge Sebutinde, SCSL, Prosecutor v. Taylor, SCSL-03-01, Transcript of 4 June 2007, p. 252: "One of the facilities that he lacks, or his lawyer lacks, is an office from which to operate. This has been, time and again, brought to the attention of the Chamber and we believe this, again, falls in the province of the Principal Defender under the Registrar. And, really, there is no need for the Trial Chamber to tell the Registrar how to do his job. It's the bottom line. The article is very clear: The accused is entitled to adequate time and facilities to prepare his case. That's the bottom line. That his lawyer would stand up today and tell us that he's operating from the cafeteria is most unfortunate. Today hes still operating from the cafeteria. I don't know if that is true or not, but it doesn't sound good to our ears. And, really, if we are to pretend that this trial is going to be fair, as indeed we hope it will be fair, then there's got to be some kind of equality of arms. Therefore, I'm going to make certain directions, after hearing from Mr. Jalloh, I want to make some specific directions to the Registrar before we rise."; p. 340: "The Registrar is directed to immediately facilitate the Principal Defender to travel to The Hague for the purpose of speaking with Mr Taylor and sorting out his defence problems. The Registrar is further directed to ensure that logistically the accused has adequate facilities, in accordance with Article 17 of the Statute, without further delay." 
proceedings and this judge's statement, to some extent, is telling concerning the uncertainty it conveys in respect of the interpretation and application of the principle of equality of arms and the notion of fairness in international criminal proceedings. Notwithstanding the challenges, this statement clearly expresses international judges' dedication to the fulfilment of both principles.

This concluding chapter seeks to summarize and synthesize the findings with regard to the way the principle of equality of arms has been conceived of in the decisions of international criminal courts. Furthermore, it seeks to develop normative reasoning as to the effect of the application of this principle on fairness in international criminal proceedings. The central question of this study as presented in the introduction was formulated as follows. How should the principle of equality of arms be interpreted and applied in international criminal proceedings? A concise answer is the following: Taking into account the inherent asymmetrical position of the defence and prosecution and the particularities of the international criminal process, the principle of equality of arms should be interpreted as an instrument for the equalization of the defence, and applied in the specific circumstances of a case appropriately tailored to the specific procedural position of the subject.

Below, this answer will be explained in more detail, generally following the structure as provided by the three sub-questions that underlie the central question:

1. What meaning is given to the principle of equality of arms in international human rights law?

2. How is the principle of equality of arms interpreted and applied in international criminal proceedings?

3. Do the particularities of the international criminal context require a different interpretation and application of the principle of equality of arms as developed in international human rights law?

\subsection{Human RightS APPROACH}

International human rights conventions, such as the ICCPR and ECHR, provide for minimum human rights standards to be implemented by states. To the extent that these standards are representative of general norms of international law, they bind international criminal justice institutions. In addition, the international human rights monitoring bodies, the HRC and ECtHR, when interpreting and applying those minimum standards, provide authoritative guidance as to the implementation of these standards generally, and with regard to the interpretation and application of equality of arms specifically. In fact, the human rights jurisprudence is indicative of the bottom line when it comes to the implementation of human rights standards.

The ECtHR has interpreted equality of arms in a criminal process as a party's right to "a reasonable opportunity to present his case under conditions that do not place 
him at a disadvantage vis-à-vis his opponent." ${ }^{.2}$ While, objectively, a party is entitled to have a reasonable opportunity to present its case, subjectively this should be done under conditions that are not disadvantageous as compared to the other party. But for parties in such a different position as in a criminal process, what does this mean? Should the opportunities be equal? If not, how then is the 'disadvantage' measured?

In the case law of the ECtHR, this reasonable opportunity to present one's case, qualified by the intention to influence the decision maker and, thus, necessitating knowledge of the adversary's submissions, has been conceptualized in the right to an adversarial trial. The principle of equality of arms and the right to an adversarial process come hand-in-hand in a criminal process and are thus particularly difficult to separate. Their role is mutually supportive and, in many specific situations, overlapping. Where a conceptual difference can be uncovered, it seems to lie in the relative nature of equality: when both parties are denied something (presenting submissions, evidence, or attending a hearing), there can be no violation of equality of arms. ${ }^{3}$ The comparative element of equality of arms implies that no disadvantage in relation to the other party is allowed. A contrario, an equal disadvantage to both parties formally preserves equality of arms. ${ }^{4}$ However, as equality of arms is only one feature of the wider concept of a fair trial, "even in the absence of a prosecuting party, a trial would not be fair if it took place in such conditions as to put the accused unfairly at a disadvantage." ${ }^{\prime}$ And such conditions are created when the accused has not been given an opportunity to comment on incriminating observations before the decision maker. This disadvantage does not thus violate equality of arms formally, but the right to a fair trial more generally by putting the accused unfairly at a disadvantage when presenting his case.

More generally, the right to a fair trial "guarantees the right of an accused to participate effectively in a criminal trial," including the principles of equality of arms and an adversarial trial. ${ }^{6}$ Although these principles are considered to be applicable not only in the trial phase proper but also in the pre-trial phase, the use of equality of arms at the pre-trial stage has been somewhat limited. One might even say that the ECtHR has been "less than unequivocal about the importance of defence rights in the

2 E.g. ECtHR, Bulut v. Austria, App. No. 17358/90, Judgment of 22 February 1996, par. 47.

3 ECtHR, Jasper v. United Kingdom, App. No. 27052/95 Judgment of 16 February 2000, par. 57. See also the case law references in TreChSEL, 2005, pp. 97-98, and footnote 110.

4 ECtHR, Monnell and Morris v. United Kingdom, App. No. 9562/81 and 9818/82, Judgment of 2 March 1987, par. 62: "To begin with, the principle of equality of arms, inherent in the notion of fairness under Article $6 \S 1$ (art. 6-1) (see the above-mentioned Delcourt judgment, Series A no. 11, p. $15, \S 28)$, was respected in that the prosecution, like the two accused, was not represented before either the single judge or the full Court of Appeal."

5 ECtHR, Monnell and Morris v. United Kingdom, App. No. 9562/81 and 9818/82, Judgment of 2 March 1987, par. 62, referring to ECtHR, Delcourt v. Belgium, App. No. 2689/65, Judgment of 17 January 1970, paras. 28, 34.

6 See e.g. ECtHR, Sevastyanov v. Russia, App. No. 37024/02, Judgment of 22 April 2010, par. 70. 
pre-trial phase of proceedings." ${ }^{\prime 7}$ The ECtHR's approach has been casuistic, without a clear-cut general statement on the extended application of Article 6 to the pre-trial proceedings, but also without limiting its application to the trial stage proper. The Court considered that "[o]ther requirements of Article $6 \ldots$ - especially of paragraph 3 (art. 6-3) - may also be relevant before a case is sent for trial of and in so far as the fairness of the trial is likely to be seriously prejudiced by an initial failure to comply with them ...." " However, the case law is still developing. What is important from an analytical point of view is the ECtHR's approach to the procedure 'as a whole.' This means, on the one hand, that the process includes all stages, from the criminal charge to the final judgment. Any procedural defect in the pre-trial stage, which can potentially jeopardize the fairness of proceedings, can and must be compensated so as not to make the process unfair. Moreover, this approach makes explicit the Court's evaluation method: it does not judge by one particular test or one particular incident. In fact, it seems that as long as there is compensation for any pre-trial rights violations, a procedure can still be labelled fair at the end of the day. ${ }^{10}$ This approach also means that the fulfilment of the minimum defence rights (Article 6-3) does not depend on the trial stage and these rights can be partially or fully vindicated at the pre-trial stage proper. ${ }^{11}$

The abovementioned meaning of equality of arms has been developed in a trial setting where an institutional inequality of arms emerged. ${ }^{12}$ Moreover, the ECtHR has based equality of arms not only on the general principle of fair trial, but also on the specific rights afforded to the accused. ${ }^{13}$ In fact, equality of arms is most clearly

7 JACKSON, 2009-c, p. 856.

8 ECtHR, Imbrioscia v. Switzerland, App. No. 13972/88, Judgment of 24 November 1993, par. 36.

9 Or "proceedings in their entirety." E.g. ECtHR, Kostovski v. The Netherlands, App. No. 11454/85, par. 39.

10 See e.g. ECtHR, Gäfgen v. Germany, App. No. 22978/05, Judgment of 1 June 2010 (Grand Chamber), par. 166.

11 E.g. the right to examine witnesses can be limited at trial phases if and when the defence has had an opportunity to question or have questioned certain witnesses at the pre-trial stage.

12 See generally WAsEKK-WIADEREK, 2000.

13 A one-time consideration in this regard is instructive (but unfortunately has not been referred to as such in subsequent case law, see Jespers v. Belgium, App. No. 8403/78, Commission's report of 14 December 1981, par. 55: “As regards the interpretation of the term 'facilities', the Commission notes firstly that in any criminal proceedings brought by a state authority, the prosecution has at its disposal, to back the accusation, facilities deriving from its powers of investigation supported by judicial and police machinery with considerable technical resources and means of coercion. It is, in order to establish equality, as far as possible, between the prosecution and the defence that national legislation in most countries entrusts the preliminary investigation to a member of the judiciary or, if it entrusts the investigation to the Public Prosecutor's Department, instructs the latter to gather evidence in favour of the accused as well as evidence against him. It is also, and above all, to establish that same equality that the 'rights of the defence', of which Art. 6(3) of the Convention gives a non-exhaustive list, have been instituted. The Commission has already had occasion to point out that the so-called 'equality of arms' principle could be based not only on Art. 6(1) but also on 
expressed in the formulation of the right of an accused to examine witnesses against him and to obtain the attendance and examination of witnesses on his behalf under the same conditions as witnesses against him. In addition, the right to adequate time and facilities (the basis for disclosure obligations) embodies the understanding of 'equalizing' the positions between the prosecution and the defence. ${ }^{14}$

With regard to the meaning of equality of arms, the HRC has taken a slightly different approach and has defined the principle as meaning "that the same procedural rights are to be provided to all the parties unless distinctions are based on law and can be justified on objective and reasonable grounds, not entailing actual disadvantage or other unfairness to the defendant." 15 This seems like a more clear-cut definition containing all the relevant elements: (1) in principle the parties should have the same procedural rights; however, (2) if justified, rights can be dissimilar; but not if (3) this dissimilarity would actually be unfair towards the accused. The emphasis on the 'same procedural rights' provides a formal understanding of equality, which is in line with the approach taken by the ECtHR. Considering the pre-trial phase, where the roles and rights of the parties differ considerably, it can be argued that this difference can be justified objectively and specifically on the basis of the different roles, powers and obligations. However, in this setting, the court would be required to consider whether the difference (for example, in material means) would lead to an actual disadvantage for the accused (not being able to prepare his case), which would endanger equality of arms. Stated this way, the court is required to 'compare the incomparable', which in practice is rather burdensome. Thus, the approach has been more objective, considering whether the accused has had a sufficient opportunity to present his case. Although the definitions provided by the ECtHR and HRC differ at face value, the net result of their interpretation and application is comparable: any procedural inequality will only be considered as violating the principle of equality of arms if there is actual prejudice towards the accused arising from the procedural inequality.

The limitations of the application of fair trial standards and equality of arms in the pre-trial stages of the proceedings, and specifically the subjective (comparative) element inherent in the meaning of equality of arms, has caused the necessary conceptual uncertainty in relation to equality of arms and its application in international criminal proceedings. Of particular importance for the international criminal procedural framework is the consideration of equality of arms in relation to material resources. The defence has time and again considered the insufficiency of (material) resources as constituting a clear instance of (institutionalized) inequality of

Art. 6(3), especially sub para. (b)" (referring to Ofner and Hopfinger v. Austria, App. Nos. 524/59 and 617/59, report of 23 November 1962, par. 46 and to Pataki and Dunshirn v. Austria, App. Nos. 591/59 and 789/60, report of 28 March 1963, par. 36).

14 See also HRC, e.g. Paul Perterer v. Austria, Comm. No. 1015/2001, Views of 20 July 2004, par. 10.6.

15 E.g. HRC, Dudko v. Australia, Comm. No. 1347/2005, Views of 23 July 2007. 
arms. The inadequacy of time and facilities, including disclosure practice, is another example of the much-voiced dissatisfaction with equality of arms in the international criminal setting.

\subsection{INTERNATIONAL CRIMINAL COURTS' INTERPRETATION OF EQUALITY OF ARMS}

Comparable to the international human rights instruments, the legal frameworks of the international criminal courts do not contain an explicit reference to equality of arms. However, the statutes of these courts do provide for similar legal protections for an accused, including the rights to examine or to obtain the attendance of witnesses under the same conditions as witnesses against him. All tribunals have unequivocally incorporated equality of arms as an essential prerequisite for a fair trial. International criminal courts have adopted the definition of the ECtHR and approached equality of arms as an obligation placed on the courts to ensure that a party has a reasonable opportunity to present its case under conditions which are no less advantageous than those of the opponent. However, two elements in particular have caused considerable confusion and uncertainty with regard to the proper interpretation and application of the principle of equality of arms: (1) the scope of the principle and (2) the interpretation of the principle as applying to both the prosecutor and the defence.

\section{Pre-trial and trial context}

From the outset, it is important to emphasize that international criminal courts have not made a principled distinction between the applicability of fair trial standards divided into the pre-trial and trial context. ${ }^{16}$ However, at face value the interpretation and application of the principle of equality of arms at the pre-trial or trial stages have been somewhat confusing. In the name of clarity, this division, but only for formally structural reasons, will be presented here.

With regard to two important elements in the pre-trial stage, namely (1) the dependence on state cooperation when collecting evidence and (2) financial and personal resources for the defence to conduct their investigations, the Appeals Chamber of the ad hoc tribunals has reasoned that the principle of equality of arms does not dictate any substantive equality between the parties. Rather this principle should be interpreted more liberally in the context of the tribunals, due to the differing operating context including the lack of the extensive enforcement powers of a state

16 The respective Articles containing the rights of the accused provide for "fair and public hearing" and several specific rights of the accused "in the determination of charges against him." See Articles 20 and $21 \mathrm{ICTR} / \mathrm{ICTY}$ Statutes (these come after Articles 19 and 20 respectively which deal with the trial process), Article 17 SCSL Statute, and Article 67 (Part V. Trial Process). 
and the complete dependence on state cooperation for investigatory powers. Equality of arms does not imply having the same resources between the parties, but prosecution and defence should be equal before the Trial Chamber. ${ }^{17}$ The Chambers should provide all the assistance to alleviate a party's investigative difficulties, however, the principle of equality of arms cannot be considered to apply to conditions outside the control of the Chamber that prevents a party from securing the attendance of certain witnesses. ${ }^{18}$ Hence, equality of arms implies 'equality of opportunities' before the court, and not 'substantive equality', in the sense of available material resources and facilities, the institutional position, equality of relief or other circumstances, which fall outside the control of the Chambers. More generally, this possibility of a more 'liberal' interpretation has provided an open-ended notion to incorporate the contextual peculiarities of the ad hoc tribunals.

At trial, the authoritative interpretation of equality of arms has been advanced in the Oric case, where the ICTY Appeals Chamber formulated a subjective and an objective element to equality of arms: basic proportionality and objective adequacy. This approach is in line with the definition as provided by the ECtHR. This twopronged test has been developed in the context of determining the proper time and the number of witnesses that the defence was allowed to have for its case presentation at trial and has been confirmed by other Trial and Appeals Chambers. This Oric test means that the time and the number of witnesses for the defence need to be reasonably proportional to that of the prosecution. In addition, the defence should have an objectively adequate time to present its case. The question that remained open was to what extent this two-pronged step is relevant for the position of the prosecution.

\section{Prosecution's entitlement to equality of arms}

There has been some debate about whether equality of arms should be interpreted as benefiting only the defence or whether the principle covers both parties and can thus benefit the prosecution. The debate started in the first ICTY case where Judge Vohrah argued that equality of arms should benefit the defence in light of prosecutions' greater resources. ${ }^{19}$ Judge McDonald rejected this view in a separate opinion to

17 ICTY, Prosecutor v. Tadić, Judgment, 15 July 1999, IT-94-1-A, A. Ch., paras. 51-52.

18 ICTY, Prosecutor v. Tadić, Judgment, 15 July 1999, IT-94-1-A, A. Ch., par. 49. Endorsed in e.g. ICTR, Prosecutor v. Kayishema and Ruzindana, Judgment, 1 June, 2001, ICTR-95-1-A, A. Ch., paras. 72-73. In this case, the Appeals Chamber reiterated the finding of the Trial Chamber that "[t]he Trial Chamber is satisfied that all the necessary provisions for the preparation of a comprehensive defence were available, and were afforded to all Defence Counsel in this case. The utilisation of those resources is not a matter for the Trial Chamber."

19 ICTY, Prosecutor v. Tadić, IT-94-1-T, T. Ch., 27 November 1996, Separate Opinion of Judge Vohrah on Prosecution Motion for Production of Defence Witness Statements. Cf. Dissenting Opinion of Judge Jean-Claude Antonetti, Presiding Judge of the Trial Chamber, Concerning the Decision on 
the same decision, arguing that procedural equality covers both parties. This view has been endorsed in several later cases since then..$^{20}$ It has even been argued that an inclination in favour of the defence results in an inequality of arms for the prosecution and " $[\mathrm{t}]$ his will be inconsistent with the minimum guarantees provided for in Article 21 paragraph 4(e), of the Statute." ${ }^{21}$ Article 21 explicitly contains the (minimum) rights of the accused, which makes the Trial Chamber's reasoning all the more confusing. It seems to equate the prosecution's equality of arms with the minimum rights of the accused, thus, extending the application of Article 21 ICTY Statute to the prosecution. But were these rights not established for the defence to elevate it to the level of the prosecution in the first place? How can the prosecutor be able to rely on these minimum rights of the accused? The Trial Chamber did not elaborate on these fundamental questions. The Chamber merely argued, in line with Judge McDonald, that in international criminal proceedings both the prosecution and defence depend on state cooperation for their investigations, which dependence equalizes their position. ${ }^{22}$

Principally, this vision seems unattainable because the argument of inherent inequality is based on the theoretical understanding that subjecting an individual to the prosecutorial apparatus within a criminal justice system that is empowered to take away that individual's liberty by way of a conviction, places that individual in an unequal position as compared to the state organ, the prosecution. As argued by Trechsel:

Full 'equality of arms' in criminal proceedings, however, is not a fitting image at all. From the very beginning of the criminal process, the prosecution and the defence are in very different positions. The prosecution acts (at least in theory) without any 'personal' interest - its sole aim is to find the truth and to ensure that the law is applied correctly, i.e. to serve justice, while the accused only acts in his or her own personal interest and is not under any duty to serve justice. While the prosecution is equipped with measures of coercion such as arrest warrants, wire-tapping, search and seizure, and has increasingly complex technology at its service, the accused has none of that at his or her disposal but is in possession, if he or she is guilty, of precise knowledge of the facts of the case. The burden of proof rests on the prosecution, and the accused

the Oral Request of the Accused Jadranko Prlić for Authorisation to Use a Laptop Computer At Hearing or to be Seated Next to His Counsel, ICTY, Prosecutor v. Prlić et al., IT-04-74-T, 29 June 2006, par. 9: "One should remember that the right to equality of arms is more generally a right of the accused because the Judges must ensure that the person being prosecuted, who is the most vulnerable person at trial, is not disadvantaged in the conduct of his defence."

20 E.g. ICTY, Prosecutor v. Delalić, Decision on the Prosecution's Motion for an Order Requiring Advance Disclosure of Witnesses by the Defence, IT-96-21-T, 4 February 1998, par. 49.

21 ICTY, Prosecutor v. Delalić, Decision on the Prosecution's Motion for an Order Requiring Advance Disclosure of Witnesses by the Defence, IT-96-21-T, 4 February 1998, par. 49.

22 ICTY, Prosecutor v. Delalić, Decision on the Prosecution's Motion for an Order Requiring Advance Disclosure of Witnesses by the Defence, IT-96-21-T, 4 February 1998, par. 49. 
can choose to remain passive and silent throughout the proceedings. Equality can only be conceived of, in this context, as a certain equivalence. One might recall fights of gladiators in ancient Rome where one was in armour and equipped with a sword, while the other was unprotected and equipped with a net and a trident. ${ }^{23}$

Although the ECtHR has defined equality of arms as a reasonable opportunity of each party to present its case under conditions which are not less advantageous than of the other party, in practice it has obviously never considered a prosecutor's appeal to that principle. ${ }^{24}$ Exactly this practice of international criminal courts applying equality of arms, and more broadly, the right to a fair trial, for the benefit of the prosecution constitutes one of the most uncertain issues in the case law of these courts. It is here that the confusing and unprincipled approach taken by several Chambers, which in effect marginalizes the rights of the accused, can have the most devastating effect on the overall fairness of the proceedings.

Although the vision of the lack of inherent inequality between the parties in international criminal context has not been explicit in later case law, the view that both prosecution and defence are entitled to benefit from equality of arms has found its clear basis in the jurisprudence of the international criminal courts. In justification of this view is has been considered that the prosecutor acts on behalf of the international community, including the victims of the crimes in question..$^{25}$ The principle of equality of arms was based on the equal treatment clause of Article 21(1) ICTY Statute, and it has been argued that it does not affect the fundamental protections accorded to an accused against which the trial proceeds. ${ }^{26}$ In this light it seems that the principle of equality of arms is not related to the minimum human rights guarantees provided for an accused in a criminal trial. ${ }^{27}$ This vision cannot be considered to be in line with the ECtHR's jurisprudence, as it makes clear that equality of arms is based both on Article 6(3) ECHR providing for minimum rights as well as on the general principle of a fair trial provided for in Article 6(1) ECHR. ${ }^{28}$ Moreover, these minimum guarantees do not provide an exhaustive list, and it is not unthinkable (at least in theory) that more protection would be needed to guarantee an accused his minimum rights and his right

23 TreChSEL, 2005, p. 96 [footnotes omitted].

24 Trechsel, 2005, p. 90, pointing out that "[o]nly individuals can benefit from the protection if international human-rights instruments and the prosecution clearly falls out with this remit."

25 ICTY, Prosecutor v. Aleksovski, Decision on Prosecutor's Appeal on Admissibility of Evidence, IT95-14/1-A, 16 February 1999, par. 25 [Aleksovski Admissibility of Evidence Decision, 16 February 1999]. Also, ICTY, Prosecutor v. Sefer Halilović, Decision on Motion for Prosecution Access to Defence Documents, IT-01-48-T, T. Ch. I, 9 May 2005, par. 8.

26 Aleksovski Admissibility of Evidence Decision, 16 February 1999, par. 25.

27 Aleksovski Admissibility of Evidence Decision, 16 February 1999, par. 25. The Appeals Chamber concluded that "[s] een in this way, it is difficult to see how a trial could ever be considered to be fair where the accused is favoured at the expense of the Prosecution beyond a strict compliance with those fundamental protections."

28 ECtHR, Vidal v. Belgium, App. No. 12351/86, Judgment of 22 April 1992, par. 33. 
to equality of arms.$^{29}$ Even if that would result in inequality towards the prosecution, this does not lead to an automatic conclusion that the overall fairness of the trial would be jeopardized.

\subsection{ApPlication OF EQUALITY OF ARMS In INTERNATIONAL CRIMINAL PROCEEDINGS}

To be fair, international criminal courts are sailing in uncharted waters when it comes to establishing proper procedures to justify all the goals of international justice. As such, these courts 'get along while going along'. The rhetoric of the jurisprudence of the international criminal courts often takes into account the rights of the accused and the individual right to a fair trial. However, this rhetoric must be backed by principled considerations of assigning these rights due weight in the overall scheme of fairness within these proceedings, something that not all Chambers have done appropriately.

Generally, the difficulties with regard to defence investigations and the inadequacy of funding that was available to the defence has been the driving force behind defence teams' appeals to equality of arms throughout the existence of the international criminal courts. In many respects, this appeal has provided the defence with a tool for emancipation, for establishing a position beyond a 'mere afterthought' but as an equal participant in the process. It is in this pre-trial stage that the most challenging issues in relation to equality of arms arise, and where the courts have struggled in adjusting their procedures to fit the realities of prosecuting atrocity crimes while best securing the fair trial rights of the accused. This section considers more specifically the application of equality of arms in the four studied areas: investigations, the disclosure regime, material resources and case presentation at trial; it intends to add to the conclusions taken in the separate Chapters rather then to replace them. An evaluation of the mechanisms that are in place to 'equalize' parties' positions, in substance as well as in appearance, and some tentative suggestions for improvement will be made.

\section{Investigations}

It is in the framework of pre-trial investigations that the parties are the most unequal. The prosecutor is assumed to have the power and support of the international

29 Cf. Dissenting Opinion of Judge Jean-Claude Antonetti, Presiding Judge of the Trial Chamber, Concerning the Decision on the Oral Request of the Accused Jadranko Prlić for Authorisation to Use a Laptop Computer at Hearing or to be Seated Next to His Counsel, ICTY, Prosecutor v. Prlić et al., IT-04-74-T, 29 June 2006, par. 6: "It should be recalled that the guarantees set out in Article 21(4) are not exhaustive and, if necessary, in the name of the principle of equality of arms and, consequently, of a fair trial, the Judges must add guarantees which the Statute does not mention in order to adjust the balance, if so required, between the resources available to the parties." 
community in his mission to bring those most responsible for heinous crimes to the dock before an international criminal court. ${ }^{30}$ The individual accused of these crimes is detained, and has to avail himself of the assistance of foreign defence counsel functioning in an uncertain and unknown system. However, as considered above, some challenges to the basic assumption of the inherent inequality between the parties in a criminal process have been voiced.

The liberal approach towards equality of arms adopted by the ad hoc tribunals towards the defence's claims of inequality of arms in relation to inadequate preparation for trial due to limited pre-trial powers and lacking state cooperation, implies

(1) the need for equal positioning of the parties before the Trial Chamber-oftentimes without appropriate reference to the difference in their roles, the inequality of powers and the limitations of the operative context;

(2) the Chamber's interventionist obligation to assist the parties' requests for any necessary assistance - taking a flexible approach and its 'equalizing' position seriously; and

(3) the Chamber's purely formal approach towards the perception of the equality of parties' positions and its own efforts to assist - equal procedural opportunity to request Chamber's assistance is enough to satisfy equality of arms.

Lacking enforcement powers, the courts are left at the mercy of cooperating states for virtually all investigative efforts. Where this cooperation has not been forthcoming, thus jeopardizing the defence's efforts to prepare properly, the international criminal courts have left a remote possibility open to stay the proceedings if a miscarriage of justice would originate from this lack of cooperation. Although a Chamber is not obliged to control factors outside its control, in this exceptional situation (which never occurred at the ad hoc tribunals) the defence would bear the burden of providing a high probability that the non-accessible evidence would indeed influence the finding of guilt or mitigate the punishment. Something that in the practice of the international criminal courts is rather difficult to do. ${ }^{31}$ In the context of the ICC, the first practice has shown that the judges are willing to stay the proceedings to ensure defence's access to exculpatory materials. Of course, the burden on the defence to substantiate the relevance of the material was elevated by prosecution's admission that it was in fact exculpatory evidence that he could not disclose to the defence.

Structurally, the ICC has purported to address the problems faced by the defence with regard to the ability to investigate properly by an explicit recognition of the objective nature of prosecutorial investigating efforts. The prosecutor is obliged to collect both incriminating and exculpatory evidence, thus alleviating the burden on

30 JONES, 2004, p. 493

31 Newton, 2011, p. 390: "[t]he difference in access to international pressure/leverage arguably represents the most significant structural limitation on equality of arms in the system of international justice." 
the defence. Vigorously enforcing the objective role of the prosecution, in substance and appearance, (1) helps ensure respect for the rights of the accused throughout the whole proceedings, and (2) creates distance between the victims and the prosecution that is necessary to detach international criminal proceedings from a 'victor's justice' and therefore to better ensure their legitimacy. It is because the prosecution represents the international community in general that the obligation is placed upon the prosecution office (as in the national setting) to ensure the proper administration of justice including the protection of the rights of the accused. The conscientious and ethical approach to the prosecutorial role is to "seek justice not victory." 32

The danger of this more objective approach to the role of the ICC prosecutor, that is common to more 'inquisitorial' systems, is the negative effect on the active participation of the defence..$^{33}$ If the prosecutor is doing most of the work, why should the defence have an opportunity to conduct its own investigations and waste scarce resources? Indeed, this is one of the critical points of the application of equality of arms within systems based on the inquisitorial tradition. In this regard, it must be considered that the example of the ECCC represents one extreme (as compared to the ad hoc tribunals): the civil law approach taken by the court, whereby the investigative judges are responsible for judicial investigation. This investigation proceeds on the basis of the submission of preliminary investigations by the prosecution and is conducted for the most part secretly in order to protect the suspect under investigation and to ensure the independence of investigations. However, this practice has been challenged by the defence as lacking any meaningful participation from a party that individually has the most at stake, the accused.

Importantly, the function of the principle of equality of arms is to protect the active participation of the defence in the process (pre-trial and trial), thereby ensuring the right to be heard and legitimizing the proceedings 'from the inside'. Demanding objectivity on the part of investigative organs must be appropriately balanced with the active participatory rights of the suspected or accused individual. At the ICC, this can, for example, take place by recognizing the ability of the defence to request concrete investigative efforts to be undertaken by the prosecution on behalf of the defence as a right. Properly reasoned requests, if dismissed, would have to be adequately reasoned by the prosecution to facilitate oversight by the Chamber.

\section{Disclosure}

Initially, an adversarial system of disclosure was established at the ad hoc tribunals to regulate access to information inter partes. However, the demands of expeditiousness and efficiency, fuelled by the realities of the prosecution of mass atrocity crimes,

32 Luban, 2010, p. 14.

33 Cf. Kohlmann, 1974, p. 319. 
have left their undeniable imprint on disclosure rules and practices. Overall, both the rules and practice changed considerably over time. Even now, in the last years of the functioning of the tribunals the disclosure rules cannot be pinned down to a clear and unequivocal regime.

Disclosure obligations more generally constitute the single most challenging issue at the international criminal courts. This study focused particularly on two issues: the development of the prosecutor's disclosure obligation in regard to exculpatory evidence (the defence's right to equality of arms) and the development of the defence's disclosure obligations (the prosecutor's 'right' to equality of arms).

A fundamental tenet of fairness in the criminal process, following from the accepted objectified role that a prosecutor is supposed to fulfil, is the disclosure of exculpatory evidence to the accused. The ad hoc tribunals grew to acknowledge the fundamental importance of the disclosure of (exculpatory) evidence to the defence and have taken a broad approach towards disclosable materials. However, the disclosure obligation was subjected to (1) actual knowledge of the prosecution about the exculpatory evidence, thus excluding any extension towards a duty to search for such evidence, and (2) confidentiality agreements under which the prosecution can collect lead evidence. Both limitations have been implemented to accommodate the realities of investigating mass crimes: the burden upon the prosecution would be unbearable if the disclosure regime would be broader than what is 'actually known' to the prosecution to be favourable to the accused case. Moreover, the collection of materials from highly sensitive sources would be impossible without having the security of confidentiality from disclosure obligations. Although the judges have strengthened their grip on controlling and coordinating the proper course of the pretrial disclosure, a great deal depends on the approach taken in individual cases by the parties. In this regard, the role of the prosecutor has been described as that of a 'minister of justice' or an 'impartial truth-seeker' helping the court to arrive at the truth, but these voices have been irregular. Little principled rhetoric has been used to emphasize the objective role of the prosecutor or the ultimate goal of the court to arrive at the truth. From the perspective of developed national criminal systems, this rhetoric might seem superfluous; however, in the development of international criminal institutions in their infancy, proper rhetoric represents the required perceptions, next to the practice as such. The following cannot be overstated: 'justice has to be seen to be done.'

More specifically, the equalizing of arms between the prosecutor and the defence would have benefited from a more principled approach towards the prosecution's disclosure practice. Although the burden on the prosecutor may not be underestimated, so may not the difficulties encountered by the defence with regard to investigations and access to evidence. Considering the principally different roles and positions is the key to a proper application of equality of arms in disclosure practice. 
This principle has played a role in 'equalizing' the disclosure rules over the years from the point of view of the prosecution. The end-result at the moment is that the disclosure obligations of the evidence that a party wants to use in its case are very much aligned. The main justification has been found in the demands of expeditiousness and efficiency. To some extent, however, the justification was based on the 'rights' of the prosecutor to be able to prepare adequately for the defence's case, thus extending equality of arms in favour of the prosecution. These principally different positions of the parties were considered to be respected by the fact that the disclosure obligations of the defence in the pre-trial phases are still very limited. When the reciprocal disclosure rule was deleted in 2003, thus limiting considerably the disclosure obligations of the defence, the prosecution criticised this development by arguing that efficiency and expeditiousness in preparing and presenting a case would suffer severely when the defence has such limited disclosure obligations as to the content of its case. The reintroduction of the more elaborate inter partes disclosure obligations of the defence in 2008 largely did not affect this concern because defence disclosure is only effectuated at the close of the prosecution's case. ${ }^{34}$ Another practice would not be defensible from the point of view of the rights of the accused and the presumption of innocence. However, the extension of defence disclosure obligations facilitates the efficiency of the prosecution's preparation for the defence case.

Although the judges of the ad hoc tribunals have 'put their foot down' as far as disclosure violations are concerned, any remedy for such violations can only be provided if the defence can substantiate that it suffered actual prejudice from the violation of the disclosure obligations. In practice, there is a high burden of proving such prejudice. In fact, most violations of the disclosure obligations by the prosecution have been explained by reasonable grounds not including mala fide practice on the part of the prosecution. Therefore, while the necessary rule changes have been effectuated to open up the possibility of sanctions for disclosure violations, which was considered necessary to improve adherence to disclosure rules, this has not led to any meaningful practice to date. In light of the importance of international prosecutions judges' emphasis on remedial action, rather than sanction, is understandable. However, judges' hesitation, almost unwillingness to sanction prosecutorial disclosure violations can create, and to some extent already has created, a perception of implied tolerance on the part of judges towards a rather serious, improper practice (not implying a mala fide character). However, and notwithstanding many practical concerns the prosecutor is facing with regard to proper disclosure implementation, a lack of sanctioning measures provides little 'encouragement' to reconsider the disclosure practice; thus, changing any (systemic) flaws that might have been prompted by the practical concerns in the first place. 
In the context of the ICC, only time will tell concerning the long-term improvement of disclosure practice by the ICC prosecutor after a double disclosure fiasco in the first case to go to trial. The Trial Chamber's immediate and proactive approach towards sanctioning the violation of disclosure obligations at the ICC must surely be applauded from the point of view of equality of arms and the protection of fairness in criminal trials. However, the importance of international prosecutions cannot be underestimated, as made perfectly clear by the Appeals Chamber in that case. Although in full agreement with the Trial Chamber's approach, still the Appeals Chamber reversed the far-reaching consequences of Trial Chamber's decisions.

At the ICC, the legal regime of disclosure is build on the developments from the ad hoc tribunals. Although the regime envisioned is formally a two-party disclosure practice, the legal regime and practice of the ICC clearly shows the influence of the civil law dossier approach. Two structural elements are of paramount importance: (1) the enhanced monitoring role of the Pre-Trial Chamber on the disclosure practice; and (2) the objective role of the prosecutor. Promoting the cooperative approach but extending vigorous oversight over the disclosure practice is how the ICC's approach to disclosure can be characterized. As argued above, from the perspective of equality of arms, the impartial attitude of the prosecutor towards the case against the accused must be emphasized and developed to better protect and equalize the rights of the accused. The initial practice of the ICC shows that the prosecutor has not reached the necessary level with regard to his objectivity requirement. More emphasis should be placed on a more inclusive, positive and cooperative approach to collecting and disclosing evidence. Clear ethical standards should be in place and guide the OTP in its search for truth. The most common but inherently vague ethical standard is the responsibility of the prosecutor to ensure a fair administration of justice generally and a fair trial for the accused in particular. In light of the ICC practice, it is the latter element that needs to guide more vigorously the exercise of the prosecutor's mandate in order to better equalize the 'arms' between the prosecutor and the defence.

\section{Institutional support for the defence}

Defence challenges concerning the inequality and inadequacy of material resources has proven to be a great source of equality of arms challenges at the ad hoc tribunals. It has been stated that " $[\mathrm{t}]$ he defense and prosecution teams continue to labor under an enduring and perhaps inevitable imbalance both in reputation and in resources." ${ }^{\prime 35}$ However, it is in this context that the Chambers have excluded the applicability of equality of arms as postulating an equality that is neither attainable nor intended in international trials. The Chambers have consistently considered that equality of 
arms does not entail equality of means and resources between the parties. Indeed, comparing the resources of the prosecution and the defence seems close to the 'apples and oranges' metaphor. It is simply not the case that the defence requires the same resources as those of the prosecution. Instead, generally adequate funding and facilities to prepare an effective defence are necessary. The defence must have an objectively adequate possibility to prepare and present its case. A comparative element, inherent in the notion of equality of arms, is taken into account within the legal aid system that underlies the material resources of most defendants at the ad hoc tribunals. Depending on the complexity of a particular case, a specific amount of legal aid is considered appropriate.

It is in this area that the 'emancipation' of the defence as an entity is most visible. From being an institutional 'afterthought', defence lawyers managed to effectively draw attention to these issues of real concern. As such, equality of arms has served as an instrument of this emancipation. Whereas in any legal aid system the defence is expected to 'cut its coat according to the cloth that it has' or rather, to work with what it is provided by the legal aid system, the 'institutionalization' of defence issues has had a positive effect on the defence's advancements both materially and institutionally within the system of international criminal courts. ${ }^{36}$

Learning from the mistakes of the ad hoc tribunals, the SCSL, the ICC and the ECCC all managed to establish some kind of institutionalized defence offices under the wings of the registry. Although the defence offices have not been set up as independent organs of international criminal courts (except at the STL), their role has been compared to the legal advisory section of the OTP. However, the major drawback of this set-up has been the dependence on an administrative organ of the court for the funding of defence-related issues. The institutional deficit of the defence has had a major impact on the perceived (in)equality of arms. In practical terms, the defence has not been considered or approached as an equal partner in state cooperation relations. Although this 'handicap' has been, to some extent, corrected by the direct involvement of the registrars, this practice has to be 'institutionalized' by the appropriate protocols, which lay down the procedures for cooperation requests both through the registrar as well as the Chamber to facilitate defence counsel's proper notice of the difficulties and specificities of the procedures involved. ${ }^{37}$

With regard to the legal aid systems installed at the international criminal court, they have been established in consultation with different national and international actors to meet the challenges of counsel in defending mass atrocity crimes. An evaluation of these systems as such was not intended in this legal study, but undoubtedly merits a proper assessment between all the stakeholders on a regular basis. A clear emanation of equality of arms within the legal aid system has been

36 SCSL, Prosecutor v. Taylor, SCSL-2003-01-T, TC III, Transcript of 25 June 2007, p. 357.

37 Cf. Fairness at the International Criminal Court, 2011. 
the development of the salary requirements of defence counsel. At the ICC, defence counsel are subject to the same enumeration scale as the one used for senior counsel at the prosecutor's office. Following this example, the STL in its legal aid policy (adopted 9 September 2011) states that "The Legal Aid Policy seeks to effectively implement this right [equality of arms] by paying defence counsel the equivalent net salary of that accorded to a senior trial attorney for the Prosecution, and by making available to the defence counsel adequate human and financial resources." ${ }^{38}$

On the one hand, this approach can be applauded, as it does seem to take 'equality of arms' in an almost literal sense seriously. On the other hand, although this approach does seem to appease the rhetoric of (in)equality of arms, it in fact says little about the defence's ability to adequately prepare for trial. It can even be argued that this rather mathematical approach to the equality of arms might actually distort the understanding of that principle in the international criminal setting. By providing a superficial satisfying perception, it might divert attention from the more underlying issues that need a (principled) resolution. Here again, the equality of arms sets out a goal to be achieved. Just as the existence of a legal aid system as such does not vindicate equality of arms, neither does the 'same salary for all' rule, although it might bring it one step closer.

Particularly from the perception of the inequality of arms, the idea for the institutionalization of a defence office has been on the agenda for many years. The argument of structural and financial independence has been advanced in support of the institutionalisation, while concerns for professional independence have been considered against it. In this regard, the defence office at the STL will be the experimental laboratory for those outstanding issues. A positive assessment of the defence office's functioning at the STL might bring home the institutionalization of the defence at the ICC, for which a change in the legal framework will have to take pace. This study endorses this endeavour. Considering institutional memory, autonomy and independence, a defence office as a separate organ of the institution might prove indispensible to eradicate any perception of inequality and to secure the rights of the defence more broadly. The defence as a fifth organ of the ICC (next to the Presidency, the OTP, the Judicial divisions and the Registry)

... would reflect, at an institutional level, the principle of equality of arms. Importantly, the benefits of a defence organ extend beyond mere symbolism or perception. It would allow the defence office to justify its own budget and would significantly ameliorate many of the difficulties that the defence counsel currently face, including obtaining state cooperation. ${ }^{39}$

38 See http:/www.stl-tsl.org/en/media/press-releases/09-09-2011-head-of-defence-office-adopts-legalaid-policy (last accessed 1 June 2012).

39 Fairness at the International Criminal Court, 2011, p. 35. 
The state cooperation regime under Part 9 of the ICC Statute obliges states to cooperate with the Court, of which the defence is not an organ. Thus, defence requests for cooperation addressed directly to states (instead of through the Registry) are responded to differently than the requests made by an organ of the Court.

\section{Case presentation}

Arguably, at the case presentation stage the parties assume their most adversary roles and can be regarded as 'equal' when compared to the pre-trial stage of proceedings. Achieving this 'full equality' between the parties was stated to be the purpose of the protection offered by the right to call and examine witnesses under the same conditions.

Therefore, a general point of departure has been the objection to sustain full equality between parties in their case presentation. To accommodate this, particularly from the perspective of the prosecution, the right to a fair trial generally, and on occasion the minimum rights in particular, have been interpreted to apply to both the defence and the prosecution (see above). Against this background, the nature of the 'fundamental protections' afforded to the accused has been more qualified to allow a balancing with the 'rights' of the prosecution to the extent that any residual disadvantage to the accused resulting from a particular application of the rules has been found to be counterbalanced by the potentially greater disadvantage suffered by the prosecution if another application would be adopted.

Considering the interpretation of the principle of equality of arms, the Chambers strongly opposed a mathematical approach, but were rather guided by the twopronged test developed in the Orić case: when allocating time and witnesses to the defence, the Chamber should take into account (1) the principle of reasonable proportionality resulting from equality of arms, and (2) objective adequacy to effectively present one's case. This two-step approach implies that whenever the first element is not complied with, the second implicitly fails. There are no decisions that have considered explicitly a situation where the first element was complied with, but not the second. There are, however, instances (like the Prlic case) where the Court decided to grant the defence slightly more time for their case presentation than accorded to the prosecution. The formulation of the Oric test in 2005 followed the development of the more managerial powers that the judges ascertained in order to expedite the proceedings. Fuelled by the more cooperative stance of Serbia in 2004, when it came to delivering indicted persons to the Tribunal and the prosecutorial policy of joint trials, the judges started to adopt a more proactive attitude towards determining the time and the number of witnesses that parties were allowed to present.

However, in practice, the Chambers generally followed a rather arithmetical approach for delineating the time for case presentation. For obvious reasons, the element of basic proportionality could not be directly instrumental to the allocation 
of time and witnesses to the prosecution. In this respect, the judges explicated that the key to limiting the defence's case is the limitation of the prosecution's case through the operation of equality of arms. This principle implicitly delineates the prosecution's case when the judges consider the need to afford approximately equal time to the defence as afforded to the prosecution. Moreover, the application of the second element, objective adequacy, has been extended to apply to delineating the prosecution case, notwithstanding the fact that this second element has been explicitly based on the 'rights of the accused' in the Oric case. When evaluating the time and the number of witnesses to be provided to the prosecution, the Chambers have taken into account the element of the objective adequacy to present the case.

The rules concerning witness examination, cross-examination, and the admissibility of evidence have been applied broadly and flexibly, taking into account the specific characteristics of the functioning of the courts. While terminology such as 'ensuring fair trial' and 'in accordance with the rights of the defence' has been prominently present in every relevant discussion, an in-depth consideration of the fundamental questions regarding the rights of the accused has often been absent/ inadequate. In this sense, the Chambers have barely considered the right to be informed of the charges, the right to examine witnesses and, more generally, the right to present evidence in defence, except an occasional mentioning of these terms. Even less consideration has been given to principled matters such as what is the basis for the prosecution's right to a fair trial and several other guarantees, formally accorded to the defence. When managing the trial process, the judges particularly focused on a rather formal procedural 'equality' between parties to the extent that in this setting the principle of equality of arms is considered vindicated as soon as the defence has been afforded exactly the same numerical value or a procedural opportunity as the prosecution. Thus, is remains unclear whether the application of equality of arms to the prosecution precludes a more than strict application of the fundamental protections afforded to the accused, in case the inequality is justified on the basis of the difference in the respective roles of the parties.

Lastly, the novelty of victim participation in the proceedings has presented many principled and practical challenges to all participants in the proceedings. From the perspective of equality of arms, the biggest challenge is how to reconcile victim participatory rights, specifically the right to lead and challenge inculpatory and exculpatory evidence, with the right of the defence not to be confronted with multiple accusers. The insufficiencies of the legal framework have been complemented with a rather broad and flexible approach to the practice of victim participation. Whereas in principle victim participation in itself does not pose an obstacle to a meaningful 'equality of arms' between parties, in practical terms the judges have to be particularly 
vigilant of the different rights and interest accorded to parties in a criminal setting and capable of separating "the relevant from the irrelevant." 40

\subsection{NORMATIVE CONSIDERATIONS: CONCEPTUALIZING FAIRNESS AND THE PRINCIPLE OF THE EQUALITY OF ARMS IN INTERNATIONAL CRIMINAL PROCEEDINGS}

\subsubsection{Fairness and the right to a fair trial}

Where the prosecution has emphasized its right to a fair trial as the basis of its motions and requests, judges' rhetoric mostly avoids references to the prosecution's right to a fair trial. A quite recent notable example is the ICTY Appeals Chamber's judgment in the Haradinaj et al. case ordering a partial retrial after the acquittal of two accused in the first instance. In the first published version of the judgment, the Appeals Chamber considered that the Trial Chamber had "inappropriately prioritized logistical considerations over the Prosecutor's right to a fair trial." ${ }^{41}$ Later this statement was corrected to state " ... over the Trial Chamber's duty to safeguard the fairness of the proceedings." 42 The prosecution argued that his right to a fair trial (Article 20(1)) is anchored in his duty to represent international community in general and the interests of victims in particular. ${ }^{43}$ As the central element of this fundamental right, the prosecutor considered to be his right to tender and challenge evidence comprehensively.

Recognizing the context of witness intimidation and the difficulties encountered by the prosecution in obtaining the testimony of two witnesses who were particularly important to the prosecution's case, the Appeals Chamber found that the Trial Chamber had failed to take adequate measures to secure the testimony of the two key witnesses. The Appeals Chamber solely focused on the severity of witness intimidation that potentially undermines the fundamental objective of the tribunal to ensure fair and expeditious proceedings with due regard to the protection of victims and witnesses.

40 ICC, Prosecutor v. Lubanga Dyilo, Trial Transcript of 7 January 2010, ICC-01/04-01/06-T-223, p. 39. The Presiding Judge Fulford stated, in the context of questioning a witness by a legal representative, that "In due course the Chamber will very carefully separate out what is relevant from what is irrelevant and, rather than interrupting counsel in every question, unless you have strenuous objections, I think it would be better to let this run. But I undertake and reassure you that we will separate, as I say, the relevant from the irrelevant."

41 ICTY, Prosecutor v. Haradinaj et al., Appeals Chamber Judgment, IT-04-84-A, 19 July 2010, par. 46.

42 ICTY, Prosecutor v. Haradinaj et al., Appeals Chamber Judgment, Corrigendum, IT-04-84-A, 23 July 2010.

43 ICTY, Prosecutor v. Haradinaj et al., Notice of Filing of Public Redacted Version of Prosecution Appeal Brief, IT-04-84-A, 17 July 2008, paras. 6-7. Arguing that “[p]rotection of the Prosecution's fair trial rights is an accepted fundamental principle of criminal proceedings in national jurisdictions where the Prosecution also represents the rights and interests of victims and society." 
The Appeals Chamber considered that the two witnesses never meaningfully testified during the trial, and therefore the prosecution was deprived of vital support for its case that resulted in a subsequent acquittal "on almost all the counts that the two witness' testimony might have helped to establish." 44 Any conceptual elaboration of the prosecution's right to a fair trial, or that of the accused for that matter, was left untouched.

According to the Presiding Judge Robinson, who dissented from the decision, the majority decision "has given to fair trial rights a hierarchical structure that finds no support in a proper interpretation and application of the Statute." ${ }^{45}$ The prosecutor's interest in obtaining the attendance and examination of witnesses, which forms a legitimate interest when considering fairness, is qualified in Article 20(1) of the Statute by 'full respect for the rights of the accused.' ${ }^{46}$ This qualification implies that the level of Trial Chamber's assistance in securing witnesses for the prosecution should not impede full respect for the rights of the accused. ${ }^{47}$ In light of the fundamentally asymmetrical nature of the criminal process, prosecutor has duties and defence has rights, and both do not apply visa versa. ${ }^{48}$ The majority decision, he argued, was thus incorrect when asserting that securing potentially important witness testimony is "much more significant" than the Trial Chamber's use of time management to secure an expeditious trial or a trial without undue delay. ${ }^{49}$

These considerations are important as they contain the proper analysis of the principle of fairness in a criminal process and the place of the rights of the accused

44 ICTY, Prosecutor v. Haradinaj et al., Appeals Chamber Judgment, IT-04-84-A, 19 July 2010, par. 38.

45 ICTY, Prosecutor v. Haradinaj et al., Partially dissenting opinion of Judge Robinson, Appeals Chamber Judgment, IT-04-84-A, 19 July 2010, par. 15. That the Statute does not explicitly address the rights of the prosecution is not surprising, Judge Robinson argued, because Article 21(4) is based on the human rights provisions regarding a right to a fair trial. However, "[t]he duty of the Trial Chamber under this Article to ensure a fair and expeditious trial is general in that it relates both to the Prosecution and the Defence. It is as a consequence of this duty that the Prosecution's interests are to be protected by a Trial Chamber, with the result that the Prosecution has a similar right to the right of the Accused in Article 21(4)(e) of the Statute to obtain the attendance and examination of witnesses."

46 ICTY, Prosecutor v. Haradinaj et al., Partially dissenting opinion of Judge Robinson, Appeals Chamber Judgment, IT-04-84-A, 19 July 2010, par. 15.

47 ICTY, Prosecutor v. Haradinaj et al., Partially dissenting opinion of Judge Robinson, Appeals Chamber Judgment, IT-04-84-A, 19 July 2010, par. 16: "If, for example, the level of assistance given is such that it will unduly interfere with the rights of the accused under Article 21(4)(c) of the Statute to be tried without undue delay, then the Trial Chamber would be in breach of its statutory duty."

48 ICTY, Prosecutor v. Haradinaj et al., Partially dissenting opinion of Judge Robinson, Appeals Chamber Judgment, IT-04-84-A, 19 July 2010, par. 17.

49 ICTY, Prosecutor v. Haradinaj et al., Partially dissenting opinion of Judge Robinson, Appeals Chamber Judgment, IT-04-84-A, 19 July 2010, 18. ("I also regret very much the label "logistical considerations", which has a derogatory ring to it when in fact a proper interpretation and application of the Statute shows that a concern with time and factors influencing the length of a party's case is no less important than concerns with other elements of fair trial rights" (par. 19). 
therein. The general understanding of the inherent asymmetry of the criminal process and the need to install certain non-reciprocal rights to provide the accused with a fair opportunity to defend himself has not been erased within international criminal proceedings. ${ }^{50}$ Even if one is to consider that there might be circumstances under which the prosecution would be placed in an unequal position concerning the collection of evidence, for example when the accused is backed by the sitting government of the state that refuses to cooperate with the prosecution to the advantage of full cooperation with the defence, this highly factually specific situation does not negate the fundamental assumption of the inherent asymmetry of a criminal process. This assumption is based on the systemic power to punish an individual and not upon the casuistic access to evidence.

However, it is exactly this lack of enforcement powers of the international criminal tribunals that has led to the more prominent positioning of the prosecution within the overall scheme of fairness within these tribunals. In fact, many Chambers, consciously or unconsciously, have extended the application of the "rights of the accused' to cover the interests of the prosecution. However, where the fairness of the proceedings is not exhausted by the rights of the accused, these constitute a fundamental consideration alongside the due concerns for the procedural interests of the prosecution and the participating victims in the sum of the overall fairness of proceedings. Balancing the rights of the accused without assigning the proper weight to the interest concerned with those of the prosecution in effect marginalizes the defence while unduly alleviating the prosecution, as these rights were provided to alleviate the defence in the first place.

Fairness within the meaning of an equilibrium or a balance as a legal concept "is a direct emanation of the idea of justice." ${ }^{11}$ The equity of the proceedings entails equilibrium between the parties, which assumes both respect for the principle of equality and the principle of adversarial proceedings and includes respect for the procedural rights of the prosecutor, the defence, and the victims as guaranteed by the relevant statutes (in systems which provide for victim participation in criminal proceedings). ${ }^{52}$ However, were equivalence implies 'sameness', the focus on the conception of equality as 'sameness' can result in the systemic negligence of the differences that might constitute important considerations for the achievement of pre-

50 See e.g. ICTY, Prosecutor v. Naletilić and Martinović, Decision on the Accused Naletilić's Motion to Continue Trial Date, IT-98-34-T, T. Ch., 31 August 2001, par. 7.

51 Situation in the DRC, Decision on the Prosecution's Application for Leave to Appeal the Chamber's Decision of 17 January 2006 on the Applications for Participation in the Proceedings of VPRS 1, VPRS 2, VPRS 3, VPRS 4, VPRS 5 and VPRS 6, ICC-01/04-135-tEN, 20 April 2006, PTC I, par. 38, referring to the Case Concerning the Continental Shelf, ICJ Reports 1982, par. 71. The Pre-Trial Chamber has approached the term 'fairness', taken from the Latin "equus", to mean equilibrium, or balance.

Ibid. 
set goals. ${ }^{53}$ The right to a fair trial, in the sense of the legally enforceable protection of individual interests, extends only to the accused in a criminal trial..$^{54}$ These interests find protection by fundamental procedural rights that are afforded to accused persons in the criminal process. ${ }^{55}$ Notably, the ICC Pre-Trial Chamber II considered that the right to a fair trial under the human rights instruments consists of two components: (1) a general one, "applicable to various types of proceedings (civil, criminal and administrative)," and (2) a specific one, "related to the rights of the defence in criminal proceedings." 56 To emphasize this more general understanding of fairness, several Chambers have considered that

[a]lthough use of the word 'fairness' in the context of a criminal trial might commonly refer to fairness for an accused, the prosecution undoubtedly is entitled to a fair opportunity to present its case. The Statute of the Tribunal obliges each Trial Chamber to 'ensure that a trial is fair and expeditious [...], with full respect for the rights of the accused', and does not provide that only an accused is entitled to be treated equitably. ${ }^{57}$

Generally considered, the whole system of international prosecution has been established to obtain justice for both the victims of crimes and the international community through the punishment of individuals who are found to be responsible for those crimes. This justice is translated into a criminal process that ensures adequate punishment through fair proceedings. The fairness of proceedings is based on the assumption that the prosecutor exercises his prerogative of establishing the legal and

53 The reference to sameness and the difference conceptualizing equality is taken from VAN LEEUWEN, 2010, pp. 10-11.

54 JACONELLI, 1997, p. 173, (“ ... any broader claim that the right-holder [of the right to a public trial] is the community at large would run foul of the fundamental view of rights - a view that is shared by the will and interest theories - as enjoyed by particular individuals in opposition to the interests of the community"). See also International Bar Association's Human Rights Institute Report, Fairness at the International Criminal Court, August 2011, p. 20: “ ... while it is necessary to preserve the fairness of the proceedings, it is essential not to misinterpret the notion of the right to a fair trial ... [which] was designed to protect the defendant against the machinery of the state with its fast resources."

55 According to Lucas rights are 'stronger' than interests; and "[i]n most cases, [...] a right is not merely a specially protected interest. Like interests, rights are assignable, but, unlike interests, rights are first-personal rather than third-personal [what other people can assume I am interested in] and have a close connection with freedom." See LuCAs, 1980, pp. 20, 25.

56 Situation in Uganda, Decision on Prosecution's Application for Leave to Appeal dated the $15^{\text {th }}$ day of March 2006 and to Suspend or Stay Consideration of Leave to Appeal dated the $11^{\text {th }}$ day of May 2006, ICC-02/04-01/05-90-US-Exp, 11 July 2006, par. 24.

57 ICTY, Prosecutor v. Milutinović et al., Decision Denying Prosecution's Request for Certification of Rule 73 Bis Issue for Appeal, IT-05-87-T, 30 August 2006, par. 10. See also Situation in Uganda, Decision on Prosecution's Application for Leave to Appeal dated the $15^{\text {th }}$ day of March 2006 and to Suspend or Stay Consideration of Leave to Appeal dated the $11^{\text {th }}$ day of May 2006, ICC-02/0401/05-90-US-Exp, 11 July 2006, par. 24. 
factual facts underlying the accusation. If this prerogative is jeopardized, the basis for a fair process and, thus, justice is relinquished. However, the understanding that the fairness of both the result and the process can only be achieved if the prosecuted party has had an adequate opportunity to participate in the process and to put forward evidence that challenges the accusation, secures certain individual rights. These rights protect an individual against any improper use of the prosecutorial prerogative and the drive 'to end impunity'. As such, these individual rights are included in the equation of procedural justice.

The fair trial standards, Jackson argues, "have been justified on two different bases": (1) autonomy and (2) accuracy. ${ }^{58}$ On the one hand, these standards seek to ensure a dignified treatment and participation of an individual throughout the criminal proceedings. On the other hand, these standards "are an expression of the need for trials as the public face of justice to reach accurate verdicts by means of a system of accusatorial or adversarial truth finding." 59 These procedural standards are thus intended to serve broader interests than only those of the individual rights of the accused ${ }^{60}$ A fine example of this double nature of fair trial standards is the right to a public trial. Whereas a trial in public can be assumed not to be on the wish list of many defendants, it is presumed to serve broader interests than those of an individual. The individual right to a public trial is retained in the negative sense: the individual has the right to complain about the non-public nature of the trial he is subjected to, but has no waiver entitlement concerning a public trial in general. ${ }^{61}$

A purely process-oriented understanding of fairness considers it to be "born of the symmetry of the dialectic process, " 62 meaning that what is fair is determined in the course of interaction between two equal parties with competing interests in a neutral forum provided by the law. The metaphor of a sporting contest is quite applicable here; an antagonistic parity determines a fair result that is accepted as such. However, this metaphor does not cover our modern conception of fairness in a criminal process that presupposes an inherent inequality between the parties. Thus, the more positive or substantive conception of fairness is "born of experience and contemplation of the eternal verities", and serves to vindicate certain predetermined values. ${ }^{63}$ It is here that the 'human rights', the 'minimum rights', the 'rights of the accused', the 'due process rights' and the 'constitutional rights' find their application. These rights are intended to equalize the positions between the prosecutor and the defence, at least on the

58 JACKSON, 2009-b, pp. 5-6.

59 JACKSON, 2009-b, pp. 5-6.

60 JACKSON, 2009-c, p. 861: "Defence rights exist arguably not just out of respect for the dignity of the individual but to safeguard institutional values that are held dear in the criminal process such as the need for accurate findings of fact and the protection of the innocent."

61 JACONELLI, 1997, preferring not to characterize public trial in rights terms.

62 UVILLER, 1999, p. 8.

63 UVILler, 1999, p. 8. 
theoretical level. The general agreement now is that a defendant in a criminal process is in an inferior position as compared to the prosecutor and that certain non-reciprocal rights have to be established to give the accused a fair opportunity to defend himself.

The sporting contest metaphor does not suffice in another sense: an antagonistic parity through complete, perfect and literal equality of resources or prerogatives between parties cannot be maintained in the context of a criminal process. It would be absurd to assume that both parties are entitled to do exactly the same. Rather, equality between the parties in a criminal process presupposes a "balanced empowerment, the allocation of respective prerogatives appropriate to the different roles of prosecution and defence in criminal litigation." ${ }^{64}$ To stay away from either the mechanical assessment of whether each party has the same rights or the unpractical consideration of theoretical equality, a functional approach is considered to be the most appropriate for the evaluative purposes in this study. Thus, a normative judgment has to be preceded by an examination of the respective roles of the contesting parties and the prerogatives that are appropriate to them. This 'appropriateness' of the "roledetermined and purpose-enhancing entitlements" 65 is contextual in the sense that the underlying values, aims and goals of a criminal justice system determine what is appropriate in a particular setting. Obviously, the specificity of an international criminal justice system in general, and of different courts and tribunals in particular, has to be given due consideration here.

\subsubsection{Two functions of the equality of arms}

To understand the scope of application of equality of arms, two conceptions of this principle have to be considered. Cassese described two distinct notions of equality of arms: as a concept developed in the case law of the ECtHR and as an essential element of the adversarial structure of proceedings. ${ }^{66}$ The function of the first, the 'human rights notion', is to elevate the defence on a par with the prosecution. This implies that the prosecution does not have the same entitlement and the occasionally more 'advantageous' position of the defence might be needed to preserve the overall balance between the parties in light of the prosecutorial advantages. The second, the 'adversarial notion', implies that equality between the parties is a necessary and sufficient condition for an adversarial trial structure where both parties must have the same rights to provide for a fair 'fight' between them. This image might be appropriate in a civil trial setting where two individuals must be provided with the same procedural opportunities to present their best case. In modern criminal justice systems, where the state takes a side against the accused, the resolving inherent

64 UviLler, 1999, pp. 16-17; p. 21: "An unfair disadvantage ... is a disabling impediment inappropriate to the task of the party suffering it."

65 Uviller, 1999, p. 18.

66 CAssese, 2008, p. 385. 
inequality between the parties actually necessitate some more individual protections for the accused, in fact the abovementioned human rights approach to the equality of arms.

Silver delineates a more limited conception of equality of arms that in a traditional understanding is more appropriate to a civil trial setting than for an adversarial criminal trial setting. He conceives of the principle of equality of arms as applying "to the procedural rights of each advocate to formulate and present her case." ${ }^{\circ 7}$ Silver acknowledges that the unique, non-reciprocal advantages that the prosecutor has are 'equalized' by the unique, non-reciprocal constitutional advantages of the accused and considers that "the principle of equality of arms, however, does not seek to alter this balance" as it would be illogical ${ }^{68}$ However, the reciprocal procedural devices, such as the ability to cross-examine or to advance evidence, "can and must exist in symmetrical balance." ${ }^{\prime 69}$ As such, the constitutional safeguards provided to the accused (the rights of the accused under the human rights framework) fall outside the scope of application of the equality of arms. This approach thus surpasses the fact that the constitutional rights or the minimum rights of the accused have been created to 'equalize' the positions of the prosecution and the defence in the first place, based on the assumption of an inherent asymmetry that exists between the parties in a criminal process. ${ }^{70}$

Combining these two ideas, the two functions of equality of arms emerge: a human rights and an adversarial function. Both functions consider equality of arms as a necessary, independent and constituent element of the fair trial principle. From the human rights perspective, the equality of arms serves the accused in order to put an inherently weaker party on a par with the stronger party, namely the prosecution representing the state system..$^{71}$ To accomplish this, an accused in a criminal trial is assigned several individual fair trial rights. These incorporate the non-reciprocal safeguards that 'level the playing field' between the two inherently unequal parties and provide for (active) participatory rights of the defence in the proceedings. A combined effect of the fulfilment of these rights considered in the broader framework of the particular trial determines the consideration of the overall fairness of the proceedings. However, vindicating these minimum rights alone might not be enough to make a trial fair as the 'rules of the game' must be fairly applied too. Thus, from this level of

67 Silver, 1990, p. 1039.

68 SiLVER, 1990, p. 1039.

69 Silver, 1990, p. 1039.

70 For a similar approach, see the above discussed Aleksovski decision.

71 ECtHR, Salduz v. Turkey, App. No. 36391/02, 27 November 2008, par. 53: "the generally recognised international human rights standards $[\ldots]$ which are at the core of the concept of a fair trial and whose rationale relates in particular to the protection of the accused against abusive coercion on the part of the authorities. They also contribute to the prevention of miscarriages of justice and the fulfilment of the aims of Article 6, notably equality of arms between the investigating or prosecuting authorities and the accused." 
(theoretical) equality between the prosecution and defence, the adversarial function of equality of arms emerges, which intends to provide for such 'fair rules'. Here, the procedural reciprocal opportunities must be provided equally to both parties so as to make the trial fair.

This second function of the equality of arms, as mentioned above, has a more natural application in a civil process setting where the parties are approached from the level of fair equality from the start. In a criminal process, the two functions are very much intertwined and often very difficult to consider separately. ${ }^{72}$ No wonder that there has been a fair amount of confusion among the legal professionals in the international criminal courts as to the applicability and the scope of the principle.

Considering the above, a more principled approach to equality of arms, the right to a fair trial and the principle of fairness must be taken in international criminal proceedings. ${ }^{73}$ The fact that the right to a fair trial of an accused is an overarching consideration does not imply that the interest of victims and witnesses and the importance of prosecution and punishment are not taken into account when making fairness considerations. It only implies that due weight is to be assigned to the different interests concerned, specifically when a delicate balancing exercise is necessary. Having regard to the different roles and responsibilities of the parties, any 'equality' between them can only be vindicated in relation to 'reciprocal' entitlements of parties before a court, such as calling witnesses and questioning those of the adversary. However, the human rights notion of equality of arms is to be prioritised as the qualifier of the procedural entitlements of other participants.

The two-pronged interpretation of equality of arms, as considered in Orić, does not only comply with the interpretation as provided by the human rights bodies, but provides for a sufficient tool for evaluating defence interests at the pre-trial or trial stage of the proceedings. The first, formal, element concerns the question whether the defence had an opportunity to prepare and present its case reasonably proportional to that of the adversary. The second, material consideration concerns the question whether a party, objectively, has had an adequate opportunity to prepare and present its case. This first element serves a preliminary function in the sense that if the opportunities between the parties are significantly disproportional, the second objective element would fail too thus leading to a violation of the principle of equality of arms. In case the opportunities are 'remotely proportional', the judges have to consider whether the given opportunity is objectively adequate to permit the defence to set forth the defence case. This assessment of the objective adequacy may be influenced by the subjective (comparative) considerations as it is the prosecutor who presents the accusations and determines, to some important extent the scope of the case..$^{74}$ The prosecution's or participating victims' opportunity to present their case

72 CAssesse, 2008, p. 386.

73 ZAPPALÀ, 2003, p. 247.

74 Cf. ICC, Prosecutor v. Lubanga Dyilo, Decision on defence's request to obtain simultaneous French 
must be reasonable, but not inconsistent with the rights of the accused. This approach incorporates both considerations of the 'sameness' and the 'differences' necessary to achieve a proper equilibrium between the parties. Fairness as the normative attribute of a trial would be vindicated as such.

\subsection{Final Comment}

It has been argued that the legitimacy of international criminal courts does not depend on the political authority that created these courts, but on the fairness of the procedures and punishment these courts will exemplify: "Tribunals bootstrap themselves into legitimacy by the quality of justice they deliver; their rightness depends on their fairness." 75 Therefore, "tribunals must earn their legitimacy rather than inheriting it" and they cannot afford to "be far from the top" of the recognized fair trial requirements. ${ }^{76}$ Although considerations of fair trial have dominated the international criminal courts' agenda, in rhetoric and practice, some inclinations have been worrying from the perspective of the position of the defendant.

To be clear, the right to a fair trial is not and cannot be seen as the same for the prosecution and the defence. In this light, neither can the principle of equality of arms. A proper understanding of the functioning of both notions is essential for their proper application. The postulate of full equality between the parties cannot be taken literally in many circumstances, as this would elevate the prosecution and marginalize the defence to the extent that the fairness of proceedings would be jeopardized. In this regard, human rights constitute minimum 'perceptions', but should function as 'maximum considerations' in the sense that they should be considered to their maximum..$^{77}$ This means that proper weight should be accorded to the rights of the accused in the overall equation of procedural fairness. To overcome the rhetoric of 'prosecution bias' following from the international criminal law emphasis on ending impunity as a goal, international criminal courts must use the human rights rhetoric by according a proper place to rights and interests where such rights and interests are involved, and by according due weight to both when balancing is needed. Avoiding

transcripts, ICC-01/04-01/06-1091, 14 December 2007, paras. 18-19: “This provision [Article67] (and in particular the phrase "in full equality") suggests that the minimum guarantees must be generously interpreted, so as to ensure the defence is placed insofar as possible on an equal footing with the prosecution, in order to protect fully the right of the accused to a fair trial. [...] An assessment of the adequacy of the facilities for the defence will clearly be influenced by the extent of those at the disposal of the prosecution, since it will in general be necessary and desirable to rectify significant disparities. However, a fact-sensitive evaluation will be required whenever unfairness is alleged, since it will be impossible to create a situation of absolute equality of arms."

75 LuBAn, 2008, p. 13.

76 LuBAN, 2008, p. 13.

77 Cf. Brems, 2009, p. 365: "It is submitted that human rights need both the definition of a nonnegotiable minimum, and a tool monitoring progress towards their full - maximal - guarantee." 
the 'hard' questions does not reflect positively on the legitimacy of the international criminal enterprise. 


\section{SAmenvatting}

Met de oprichting van de ad hoc tribunalen voor Joegoslavië en Rwanda is in de jaren negentig van de vorige eeuw een nieuw impuls gegeven aan de vervolging door internationale straftribunalen van internationale misdrijven, waaronder genocide, misdrijven tegen de menselijkheid en oorlogsmisdrijven. Ongetwijfeld hebben deze tribunalen het pad geëffend voor de totstandkoming van een permanent Internationaal Strafhof (ICC). Na de berechting van de belangrijkste Duitse en Japanse militaire en politieke leiders van de Tweede Wereldoorlog door de Militaire Tribunalen van Neurenberg en Tokio eind jaren veertig van de vorige eeuw, bevond het internationaal strafrecht zich in een winterslaap. De opleving van dit rechtsgebied die is teweeggebracht door de internationale tribunalen heeft veel academische aandacht gegenereerd. Strafrechtelijke leerstukken van materiële en formele aard moesten worden heroverwogen in een strafrechtelijke context die compleet anders is dan die van een nationaal strafrechtelijk systeem. Zowel juridisch-technisch als praktisch, zijn deze internationale straftribunalen gebaseerd op een mengeling van internationaalrechtelijke, strafrechtelijke en mensenrechtelijke beginselen. Deze beginselen worden uitgedragen door mensen met zeer uiteenlopende achtergronden maar met een gezamenlijke ambitie; de verwerkelijking van de doelstellingen van deze instituties. De doelstelling van deze tribunalen is niet alleen de vervolging en bestraffing van verdachten van internationale misdrijven, maar ook het bewerkstellingen van vrede en veiligheid in gebieden die worden geteisterd door (burger)oorlogen; een historische verslaglegging van de misdaden, het brengen van rechtvaardigheid voor de slachtoffers van deze misdaden en het verzoenen van tegenover elkaar staande bevolkingsgroepen.

Eén van de generieke doelstellingen van een modern liberaal strafrechtssysteem is een effectieve en efficiënte vervolging en bestraffing van normovertreders door middel van een accuraat en eerlijk strafproces. Hoewel de nadruk in de academische literatuur over de internationale straftribunalen in het begin vooral lag op de materieelrechtelijke leerstukken (wie worden er vervolgd en voor welke misdrijven), werd later de aandacht verlegd naar het strafproces (hoe moet er worden vervolgd). Het begrip 'eerlijk proces' staat hierbij centraal. De belanghebbenden beseften dat de procedures alleen legitimiteit zouden verkrijgen als deze zowel intern als extern als eerlijk zouden worden ervaren. De invulling van vage normen als 'eerlijk proces' werden door de oprichters van de internationale strafhoven aan de instituties zelf overgelaten. Dat de rechten van de mens zoals ontwikkeld op internationaal 
niveau hierbij een belangrijke rol zouden spelen, werd als vanzelfsprekend beschouwd.

Het recht op een eerlijk proces, zoals vastgelegd in de internationale mensenrechtenverdragen en conventies, wordt in de praktijk uitgelegd in termen van morele en institutionele waarborgen en een aantal concreet geformuleerde rechten die aan een verdachte toekomen. Eén van de centrale rechtsbeginselen die invulling geven aan het recht op een eerlijk proces, is het equality of arms-beginsel (letterlijk 'gelijkheid van wapenen'). Dit beginsel is in de moderne Europese strafprocedures geïntroduceerd door het Europese Hof voor de Rechten van de Mens (EHRM) en ziet op de noodzaak een procedurele gelijkheid tussen de procespartijen te creëren waardoor deze een gelijke kans hebben hun zaak voor een rechter te bepleiten. Hoewel het beginsel aanvankelijk in een civiele procedure werd geïntroduceerd, vond het al snel zijn weg naar het strafrecht.

In moderne strafrechtelijke systemen speelt de overheid een centrale rol bij de vervolging van bestraffing van normovertreders. Deze constatering brengt mee dat er van een gelijkwaardigheid van procesdeelnemers theoretisch geen sprake kan zijn. De openbare aanklager gesteund door een krachtig staatsapparaat is meestal degene die een vervolging tegen een verdachte initieert. Met machtsconcentratie ligt machtsmisbruik op de loer; daarom erkennen de belangrijke algemene internationale mensenrechtenverdragen de fundamentele waarde van het recht op een eerlijk proces en een aantal specifieke rechten ten behoeve van een verdachte. De internationale straftribunalen erkennen dit ook, daarom bevatten alle oprichtingsstatuten bepalingen die een eerlijk proces beogen te waarborgen en de verdachte expliciete minimum rechten toekennen.

De context waarin de internationale strafhoven invulling moeten geven aan de norm van een eerlijk proces is gecompliceerd. Redenen hiervoor zijn bijvoorbeeld de complexiteit van de zaken, de beperkte financiële middelen en de afhankelijkheid van de medewerking van staten voor de meeste onderzoekshandelingen. Het lijkt voor de hand te liggen in internationale strafprocedures een andere invulling te geven aan het equality of arms-beginsel dan in de nationale context onder invloed van mensenrechtelijke toezichtsmechanismen. Tegen deze achtergrond staat in dit onderzoek de volgende vraag centraal: hoe zou het equality of arms-beginsel moeten worden geïnterpreteerd en toegepast in internationale strafprocedures? Voor de beantwoording van deze vraag is een drietal sub-vragen geformuleerd. 1) Welke invulling heeft het equality of arms-beginsel gekregen in het internationale recht van de rechten van de mens? 2) Hoe is het equality of arms-beginsel geïnterpreteerd en toegepast in internationale strafprocedures? 3) Vereisen de karakteristieke kenmerken van het internationaal strafrecht een andere benadering van het equality of armsbeginsel dan zoals dit beginsel is ontwikkeld in het recht van de internationale mensenrechten? 
De normatieve typering van equality of arms die als uitgangspunt van dit onderzoek dient, is dat het eerder een rechtsbeginsel dan een rechtsregel of een recht is. Rechtsbeginselen vertegenwoordigen de ratio van de meer specifieke rechtsregels en functioneren op een normatief niveau als richtinggevend en normerend voor de toepassing van deze rechtsregels. Een belangrijke consequentie hiervan is dat het moeilijk, zo niet onmogelijk is een duidelijke definitie te geven van een beginsel, nu het alleen de richting aangeeft voor de toepassing van de positiefrechtelijke uitwerking van het beginsel in rechtsregels. In de literatuur worden twee concepten van het equality of arms-beginsel onderscheiden, namelijk de mensenrechtelijke, gericht op het verheffen van de inherent zwakkere verdachte tot het niveau van de sterkere aanklager en de adversaire die erop gericht is om condities en regels te creëren voor een eerlijke strijd tussen twee gelijkwaardige partijen. In deze lijn zetten twee parameters het normatieve kader voor dit onderzoek uit: de mensenrechten normen zoals met name uitgelegd door internationale mensenrechteninstanties en de verschillende nationale strafprocesrechtelijke modellen, doelstellingen en uitgangspunten. Wat betreft de mensenrechteninstanties is gekozen voor het Europees Hof voor de Rechten van de Mens (EHRM), en het VN Mensenrechtencomité. De keuze voor deze twee is ingegeven door, onder andere, het belang van deze toezichtsmechanismen en hun jurisprudentie voor de internationale straftribunalen. Centraal in dit onderzoek staan (1) De tribunalen voor Joegoslavië en Rwanda als pioniers van de moderne strafrechtspleging en voorlopers van (2) het Internationaal Strafhof, een permanent hof dat wordt gezien als het belangrijkste hof voor de vervolging van internationale misdrijven op internationaal niveau. Ook de 'geïnternationaliseerde' strafhoven voor Sierra Leone en Cambodja worden maar, in mindere mate, onderzocht. Getracht wordt te komen tot een normatieve invulling van het equality of arms-beginsel in internationale strafprocedures en de (potentiële) invloed ervan op de invulling van het begrip eerlijk proces.

In hoofdstuk 2 en 3 worden de twee noties besproken van het equality of armsbeginsel (de mensenrechtelijke en de adversaire) die dienen als gereedschap voor de analyse in dit onderzoek. Zodoende wordt een basis gelegd voor de evaluatie van de rechtspraktijk van internationale straftribunalen. Hoofdstuk $\mathbf{2}$ besteedt aandacht aan de rol van mensenrechtelijke normen in internationale strafprocedures in het algemeen, en meer specifiek aan de interpretatie en toepassing van het equality of arms-beginsel in het recht van de internationale mensenrechten. Hierbij worden de mensenrechtelijke normen zoals uitgelegd door het EHRM en het Mensenrechtencomité, benaderd als ondergrens. Voor zover de minimumnormen zoals neergelegd in internationale conventies onderdeel zijn gaan vormen van het internationaal gewoonterecht of de algemene rechtsbeginselen, zijn deze normen ook bindend voor internationale straftribunalen. Aangenomen wordt dat het verlagen van 
deze normen voor de internationale tribunalen, een negatief effect zal hebben op de legitimiteit en het voortbestaan van deze instituties.

Het EVRM legt het equality of arms-beginsel uit als een recht van een procespartij op een redelijke mogelijkheid om eigen argumenten te presenteren zonder benadeeld te worden ten opzichte van de tegenpartij. Dit betekent dat een procespartij objectief gezien een redelijke mogelijkheid moet hebben gehad zijn eigen zaak naar voren te brengen en subjectief gezien moet kunnen opereren onder voorwaarden die niet nadeliger zijn dan die van de tegenpartij. In de rechtspraak van het EHRM is deze objectieve mogelijkheid eigen argumenten naar voren te brengen ook geconceptualiseerd in de vorm van het adversaire proces- beginsel dat inhoudt dat een procespartij op de hoogte moet zijn van de standpunten van de tegenpartij. De beginselen van equality of arms en het adversaire proces zijn met elkaar verbonden en bijzonder moeilijk te separeren. De conceptuele verscheidenheid tussen beide begrippen ligt in het relatieve karakter van 'gelijkheid': wanneer beide partijen een gelijke ongelijkheid genieten (zowel de aanklager als de verdachte heeft geen toegang tot een bepaalde procedure), is er geen strijd met het equality of arms-beginsel. Het equality of arms-beginsel wordt geacht te zijn gebaseerd zowel op de individuele minimum rechten van de verdachte als ook op het meer generieke recht op een eerlijk proces. Meer algemeen waarborgt het recht op een eerlijk proces het recht van een verdachte om actief deel te nemen aan het eigen proces. Belangrijk is dat het Europese Hof het proces 'als een geheel' beschouwd. Deze benadering betekent dat de waarborging van de minimum rechten die aan de verdachte zijn toegekend, niet afhangt van de realisering in het eindonderzoek maar ook kan worden geëffectueerd in het vooronderzoek.

De benadering van het Mensenrechtencomité wijkt formeel gezien af van het EHRM in de zin dat het equality of arms-beginsel inhoudt dat in principe dezelfde procedurele rechten aan alle procespartijen worden toegekend, tenzij de wet een onderscheid maakt op objectieve en redelijke gronden. Materieel gezien leiden de benaderingen van het EHRM en het Mensenrechtencomité tot een vergelijkbare uitkomst: elke procedurele ongelijkheid zal alleen dan tot een schending van het equality of arms-beginsel leiden, wanneer er daadwerkelijk nadeel door de verdachte is geleden die is veroorzaakt door de procedurele ongelijkheid.

Hoofdstuk 3 geeft indicaties voor een evaluatief kader vanuit strafprocesrechtelijk perspectief. In dit hoofdstuk worden de grondslagen van het equality of arms-beginsel als de drager van een adversaire strafproces nader bekeken. De rechtstheoretische grondslagen worden afgeleid uit het concept van procedurele rechtvaardigheid. Dit concept is gebaseerd op de bredere noties van legitimiteit en geeft een nadere invulling aan de beginselen van participatie, waarheidsvinding en efficiëntie. De contextuele belangenafweging (balancing) is een centraal element bij de bespreking van de uiteenlopende waarden en doelstellingen die aan een strafproces ten grondslag 
liggen en deze normeren. Twee mogelijke implementatievormen van het concept van procedurele rechtvaardigheid worden nader bezien: het adversaire en het inquisitoire model. Als instrument voor een rechtsvergelijkende invalshoek worden deze twee typeringen als dichotome ideaal-types geconceptualiseerd. Het kardinale verschil tussen beide typeringen bevindt zich op het terrein van de verdeling van verschillende bevoegdheden en rechten over de procespartijen en de positie die zij in het strafproces innemen.

Vanuit een traditioneel adversair perspectief dient er een formele gelijkheid tussen de procespartijen te bestaan. Toch wordt deze 'fair play' benadering als inadequaat ervaren in een strafrechtelijke context waarin de inherente ongelijkheid tussen de vertegenwoordiger van de staat en het individu moet worden erkend. Procedurele rechtvaardigheid wordt dan ook in stand gehouden door de waarborging van bepaalde rechten waarop een verdachte aanspraak kan maken. Over de rol welke deze waarborgen zouden moeten spelen, bestaan verschillende visies. Eén is dat de strikte naleving van deze waarborgen de procedurele gelijkheid in stand houdt. Een andere visie maakt onderscheid tussen wederkerige en niet-wederkerige waarborgen. De minimum rechten die aan de verdachte toekomen, is het voorbeeld van de laatste, net als de institutionele en materiële voordelen die een aanklager geniet. Deze niet-wederkerige rechten zijn absoluut in de zin dat er geen vergelijking mogelijk is. Wederkerige rechten worden relatief afgemeten en toegepast: wat de een krijgt, krijgt de ander ook (zoals het recht om elkaars getuigen te ondervragen). Zo bezien vindt het equality of arms- beginsel alleen toepassing in de relatie tot de wederkerige rechten en plichten.

De rol van het equality of arms-beginsel lijkt op het eerste gezicht in een puur inquisitoir strafproces waar de rechter de taak heeft om de materiële waarheid te onderzoeken alvorens tot een oordeel te komen, beperkt. De kritiek op de inquisitoire procesvoering in het licht van het equality of arms-beginsel, richt zich met name op de beperkte rol van de verdachte, te weten als object van onderzoek. Daarentegen worden andere, in het adversaire proces vanuit equality of arms problematische elementen, wel goed ondervangen in het inquisitoire stelsel, zoals de interne openbaarheid.

Tot slot moet worden opgemerkt dat, hoewel het strafprocesrecht van de ad hoc tribunalen aanvankelijk zeer adversair van aard was, door een de wijziging van procedurele regels en de actievere opstelling van de rechters, de internationale strafprocessen een sui generis karakter hebben gekregen. In de praktijk worden de normen voornamelijk ingevuld aan de hand wat het beste past binnen de specifieke omstandigheden waarin de tribunalen opereren. De traditie waar de zittende rechter vandaan komt en de visie dat internationaal strafproces een compromis tussen adversiare en inquisitoire systemen moet uitstralen hebben een belangrijke invloed uitgeoefend op de wijze waarop de normen in de praktijk worden ingevuld. 
De hoofdstukken 4 tot en met 7 beschrijven en analyseren de internationale strafprocedures aan de hand van vier thema's die verband houden met equality of arms: het vooronderzoek en de rol van de partijen in de voorbereiding van de rechtszaak; het regime van openbaarmaking van eigen onderzoeksresultaten die dienen als processtukken; de institutionele positie van de verdediging en de middelen om de eigen zaak voor te bereiden; en de presentatie van het bewijs ter terechtzitting. Deze thema's zijn met name gekozen omdat hierover veel is geprocedeerd.

Een individu, zelfs een (voormalig) staatshoofd, is niet tegen de macht van de internationale aanklager opgewassen, omdat deze gesteund wordt door de internationale gemeenschap van staten; zo luidt een veelgehoord argument. Hoofdstuk 4 presenteert de resultaten naar het onderzoek over hoe internationale rechters dit argument hebben benaderd en welke maatregelen zijn genomen om de schijn van ongelijkheid te compenseren. In dit hoofdstuk wordt aandacht besteed aan de positie van de aanklager als onafhankelijke waarheidsvinder, aan de mogelijkheid voor de verdediging om eigen onderzoek in te stellen, de problematiek van de samenwerking met de staten en de procedure rondom het verkrijgen van een assistentiebevel van de rechters, en de functionele immuniteit van het verdedigingsteam. De algemene lijn van de tribunalen wanneer zij worden geconfronteerd met het argument dat de verdediging niet in staat is gebleken om zich voldoende voor te bereiden op de zitting door de gebrekkige samenwerking met de staten, is de 'liberale benadering' zoals voor het eerst uitgesproken door het Joegoslavië tribunaal in de zaak Tadić. Deze benadering van het equality of arms-beginsel binnen internationale procedures betekent in de eerste plaats dat de aanklager en de verdediging zich voor het tribunaal in principieel gelijke posities bevinden, in de tweede plaats dat de rechters de verantwoordelijkheid dragen om de partijen actief te assisteren in het verkrijgen van de nodige medewerking van de staten en in de derde plaats dat de rechters een puur procedurele benadering hebben gekozen met betrekking tot de waarborging van het equality of arms-beginsel. Dit vaak met weinig expliciete aandacht voor de ongelijkheid tussen de procespartijen zoals deze in het strafproces en de werkelijkheid bestaat.

Met name de neutrale rol van de aanklager verdient meer aandacht. Een objectieve aanklager kan in potentie de (schijn) van ongelijkheid tussen de procespartijen met betrekking tot de onderzoeksmogelijkheden, opheffen. Zonder uit het oog te verliezen dat het voor de aanklager moeilijk is de rol van een 'quasi-magistraat' en een adversaire partij te vereenzelvigen, moeten rechters consistenter en explicieter de rol van een 'quasi-magistraat' onderstrepen.

Met betrekking tot het honoreren van verzoeken tot assistentie zijn rechters in de praktijk redelijk flexibel geweest. Hoewel het uitvaardigen van een bindend bevel tot samenwerking als een ultimum remedium werd gezien, is de drempel voor de verdediging om zo een assistentiebevel te verkrijgen niet te hoog. Rechters hebben op verschillende manieren getracht medewerking van de staten met de verdediging 
te bewerkstelligen. Soms kozen rechters ervoor om via de aanklager de door de verdediging benodigde materialen van een niet-coöperatieve staat te verkrijgen. Ambtenaren van een staat werden zelfs onder dwang van een sanctie opgeroepen om bij het tribunaal te verschijnen ten behoeve van een ex parte interview met het verdedigingsteam. Het uitvaardigen van aan subpoena voor een staat werd onaanvaardbaar geacht in het licht van het belang van het soevereiniteitsbeginsel. Desalniettemin moet in de context van het Internationaal Strafhof, de procedure voor het verkrijgen van de medewerking van staten ten behoeve van de verdediging, beter worden gestroomlijnd. Er dient een beter juridisch- en beleidskader te worden ontwikkeld. Met name het vereiste dat een redelijke inspanning van de verdediging wordt gevergd, is niet duidelijk. Wat moet de verdediging in praktische termen ondernemen en op welke wijze moet zij haar verzoek onderbouwen, om assistentie van de rechters te verkrijgen? De huidige benadering, waarin de verdediging eerst zelfstandig, daarna via de Registry en daarna via rechters, staten moet verzoeken om bepaalde gegevens te leveren of onderzoekshandelingen uit te voeren is, vanuit het perspectief van de schaarsheid van middelen, bestempeld als omslachtig en arbeidsintensief.

Hoofdstuk 5 bespreekt het regime van de toegang tot processtukken bij internationale strafhoven. Het equality of arms-beginsel wordt mede geëffectueerd door het recht van de verdediging om voldoende tijd en middelen ter beschikking te hebben voor de voorbereiding en presentatie. Dit recht omvat als een belangrijke voorwaarde toegang tot de materialen waarop de aanklacht is gebaseerd. Tevens wordt de objectieve rol van de aanklager als een 'quasi-magistraat' onderstreept door de verplichting om de verdediging ten minste toegang te verschaffen tot potentieel ontlastend materiaal. Alle internationale tribunalen hebben het adversaire systeem van disclosure gekozen wat betreft de toegang tot en uitwisseling van processtukken. De ratio van disclosure is te voorkomen dat de tegenpartij onverhoeds met onbekende gegevens wordt geconfronteerd en dient de procedurele rechtvaardigheid. Vanwege de machtsongelijkheid tussen aanklager en verdachte, hangt het kunnen voorbereiden van een verdediging voor een groot deel af van de toegang tot de processtukken. Zonder deze toegang heeft het equality of arms-beginsel geen betekenis. Het disclosure regime heeft veel debat gegenereerd en bij de verdediging tot veel frustratie en klachten geleid. Onderzocht wordt hoe het disclosure regime heeft geleid tot een betekenisvolle interpretatie en toepassing van equality of armsbeginsel. Kort wordt ingegaan op de algemene verplichting van de aanklager om processtukken aan de verdediging te overleggen en de uitzonderingen die hierop van toepassing zijn. De nadruk van dit hoofdstuk ligt op de verplichting van de aanklager om potentieel ontlastend bewijs aan de verdediging de overhandigen. Ook wordt ingegaan op de disclosure-verplichtingen zoals deze gelden voor de verdediging, nu deze verplichtingen theoretisch gezien een enigszins problematische relatie hebben 
tot de verdedigingsrechten. Interessant hierbij is in hoeverre het beginsel van equality of arms de ontwikkeling van deze verplichtingen hebben gestuurd.

Bij de ad hoc tribunalen hebben de ervaringen die in de praktijk zijn opgedaan, geleid tot aanzienlijke aanpassingen van het oorspronkelijke disclosure systeem. Deze veranderingen zijn ingegeven door overwegingen van procedurele rechtvaardigheid, equality of arms, het beginsel van interne openbaarheid en een efficiënte procesvoering. Het fundamentele belang van de verdediging om toegang te hebben tot potentieel ontlastend bewijs, werd door de rechters onderstreept. Zij hebben er voor gekozen de aanklager ruime disclosure verplichtingen op te leggen. Het veranderde karakter van het disclosure regime heeft er toe bijgedragen dat zelfs in de laatste jaren van het functioneren van de ad hoc tribunalen, dit regime niet kan worden bestempeld als helder en ondubbelzinnig. In het algemeen kan worden gesteld dat rechters weinig principiële overwegingen hebben gewijd aan de relatie tussen disclosure en de (objectieve) rol van de aanklager en de ultieme verantwoordelijkheid van de rechter voor de waarheidsvinding.

Door de jaren heen heeft het equality of arms-beginsel bijgedragen aan het gelijktrekken van de disclosure verplichtingen van de partijen. De eindstand bij de ad hoc tribunalen is op dit moment dat op beide partijen de (gelijke) verplichting rust om het materiaal dat ter terechtzitting gebruikt zal worden, toegankelijk te maken voor de tegenpartij en de rechters. Het disclosure regime bij het Internationaal Strafhof bouwt voort op het systeem van de ad hoc tribunalen, zoals dit bestond ten tijde van totstandkoming van het ICC- Statuut. Globaal genomen bestaat het disclosure regime uit twee soorten verplichtingen die in meer of mindere mate gelden voor beide procespartijen: één is disclosure stricto sensu (het delen van het bewijs dat ter terechtzitting zal worden aangedragen) en de andere is dat de tegenpartij toegang moet worden verschaft tot bepaalde materialen. Opmerkelijk is dat bij het Joegoslavië tribunaal laatst genoemde verplichting voor de verdediging uiteindelijk is afgeschaft. Maar het ICC regime bevat meer 'inquisitoire' elementen. Dit komt tot uiting in twee structurele elementen: (1) de actieve, controlerende rol van de PreTrial Chamber die meebrengt dat alle inter partes disclosure ook aan de rechters moet worden voorgelegd; en (2) de expliciete objectieve rol die de aanklager verplicht om onderzoek te doen naar zowel belastend als ontlastend materiaal ter fine van de waarheidsvinding. Vanaf het begin hebben de ICC rechters sterk het coöperatieve karakter van de disclosure praktijk onderstreept. Tegelijkertijd worden de lijnen strak gehouden als het gaat om de verantwoordelijkheid van de procespartijen voor het bijdragen aan een eerlijk en efficiënt proces. De eerste praktijk van het Strafhof laat zien dat het verwezenlijken van de objectieve rol van de aanklager zo makkelijk nog niet is. In de eerste zaak voor het hof, de Lubanga zaak, werd tot twee keer toe een schorsing van de zaak en vrijlating van de verdachte bevolen vanwege de disclosure praktijk van de aanklager. 
Ten aanzien van de sanctionering van de overtreding van disclosure verplichtingen door de aanklager, heeft de rechter in een aantal gevallen uitsluiting van bewijs bevolen. Talloze waarschuwingen, bevelen om de voortgang van de dislcosure te rapporteren en aanhouding van de zaak om de verdediging de tijd te geven om de laat toegankelijk gemaakte documenten alsnog te kunnen bestuderen, zijn de voornaamste acties die zijn ondernomen. Sommigen hebben gepleit voor een strengere sanctionering van de disclosure overtredingen. Maar rechters hebben voor een terughoudende aanpak gekozen die meer is gericht op herstel van geleden nadeel dan op het sanctioneren per se. Deze rechterlijke aarzeling, bijna onwil, om de disclosure overtredingen te sanctioneren heeft veel frustratie bij de verdedigingsteams veroorzaakt. Betoogd wordt dat de geringe aandacht voor de sanctionering van dislcosure overtredingen de perceptie creëert van rechterlijke tolerantie voor een zeer onbehoorlijke praktijk. Voorts geeft het gebrek aan sanctionering weinig stimulans tot zoeken naar een oplossing voor de tekortkomingen in het systeem die wellicht de oorzaak vormen van de praktische problemen met betrekking tot de disclosure.

Hoofdstuk 6 richt zich op een ander belangrijk punt van aandacht met betrekking tot de implementatie van het equality of arms-beginsel, namelijk het hebben van voldoende (financiële) middelen om de verdediging voor te kunnen bereiden. De discrepantie tussen de middelen die de procespartijen tot beschikking hebben en de daaruit voortvloeiende (schijn van) ongelijkheid, is een herhaaldelijk door de verdediging aangevoerd argument. Dit argument wordt vaak in de sleutel van equality of arms gepresenteerd. Tevens was de institutionele inbedding, of het gebrek ervan, een bron van frustratie en de perceptie van ongelijkheid. Twee thema's moeten worden onderscheiden: (1) het recht voldoende faciliteiten ter beschikking te hebben ter voorbereiding van de verdediging; en (2) het recht zich in persoon of door middel van een advocaat te kunnen verdedigen, indien men zelf niet voldoende middelen heeft, op kosten van het tribunaal. Dit hoofdstuk onderzoekt de invulling van het equality of arms-beginsel vanuit een institutioneel perspectief en geeft een nadere analyse van de institutionele positionering van de verdediging en de manier waarop de tribunalen invulling hebben gegeven aan het recht op een kosteloze rechtsbijstand. Meer specifiek is ervoor gekozen om te onderzoeken hoe de strafhoven de klachten over onvoldoende middelen hebben afgedaan en welke ruimte er is gecreëerd voor reparatie.

De rol van het equality of arms-beginsel waar het gaat om het ter beschikking stellen van middelen en faciliteiten die aan de procespartijen ter beschikking staan, is niet geheel evident noch onomstreden. Bezien vanuit het verschil van de rollen van de procespartijen is het duidelijk dat equality of arms niet inhoudt dat er een volledige gelijkheid van middelen en faciliteiten tussen de procespartijen moet worden gecreëerd. Noch is het zo dat vanwege de onmogelijkheid een directe vergelijking te maken tussen de partijen, er aan het equality of arms-beginsel in deze 
sfeer helemaal geen betekenis toekomt. Als fundamenteel beginsel is equality of arms intrinsiek verbonden met elk systeem van rechtsbijstand omdat de ratio van een dergelijk systeem, het voorkomen van procedurele ongelijkheid tussen de aanklager en de verdachte nastreeft.

De benadering die de tribunalen hebben gekozen is dat het equality of armsbeginsel niet letterlijk moet worden opgevat. Dit beginsel houdt dus niet in dat de aanklager en de verdachte dezelfde financiële, technische en personele middelen ter beschikking moeten worden gesteld. Aldus is de toepassing van het beginsel beperkt en lijkt het geen zelfstandige inhoud te kennen in de context van de ongelijkheid tussen partijen op het gebied van middelen en faciliteiten. Naast deze retoriek staat de praktijk waarbij de rechters hebben vastgehouden aan het principe alleen te willen ingrijpen als de verdediging aannemelijk kan maken dat ontoereikende middelen tot ondermijning van een eerlijk proces zou leiden. Hierbij staat de vraag centraal of de verdediging zich adequaat heeft kunnen voorbereiden. Op dit gebied is de verdediging zelf in sterke mate verantwoordelijk voor een goede verdeling van de ter beschikking gestelde midden. Opmerkelijk is dat op één gebied met betrekking tot de financiële verdeling, het equality of arms-beginsel een letterlijke uitwerking heeft gekregen. De verdediging heeft herhaaldelijk betoogd dat er een bepaalde mate van gelijkwaardigheid van middelen moet worden gecreëerd tussen de aanklager en de verdediging om tot een betekenisvolle toepassing van het equality of armsbeginsel te komen. Zodoende zijn de salarissen van de senior aanklagers en de advocaten bij het Internationaal Strafhof en het Speciaal Tribunaal voor Libanon, vrijwel gelijkgetrokken. Betoogd wordt dat hoewel deze benadering de gemoederen ten aanzien van de ongelijkheid tussen de procespartijen enigszins tot bedaren heeft gebracht, dit in feite weinig zegt over de mogelijkheid van de verdediging zich voldoende te kunnen voorbereiden op de zaak.

Tot slot, de gelijktrekking van procespartijen heeft ook vanuit het institutioneel perspectief aandacht gekregen. Buiten de $a d$ hoc tribunalen om heeft de verdediging zich georganiseerd in een redelijk functionerende orde van advocaten en erkenning afgedwongen bij de tribunalen. Strafhoven die later in het leven zijn geroepen hebben allen een soort van institutionele positie voor de verdediging gecreëerd. Bij het Speciale Tribunaal voor Libanon heeft de verdediging zelfs een positie als vierde institutionele orgaan verkregen. Over de wenselijkheid van het creëren van een vaste institutionele inbedding van de verdediging als een orgaan van de strafhoven bestaan uiteenlopende meningen. Deze studie onderschrijft de initiatieven ter versterking van institutionele positie van de verdediging.

De focus van Hoofdstuk 7 ligt op het eindonderzoek. In deze fase nemen de partijen de meest adversaire posities in en leggen zij hun visie op de zaak aan een panel van rechters voor. Alle onderzochte tribunalen (behalve het Cambodja tribunaal), structureren het eindonderzoek in fasen. Eerst vindt de bewijspresentatie door de 
aanklager plaats, daarna komt de verdediging aan het woord. Rechters kunnen te allen tijde vragen stellen aan getuigen en kiezen er vaak voor om dat zo veel mogelijk aan het begin te doen, of na afloop, om de strategie van de procespartij zo veel mogelijk in stand te laten. Eventueel participerende slachtoffers hebben de mogelijkheid hun visie naar voren te brengen na de aanklager, maar voor de verdediging. De procespartijen lijken het meest gelijk in deze fase van het onderzoek. Aan beiden moet voldoende mogelijkheden worden geboden de eigen zaak naar behoren te presenteren. Hoewel het primaat van bewijsvoering nog steeds bij de partijen ligt, hebben de rechters een steeds actievere en controlerende rol op het terrein van de presentatie van het bewijs naar zich toegetrokken. Hierbij wordt de bewijspresentatie door de aanklager als voorbeeld genomen voor de verdediging in termen van de hoeveelheid tijd die en het aantal mogelijke getuigen dat aan de verdediging ter beschikking wordt gesteld.

Van groot belang is de doelstelling om volledige gelijkheid tussen de partijen te waarborgen. Zo heeft de Appeals Chamber van het Joegoslavië tribunaal geconcludeerd dat het moeilijk zou zijn te bevatten hoe een proces als eerlijk zou kunnen worden bestempeld indien de verdediging ten koste van de aanklager zou worden bevoordeeld. Dit natuurlijk afgezien van de strikte naleving van de fundamentele rechten van de verdachte. Andere kamers hebben eveneens in hun beslissingen 'het recht van de aanklager op adequate tijd voor presentatie van bewijs' tegen het recht van de verdachte afgewogen. In de Orić-zaak hebben de rechters een mathematische interpretatie van het equality of arms-beginsel uitgesloten. Bepaald is onder andere dat de tijd die de verdediging ter beschikking krijgt en de hoeveelheid getuigen die zij mag oproepen, proportioneel ten aanzien van de aanklager en 'objectief adequaat' moet zijn. In de praktijk echter, hebben rechters de tijd en het aantal getuigen eerder op mathematische wijze bepaald.

Terwijl zinsneden als 'het waarborgen van een eerlijk proces' of 'in overeenstemming met de rechten van de verdachte', aan bod zijn gekomen in bijna iedere relevante discussie, is een diepgaande evaluatie van de meer fundamentele vraagstukken ten aanzien van de verdedigingsrechten niet of nauwelijks te vinden. Nog minder aandacht is besteed aan reflectie over principiële vragen zoals de basis voor het recht van de aanklager op een eerlijk proces en ook andere rechten die formeel gezien alleen de verdachte toekomen.

Tot slot, het nieuwe structurele element van de participatie van slachtoffers bij het Internationaal Strafhof en het Cambodja tribunaal heeft voor veel uitdagingen gezorgd zowel uit principieel, alsook uit praktisch perspectief. Bezien vanuit het equality of arms-beginsel, is één van de grootse uitdagingen voor deze hoven, een manier te vinden hoe participatierechten van slachtoffers, vooral het recht om getuigen te ondervragen en bewijs aan te dragen, te verzoenen zijn met het recht van de verdachte niet geconfronteerd te worden met meerdere aanklagers. Op zichzelf bevat slachtofferparticipatie geen principiële obstakels voor een betekenisvolle toepassing van het equality of arms-beginsel tussen partijen. Echter, in de praktijk 
heeft slachtofferparticipatie de procespartijen voor veel uitdagingen gesteld. Vanuit een praktisch perspectief moeten rechters bedachtzaam zijn op de verschillen tussen de rechten en de belangen van de participanten in het strafproces.

Tot slot presenteert Hoofdstuk 8 de synthese en de conclusies die uit dit onderzoek voortvloeien. Hieronder zullen de algemene lijnen worden weergegeven. De meer specifieke conclusies zijn al in de bespreking per hoofdstuk aan bod gekomen. Drie elementen die volgen uit de centrale vraag, hoe zou het equality of arms-beginsel moeten worden geïnterpreteerd en toegepast in internationale strafprocedures, zullen worden besproken: (1) de interpretatie en (2) de toepassing van het equality of armsbeginsel in internationale strafprocedures; en (3) normatieve overwegingen in relatie tot de benadering van het concept van een eerlijk proces in het algemeen en het equality of arms-beginsel in het bijzonder.

Internationale tribunalen hebben zich over de hele linie de benadering van het EHRM en het Mensenrechtencomité betreffende het equality of arms-beginsel eigen gemaakt. Niettemin lijkt er verwarring en onzekerheid te bestaan over de reikwijdte van het equality of arms-beginsel. Twee punten zijn van bijzonder belang, namelijk de interpretatie en toepassing van het beginsel in het vooronderzoek en het eindonderzoek; en het idee dat het beginsel zowel van toepassing is op de verdediging als op de aanklager. Met betrekking tot de twee belangrijke karakteristieken van het vooronderzoek in internationale strafprocedures, namelijk de afhankelijkheid van de medewerking van staten en de behoefte van de verdediging aan financiële en personele middelen om eigen onderzoek te verrichten, blijkt uit de jurisprudentie van de ad hoc tribunalen dat het equality of arms-beginsel geen substantiële gelijkheid tussen procespartijen inhoudt. Dit beginsel moet blijkbaar 'liberaler' worden uitgelegd dan in een nationale context, vanwege de volledige afhankelijkheid van de tribunalen van de medewerking van de nationale staten. In het algemeen heeft deze meer liberale uitleg van het equality of arm-beginsel de mogelijkheid geopend rekening te houden met de karakteristieken van de context waarin de tribunalen moeten opereren. In het eindonderzoek is het equality of arms-beginsel uitgelegd in het licht van twee elementen, namelijk de proportionaliteit en 'objectieve adequaatheid'. Beiden zijn noodzakelijk voor het bepalen van de tijd die aan de verdediging ter beschikking wordt gesteld, voor de presentatie van het bewijs en de hoeveelheid getuigen die zij mag oproepen. Hoewel een mathematische toepassing van het equality of armsbeginsel werd uitgesloten, blijkt het in de praktijk moeilijk te zijn de presentatie van het bewijs op een andere manier te reguleren. De eis van gelijkheid tussen de partijen wordt hier tamelijk letterlijk opgevat.

Het werd snel duidelijk dat het equality of arms-beginsel ook relevant is voor de aanklager. Het 'eerlijk proces'-beginsel is alomvattend uitgelegd en aldus toepasselijk geacht op alle procesdeelnemers (aanklager, verdediging en participerende slachtoffers). Als rechtvaardiging voor deze uitleg hebben de internationale rechters 
vaak verwezen naar de afhankelijkheid van beide partijen van de samenwerking van staten en het feit dat de aanklager zowel de internationale gemeenschap als de slachtoffers vertegenwoordigd. In deze benadering functioneert het equality of armsbeginsel tussen de procespartijen en heeft het geen invloed op de fundamentele rechten van de verdachte. Deze uitleg strookt niet met de benadering van het EHRM en het Mensenrechtencomité die het equality of arms-beginsel zowel op het algemene recht op een eerlijk proces als op de minimumrechten van de verdachte hebben gebaseerd.

Het systeem van de internationale vervolging van internationale misdrijven is in het leven geroepen om te zorgen voor gerechtigheid voor de slachtoffers en de internationale gemeenschap. Het concept van procedurele rechtvaardigheid, wat is vertaald naar een strafproces dat een adequate bestraffing door middel van een eerlijk proces bereikt, is geworteld in het idee van gerechtigheid. Hiervoor heeft de aanklager een verplichting te bewijzen dat de verdachte zich schuldig heeft gemaakt aan de feiten die aan een aanklacht ten grondslag liggen. Indien deze verplichting niet kan worden geëffectueerd, vervalt de basis voor een eerlijk en accuraat oordeel, en daarmee een rechtvaardige uitkomst. Echter, rechtvaardigheid in de zin van een accurate uitkomst alsook in de zin van een eerlijk proces, kan alleen worden bereikt indien de verdachte een redelijke kans tot participatie heeft gekregen de aanklacht te weerleggen. Om dit mogelijk te maken is het waarborgen van bepaalde individuele rechten van groot belang. Deze rechten beschermen het individu tegen het oneigenlijk gebruik door de aanklager van zijn macht.

Het recht op een eerlijk proces, in de zin van een juridisch afdwingbare bescherming van een individu, is het recht van de verdachte in het strafproces. De belangen van de verdachte worden beschermd door de procedurele rechten waarop hij aanspraak kan maken. Deze procedurele rechten vinden hun rechtvaardiging in twee verschillende gronden, namelijk (1) autonomie en (2) accuraatheid. De procedurele rechten van de verdachte beschermen niet alleen de belangen van een menswaardige behandeling en van de mogelijkheid tot participatie van een individu, maar benadrukken ook het belang van accurate beslissingen die door middel van een adversaire manier van waarheidsvinding tijdens het proces moeten worden verkregen. Deze procedurele rechten dienen dus meer belangen dan uitsluitend de bescherming van de individuele rechten.

Procedurele rechtvaardigheid in de zin van een equilibrium of balans omvat het respect voor de gelijkwaardigheid tussen de procesdeelnemers. Echter, de nadruk op gelijkwaardigheid in de zin van uniformiteit kan resulteren in een systematische veronachtzaming van de verschillen tussen de partijen. Een symmetrie in het strafproces is niet haalbaar; de gelijkheid tussen partijen komt tot uitdrukking in 'balanced empowerment' - de voorrechten worden naar gelang het procesbelang en de procesposities toegekend. Om niet te verzanden in de mechanische afweging of iedere procespartij dezelfde rechten heeft gekregen of in de puur theoretische overwegingen over gelijkheid, ligt een functionele benadering het meest voor de 
hand. Een normatief oordeel dient dan te worden voorafgegaan door een onderzoek naar de contextuele procesposities en de belangen van de partijen alsmede naar de toegekende structurele (voor)rechten.

Om het toepassingsbereik van het equality of arms-beginsel te begrijpen, moeten twee functies van dit beginsel in het oog worden gehouden, de mensenrechtelijke en de adversaire. Deze studie onderschrijft dat een principiële benadering van het equality of arms-beginsel, het recht op een eerlijk proces en het beginsel van procedurele rechtvaardigheid moet worden toegepast in internationale strafprocedures. Het toekennen van het recht op een eerlijk proces aan de verdachte impliceert niet dat voor andere procesdeelnemers het beginsel van de procedurele rechtvaardigheid niet geldt, maar houdt wel in dat een passend gewicht moet worden toegekend aan de verschillende belangen van de verschillende procespartijen. Hoewel in het licht van de rollen en verantwoordelijkheden van de procespartijen, alleen wat betreft de 'wederkerige' rechten gelijkheid kan worden geëffectueerd, moet de mensenrechtelijke functie van het equality of arms-beginsel prioriteit genieten en dient ter afbakening van procedurele rechten van andere deelnemers.

De tweeledige Orić test is in lijn met de benadering van het EHRM en het Mensenrechtencomité en is een geschikt instrument om de verdedigingsbelangen in het strafproces te evalueren. Het eerste, formele element betreft de vraag of de verdediging een mogelijkheid heeft gehad om eigen argumenten naar voren te brengen op een manier die enigszins proportioneel is met die van de aanklager. Het tweede, materiële element ziet op de vraag of deze mogelijkheid redelijk adequaat was. Het eerste element betreft primair een voorvraag. Bij een negatief antwoord is het onderzoek naar de 'objectieve adequaatheid' overbodig. Indien er sprake is van enigszins proportionele verhoudingen, zal het tweede element onderzoek behoeven. Bij de waardering wat nu objectief gezien nodig is voor de verdediging om een zaak adequaat te kunnen voorbereiden en te presenteren, kunnen subjectieve (vergelijkende) elementen van invloed zijn; het is nu eenmaal de aanklager die de zaak aanbrengt, beschuldigen uit, en voor een groot deel de omvang van deze beschuldigingen bepaalt. De aanklager of de participerende slachtoffers wordt de mogelijkheid geboden hun zaak naar voren te brengen, zolang dit niet in strijd is met de rechten van de verdachte. Deze benadering houdt rekening met de belangrijkste factoren die nodig zijn bij het bepalen van een procedureel evenwicht tussen de partijen waardoor de gewenste procedurele rechtvaardigheid wordt gewaarborgd.

Ter afsluiting, betoogd is dat de legitimiteit die de internationale tribunalen kunnen uitdragen voornamelijk afhangt van de kwaliteit van hun procesvoering. Of zij in staat zijn 'gerechtigheid' te brengen hangt af van de mate waarin zij procedurele rechtvaardigheid kunnen realiseren. Hoewel overwegingen over een 'eerlijk proces' zowel in de retoriek als in de praktijk van internationale tribunalen een prominente rol spelen, kunnen sommige toepassingen als zorgelijk worden bestempeld vanuit het perspectief van de rechten van de verdachte. Het 'recht' op een eerlijk proces betekent 
voor de aanklager en de verdediging niet hetzelfde. Dit geldt ook voor het equality of arms-beginsel. Het postulaat van volledige gelijkheid tussen de procespartijen kan in vele situaties niet letterlijk worden opgevat, omdat dit de rechten van de verdachte zou marginaliseren en de aanklager, ten onrechte, bevoordelen, waardoor procedurele rechtvaardigheid in het geding kan komen. De rechten van de verdachte zijn geformuleerd als minimumnormen, maar het streven zou moeten zijn naar een maximale verwezenlijking van deze rechten. Relevante rechten en belangen mogen niet uit het oog worden verloren. Aan de rechten en belangen van de verdediging moet te allen tijde voldoende gewicht worden toegekend wanneer een belangenafweging met andere procesdeelnemers noodzakelijk is. 


\section{BibliograPHY}

Akande, Dapo, Sources of International Criminal Law, in: Antonio Cassese (ed.), The Oxford Companion to International Criminal Justice, (Oxford: Oxford University Press), 2009, pp. 41-53.

Akandji-Kombe, Jean-François, Positive Obligations under the European Convention on Human Rights: a Guide to the Implementation of the European Convention on Human Rights, (Strasbourg: Council of Europe), 2007, Human Rights Handbooks No. 7.

Alexander, Larry and Ken Kress, Against Legal Principles, Iowa Law Review, vol. 82, no. 3, 1997, pp. 739-786.

Alexy, Robert, A Theory of Constitutional Rights, (Oxford: Oxford University Press), 2002.

Allen, Ronald J., Truth and its Rivals, Hastings Law Journal, vol. 49, no. 2, 1997/1998, pp. 309-320.

Ambos, Kai, Confidential Investigations (Article 54(3)(e) ICC Statute) vs. Disclosure Obligations: The Lubanga Case and National Law, New Criminal Law Review, vol. 12, no. 4, 2009, pp. 543-568.

Ambos, Kai, The Status, Role and Accountability of the Prosecutor of the International Criminal Court: A Comparative Overview on the Basis of 33 National Reports, European Journal of Crime, Criminal Law and Criminal Justice, vol. 8, no. 3, 2000, pp. 89-118.

Arbour, Louise, Armed Conflicts and Access to International Justice: The Need for an Independent and Effective Prosecutor In the Permanent International Criminal Court, Windsor Yearbook of Access to Justice, vol. 17, 1999, pp. 207-220.

Arendt, Hannah, Eichmann in Jerusalem: A Report on the Banality of Evil, (Penguin Books), 2006.

Ashworth, A.J., Concepts of Criminal Justice, Criminal Law Review, vol. 26, 1979, pp. 412-427.

Ashworth, Andrew and Mike Redmayne, The Criminal Process, $3^{\text {rd }}$ ed., (Oxford: Oxford University Press), 2010.

Assembly of State Parties, Report of the Bureau on Cooperation, ICC-ASP/6/21, 19 October 2007.

Asser, Daan, Audi et Alteram Partem: a Limit to Judicial Activity, in: A.D.E. Lewis and D.J. Ibbetson (eds.), The Roman Law Tradition, (Cambridge: Cambridge University Press), 1994, pp. 209-223.

Ávila, Humberto, Theory of Legal Principles, (Dordrecht: Springer), 2007.

Bass, Gary Jonathan, Stay the Hand of Vengeance: The Politics of War Crimes Tribunals, (Princeton University Press), 2001.

Bassiouni, Cherif M., Human Rights in the Context of Criminal Justice: Identifying International Procedural Protections and Equivalent Protections in National Constitutions, Duke Journal of Comparative and International Law, vol. 3, 1993, pp. 235-297.

Bassiouni, Cherif M., Negotiating the Treaty of Rome on the Establishment of an International Criminal Court, Cornell International Law Journal, vol. 32, no. 3, 1999, pp. 443-470. 
Bibliography

Bayles, Michael, Hart vs. Dworkin, Law and Philosophy, vol. 10, no. 4, 1991, pp. 349-381. Bergsmo, Morten and Kruger, Pieter Article 54: Duties and Powers of the Prosecutor with Respect to Investigations, in: Otto Triffterer (ed.), Commentary on the Rome Statute of the International Criminal Court: Observers' Notes, Article by Article, $2^{\text {nd }}$ ed., (Munich: Beck), 2008, pp. 1077-1088.

Bergsmo, Morten and Wiley, William H., Human Rights Professionals and the Criminal Investigation and Prosecution of Core International Crimes, in: Siri Skåre, Ingvild Burkey and Hege Mørk (eds.), NORDEM Manual on Human Rights Monitoring. An Introduction for Human Rights Field Officers, (Norwegian Centre for Human Rights, University of Oslo), 2008, available at: http://www.jus.uio.no/smr/english/about/programmes/nordem/ publications/manual/current/kap10.pdf (last accessed on 27 January 2012).

Bitti, Gilbert, Article 64, in: Otto Triffterer (ed.), Commentary on the Rome Statute of the International Criminal Court: Observers' Notes, Article by Article, $2^{\text {nd }}$ ed., (Munich: Beck), 2008, pp. 1199-1218.

Black's Law Dictionary, $7^{\text {th }}$ ed., Bryan A. Garner (ed.), (West Group), 1999.

Blackstone, William, Commentaries on the Laws of England, Book the Third (London: Dawsons of Pall Mall), 1966. - reprint of the first edition Oxford: Clarendon Press, 1768.

Blackstone, William, Commentaries on the Laws of England, Book the Fourth (Boston: Beacon Press), 1962.

Block, Michael K. ... [et al.], An Experimental Comparison of Adversarial versus Inquisitorial Procedural Regimes, American Law and Economics Review, vol. 2, no. 1, 2000, pp. 170-194.

Boas, Gideon ... [et al.], International Criminal Procedure, (New York: Cambrige University Press), 2011.

Bonomy, Iain, The Reality of Conducting a War Crimes Trial, Journal of International Criminal Justice, vol. 5, no. 2, 2007, pp. 348-359.

Borchert, Donald M. (ed.), Encyclopedia of Philosophy, $2^{\text {nd }}$ rev. and updated ed., (Detroit etc.: Macmillan Reference USA), 2006.

Boyne, Shawn Marie, Uncertainty and the Search for Truth at Trial: Defining Prosecutorial "Objectivity" in German Sexual Assault Cases, Washington and Lee Law Review, vol. 67, no. 4, 2010, pp. 1287-1360.

Bracey, Christopher A., Truth and Legitimacy in the American Criminal Process, Journal of Criminal Law and Criminology, vol. 90, no. 2, 1999-2000, pp. 691-728.

Brady H., Disclosure of Evidence, in: Roy S. Lee and Håkan Friman (eds.) The International Criminal Court, Elements of Crimes and Rules of Procedure and Evidence, (Transnational Publishers), 2001.

Brems, Eva, Human Rights: Minimum and Maximum Perspectives, Human Rights Law Review, vol. 9, no. 3, 2009, pp. 349-372.

Brennan, William J. Jr., The Criminal Prosecution: Sporting Event or Quest for Truth? A Progress Report, Washington University Law Quarterly, vol. 68, no. 1, 1990, pp. 1-18.

Brubacher, Matthew R., Prosecutorial Discretion within International Criminal Court, Journal of International Criminal Justice, vol. 2, no. 1, 2004, pp. 71-95.

Buergenthal, Thomas, Dinah Shelton and David P. Stewart, International Human Rights in a Nutshell, $3^{\text {rd }}$ ed., (St. Paul, MN: West), 2002. 
Bufford, Samuel L., Center of Main Interests, International Insolvency Case Venue, and Equality of Arms: the Eurofood Decision of the European Court of Justice, Northwestern Journal of International Law and Business, vol. 27, no. 2, 2007, pp. 351-420.

Byrne, Rosemary, The New Public International Lawyer and the Hidden Art of International Criminal Trial Practice, Connecticut Journal of International Law, vol. 25, no. 2, 2010, pp. 243-304.

Cançado Trindade, Antonio Augusto, The Merits of Coordination of International Courts on Human Rights, Journal of International Criminal Justice, vol. 2, no. 2, 2004, pp. 309-312.

Cassese, Antonio, Opinion: The ICTY and Human Rights, European Human Rights Law Review, vol. 2, 1997, pp. 329-352.

Cassese, Antonio, On the Current Trends towards Criminal Prosecution and Punishment of Breaches of International Humanitarian Law, European Journal of International Law, vol. 9, no. 1, 1998, pp. 2-17.

Cassese, Antonio, The Statute of the International Criminal Court: Some Preliminary Reflections, European Journal of International Law, vol. 10, 1999, pp. 144-171.

Cassese, Antonio, The Contribution of the International Criminal Tribunal for the Former Yugoslavia to the Ascertainment of General Principles of Law Recognized by the Community of Nations', in: Sienho Yee and Wang Tieya (eds.), International Law in the Post-Cold War World: Essays in Memory of Li Haopei, (Routledge), 2001, pp. 43-55.

Cassese, Antonio, The Influence of the European Court of Human Rights on International Criminal Tribunals: Some Methodological Remarks, in: Morten Bergsmo (ed.), Human Rights and Criminal Justice for the Downtrodden: Essays in Honour of Asbjørn Eide, (Martinus Nijhoff), 2003, pp. 19-52.

Cassese, Antonio, Report on the Special Court for Sierra Leone, Submitted by the Independent Expert Antonio Cassese, 12 December 2006, available at: http://www.sc-sl.org/LinkClick. aspx?fileticket=VTDHyrHasLc $=\&$ (last accessed on 27 January 2012).

Cassese, Antonio, International Criminal Law, (Oxford: Oxford University Press), 2008.

Ceva, Emanuela, 'Audi Alteram Partem 'but Why? On Procedural Equality and Justice, (Human Development, Capability and Poverty International Research Cenre Working Paper), 2008, availableat:http://www.iusspavia.it/UserFiles/File/HDC-IRC/Working\%20Papers/200903-18\%20Ceva\%20WP\%20IUSS\%202008.pdf (last accessed on 27 January 2012).

Christie, George C., The Model of Principles, Duke Law Journal, 1968, no. 4, pp. 649-670.

Cogan, Jacob Katz, The Problem of Obtaining Evidence for International Criminal Courts, Human Rights Quarterly, vol. 22, no. 2, 2000, pp. 404-427.

Cohen-Eliya, Moshe and Iddo Porat, American Balancing and German Proportionality: The Historical Origins, International Journal of Constitutional Law, vol. 8, no. 2, 2010, pp. 263-286.

Cole, George F., Stanislaw J. Frankowsky and Marc G. Gertz (eds.), Major Criminal Justice Systems: A Comparative Survey, (Newburry Park: Sage), 1987.

Combs, Nancy Amoury, Guilty Pleas in International Criminal Law: Constructing a Restorative Justice Approach, (Palo Alto: Stanford University Press), 2007.

Combs, Nancy A. Fact-Finding without Facts: The Uncertain Evidentiary Foundations of International Criminal Convictions, (Cambridge: Cambridge University Press), 2010.

Connolly, William E., The Challenge to Pluralist Theory, in: William E. Connolly (ed.), The Bias of Pluralism, (New York: Atherton Press), 1969. 
Bibliography

Corker, David and Stephen Parkinson, Disclosure in Criminal Proceedings, (Oxford: Oxford University Press), 2009.

Côté, Luc, Reflections on the Exercise of Prosecutorial Discretion in International Criminal Law, Journal of International Criminal Justice, vol. 3, no. 1, 2005, pp. 162-186.

Côté, Luc, International Criminal Justice: Tightening up the Rules of the Game, International Review of the Red Cross, vol. 88, no. 861, 2006, pp. 133-144.

Crane, David M., Terrorists, Warlords, and Thugs, American University International Law Review, vol. 21, no. 4, 2006, pp. 505-516.

Damaška, Mirjan, Evidentiary Barriers to Conviction and Two Models of Criminal Procedure: A Comparative Study, University of Pennsylvania Law Review, vol. 121, no. 3, 19721973, pp. 506-589.

Damaška, Mirjan, The Faces of Justice and State Authority: A Comparative Approach to the Legal Process, (New Haven: Yale University Press), 1986.

Damaška, Mirjan, Evidence Law Adrift, (New Haven: Yale University Press), 1997. [Damaška, 1997-a].

Damaška, Mirjan, Rational and Irrational Proof Revisited, Cardozo Journal of International and Comparative Law, vol. 5, no. 1, 1997, pp. 25-40. [Damaška, 1997-b].

Damaška, Mirjan, The Uncertain Fate of Evidentiary Transplants: Anglo-American and Continental Experiments, American Journal of Comparative Law, vol. 45, no. 4, 1997, pp. 839-852. [Damaška, 1997-c].

Damaška, Mirjan, Truth in Adjudication, Hastings Law Journal, vol., 49, no. 2, 1997-1998, pp. 289-308.

Damaška, Mirjan, Epistemology and Legal Regulation of Proof, Law, Probability and Risk, vol. 2, 2003, pp. 117-130.

Damaška, Mirjan, Negotiated Justice in International Criminal Courts, Journal of International Criminal Justice, vol. 2, no. 4, 2004, pp. 1018-1039.

Damaška, Mirjan, What is the Point of International Criminal Justice?, Chicago-Kent Law Review, vol. 83, 2008, pp. 329-368.

Damaška, Mirjan, Problematic Features of International Criminal Procedure, in: Antonio Cassese ... [et al.] (ed.), The Oxford Companion to International Criminal Justice, (Oxford: Oxford University Press), 2009, pp. 175-186.

Damaška, Mirjan, Keynote Address, Concluding Conference International Criminal Procedure Expert Framework, 27-28 October 2011, Peace Palace, The Hague, (on file with author).

Danner, Allison Marston, Enhancing the Legitimacy and Accountability of Prosecutorial Discretion at the International Criminal Court, American Journal of International Law, vol. 97, 2003, pp. 510-552.

Danner, Allison Marston and Jenny S. Martinez, Guilty by Associations: Joint Criminal Enterprise, Command Responsibility, and the Development of International Criminal Law, California Law Review, vol. 93, 2005, pp. 75-169.

David, Marian A., Correspondence and Disquotation: An Essay on the Nature of Truth, (Oxford: Oxford University Press), 1994.

Davis, Angela J., Arbitrary Justice: the Power of the American Prosecutor, (Oxford University Press), 2007.

De Bertodano, Sylvia, What Price Defence? Resourcing the Defence at the ICTY, Journal of International Criminal Justice, vol. 2, no. 2, 2004, pp. 503-508. 
De Doelder, Hans, The Public Prosecution in the Netherlands, European Journal of Crime, Criminal Law and Criminal Justice, vol. 8, no. 3, 2000, pp. 187-209.

De Smet, Simon, A Structural Analysis of the Role of the Pre-Trial Chamber in the Fact-finding Process of the ICC, in: Carsten Stahn and Göran Sluiter, The Emerging Practice of the International Criminal Court, (Leiden: Martinus Nijhoff Publishers), 2009, pp. 405-440.

Del Ponte, Carla and Chuck Sudetic, Madam Prosecutor: Confrontations with Humanity's Worst Criminals and the Culture of Impunity, (New York: Other Press), 2009.

Delmas-Marty, Mireille and J. R Spencer (eds.), European Criminal Procedures, (Cambridge: Cambridge University Press), 2002.

Delmas-Marty, Mireille, Comparative Criminal Law as a Necessary Tool for the Application of International Criminal Law, in: Antonio Cassese (ed.), The Oxford Companion to International Criminal Justice, (Oxford: Oxford University Press), 2009, pp. 97-103.

Devlin, Patrick, The Criminal Prosecution in England, (Oxford University Press), 1960.

Doak, Jonathan, Victims' Rights in Criminal Trials: Prospects for Participation, Journal of Law and Society, vol., 32 no. 2, 2005, pp. 294-316.

Drumbl, Mark A., Atrocity, Punishment, and International Law, (Cambridge University Press), 2007.

Drumbl, Mark, International Criminal Law: Taking Stock of a Busy Decade, Melbourne Journal of International Law, vol. 10, 2009, pp. 38-45.

Duff, Peter, Crime Control, Due Process and 'The Case for the Prosecution', A Problem of Terminology?, British Journal of Criminology, vol. 38, no. 4, 1998, pp. 611-615.

Duff, R.A., Trial and Punishments, (Cambridge: Cambridge University Press), 1986.

Dworkin, Ronald, Taking Rights Seriously, (London: Duckworth), 1977.

Dworkin, Ronald, Sovereign Virtue: The Theory and Practice of Equality, (Cambridge MA: Harvard University Press), 2000.

Ellison, Louise Elaine, A Comparative Study of Rape Trials in Adversarial and Inquisitorial Criminal Justice Systems, 1997 (unpublished PhD thesis, University of Leeds).

Englich, Birte, Thomas Mussweiler, and Fritz Strack, the last Word in Court: a Hidden Disadvantage for the Defence, Law and Human Behavior, vol. 29, no. 6, 2005, pp. 705-722.

Esmein, A., A History of Continental Criminal Procedure, (Little, Brown and Company), 1913.

Fairchild, Erika S. and Harry Dammer, Comparative Criminal Justice Systems, $2^{\text {nd }}$ ed., (Belmont: Wadsworth), 2001.

Fairlie, Megan, The Marriage of Common and Continental Law at the ICTY and Its Progeny, Due Process Deficit, International Criminal Law Review, vol. 4, 2004, pp. 243-319.

Fairness at the International Criminal Court, International Bar Association's Human Rights Institute Report, 2011, available at: http://www.ibanet.org (last accessed on 27 January 2012).

Fawcett, J.E.S., The Application of the European Convention on Human Rights, $2^{\text {nd }}$ ed., (Oxford: Clarendon Press), 1987.

Fedorova, Masha, I., Reconciling the Prosecutor's Duty to Search for Truth with the Principle of Equality of Amrs at the ICC, in: Marianne F.H. Hirsch Ballin ... [et al.] (eds), Shifting Responsibilities in Criminal Justice, Critical Portrayals of the Changing Role and Content of a Fragmented Globalizing Law Domain, (Den Haag: Eleven International Publishing), 2012, pp. 165-191. 
Bibliography

Fedorova, Masha and Göran Sluiter, Human Rights as Minimum Standards in International Criminal Proceedings, Human Rights and International Legal Discourse, vol. 3, no. 1, 2009, pp. 9-56.

Felde, Kitty ... [et al.], Prosecutor v. Dusko Tadic, American University International Law Review, vol. 13, 1998, pp. 1441-1468.

Field, Stewart and Andrew West, Dialogue and the Inquisitorial Tradition: French Defence Lawyers in the Pre-Trial Criminal Process, Criminal Law Forum, vol. 14, no. 3, 2003, pp. 261-316.

Field, Stewart, Fair Trials and Procedural Tradition in Europe, Oxford Journal of Legal Studies, vol. 29, no. 2, 2009, pp. 365-387.

Filling the Gap in the Rome Statute on Defence, Paper of the American Non-Governmental Organisations Coalition for the International Criminal Court, 30 August 2005, available at: http://www.amicc.org/docs/Filling\%20the\%20Gap\%20in\%20the\%20Rome\%20Statute.pdf (last accessed 27 January 2012).

First Challenges: An Examination of Recent Landmark Developments at the International Criminal Court, An International Bar Association Human Rights Institute Report, (London: International Bar Association Human Rights Institute Report), June 2009, available at: http://www.icc-cpi.int/iccdocs/doc/doc881898.pdf (last accessed on 27 January 2012).

Frank, Jerome, Courts on Trial: Myths and Reality in American Justice, (Princeton, New Jersey: Princeton University Press), 1973.

Frankel, Marvin E., The Search for Truth: An Umpireal View, University of Pennsylvania Law Review, vol. 123, no. 5, 1975, pp. 1031-1059.

Friman, Håkan ... [et al.], Measures available to the International Criminal Court to Reduce the Length of Proceedings: Informal Expert Paper, 2003, available at: http://www.icccpi.int (last accessed on 27 January 2012).

Fulford, Adrian, The Reflections of a Trial Judge, Criminal Law Forum, vol. 22, no. 1/2, 2011, pp. 215-223.

Fuller, Lon L., The Adversary System: Talks on American Law, edited by Harold J. Berman, (New York: Vintage Books), 1961.

Galbraith, Jean, The Pace of International Criminal Justice, Michigan Journal of International Law, vol. 31, no. 1, 2009, pp. 79-156.

Gallavin, Chris, Prosecutorial Discretion within the ICC: Under the Pressure of Justice, Criminal Law Forum, vol. 17, no. 1, 2006, pp. 43-58.

Gallmetzer, Reinhold, The Trial Chamber's Discretionary Power to Devise the Proceedings before it and its Exercise in the Trial of Thomas Lubanga Dyilo, in: Carsten Stahn and Göran Sluiter, The Emerging Practice of the International Criminal Court, (Leiden: Martinus Nijhoff Publishers), 2009, pp. 501-524.

Gershman, Bennet L., The New Prosecutors, University of Pittsburgh Law Review, vol. 53, 1992, pp. 393-458.

Gershman, Bennett L., The Prosecutor's Duty to Truth, Georgetown Journal of Legal Ethics, vol. 14, no. 2, 2001, pp. 309-354.

Gibson, Kate and Daniella Rudy, A New Model of International Criminal Procedure, Journal of International Criminal Justice, vol. 7, no. 5, 2009, pp. 1005-1022.

Glaser, Julius, Handbuch des Strafprozesses, (Leipzig: Duncker and Humblot), 1883, Part I. 
Goldstein, Abraham S., The State and The Accused: Balance of Advantage in Criminal Procedure, Yale Law Journal, vol. 69, no. 7, 1960, pp. 1149-1199.

Goldstein, Abraham S., Reflection on Two Models: Inquisitorial Themes in American Criminal Procedure, Stanford Law Review, vol. 26, no. 5, 1974, pp. 1009-1026.

Goldston, James A., More Candour about Criteria, The Exercise of Discretion by the Prosecutor of the International Criminal Court, Journal of International Criminal Justice, vol. 8, no. 2, 2010, pp. 383-406.

Goldstone, Danielle E., Embracing Impasse: Admissibility, Prosecutorial Discretion, and the Lessons of Uganda for the International Criminal Court, Emory International Law Review, vol. 22, no. 2, 2008, pp. 761-798.

Goldwasser, Katherine, Limiting a Criminal Defendant's Use of Peremptory Challenges: On Symmetry and the Jury in a Criminal Trial, Harvard Law Review, vol. 102, no. 4, 1989, pp. 808-840.

Goodpaster, Gary, On the Theory of American Adversary Criminal Trial, Journal of Criminal Law and Criminology, vol. 78, 1987, p. 118-154.

Gradoni, Lorenzo, International Criminal Courts and Tribunals: Bound by Human Rights Norms ... or Tied Down?, Leiden Journal of International Law, vol. 19, no. 3, 2006, pp. 847-873.

Grande, Elisabetta, Dances of Criminal Justice: Thoughts on Systemic Differences and the Search for the Truth, in: John Jackson, Maximo Lager and Peter Tillers (eds.), Crime, Procedure and Evidence in A Comparative and International Context: Essays in Honour of Professor Mirjan Damaška, (Oxford and Portland: Hart Publishing), 2008, pp. 145-164.

Greenawalt, Alexander K.A., Justice without Politics? Prosecutorial Discretion and the International Criminal Court, NYU Journal of International Law and Politics, vol. 39, 2007, pp. 583-673.

Groenhuijsen, M.S., Mondige of gefortuneerde verdachten en de equality of arms in het strafproces, Delikt en Delikwent, vol. 24, no. 8, 1994, pp. 781-785.

Groome, Dermot M., Re-evaluating the Theoretical Basis and Methodology of International Criminal Trials, Penn State International Law Review, vol. 25, no. 4, 2007, pp. 791-802.

Guariglia, Fabricio, Kenneth Harris and Gudrun Hochmayr, Article 57: Functions and powers of the Pre-Trial Chamber, in: Otto Triffterer (ed.), Commentary on the Rome Statute of the International Criminal Court: Observers' Notes, Article by Article, $2^{\text {nd }}$ ed., (Munich: Beck), 2008, pp. 1117-1132.

Gustafsson, Martin, On Rawls's Distinction between Perfect and Imperfect Procedural Justice, Philosophy of the Social Sciences, vol. 34, no. 2, 2004, pp. 300-305.

Halvorsen, Vidar, Is it Better that Ten Guilty Persons Go Free Than that One Innocent Person be Convicted?, Criminal Justice Ethics, vol. 23, no. 2, 2004, pp. 3-13.

Hampshire, Stuart, Justice is Strife, Philosophy and Social Criticism, vol. 28, no. 6, 2002, pp. 635-645.

Hart, H.L.A. Prolegomenon to the Principles of Punishment, in Punishment and Responsibility: Essays in the Philosophy of Law, (New York: Oxford University Press), 1968, pp. 1-27.

Hart, H.L.A, The Concept of Law, $2^{\text {nd }}$ ed. with a postscript ed. by Penelope A. Bulloch and Joseph Raz, (Oxford: Clarendon Press, 1994).

Hatchard, John, Barbara Huber and Richard A. Vogler (eds.), Comparative Criminal Procedure, (London: British Institute of International and Comparative Law), 1996. 
Bibliography

Hessler, Stephen E., Asymmetry, Fairness, and Criminal Trials, Michigan Law Review, vol. 99, no. 6, 2001, pp. 1560-1582.

Higgins, Gillian, The Impact of the Size, Scope, and Scale of the Milosevic Trial and the Development of Rule 73bis before the ICTY, Northwestern Journal of International Human Rights, vol. 7, no. 2, 2009, pp. 239-260.

Hocking, John, Legal Aid and Defence Support at the ICTY, Address of Mr. John Hocking, registrar, United Nations International Criminal Tribunal for the Former Yugoslavia, Meeting of Registrars of Final/Appellate, Regional and International Courts, Ottawa, Canada, 14-16 April 2010, available at: http://www.icty.org (last accessed 1 June 2012).

Hodgson, Jacqueline, The Police, The Prosecutor and the Juge d'Instruction: Judicial Supervision in France, Theory and Practice, British Journal of Criminology, vol. 41, no. 2, 2001, pp. 342-361.

ICTY Manual on Developed Practices. Prepared in conjunction with UNICRI as part of a project to preserve the legacy of the ICTY, (Turin: UNICRI publishers), 2009, available at: http://www.icty.org (last accessed 28 May 2012).

Jackson, Robert H., The Federal Prosecutor, Journal of Criminal Law and Criminology, vol. 31, no. 1, 1940, p. 3-6.

Jackson, Robert H., Some Problems in Developing an International Legal System, Temple Law Quarterly, vol. 22, no. 2, 1948-1949, p. 147-158.

Jackson, John D., Theories of Truth finding in Criminal Procedure: An Evolutionary Approach, Cardozo Law Review, vol. 10, no. 3, 1988, pp. 475-528.

Jackson, John D., The Effect of Legal Culture and Proof in Decision to Prosecute, Law, Probability and Risk, vol. 3, no. 2, 2004, pp. 109-132.

Jackson, John D., The Effect of Human Rights on Criminal Evidentiary Prosesses: Towards Convergence, Divergence or Realignment?, Modern Law Review, vol. 68, no. 5, 2005, pp. 737-764.

Jackson, John, The Ethical Implications of the Enhanced Role of the Public Prosecutor, Legal Ethics, vol. 9, no. 1, 2006, p. 35-55. [Jackson 2006-a].

Jackson, John, The Role of the Public Prosecution Service within the Administration of Justice, Paper presented at the Workshop on Human Rights and Pre-Trial Procedures: Investigations, Arrest and Pre-Trial Detention, 6-7 December 2006 in Cairo, available at: http://www.pogar.org/publications/arabniaba/hr/cairo/roleprosecution-jackson-e.pdf (last accessed on 27 January 2012). [Jackson 2006-b].

Jackson, John, Maximo Lager and Peter Tillers (eds.), Crime, Procedure and Evidence in A Comparative and International Context: Essays in Honour of Professor Mirjan Damaška, (Oxford and Portland: Hart Publishing), 2008.

Jackson, John, Finding the Best Epistemic Fit for International Criminal Tribunals, Journal of International Criminal Justice, vol. 7, no. 1, 2009, pp. 17-40. [Jackson 2009-a].

Jackson, John, Autonomy and Accuracy in the Development of Fair Trial Rights, University College Dublin, Working Paper in Law, Criminology and Socio-Legal Studies Research Paper No. 09/2009, available at: http://ssrn.com/abstract=1407968 (last accessed on 27 January 2012). [Jackson, 2009-b].

Jackson, John D., Re-Conceptualizing the Right of Silence as an Effective Fair Trial Standard, International and Comparative Law Quarterly, vol. 58, no. 4, 2009, pp. 835-862. [Jackson 2009-c]. 
Jacobs, Dov, A Samson at the International Criminal Court: The Powers of the Prosecutor at the Pre-Trial Phase, The Law and Practice of International Courts and Tribunals, vol. 6, no. 2, 2007, pp. 317-341.

Jaconelli Joseph, Rights Theories and Public Trial, Journal of Applied Philosophy, vol. 14, no. 3, 1997, pp. 169-176.

Jalloh, Charles C., Special Court for Sierra Leone: Achieving Justice?, Michigan Journal of International Law, vol. 32, no. 3, 2011, pp. 395-460.

Jallow, Hassan B., Prosecutorial Discretion and International Justice, Journal of International Criminal Justice, vol. 3, no. 3, 2005, pp. 145-161.

Jehle, Jörg-Martin, Marianne Wade, Beatrix Elsner, Prosecution and Diversion within Criminal Justice Systems in Europe. Aims and Design of a Comparative Study, European Journal on Criminal Policy and Research, vol. 14, no. 2-3, 2008, pp. 93-99.

Jehle, Jörg-Martin, Paul Smit and Josef Zila, The Public Prosecutor as Key-Player: Prosecutorial Case-Ending Decisions, Journal on Criminal Policy and Research, vol. 14, no. 2-3, 2008, pp. 161-179.

Jescheck, Hans-Heinrich, The Discretionary Powers of the Prosecuting Attorney in West Germany, American Journal of Comparative Law, vol. 18, no. 3, 1970, pp. 508-517.

Jones, John R.W.D., The Gamekeeper-Turned-Poacher's Tale, Journal of International Criminal Justice, vol. 2, no. 2, 2004, pp. 486-494.

Jordash, Wayne and Scott Martin, Due Process and Fair Trial Rights at the Special Court: How the Desire for Accountability Outweighed the Demands of Justice at the Special Court for Sierra Leone, Leiden Journal of International Law, vol. 23, 2010, pp. 585-608.

Jörg, Nico, Stewart Field and Chrisje Brants, Are Inquisitorial and Adversarial Systems Converging?, in: Phil Fennell ... [et al.] (eds.), Criminal Justice in Europe: A Comparative Study, (Oxford: Clarendon), 1995, pp. 41-56.

Jørgensen, Nina H.B., The Problem of Self-Representation at International Criminal Tribunals,

Striking a Balance between Fairness and Effectiveness, Journal of International Criminal Justice, vol. 4, no. 1, 2006, pp.64-77.

Jouet, Mugambi, Reconciling the Conflicting Rights of Victims and Defendants at the International Criminal Court, Saint Louis University Public Law Review, vol. 26, no. 2, 2007, pp. 249-308.

Kaplow, Louis and Steven Shavell, Fairness Versus Welfare: Notes on the Pareto Principle, Preferences, and Distributive Justice, Journal of Legal Studies, vol. 32, no. 1, 2003, pp. 331-362.

Kaptein, H.J.R. Strijd om strafrechtelijke waarheid: deskundigen inbreng van buiten blijft nog wel even belangrijk [A struggle for truth in criminal law: external experts contribution will still be important], Expertise en Recht, no. 3, 2009, pp. 53-61.

Karnavas, Michael G., Gathering Evidence in International Criminal Trials: The View of the Defence Lawyer, in: Michael Bohlander (ed.), International Criminal Justice: a Critical Analysis of Institutions and Procedures, (London: Cameron May), 2007, pp. 75-152.

Kausch, Erhard, Der Staatsanwalt: Ein Richter vor dem Richter? Untersuchungen zu Paragraph 153 a StPO, (Berlin: Duncker and Humblot), 1980.

Kay, Steven and Bert Swart, The Role of Defence, in: Antonio Cassese, Paola Gaeta and John R.W.D. Jones (eds.), The Rome Statute of the International Criminal Court: A Commentary, (Oxford University Press), Vol. II, 2002, pp. 1423-1424. 
Bibliography

Kay, Steven and Gillian Higging, The Right to Self-Representation: the Lawyers in the Eye of the Storm, (International Criminal Law Bureau), 2010, available at: http://www. internationallawbureau.com (last accessed on 20 June 2012).

Kelly, John M., Audi Alteram Partem, Natural Law Forum, vol. 9, 1964, p. 103-110.

Kirsch, Stefan, Finding the Truth at the International Criminal Court, in: Thomas Kruessmann (ed.), ICTY: Towards a Fair Trial?, (Graz: Neuer Wissenschaftlicher Verlag), 2008, pp. 47-62.

Klinkner, Melanie, Forensic Science Expertise for International Criminal Proceedings: An Old Problem, A New Context and A Pragmatic Resolution, The International Journal of Evidence and Proof, vol. 13, 2009, pp. 102-129.

Klip, André and Göran Sluiter (eds.) Annotated Leading Cases of International Criminal Tribunals. The International Criminal Tribunal for the Former Yugoslavia 2000-2001, vol. 5, (Antwerp: Intersentia), 2003.

Knoops, Geert-Jan Alexander and Robert R. Amsterdam, The Duality of State Cooperation within International and National Criminal Cases, Fordham International Law Journal, vol. 30, no. 2, 2006-2007, pp. 260-295.

Knoops, Geert-Jan Alexander, The Dichotomy between Judicial Economy and Equality of Arms within International and Internationalized Criminal Trials: A Defense Perspective, Fordham International Law Journal, vol., 28, no. 6, 2005, pp. 1566-1594.

Kohlbacher, Ursula, Verteidigung und Verteidigungsrechte unter dem Aspekt der "Waffengleichheit", [s.1.: s.n.], 1978. - Dissertation University of Zürich.

Kohlmann, Günter, Waffengleichheit im Strafprozess?, in: Jürgen Baumann and Klaus Tiedemann, Einheit und Vielfalt des Strafrechts, (Tübingen: J.C.B. Mohr/ Paul Siebeck), 1974, pp. 311-322.

Kolb, Robert, The Jurisprudence of the European Court of Human Rights in Detention and Fair Trial in Criminal Matters from 1992 to the end of 1998, Human Rights Law Journal, vol. 21, no. 9-12, 2000, pp. 348-373.

Kress, Claus, The Procedural Law of the International Criminal Court in Outline, Anatomy of a Unique Compromise, Journal of International Criminal Justice, vol. 1, 2003, pp. 603-617.

Kress, Claus and Kimberly Prost, Article 99: Execution of Requests under Articles 93 and 96, in: Otto Triffterer (ed.), Commentary on the Rome Statute of the International Criminal Court: Observers' Notes, Article by Article, $2^{\text {nd }}$ ed., (Munich: Beck), 2008, pp. 1621-1630.

$\mathrm{Ku}$, Julian and Jide Nzelibe, Do International Criminal Tribunals Deter or Exacerbate Humanitarian Atrocities?, Washington University Law Quarterly, vol. 84, no. 4, 2006, pp. 777-834.

Kwon, O-Gon, The Challenge of an International Criminal Trial as Seen from the Bench, Journal of International Criminal Justice, vol. 5, no. 2, 2007, pp. 360-376.

Langbein, John H., Controlling Prosecutorial Discretion in Germany, University of Chicago Law Review, vol. 41, no. 3, 1974, pp. 439-467.

Langbein, John H., The German Advantage in Civil Procedure, University of Chicago Law Review, vol. 52, no. 4, 1985, pp. 823-866.

Langbein, John H., The Origins of Adversary Criminal Trial, (Oxford: Oxford University Press), 2003. 
Langer, Maximo and Joseph W. Doherty, Managerial Judging Goes International, but Its Promise Remains Unfulfilled: An Empirical Assessment of the ICTY Reforms, Yale Journal of International Law, vol. 36, no. 2, 2011, pp. 241-306.

Langer, Maximo, The Rise of Managerial Judging in International Criminal Law, American Journal of Comparative Law, vol. 53, no. 4, 2005, pp. 835-910.

Larenz, Karl, Richtiges Recht: Grundzüge einer Rechtsethik, (Munich: Beck), 1979.

Laufer, W. S. The Rhetoric of Innocence, Washington Law Review, vol. 70, no. 2, 1995, pp. 329-422.

Lee, Roy S. (ed.), The International Criminal Court: The Making of the Rome Statute: Issues Negotiations and Results, (The Hague: Kluwer), 1999.

Leeson, Peter T., Trial by Battle, Journal of Legal Analysis, vol. 3, no. 1, 2011, pp. 341-375.

Lind, E. Allan, John Thibaut and Laurens Walker, Discovery and Presentation of Evidence in Adversary and Non Adversary Proceedings, Michigan Law Review, vol. 71, no. 6, 1973, pp. 1129-1144.

Luban, David, Are Criminal Defenders Different?, Michigan Law Review, vol. 91, no. 7, 1993, pp. 1729-1766.

Luban, David, Fairness to Rightness: Jurisdiction, Legality, and the Legitimacy of International Criminal Law, 2008, available at: http://scholarship.law.georgetown.edu/ fwps_papers/67 (last accessed on 27 January 2012).

Luban, David, The Conscience of a Prosecutor, Georgetown Public Law and Legal Theory Research Paper No. 10-27, May 2010, available at: http://ssrn.com/abstract=1614963, (last accessed on 1 June 2012).

Lucas, John Randolph, On Justice = Peri Dikaiou, (Oxford: Clarendon Press), 1980.

Luna, Erik and Marianne Wade, Prosecutors as Judges, Washington and Lee Law Review, vol. 67, 2010, pp. 1413-1532.

Macdonald, Stuart, Constructing a Framework for Criminal Justice Research: Learning from Packer's Mistakes, New Criminal Law Review, vol. 11, 2008, pp. 257-311.

May, Richard and Marieke Wierda, International Criminal Evidence, (Ardsley NY: Transnational), 2002.

Markovits, Inga, Playing the Opposite Game: On Mirjan Damaška's Faces of Justice and State Authorities, Stanford Law Review, vol. 41, no. 5, 1989, pp. 1313-1342.

McCarthy, Thomas, The Critical Theory of Jurgen Habermas, (Cambridge: MIT Press), 1978.

McGonigle Leyh, Brianne, Procedural Justice? Victim Participation in International Criminal Proceedings, (Antwerp: Intersentia), 2011.

McIntyre, Gabrielle, Equality of Arms: Defining Human Rights in the Jurisprudence of the International Criminal Tribunal for the former Yugoslavia, Leiden Journal of International Law, vol. 16, 2003, pp, 269-320.

McMunigal, Kevin C., Are Prosecutorial Ethics Standards Different? Fordham Law Review, vol. 68 , no. 5, 2000, pp. 1453-1472.

Mégret, Fredric and Florian Hoffmann, The UN as a Human Rights Violator? Some Reflections on the United Nations Changing Human Rights Responsibilities, Human Rights Quarterly, vol. 25, no. 2, 2003, pp. 314-342.

Mégret, Frédéric, Beyond "Fairness": Understanding the Determinants of International Criminal Procedure, UCLA Journal of International Law and Foreign Affairs, vol. 14, 2009, pp. 37-76. 
Bibliography

Melilli, Kenneth J., Prosecutorial Discretion in an Adversary System, Brigham Young University Law Review, no. 3, 1992, pp. 669-704.

Meron, Theodor, Comments in the International Law Association Panel on the Yugoslav Tribunal, ILSA Journal of International and Comparative Law, vol. 5, no. 2, 1999, pp. 347-350.

Merryman, John Henry, The Civil Law Tradition: An Introduction to the Legal Systems of Western Europe and Latin America, (Palo Alto: Stanford University Press), 1969.

Mettraux, G. and A. Cengic, The Role of a Defence Office: Some Lessons from Recent and not so Recent War Crimes Precedents, in: Michael Bohlander (ed.), International Criminal Justice: A Critical Analysis of Institutions and Procedures, (London: Cameron May), 2007, pp. 391-428.

Mevis, P.A.M., Capita Strafrecht: Een Thematische Inleiding, (Nijmegen: Ars Aequi Libri), 2009.

Mineshima, Dale, The Rule of Law and EU Expansion, Liverpool Law Review, vol. 24, 2002, pp. 73-87.

Minow, Martha, Between Vengeance and Forgiveness: Facing History after Genocide and Mass Violence, (Boston MA: Beacon Press), 1998.

Miraglia, Michela, The First Decision of the ICC Pre-Trial Chamber, Journal of International Criminal Justice, vol. 4, no. 1, 2006, pp. 188-195.

Moesenthin, Michael, Commentary Michael Moesenthin, in: André Klip and Göran Sluiter (eds.), Annotated Leading Cases of International Criminal Tribunals. The International Criminal Tribunal for the Former Yugoslavia 2004, vol. 20, (Antwerp: Intersentia), 2010, pp. 211-221.

Moisidis, Cosmas, Criminal Discovery: From Truth to Proof and Back Again, (Sydney: Institute of Criminology Press), 2008.

Moore, Hugh, A Dictionary of Quotations from Various Authors in Ancient and Modern Languages, (London: Gilbert and Rivington), 1831.

Morrison, Howard, Practice at the ad hoc Tribunals for the former Yugoslavia and Rwanda, in: Martine Hallers, Chantal Joubert and Jan Sjöcrona (eds.), The Position of the Defence at the International Criminal Court and the Role of the Netherlands as the Host State, (Purdue University Press), 2002, pp. 43-48.

Møse, Erik, Impact of Human Rights Conventions on the Two Ad Hoc Tribunals, in: Morten Bergsmo (ed.), Human Rights and Criminal Justice for the Downtrodden: Essays in Honour of Asbjørn Eide, (Leiden: Martinus Nijhoff), 2003, pp. 179-208.

Mosteller, Robert P., Discovery against the Defense: Tilting the Adversarial Balance, California Law Review, 1986, pp. 1567-1685.

Murphy, Peter, No Free Lunch, No Free Proof: the Indiscriminate Admission of Evidence is a Serious Flaw in International Criminal Trials, Journal of International Criminal Justice, vol. 8, no. 2, 2010, pp. 539-573.

Negri, Stefania, Equality of Arms: Guiding Light or Empty Shell?, in: Michael Bohlander (ed.), International Criminal Justice: A Critical Analysis of Institutions and Procedures, (London: Cameron May), 2007, pp. 13-73.

Nelken, David, Three Problems in Employing the Concept of Legal Culture, in: Fred Bruinsma and David Nelken (eds.), Explorations in Legal Cultures, ('s-Gravenhage: Reed Business BV), 2007, pp. 11-28. 
Nelson, William, The Very Idea of Pure Procedural Justice, Ethics, vol. 90, no. 4, 1980, pp. 502-511.

Newton, Michael A., Evolving Equality: Evolving Equality: The Development of the International Defense Bar, Stanford Journal of International Law, vol. 47, no. 2, 2011, pp. 379-440.

Nowak, Manfred, U.N. Covenant on Civil and Political Rights CCPR Commentary, $2^{\text {nd }}$ rev. ed., (Kehl am Rhein: Engel Verlag), 2005.

Ntanda Nsereko, Daniel D. Prosecutorial Discretion Before National Courts and International Tribunals, Journal of International Criminal Justice, vol. 3, no. 1, 2005, pp. 124-144.

Orie, Alphons, Accusatorial v. Inquisitorial Approaches in International Criminal Proceedings Prior to the Establishment of the ICC and in the Proceedings before the ICC, in: Antonio Cassese, Paola Gaeta and John R.W.D. Jones (eds.), The Rome Statute of the International Criminal Court: A Commentary, (Oxford University Press), vol. II, 2002, pp. 1439-1495.

Packer, Herbert L., Two Models of Criminal Process, University of Pennsylvania Law Review, vol. 113, no. 1, 1964-1965, pp. 1-68.

Packer, Herbert L., The Limits of the Criminal Sanction, (Palo Alto: Stanford University Press), 1968.

Pakes, Francis J., Styles of Trial Procedure at the International Criminal Tribunal for the Former Yugoslavia, in Peter J. Van Koppen, and Steven D. Penrod (eds.), Adversarial versus Inquisitorial Justice: Psychological Perspectives on Criminal Justice Systems, (New York etc.: Kluwer Academic, Plenum Publishers), 2003, pp. 309-319.

Perry, Stephen R., Two Models of Legal Principles, Iowa Law Review, vol. 82, no. 3, 1997, pp. 787-820.

Peskin, Viktor, International Justice in Rwanda and the Balkans, Virtual Trials and the Struggle for State Cooperation, (Cambridge: Cambridge University Press), 2008.

Pizzi,William and Luca Marafioti, The New Italian Code of Criminal Procedure: The Difficulties of Building an Adversarial Trial System on a Civil Law Foundation, Yale Journal of International Law, vol. 17, no. 1, 1992, pp. 1-40.

Pizzi, William T., Trials Without Truth: Why Our System of Criminal Trial Has Become an Expensive Failure and What We Need to Do to Rebuild It, (New York: New York University Press), 1999.

Plotnikoff, Joyce and Richard Woolfson, 'A Fair Balance'? Evaluation of the Operation of Disclosure Law, (London: Home Office), 2001, available at: http://webarchive. nationalarchives.gov.uk/20110218135832/http://rds.homeoffice.gov.uk/rds/pdfs/occ76disclosures.pdf (last accessed on 2 June 2012).

Porat, Iddo, The Dual Model of Balancing: A Model for the Proper Scope of Balancing in Constitutional Law, Cardozo Law Review, 2006, vol. 27, no. 3, pp. 1393-1448.

Posner, Eric A., Political Trials in Domestic and International Law, Duke Law Journal, vol. 55, no. 1, 2005, pp. 75-152.

Pradel, Jean, Rapport Général, Revue Internationale de Droit Pénal, vol. 63, 1992.

Pradel, Jean, Criminal Procedure 127, in: George A. Bermann and Etienne Picard (eds.), Introduction to French Law, (Alphen aan den Rijn: Kluwer Law International), 2008, pp. 127-146.

Prakken, Ties and Taru Sponken, Handboek Verdediging, $2^{\text {nd }}$ ed., (Deventer: Kluwer), 2009. 
Bibliography

Rastan, Rod, Testing Co-operation: The International Criminal Court and National Authorities, Leiden Journal of International Law, vol. 21, no. 2, 2008, pp. 431-456.

Rawls, John, A Theory of Justice, (Cambridge MA: The Belknap Press of Harvard University Press), 1971.

Raz, Joseph, Legal Principles and the Limits of Law, Yale Law Journal, vol. 81, no. 5, 1972 , pp. 823-854.

Reichel, Philip L., Comparative Criminal Justice Systems: a Topical Approach, (Upper Saddle River: Prentice Hall), 1999.

Riley, Henry Thomas, Dictionary of Latin Quotations, Proverbs, Maxims, and Mottos, Classical and Mediceval, including Law Terms and Phrases, (London: Bell and Daldy), 1866.

Roach, Kent, Four Models of the Criminal Process, Journal of Criminal Law and Criminology, vol. 89, no. 2, 1999, pp. 671-716.

Roberts, Paul, Comparative Criminal Justice Goes Global, Oxford Journal of Legal Studies, vol. 28, no. 2, 2008, pp. 369-391.

Roper, Steven D. and Lillian A. Barria, State Co-operation and International Criminal Court Bargaining Influence in the Arrest and the Surrender of Suspects, Leiden Journal of International Law, vol. 21, no. 2, 2008, pp. 457-476.

Rubin, Edward L., Law and the Methodology of Law, Wisconsin Law Review, 1997, pp. 521-566.

Safferling, Christopher J.M., Towards an International Criminal Procedure, (Oxford: Oxford University Press), 2001.

Safferling, Christoph J.M., Audiatur et Altera pars: die prozessuale Waffengleichheit als Prozessprincip?, Qui statuit alliquid parte inaudita altera, Aequm liquet statuerit haud aequs fuit. Neue Zeitschrift für Strafrecht, vol. 4, no. 4, 2004, pp. 181-188.

Safferling, Christoph, The Rights and Interests of the Defence in the Pre-Trial Phase, Journal of International Criminal Justice, vol. 9 no. 3, 2011, pp. 651-667.

Saland, Per, International Criminal Law Principles, in: Roy S. Lee (ed.), The International Criminal Court: The Making of the Rome Statute: Issues Negotiations and Results, (The Hague: Kluwer), 1999, p. 189-216.

Salzburg, Stephen A. and Daniel J. Capra, American Criminal Procedure, Cases and Commentary, $7^{\text {th }}$ ed. (Thomson West) 2006.

Sandermann, Almut, "Waffengleichheit" im Strafprozeß, Zu den Rechtlichen Grundlagen dieses Rechtsinstituts, (s.1.: Aku-Fotodruck Agentur 5), 1975 - Inaugural Dissertation University of Cologne.

Sanders, Andrew, Core Values, the Magistracy, and the Auld Report, Journal of Law and Society, vol. 29, no. 1, 2002, pp. 324-341.

Sanders, Andrew and Richard Young, Criminal Justice, $2^{\text {nd }}$ ed., (Oxford: Oxford University Press), 2006.

Schabas, William A., Sentencing by International Tribunals: A Human Rights Approach, Duke Journal of Comparative and International Law, vol. 7, 1997, pp. 461-517.

Schabas, William A., Prosecutorial Discretion v. Judicial Activism at the International Criminal Court, Journal of International Criminal Justice, vol. 6, no. 4, 2008, pp. 731-762.

Schabas, William A., Article 67: Rights of the Accused, in: Otto Triffterer (ed.), Commentary on the Rome Statute of the International Criminal Court: Observers' Notes, Article by Article, $2^{\text {nd }}$ ed., (Munich: Beck), 2008. 
Schabas, William A., The International Criminal Court: A Commentary on the Rome Statute, (Oxford: Oxford University Press), 2010. [2010-a].

Schabas, William A., Inappropriate Comments from the Prosecutor of the International Criminal Court, 16 July 2010, William Schabas's blog at: http://humanrightsdoctorate. blogspot.com/2010/07/inappropriate-comments-from-prosecutor.html (last accessed 27 January 2012).

Schabas, William A., More on Intermediaries from the Lubanga Trial Chamber: Can it Really Take 'Appropriate Action'? 14 July 2010, William Schabas's blog at: http:// humanrightsdoctorate.blogspot.com/2010/07/more-on-intermediaries-from-lubanga. html (last accessed 27 January 2012).

Scharf, Michael P., Self-Representation versus Assignment of Defence Counsel before International Criminal Tribunals, Journal of International Criminal Justice, vol. 4, no. 1, 2006, pp. 31-46.

Scheffer, David, A Review of the Experiences of the Pre-Trial and Appeals Chambers of the International Criminal Court Regarding the Disclosure of Evidence, Leiden Journal of International Law, vol. 21, 2008, pp. 151-163.

Schuon, Christine, International Criminal Procedure: A Clash of Legal Cultures, (T.M.C. Asser Press), 2010.

Schwarzenberger, Georg, The Inductive Approach to International Law, (London: Stevens and Sons), 1965.

Sheppard, Blair H. and Neil Vidmar, Adversary Pretrial Procedures and Testimonial Evidence: Effects of Lawyer's Role and Machiavellianism, Journal of Personality and Social Psychology, vol. 39, 1980, pp. 320-332.

Silver, Jay Sterling, Equality of Arms and the Adversarial Process: A New Constitutional Right, Wisconsin Law Review, 1990, pp. 1007-1041.

Simon, William H., The Ethics of Criminal Defence, Michigan Law Review, vol. 91, no. 7, 1993, pp. 1703-1728.

Simon, David A., Equal Before the Law: Toward a Restoration of Gideon's Promise, Harvard Civil Rights- Civil Liberties Law Review, vol. 43, 2008, pp. 581-594.

Sklansky, David Alan, Anti-Inquisitorialism, Harvard Law Review, vol. 122, no. 6, 2009, pp. 1634-1705.

Sluiter, Göran, International Criminal Adjudication and the Collection of Evidence: Obligations of States, (Antwerpen: Intersentia), 2002.

Sluiter, Göran, International Criminal Proceedings and the Protection of Human Rights, New England Law Review, vol. 37, no. 4, 2003, pp. 935-948.

Sluiter, Göran, Compromising the Authority of International Criminal Justice: How Vojislav Šešelj Runs his Trial, Journal of International Criminal Justice, vol. 5, no. 4, 2007, pp. 529-536.

Sluiter, Göran, "I Beg You, Please Come Testify": The Problematic Absence of Subpoena Powers at the ICC, New Criminal Law Review, vol. 12, no. 4, 2009, pp. 590-608.

Sluiter, Göran, Atrocity Crimes Litigation: Some Human Rights Concerns Occasioned by Selected 2009 Case Law, Northwestern Journal of International Human Rights, vol. 8, no. 3, 2010, pp. 248-268. 
Bibliography

Sluiter, Göran and William Schabas, International Law Association, The Hague Conference 2010, Committee on International Criminal Court, Fourth Report, 2010 (available at http://www.ila-hq.org/en/committees/index.cfm/cid/1011, last accessed on 1 June 2012).

Smith, David J., Case Construction and the Goals of Criminal Process, British Journal of Criminology, vol. 37, no. 3, 1997, pp. 319-346.

Solum, Lawrence B., Procedural Justice, Southern California Law Review, vol. 78, no. 1, 2004, pp. 181-322.

Spencer, J.R, Introduction, in: Mireille Delmas-Marty and J. R. Spencer (eds.), European Criminal Procedures, (Cambridge: Cambridge University Press), 2002, pp. 1-75.

Sprack, John, The Criminal Procedure and Investigations Act 1996: The Duty to Disclosure, Criminal Law Review, 1997, pp. 308-320.

Stahn, Carsten, Judicial Review of Prosecutorial Discretion: On Experiments and Imperfections, in: Göran Sluiter and Sergey Vasiliev (eds.), International Criminal Procedure: Towards a Coherent Body of Law, (London: Cameron May), 2009, pp. 239-270.

Steiner, Dirk, Das Fairnessprinzip im Strafprozess, (Frankfurt: Peter Lang), 1995.

Stevens, Lonneke and Willem-Jan Verhoeven, Raadsman bij politieverhoor: Invloed van voorafgaande consultatie en aanwezigheid van raadslieden op de organisatie en wijze van verhoren en de proceshouding van verdachten, (Den Haag: Boom), 2010.

Stone, Jon R., The Routledge Dictionary of Latin Quotations, (New York: Routledge Taylor and Francis Group), 2005.

Summers, Robert S., Evaluating and Improving Legal Processes: A Plea for "Process Values", Cornell Law Review, vol. 60, no. 1, 1974, pp. 1-52.

Summers, Robert S., Formal Legal Truth and Substantive Truth in Judicial Fact-Finding: Their Justified Divergence in Some Particular Cases, Law and Philosophy, vol. 18, no. 5, 1999, pp. 497-511.

Summers, Sarah, Fair Trials: The European Criminal Procedural Tradition and the European Court of Human Rights, (Oxford: Hart Publishing), 2007.

Sward, Ellen E., Values, Ideology, and the Evolution of the Adversary System, Indiana Law Journal, vol. 64, 1989, pp. 301-356.

Swart, Bert, Damaška and the Faces of International Criminal Justice, Journal of International Criminal Justice, vol. 6, no. 1, 2008, pp. 87-114.

Swoboda, Sabine, The ICC Disclosure Regime: A Defence Perspective, Criminal Law Forum, vol. 19 , no. 3/4, 2008, pp. 449-472.

Temminck Tuinstra, Jarinde, Assisting an Accused to Represent Himself: Appointment of Amici Curiae as the Most Appropriate Option, Journal of International Criminal Justice, vol. 4, no. 1, 2006, pp. 47-63.

Temminck Tuinstra, Jarinde P.W., Defence Counsel in International Criminal Law, (The Hague: T.M.C. Asser Press), 2009.

Thibaut, John W. and Laurens Walker, Procedural Justice: A Psychological Analysis, (Hillsdale, NJ: Laurence Erlbaum Associates), 1975.

Thompson, Alison and Michelle Staggs, The Defence Office at the Special Court for Sierra Leone: A Critical Perspective, (Berkeley: University of California, War Crimes Study Center), 2007, available at: http://socrates.berkeley.edu/ warcrime/documents/ DefenceOfficeReport.pdf. 
Tijssen, Hervé, De juridische dissertatie onder de loep, [Legal dissertation under the magnifying glass], (Den Haag: Boom Juridische Uitgevers), 2009.

Tolbert, David, The ICTY and Defense Counsel: A Troubled Relationship, New England Law Review, vol. 37, no. 4, 2003, pp. 975-986.

Tomlinson, Edward A., Nonadversarial Justice: The French Experience, Maryland Law Review, vol. 42, no. 1, 1983, pp. 131-195.

Toney, Raymond J., English Criminal Procedure Under Article 6 of the European Convention on Human Rights: Implications for Custodial Interrogations Practices, Houston Journal of International Law, vol. 24, no. 3, 2002, pp. 411-474.

Trechsel, Stefan, Comparative Observations on Human Rights Law and Criminal Law, Saint Louis-Warsaw Transatlantic Law Journal, 2000, pp. 1-28.

Trechsel, Stefan, Human Rights in Criminal Proceedings, (Oxford: Oxford University Press), 2005.

Tulkens, Françoise, The Paradoxical Relationship between Criminal Law and Human Rights, Journal of International Criminal Justice, vol. 9, no. 3, 2011, pp. 577-595.

Turner, Jenia Iontcheva, Defence Perspectives on Law and Politics in International Criminal Trials, Virginia Journal of International Law, vol. 48, no. 3, 2008, pp. 529-594.

Turone, Giuliano, Powers and Duties of the Prosecutor, in: Antonio Cassese, Paola Gaeta and John R.W.D. Jones (eds.), The Rome Statute of the International Criminal Court: a Commentary, (Oxford University Press), vol. II, 2002.

Tyler, Tom R. and Maura A. Belliveau, Tradeoffs in Justice Principles: Definitions of Fairness, in: Barbara Benedict Bunker and Jeffrey Z. Rubin (eds.), Conflict, Cooperation, and Justice: Essays Inspired by the Work of Morton Deutsch, (San Francisco: Jossey-Bass Inc. Publishers), 1995, pp. 291-314.

Uviller, H. Richard, The Tilted Playing Field: is Criminal Justice Unfair?, (New Haven: Yale University Press), 1999.

Uviller, H. Richard, The Neutral Prosecutor: The Obligation of Dispassion in a Passionate Pursuit, Fordham Law Review, vol. 68, no. 5, 2000, pp. 1695-1718.

Van der Meij, Patrick, De wankele status van de rechter-commissaris in strafzaken: Een betoog waarom een wetsvoorstel niet het stempel 'versterking' mag dragen, Nederlands Juristenblad, vol. 83, no. 39, 2008, pp. 2444-2450.

Van der Meij, P.P.J., De rechter-commissaris als onmisbare schakel in het strafrechtelijk vooronderzoek, Trema, vol. 8, no. 8, 2010, pp. 331-338.

Van der Wilt, Harmen, Why International Criminal Lawyers Should Read Mirjan Damaška, in: Carsten Stahn and Larissa van den Herik (eds.), Future Perspectives on International Criminal Justice, TMC Asser Press, 2010, pp. 44-57.

Van Dijk, P. ... [et al.] (eds.), Theory and Practice of the European Convention on Human Rights, $4^{\text {th }}$ ed., (Antwerpen: Intersentia), 2006.

Van Kempen, P.H.P.H.M.C., Repressie door mensenrechten: over positieve verplichtingen tot aanwending van strafrecht ter bescherming van fundamentele rechten, (Nijmegen: Wolf Legal Publishers), 2008, Inaugural Lecture Radboud University Nijmegen.

Van Koppen, Peter J. and Steven D. Penrod (eds.), Adversarial versus Inquisitorial Justice: Psychological Perspectives on Criminal Justice Systems, (New York etc.: Kluwer Academic, Plenum Publishers), 2003. 
Bibliography

Van Leeuwen, Fleur, Women's Rights are Human Rights: The Practice of the Human Rights Committee and the Committee on Economic, Social and Cultural Rights, (Antwerp: Intersentia), 2010.

Van Tuyl, Penelope, Effective, Efficient, and Fair? An Inquiry into the Investigative Practices of the Office of the Prosecutor at the Special Court for Sierra Leone, (Berkley CA: War Crimes Study Center, University of California, Berkeley), 2008, available at: http://www. ocf.berkeley.edu/ changmin/SL-Reports/Effective_Efficient_andFair.pdf, (last accessed on 27 January 2012).

Vargha, Julius, Die Verteidigung in Strafsachen: historisch und dogmatisch dargestellt, (Aalen: Scientia) 1994. Original: Vienna: Manz'sche k k Hof-Verlag und Univ Buchhandlung, 1879 .

Vasiliev, Sergey V., The Role and Legal Status of the Prosecutor in International Criminal Trials, 2010, available at http://ssrn.com/abstract=1715465 (last accessed on 27 January 2012).

Verrest, P.A.M., Raison d'être, Een onderzoek naar de role van de rechter-commissaris in ons strafrecht, (Den Haag: Boom Juridische Uitgevers), 2011.

Vogler, Richard, A World View of Criminal Justice, (Aldershot: Ashgate), 2005.

Vouin, Robert, Role of the Prosecutor in French Criminal Trials, American Journal of Comparative Law, vol. 18, 1970, pp. 483-497.

Wasek-Wiaderek, Małgorzata, The Principle of "Equality of Arms" in Criminal Procedure Under Article 6 of the European Convention on Human Rights and Its Functions in Criminal Justice of Selected European Countries: A Comparative View, (Leuven: Leuven University Press), 2000.

Webb, P. Philippa, The ICC Prosecutor's Discretion Not To Proceed in the Interests of Justice, Criminal Law Quarterly, vol. 50, no. 3, 2005, pp. 305-348.

Weber, Max, Objectivity in Social Science and Social Policy, in: Max Weber on the Methodology of the Social Sciences, translated and edited by Edward A. Shils and Henry A. Finch, (New York: Free Press), 1949, pp. 50-112.

Weichbrodt, Johannes, Der verbotene Beweis im Straf- und Zivilprozess: Zur Rolle strafprozessualer Beweisverbote bei der Durchsetzung zivilrechtlicher Ansprüche, (Tübingen: Mohr Siebeck), 2012.

Weigend, Thomas, Is The Criminal Process About The Truth? A German Perspective, Harvard Journal of Law and Public Policy, vol. 26, no. 1, 2003, pp. 157-174.

Weigend, Thomas, The Decay of the Inquisitorial Ideal: Plea Bargaining Invades German Criminal Procedure, in: John Jackson, Maximo Lager and Peter Tillers (eds.), Crime, Procedure and Evidence in A Comparative and International Context: Essays in Honour of Professor Mirjan Damaška, (Oxford and Portland: Hart Publishing), 2008, pp. 39-64.

Westerman, Pauline and Marc Wissink, Rechtsgeleerdheid als rechtswetenschap, Nederlands Juristenblad, 2008, pp. 503-507.

Whiting, Alex, Lead Evidence and Discovery Before the International Criminal Court: The Lubanga Case, UCLA Journal of International Law and Foreign Affairs, vol. 14, 2009, pp. 207-233.

Wigmore, John Henry, Evidence in Trials and Common Law, Wigmore on Evidence, (Boston, MA [etc.]: Little, Brown and Co), 1976. 
Wilson, Richard Ashby, Judging History: The Historical Record of the International Criminal Tribunal for the Former Yugoslavia, Human Rights Quarterly, vol. 27, no. 3, 2005, pp. 908-942.

Wippman, David, Atrocities, Deterrence, and the Limits of International Justice, Fordham International Law Journal, vol., 23, no. 2, 1999-2000, pp. 473-488.

Whitman, James Q., The Origins of Reasonable Doubt: Theological Roots of the Criminal Trial, (Orwigsburg: Keystone Typesetting, Inc.), 2008.

Whitman, James Q., No Right Answer?, in: John Jackson, Maximo Lager and Peter Tillers (eds.), Crime, Procedure and Evidence in a Comparative and International Context: Essays in Honour of Professor Mirjan Damaška, (Oxford and Portland: Hart Publishing), 2008, pp. 371-392.

Wladimiroff, Michail, Cooperation on Criminal Matters: A Defence Lawyer's Perspective, in: Rodrigo Yepes-Enríquez and Lisa Tabassi (eds.), Treaty Enforcement and International Cooperation in Criminal Matters with Special Reference to the Chemical Weapons Convention, (The Hague: T.M.C. Asser Press), 2002, pp. 242-250.

Young, Rebecca, Internationally Recognized Human Rights' Before the International Criminal Court, International and Comparative Law Quarterly, vol. 60, no. 1, 2011, pp. 189-208.

Zahar, Alexander, Legal Aid, Self-Representation, and the Crisis at the Hague Tribunal, Criminal Law Forum, vol. 19, no. 2, 2008, pp. 241-263.

Zahar, Alexander and Sluiter, Göran, International Criminal Law. A Critical Introduction, (Oxford: Oxford University Press), 2009.

Zappalà, Salvatore, Human Rights in International Criminal Proceedings, (Oxford: Oxford University Press), 2003.

Zappalà, Salvatore, The Prosecutor's Duty to Disclose Exculpatory Materials and the Recent Amendment to Rule 68 ICTY RPE, Journal of International Criminal Justice, vol. 2, no. 4, 2004, pp. 620-630.

Zappalà, Salvatore, The Rights of Victims v. the Rights of the Accused, Journal of International Criminal Justice, vol. 8, no. 1, 2010, pp. 137-164. 


\section{Table of Cases}

\section{European Commission on Human Rights}

Austria v. Italy, App. No. 788/60, 31 March 1963.

Can v. Austria, App. No. 9300/81 report of 12 July 1984.

Dorigo v. Italy, App. No. 33286/96, report of 9 September 1998.

Haase v. Germany, App. No. 7412/76, 12 July 1977.

Jespers v. Belgium, App. No. 8403/78, 14 December 1981.

Nielsen v. Denmark, App. No. 343/57, decision of 2 September 1959.

Nielsen v. Denmark, App. No. 343/57, report of 15 March 1961.

Ofner and Hopfinger v. Austria, App. No. 524/59 and 617/59, 23 November 1962.

Pataki and Dunshirn v. Austria, App. No. 596/59 and 789/60, 28 March 1963.

$X$ v. Sweden, App. No. 434/58, 30 June 1959.

X. v. Austria, App. No. 1816/63, 7 March 1964.

\section{European Court on Human Rights}

Allan v. UK, Appl. No. 48539/99, 5 November 2002.

Asch v. Austria, App. No. 12398/86, 26 April 1991.

Axen v. Germany, App. No. 8273/78, 8 December 1983.

Balsyte-Lideikiene v. Lithuania, App. No. 72596/01, 4 November 2008.

Barbera, Messegué and Jabardo, v. Spain, App. Nos. 10588/83, 10589/83, 10590/83, 6 December 1988.

Belziuk v. Poland, App. No. 23103/93, 25 March 1998.

Berger v. France, App. No. 48221/99, 3 December 2002.

Birutis and others v. Lithuania, App. Nos. 47698/99 and 48115/99, 28 March 2002.

Bonisch v. Austria, App. No. 8658/79, 6 May 1985.

Borgers v. Belgium, App. No. 12005/86, 30 October 1991.

Brandstetter v. Austria, App. Nos. 1170/84, 12876/87, 13468/87, 28 August 1991.

Bulut v. Austria, App. No. 17358/90, 22 February 1996.

Chahal v. the United Kingdom, App. No. 22414/93, 15 November 1996.

Delcourt v. Belgium, App. No. 2689/65 17 January 1970.

Dombo Beheer BV v. Netherlands, App. No. 14448/88, 27 October 1993.

Doorson v. Netherlands, App. No. 20524/92, 26 March 1996.

Edwards and Lewis v. United Kingdom, App. Nos. 39647/98 and 40461/98, 27 October 2004.

Edwards v.The United Kingdom, App. No. 13071/87, 19 December 1992.

Ekbatani v. Sweden, App. No. 10563/83, 26 May 1988.

Engel et al. v. The Netherlands, App. Nos. 5100/71; 5101/71; 5102/71; 5354/72; 5370/72,

8 June 1976. 
Table of Cases

Ernst and others v. Belgium, App. No. 33400/96, 15 July 2003.

Feldbrugge v. The Netherlands, App. No. 8562/79, 29 May 1986.

Ferrari-Bravo v. Italy, App. No. 9627/81, 14 March 1984.

Foucher v. France, App. No. 22209/93, 18 March 1997.

Gäfgen v. Germany, App. No. 22978/05, Grand Chamber, 1 June 2010.

Garcia Alva v. Germany, App. No. 23541/94, 13 February 2001.

GB v. France, App. No. 44069/98, 2 October 2001.

Gorraiz Lizarraga and others v. Spain, App. No. 62543/00, 27 April 2004.

Hentrich v. France, App. No. 13616/88, 22 September 1994.

I.J.L. and others. v. The United Kingdom, App. No. 29522/95, 30056/96 and 30574/96,

19 September 2000.

Ilijkov v. Bulgaria, App. No. 33977/96, 26 July 2001.

Imbrioscia v. Switzerland, App. No. 13972/88, 24 November 1993.

Isgrò v. Italy, App. No. 11339/85, 19 February 1991.

Jasper v. United Kingdom, App. No. 27052/95, 16 February 2000.

Juričić v. Croatia, App. No. 58222/09, 26 July 2011.

Kampanis v. Greece, App. No. 17977/91, 13 July 1995.

Khuzhin and others v. Russia, 13470/02, 23 October 2008.

Korolev v. Russia (no.2), App. No. 5447/03, 1 April 2010.

Kostovski v. Netherlands, App. No. 11454/85, 20 November 1989.

Kraska v. Switzerland, App. No. 13492/88, 19 April 1993.

Kremzow v. Austria, App. No. 12350/86, 21 September 1993.

Kuopila v. Finland, App. No. 27752/95, 27 April 2000.

Lamy v. Belgium, App. No. 10444/83, 30 March 1989.

Lanz v. Austria, App. No. 24430/94, 31 January 2002.

Lexa v. Slovakia (no. 2), App. No. 34761/03, 5 January 2010.

Luca v. Italy, App. No. 33354/96, February 2001.

Lüdi v. Switzerland, App. No. 2433/86, of 15 June 1992.

M.C. v. Bulgaria, App. No. 39272/98, 4 December 2003.

Mattoccia v. Italy, App. No. 23969/94, 25 July 2000.

Miailhe v. France (No.2), Appl. No.18978/91, 26 September 1996.

Mirilashvili v. Russia, App. No. 6293/04, 11 December 2008.

Moiseyev v. Russia, App. No.62936/00, 9 October 2008.

Monnell and Morris v. United Kingdom, App. No. 9562/81 and 9818/82, 2 March 1987.

Mooren v. Germany, App. No. 11364/03, Grand Chamber, 9 July 2009.

Moreira de Azevedo v. Portugal, 23 October 1990.

Niedbala v. Poland, App. No. 27915/95, 4 July 2000.

Öcalan v. Turkey, App. No. 46221/99, 12 May 2005.

Perez v. France, App. No. 47287/99, 12 February 2004.

Reinhardt and Slimane-Kaïd v. France, App. No. 23043/93 and 22921/93, 31 March 1998.

Rowe and Davis v. United Kingdom, App. No. 28901/95, 16 February 2000.

Ruiz-Mateos v. Spain, App. No. 12952/87, 23 June 1993.

Saïdi v. France, App. No. 14647/89, 20 September 1993.

Salduz v. Turkey, App. No. 36391/02, 27 November 2008.

Sanchez-Reisse v. Switzerland, App. No. 9862/82, 21 October 1986. 
Schenk v. Switzerland, App. No. 10862/84, 12 July 1988.

Sevastyanov v. Russia, App. No. 37024/02, 22 April 2010

Solakov v. Former Yugoslav Republic of Macedonia, App. No. 47023/99, 31 October 2001.

Toth v. Austria, App. No. 11894/85, 12 December 1991.

Unterpertinger v. Austria, App. No. 9120/80, 24 November 1986.

Van Mechelen and others v. The Netherlands, App. Nos. 21363/93, 21364/93, 21427/93,

22056/93, 23 April 1997.

Vidal v. Belgium, App. No. 12351/86, 22 April 1992.

Winterwerp v. the Netherlands, App. No. 6301/73, 24 October 1979.

Zhuk v. Ukraine, App. No. 45783/05, 21 October 2010.

\section{Inter-American Court on Human Rights}

19 Merchants v. Colombia, 12 June 2002.

Castillo-Petruzzi et al v. Peru, 4 September 1998.

Juvenile Reeducation Institute v. Paraguay, 2 September 2004.

Plan de Sánchez Massacre v. Guatemala, 19 November 2004.

\section{United Nations Human Rights Committee}

Ä̈relä and Näkkäläjärvi v. Finland, Comm. No. 779/97, Views of 24 October 2001.

B.d.B. et al. v. The Netherlands, Comm. No. 273/1988 Inadmissibility decision, 2 May 1989.

Dieter Wolf v. Panama, Comm. No. 289/1988, Views of 26 March 1992.

Dudko v. Australia, Comm. No. 1347/2005, Views of 23 July 2007.

Harward v. Norway, Comm. No. 451/1991, Views of 15 July 1994.

Jansen-Gielen v. Netherlands, Comm. No. 846/99, Views of 3 April 2001.

Jessop v. New Zealand, Comm. No. 1758/2008, Views of 29 March 2011.

José Antonio Martínez Muñoz v. Spain, Comm. No. 1006/2001, Views of 30 October 2003.

Joseph Kavanagh v. Ireland, Comm. No. 819/1998, Views of 4 April 2001.

Larrañaga v. The Philippines, Comm. No. 1421/2005, Views of 24 July 2006.

Lassâad Aouf v. Belgium, Comm. No. 1010/2001, Views of 17 March 2006.

Little v. Jamaica, Comm. No. 283/1988, Views of 19 November 1991.

Lloydell Richards v. Jamaica, Comm. No. 535/1993, Views of 31 March 1997.

Morael v. France, Comm. No. 207/86, Views of 28 July 1989.

Paul Perterer v. Austria, Comm. No. 1015/2001, Views of 20 July 2004.

Salvador Martínes Puertas v. Spain, Comm. No. 1183/2003, Inadmissibility decision of 27 March 2006.

Sawyers and McLean v. Jamaica, Comm. Nos. 226/1907 and 256/1981, Views of 11 April 1991.

\section{International Criminal Tribunal for the former Yugoslavia}

Prosecutor v. Aleksovski, IT-95-14/1, A. Ch., 16 February 1999, Decision on Prosecutor's Appeal on Admissibility of Evidence.

Prosecutor v. Aleksovski, IT-95-14/1-A, A. Ch., 24 March 2000, Judgment. 
Prosecutor v. Blagojević et al., IT-02-60-PT, 12 December 2002, Joint Decision on Motions Related to Production of Evidence.

Prosecutor v. Blagojević et al., IT-02-60-PT, 21 January 2003, Decision on Joint Defence Motions for Reconsideration of Trial Chamber's Decision to Review all Discovery Materials Provided to the Accused by the Prosecution.

Prosecutor v. Blagojević et al., IT-02-60-AR73, IT-02-60-AR73.2 and IT-02-60-AR73.3, A. Ch., 8 April 2003, Decision.

Prosecutor v. Blagojević and Jokić, IT-02-60-T, T. Ch., 13 September 2004, Decision on the Prosecution's Alternative Request to Admit Evidence in Rebuttal and Incorporated Motion to Admit Evidence Under Rule 92bis in its Case on Rebuttal and to Re-Open its Case for a Limited Purpose.

Prosecutor v. Blaškić, IT-95-14-PT, 27 January 1997, Decision on the Production of Discovery Materials.

Prosecutor v. Blaškić, IT-95-14, A. Ch., 29 October 1997, Judgment on the Request of the Republic Of Croatia for Review of the Decision of Trial Chamber II of 18 July 1997.

Prosecutor v. Blaškić, IT-95-14, T. Ch, 15 July 1998, Decision on the Defence Motion for Sanctions for the Prosecutor's Failure to Comply with Sub-Rule 66(A) of the Rules and the Decision of 27 January 1997 Compelling the Production of all Statements of the Accused.

Prosecutor v. Blaškić, IT-95-14-T, T. Ch., 3 September 1998, Decision on the Prosecutor's Motion for Seven (7) Days Advance Disclosure of Defence Witnesses and Defence Witness Statements.

Prosecutor v. Blaškić, IT-95-14-A, A. Ch., 26 September 2000, Decision on the Appellant's Motions for the Production of Material, Suspension or Extension of the Briefing Schedule, and Additional Filings.

Prosecutor v. Blaškić, IT-95-14-A, 4 March 2004, Decision on Prosecution's Application to Seek Guidance from the Appeals Chamber regarding Redaction of the Statement of "Witness Two" for the purposes of Disclosure to Dario Kordić under Rule 68.

Prosecutor v. Blaškić, IT-95-14-A, 30 March 2004, Confidential Decision on Prosecution's Application to Seek Guidance from the Appeals Chamber regarding Redaction of the Statement of "Witness Two" for the Purposes of Disclosure to Paško Ljubičić under Rule 68.

Prosecutor v. Blaškić, IT-95-14-A, 29 July 2004, Appeal Judgement.

Prosecutor v. Bralo, IT-95-17-A, 30 August 2006, Decision on Motions for Access to Ex Parte Portions of the Record on Appeal and for Disclosure of Mitigating Material.

Prosecutor v. Brdjanin and Talić, IT-99-36-PT, T. Ch., 2 May 2001, Motion to Dismiss the Indictment.

Prosecutor v. Brdjanin and Talić, IT-99-36-PT, T. Ch., 16 May 2001, Decision on Second Motion by Brđjanin to Dismiss the Indictment.

Prosecutor v. Brđjanin and Talić, IT-99-36-T, 6 May 2002, Public Version of the Confidential Decision on the Alleged Illegality of Rule 70.

Prosecutor v. Brdjanin, IT-99-36-T, 30 October 2002, Decision on Motion For Relief from Rule 68 Violations by the Prosecutor and for Sanctions to be Imposed Pursuant to Rule 68bis and Motion for Adjournment while Matters Affecting Justice and Fair Trial Can be Resolved. 
Table of Cases

Prosecutor v. Brđjanin and Talić, IT-99-36-AR73.9, A. Ch., 11 December 2002, Decision on Interlocutory Appeal.

Prosecutor v. Brđjanin, IT-99-36-A, 7 December 2004, Decision on Appellant's Motion for Disclosure Pursuant to Rule 68 and Motion for an Order to the Registrar to Disclose Certain Materials.

Prosecutor v. Delalić et al., IT-96-21-T, T. Ch. II, 26 September 1996, Decision on the Motion of the Accused Zejnil Delalić for the Disclosure of Evidence.

Prosecutor v. Delalić et al., IT-96-21-T, T. Ch. I, 3 February 1997, Decision on the Application for Adjournment of the Trial Date.

Prosecution v. Delalić et al., IT-96-21-T, 1 May 1997, Decision on the Motion on Presentation of Evidence by the Accused, Esad Landžo.

Prosecutor v. Delalić et al., IT-96-21-T, T. Ch., 8 July 1997, Decision on the Motion Ex Parte by the Defence of Zdravko Mucić concerning the Issue of a Subpoena to an Interpreter.

Prosecutor v. Delalić, IT-96-21-T, 4 February 1998, Decision on the Prosecution's Motion for an Order Requiring Advance Disclosure of Witnesses by the Defence.

Prosecutor v. Delalič et al., IT-96-21-T, T. Ch., 4 February 1998, Décision relative à la requête de l'accusation aux fins de communication à l'avance de l'identité des témoins à décharge.

Prosecutor v. Delalić et al., IT-96-21-T, 24 May 1998, Joint Request by the Defendants Delalić, Mucić, Delić and Landžo Regarding Presentation of Evidence.

Prosecutor v. Delalić et al., IT-96-21-T, T. Ch. II, 12 June 1998, Decision on the Motion of the Joint Request of the Accused Persons regarding the Presentation of Evidence, dated 24 May 1998.

Prosecution v. Delalić et al., IT-96-21-T, 1 July 1998, Decision on the Motion by Defendant Delalić Requesting Procedures for Final Determination of the Charges against Him.

Prosecutor v. Delalić et al., IT-96-21-T, T. Ch. II, 19 August 1998, Decision on the Prosecution's Alternative Request to Reopen the Prosecution's Case.

Prosecutor v. Delalić et al., IT-96-21-A, A. Ch., 20 February 2001, Judgment.

Prosecutor v. Delić, IT-04-83-PT, 5 July 2007, Decision on Prosecution Motion for Suspension of the Commencement of Trial and All Related Proceedings.

Prosecutor v. Delić, IT-04-83-AR73.1, 15 April 2008, Decision on Rasim Delić's Interlocutory Appeal Against Trial Chamber's Oral Decisions on Admission of Exhibits 1316 and 1317.

Prosecutor v. Delić, IT-04-83-T, 24 April 2008, Reasons for Oral Decision on Admission of Exhibits 1316 and 1317.

Prosecutor v. Galić, IT-98-29-AR73, 14 December 2001, Bench of Three Judges of the Appeals Chamber, Decision on Application by Prosecution for Leave to Appeal.

Prosecutor v. Galić, IT-98-29-T, T. Ch., 3 July 2002, Decision Concerning the Expert Witnesses Ewa Tabeau and Richard Philipps.

Prosecutor v. Galić, IT-98-29-T, T. Ch., 21 February 2003, Decision on the Prosecution Motion for Reconsideration of the Admission of the Expert Report of Professor Radinović.

Prosecutor v. Galić, T-98-29-A, A. Ch., 30 November 2006, Judgment.

Prosecutor v. Gotovina et al., IT-06-90-T, 17 July 2009, Decision on Čermak's Defence Motion to Add a Witness to Its Rule 65ter $(\mathrm{G})$ Witness List.

Prosecutor v. Gotovina et al., IT-06-90-T, 22 September 2009, Decision on Čermak Defence's Second and Third Motions to Add a Witness to its Rule 65ter $(\mathrm{G})$ Witness List. 
Prosecutor v. Gotovina et al., IT-06-90-T, 15 October 2009, Decision on Čermak Defence's Fourth Motion to Amend the Rule 65ter $(\mathrm{G})$ Witness List.

Prosecutor v. Gotovina et al., IT-06-90-T, 15 January 2010, Reasons for Granting Markać Defence's Motion to Add Witness MM-28 (Renamed from MM-26) to its Rule 65ter(G) Witness List.

Prosecutor v. Gotovina, IT-06-90-T, 12 March 2010, Decision on Request for Permanent Restraining Orders Directed to the Republic of Croatia.

Prosecutor v. Gotovina et al., IT-06-90-AR73.5, 14 February 2011, Decision on Gotovina Defence Appeal Against 12 March 2010 Decision on Request for Permanent Restraining Orders directed to the Republic of Croatia.

Prosecutor v. Hadžihasanvić, IT-01-47-PT, T. Ch. 12 September 2003, Decision on defence access to EUMM archives.

Prosecutor v. Hadžihasanović and Kubura, IT-01-47-T, T. Ch. II, 4 February 2005, Decision on Defence Motion Seeking Clarification of the Trial Chamber's Objective in its Questions Addressed to Witnesses.

Prosecutor v. Hadžihasanović and Kubura, IT-01-47-T, T. Ch. II, 1 June 2005, Decision on the Prosecution's Application to Re-Open its Case.

Prosecutor v. Halilović, IT-01-48-PT, T. Ch. I, 4 July 2003, Decision on Defence Appeal for the Pre-Trial Conference to be postponed.

Prosecutor v. Halilović, IT-01-48-PT, 14 November 2003, Decision on Defence Motion for Identification of Suspects and Other Categories among its Proposed Witnesses.

Prosecutor v. Halilović, IT-01-48-AR73, 21 June 2004, Decision on the Issuance of Subpoenas.

Prosecutor v. Halilović, IT-01-48-T, T. Ch. I, 9 May 2005, Decision on Motion for Prosecution Access to Defence Documents.

Prosecutor v. Halilović, IT-01-48-T, T. Ch. I, 9 May 2005, Decision on Motion for Prosecution Access to Defence Documents Used in Cross-Examination of Prosecution Witnesses.

Prosecutor v. Halilović, IT-01-48-T, T. Ch. I, Section A, 21 July 2005, Decision on Prosecution Motion to Call Rebuttal Evidence.

Prosecutor v. Haradinaj et al., IT-04-84-PT, 22 February 2007, Decision Pursuant to Rule $73 b i s(\mathrm{D})$.

Prosecutor v. Haradinaj et al., IT-04-84-A, 17 July 2008, Notice of Filing of Public Redacted Version of Prosecution Appeal Brief.

Prosecutor v. Haradinaj et al., IT-04-84-A, 23 July 2010, Appeals Chamber Judgment.

Prosecutor v. Karadžić, IT-95-05/18, 11 September 2003, Search Warrant for the Public Security Centre (CJB) Srpsko Sarajevo, (Duty Judge May).

Prosecutor v. Karadžić, IT-95-5/81-I, 29 August 2008, Decision on the Accused's Request for Copies of Search Warrants.

Prosecutor v. Karadžić, IT-95-5/18-PT, 28 January 2009, Decision on Accused Motion for Adequate Facilities and Equality of Arms: Legal Associates.

Prosecutor v. Karadžić, IT-95-5/18-PT, T. Ch., 8 July 2009, Decision on Motion for Subpoena to Douglas Lute and John Feeley.

Prosecutor v. Karadžić, IT-95-5/18-PT, T. Ch. I, 8 October 2009, Decision on the Application of Rule 73 bis.

Prosecutor v. Karadžić, IT-95-5/18-T, President Decision, 17 December 2009, Decision on Appeal of OLAD Decision in Relation to Additional Pre-Trial Funds. 
Prosecutor v. Karadžić, IT-95-5/18-AR73.7, 31 March 2010, Decision on Appeal from Decision on Motion for Further Postponement of Trial.

Prosecutor v. Karadžić, IT-95-5/18-T, T. Ch., 2 July 2010, Decision on Accused's Motion for Additional Time to Prepare Cross-Examination of Momčilo Mandić.

Prosecutor v. Karadžić, IT-95-5/18-T, T. Ch., 2 November 2010, Decision on Accused's Eighteenth to Twenty-First Disclosure Violation Motions.

Prosecutor v. Karadžić, IT-95-5/18-T, T. Ch., 11 November 2010, Decision on Accused's Twenty-Second, Twenty-Fourth and Twenty-Sixth Disclosure Violation Motion.

Prosecutor v. Karadžić, IT-95-5/18-T, T. Ch., 10 December 2010, Decision on Prosecution's Request for Reconsideration of Trial Chamber's 11 November 2010 Decision.

Prosecutor v. Karadžić, IT-95-5/18-T, T. Ch., 29 March 2011, Decision on Accused's ThirtySeventh to Forty-Second Disclosure Violation Motions With Partially Dissenting Opinion of Judge Kwon.

Prosecutor v. Karadžić, IT-95-5/18-T, T. Ch., 8 April 2011, Invitation to Germany Regarding Motion for Subpoena of Christoph Von Bezold.

Prosecutor v. Karadžić, IT-95-5/18-T, T. Ch., 30 June 2011, Decision on Accused's FortyNinth and Fiftieth Disclosure Violation Motions.

Prosecutor v. Karadžić, IT-95-5/18-T, T. Ch., 22 November 2011, Decision on Accused's Sixtieth, Sixty-First, Sixty-Third, and Sixty-Fourth Disclosure Violation Motions.

Prosecutor v. Kordić and Čerkez, IT-95-14-PT, 26 February 1999, Order on Motion to Compel Compliance by Prosecution with Rule 66(A) and 68.

Prosecutor v. Kordić and Čerkez, IT-95-14/2-T, Transcript of 31 May 1999,

Prosecutor v. Kordić and Čerkez, IT-95-14/2-T, T. Ch., 25 June 1999, Decision Stating Reasons for Trial Chamber's Ruling of 1 June 1999 Rejecting Defence Motion to Suppress Evidence.

Prosecutor v. Kordic and Čerkez, IT-95-14/2-AR108bis, 9 September 1999, Decision on the Request of the Republic of Croatia for a Review of a Binding Order.

Prosecutor v. Kordić and Čerkez, IT-95-14/2, 18 July 2000, Order to Bosnia and Herzegovina for the Production of Documents.

Prosecution v. Kordić and Čerkez, IT-95-14/2-T, Oral Decision of 18 October 2000, T. 26647.

Prosecutor v. Kordić and Čerkez, IT-95-14/2, 1 December 2000, Decision on Prosecutor's Submissions Concerning "Zagreb Exhibits" and Presidential Transcripts.

Prosecutor v. Kordić and Čerkez, IT-95-14/2-A, A. Ch., 11 May 2001, Decision on Motions to Extend Time for Filing Appellant's Briefs.

Prosecutor v. Kordić and Čerkez, IT-95-14/2, 20 June 2001, Order to Bosnia and Herzegovina for the Production of Documents, 18 July 2000, Application for Issuance of an Order to Bosnia-Herzegovina Compelling the Production of Documents and Other Materials.

Prosecutor v. Kordić and Čerkez, Status Conference, IT-95-14/2, 22 June 2001, T. 2852228523, 28525-28528.

Prosecutor v. Kordić and Čerkez, IT-95-14/2-A, A. Ch., 11 September 2001, Decision on the Application by Mario Čerkez for Extension of Time to File his Respondent's Brief.

Prosecutor v. Kordić and Čerkez, IT-95-14/2-A, 17 December 2004, Appeals Chamber, Judgment. 
Table of Cases

Prosecutorv. Krajišnik and Plavšić, IT-00-39 \& IT-00-40/1, 19 July 2001, Decision on Motion from Momcilo Krajišnik to Compel Disclosure of Exculpatory Evidence Pursuant to Rule 68.

Prosecutor v. Krajišnik and Plavšić, T. Ch. 1 August 2001, Decision on Prosecution Motion for Clarification in Respect of Application of Rules 65, 66(B) and 67(C).

Prosecutor v. Krajišnik and Plavšić, IT-00-39 \& 40-PT, T. Ch., 26 April 2002, Decision on Defence Motion for Access to Certain Search Warrants.

Prosecutorv vrajišnik, IT-00-39-T, T. Ch. I, 21 September 2004, Decision on Defence Motion for Adjournment (written reasons).

Prosecutor v. Krajišnik, IT-00-39-T, T. Ch. I, 4 March 2005, Decision on (second) Defence Motion for Adjournment.

Prosecutor v. Krajišnik, IT-00-39-AR73.1, A. Ch., 25 April 2005, Decision on Interlocutory Appeal of Decision on Second Defence Motion for Adjournment.

Prosecutor v. Krajišnik, IT-00-39-T, T. Ch. I, 9 February 2006, Order on Prioritizing Defence Witnesses.

Prosecutor v. Krajišnik, IT-00-39-T, 16 August 2006, Reasons for Decision Denying Motion for Time to Call Additional Witnesses.

Prosecutor v. Krajišnik, IT-00-39-T, 23 August 2006, Defence Application for Certification Pursuant to Rule 73(B) of the Rules of Procedure and Evidence to Appeal Against Decision on Defence Motion for Time to Call Additional Witnesses.

Prosecutor v. Krajišnik, IT-00-39-T, T. Ch. I, 24 August 2006, Decision on Defence Motion Pursuant to Rule 85(A)(vi) - Including Reasons for Denial in Part.

Prosecutor v. Krajišnik, IT-00-39-T, T. Ch., 27 September 2006, Judgment.

Prosecutor v. Krajišnik, IT-00-39-A, A. Ch., 11 September 2007, Decision on Krajišnik's Request and on Prosecution Motion.

Prosecutor v. Krnojelac, IT-97-25-PT, 14 September 1999, Record of Rulings Made in Status Conference.

Prosecutor v. Krstić, IT-98-33-T, 25 April 2001, Decision on the Defence Motion to Exclude Exhibits in Rebuttal Evidence and Motion for Continuance (confidential), 4 May 2001 (public version).

Prosecutorv. Krstić, IT-98-33-A, A. Ch., 20 February 2003, Defence Reply to the Prosecution's Response to Defence Motions for Admission of Additional Evidence under Rule 115.

Prosecutor v. Krstić, IT-98-33-A, 27 March 2003, Appeals Chamber, Decision on Prosecution's Motion to Be Relieved of Obligation to Disclose Sensitive Information Pursuant to Rule 66(C).

Prosecutor v. Krstić, IT-98-33-A, A. Ch., 1 July 2003, Decision on Application of Subpoenas.

Prosecutor v. Krstić, IT-98-33-A, 19 April 2004, Appeal Judgment.

Prosecutor v. Kupreškić et al., IT-96-16-I, 10 November 1995, Decision on the Review of Indictment.

Prosecutor v., Kupreškić et al., IT-95-19-T, T. Ch. II, 21 September 1998, Decision on the Communication between Parties and their Witnesses.

Prosecutor v. Kupreškić et al., IT-95-16-T, T. Ch., 11 January 1999, Decision.

Prosecutor v. Kupreškić et al., IT-95-16-T, 14, January 2000, Judgment and Sentence.

Prosecutor v. Kvočka et al., IT-98-30/1-A, A. Ch., 7 February 2003, Decision on Review of Registrar's Decision to Withdraw Legal Aid from Zoran Žigić. 
Prosecutor v. Lukić and Lukić, IT-98-32/1-T, T. Ch., 23 July 2008, Decision on Second Prosecution Motion for the Admission of Evidence Pursuant to Rule 92bis (Two Expert Witnesses).

Prosecutor v. Lukić and Lukić, IT-98-32/1-AR73.1, 16 October 2008, Decision on the Prosecution's Appeal against the Trial Chamber's order to Call Alibi Rebuttal Evidence During the Prosecution's Case in Chief.

Prosecutor v. Lukić and Lukić, IT-98-32/1-T, T. Ch. III, 3 November 2008, Decision on Milan Lukic's Motion to Suppress Testimony for Failure of Timely Disclosure with Confidential Annexes A and B.

Prosecutor v. Lukić and Lukić, IT-98-32/1-T, 26 November 2008, Order Pursuant to Rule $73 \mathrm{ter}$ of the Rule of Procedure and Evidence.

Prosecutor v. Slobodan Milošević, IT-02-54-AR73, 16 May 2002, Reasons for Refusal of Leave to Appeal from Decision to Impose Time Limit.

Prosecutor v. Slobodan Milošević, IT-02-54-AR108bis \& AR73.3, A. Ch., 23 October 2002, Public Version of Confidential Decision on the Interpretation and Application of Rule 70.

Prosecutor v. Slobodan Milošević, IT-02-54-AR73.6, 20 January 2004, Decision on the Interlocutory Appeal by the Amici Curiae against the Trial Chamber Order Concerning the Presentation and Preparation of the Defence Case.

Prosecutor v. Slobodan Milošević, IT-02-54-T, T. Ch., 25 February 2004, Order Rescheduling and Setting the Time Available to Present the Defence Case.

Prosecutor v. Milošević, IT-02-54-A, A. Ch., 1 November 2004, Decision on Interlocutory Appeal of the Trial Chamber's Decision on the Assignment of Defence Counsel.

Prosecution v. Slobodan Milošević, IT-02-54-T, T. Ch., 17 May 2005, Decision on Prosecution Motion for Reconsideration Regarding Evidence of Defence Witnesses Mitar Balević, Vladislav Jovanović, Vukasin Andrić, and Dobre Aleksovski and Decision Proprio Motu Reconsidering Admission of Exhibits 837 and 838 Regarding Evidence of Defence Witness Barry Lituchy.

Prosecutor v. Slobodan Milošević, IT-02-54-T, T. Ch. I, 12 December 2005, Decision in Relation to Severance, Extension of Time and Rest.

Prosecutor v. Slobodan Milošević, IT-02-54-T, T. Ch. I, 13 December 2005, Decision on Application for a limited Re-Opening of the Bosnia and Kosovo Components of the Prosecution Case with Confidential Annex.

Prosecutor v. Dragomir Milošević, IT-98-2911-PT, 12 December 2006, Decision on Amendment of the Indictment and Application of Rule 73bis(D).

Prosecutor v. Dragomir Milošević, IT-98-29/1-T, 3 April 2007. Decision on Prosecution's Motion Pursuant to Rule 73bis(F).

Prosecutor v. Dragomir Milošević, IT-98-29/1-T, T. Ch. III, 26 June 2007, Decision on the Prosecution's Motion for Defence Compliance with Rule 65ter $(\mathrm{G})$.

Prosecutor v. Milutinović et al., IT-99-37-PT, 16 June 2003, Registry Comments on Defence Motion for Additional Funds.

Prosecutor v. Milutinović et al., IT-99-37-AR73.2, A. Ch., 13 November 2003, Decision on Interlocutory Appeal on Motion for Additional Funds.

Prosecutor v. Milutinović et al., IT-99-37-AR73.2, A. Ch., 13 November 2003, Decision on Interlocutory Appeal on Motion for Additional Funds, Dissenting Opinion of Judge Hunt. 
Table of Cases

Prosecutor v. Milutinović et al., IT-05-87-PT, 17 November 2005, Decision on Second Application of Dragoljub Ojdanić for Binding Orders Pursuant to Rule 54bis.

Prosecutor v. Milutinović et al., IT-05-87-PT, T. Ch., 23 November 2005, Decision on Second Application of Dragoljub Ojdanić for Binding orders pursuant to Rule 54bis.

Prosecutor v. Milutinović et al., IT-05-87/AR108bis.2, A. Ch., 12 May, 2006, Decision on Request of the United States of America for Review.

Prosecutor v. Milutinović et al., IT-05-87-T, 11 July 2006, Decision on Application of Rule 73 bis.

Prosecutor v. Milutinović et al., IT-05-87-T, T. Ch. III, 30 August 2006, Decision on Prosecution's Request for Certification of Rule 73bis Issue for Appeal.

Prosecutor v. Milutinović et al., IT-05-87, 29 September 2006, Decision on Ojdanić Motion for Disclosure of Witness Statements and for Finding of Violation of Rule 66(A)(ii).

Prosecutor v. Milutinović et al., IT-05-87-T, 9 October 2006, General Ojdanić's Motion to Preclude Parties from Calling Expert Witnesses.

Prosecutor v. Milutinović et al., IT-05-97-T, 16 November 2006, Decision on Ojdanić Motion to Preclude Parties from Calling Expert Witnesses.

Prosecutor v. Milutinović et al., IT-05-87-T, 16 January 2007, Decision on Renewed Prosecution Motion for Leave to Amend Its Rule 65ter List to Add Michael Phillips and Shaun Byrnes.

Prosecutor v. Milutinović et al., IT-05-87-T, T. Ch., 23 July 2007, General Ojdanić's Third Motion for Stay of Proceedings.

Prosecutor v. Milutinović et al., IT-05-87-T, T. Ch., 5 October 2007, Decision on Prosecution Request for Disclosure of Further Information Regarding Witnesses to be Called by Lazarević and Lukić Defences.

Prosecutor v. Milutinović et al., IT-05-87-T, 7 April 2009, Order Regarding Prosecution's Submission with Respect to Rule 73bis(D).

Prosecutor v. Mrksić, IT-95-13/1-AR73, 4 June 2003, Defence Brief on an Interlocutory Appeal on Trial Chamber's Decision on Defence Motion Requesting the Determination of Rules for Communicating with Potential Witnesses of the Opposite Party.

Prosecutor v. Mrksić, IT-95-13/1-AR73, 16 June 2003, Prosecution's Response to the 'Defence Brief on an Interlocutory Appeal on Trial Chamber's Decision on Defence Motion Requesting the Determination of Rules for Communicating with Potential Witnesses of the Opposite Party'.

Prosecutor v. Mrksić, IT-95-13/1-AR73, A. Ch., 30 July 2003, Decision on Defence Interlocutory Appeal on Communication with Potential Witnesses of the Opposite Party.

Prosecutor v. Mucić, IT-96-21-A, A. Ch., 20 February 2001, Judgement.

Prosecutor v. Naletilic and Martinović, IT-98-34-T, T. Ch., 31 August 2001, Decision on the Accused Naletilić's Motion to Continue Trial Date.

Prosecutor v. Naletilić and Martinović, IT-98-34-T, T. Ch., 15 April 2002, Decision on the Prosecution Motion to preclude Defence Witnesses Damir Zorić and Milan Kovać from testifying.

Prosecutor v. Naletilić and Martinović, IT-98-34-T, 16 September 2002, Decision on Joint Motions for Order Allowing Defence Counsel to Inspect Documents in the Possession of the Prosecution. 
Prosecutor v. Naletilić and Martinović, IT-98-34-T, T. Ch. I, section A, 25 October 2002, Decision on Accused Naletilić's Request For Issuance Of Subpoena Duces Tecum Per Rule 54.

Prosecutor v. Orić, IT-03-68-AR73, A. Ch., 26 March 2004, Public Redacted Version of "Decision on Interlocutory Appeal Concerning Rule 70" issued on March 24, 2004.

Prosecutor v. Orić, IT-03-68-AR73.2, A. Ch., 20 July 2005, Interlocutory Decision on Length of Defence Case.

Prosecutor v. Orić, IT-03-68-T, T. Ch., 27 October 2005, Decision on Urgent Defence Motion Regarding Prosecutorial Non-Compliance With Rule 68.

Prosecutor v. Orić, IT-03-68-T, T. Ch., 13 December 2005, Decision on Ongoing Complaints About Prosecutorial Non-Compliance With Rule 68 of the Rules.

Prosecutor v. Perišić, IT-04-81-PT, T. Ch. III, 1 February 2007, Motion for Appointment of Amicus Counsel to report to Chamber on Inequality of Arms afforded the Defence.

Prosecutor v. Perišić, IT-04-81-PT, T. Ch. III, 15 May 2007, Decision on Application of Rule 73 bis and Amendment of Indictment.

Prosecutor v. Perišić, IT-04-81-PT, T. Ch. III, 18 June 2007, Decision on Motion to Appoint Amicus Curiae to Investigate Equality of Arms.

Prosecutor v. Perišić, IT-04-81-PT, 27 June 2008, Ruling in Relation to Report on Reduction of Length of Prosecution Case.

Prosecutor v. Perišić, IT-04-81-T, T. Ch., 10 March 2009, Decision on Expert Report by Richard Philipps.

Prosecutor v. Popović et al. IT-05-88-AR.73.2, A. Ch., 30 January 2008, Decision on Joint Defence Interlocutory Appeal Concerning the Status of Richard Butler as an Expert Witness.

Prosecutor v. Popović et al., IT-05-88-T, 19 February 2009, Redacted Version of "Decision on Motion on Behalf of Drago Nikolic Seeking Admission of Evidence Pursuant to Rule 92 Quarter", Filed Confidentially on 18 December 2008.

Prosecutor v. Prlić et al., IT-04-74-AR73.2, 4 July 2005, Decision on Joint Defence Interlocutory Appeals Against the Trial Chamber's Oral Decision of 8 May 2006 Relating to Cross-Examination by Defence and on Association of Defence Counsel's Request for Leave to File an Amicus Curiae Brief.

Prosecutor v. Prlić et al., IT-04-74-PT, T. Ch. II, 28 April 2006, Revised Version of the Decision Adopting Guidelines on Conduct of Trial Proceedings.

Prosecutor v. Prlić et al., IT-04-74-T, 29 May 2006, Decision on Defence Request Filed Jointly by the Six Accused for Certification of Interlocutory Appeal Against the Oral Decision of 8 May on time Allocated for Cross-Examination by Defence.

Prosecutor v. Prlić et al., IT-04-74-T, 29 June 2006, Decision on the Oral Request of the Accused Jadranko Prlić for Authorisation to Use a Laptop Computer At Hearing or to be Seated Next to His Counsel.

Prosecutor v. Prlić et al., IT-04-74-T, T. Ch. III, 13 November 2006, Decision on Adoption of New Measures to Bring the Trial to an End Within the Reasonable Time.

Prosecutor v. Prlić et al., IT-04-74, 29 November 2006, Decision on Admission of Evidence, 13 July 2006, Decision Amending the Decision on Admission of Evidence Dated 13 July 2006. 
Prosecutor v. Prlić et al., IT-04-74-AR73.4, A. Ch., 6 February 2007, Decision on Prosecution Appeal Concerning the Trial Chamber's Ruling Reducing Time for the Prosecution Case.

Prosecutor v. Prlić et al., IT-04-74-T, T. Ch. III, 1 March 2007, Decision Following the Appeals Chamber Decision of 6 February 2007 Concerning Appeal Against Reducing Time for the Prosecution Case.

Prosecutor v. Prlić et al., IT-04-74-AR73.4, A. Ch., 11 May 2007. Decision on Prosecution Appeal Following Trial Chamber's Decision on remand and Further Certification.

Prosecutor v. Prlić et al., IT-04-74-T, T. Ch., 22 August 2007, Decision Allocating Additional Times for Completion of Case-in-Chief.

Prosecutor v. Prlic et al., IT-04-74-T, 28 January 2008, Decision on Motion for Extension of Time for the Commencement of the Defence Case and Adopting a New Schedule.

Prosecutor v. Prlić et al., IT-04-47-T, 24 April 2008, Decision Adopting Guidelines for the Presentation of Defence Evidence.

Prosecutor v. Prlić et al., IT-04-74-T, T. Ch. III, 25 April 2008, Decision Allocating Time to the Defence to Present its Case.

Prosecutor v. Prlić et al., IT-04-74-T, T. Ch. III, 29 May 2008, Decision on Petković Defence Motion for Certification to Appeal the Decision of 24 April 2008.

Prosecutor v. Prlić, IT-04-74-AR73.7, A. Ch., 1 July 2008, Decision on Defendants Appeal Against "Décision Portant Attribution du Temps à la Défence pour la Présentation des Moyens à Décharge".

Prosecutor v. Prlić et al., IT-04-73-T, T. Ch. III, 4 July 2008, Decision on Prosecution Motion Concerning Use of Leading Questions, the Attribution of Time to the Defence Cases, the Time Allowed for Cross-Examination by the Prosecution, and Associated Notice Requirements.

Prosecutor v. Prlić et al., IT-04-47-AR73.8, A. Ch., 18 July 2008, Decision on Petković's and Praljak's Appeals against the Trial Chamber's Decision Adopting Guidelines for the Presentation of Defence Evidence.

Prosecutor v. Prlić et al., IT-04-74-T, T. Ch. III, 27 November 2008, Decision on Scope of Cross-Examination under Rule 90(H) of the Rules.

Prosecutor v. Prlić et al., IT-04-74-T, T. Ch. III, 27 November 2008, Decision on Presentation of Documents by the Prosecution in Cross-Examination of Defence Witnesses.

Prosecutor v. Prlić et al., IT-04-74-T, T. Ch. III, 27 November 2008, Partially Dissenting Opinion of Presiding Judge Jean-Claude Antonetti Regarding the Decision on Presentation of Documents by the Prosecution in Cross-Examination of Defence Witnesses.

Prosecutor v. Prlić et al., IT-04-74-AR.73.12, 5 December 2008, Decision on Slobodan Praljak's Appeal of the Trial Chamber's 13 October 2008 Order Limiting the Translation of Defence Evidence.

Prosecutor v. Prlić et al., IT-04-74-AR73.14, A. Ch., 26 February 2009, Decision on the Interlocutory Appeal against the Trial Chamber's Decision on Presentation of Documents by the Prosecution in Cross-Examination of Defence Witnesses.

Prosecutor v. Prlić et al., IT-04-74-AR73.16, 3 November 2009, Decision on Jadranko Prlić's Interlocutory Appeal Against the Decision on Prlić Defence Motion for Reconsideration of the Decision on Admission of Documentary Evidence.

Prosecutor v. Šešelj, IT-03-67-T, 8 November 2006, Decision on the Application of Rule 73bis. 
Prosecutor v. Šešelj, IT-03-67-PT, 30 July 2007, Decision on the Financing the Defence of the Accused.

Prosecutor v. Šešelj, IT-03-67-PT, T. Ch., 30 October 2007, Decision on Implementing the Financing of the Accused.

Prosecutor v. Šešelj, IT-03-67-PT, T. Ch., 23 April 2009, Decision on Financing of Accused's Defence.

Prosecutor v. Šešelj, IT-03-67-T, T. Ch. III, 29 June 2010, redacted Version of the Decision in Reconsideration of the Decision of 15 May 2007 on Vojislav Šešelj's Motion for Contempt against Carla Del Ponte, Hildegard Uertzretzlaff and Daniel Saxon.

Prosecutor v. Šešelj, IT-03-67-T, T. Ch. III, 2 November 2010, Redacted Version of Decision on Financing of Defence, Filed on 29 October 2010.

Prosecustor v. Simić et al., IT-95-9-T, 23 October 2002, Order in respect of Pre-Defence Filings and Scheduling.

Prosecutor v. Stakić, IT-97-24-A, 22 March 2006, Appeals Chamber Judgment.

Prosecutor v. Stanišić and Župljanin, IT-08-91-T, T. Ch. II, 21 October 2009, Decision Denying the Prosecution Motion for Reconsideration of the Order Limiting the Number of Witnesses it May Call at Trial.

Prosecutor v. Stanišić and Simatović, IT-03-69-PT, T. Ch. III, 4 February 2008, Decision Pursuant to Rule 73 bis(D).

Prosecutor v. Stanišić and Simatović, IT-03-69-T, T. Ch. I, 10 March 2011, Decision on Stanišić Defence Motion for Equality of Arms and Immediate Suspension of the Trial and on Association of Defence Counsel (ADC-ICTY) Motion for Leave to Appear as Amicus Curiae.

Prosecutor v. Stanišić and Simatović, IT-03-69-T, 27 May 2011, Decision on Urgent Prosecution Motion for Disclosure of Witness details and for Modification of the Scheduling Order of 1 April 2011.

Prosecutor v. Tadić, IT-94-1-T, T. Ch., 10 August 1995, Protective Measures Decision.

Prosecutor v. Tadić, IT-94-1-AR72, A. Ch., 2 October 1995, Judgment.

Prosecutor v. Tadić, IT-94-I-T, 27 November 1996, Prosecution Motion for Production of Defence Witness Statements.

Prosecutor v. Tadić, IT-94-I-T, 27 November 1996, Separate and Dissenting Opinion of Judge McDonald on Prosecution Motion for Production of Defence Witness Statements.

Prosecutor v. Tadić, IT-94-I-T, 27 November 1996, Separate Opinion of Judge Vohrah on Prosecution Motion for Production of Defence Witness Statements.

Prosecutor v. Tadić, IT-94-I-T, 27 November 1996, Separate Opinion of Judge Stephen on Prosecution Motion for Production of Defence Witness Statements.

Prosecutor v. Tadić, IT-94-1-A, A. Ch., 15 July 1999, Judgment.

Prosecutor v. Tolimir, IT-05-88/2-T, T. Ch. I, 4 March 2010, Decision on the Accused's Information and Requests for the Trial Chamber.

\section{International Criminal Tribunal for Rwanda}

Prosecutor v. Bagosora et al., ICTR-98-41-T, T. Ch., 10 July 2002, Request to the Government of United States of America for Cooperation. 
Prosecutor v. Bagosora et al., ICTR-98-41-T, T. Ch., 10 March 2004, Request to the Government of Rwanda for Cooperation and Assistance Pursuant to Article 28 of the Statute.

Prosecution v. Bagosora et al., ICTR-98-41-T, T. Ch. I, 26 April 2005, Decision on Modalities for Examination of Defence Witnesses.

Prosecutor v. Bagosora et al., ICTR-98-41-AR73 \& ICTR-98-41-AR73(B), 6 October 2005, Decision on Interlocutory Appeals of Decision on Witness Protection Orders.

Prosecutor v. Bagosora et al., ICTR-98-41-T, T. Ch., 31 October 2005, Decision on Request to the Republic of Togo for Assistance Pursuant to Article 28 of the Statute.

Prosecutor v. Bagosora et al., ICTR-98-41-T, 8 March 2006, Decision on Disclosure of Defence Witness Statements in the Possession of the Prosecution Pursuant to Rule 68(A).

Prosecutor v. Bagosora et al., ICTR-98-41-T, 6 October 2006, Decision on Request for Cooperation of the Government of France.

Prosecutor v. Bagosora et al., ICTR-98-41-T, T. Ch., 18 April 2007, Decision on Ntabakuze Petition for a Writ of Mandamus and Related Defence Requests.

Prosecutorv. Bagosora et al., ICTR-98-41-T, T. Ch. 10 March 2008, Request to the Government of Rwanda for Cooperation and Assistance Pursuant to Article 28 of the Statute.

Bagosora et al v. Prosecutor, ICTR-98-41-A, A. Ch., 6 October 2010, Decision on Aloys Ntabakuze's Motion for Injunctions against the Government of Rwanda Regarding the Arrest and Investigation of Lead Counsel Peter Erlinder.

Bagosora et al. v. Prosecutor, ICTR-98-41-A, 27 January 2011, Decision on Aloys Ntabakuze's Motion for Stay of Proceedings.

Bagosora et al. v. Prosecutor, ICTR-98-41-A, 15 March 2011, Decision on Aloys Ntabakuze's Motions for Video-Conference Participation of Lead Counsel in the Appeal Hearing and for the Withdrawals of Registrar's Public Decision.

Bagosora et al. v. Prosecutor, ICTR-98-41A-A, A. Ch., 21 April 2011, Order Imposing Sanctions on Ntabakuze's Lead Counsel.

Barayagwiza v. Prosecutor, ICTR 97-19-AR72, A. Ch., 3 November 1999.

Prosecutorv. Barayagwiza, ICTR-97-19-AR72, A. Ch., 31 March 2000, Decision(Prosecutor's Request for Review or Reconsideration).

Prosecutorv. Barayagwiza, ICTR-97-19-AR72, A. Ch., 31 March 2000, Decision (Prosecutor's Request for Review or Reconsideration), Separate Opinion of Judge Shahabuddeen.

Prosecutor v. Bizimungu et al., ICTR-99-50-T, 23 April 2004, Decision on Motion of Accused Biramumpaka for Disclosure of Exculpatory Evidence.

Prosecutor v. Bizimungu et al., ICTR-99-50-I, T. Ch. 5 May 2004, Decision on Prosper Mugiraneza's Motion to Require Strict Compliance with Rule 66(A)(ii).

Prosecutor v. Bizimungu et al., ICTR-99-56-T, 13 February 2006, Decision on Nzuwonemeye's Motion Requesting the Cooperation of the Government of Ghana Pursuant to Article 28 of the Statute.

Prosecutor v. Bizimungu et al., ICTR-99-50-T, T. Ch., 25 September 2006, Decision on Casimir Bizimungu's Request for Disclosure of the Bruguiere Report and the Cooperation of France.

Prosecutor v. Bizimungu et al., ICTR-99-50-T, T. Ch., 21 February 2008, Decision on Motion of Jérôme-Clément Bicamumpaka to Admit the Report of Expert Dr Bernard Lugan into Evidence. 
Prosecutor v. Bizimungu et. al, ICTR-99-50-T, T. Ch., 23 July 2008, Decision on Justin Mugenzi's Request for Disclosure Order.

Prosecutor v. Bizimungu et al., ICTR-99-50-T, 30 October 2008, Decision on Proseper Mugiraneza's Motion Regarding Cooperation with the Republic of Burundi.

Prosecutor v. Bizimungu et al., ICTR-99-50-T, T. Ch., 30 September 2011, Judgment and Sentence.

Prosecutor v. Gatete, ICTR-2000-61-PT, 13 October 2009, Decision on Defence Motions for Disclosure Pursuant to Rule 66(A)(ii) and Commencement of Trial.

Prosecutor v. Kajelijeli, Judgement, ICTR-98-44A-A, 23 May 2005.

Prosecutor v. Kalimanzira, ICTR-05-88-A, A. Ch., 20 October 2010, Appeals Chamber Judgement.

Prosecutor v. Karemera et al., ICTR-98-44, 20 October 2003, Decision on the Defence Notification of Failure to Comply with Trial Chamber Order and Motion for Remedial Measures.

Prosecutor v. Karemera et al., ICTR-98-44-PT, T. Ch. III, 7 December 2004, Decision on Severance of André Rwamakuba and Amendments to the Indictment.

Prosecutor v. Karemera et al., ICTR-98-44-PT, T. Ch. III, 23 February 2005, Decision on Joseph Nzirorera's Motion to Request the Cooperation of the Government of a State

Prosecutor v. Karemera et al., ICTR-98-44-T, T. Ch. II, 8 February 2006, Decision on Defence Motion for Issuance of Subpoena to Witness T.

Prosecutor v. Karemera et al., ICTR-98-44-AR73.6, 28 April 2006, Decision on Joseph Nzirorera's Interlocutory Appeal.

Prosecutor v. Karemera et al., ICTR-98-44-AR73.7, 30 June 2006, Decision on Interlocutory Appeal Regarding the Role of the Prosecutor's Electronic Disclosure Suite in Discharging Disclosure Obligations.

Prosecutor v. Karemera et al., ICTR-98-44-AR73.13, A. Ch., 14 May 2008, Decision on "Joseph Nzirorera's Appeals from Decision on Tenth Rule 68 Motion.

Prosecutor v. Kayishema and Ruzindana, ICTR-95-1-A, A. Ch., 1 June 2001, Judgment (Reasons).

Prosecutor v. Mpambara, ICTR-2001-65-1, 28 February 2002, Decision Defence Motion for Disclosure of Documents and Objections Regarding the Legality of Procedures.

Prosecutor v. Mpambara, ICTR-2001-65-1, 22 October 2002, Decision (Defence Motion for Release of the Accused).

Prosecutor v. Nahimana et al., ICTR-99-52-T, 5 June 2003, Decision on the motion to stay the proceedings in the trial of Ferdinand Nahimana.

Prosecutor v. Nahimana et al., ICTR-99-52-A, 30 October 2006, Decision on Appellant Jean-Bosco Barayagwiza's Motion Requesting That the Prosecution Disclosure of the Interview of Michel Bagaragaza Be Expunged from the Record.

Nahimana et al. v. Prosecutor, ICTR-99-52-A, 27 November 2006, Decision on Motions Relating to the Appellants Hassan Ngeze's and the Prosecution's Requests for Leave to Present Additional Evidence of Witness $\mathrm{ABC} 1$ and EB.

Nahimana et al. v. Prosecutor, ICTR-99-52-A, 8 December 2006, Decision on Appellant Jean-Bosco Barayagwiza's Motions for Leave to Present Additional Evidence pursuant to Rule 115 of the Rules of Procedure and Evidence. 
Prosecutor v. Ndayambaje, ICTR-96-8-T, 25 September 2001, Decision on Defence Motion for Disclosure, Rules 66, 70(A), and 73 of the Rules.

Prosecutor v. Ndindiliyimana et al., ICTR-00-56-T, 22 September 2008, Decision on Defence Motion Alleging Violation of the Prosecutor's Disclosure Obligations Pursuant to Rule 68.

Prosecutor v. Ngirabatware, ICTR-99-54-T, 12 June 2009, Decision on Trial Date.

Prosecutor v. Ngirabatware, ICTR-99-54-T, T. Ch. II, 30 March 2011, Decision on Prosecution Motion Requesting a cooperation order directed to France.

Prosecutor v. Niyitegeka, ICTR-96-14-A, 9 July 2004, Appeals Judgement.

Prosecutor v. Nshogoza, ICTR-07-91-T, T. Ch., 10 February 2009, Decision on Defence Motion for Order to Prosecutor to Comply with his Disclosure Obligations and Motion for Stay of Proceedings die to the on-going Violation of the Prosecutor's disclosure obligations.

Prosecutor v. Ntagerura et al., ICTR-99-46-T, T. Ch., 21 May 2003, Decision on the Prosecutor's Motion for Leave to Call Evidence in Rebuttal Pursuant to Rules 54, 73, and 85(A)(iii) of the Rules of Procedure and Evidence.

Prosecutor v. Nyiramasuhuko et al., ICTR-97-21-T, 18 September 2001, Decision on the Defence Motion for the Disclosure of the Declaration of the Prosecutor's Witnesses Detained in Rwanda and all Other Documents and Information Pertaining to the Judicial Proceedings in their Respect.

Prosecutor v. Nzirorera et al., ICTR-98-44-I, 4 September 2003, Decision on the Request to the Governments of United States of America, Belgium, France and Germany for Cooperation.

Prosecutor v. Nzirorera et al., ICTR-98-44-I, T. Ch. III, 20 October 2003, Decision on the Defence Motion for Subpoena to Witness G.

Prosecutor v. Renzaho, ICTR-97-31-T, T. Ch., 14 July 2009, Judgment and Sentence.

Prosecutor v. Semanza, ICTR-97-20-T, T. Ch. III, 27 March 2002, Decision on the Prosecutor's Motion for Leave to Call Rebuttal Evidence and the Prosecutor's Supplementary Motion for Leave to Call Rebuttal Evidence.

Prosecutor v. Simba, ICTR-01-76-T, 1 November 2004, Decision on Matters Related to Witness KDD's Judicial Dossier.

Prosecutor v. Simba, Decision on Defence Motion to Obtain Judicial Records Pursuant to Rule 68, ICTR-01-76-T, T. Ch., 4 October 2004.

\section{International Criminal Court}

Prosecutor v. Abdallah Banda Abakaer Nourain and Saleh Mohammed Jerbo Jamus, ICC02/05-03/09, 17 November 2010, Decision on the "Defence Application pursuant to Article 57(3)(b) of the Statute for an order for the preparation and transmission of a cooperation request to the Government of the Republic of Sudan".

Prosecutor v. Abdallah Banda Abakaer Nourain and Saleh Mohammed Jerbo Jamus, ICC02/05-03/09-105, 19 November 2010, Defence Application for Leave to Appeal the "Decision on the 'Defence Application pursuant to Article 57(3)(b) of the Statute for an order for the preparation and transmission of a cooperation request to the Government of the Republic of Sudan"” of 17 November 2010. 
Prosecutor v. Abdallah Banda Abakaer Nourain and Saleh Mohammed Jerbo Jamus, ICC02/05-03/09-109, 30 November 2010, Decision on the "Defence Application for Leave to Appeal the 'Decision on the 'Defence Application pursuant to Article 57(3)(b) of the Statute for an order for the preparation and transmission of a cooperation request to the Government of the Republic of Sudan' of 17 November 2010".

Prosecutor v. Ahmad Muhammad Hurun ("Ahmad Hurun") and Ali Muhammad Ali AbdAl-Rahman ("Ali Kushayb"), ICC-02/05-01/07, T. Ch., 25 May 2010, Decision, Public Document Informing the United National Security Council about the lack of cooperation by the Republic of Sudan, Situation in Darfur, Sudan.

Prosecutor v. Bahr Idriss Abu Garda, ICC-02/05-02/09-18, 30 May 2009, PTC I, Decision Scheduling a Hearing on Issues relating to Disclosure between the Parties.

Prosecutor v. Bahr Idriss Abu Garda, ICC-02/05-02/09-35, PTC I, 15 July 2009, Second Decision on issues relating to Disclosure.

Prosecutor v. Omar Hassan Ahmad Al Bashir, ICC-02/05-01/09, 30 July 2010, Notification of Public Statement by the Prosecutor.

Prosecutor v. Omar Hassan Ahmad Al Bashir, ICC-02/05-01/09-3, PTC I, 4 March 2009, 2009, Decision on the Prosecution's Application for a Warrant of Arrest against Omar Hassan Ahmad Al Bashir.

Prosecutorv. Bemba, ICC-01/05-01/08-14, 10 June 2008, PTC III, Decision on the Prosecutor's Application for a Warrant of Arrest against Jean-Pierre Bemba Gombo.

Prosecutor v. Bemba, ICC-01/05-01/08-55, 31 July 2008, Decision on the Evidence Disclosure System and Setting a Timetable for Disclosure between the Parties.

Prosecutor v. Bemba, ICC-01/05-01/08, A. Ch., 16 December 2008, Judgment on the Appeal of Mr Jean-Pierre Bemba Gombo against the decision of the Pre-Trial Chamber III entitled 'Decision on application for interim release'.

Prosecutor v. Bemba, ICC-01/05-01/08-336, 29 December 2008, Decision on the Schedule for the Confirmation of Charges Hearing.

Prosecutor v. Bemba Gombo, ICC-01/05-01/08-695, T. Ch., 12 February 2010, Decision on the Procedures to be adopted for Instructing Expert Witnesses.

Prosecutor v. Bemba Gombo, ICC-01/05-01/08-807-Corr, T. Ch., 12 July 2010, Decision on the participation of victims in the trial and on 86 applications by victims to participate in the proceedings.

Prosecutor v. Bemba Gombo, ICC-01/05-01/08-928, 7 October 2010, T. Ch., Decision on the Prosecution's Request for Approval of a Proposed Expert and for Extension of Time for the Submission of the Expert Report.

Prosecutor v. Bemba Gombo, ICC-01/05-01/08, 1 November 2010, Defence Application for Appropriate Decisions by Trial Chamber III Prior to Commencement of the Trial Scheduled for 22 November 2010, (Trial Chamber's Decision to that Motion dated 16 November 2010).

Prosecutor v. Bemba, ICC-01/05-01/08, 19 November 2010, Decision on Directions for the Conduct of the Proceedings.

Prosecutor v. Bemba, ICC-01/05-01/08-1022, 19 November 2010, Decision on the admission into evidence of materials contained in the prosecution's list of evidence.

Prosecutor v. Bemba, ICC-01/05-01/08-1386, 3 May 2011, Judgment on the appeals of Mr. Jean-Pierre Bemba Gombo and the Prosecutor against the decision of the Trial 
Chamber III entitled "Decision on the admission into evidence of materials contained in the prosecution's list of evidence".

Prosecutor v. Callixte Mbarushimana, ICC-01/04-01/10-31, 5 January 2011, PTC I, Prosecution Response to the 'Defence Request for Disclosure'.

Prosecutor v. Callixte Mbarushimana, ICC-01/04-01/10, PTC I (Single Judge), 24 March 2011, Decision on the "Defence Request for an order for State Cooperation Pursuant to Article 57(3)(b) of the Rome Statute".

Prosecutor v. Callixte Mbarushimana, ICC-01/04-01/10-87, PTC I, 30 March 2011, Decision on issues relating to disclosure.

Prosecution v. Callixte Mbarushimana, ICC-01/04-01/10-93, 5 April 2011, Prosecution's Application for leave to Appeal the 'Decision on issues relating to disclosure, ICC01/04-01/10-87.

Prosecution v. Callixte Mbarushimana, ICC-01/04-01/10-94, PTC I, 10 April 2011, Defence Reponse to the Prosecution's Request for Leave to Appeal Decision ICC-01/04-01/10-87.

Prosecutor v. Callixte Mbarushimana, ICC-01/04-01/10-116, PTC I, 21 April 2011, Decision on the Prosecution's Application for leave to Appeal the 'Decision on issues relating to disclosure', ICC-01/04-01/10-87.

Prosecutor v. Katanga, ICC-01/04-01/07, 25 April 2008, Decision on the "Defences Application pursuant to Article 57(3)(b) of the Statute to Seek Cooperation of the Democratic Republic of Congo (DRC)".

Prosecutor v. Katanga, ICC-01/04-01/07-257, PTC I, 10 March 2008, Decision on the Joinder of the Cases Against Germain Katanga and Mathieu Ngudjolo Chui.

Prosecutor v. Katanga, ICC-01/04-01/07, 25 April 2008. Decision on the "Defence's Application pursuant to Article 57(3)(b) of the Statute to Seek Cooperation of the Democratic Republic of Congo (DRC)".

Prosecutor v. Katanga and Ngudjolo, ICC-01/04-01/07-475, 13 May 2008, Judgment on the appeal of the Prosecutor against the decision of Pre-Trial Chamber I entitled "First Decision on the Prosecution Request for Authorisation to Redact Witness Statements".

Prosecutor v. Katanga and Ngudjolo Chui, ICC-01/04-01/07, 20 June 2008, Decision on Article 54(3)(e) Documents Identified as Potentially Exculpatory or Otherwise Material to the Defence's Preparation for the Confirmation Hearing.

Prosecutor v. Katanga and Ngudjolo Chui, ICC-01/04-01/07-717, PTC II, 30 September 2008, Decision on the Confirmation of Charges.

Prosecutor v. Katanga and Ngudjolo, ICC-01/04-01/07-776, 26 November 2008, Judgement on the Appeals of the Prosecutor against the "Decision on Evidentiary Scope of the Confirmation Hearing, Preventive Relocation and Disclosure under Article 67(2) of the Statute and Rule 77 of the Rules" of Pre-Trial Chamber I.

Prosecutor v. Katanga and Ngudjolo Chui, ICC-01/04-01/07-1665-Corr, T. Ch. II, ICC, 1 December 2009, Directions for the conduct of the proceedings and testimony in accordance with Rule 140.

Prosecutor v. Katanga and Ngudjolo Chui, ICC-01/04-01/07-1788-tENG, T. Ch., 22 January 2010, Decision on the Modalities of Victim Participation at Trial.

Prosecutor v. Katanga and Ngudjolo Chui, ICC-01/04-01/07-2388, T. Ch., 14 September 2010, Decision on the Public Document "Prosecution's Application Concerning Disclosure Pursuant to Rules 78 and 79(4)" by the Defence. 
Table of Cases

Prosecutor v. Katanga and Ngudjolo, ICC-01/04-01/07-2681, 3 February 2011, Decision on Agreements as to Evidence.

Prosecutor v. Lubanga Dyilo, ICC-01/04-01/06-103, 17 March 2006, Decision on the Defence Request for Unrestricted Access to the Entire File of the Situation in the Democratic Republic of the Congo.

Prosecutor v. Lubanga Dyilo, ICC-01/04-01/06-102, 15 May 2006, Decision on the Final System of Disclosure and the Establishment of a Timetable.

Prosecutor v. Lubanga Dyilo, ICC-01/04-01/06-108, PTC I, 19 May 2006. Situation in the $D R C$, Decision Establishing General Principles Governing Applications to Restrict Disclosure pursuant to Rule 81(2) and (4) of the Statute.

Prosecutor v. Lubanga Dyilo, ICC-01/04-01-06-355, PTC I, 25 August 2006, Decision on the Prosecution Practice to Provide to the Defence Redacted Versions of Evidence and Materials without Authorization by the Chamber.

Prosecutor v. Lubanga Dyilo, ICC-01/04-01/06-424, A. Ch., 12 September 2006, Situation in the DRC, Separate Opinion of Judge Georghios M. Pikis, Decision on the Prosecutor's 'Application for Leave to Reply to 'Conclusions de la défense en réponse au mémoired'appel du Procureur'.

Prosecutor v. Lubanga Dyilo, ICC-01/04-01/06, 13 October 2006, Judgment on the Prosecutor's appeal against the decision of Pre-Trial Chamber I entitled "Decision Establishing General Principles Governing Applications to Restrict Disclosure pursuant to Rule 81(2) and (4) of the Rules of Procedure and Evidence".

Prosecutor v. Lubanga Dyilo, ICC-1/04-01/06-679, PTC I, 8 November 2006, Decision on the Practices of Witness Familiarisation and Witness Proofing.

Prosecutor v. Lubanga Dyilo, ICC-01/04-01/06-718, PTC I, 17 November 2006, Decision on Defence Requests for Disclosure of Materials.

Prosecutor v. Lubanga Dyilo, ICC-01/04-01/06-773, A. Ch., 14 December 2006, Judgment on the appeal of Mr. Thomas Lubanga Dyilo against the decision of Pre-Trial Chamber I entitled "First Decision on the Prosecution Requests and Amended Requests for Redactions under Rule 81."

Prosecutor v. Lubanga Dyilo, ICC-01/04-01/06-772, A. Ch., 14 December 2006, Judgment on the Appeal of Mr. Thomas Lubanga Dyilo against the Decision on the Defence Challenge to the Jurisdiction of the Court pursuant to Article 19(2)(a) of the Statute of 3 October 2006.

Prosecutor v. Lubanga Dyilo, ICC-01/04-01/06-803-tEN, PTC I, 29 January 2007, Decision on Confirmation of Charges.

Prosecutor v. Lubanga Dyilo, ICC-01/04-01/06, PTC I, 5 February 2007, Application for Leave to Appeal Pre-Trial Chamber I's, 29 January 2007 'Décision sur la confirmation des charges'.

Prosecutor v. Lubanga Dyilo, ICC-01/04-01/06-925, A. Ch., 13 June 2007, Separate Opinion of Judge Pikis, Decision of the Appeals Chamber on the Joint Application of Victims a/0001/06 to a/0003/06 and a/0105/06 concerning the "Directions and Decision of the Appeals Chamber" of 2 February 2007.

Prosecutor v. Lubanga Dyilo, ICC-01/04-01/06-953, 12 September 2007, Prosecution's submission regarding the subjects that require early determination: status of the evidence 
heard by the Pre-Trial Chamber; status of decision of the Pre-Trial Chamber; and the manner in which evidence shall be submitted.

Prosecutor v. Lubanga Dyilo, ICC-01/04-01/06, T. Ch. I, 26 September 2007, Redacted version of "Decision on the prosecution's filing entitled "Prosecution's provision of information to the Trial Chamber" filed on 3 September 2007", Annex 1.

Prosecutor v. Lubanga Dyilo ICC-01/04-01-06, 9 November 2007, Decision Regarding the Timing and Manner of Disclosure and the Date of Trial.

Prosecutor v. Lubanga Dyilo, ICC-01/04-01/06-1049, T. Ch. I, 30 November 2007, Decision Regarding the Practices Used to Prepare and Familiarise Witnesses for Giving Testimony at Trial.

Prosecutor v. Lubanga Dyilo, ICC-01/04-01/06-1069, 10 December 2007, Decision on the Procedures to be adopted for Instructing Expert Witnesses.

Prosecutor v. Lubanga Dyilo, ICC-01/04-01/06-1084, 13 December 2007, Decision on the Status Before the Trial Chamber of the Evidence heard by the Pre-Trial Chamber and the decision of the Pre-Trial Chamber in Trial Proceedings, and the Manner in which evidence shall be submitted.

Prosecutor v. Lubanga Dyilo, ICC-01/04-01/06-1091, 14 December 2007, Decision on defence's request to obtain simultaneous French transcripts.

Prosecutor v. Lubanga Dyilo, ICC-01/04-01/06-1119, T. Ch. I, 18 January 2008, Decision on Victim Participation.

Prosecutor v. Lubanga Dyilo, ICC-01/04-01/06-1140, T. Ch. I, 29 January 2008, Decision on various issues related to witness' testimony during trial.

Prosecutor v. Lubanga Dyilo, ICC-01/04-01/06-1179, T. Ch. I, 20 February 2008, Decision on Agreements between the Parties.

Prosecutor v. Lubanga Dyilo, ICC-01/04-01/06-1220-tENG, 10 March 2008, Defence Appeal against Trial Chamber I's 18 January 2008 Decision on Victims' Participation.

Prosecutor v. Lubanga Dyilo, ICC-01/04-01/06-1235, T. Ch., 20 March 2008, Decision on Disclosure by the Defence.

Prosecutor v. Lubanga Dyilo, ICC-01/04-01/06-1291, 22 April 2008, Réponse de la Défense à la "Prosecution's submissions on undisclosed documents containing potentially exculpatory information" datée du 28 mars 2008.

Prosecutor v. Lubanga Dyilo, 24 April 2008, ICC-01/04-01/06-1311-Anx2, Decision on disclosure issues, responsibilities for protective measures and other procedural matters.

Prosecutor v. Lubanga Dyilo, ICC-01/04-01/06, 8 May 2008, Decision Issuing a Confidential and a Public Redacted Version of Decision on Disclosure issues, responsibilities for protective measures and other procedural matters.

Prosecutor v. Lubanga Dyilo, ICC-01/04-01/06-1399, T. Ch., 13 June 2008, Decision on the Admissibility of Four Documents.

Prosecutor v. Lubanga Dyilo, ICC-01/04-01/06-1401, T. Ch., 13 June 2008, Decision on the Consequences of Non-disclosure of Exculpatory Materials Covered by Article 54(3)(e) Agreements and the Application to Stay the Prosecution of the Accused, together with Certain Other Issues Raised at the Status Conference on 10 June 2008.

Prosecutor v. Lubanga Dyilo, ICC-01/04-01/06-1407, T. Ch., 23 June 2008, Prosecution's Application for Leave to Appeal "Decision on the Consequences of Non-disclosure of Exculpatory Materials Covered by Article 54(3)(e) Agreements and the Application to 
Stay the Prosecution of the Accused, together with Certain Other Issues Raised at the Status Conference on 10 June 2008.

Prosecutor v. Lubanga Dyilo, ICC-01/04-01/06-1432, A. Ch., 11 July 2008, Judgment on the Appeals of the Prosecutor and the Defence against Trial Chamber I's Decision on Victims' Participation of 18 January 2008.

Prosecutor v. Lubanga Dyilo, ICC-01/04-01/06-1432, A. Ch., 11 July 2008, Partly Dissenting Opinion of Jugde Pikis, Judgment on the Appeals of the Prosecutor and the Defence against Trial Chamber I's Decision on Victims' Participation of 18 January 2008.

Prosecutor v. Lubanga Dyilo, ICC-01/04-01/06 OA13, 24 July 2008, Prosecution's Document in Support of Appeal against Decision to Stay Proceedings.

Prosecutor v. Lubanga Dyilo, ICC-01/04-01/06-OA 13, 21 October 2008, Judgment on the Appeals of the Prosecutor against the decision of Trial Chamber I entitled "Decision on the Consequences of Non-disclosure of Exculpatory Materials Covered by Article 54(3)(e) Agreements and the Application to Stay the Prosecution of the Accused, together with Certain Other Issues Raised at the Status Conference on 10 June 2008.

Prosecutor v. Lubanga Dyilo, ICC-01/04-01/06-1644, 23 January 2009, Reasons for Oral Decision Lifting the Stay of Proceedings.

Prosecutor v. Lubanga Dyilo, ICC-01/04-01/06, T. Ch. I, 21 January 2009, Decision on the defence application for disclosure of victims' applications.

Prosecutor v. Lubanga Dyilo, ICC-01/04-01/06-2032-Anx, T. Ch. I, 29 June 2009, Decision on the request by victims a/0225/06, a/0229/06 and a/0270/07 to express their views and concerns in person and to present evidence during the trial.

Prosecutor v. Lubanga Dyilo, ICC-01/04-01/06-2032, T. Ch., 9 July 2009, Order issuing public redacted version of the "Decision on the request by victims a/ 0225/06, a/0229/06 and a/0270/07 to express their views and concerns in person and to present evidence during the trial".

Prosecutor v. Lubanga Dyilo, ICC-01/04-01/06-2127, T. Ch. I, 16 September 2009, Decision on the Manner of Questioning Witnesses by the Legal Representatives of Victims.

Prosecutor v. Lubanga Dyilo, Transcript of 9 December 2009, ICC-01/04-01/06-T-222-ENG, 7 January 2010, ICC-01/04-01/06-T-223-ENG and 8 January 2010, ICC-01/04-01/06-T224-ENG.

Prosecutor v. Lubanga Dyilo, ICC-01/04-01/06-2310-Red, 25 February 2010, Prosecution's Submissions in Response to Trial Chamber's Oral Request of 10 February 2010.

Prosecutor v. Lubanga Dyilo, ICC-01/04-01/06-2340, T. Ch., 11 March 2010, Decision on the Defence Observations Regarding the Right of the Legal Representatives of Victims to Question Defence Witnesses and on the Notion of Personal interest and Decision on the Defence Application to Exclude certain Representatives of Victims from the Chamber during the Non-Public Evidence of Various Defence Witnesses.

Prosecutor v. Lubanga Dyilo, ICC-01/04-01/06-2360, T. Ch. I, 18 March 2010, Decision on Judicial Questioning.

Prosecutor v. Lubanga Dyilo, ICC-01/04-01/06-2434-Red2, 31 May 2010, Redacted Decision on Intermediaries.

Prosecutor v. Lubanga Dyilo, ICC-01/04-01/06-2362, 19 March 2010, Prosecution Proposed Procedure for Dealing with Intermediaries. 
Prosecutor v. Lubanga Dyilo, ICC-01/04-01/06-2404, 29 April 2010, Decision on the "Requête de la Défense sollicitant l'autorisation d'interjeter appeal de la decision orale du 4 mars 2010 autorisant l'utilisation et le depot en prevue de trios photographies".

Prosecutor v. Lubanga Dyilo, ICC-01/04-01/06-2434-Red2, 31 May 2010, Redacted Decision on Intermediaries.

Prosecutor v. Lubanga Dyilo, ICC-01/04-01/06-2516, 7 July 2010, Prosecution's Urgent Provision of Further Information Following Consultation with the VWU, to Supplement the Request for Variation of the Time-Limit or Stay.

Prosecutor v. Lubanga Dyilo, ICC-01/04-01/06-2517-Red, T. Ch. I, 8 July 2010, Redacted Decision on the Prosecution's Urgent Request for Variation of the Time-Limit to Disclose the Identity of Intermediary 143 or Alternatively to Stay Proceedings Pending Further Consultations with the VWU.

Prosecutor v. Lubanga Dyilo, ICC-01/04-01/06-2512, T. Ch. I, 8 July 2010, Prosecution's Urgent Request for Variation of the Time-Limit to Disclose the Identity of Intermediary 143 or Alternatively to Stay Proceedings Pending Further Consultations with the VWU.

Prosecutor v. Lubanga Dyilo, ICC-01/04-01/06, T. Ch. I, 12 May 2010, Decision on the Press Interview with Ms Le Fraper du Hellen.

Prosecutor v. Lubanga Dyilo, ICC-01/04-01/06-2544-Red, 30 July 2010, Prosecution's Document in Support of Appeal against Trial Chamber I's Decision of 8 July 2010 to stay the proceedings for abuse of process.

Prosecutor v. Lubanga Dyilo, ICC-01/04-01/06 OA 18, A. Ch., 8 October 2010, Judgment on the Appeal of the Prosecutor against the Decision of Trial Chamber I of 8 July 2010 entitled "Decision on the Prosecution's Urgent Request for Variation of the Time-Limit to Disclose the Identity of Intermediary 143 or Alternatively to Stay Proceedings Pending Further Consultations with the VWU.

Prosecutor v. Lubanga Dyilo, ICC-01/04-01/06-2624, 12 November 2010, Decision on the scope of the prosecution's disclosure obligations as regards defence witnesses.

Prosecutor v. Lubanga Dyilo, ICC-01/04-01/06-2727-Red, T. Ch. I, 28 April 2011, Redacted Decision on the Prosecution's Application to Admit Rebuttal Evidence from Witness DRC-OTP-WWWW-0005.

Prosecutor v. Samoei Ruto, Kiprono Kosgey and Arap Sang, ICC-01/09-01/11-44, PTC II, 6 April 2011, Decision Setting the Regime for Evidence Disclosure and Other Related Matters.

Prosecutor v. Samoei Ruto, Kiprono Kosgey and Arap Sang, ICC-01/09-01/11-44, PTC II, 13 April 2011, Prosecution's Application for Leave to Appeal the "Decision Setting the Regime for Evidence Disclosure and Other Related Matters".

Prosecutor v. Samoei Ruto, Kiprono Kosgey and Arap Sang, ICC-01/09-01/11-74, PTC II, 2 May 2011, Decision on the Prosecution's Application for Leave to Appeal the "Decision Setting the Regime for Evidence Disclosure and Other Related Matters",

Prosecutor v. Samoei Ruto, Kiprono Kosgey and Arap Sang, ICC-01/09-01/11-74, PTC II, 2 May 2011, Decision on the Prosecution's Application for Leave to Appeal the "Decision Setting the Regime for Evidence Disclosure and Other Related Matters".

Situation in the Central African Republic, Decision Requesting Information on the Status of the Preliminary Examination of the Situation in the Central African Republic, ICC01/05, PTC III, 30 November 2006. 
Situation in Darfur, Decision on the Requests of the OPCD and the Production of Relevant Supporting Documentation Pursuant to Regulation 86(2) of the Regulations of the Court and on the Disclosure of Exculpatory Materials by the Prosecutor, ICC-02/05-110, 3 December 2007

Situation in Darfur, Sudan, Corrigendum to Decision on the Applications for Participation in the Proceedings of Applicants a/0011/06 to a/0015/06, a/0021/07, a/0023/07 to a/0033/07 and a/0035/07 to a/0038/07", ICC-02/05-111-Corr, 14 December 2007.

Situation in the Democratic Republic of the Congo, Décision sur les Demandes de Participation á la Procedure de VPRS 1, VPRS 2, VPRS 3, VPRS 4, VPRS 5 et VPRS 6, PTC, ICC-01/04101, 17 January 2006 (English translation of 22 March 2006, ICC-01/04-10-tEN-Corr).

Situation in the Democratic Republic of the Congo, ICC-01/04-103, 23 January 2006 and ICC-01/04-141, 24 April 2006.

Situation in the Democratic Republic of the Congo, Decision on the Prosecutor's Application for Leave to Appeal the Chamber's Decision of 17 January 2006 on the Applications for Participation in the Proceedings of VPRS 1, VPRS 2, VPRS 3, VPRS 4, VPRS 5 and VPRS 6, PTC, ICC-01/04-135-tEN, 31 March 2006.

Situation in Democratic Republic of the Congo, "Judgment on victim participation in the investigation stage of the proceedings in the appeal of the OPCD against the decision of Pre-Trial Chamber I of 7 December 2007 and in the appeals of the OPCD and the Prosecutor against the decision of Pre-Trial Chamber I of 24 December 2007" 19 December 2008 (ICC-01/04-556).

Situation in Democratic Republic of the Congo, Prosecution's Application for Leave to Appeal Pre-Trial Chamber I's Decision on the Application for Participation in the Proceedings of VPRS 1, VPRS 2, VPRS 3, VPRS 4, VPRS 5 and VPRS 6, ICC-01/04-103, 23 January 2006.

Situation in Democratic Republic of the Congo, Décision sur les Demandes de Participation á la Procedure de VPRS 1, VPRS 2, VPRS 3, VPRS 4, VPRS 5 et VPRS 6, PTC, ICC-01/04101, English translation of 22 March 2006, ICC-01/04-10-tEN-Corr, 17 January 2006.

Situation in Uganda, No. ICC-02/04-103, 20 August 2007.

\section{Special Tribunal for Lebanon}

Order Regarding the Detention of Persons in Lebanon in Connection with the Case of the Attack against Prime Minister Rafiq Hariri and Others, CH/PTJ/2009/06, Pre-Trial Judge, 29 April 2009.

\section{Special Court for Sierra Leone}

Prosecutor v. Brima, Kamara and Kanu, SCSL-04-16-A, 3 March 2008, Judgment.

Prosecutor v. Brima, Kamara and Kanu, SCSL-04-16-PT, 1 June 2004, Decision on Defence Motion in Respect of Santigie Borbour Kanu for an Order Under Rule 54 with Respect to Release of Exculpatory Evidence.

Prosecutor v. Brima et al., SCSL-04-16-T, 4 May 2005, Decision on Joint Defence Motion on Disclosure of all Original Witness Statements, Interview Notes and Investigator's Notes Pursuant to Rules 66 and/or 69. 
Table of Cases

Prosecutor v. Brima et al., SCSL-04-16, A. Ch., 8 December 2005, Decision on Brima-Kamara Defence Appeal Motion.

Prosecutor v. Brima et al., SCSL-04-16-T, 28 September 2006, Decision on Confidential Prosecution Motion to Reopen the Prosecution Case to Present an Additional Prosecution Witness.

Prosecutor v. Brima et al., SCSL-04-16-T, 14 November 2006, Decision on Confidential Motion to Call Evidence in Rebuttal.

Prosecutor v. Norman et al., SCSL-04-14-T, 16 July 2004, Decision on Disclosure of Witness Statements and Cross-Examination.

Prosecutor v. Norman et al., SCSL-04-14-T, T. Ch. I, 10 November 2006. Decision on the Impermissibility of Eliciting Evidence Involving the Second Accused through CrossExamination of Witness Called by the Third Accused.

Prosecutor v. Sesay et al., SCSL-04-15-T, T. Ch., 1 August 2006, Decision on Defence Motion to Request the Trial Chamber to Rule that the Prosecution Moulding of Evidence is Impermissible.

Prosecutor v. Sesay et al., SCSL-2004-15-T, T. Ch., 30 June 2008, Written Reasons - Decision on the Admissibility of Certain Prior Statements of the Accused Given to the Prosecution.

Prosecutor v. Sesay, Kallon, Gbao, SCSL-04-15-T, 2 March 2009, Trial Chamber Judgment.

Prosecutor v. Sesay, Kallon, Gbao, SCSL-04-15-A, 26 October 2009, Appeals Chamber Judgment.

Prosecutor v. Taylor, SCSL-2003-01-T, T. Ch. II, 4 June 2007, Transcript.

Prosecutor v. Taylor, SCSL-03-01, 4 June 2007, Prosecution Opening Statement.

Prosecutor v. Taylor, SCSL-2003-01-T, T. Ch. II, 25 June 2007, Transcript.

Prosecutor v. Taylor, SCSL-03-1-T, T. Ch. I, 30 November 2009, Decision on Prosecution Motion in Relation to the Applicable Legal Standards Governing the Use and Admission of Documents by the Prosecution during Cross-Examination.

Prosecutor v. Taylor, SCSL-03-1-T, 9 February 2010, Decision on Urgent Applications for Leave to Appeal Oral Decisions of 18, 21, 25 and 26 January 2010 on Use of Documents in Cross-Examination.

Prosecutor v. Taylor, SCSL-03-1-T, 29 March 2010, Decision on Prosecution Request for Orders in Relation to the Scheduling of the Remainder of the Case.

Prosecutor v. Taylor, SCSL-03-01-T, 11 November 2010, Decision on Public with Confidential Annexes A-J and Public Annexes K-O Defence Motion Requesting an Investigation into Contempt of Court by the Office of the Prosecutor and Its Investigators.

Prosecutor v. Taylor, SCSL-03-01-T, A. Ch., 21 January 2011, Decision on Public Defence Notice of Appeal and Submissions Regarding the Decision on the Defence Motion Requesting an Investigation into Contempt of Court by the Office of the Prosecutor and Its Investigators.

\section{Extraordinary Chambers in the Courts of Cambodia}

Prosecutor v. Kaing Guek Eav, 001/18-07-2007-ECCC/TC, T. Ch., 17 February 2009, Transcript of Proceedings, Initial Hearing Day 1.

Prosecutor v. Kaing Guek Eav, 001/18-07-2007-ECCC/TC, T. Ch., 18 February 2009, Transcript of Proceedings, Initial Hearing Day 2. 
Prosecutor v. Kaing Guek Eav, 001/18-07-2007/ECCC/TC, 20 March 2009, Direction on the Scheduling of the Trial.

Prosecutor v. Kaing Guek Eav, 001/18-07-2007-ECCC/TC, T. Ch., 16 June 2009, Transcript of Trial Proceedings, Day 29.

Prosecutor v. Kaing Guek Eav, 001/18-07-2007-ECCC/TC, T. Ch., 22 June 2009, Transcript of Trial Proceedings, Day 31.

Prosecutor v. Kaing Guek Eav, 001/18-07-2007-ECCC/TC, T. Ch., 27 August 2009, Transcript of Trial Proceedings, Day 66.

\section{USA Case law}

U.S. Supreme Court, Bell v. Cone, 535 U.S. 685 (2002), 243 F.3d 961).

U.S. Supreme Court, Brady v. Maryland, 373 U.S. 83 (1963).

U.S. Supreme Court, Cafeteria Workers v. McElroy, 367 U. S. 886, 367 U. S. 895 (1961).

U.S. Supreme Court, Gideon v. Wainwright, 372 U. S. 335, 372 U. S. 344 (1963).

U.S. Supreme Court, Herring v. New York, 422 U.S. 853, 862 (1975).

U.S. Supreme Court, Kremer v. Chemical Constr. Corp., 456 U.S. 461 (1982).

U.S. Supreme Court, Malloy v. Hogan, 378 U.S. 1 (1964).

U.S. Supreme Court, McNeil v. Wisconsin, 501 U.S. 171, 111 S.Ct. 2204 (1991).

U.S. Supreme Court, Murphy v. Waterfront Comm'n, 378 U.S. 52 (1964).

U.S. Supreme Court, U.S. v. Agurs, 427 U.S. 97 (1976).

U.S. Supreme Court, Wardius v. Oregon, 412 U.S. 470, 474 (1973).

U.S. Supreme Court, Washington v. Texas, 388 U. S. 14, 388 U. S. 22 (1967).

U.S. Supreme Court, Williams v. Florida, 399 U.S. 78, 112 (1970).

U.S. Court of Appeals, United States v. O'Keefe, 128 F. 3d 885, 897 ( $5^{\text {th }}$ Cir. 1997).

Inland Empire Council v. Millis, 325 U.S. 697, 325 U. S. 710 (1945).

Mitchell v. W.T. Grant Co., 416 U. S. 600, 416 U.S. 610 (1974).

U.S. v. Tucker, 249 F.R.D. 58, S.D.N.Y., 2008.

United States v. Turkish, 623 F.2d 769, 774-775 (2 $2^{\text {nd }}$ Cir. 1980).

United States v. Garsson, 291 Fed. 646, 649 (S.D.N.Y. 1923).

Weatherford v. Bursey, 429 U.S. 545, 559 (1977).

\section{United Kingdom}

Court of King's Bench, Ashford v. Thornton [(1818) 106 ER 149], 16 April 1818.

$R$ v. Bryant and Dickson (1946) 31 Cr App R 146.

\section{The Netherlands}

Hoge Raad, 30 June 2009, LJN BH3079, NJ 2009, 349. 


\section{Curriculum Vitae}

Masha Fedorova studied Dutch law at Utrecht University where she obtained her Master degree (LL.M.), cum laude, in 2004. She specialized in Dutch criminal law and international law, and wrote a combined Master thesis on international criminal law. Soon after the graduation, she began working at Utrecht University's Netherlands Institute of Human Rights (SIM) as a junior researcher/ lecturer on a two-year project entitled 'International Criminal Tribunal for the Former Yugoslavia Database'. In this capacity she was responsible for research, analysis and digital documentation of the case law of the Yugoslavia tribunal. During that time she wrote a research proposal applying for a grant with the Netherlands Organisation for Scientific Research (NWO) Mozaic Programme. In 2006, she was awarded a four-year research grant and continued working at SIM in the capacity of a PhD candidate. Next to her $\mathrm{PhD}$ research, she has published various articles, has taught international law and has presented on various occasions on topics related to (international) criminal law and human rights. In November 2009, she made a research visit to the Extraordinary Chambers in the Court of Cambodia, Phnom Penh, Cambodia. From January 2012 she holds an assistant professor position in Criminal Law and Criminal Procedure at Radboud University Nijmegen, the Netherlands. 


\section{School of Human Rights Research Series}

The School of Human Rights Research is a joint effort by human rights researchers in the Netherlands. Its central research theme is the nature and meaning of international standards in the field of human rights, their application and promotion in the national legal order, their interplay with national standards and the international supervision of such application. The School of Human Rights Research Series only includes English titles that contribute to a better understanding of the different aspects of human rights.

Editorial Board of the Series

Prof. dr. J.E. Goldschmidt (Utrecht University), Prof. dr. D.A. Hellema (Utrecht University), Prof. dr. W.J.M. Van Genugten (Tilburg University), Prof. dr. M.T. Kamminga (Maastricht University), Prof. dr. P.A.M. Mevis (Erasmus University Rotterdam), Dr. J.-P. Loof (Leiden University) and Dr. O.M. Ribbelink (Asser Institute).

For previous volumes in the series, please visit http://shr.intersentia.com.

\section{Published titles within the Series}

45 Marloes van Noorloos, Hate Speech Revisited. A comparative and historical perspective on hate speech law in the Netherlands and England \& Wales

ISBN 978-1-78068-032-3

46 Hanneke Senden, Interpretation of Fundamental Rights in a Multilevel Legal System. An analysis of the European Court of Human Rights and the Court of Justice of the European Union

ISBN 978-1-78068-027-9

47 Otto Spijkers, The United Nations, the Evolution of Global Values and International Law ISBN 978-1-78068-036-1

48 Karin Veegens, A Disrupted Balance? Prevention of terrorism and compliance with fundamental legal rights and principles of law - The Dutch anti-terrorism legislation ISBN 978-1-78068-042-2

49 Antenor Hallo de Wolf, Reconciling Privatization with Human Rights ISBN 978-1-78068-049-1

50 Marie-José van der Heijden, Transnational Corporations and Human Rights Liabilities: Linking Standards of International Public Law to National Civil Litigation Procedures ISBN 978-94-000-0195-4

51 Marthe Lot Vermeulen, Enforced Disappearance. Determining State Responsibility under the International Convention for the Protection of All Persons from Enforced Disappearance ISBN 978-1-78068-065-1

52 Vera Vriezen, Amnesty justified? The need for a case by case approach in the interests of human rights ISBN 978-1-78068-075-0

53 Maite San Giorgi, The Human Right to Equal Access to Health Care ISBN 978-1-78068-081-1

54 Jeroen Blomsma, Mens rea and defences in European criminal law ISBN 978-1-78068-104-7 
